\title{
Reconnaissance Investigation of Water Quality, Bottom Sediment, and Biota Associated with Irrigation Drainage in and near Stillwater Wildlife Management Area, Churchill County, Nevada, 1986-87
}

By Ray J. Hoffman, ${ }_{1}^{1}$ Robert J. Hallock, ${ }^{2}$ Timothy G. Rowe, Michael S. Lico, Howard L. Burge, and Steven P. Thompson ${ }^{2}$

1 U.S. Geological Survey

2 U.S. Fish and Wildlife Service

U.S. GEOLOGICAL SURVEY

Water-Resources Investigations Report 89-4105

Prepared in cooperation with the

U.S. FISH AND WILDLIFE SERVICE and

U.S. BUREAU OF RECLAMATION

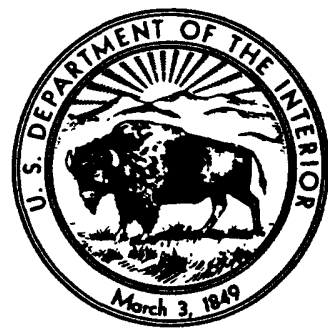

Carson City, Nevada 1990 


\section{DEPARTMENT OF THE INTERIOR}

\section{MANUEL LUJAN, JR., Secretary}

\section{U.S. GEOLOGICAL SURVEY}

Dallas L. Peck, Director

For additional information write to:

U.S. Geological Survey Room 227, Federal Building 705 North Plaza Street Carson City, NV 89701
Copies of this report may be purchased from:

U.S. Geological Survey Books and Open-File Reports Section Federal Center, Building 810

Box 25425

Denver, CO 80225 


\section{CONTENTS}

Abstract - -

Introduction -.... 2

Background --..-.-. 2

Purpose and scope -

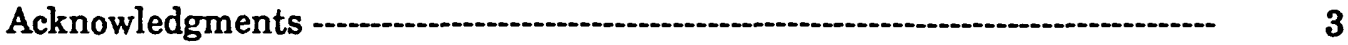

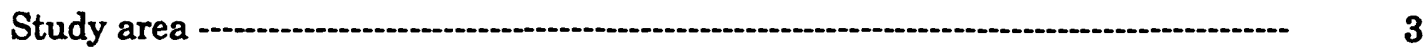

Location -.-1- 3

History -

Climate - -

Geology - 7

Soils -

Water use -

Hydrologic setting -

Fallon agricultural area

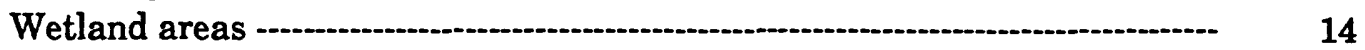

Previous studies

Sample collection and analysis -

Water samples - 19

Bottom-sediment samples - - 21

Biological samples - 22

Results of the reconnaissance investigation

Determination of contaminant criteria --..- 24

Surface- and ground-water quality -...-..- 29

Dissolved solids -...-...- 30

Trace elements -

Radioactive substances --.-.-.-.- 37

Nitrogen, phosphorus, and carbon -

Bottom-sediment samples -

Trace elements -

Organochlorine pesticides -...-...- 44

Biological samples -

Arsenic -

Boron -

Chromium - -

Copper -

Mercury - - 56

Selenium -a-a.c- 62

Zinc - 68 
Public health warnings - 69

Biological effects of contaminants

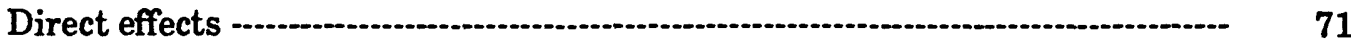

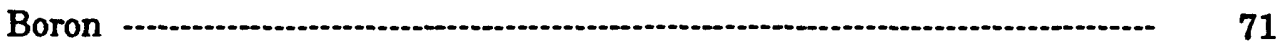

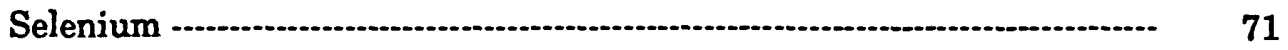

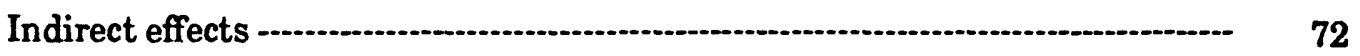

Concentration of dissolved solids, dissolved oxygen, and dissolved un-ionized ammonia -................................................ 73

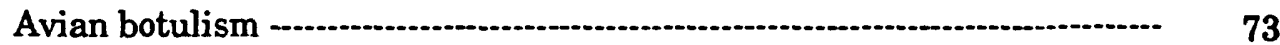

Trace-element toxicity in birds ...................................................

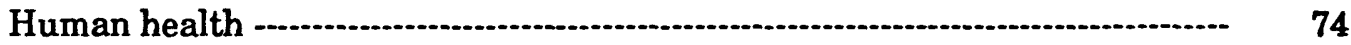

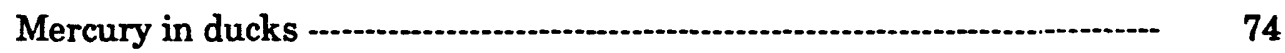

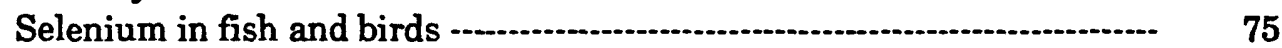

Summary

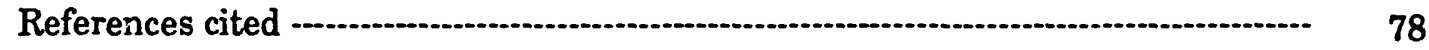

Supplemental data

\section{ILLUSTRATIONS}

[Plate in pocket at back of report.]

Plate 1. Sampling sites for water quality, bottom sediment, and biota, Department of the Interior Irrigation Drainage Study, Stillwater Wildlife Management Area, Nevada, 1986-87

Figure 1. Aerial photo of Stillwater Wildlife Management Area, Nevada, looking toward the northeast

2. Map of irrigated acreage in the Fallon agricultural area of the Newlands Project, Nevada

3. Graph showing discharge from Lahontan Reservoir, 1985-87 ......... 10

4. Schematic diagram of the flow system of the Newlands Project ......- 11

5. Map showing flow patterns for the Stillwater National Wildlife Refuge and Wildlife Management Area 
Figures 6-9. Graphs showing concentrations in surface-water samples in the background sites, Carson Lake, and Stillwater Wildlife Management Area, 1986-87, for:

6. Dissolved solids

7. Dissolved sodium

8. Dissolved arsenic

9. Dissolved boron

10. Graph showing relation between log dissolved boron to log dissolved solids from agricultural drains and lakes in the Carson Desert, 1986-87

11. Graph showing dissolved un-ionized ammonia concentrations for surface-water samples in the background sites, Carson Lake, and Stillwater Wildlife Management Area, 1986-87

12. Graph showing arsenic concentrations found in composite insect samples in the background sites, Carson Lake, and Stillwater Wildlife Management Area, 1986-87

13-16. Graphs showing arithmetic means, medians, and maximum-minimum ranges of:

13. Arsenic concentrations found in tissue of carp and mosquito fish

14. Arsenic concentrations found in livers of juvenile coots and juvenile black-necked stilts

15. Boron concentrations found in tissues of hardstem bulrush seed and sago pondweed

16. Boron concentrations found in filamentous algal tissue ------

17. Graph showing boron concentrations found in composite insect samples

18-21. Graphs showing arithmetic means, medians, and ranges of:

18. Boron concentrations found in livers of avocets and coots -.--

19. Boron concentrations found in livers of black-necked stilt juveniles

20. Chromium concentrations found in tissue of carp

21. Copper concentrations found in tissue of carp and mosquito fish

22. Graph showing mercury concentrations found in composite insect samples in the background sites, Carson Lake, and Stillwater, Fernley, and Humboldt Wildlife Management Areas, 1986-87 
Figures 23-26. Graphs showing arithmetic means, medians, and ranges of mercury concentrations found in:

23. Fish tissues of carp and mosquito fish

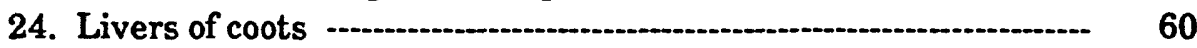

25. Livers of black-necked stilt adults and juveniles -................. 61

26. Mallard, redhead, and shoveler duck liver, muscle, and skin tissue

27. Graph showing selenium concentrations found in composite insect samples in the background sites, Carson Lake, and Stillwater, Fernley, and Humboldt Wildlife Management Areas, 1986-87

28-32. Graphs showing arithmetic means, medians, and maximum-minimum ranges of:

28. Selenium concentrations found in tissue of carp and mosquito fish -..-...-...-...- 65

29. Selenium concentrations found in livers of coots -.............. 66

30. Selenium concentrations found in livers of black-necked stilt adults and juveniles -

31. Zinc concentrations found in carp tissue

32. Selenium concentrations found in mallard, redhead, and shoveler duck liver, muscle, and skin tissue

\section{TABLES}

Table 1. Comparison of past (pre-1905) and present (1987) acreage of major wetlands in northwestern Nevada

2. Acres of emergent vegetation within major wetland units of Stillwater Wildlife Management Area in 1959, 1970, and 1987

3. Surface-water and ground-water sampling sites in and near Stillwater Wildlife Management Area and Carson Lake, Nevada, 1986-87, and rationale for site selection

4. Analytical reporting limits for trace elements and radiochemicals in water and bottom sediment, and for trace elements only in plant, insect, fish, and bird tissue

5. Analytical reporting limits for organochlorine compounds in bottom sediment and in plant, insect, fish, and bird tissue, 1986-87

6. Nevada water-quality criteria for toxic constituents according to designated beneficial use 
Table 7. Federal and State criteria for water and contaminant residue in biota that may adversely affect fish and wildlife, and human health

8. Statistical summary of field measurements for surface-water samples in and near Stillwater Wildlife Management Area and Carson Lake, 1986-87

9. Particle-size distribution in bottom-sediment samples from surfacewater sites in and near Stillwater Wildlife Management Area and Carson Lake, 1987

10. Summary of inorganic and organic constituents in water, bottom sediment, and biota shown to be of potential concern to human health, fish, and wildlife

11. Data from field measurements of physical and chemical constituents for surface-water samples in and near Stillwater Wildlife Management Area and Carson Lake, 1986-87

12. Data on water hardness and major dissolved chemical constituents for surface-water samples in and near Stillwater Wildlife Management Area and Carson Lake, 1986-87

13. Data on nutrient constituents for surface-water samples in and near Stillwater Wildlife Management Area and Carson Lake, 1986-87

14. Data on trace-element constituents for surface-water samples in and near Stillwater Wildlife Management Area and Carson Lake, 1986-87 -...-

15. Data on dissolved radiochemical constituents for surface-water samples in and near Stillwater Wildlife Management Area and Carson Lake, 1986-87

16. Data on total trace-element constituents and carbon in bottomsediment samples in and near Stillwater Wildlife Management Area and Carson Lake, 1986-87

17. Organochlorine pesticide residues and carbon in bottom-sediment samples in and near Stillwater Wildlife Management Area and Carson Lake, 1986-87

18. Data on physical and chemical constituents for ground-water samples in and near Stillwater Wildlife Management Area and Carson Lake, 1986 -.-

19. Data on trace-element constituents and percent moisture of biological samples in Stillwater Wildlife Management Area, Carson Lake, Fernley Wildlife Management Area, and Humboldt Wildlife Management Area, 1985-87 


\section{CONVERSION FACTORS AND ABBREVIATIONS}

"Inch-pound" units of measure used in this report may be converted to metric (International System) units by using the following factors:

\section{Multiply}

Acre

Acre foot (acre-ft)

Acre-foot per day (acre-ft/d)

Acre-foot per year (acre-ft/yr)

Cubic foot per second $\left(\mathrm{ft}^{3} / \mathrm{s}\right)$

Foot (ft)

Inch (in.)

Mile (mi)

Square foot $\left(\mathrm{ft}^{2}\right)$

Square mile $\left(\mathrm{mi}^{2}\right)$

Ton, short

Ounce
By

4,047

1,233

0.001233

0.001233

0.02832

0.3048

2.54

1.609

0.09290

2.590

0.9072

28.35
To obtain

Square meter $\left(\mathrm{m}_{3}^{2}\right)$

Cubic meter $\left(\mathrm{m}^{3}\right)$

Cubic hectometer per day $\left(\mathrm{hm}_{3}^{3} \mathrm{~d}\right)$

Cubic hectometer per year $\left(\mathrm{hm}^{3} / \mathrm{yr}\right)$

Cubic meter per second $\left(\mathrm{m}^{3} / \mathrm{s}\right)$

Meter (m)

Centimeter $(\mathrm{cm})$

Kilometer $(\mathrm{km})$

Square meter $\left(\mathrm{m}^{2}\right)$

Square kilometer $\left(\mathrm{km}^{2}\right)$

Metric ton $(t)$

Gram

For temperature, degrees Celsius $\left({ }^{\circ} \mathrm{C}\right)$ may be converted to degrees Fahrenheit $\left({ }^{\circ} \mathrm{F}\right)$ by using the formula ${ }^{\circ} \mathrm{F}=\left[1.8\left({ }^{\circ} \mathrm{C}\right)\right]+32$.

Degrees Fahrenheit $\left({ }^{\circ} \mathrm{F}\right)$ may be converted to degrees Celsius $\left({ }^{\circ} \mathrm{C}\right)$ by using the formula ${ }^{\circ} \mathrm{C}=0.556\left({ }^{\circ} \mathrm{F}-32\right)$.

\section{SEA LEVEL}

In this report, "sea level" refers to the National Geodetic Vertical Datum of 1929 (NGVD of 1929), which is derived from a general adjustment of the first-order leveling networks of both the United States and Canada (formerly called "Sea-Level Datum of 1929"). 


\title{
RECONNAISSANCE INVESTIGATION OF WATER QUALITY, BOTTOM SEDIMENT, AND BIOTA ASSOCIATED WITH IRRIGATION DRAINAGE IN AND NEAR STILLWATER WILDLIFE MANAGEMENT AREA, CHURCHILL COUNTY, NEVADA, 1986-87
}

\author{
By \\ Ray J.Hoffman, ${ }^{1}$ Robert J. Hallock, ${ }^{2}$ \\ Timothy G. Rowe,' Michael S. Lico,' \\ Howard L. Burge, and Steven P. Thompson ${ }^{2}$
}

\begin{abstract}
A reconnaissance-level investigation was initiated in 1986 to determine whether the quality of irrigation drainage in and near the Stillwater Wildlife Management Area, Nevada, has caused or has potential to cause harmful effects on human health or fish and wildlife, or may adversely affect the suitability of water for beneficial uses. Samples of surface and ground water, bottom sediment, and biota were collected from sites upstream and downstream from the Fallon agricultural area in the Carson Desert. Samples of each of the three media were analyzed for a suite of potentially toxic trace elements, including selenium. Other analyses included radioactive substances, major dissolved constituents, and nutrients in water; and pesticide residues in bottom sediments and biota. Water samples were collected four times from June 1986 to September 1987, bottom-sediment samples once during low-flow conditions, and biological samples spanning June-November 1986 and April-August 1987.

In areas affected by irrigation drainage, concentrations of the following constituents commonly were found to exceed baseline concentrations or Federal and State criteria for the protection of aquatic life or the propagation of wildlife: In water, arsenic, boron, dissolved solids, sodium, and un-ionized ammonia; in bottom sediments, arsenic, lithium, mercury, molybdenum, and selenium; and in biota, arsenic, boron, chromium, copper, mercury, selenium, and zinc. In some wetlands, selenium and mercury appear to be biomagnified (the accumulation of progressively higher concentrations by successive trophic levels of a food chain), whereas arsenic is bioaccumulated (uptake by biota is several orders of magnitude greater than the concentrations in water or food). Some radioactive substances were substantially higher at the downstream sites compared with upstream background sites, but the significance of this to wildlife is unknown at present. Pesticide contamination in bottom sediments and biota was insignificant.
\end{abstract}

Adverse biological effects observed during this reconnaissance included gradual vegetative changes and species loss, fish die-offs, waterfowl disease epidemics, and persistent and unexplained deaths of migratory birds.

1 U.S. Geological Survey

2 U.S. Fish and Wildlife Service 


\section{INTRODUCTION}

\section{Background}

During the past several years, concern has increased about the quality of irrigation drainage, both surface and subsurface water draining irrigated land, and its potential effects on human health, fish, and wildlife. High concentrations of selenium have been detected in subsurface drainage from irrigated land in the western part of the San Joaquin Valley in California. In 1983, incidences of mortality, birth defects, and reproductive failures in waterfowl were discovered by the U.S. Fish and Wildlife Service at Kesterson National Wildlife Refuge in the western San Joaquin Valley, where irrigation drainage was impounded. In addition to selenium, arsenic, toxic heavy metals, and pesticide residues have been detected in numerous areas in the western United States that receive irrigation drainage.

Because of concems expressed by the U.S. Congress, the Department of the Interior (DOI) began a program in late 1985 to identify the nature and the extent of water-quality problems induced by irrigation drainage that might exist in the westem United States. In October 1985, an interbureau group, the Task Group on Irrigation Drainage, was formed within the DOI. The Task Group subsequently prepared a comprehensive plan for reviewing irrigation-drainage concerns for which the DOI has responsibility.

Initially, the Task Group identified 19 areas in 13 States that warranted reconnaissance-level investigations. These locations relate to three specific areas of DOI responsibilities: (1) irrigation or drainage facilities constructed or managed by the Department of the Interior; (2) National Wildlife Refuges that receive irrigation drainage; and (3) other migratory bird or endangered-species management areas that receive water from Department-funded projects.

Nine of the 19 locations were selected for reconnaissance investigations in 1986. These areas are:

$\begin{array}{ll}\text { Arizona-California: } & \begin{array}{l}\text { Lower Colorado-Gila River Valley area } \\ \text { Salifornia: }\end{array} \\ \text { Salton Sea area } \\ \text { Tulare Lake area } \\ \text { Suntana: } & \begin{array}{l}\text { Sun River Reclamation Project area } \\ \text { Milk River Reclamation Project area }\end{array} \\ \text { Nevada: } & \text { Stillwater Wildlife Management Area } \\ \text { Texas: } & \text { Lower Rio-Grande-Laguana Atascosa National Wildlife Refuge area } \\ \text { Utah: } & \text { Middle Green River Basin area } \\ \text { Wyoming: } & \text { Kendrick Reclamation Project area }\end{array}$

Each reconnaissance investigation was conducted by interbureau field teams composed of a scientist from the U.S. Geological Survey as team leader, with additional Geological Survey staff, and scientists from the U.S. Fish and Wildlife Service and U.S. Bureau of Reclamation representing several different disciplines. The investigations were directed toward determining whether irrigation drainage: (1) has caused or has the potential to cause significant harmful effects on human health, fish, and wildlife, or (2) may reduce the suitability of water for beneficial uses. 


\section{Purpose and Scope}

This report describes the results of the 2-year reconnaissance investigation of irrigation-related contaminants and their effects on wildlife areas within and near the Stillwater Wildlife Management Area, near Fallon, Nev. (plate 1). The report documents the concentrations of organic and inorganic constituents in water, bottom sediments, and biota in the wildlife areas and relates analytical results to various numerical guidelines and background information. The study was done to meet the two objectives stated in the background section.

The study included the collection and analysis of physical, chemical, and biological data from 32 surfacewater sites and 6 shallow ground-water sites in the study area from June 1986 to September 1987.

\section{Acknowledgments}

The authors of this report gratefully acknowledge the following individuals who provided valuable assistance in the field and in the office during the course of this investigation: Roy Leach and Norman A. Saake of the Nevada Department of Wildlife; James J. Cooper and Douglas Zimmerman of the Nevada Division of Environmental Protection; Theodore G. Roefs and Thomas A. Strekal of the U.S. Bureau of Reclamation; Ronald M. Anglin, Timothy Bowman, Eugene E. Duffney, Kenneth L. Merritt, and Patricia D. Rice of the U.S. Fish and Wildlife Service; and Lyman F. McConnell and Willis Hyde of the Truckee-Carson Irrigation District.

\section{STUDY AREA}

\section{Location}

The Stillwater Wildlife Management Area (WMA) is in the Carson Desert hydrographic area (Rush, 1968, plate 1) of the lower Carson River basin, in Churchill County, about 70 miles east of Reno in western Nevada (plate 1 and figure 1). The Carson Desert, known locally as Lahontan Valley, occupies a mostly flat area of about $2,020 \mathrm{mi}^{2}$. It is one of the largest basin-fill valleys in northern Nevada and is the terminus (namely, the Carson Sink) for the Carson River and, during exceptionally high runoff years, the Humboldt River. The Carson Sink is a nearly barren, flat, salt-encrusted playa that occupies an area of about $400 \mathrm{mi}^{2}$ at the northeast boundary of Stillwater WMA. Carson Lake, in the southern part of the Carson Desert, was included in this reconnaissance investigation (plate 1). These historic wetlands (Simpson, 1876, p. 85) are about 25 miles south of Stillwater WMA and are an important wildlife area. Later in the reconnaissance, biological samples were collected from other wildlife areas because of their proximity to Stillwater WMA, and because they also receive irrigation drainage from DOI projects. These areas, also shown in plate 1, include Fernley Wildlife Management area near Fernley, Nev., about 15 miles west of Stillwater WMA, and Humboldt Wildlife Management area, near and including parts of Humboldt Lake, about 30 miles north of Stillwater WMA (inset 2, plate 1). 


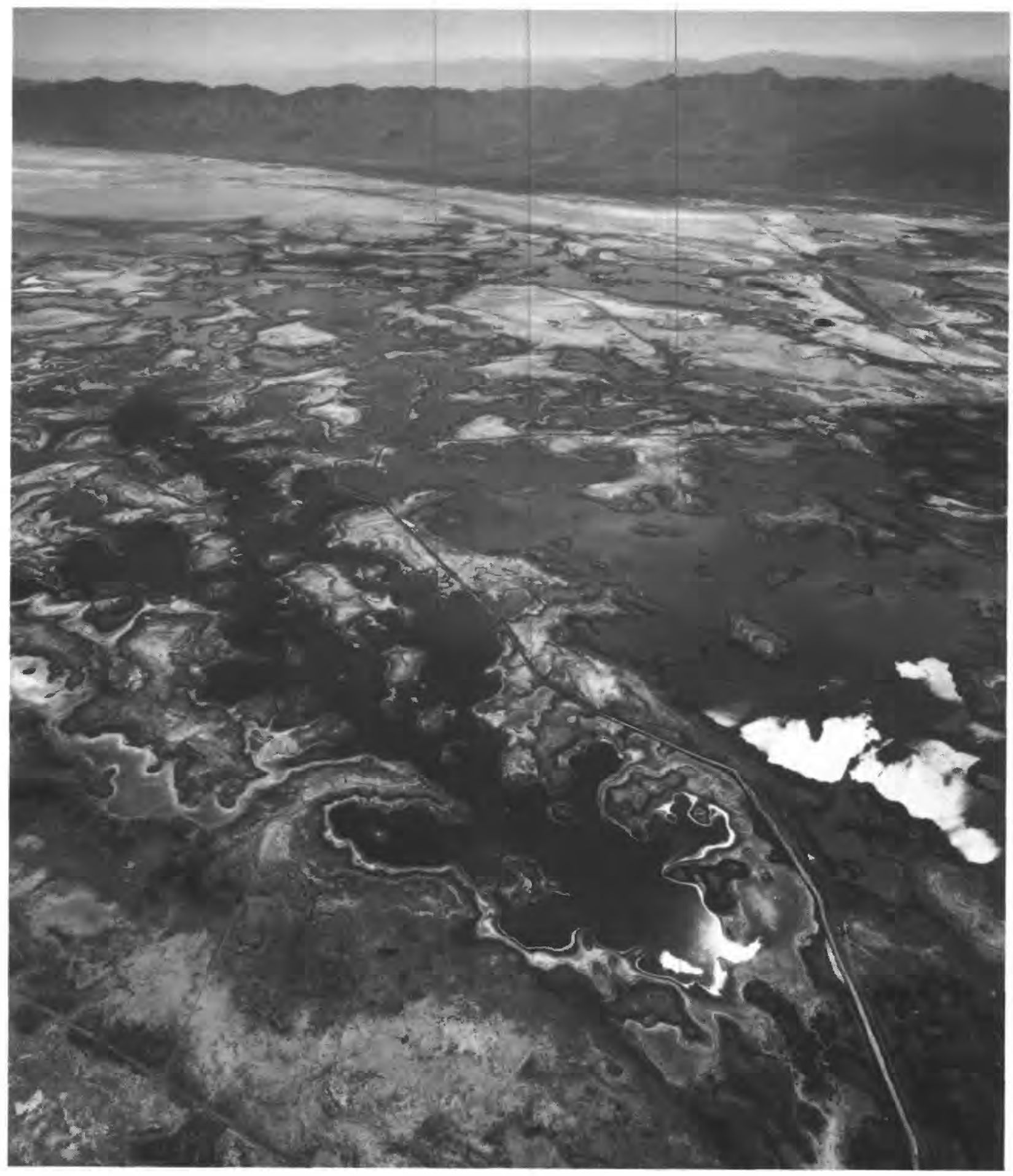

FIGURE 1.-Aerial photo of Stillwater Wildlife Management Area, Nevada, looking toward the northeast. Millens Lake is located in leftcenter foreground, Lead Lake in right foreground, and Stillwater Range in background. U.S. Fish and Wildife Service photograph taken July 1987 from altitude of 10,000 feet above sea level $(6,200$ feet above ground level). 


\section{History}

Archaeological research indicates that humans have occupied the Carson Sink and Stillwater Marsh for at least 5,000 years (Raven and Elston, 1988). The marsh provided the ancient inhabitants with abundant food resources, including seeds and tubers from cattail, alkali bulrush, and hardstem bulrush; fish; waterfowl and their eggs; and marsh mammals.

In 1902, the Bureau of Reclamation began the Newlands [irrigation] Project. This project, completed in 1915 , included a system of dams and canals that reflected the desire to develop an agricultural economy in arid Churchill and Lyon Counties by diversion and storage of natural streamflow. This irrigation project has had a substantial effect on the hydrologic regime and, consequently, on the biologic community in the wetlands. The Newlands Project system is described in more detail in the Hydrologic Setting section of this report.

Historically, before the Newlands Project, the arid region of northwestern Nevada contained about 172,000 acres of shallow freshwater wetlands. Of this amount, 33,000 acres in the Stillwater Marsh, 26,000 acres at the mouth of the Carson River in the Carson Sink (the Fallon National Wildlife Refuge), and about 27,000 acres in Carson Lake were terminal drainage areas for the Carson river and directly impacted by the Newlands Project. Since 1905, however, the quality and quantity of the water reaching the terminal wetlands has declined primarily due to consumptive use of irrigation water by plant crops. A comparison of the estimated wetland loss and associated aquatic vegetation loss in acres is given in tables 1 and 2.

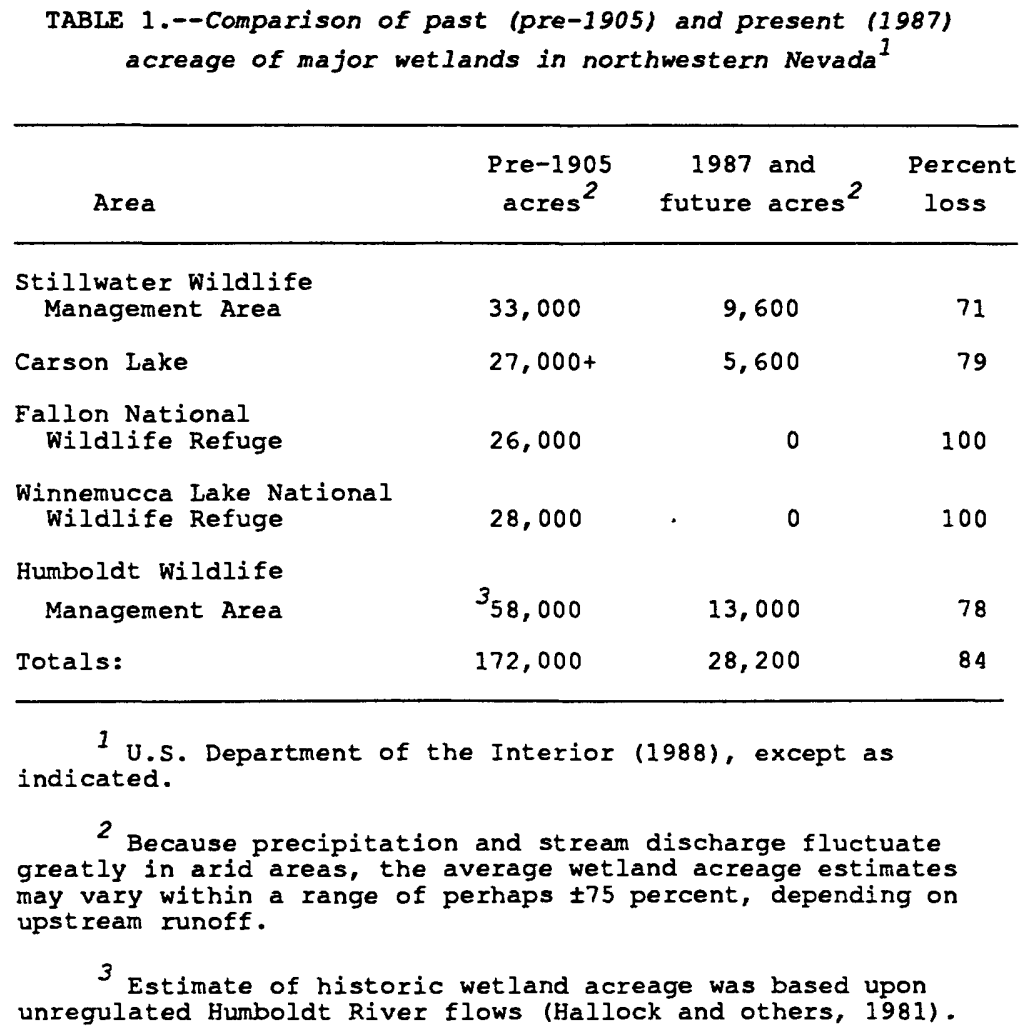




\begin{tabular}{|c|c|c|c|}
\hline Area & $1959^{a}$ & $1970^{a}$ & $1987^{b}$ \\
\hline $\begin{array}{l}\text { Refuge Units: } \\
\text { Stillwater Point Reservoir } \\
\text { Upper Foxtail } \\
\text { Lower Foxtail } \\
\text { Dry lake } \\
\text { Cattail Lake }\end{array}$ & $\begin{array}{r}132 \\
40 \\
220 \\
54 \\
20\end{array}$ & $\begin{array}{r}90 \\
10 \\
181 \\
20 \\
2\end{array}$ & $\begin{array}{r}105 \\
47 \\
115 \\
102 \\
14\end{array}$ \\
\hline Refuge Totals: & 466 & 303 & 383 \\
\hline $\begin{array}{l}\text { Management Area Units: } \\
\text { Goose Lake } \\
\text { Tule Lake } \\
\text { Nutgrass } \\
\text { Swan Lake } \\
\text { Pintail Bay }\end{array}$ & $\begin{array}{r}372 \\
0 \\
2,100 \\
360 \\
45\end{array}$ & $\begin{array}{r}55 \\
1 \\
1,325 \\
3 \\
55\end{array}$ & $\begin{array}{r}72 \\
5 \\
100 \\
60 \\
1\end{array}$ \\
\hline $\begin{array}{l}\text { Management Area Totals: } \\
\text { Overall Totals (rounded): }\end{array}$ & $\begin{array}{l}2,877 \\
3,300\end{array}$ & $\begin{array}{l}1,439 \\
1,700\end{array}$ & $\begin{array}{l}238 \\
600\end{array}$ \\
\hline $\begin{array}{l}a \text { Data from vegetation } \\
\text { U.S. Fish and Wildlife Servi } \\
b \text { Data derived by plani } \\
\text { photos of the area. }\end{array}$ & $\begin{array}{l}\text { urvey re } \\
\text { e. } \\
\text { etering }\end{array}$ & 1987 & the \\
\hline
\end{tabular}

An extensive wetland ecosystem existed in the topographic low areas of the Carson Desert prior to the completion of the Newlands Project in 1915. As described by early pioneers to Russell (1885, p. 44-45), Carson Lake (formerly named South Carson Lake) before 1862 received the entire runoff from the Carson River, but there existed an abandoned channel branching from it and trending northward. Furthermore, during high runoff periods, [South] Carson Lake overflowed through a notch at its northeast end. The water then flowed northward along a small channel (Stillwater Slough) and discharged into the Carson Sink (formerly named North Carson Lake) near the present Stillwater Marsh. During a flood in 1862, the Carson River divided into two streams after entering the Carson Desert. The abandoned river channel was recaptured by the high flow which allowed the river to flow along the two branches--one northward directly to Carson Sink, the other to Carson Lake. In 1892, Carson Lake had a surface area of about 25,600 acres.

The Stillwater WMA was established in 1948 by cooperative agreement with the U.S. Fish and Wildlife Service (USFWS), the Nevada Department of Wildlife, and the Truckee-Carson Irrigation District. The agreement called for approximately 224,000 acres of the Bureau of Reclamation's Newlands Project to be developed and managed as Stillwater WMA, with about 24,000 acres of that area to be reserved as the Stillwater National Wildlife Refuge (NWR) for administration as a nonhunting sanctuary. The Stillwater NWR and WMA are part of the largest remaining marsh in Nevada and were established through the construction of irrigation canals, dams, earth plugs, and water-control structures to provide a nesting, resting, and feeding area for ducks, geese, and other migratory birds (including the endangered bald eagle) that utilize the Pacific Flyway. The importance of these wetlands for migratory birds is described in the Wetland Areas section of this report. 
The U.S. Fish and Wildlife Service is responsible for day-to-day management of Stillwater WMA. Waterrelated public uses of Stillwater WMA include waterfowl hunting (excluding the NWR), fishing, birdwatching, and swimming. About 23,000 acres of waterfowl habitat have been developed and restored at Stillwater WMA/NWR, including 16 main impoundments. The marsh obtains its water from controlled releases from irrigation canals, surface and subsurface agricultural return flows from flood-irrigated lands, and precautionary flood releases (spills) from Lahontan Reservoir. Sufficient water has been available to maintain an average of 14,000 wetland acres in recent years. A limited water right was established in 1987 to secure the available agricultural drainage and precautionary spill water for Stillwater WMA.

\section{Climate}

Most of western Churchill County is classified as mid-latitude desert with cold winters and hot summers. For the period of record, 1941-1970 (Dollarhide, 1975, p. 2-3), the average daily minimum temperature in January was $17.4^{\circ} \mathrm{F}$, and the average daily maximum in July was $92.5^{\circ} \mathrm{F}$. The Sierra Nevada range to the west is an effective orographic barrier to the movement of air moisture. This rain-shadow effect allows little moisture to fall in the Carson Desert. The average annual precipitation from 1941 to 1970 was about 5 inches (Dollarhide, 1975, p. 2-3), whereas the average annual evapotranspiration rate for lakes and wetlands in the area has been reported by Morgan (1982, p. 33-37) to be about 54 inches and by U.S. Bureau of Reclamation (1987b, p. 2-24) to be about 60 inches. The high rate of evapotranspiration compared to the rate of precipitation attests to the aridity of the area.

\section{Geology}

The surficial deposits of the Fallon-Stillwater area are unconsolidated, fine-grained Pleistocene lake and playa deposits, young fan gravels, and prograding delta deposits of Quaternary age (Willden and Speed, 1974). The area is in an intermontane valley that generally is encircled by mountain ranges composed of a variety of igneous, sedimentary, and metamorphic rocks that are described in detail by Willden and Speed. Depth to bedrock in the valley is known to exceed 8,000 feet (Glancy, 1986, p. 36).

\section{Soils}

The soils in the Fallon-Fernley area are described by Strahorn and Van Duyne (1911) and by Dollarhide (1975). In general, the soils range from sands to clays with medium textures predominating; the soil porewater and surface water in the area are typically alkaline. Extensive zones of caliche are not known to exist. In 1986, arsenic, boron, and selenium concentrations were determined in about 135 samples along the profile of 15 shallow bore holes in the 8,000-acre Fallon Indian Reservation (CH2M-Hill, Redding, Calif., written commun., 1986). The dry-weight concentration of these three elements in the sediments ranged from 3.5 to 65 micrograms per gram $(\mu \mathrm{g} / \mathrm{g}$ ) for arsenic, 0.9 to $85 \mu \mathrm{g} / \mathrm{g}$ for hot-water soluble boron, and $<0.2$ to $3.4 \mu \mathrm{g} / \mathrm{g}$ for selenium. The maximum dry weight concentrations of arsenic and selenium in the sediments exceed the geochemical baseline of 1.2 to $22 \mu \mathrm{g} / \mathrm{g}$ and 0.039 to $1.4 \mu \mathrm{g} / \mathrm{g}$ for arsenic and selenium, respectively, for soils from the westem United States (R.C. Severson, U.S. Geological Survey, written commun., 1987). The selenium and arsenic contents of the unconsolidated rocks for most of the Carson Desert are unknown. 
In 1987, the U.S. Geological Survey did a survey of soil geochemistry of the Carson River basin. Surficial soil samples and subsurface sediment/water samples were collected and analyzed to determine the concentration of a variety of trace elements. Soils in the Carson Desert, which include Stillwater WMA and Carson Lake wetlands (260 samples), and in Femley WMA (26 samples), were sampled as part of the geochemical survey. These data will be evaluated using a Geographic Information System to determine if a discemible relation exists between solid-phase geochemistry and soil-water chemistry in order to provide a regional description of ground-water quality as part of the Carson River basin National Water-Quality Assessment study (Welch and Plume, 1987).

\section{Water Use}

Uses of surface water in the Carson Desert and vicinity include: (1) irrigated agriculture; (2) maintenance of waterfowl and fishery habitats; (3) recreational use by the public such as hunting, fishing, birdwatching, swimming, and camping; and (4) to a limited extent, municipal and light-industrial purposes.

Alfalfa is the principal irrigated crop, in terms of acreage and revenue, in the Fallon agricultural area (figure 2). About 70 percent of the total irrigated acreage (62,000 acres in 1985) and 85 percent of the total crop revenue $(\$ 17,650,000$ in 1985) involves alfalfa production (U.S. Bureau of Reclamation, 1986, p. VI-3942). The remaining 30 percent of irrigated acreage consists mostly of pasture on which beef and dairy cattle, and sheep feed. Other crops include barley, wheat, corn, and vegetables. Alfalfa also is the principal irrigated crop in the Fernley and Lovelock agricultural areas.

\section{HYDROLOGIC SETTING}

\section{Fallon Agricultural Area}

The principal source of irrigation water for the Fallon-Stillwater area is Lahontan Reservoir, which is fed directly by the Carson River and by the Truckee River by way of the Truckee Canal (plate 1). The quantity of water released to the study area (the Carson Desert) from Lahontan Reservoir averages about 416,300 acre-ft/yr or 1,140 acre-ft/d (U.S. Department of the Interior, 1988, p. 6, appendix E). This estimate is based on U.S. Geological Survey streamflow data from 1967 through 1986. Near-average amounts of precipitation (figure 3) were recorded at Fallon during water years 1985 (4.43 in.), 1986 (4.18 in.), and 1987 (4.18 in.). The larger discharge from Lahontan Reservoir in 1986 reflects precautionary flood release because of above-normal precipitation in the headwaters of the two rivers.

The main source of water for Fernley WMA is the Truckee Canal. Water reaches Fernley WMA principally in three ways: (1) Agricultural return flows (from farm deliveries of about 26,000 acre-ft/yr diverted from the Truckee Canal; Willis Hyde, Truckee Carson Irrigation District, oral commun., 1988); (2) operational losses associated with farm deliveries; and (3) substantial seepage from the Truckee Canal (about 18,000 acre-ft/yr, according to Van Denburgh and Arteaga, 1985, p. 6). 


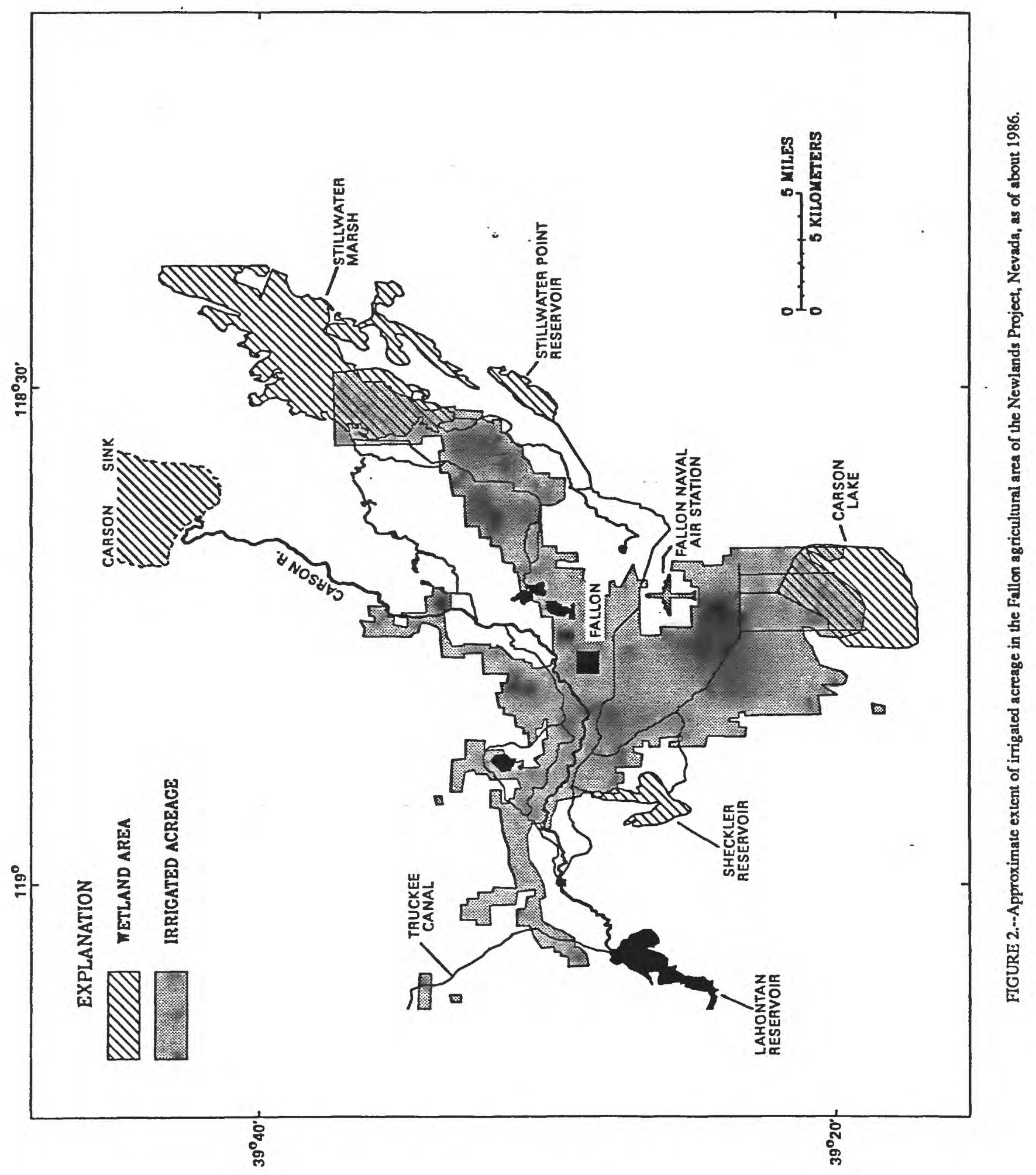




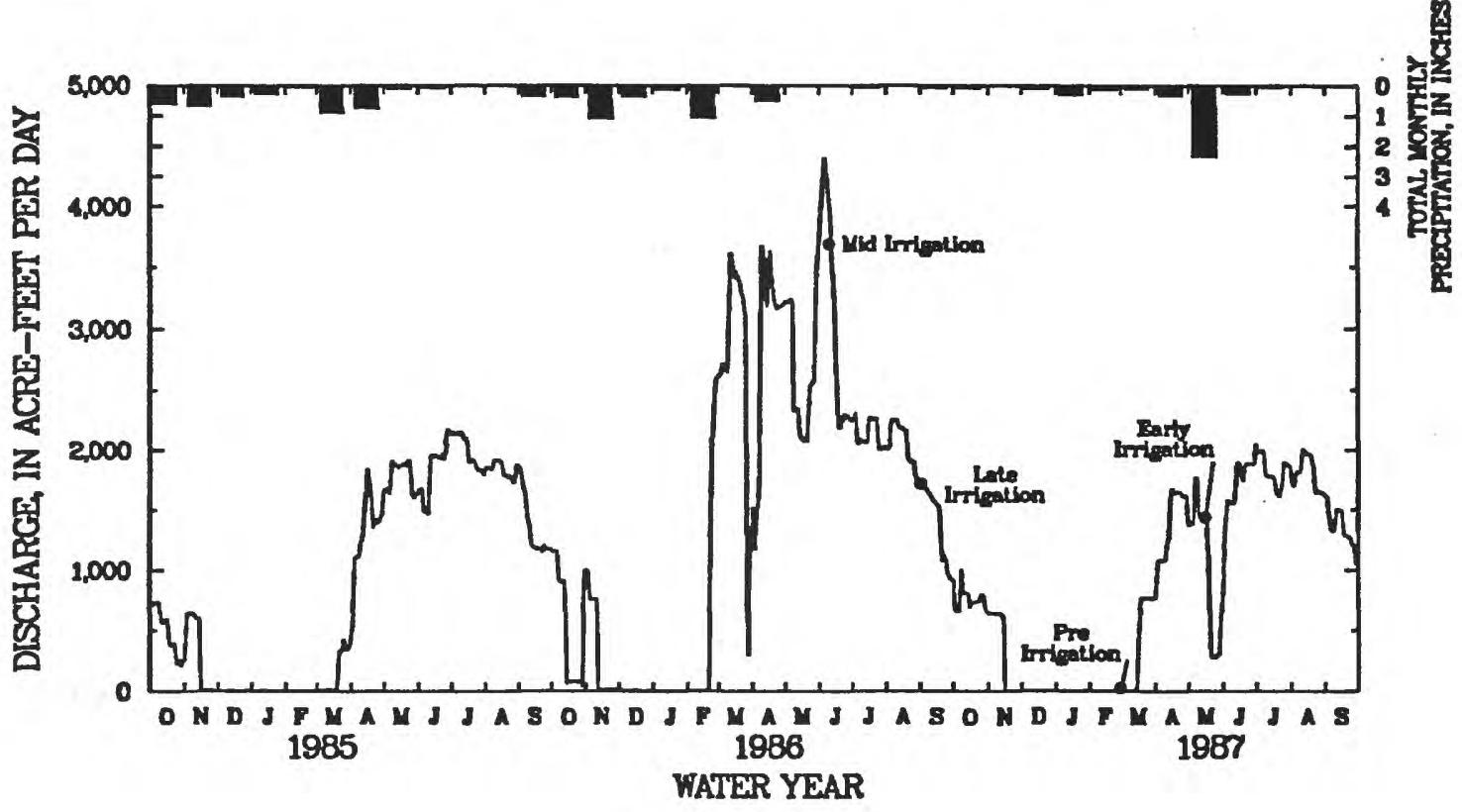

FIGURE 3.--Daily discharge from Lahontan Reservoir, as measured at the Carson River below Lahontan Reservoir gage, and total monthly precipitation at the Fallon Experimental Station in Fallon National Climatic Center (1985-88), water years 1985-87. Circles indicate sampling periods for water-quality variables. See text for explanation.

The main source of water for Humboldt WMA is the Humboldt River from Rye Patch Reservoir (with an average annual diversion of 125,500 acre-ft, but a farm delivery of about 93,400 acre-ft; Pershing County Water Conservation Unit, written commun., 1987). (Rye Patch Reservoir, 40 miles north of Humboldt WMA, is outside the area shown on plate 1.) The Humboldt WMA receives agricultural drainage from irrigated lands (about 36,000 acres) serviced by the Bureau of Reclamation Humboldt Project and operated by the Pershing County Water Conservation District. Inflow from agricultural drainage and from operational and precautionary spills reach the Humboldt WMA to maintain an average of about 12,800 acres of wetlands.

Agricultural return flows eventually empty into the lower elevation areas, including Stillwater WMA, Carson Lake, and Fernley and Humboldt WMA's. Because of local interest and relative importance as wetland habitat, the remainder of this report will focus on those areas impacted by the Newlands Project: Stillwater WMA, Fernley WMA, and Carson Lake.

To illustrate the complexity of the irrigation network in the study area, a schematic diagram of the flow systems that compose the Newlands Project is shown in figure 4. This schematic, by design, crudely oversimplifies the true flow system of nearly 70 miles of main canals, 300 miles of laterals, and 350 miles of open return drains (U.S. Bureau of Reclamation, 1986, p. I-4). The total area implied in figure 4 represents about $2,100 \mathrm{mi}^{2}$, of which about 66,300 acres were flood-irrigated for agricultural purposes in 1987 . This total cropland acreage includes 4,300 acres in the Fernley area (U.S. Department of the Interior, 1988, p. 30). 


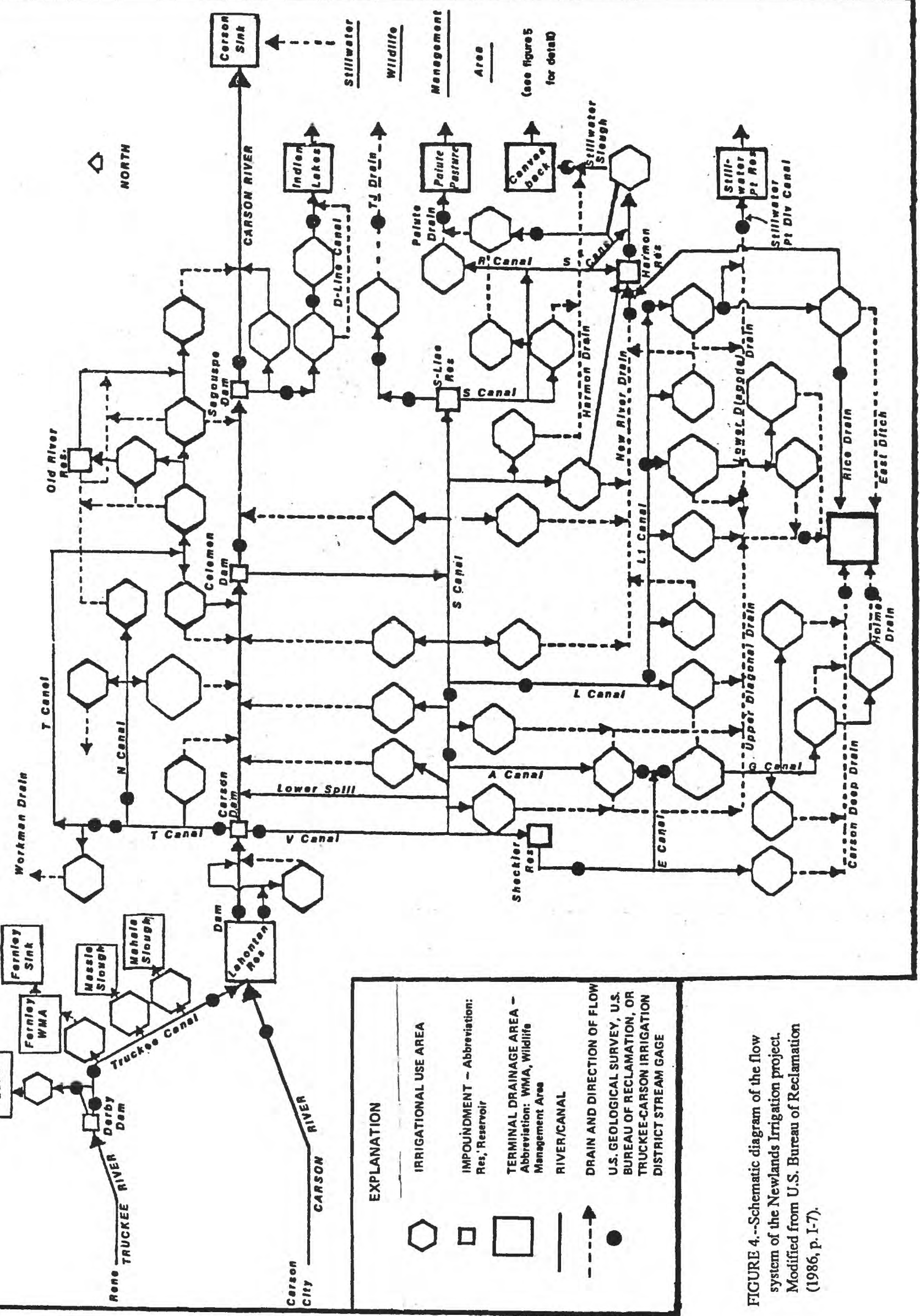


The routing of agricultural drainage water for wildlife resources in the area's wetlands has its own degree of complexity that defies simple description. A generalized flow map for Stillwater National Wildlife Refuge and Wildlife Management Area is shown in figure 5.

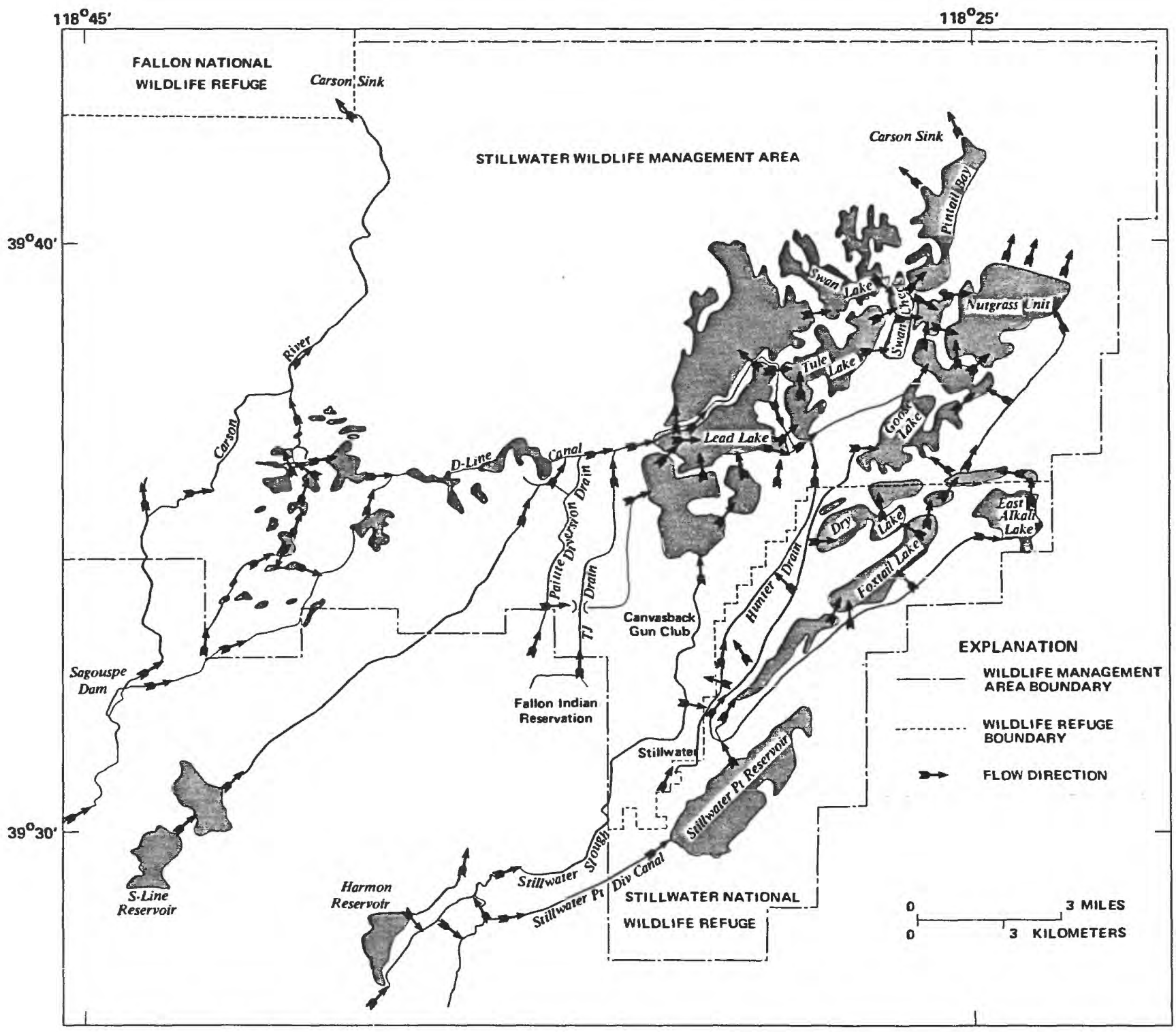

FIGURE 5.-Flow patuerns for the Stillwater National Wildlife Refuge and Wildlife Management Area (WMA). Modified from U.S. Department of the Interior (1988, Appendix E). 
Water released for agricultural use or spilled (precautionary, as for floodwater storage) from Lahontan Reservoir is routed through the Fallon agricultural area. The released water flows about a mile downstream and is diverted at the Carson River Diversion Dam (constructed in 1905) to the northeast by way of the "T" canal and southeast by way of the "V" canal (plate 1 and figure 4). From these two canals, secondary canals branch off to deliver water to an extensive system of laterals that distribute water through numerous farm headgates for flood irrigation of fields.

Because streamflow to the Stillwater and Carson Lake wetlands is inadequately monitored, the quantity of irrigation return flows that reach these wildlife areas is imprecisely known. During nonspill years, the quantity of surface water that flows to the wetlands has been estimated to be about 25 percent of the Lahontan Reservoir releases minus about 35,000 acre-ft of loss due to evapotranspiration and seepage to the shallow alluvial aquifer (U.S. Bureau of Reclamation, 1987b, p. 2-24). As a result of the drought in 1976 and 1977, the annual quantity of irrigation return flow to Stillwater WMA was about 22,000 acre-ft in 1977 and about 27,000 acre-ft in 1978, ' compared to an average of about 75,000 acre-ft for years $1967-81$, exclusive of streamflow extremes in 1969, 1970, 1977, 1978, and 1980. During operational spills, the water is routed down the "T" and "V" canals, and perhaps down the Carson River channel, depending on the magnitude of the streamflow. Such infrequent spills may bring abundant good-quality water to the Indian Lakes (about 11 miles northeast of Fallon; plate 1) and Stillwater Point Reservoir--for subsequent distribution to the Stillwater Marsh--and to Carson Lake.

Outflows from Stillwater WMA, if any, discharge to the Carson Sink, which during abnormally high flow years (for example 1982-84) may receive overflows from the Humboldt River. The water in these closed basins ultimately leaves by evapotranspiration; thus, the dissolved constituents in the water tend to become concentrated over time. Carson Sink gained national attention in early 1987 when an estimated 7 million fish (tui chub) and about 1,500 waterfowl were reported dead or dying in the water-filled playa that normally is dry. Wildlife biologists speculate that the fish were killed as they reached their maximum salt-tolerance levels as the water level receded, and have evidence that the birds were killed by avian cholera, a bacterial infection (Rowe and Hoffman, 1989).

As a consequence of irrigating this desert land, the shallow ground water in the Fallon agricultural area has risen about 60 feet. The rise in the water table, attributed to seepage from the canals, laterals, and irrigated fields, occurred from about 1906 to 1930 (Rush, 1972). Drains were dug to provide adequate drainage of the soil profile to support the permanent irrigated agriculture. This near-surface lens of irrigation-induced freshwater in the alluvial aquifer is used as a domestic drinking-water supply for much of rural Fallon. The neamess of this aquifer to the land surface increases susceptibility to contamination by man's activities, and to evapotranspirative concentration of salts. The City of Fallon and the Fallon Naval Air Station obtain their drinking water from a localized deeper basalt-aquifer system as opposed to the shallow alluvial aquifer.

1 Because upstream reservoir storage usually exceeds the annual irrigation usage, the effect of a regional drought on the Fallon agricultural area generally is not manifest until 1 to 2 years after a drought begins. 
Glancy $(1986$, p. 6) categorized the Fallon area valley-fill aquifers into four general hydrologic systems: "(1) a shallow alluvial aquifer system extending from near land surface to a depth of about $50 \mathrm{ft}$; (2) an intermediate-depth alluvial aquifer system underlying the shallow system and extending from about $50 \mathrm{ft}$ to depths that may be as great as 500 to $1,000 \mathrm{ft}$ in some areas; (3) a basalt-aquifer system that is as shallow as $200 \mathrm{ft}$ (except at Rattlesnake Hill where it is surficially exposed) but may be as deep as 1,000 ft in places; and (4) a deep alluvial aquifer system underlying the intermediate alluvial and basalt systems, generally below depths of 500 to $1,000 \mathrm{ft}$."

Water in the shallow alluvial aquifer in the Fallon agricultural area has an eastward component of flow: Much of it flows northeast to Carson Sink; the remainder flows southeast to Carson Lake.

In general, the shallow water table (less than 30 feet) rises and falls in response to flood irrigation. During the irrigation season (mid-March to mid-November), the water level rises and usually reaches a maximum elevation about September. The water level then gradually declines during the non-irrigation season and reaches a minimum level about April (Sinclair and Loeltz, 1963, p. AA10-12).

\section{Wetland Areas}

The combined wetlands evaluated during this study have averaged 55,500 acres. Of this amount, 43,600 acres is associated with the Newlands Project (U.S. Department of the Interior, 1988, Appendix E, p. 17), and 12,846 acres with the Humboldt Project (Hallock and others, 1981, p. 25). As mentioned previously, a combination of Carson and Truckee River waters maintain the Newlands Project and associated wetlands (plate 1). The Humboldt Project and adjacent wetlands are maintained almost entirely by the Humboldt River. Annual precipitation may account for only 10 percent of wetland water supplies.

Wetlands investigated during this study are terminal; that is, water that flows to them remains there until it is eventually lost to evapotranspiration. Most of the cumulative dissolved-solids load carried by the water to the wetlands remain. The major wetland management areas are designed to minimize the impact of dissolvedsolids and potential-toxicant accumulation. Wildlife management areas are typically designed as a series of ponds, sequentially connected. The first (initial) unit, or pond, receives the freshest water where some dissolved solids are concentrated by evapotranspiration. This water is eventually discharged into a secondary unit, or units, where evapotranspiration further concentrates dissolved solids. Normally, the third, or tertiary, unit is at or near the point where the water, because of its high dissolved-solids content, will no longer support vascular aquatic vegetation, a source of food for waterfowl. The tertiary pond, therefore, is considered unsuitable for wildlife management.

Prior to agricultural development in the region, most of the water of Carson, Truckee, and Humboldt Rivers flowed unregulated to the wetlands. In some instances, wetlands were naturally arranged to form initial, secondary, and even tertiary, units. There were large acreages of wetlands (table 1), and based on historical observations (Simpson, 1876, p. 85), water quality in terms of dissolved solids, was good throughout most of the wetlands. 
From Stillwater WMA, excavated remains of clams, mink, and river otter reflect a freshwater marsh of high quality (U.S. Department of the Interior, 1988, Appendix E, p. 23). Thompson and Merritt (1988, p. 40) summarized many of the outstanding facts concerning the value of the study area to migratory birds and other wildlife:

"Westem Nevada wetlands have long been recognized as an important area for migratory birds in the Pacific flyway. Lahontan Valley supports, on an annual basis, approximately 75 percent of the state's duck, 50 percent of the state's Canada goose, and 65 percent of the state's tundra swan populations. One-third to one-half of the Pacific flyway's population of canvasbacks stop to use the Stillwater and Carson Lake marshes in the fall. The valley's wetlands have produced around 7,000 redhead ducklings annually, while Carson Lake serves as a major concentration area for snow geese, supporting over 90 percent of the state's population. Lahontan Valley also supports the largest part of the muskrat resource found in the state, with approximately 30,000 harvested in 1983-84. In addition, these marshes provide important nesting and feeding habitat for many nongame wildlife species."

Within Stillwater WMA during recent years:

"...wildlife populations are impressive, with peaks of 12,000 tundra swans, 25,000 canvasbacks, 20,000 redheads, 70 bald eagles, 30,000 American white pelicans, and with waterfowl peaks of over 250,000 . The numbers of shorebirds and marshbirds are phenomenal with thousands of black-necked stilts, American avocets, long-billed dowitchers, white-faced ibis, and egrets. Based on the numbers of shorebirds found in both the Carson Lake and Stillwater Wildlife Management Area, the area has been classified as a "Hemispheric Reserve" within the Western Hemisphere Shorebird Reserve Network by an international panel of experts."

Some wetlands were formed, in part, by the Newlands Project. These areas include Fernley WMA, Massie and Mahala Sloughs, four large regulatory reservoirs, and a series of small unnamed wetlands throughout the irrigation project.

A decision by the Secretary of the Interior in 1988 regarding the reduction of released water from Lahontan Reservoir is anticipated to further diminish wetlands. The estimated average wetland acreage (43,600 acres from 1967-86) in the Lahontan Valley may be reduced to an average of about 25,400 acres (U.S. Department of the Interior, 1988, Appendix E, p. 17). Most of this loss will occur at Stillwater WMA and Carson Lake. In these areas the potential toxicant loads transported by drainwater probably will remain nearly constant, but the concentrations probably will increase about twofold (U.S. Department of the Interior, 1988, Appendix E, p. 41-60). 


\section{PREVIOUS STUDIES}

Prior to this investigation, few studies had documented the occurrence and distribution of potentially toxic trace constituents in surface water, sediment, or biota in Stillwater WMA. In 1971-72, a limited number of samples were collected for the determination of total recoverable mercury in surface water (concentrations ranged from 0.4 to $4.3 \mu \mathrm{g} / \mathrm{L}$ ) and in sediment from the Carson River, canal, and drain bottoms (concentrations ranged from 0.05 to $4.0 \mu \mathrm{g} / \mathrm{g}$, dry weight) downstream from Lahontan Reservoir (Van Denburgh, 1973). In a follow-up study almost a decade later, Cooper and others (1985, p. 10-54) made a detailed examination of mercury in surface water $(<0.5$ to $5.3 \mu \mathrm{g} / \mathrm{L})$, bottom sediment $(<0.25$ to $14.7 \mu \mathrm{g} / \mathrm{g}$, dry weight), and in fish muscle ( 0.16 to $2.85 \mu \mathrm{g} / \mathrm{g}$, wet weight) at six sites below Lahontan Reservoir. Neither of the above two studies, however, collected samples from Stillwater WMA or Carson Lake. In 1986, the Nevada Department of Environmental Protection continued their sampling program for mercury in the lower Carson River basin to include additional sites in Stillwater WMA (J.J. Cooper, Nevada Department of Environmental Protection, written commun., 1986).

During 1959-62, and coincident with the second most severe drought recorded in Nevada, the U.S. Department of Agriculture collected water samples from canals and drains in the Fallon agricultural area for analysis of major cations and selected anions. The water samples were collected from 16 sites at a nearmonthly frequency from August 1959 to May 1961, and occasionally thereafter until April 1962 (Rollins, 1965). (It should be noted that the concentrations of "total salts" [ranging from 320 to $45,500 \mathrm{mg} / \mathrm{L}$ ] reported by Rollins [1965, p. 24-43] are estimates based on specific-conductance measurements.) Since 1969, Federal and State Wildlife biologists have monitored the conductivity of important drains and wetlands in Stillwater WMA and the Carson Lake area using specific-conductance meters and probes. The long-term conductance data and similar data given by Rollins (1965) suggest that the dissolved-solids content of irrigation drain water to the wetlands has been about 600 milligrams per liter (mg/L), on the average, from 1967 to 1986.

From October 1985 through September 1986, the U.S. Bureau of Reclamation conducted a waterquality sampling program within the Fallon Indian Reservation. Water samples were collected on a nearmonthly frequency at two canal and eight drain sites, and six shallow ( $<30$ feet) ground-water wells. The water samples were analyzed for several trace elements, major chemical constituents, and pesticides. Concentrations of selected dissolved trace elements in samples of drain water ranged from $<1$ to $560 \mu \mathrm{g} / \mathrm{L}$ arsenic; $<1$ to $26 \mu \mathrm{g} / \mathrm{L}$ selenium; and $<0.1$ to $0.3 \mu \mathrm{g} / \mathrm{L}$ mercury (U.S. Bureau of Reclamation, 1987a, p. B1B24).

Brown and others (1986) provide a comprehensive overview of the hydrologic characteristics of the Carson River and Truckee River drainage systems. Stabler (1904), Glancy and Katzer (1975), Olmsted and others (1975), Morgan (1982), Glancy (1986), and Lico and others (1987) each discussed--to varying degrees of detail particular to each study--the quality of ground water in the Carson Desert.

In 1985, white-faced ibis (Plegadis chihi) eggs from Carson Lake were found to contain elevated concentrations of selenium and mercury residues when compared to other bird species from Kesterson National Wildlife Refuge, Calif. The maximum mean concentrations were $5.7 \mu \mathrm{g} / \mathrm{g}$ dry weight for selenium and $0.82 \mu \mathrm{g} / \mathrm{g}$ dry weight for mercury (Henny, 1987). 


\section{SAMPLE COLLECTION AND ANALYSIS}

The data-collection program for this reconnaissance was designed to collect samples at times that corresponded to significant irrigation practices in the study area and at times that related to significant biological productivity and life-cycle patterns of resident and migratory species. Thus, four time periods were selected for the collection of samples:

March--pre-irrigation season; maximum dissolved constituents in irrigation return flows and time of probable maximum impacts due to previous irrigation season.

Mid-May--early irrigation season; early-nesting birds.

June-July--mid-irrigation season; late-nesting birds.

August-September--late irrigation season; maximum water temperatures; highest annual metabolic activity of aquatic organisms; botulism period.

The principal data-collection effort began in June 1986 during the mid-irrigation season. Consequently, the March (pre-irrigation) and mid-May (early irrigation) samples were collected in 1987. In addition, prereconnaissance water samples were collected from three drain sites in February 1986 (of which two were retained through the reconnaissance study), and water samples were collected from five sites in July 1987 that were funded by another Federal program. These five 1987 sites are identified as supplemental sites in table 3 and in the data tables at the end of this report. Onsite measurements included water discharge, water and air temperature, dissolved oxygen, $\mathrm{pH}$, specific conductance, and alkalinity. For ground water, redox potential (Eh) and sulfide concentration were also measured.

Samples of ground water (subsurface flow) were collected from six shallow wells (less than 30 feet deep) immediately upgradient of Stillwater WMA and Carson Lake in August 1986.

Bottom-sediment samples were collected only once at 17 surface-water sites in September 1986 or March 1987 , depending on ambient low-flow conditions.

The collection of biological samples proved to be a more difficult task than was anticipated during the planning stage. The success of the collection effort was largely dependent on the availability and size of target species. Most of the nearly 730 biological samples were collected from June 1986 through November 1986 and from April 1987 through August 1987. All basic data are given in tables 11-19 at the back of the report. 
TABLE 3.--Surface-water and ground-water sampling sites in and near stillwater wildlife Management Area and Carson Lake, Nevada, 1986-87, and rationale for site selection

\begin{tabular}{cc}
$\begin{array}{c}\text { Site } \\
\text { number } \\
(\mathrm{pl} \text { (1) }\end{array}$ & U.S. Geological \\
Survey ite & Sitentification name \\
\hline
\end{tabular}

\section{BACKGROUND SITES}

01 WILLIAMS SLOUGH nr Genoa, NV ${ }^{1}$
02 WASHOE LAKE nr Carson City, NV

03 CARSON RIVER blW LAHONTAN RES nI Fallon, NV ${ }^{1} \quad 10312150$

04 SHECKLER RESERVOIR at OUTLET nr Fallon, NV ${ }^{1} \quad 10312165$

\section{CARSON IAKE SITES}

05

06

07

08

CARSON LAKE, BIG WATER UNIT, nr Fallon, $\mathrm{NV}^{I}$

\section{STIIIWATER WMA SITES}

09

CARSON LAKE DRAIN abv CARSON LAKE nI Fallon, NV ${ }^{1} 10312180$ CARSON LAKE, SPRIG POND UNIT, nI Fallon, NV ${ }^{1} \quad 391951118445001$

CARSON LAKE, ISLAND UNIT, nr Fallon, NV

392108118413501

391743118424301

PAIUTE DRAIN at WILDLIFE ENT nr Stillwater, NV ${ }^{1} 10312270$ TJ DRAIN at WILDLIFE ENTRANCE nr Stillwater, NV 10312274

PAIUTE DRAIN blw TJ DRAIN nr stillwater, NV ${ }^{1}$ LEAD LAKE at MILIENS LANDING nr stillwater, $\mathrm{NV}^{1}$

10312277 SOUTH IEAD LAKE nr Stillwater, $\mathrm{NV}^{1}$

393654118315501

393643118310501

LOWER DIAGONAL DRAIN at HWY $50 \mathrm{nr}$ Fallon, NV

10312190

STILLWATER PT. DIV. DRAIN nr stillwater, $\mathrm{NV}^{1}$ STILLWATER POINT RES. SOUTH nr Stillwater, NV ${ }^{l}$

10312215

392950118315201

STILLWATER POINT RES. NORTH nr Stillwater, $\mathrm{NV}^{1}$

393154118285401

STILLWATER SLOUGH at Stillwater, $\mathrm{NV}^{1}$

10312218

STILLWATER SLOUGH CUTOFF DRAIN nr Stillwater, NV 10312220

\section{SUPPLEMENTAL STILLWATER WMA SITES}

HUNTER DRAIN at DIVISION RD. nr Stillwater, NV

1031221920

IEAD IK CANAL at HUNTER RD CROSSING nr Stillwater 1031221930

CATTAII LAKE at OUTLET nr Stillwater, NV

SWAN CHECK at OUTLET nr Stillwater, NV

393601118255401

PINTAIL BAY nI CENTER nr Stillwater, NV

393907118263101

394115118253201

\section{GROUND-WATER SITES ${ }^{2}$}

101 N2O E31 19CBD 2 DH-102B

101 N2O E31 33BDA 1 SW-AH-I

101 N19 E30 33ADD 1 HL-AH-5A

101 N19 E30 34BAA 1 HL-AH-6A

101 N19 $E 31$ 19DAA 1 SW-AH-2

101 N17 $E 29$ 17ADD 2 CL-AH-2B
393459118330602 393327118304101 392758118365102 392828118361201

392941118321401

392018118444302
Background site for Carson River system Background site for Truckee River system (albeit potential for elevated mercury concentration)

Background site, initial input of irrigation to Newlands Project area, historical $Q W$ data

Background for reservoir quality data in Newlands Project area as upgradient from applied irrigation water

Main input to Carson Iake

Terminal drainage, wildlife concern

Terminal drainage, wildlife concern, historical deposition area for former channels of the Carson River

Terminal drainage, wildlife concern high salinity

Input to Lead Lake

Input to Paiute Drain, high trace element concentrations at upstream locations

Main input to Lead Lake

Deposition area from Paiute Drain, wildlife concern

Secondary impoundment, wildlife concern, historical recreational use area

Supplemental site on initial survey

Main input to stillwater WMA

Primary impoundment for Stillwater WMA, deposition area, Stillwater Point Diversion Drain

Primary impoundment for stillwater WMA, wildlife concern

Main input to Canvasback area, historical stream channel

Input to Canvasback area (discontinued 9/86)

Input to Lead Lake canal, USFWS concern Main output of Lead Lake, USFWS concern Secondary impoundment, USFWS concern Secondary impoundment, USFWS concern Terminal impoundment, USFWS concern, and high salinity

TJ Drain area

Hunter Drain area

Harmon Reservoir area

Lower Diagonal Drain area

Stillwater Pt Diversion Drain area

Carson Lake wetlands area

1 Sites where samples of bottom sediment were collected for trace-element analysis.

2 Ground-water sites are designated by local (Nevada) USGS identification. 


\section{Water Samples}

The measurement of onsite variables and the collection of water samples were done according to the procedures of the U.S. Geological Survey (1977, chapters 1 and 5). The pH meter and electrode system was calibrated using two buffers (a pH 7 and 4 or 10 buffer) that bracketed the expected range of $\mathrm{pH}$. Beginning in May 1987, a pH electrode employing a double-junction design was used for all subsequent $\mathrm{pH}$ measurements. The double-junction feature minimizes interferences caused by high concentrations of sulfides and dissolved solids (particularly sodium) in sample water. Alkalinity was determined immediately after sample collection by incremental titration with $0.1600 \mathrm{~N}$ sulfuric acid (Barnes, 1964). Laboratory analysis of water samples emphasized those components shown in table 4. Additional analysis included major dissolved constituents (calcium, magnesium, sodium, potassium, bicarbonate and carbonate, sulfate, fluoride, and silica); dissolved solids residue on evaporation at $180^{\circ} \mathrm{C}$; nutrients (phosphorus, ammonia, nitrite and nitrate); and organic carbon.

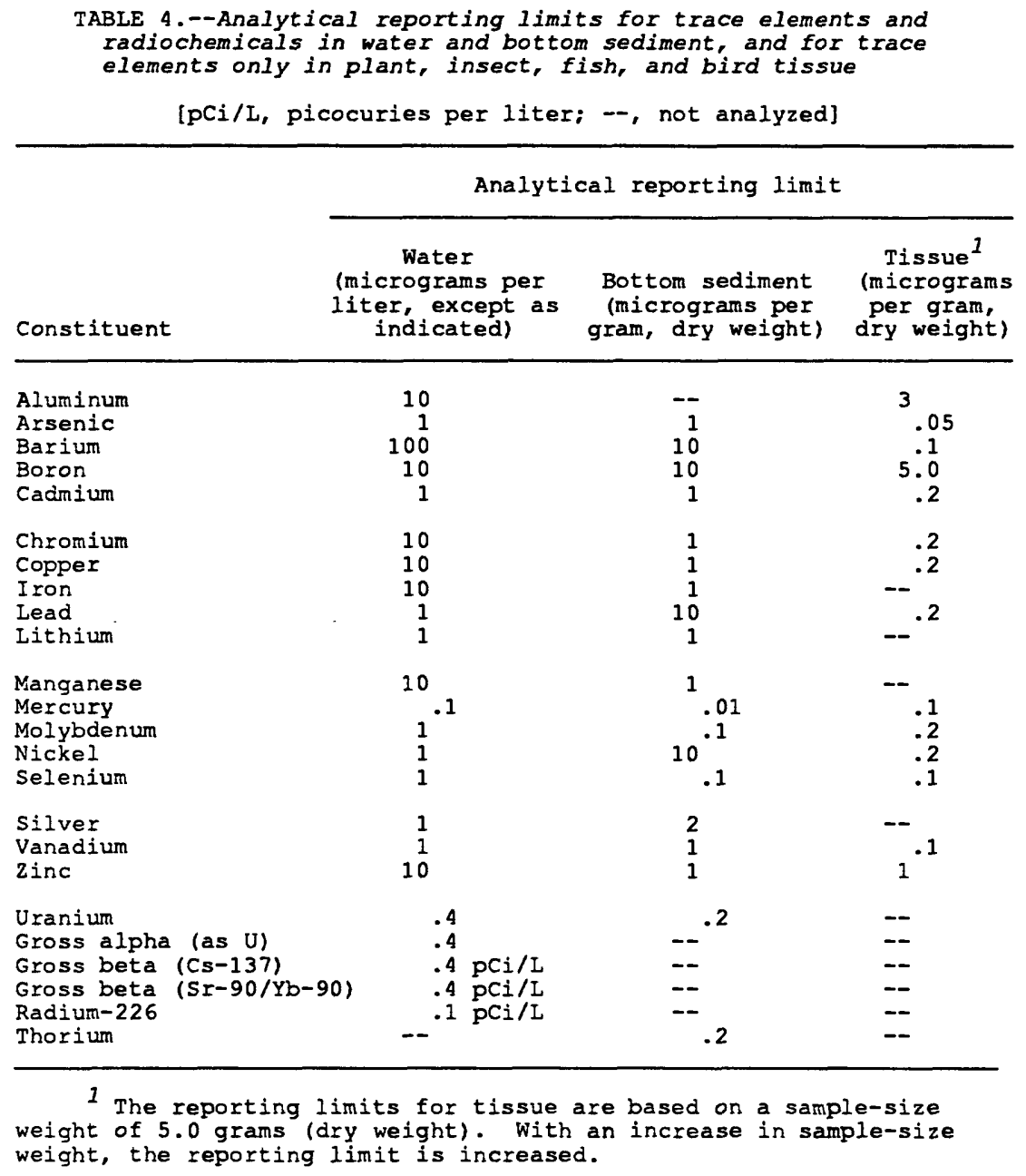


All the un-ionized ammonia values reported in the data tables at the back of this report are based on the calculations of Thurston and others (1974) at zero salinity, or zero dissolved-solids concentration. As an additional check, those un-ionized ammonia values that exceeded the $0.0164-\mathrm{mg} / \mathrm{L}$ criterion for the protection of aquatic life were compared with the fraction of un-ionized ammonia given by Skarheim (1973) as a function of dissolved-solids concentration as well as $\mathrm{pH}$ and temperature. The difference between the two methods ( $0 \mathrm{mg} / \mathrm{L}$ dissolved solids compared to ambient $2,000 \mathrm{mg} / \mathrm{L}$ dissolved solids) amounted to a maximum decrease in the concentration of un-ionized ammonia of only $0.006 \mathrm{mg} / \mathrm{L}$.

The redox potential, or Eh, of ground water was determined using the method of Thorstenson and Fisher (1979), which uses a platinum-calomel combination electrode. Sulfide was determined by specificion electrode using the method of Lico and others (1982).

Analyses of surface and ground water were made by the U.S. Geological Survey water-quality laboratory in Denver, Colo., using the methods described by Fishman and Friedman (1985) and Wershaw and others (1987). The types of trace chemical determinations in water and their respective reporting limits are given in table 4. The concentrations of major dissolved constituents are listed in the tables at the back of this report.

In addition to the normally stringent quality-assurance practices of the U.S. Geological Survey for chemical analysis of water (Friedman and Erdmann, 1982), field blanks were processed for trace-element analysis during three surface-water sampling rounds. Such data can provide valuable information on the potential for inadvertent contamination that may result from the various sample-handling activities in the field and in the laboratory.

In this reconnaissance, a field blank was a volume of deionized water that was treated as a sample in all aspects, including exposure to water-sample containers (collecting bottle and churn splitter), filtration apparatus, chemical preservatives, holding times, and laboratory processing. The field-blank data are listed in the following table and show that nearly all determinations were at or below analytical reporting limits. Exceptions to this statement were boron, at twice the reporting limit of $10 \mu \mathrm{g} / \mathrm{L}$ in the May 1987 blank, and zinc at four times the reporting limit of $10 \mu \mathrm{g} / \mathrm{L}$, also in the May 1987 blank.

Overall, the field-blank data indicated that inadvertent gross trace-element contamination of water samples was either nonexistent or insignificant from a toxicity standpoint. The high concentration of zinc in the May 1987 blank is unexplained. A December 1987 trace-element analysis of source deionized water showed a zinc concentration of only $4 \mu \mathrm{g} / \mathrm{L}$.

The methods for computing estimates of summary statistics of trace-element and nutrient data of water that contain "less-than" values are those of Gilliom and Helsel (1984) and Helsel and Gilliom (1985). 
Dissolved trace-element and radiochemical concentrations in

field blanks for quality-assurance purposes

[--, no data available; <, less than]

\begin{tabular}{|c|c|c|c|c|c|c|c|c|c|c|c|}
\hline DATE & $\begin{array}{c}\text { ARSENIC, } \\
\text { DIS- } \\
\text { SOLVED } \\
\text { (UG/I } \\
\text { AS AS) }\end{array}$ & $\begin{array}{l}\text { BARIUM, } \\
\text { DIS- } \\
\text { SOLVED } \\
\text { (UG/L } \\
\text { AS BA) }\end{array}$ & $\begin{array}{l}\text { BORON, } \\
\text { DIS- } \\
\text { SOIVED } \\
\text { (UG/L } \\
\text { AS B) }\end{array}$ & $\begin{array}{l}\text { CADMIUM } \\
\text { DIS- } \\
\text { SOLVED } \\
\text { (UG/L } \\
\text { AS CD) }\end{array}$ & $\begin{array}{l}\text { CHRO- } \\
\text { MIUM, } \\
\text { DIS- } \\
\text { SOLVED } \\
\text { (UG/L } \\
\text { AS CR) }\end{array}$ & $\begin{array}{c}\text { CHRO- } \\
\text { MIUM, } \\
\text { HEXA- } \\
\text { VALENT, } \\
\text { DIS. } \\
\text { (UG/L } \\
\text { AS CR) }\end{array}$ & $\begin{array}{l}\text { COPPER, } \\
\text { DIS- } \\
\text { SOLVED } \\
\text { (UG/L } \\
\text { AS CU) }\end{array}$ & $\begin{array}{l}\text { LEAD, } \\
\text { DIS- } \\
\text { SOLVED } \\
\text { (UG/L } \\
\text { AS PB) }\end{array}$ & $\begin{array}{l}\text { LITHIUM } \\
\text { DIS- } \\
\text { SOLVED } \\
\text { (UG/L } \\
\text { AS LI) }\end{array}$ & $\begin{array}{c}\text { MERCURY } \\
\text { DIS- } \\
\text { SOLVED } \\
\text { (UG/L } \\
\text { AS HG) }\end{array}$ & $\begin{array}{l}\text { MOLYB- } \\
\text { DENUM, } \\
\text { DIS- } \\
\text { SOLVED } \\
\text { (UG/L } \\
\text { AS MO) }\end{array}$ \\
\hline $\begin{array}{c}\text { AUG } 1986 \\
28.20 \\
\text { MAR } 1987\end{array}$ & $<1$ & $<100$ & $<10$ & $<1$ & $<10$ & $<1$ & $<10$ & $<5$ & -- & $<0.1$ & $<1$ \\
\hline${ }_{M A Y}^{13} \cdots$ & $<1$ & 100 & $<10$ & $<1$ & $<10$ & -- & 10 & $<5$ & -- & $<0.1$ & $<1$ \\
\hline $18 \ldots$ & $<1$ & $<100$ & 20 & $<1$ & $<10$ & -- & $<10$ & 7 & $<10$ & $<0.1$ & $<1$ \\
\hline DATE & $\begin{array}{l}\text { NICKEL, } \\
\text { DIS- } \\
\text { SOLVED } \\
\text { (UG/I } \\
\text { AS NI) }\end{array}$ & $\begin{array}{l}\text { SEIE- } \\
\text { NIUM, } \\
\text { DIS- } \\
\text { SOLVED } \\
\text { (UG/L } \\
\text { AS SE) }\end{array}$ & $\begin{array}{c}\text { SILVER, } \\
\text { DIS- } \\
\text { SOLVED } \\
\text { (UG/L } \\
\text { AS AG) }\end{array}$ & $\begin{array}{l}\text { VANA- } \\
\text { DIUM, } \\
\text { DIS- } \\
\text { SOLVED } \\
\text { (UG/L } \\
\text { AS V) }\end{array}$ & $\begin{array}{l}\text { ZINC, } \\
\text { DIS- } \\
\text { SOLVED } \\
\text { (UG/L } \\
\text { AS ZN) }\end{array}$ & $\begin{array}{l}\text { URANIUM } \\
\text { NATURAL } \\
\text { DIS- } \\
\text { SOLVED } \\
\text { (UG/L } \\
\text { AS U) }\end{array}$ & $\begin{array}{c}\text { GROSS } \\
\text { BETA, } \\
\text { DIS- } \\
\text { SOLVED } \\
\text { (PCI/L } \\
\text { AS } \\
\text { CS-137) }\end{array}$ & $\begin{array}{l}\text { GROSS } \\
\text { ALPHA, } \\
\text { DIS- } \\
\text { SOLVED } \\
\text { (UG/L } \\
\text { AS } \\
\text { U-NAT) }\end{array}$ & $\begin{array}{l}\text { GROSS } \\
\text { BETA, } \\
\text { DIS- } \\
\text { SOLVED } \\
\text { (PCI/I } \\
\text { AS SR/ } \\
\text { YT-90) }\end{array}$ & \multicolumn{2}{|c|}{$\begin{array}{c}\text { RA-226, } \\
\text { DIS- } \\
\text { SOLVED, } \\
\text { PIAN- } \\
\text { CHET } \\
\text { CH } \\
\text { COUNT } \\
(P C I / L)\end{array}$} \\
\hline $\begin{array}{c}\text { AUG } 1986 \\
28 \ldots \\
\text { MAR } 1987\end{array}$ & 1 & $<1$ & $<1$ & $<1$ & $<10$ & $<0.4$ & 0.5 & $<0.5$ & 0.5 & \multicolumn{2}{|c|}{0.1} \\
\hline $\begin{array}{c}13 \ldots \\
\text { MAY } \\
18 \ldots\end{array}$ & $<1$ &.$<1$ & $<1$ & $<1$ & $<10$ & -- & -- & -- & -- & \multicolumn{2}{|c|}{--} \\
\hline
\end{tabular}

\section{Bottom-Sediment Samples}

Samples of bottom sediment were collected in the mouths of drains and from areas of deposition in lakes that receive discharge from respective drains. The samples were collected using either a pretreated wide-mouth glass jar (baked at $300-350^{\circ} \mathrm{C}$ overnight) or a US BMH-80 stainless-steel, rotary-scoop sampler (Federal InterAgency Sedimentation Project, 1986, p. 108-109), depending on the depth and composition of deposited material. At each site, the bottom material was sampled to a sediment depth of 2 to 3-1/2 inches. Usually 5 to 7 equally spaced samples were collected in the cross section of a drain; and, in a lake environment, 10 to 15 randomly spaced samples were collected from within a $400-\mathrm{ft}^{2}$ area. The individual samples collected from each site subsequently were composited in a stainless-steel bucket and thoroughly mixed using a stainless-steel spoon. The well-mixed sample was then split into three samples: one bulk sample for trace-element analysis; a second non-sieved sample for particle-size analysis; and a third for organochlorine-pesticide analysis, which was sieved in the field using native water through a nylon sieve for the less-than 63-micrometer particle-size fraction (the sand-silt break). The samples for pesticide residue analysis were stored in pretreated glass jars (as above) and maintained at $4{ }^{\circ} \mathrm{C}$ until analyzed.

Trace-element and percent-carbon analysis of bottom-sediment samples were done by a U.S. Geological Survey geochemical laboratory in Denver, Colo. The bulk samples were air dried, mechanically disaggregated, sifted through a less-than 63-micrometer sieve, and rigorously digested with hydrochloric acid, hydrofluoric acid, perchloric acid, and aqua regia (mixture of hydrochloric acid and nitric acid) prior to analysis. After digestion, the inorganic extracts were processed using the methods given by Severson and others (1987, p. 34). Laboratory determinations of arsenic, mercury, and selenium were done by atomic-absorption spectroscopy (arsenic and selenium by continuous flow hydride generation and mercury by cold vapor); uranium and 
thorium by neutron activation; and all others, except boron, by inductively coupled plasma analysis. The rigorous digestion procedures resulted in determinations that represent total extractable elements, reported in terms of dry weight. Boron, however, was extracted using a hot-water method that closely approximates the biologically available fraction in the sediment. Pesticide analyses, reported in terms of dry weight, were done by the U.S. Geological Survey water-quality laboratory in Denver, Colo., using the methods described by Wershaw and others (1987). Particle-size analysis was done at the U.S. Geological Survey sediment laboratory in Iowa City, Iowa, using the procedures described by Guy (1969). The types of chemical determinations in bottom-sediment samples and their respective reporting limits are given in tables 4 and 5 .

\section{Biological Samples}

Biological samples were collected from June 1986 through September 1987. The sampling locations are shown on plate 1. Emphasis was placed upon juvenile bird livers, whole fish, aquatic insects, and aquatic plants. Where possible, the same species were collected from each area; however, substitutions were made as necessary. During 1986, an exceptionally wet water year in headwater areas of the Carson and Truckee Rivers, most wetlands within the study area contained water and aquatic organisms of some type. In 1987, however, a drought began and coincidentally farmers and the Truckee-Carson Irrigation District were under Federal Court order to conserve water. Consequently, several wetland units dried up, and organisms were not available for sampling. On the basis of State and Federal biologist's observations of migratory bird mortality and high values of specific conductance, several additional sampling sites were added to the original study plan during 1986 and 1987. These sites included Humboldt and Toulon Lakes in Humboldt WMA; Fernley WMA; Goose Lake, Pintail Bay, and Dry Lake in Stillwater WMA; and Massie and Mahala Sloughs (plate 1). In addition, a limited number of samples were collected from various agricultural drains entering many of the wetland segments shown on plate 1. These drain locations are not illustrated for logistic reasons.

All biological samples were analyzed by the U.S. Fish and Wildlife Service, Patuxent Analytical Control Facility, Laurel, Md., and their contract laboratories. The resulting data had appropriate quality-assurance documentation attached.

Types of laboratory analyses of biological tissues for selected trace elements and pesticides are shown in tables 4 and 5. The analytical procedures are those described by U.S. Fish and Wildlife Service (1985).

During 1986, 181 biological samples were submitted for analysis of organochlorine pesticide residues. Reporting limits for organic compounds are shown in table 5. Because the results for these samples were less than the analytical reporting limits, and because the study area has no history of exceptional organochlorine use, such analysis was discontinued in 1987.

Juvenile birds which have been exposed only to the contaminants in the study area after hatching were collected for analysis to address accumulation of contaminants within the study areas. Coots (Fulica americana) were available in most study areas. Where available, black-necked stilts (Himantopus mexicanus) were collected, to complement coot collections. Stilts are more dependent than coots on invertebrates in their diet, and were thought to represent different pathways of potential contaminant accumulation. Several sets of stilt adults were also collected to further establish accumulation of potential contaminants. 


\begin{tabular}{|c|c|c|}
\hline \multirow[b]{2}{*}{ Constituent } & \multicolumn{2}{|c|}{ Analytical reporting limit } \\
\hline & $\begin{array}{c}\text { Bottom material } \\
\text { (micrograms per } \\
\text { kilogram, dry weight) }\end{array}$ & $\begin{array}{c}\text { Tissue } \\
\text { (micrograms per } \\
\text { gram, wet weight) }\end{array}$ \\
\hline $\begin{array}{l}\text { Aldrin } \\
\text { Chlordane } \\
\text { DDD } \\
\text { DDE } \\
\text { DDT }\end{array}$ & $\begin{array}{r}0.1 \\
1.0 \\
.1 \\
.1 \\
.1\end{array}$ & $\begin{array}{r}0.01 \\
.01 \\
.01 \\
.01\end{array}$ \\
\hline $\begin{array}{l}\text { Dieldrin } \\
\text { Endosulfan } \\
\text { Endrin } \\
\text { Heptachlor } \\
\text { Heptachlor epoxide }\end{array}$ & $\begin{array}{l}.1 \\
.1 \\
.1 \\
.1 \\
.1\end{array}$ & $\begin{array}{r}.01 \\
-.01 \\
-.01\end{array}$ \\
\hline $\begin{array}{l}\text { Lindane } \\
\text { Methoxychlor } \\
\text { Mirex } \\
\text { Nonachlor } \\
\text { Oxychlordane }\end{array}$ & $\begin{array}{r}.1 \\
.1 \\
.1 \\
-- \\
--\end{array}$ & $\begin{array}{l}-- \\
-- \\
-01 \\
.01 \\
.01\end{array}$ \\
\hline $\begin{array}{l}\text { PCB } \\
\text { Perthane } \\
\text { Toxaphene }\end{array}$ & $\begin{array}{r}1.0 \\
1.0 \\
10\end{array}$ & $\stackrel{-1}{--}$ \\
\hline $\begin{array}{l}1 \text { The reportin } \\
\text { ize weight of } 109 \\
\text { ample-size weight, }\end{array}$ & $\begin{array}{l}\text { imits for tissue are } \\
\text { s, wet weight. With } \\
\text { e reporting limit is }\end{array}$ & $\begin{array}{l}\text { oased on a sample- } \\
\text { an increase in } \\
\text { increased. }\end{array}$ \\
\hline
\end{tabular}

Birds were collected by hand, with dip nets, and with a shotgun using steel shot. Birds were weighed, stored on ice, and the livers were removed within a few hours after collection. A few whole birds were frozen prior to liver removal. Livers were removed with sterile scalpel blades, and rubber gloves were used throughout. Acetone and deionized water were used routinely to rinse gloved hands and tools before and after each bird was handled. The samples were labeled and frozen in nitric-acid-washed jars. Because stilt livers are relatively small, each sample was composed of livers from two birds. Field notes of each specimen were maintained. Emphasis was not placed on bird reproduction and bird eggs in this reconnaissance because research on these aspects was being conducted concurrently at Stillwater WMA and Carson Lake by Dr. Charles Henny, U.S. Fish and Wildlife Service, Patuxent Wildlife Research Center. His data are not available as of this writing.

To determine if public health warning criteria were being exceeded in edible tissues, ducks were collected with a shotgun using steel shot. Juvenile birds were shot in July 1987, and several adult birds were included to fulfill sample-size objectives. Adult ducks collected in July probably had lived in the study area for several months and presumably had the opportunity to accumulate contaminants.

Samples of breast muscle, skin, and liver were collected from 15 mallards (Anas platyrhynchos); 10 redheads (Aythya americana); and 7 northern shovelers (Anas clypeata) to determine if contaminants accumulated in edible portions (Klasing and Pilch, 1988, p. 9). 
Fish were collected with dip nets, seines, or gill nets. Carp (Cyprinus carpio) were available in most study areas in 1986 . Where possible, approximately 1-pound $(0.5 \mathrm{~kg})$, whole fish were taken. In some instances, fish in the 4-to-10-ounce $(0.1$ to $0.3 \mathrm{~kg})$ range were taken. Game fish, though rarely found, were also taken. Fish were wrapped in Saran wrap ${ }^{2}$ and placed in Ziploc ${ }^{1}$ sealable plastic bags and maintained on ice until they could be frozen. Mosquito fish (Gambusia affinis) were placed directly into nitric-acid-washed jars, stored on ice, and frozen as soon as possible.

Composite insect samples were collected with a kick net. Hemipterans (true bugs) were taken from the water column, placed in nitric acid-washed jars, chilled, and frozen. Dipteran (two-winged flies) larvae were generally within detrital masses; these were chilled and hand-picked over a 1- to 3-day period. Cleaned samples were then frozen in nitric acid-washed jars. Minimum sample size for insects was about 0.5 ounce (14.2 g), live weight.

Composite samples of vascular plants and filamentous algae were generally gathered by hand. Plant species and tissues were selected on the basis of availability and speculated use as a wildlife food. An exception was rooted portions of emergents, which required a shovel to extract and extensive rinsing with pond water. Plants were stored in plastic bags, chilled, and frozen as soon as possible. Seeds were hand-sifted from vegetative matter after a drying period. The seeds were then frozen with other samples. Species included Typha, Scirpus acutus, Scirpus poludosus, Potamageton sp., unidentified filamentous algae, and the muskgrass (Chara sp.).

\section{RESULTS OF THE RECONNAISSANCE INVESTIGATION}

\section{Determination of Contaminant Criteria}

Water-quality criteria are recommended limiting concentrations of potentially toxic constituents for the protection of human health, aquatic life, or crops. The criteria used in this report for comparative purposes (table 6) were obtained primarily from codified documents for Nevada water-quality criteria. ${ }^{2}$ The State criteria generally are those recommended by the U.S. Environmental Protection Agency in accordance with the Water Quality Act of 1987 and documented as Public Law 100-4. If a State water-quality criterion was lacking for a particular constituent, information from other published sources was gathered, examined for its applicability to the study area, and compared to the data collected as part of this reconnaissance. Such information is cited in the text where appropriate. In addition, data from upstream background sites (those unaffected by irrigation drainage) were used to compare and contrast with corresponding data from the downstream sites affected by irrigation drainage.

1 The use of trade names in this report is for identification purposes only and does not constitute endorsement by the U.S. Geological Survey or the U.S. Fish and Wildlife Service.

2 Surface waters downstream from Lahontan Dam are classified by Nevada as C or D, with D being the lowest class. Such waters are defined as those being in areas with moderate-to-heavy human habitation, moderate-to-heavy industrial development, with intensive agricultural practices, and whose drainage basin is substantially altered by man's activities. These waters commonly receive discharges from a mixture of sources. Federal or State water-quality standards do not apply for $C$ and D waters--only criteria, which are used as guidelines. 
TABLE 6.--Nevada water-guality criteria (single value) for toxic constituents according to designated beneficial use

[mg/L, milligrams pex I1tex; --, not applicable; all constituents in micrograms per liter except as noted]

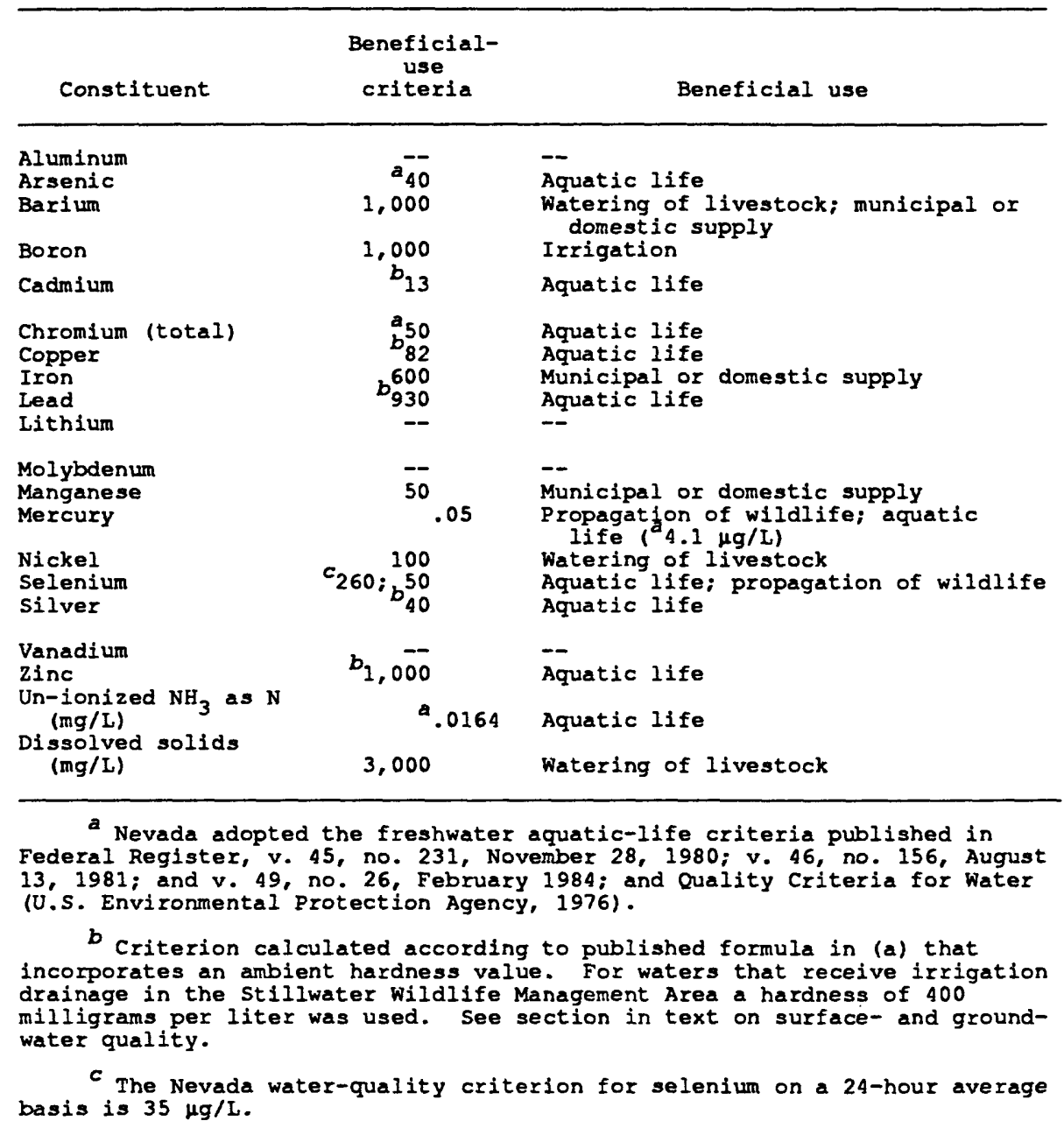

The reader should be aware that the water-quality criteria shown in table 6 for the protection of aquatic organisms, do not represent final acute (or chronic) toxicity test values (for example, the results of 24-hour or 96-hour LC50 tests) such as those represented in table 7. In developing single-value criteria, the application of a safety factor is included by a regulatory agency to provide a reasonable degree of safety for untested organisms. For example, the results of a 96-hour bioassay for a particular trace element is multiplied by an arbitrary value of 0.01 (U.S. Environmental Protection Agency, 1976, p. 2) or 0.50 (Stephans and others, 1985, p. 17), depending on when a particular criterion was developed. The similarity between the $40-\mu \mathrm{g} / \mathrm{L}$-arsenic water-quality criterion in table 6 and the effect level in water in table 7 is coincidental.

Sediment quality criteria (SQC) for pesticides were obtained from "Interim sediment criteria values for non-polar hydrophobic organic contaminants" (U.S. Environmental Protection Agency, 1988, p. 35). The SQC values are not final and are used only as guidelines. 
TABLE 7.--Federal and State criteria for water and contaminant residue in biota that may adversely affect fish and wildife, and human health

[Reference sources are indicated by a letter and page number, in the parentheses; complete citations follow the table.]

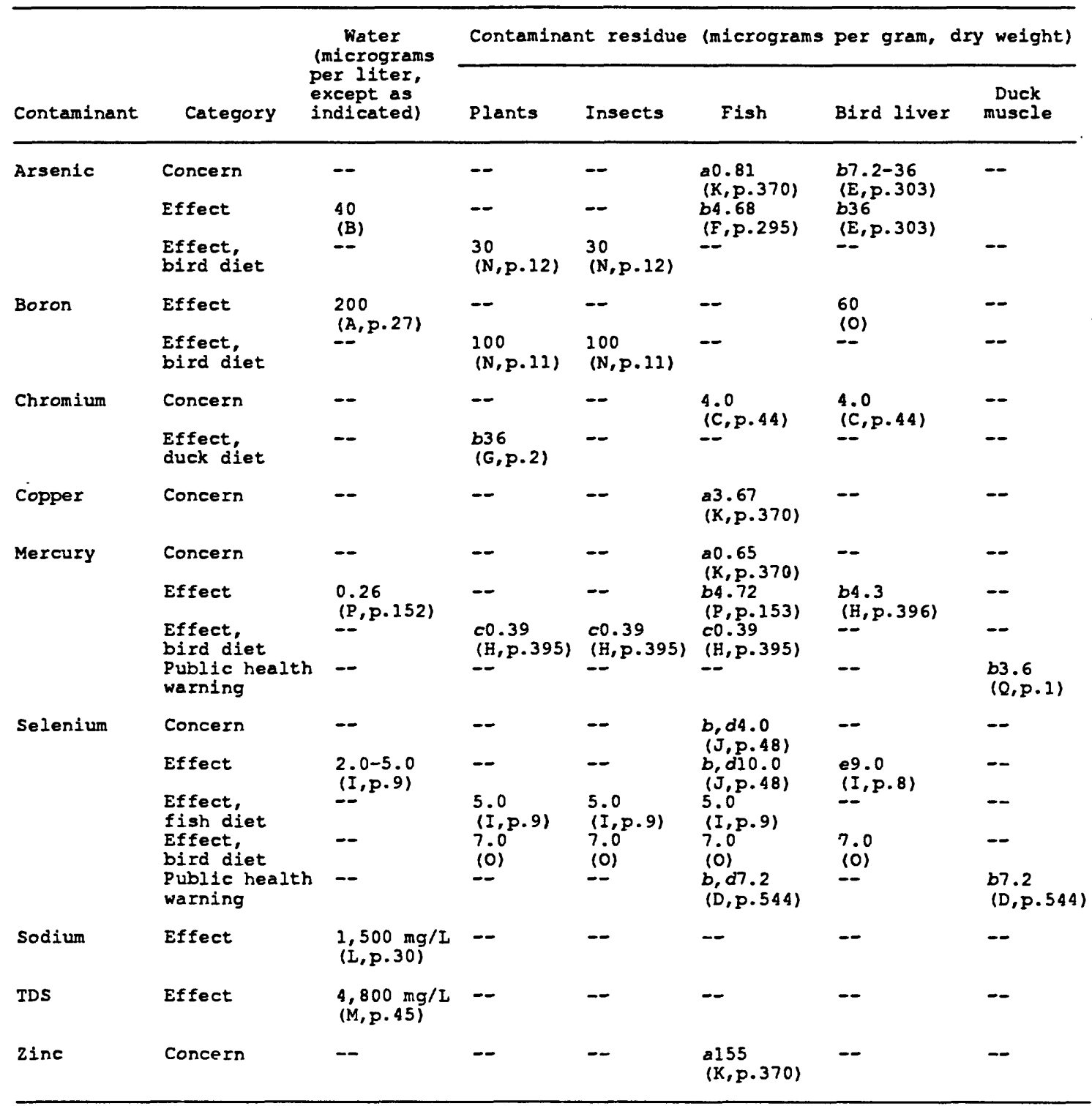

a Based upon 85th-percentile concentrations averaged for the periods 1978-79 and 1980-81 and multiplied by 3.6 to represent dry weight.

$b$ Original wet weight data multiplied by 3.6 to approximate dry weight.

$c$ Same as $b$, above, and divided by 0.93 to convert methylmercury to total mercury (J.F. Moore, Patuxent Wildlife Research Center, U.S. Fish and Wildife Service, oral commun., ig89).

d Muscle to whole-body ratio for selenium in fish is $1: 1$ (J, p. 31 ).

e Based upon the average liver wet-weight concentrations for female mallards, adjusted for 71 percent moisture.

References used for criteria to categorize contaminant levels in biological samples, water, and human health, cited above:

A. Birge, W.J., and Black, J.A., 1977, Sensitivity of vertebrate embryos to boron compounds: U.S. Environmental Protection Agency Report EPA-560/1-75-008, 64 p.

B. Birge, W.J., 1978, Embryo-larval bioassays on inorganic cool elements and in situ biomonitoring of coal-waste effluents, in Samuel, D.E., and others, surface mining and fish/wildife needs in the eastern United States: Report PB 298353, p. 97. Available only through National Technical Information Service, Springfield, Va. 22161 . 


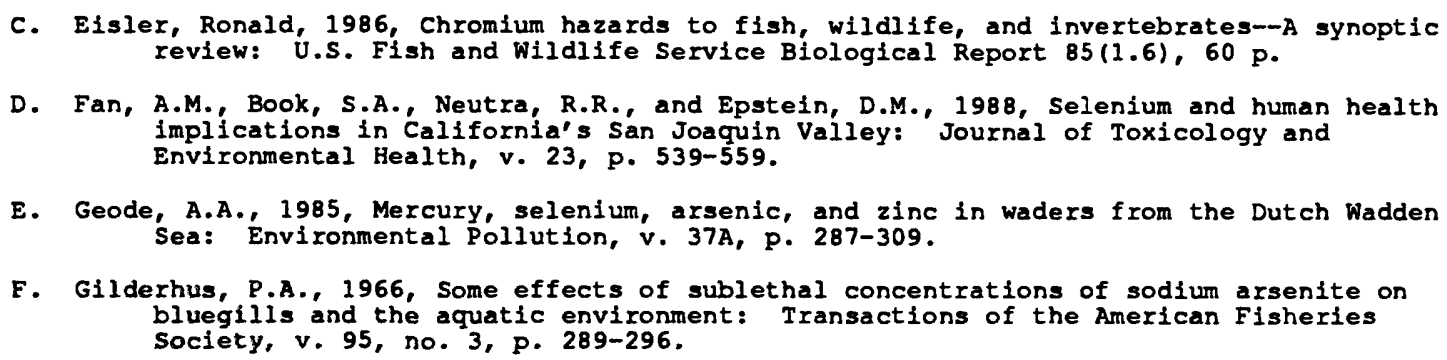

D. Fan, A.M., Book, S.A., Neutra, R.R., and Epstein, D.M., 1988, Selenium and human health implications in California's San Joaquin Valley: Journal of Toxicology and Environmental Health, v. 23, p. 539-559.

E. Geode, A.A., 1985, Mercury, selenium, arsenic, and zinc in waders from the Dutch Wadden Sea: Environmental Pollution, v. 37A, p. 287-309.

F. Gilderhus, P.A., 1966, Some effects of sublethal concentrations of sodium arsenite on bluegilis and the aquatic environment: Transactions of the American Fisheries Society, v. 95, no. 3, p. 289-296.

G. Haseltine, S.D., Sileo, L., Hoffman, O.J., and Mulhern, B.M., 1985, Effects of chromium on reproduction and growth of black duck: U.S. Fish and Wildlife Service, unpublished report, $25 \mathrm{p}$.

H. Heinz, G.H., 1979, Methylmercury--Reproductive and behavioral effects on three generations of mallard ducks: Journal of Wildlife Management, v. 43, no. 2, p. 394-401.

I. Lemly, D.A., and Smith, G.J., 1987, Aquatic cycling of selenium--Implications for fish and wildife: U.S. Fish and Wildife Service Leaflet 12, 10 p.

J. Lillebo, P.H., Shaner, S., Carlson, P., Richard, N., and Dubarry, Paul, 1988, Regulation of agricultural drainage to the San Joaquin River--Appendix D. Water quality criteria for selenium and other trace elements for protection of aquatic life and its uses in the San Joaquin Valley: California State Water Resources Control Board Report W.0. 85-1, 151 p.

K. Lowe, T.P., May, T.W., Brumbaugh, W.G., and Kane, D.A., 1985, National contaminant biomonitoring program--Concentrations of seven elements in freshwater fish, 1978-81: Archives of Environmental Contaminants and Toxicology, v. 14, p. 363-388.

L. Mitcham, S.A., and Wobesen, G., $1988 \mathrm{a}$, Effects of sodium and magnesium sulfate in drinking water on mallard ducklings: Journal of Wildlife Diseases, v. 24, no. 1, p. $30-44$.

M. Mitcham, S.A., and Wobesen, G., 1988b, Toxic effects of natural saline waters on mallard ducklings: Journal of Wildlife Diseases, v. 24, no. 1, p. 45-50.

N. Patuxent Wildlife Research Center, 1987, Effects of irrigation drainage on wildlife: Laurel, Md., U.S. Fish and Wildlife Service, annual report FY 1987.

0. Smith, G.J., Patuxent wildlife Research Center, 1989, U.S. Fish and Wildlife Service, Laurel, Md., oral communication.

P. Snarski, V.M., and Olson, G.F., 1982, Chronic toxicity and bioaccumulation of mercury chloride in the fathead minnow (Pimephales promelas): Aquatic Toxicology, v. 2, p. 143-156.

Q. U.S. Food and Drug Administration, 1984, Compliance policy guide for methyl mercury in fish: Report 7108.07 , Federal Register, v. 49, no. 45663, 1 p.

Two general comparative categories are used for fish and wildlife in table 7: (1) concern level and (2) effect level. Concern levels in tissue are defined as those which are unusually high compared with background levels and are viewed as indicators of potential contaminant exposure in the food chain. They are not associated with known adverse biological impacts. In some instances for fish, the USFWS National Contaminant Biomonitoring Program 85th-percentile level is used to define concern levels (Lowe and others, 1985). Effect levels of contaminants in tissue and water are defined as those which can be expected to adversely impact some organisms in some way. Impacts include reduced growth, reproductive disorders, and mortality. Effect levels leave no margin of safety for fish and wildlife. In some instances, criteria are based on dietary levels expected to adversely affect the same or higher tropic level organisms. Data exist for relatively few species. Many of these effect criteria are developed in the laboratory, from one species under one set of controlled environmental conditions. Similar effects may be associated with higher or lower residue concentrations in other species. Extensive search of available literature on toxicology indicates that the criteria used here are the most reliable. However, effect levels should not be considered as absolute values. They are best viewed as threshold values above which some species, under some conditions, would be adversely impacted. 
Criteria for human health were obtained from public health warnings for consumption of fish and duck muscle previously issued in this study area and in California. A safety margin is incorporated into the formulation of these criteria that recognizes personal habits of various consumer groups and the rate at which various fish and duck species accumulate toxic elements. These criteria are used here only as a guideline.

A public health waming for mercury was issued in 1986 by the Nevada Division of Health regarding consumption of fish from the study area. The basis for this waming is documented concentrations of mercury in fish muscle (Cooper and others, 1985, p. 44) and the U.S. Food and Drug Administration's compliance policy guide for mercury, $1.0 \mu \mathrm{g} / \mathrm{g}$ wet weight $(3.6 \mu \mathrm{g} / \mathrm{g}$ dry weight). When compliance policy guides are issued, it is assumed that they apply to similar foods. In this instance, duck muscle is equated to fish muscle. Therefore, the criterion used in this study to evaluate mercury in waterfowl muscle is $3.6 \mu \mathrm{g} / \mathrm{g}$ dry weight.

In March 1989, the Nevada Division of Health issued another public health warning, for mercury in shoveler duck muscle from Carson Lake. The warning was issued, in part, on the basis of data collected during a follow up study to this reconnaissance.

The California Department of Health Services has issued similar warnings for waterfowl consumption in several areas where selenium in waterfowl muscle may approach or exceed $2.0 \mu \mathrm{g} / \mathrm{g}$ wet weight or 7.2 $\mu \mathrm{g} / \mathrm{g}$ dry weight (Fan and others, 1988, p. 544). At this time, the U.S. Food and Drug Administration has not issued a compliance policy guide for selenium in human food. Lillebo and others $(1988$, p. 31) evaluated selenium in whole fish and fish muscle and concluded that residue levels from both media could be viewed as equivalent. On this basis, the public health warning action level of $7.2 \mu \mathrm{g} / \mathrm{g}$ dry weight in waterfowl muscle is extended as a criterion for selenium in whole-body fish analyzed in this study. S.A. Book and A.M. Fan (Califomia Department of Health Services, written commun., 1986) and Lillebo and others (1988, p. 38) have developed recommendations based upon a public health warning action level of $1.0 \mu \mathrm{g} / \mathrm{g}$ selenium wet weight in fish muscle. Since the $2 \mu \mathrm{g} / \mathrm{g}$ wet weight $(7.2 \mu \mathrm{g} / \mathrm{g}$ dry weight) action level is currently in use, this criterion is used to evaluate selenium residue in whole fish in this study.

Other effects may be occurring for which criteria (and contaminants, for that matter) have not been determined. Sublethal impacts are difficult to document. The relation between environmental contaminants, stress, and disease is difficult to document. This study area has a history of disease outbreaks and of persistent and unexplained migratory-bird mortality. Synergistic or antagonistic interactions between contaminants and (or) between contaminants and disease organisms also may be a factor in the study area. Indirect impacts also may be occurring. For instance, contaminants may be directly impacting the kinds and quantities of food-chain organisms and, in response, organisms at higher trophic levels may be under stress.

1 Synergism is the combined action of two or more contaminants to produce an effect (usually harmful) that could not be accomplished by the action of one contaminant alone. Antagonism is the counteraction between two contaminants that lessens the harmful effects of one or the other. 


\section{Surface- and Ground-Water Quality}

Field measurements and water samples were collected mainly in June 1986, September 1986, March 1987, and May 1987 to coincide with seasonal irrigation patterns in the Fallon agricultural area. A statistical summary of the field measurements in table 11 is shown in table 8. These data and visual observations indicate that lakes (wetlands) that receive irrigation drainage are typically warm (during the summer), shallow (less than 5 feet), turbid, alkaline (pH 7.8 to 10), and supersaturated with respect to dissolved oxygen during the daytime. In addition, these lakes had a median hardness of $440 \mathrm{mg} / \mathrm{L}$ as $\mathrm{CaCO}_{3}$ and the drains had a median hardness of $370 \mathrm{mg} / \mathrm{L}$ as $\mathrm{CaCO}_{3}$, and thus are classified as very hard (Hem, 1985, p. 159).

Streamflow in the drains ranged from 0.51 to $97 \mathrm{ft}^{3} / \mathrm{s}$. Specific conductance (a surrogate measure of dissolved solids) in irrigation drain water ranged from 566 to 41,000 microsiemens per centimeter at $25^{\circ} \mathrm{C}$ $(\mu \mathrm{S} / \mathrm{cm}$ ) with a median of $1,990 \mu \mathrm{S} / \mathrm{cm}$. In contrast, conductance of the source water for irrigation (Carson River below Lahontan Reservoir, a background site) ranged from about 200 to $400 \mu \mathrm{S} / \mathrm{cm}$ with a median of about $250 \mu \mathrm{S} / \mathrm{cm}$. Conductance in samples of representative lake water affected by irrigation return flow ranged from about 300 to $8,600 \mu \mathrm{S} / \mathrm{cm}$, with a median of about $3,400 \mu \mathrm{S} / \mathrm{cm}$. By comparison, the background lake sites had a median conductance of only $360 \mu \mathrm{S} / \mathrm{cm}$. These data indicate an overall large (eightfold to tenfold) increase in dissolved solids in the downstream direction principally as a result of irrigation drainage in the study area.

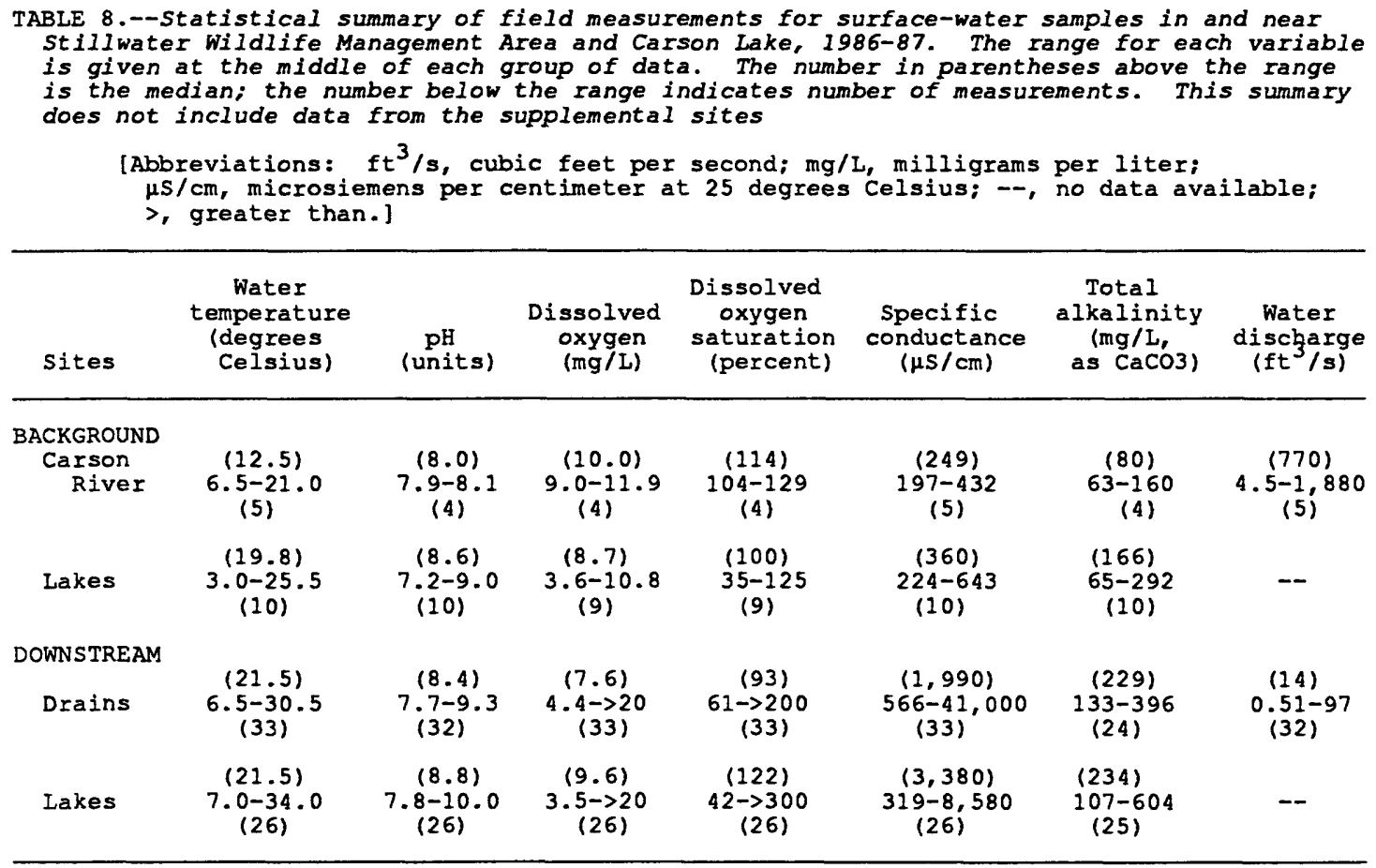




\section{Dissolved Solids}

The total concentration of solids dissolved in water is important for both its osmotic effect on plants and animals and, in relation to high values of hardness, for lessening toxicity of some trace elements to freshwater biota.

Gravimetric analysis of dissolved-solids concentration was incorporated into the sampling protocol beginning with the September 1986 sampling round at most sites. In those few instances where actual values are lacking, the concentration of dissolved solids was estimated by solving linear, least-squares regression equations for the following ranges of specific-conductance measurements:

For specific conductance (SC) less than $5,000 \mu \mathrm{S} / \mathrm{cm}$ (microsiemens per centimeter at $25^{\circ} \mathrm{C}$ ):

Dissolved solids, in $\mathrm{mg} / \mathrm{L}$ (milligrams per liter) $=0.584(\mathrm{SC})+22.1\left(\mathrm{r}^{2}=0.991, \mathrm{n}=47, \alpha 0.05\right)$

For specific conductance from 5,000 to $9,000 \mu \mathrm{S} / \mathrm{cm}$ :

Dissolved solids, in $\mathrm{mg} / \mathrm{L}=0.682(\mathrm{SC})-269\left(\mathrm{r}^{2}=0.988, \mathrm{n}=7, \alpha 0.05\right)$

Each linear regression was developed using the 1986-87 reconnaissance data. The estimated dissolvedsolids values are noted as such in the data table at the back of this report (table 12). The reader is cautioned that it is unadvisable to extrapolate the functional relation between specific conductance and dissolved-solids concentration (or other variable of interest) beyond the range of the data that were used to develop the relation.

As mentioned previously, the specific-conductance data in general showed an overall downstream increase in dissolved solids. More specifically, however, the concentration of dissolved solids increased nearly nine-fold for the five drain sites that discharge to Stillwater Wildlife Management Area (median 1,590 mg/L, $n=21$ ) from the background site, Carson River below Lahontan Reservoir (median $168 \mathrm{mg} / \mathrm{L}, \mathrm{n}=4$ ).

A bar graph of dissolved solids (figure 6) shows that the highest concentrations were found most commonly ( 9 of 12 downstream sites) during the pre-irrigation season; and the lowest concentrations were found most commonly ( 8 of 12 sites) during the late-irrigation season. This seasonal trend in dissolved-solids concentration compares favorably with that shown by near-monthly measurements of specific conductance of drainwater in the area (Rollins, 1965, p. 13).

According to Mitcham and Wobeser (1988a), natural water whose specific conductance equals or exceeds $7,500 \mu \mathrm{mhos} / \mathrm{cm}$ (equivalent to microsiemens per centimeter)--when a freshwater source is not available--adversely affects ducklings. Within the study area, this conductivity equates to about $4,800 \mathrm{mg} / \mathrm{L}$ dissolved solids (equation 2). The 4,800-mg/L effect level was exceeded at the Carson Lake-Islands Unit, TJ Drain, and Paiute Drain below TJ Drain (figure 6). Refuge wildlife biologists speculate that the $4,800-\mathrm{mg} / \mathrm{L}$ limit is exceeded regularly in the secondary and tertiary wetland units such as Cattail Lake and Pintail Bay in the Stillwater WMA. During regional drought conditions, concentrations of dissolved solids in waters within other wetland units may exceed biological-effect criteria. 
The data shown for each sampling site in figures 6-9 and 11, are arranged from left to right to simulate a single-year irrigation season, rather than arranged in actual chronological order. Such arrangement of the data assumes that no major environmental changes occurred between the 1986 and 1987 irrigation seasons. Although more water was released (operational spills) from Lahontan Reservoir during the first half of 1986 (before the first sampling round in June 1986) than for an equivalent period in 1985 and 1987 (figure 3), the amount of irrigation water delivered (headgate) to the farmers--209,100 acre-feet in 1985, 221,800 acre-feet in 1986, and 209,000 acre-feet in 1987--was nearly the same. The difference in headgate delivery between 1986 and 1987, for example, was only about 6 percent. Irrigation practices in the study area probably did not change substantially during the 1986-87 sampling period. Much of the excess, or spilled, water in early 1986, flowed to topographically low elevation areas in Stillwater WMA and Carson Lake, thus the results of the June 1986 (mid-irrigation) sampling round may be atypical for a similar period in a non-spill year such as 1985 and 1987.

Of the principal sampling sites, TJ Drain (site 10 in plate 1) commonly had the highest concentration of dissolved solids, with a recorded maximum of $29,800 \mathrm{mg} / \mathrm{L}$ at $0.51 \mathrm{ft}^{3} / \mathrm{s}$ during the pre-irrigation season (figure 6). The highest dissolved-solids concentration $(53,400 \mathrm{mg} / \mathrm{L})$ recorded in this study was in a water sample collected in July 1987 from Hunter Drain, a supplemental site (site 20 in plate 1; not shown in figure 6). Drainflow at that time was $0.21 \mathrm{ft}^{3} / \mathrm{s}$. Comparison of the water chemistry of this sample (tables 12-14) with those given by Morgan (1982, p. 54-55), suggests that the drain was receiving inflow from seepage of shallow saline ground water rather than from agricultural drain water. The next highest dissolved-solids concentration $(35,000 \mathrm{mg} / \mathrm{L})$ was from another supplemental site, Pintail Bay (a tertiary unit; site 24 in plate 1), in July 1987. For comparison, the concentration of dissolved solids in sea water averages about $35,000 \mathrm{mg} / \mathrm{L}$ (McKee and Wolf, 1963, p. 184). (Recall that the five supplemental sites were sampled only once during this reconnaissance investigation).

According to Mitcham and Wobeser (1988b), sodium--a major dissolved ion in natural water--in excess of $1,500 \mathrm{mg} / \mathrm{L}$ is an effect level for ducklings in that the experimental results showed a decrease in further growth. At background sites for this study, the concentration of sodium is typically less than $50 \mathrm{mg} / \mathrm{L}$ (figure 7). For wetland areas, the $1,500-\mathrm{mg} / \mathrm{L}$ limit was exceeded at one site in Carson Lake and at two supplemental sites, Cattail Lake (2,800 mg/L; site 22 in plate 1) and Pintail Bay (11,000 mg/L; site 24 in plate 1) in Stillwater WMA. On the basis of field measurements of specific conductance, refuge biologists speculate that this effect concentration is exceeded regularly in the tertiary, or most downstream wetland units, and that under drought conditions, water in other wetland units also may contain concentrations of sodium that are higher than $1,500 \mathrm{mg} / \mathrm{L}$.' Noteworthy in figure 7 are the results of two water samples from TJ Drain that contained extremely high concentrations of sodium $(8,000$ and $4,900 \mathrm{mg} / \mathrm{L})$.

1 Examination of the specific conductance and sodium data collected as part of this study, shows that the $1,500-\mathrm{mg} / \mathrm{L}$ effect level for sodium is exceeded when specific conductances are greater than $8,000 \mu \mathrm{S} / \mathrm{cm}$ (or a dissolved-solids concentration of $5,200 \mathrm{mg} / \mathrm{L}$ ). 


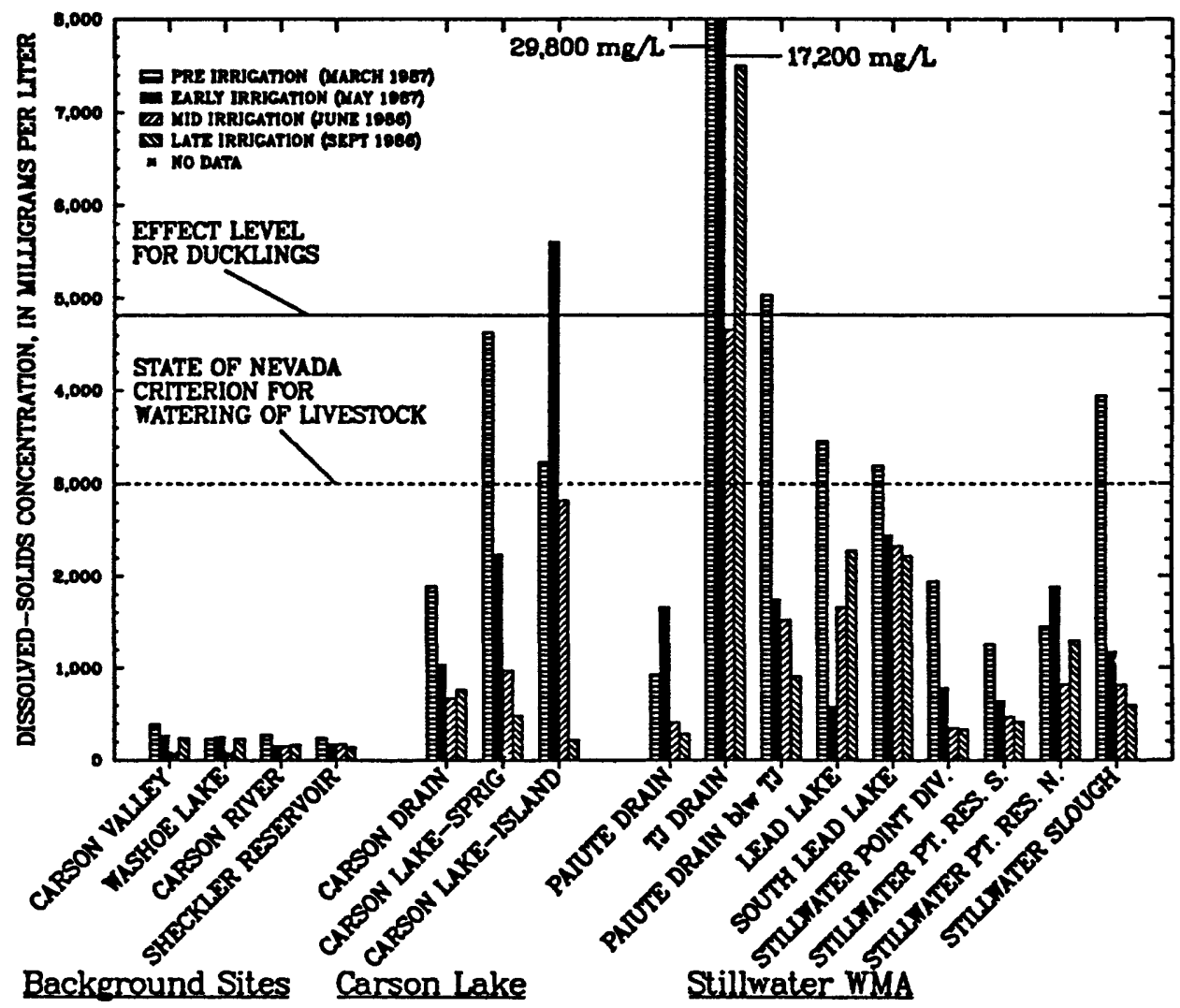

FIGURE 6.--Dissolved solids concentrations for surface-water samples in the background sites, Carson Lake, and Stillwater Wildlife Management Area, in downstream order, 1986-87. Effect level for ducklings where a source of freshwater is unavailable is $4,800 \mathrm{mg} / \mathrm{L}$ (Mitcham and Wobesen, 1988a, p. 49). Concentrations exceeding effect level may adversely impact the organism. Water-quality criteria are recommended limiting concentrations for the protection of human health, aquatic life, or crops. Note: chronological data for 1986-87 are rearranged to simulate a single-year irrigation season.

A probable source of the high sodium concentrations in TJ Drain is inflow of saline ground water by seepage. The TJ drainage system was completed as recently as $1982-83$ to lower the shallow water table in the Fallon Indian Reservation (plate 1) for agricultural purposes. Thus, TJ Drain is relatively young compared with most other drains in the study area, which were constructed in the early 1900's.

In terms of individual constituents, the samples of drain and lake water were typically dominated by chloride, sodium, and sulfate (listed in order of decreasing concentration). These three constituents are commonly found in high concentrations in drain water in areas of low rainfall and irrigated agriculture.

For the six shallow ground-water sites (subsurface flow), the concentration of dissolved solids was highly variable from site to site and ranged from 12,800 to $70,700 \mathrm{mg} / \mathrm{L}$ (table 18). The highest concentration (70,700 $\mathrm{mg} / \mathrm{L}$ ) was found in water from observation well HL-AH-5A (site 27 in plate 1), about 4 miles upgradient of Stillwater Point Reservoir. 


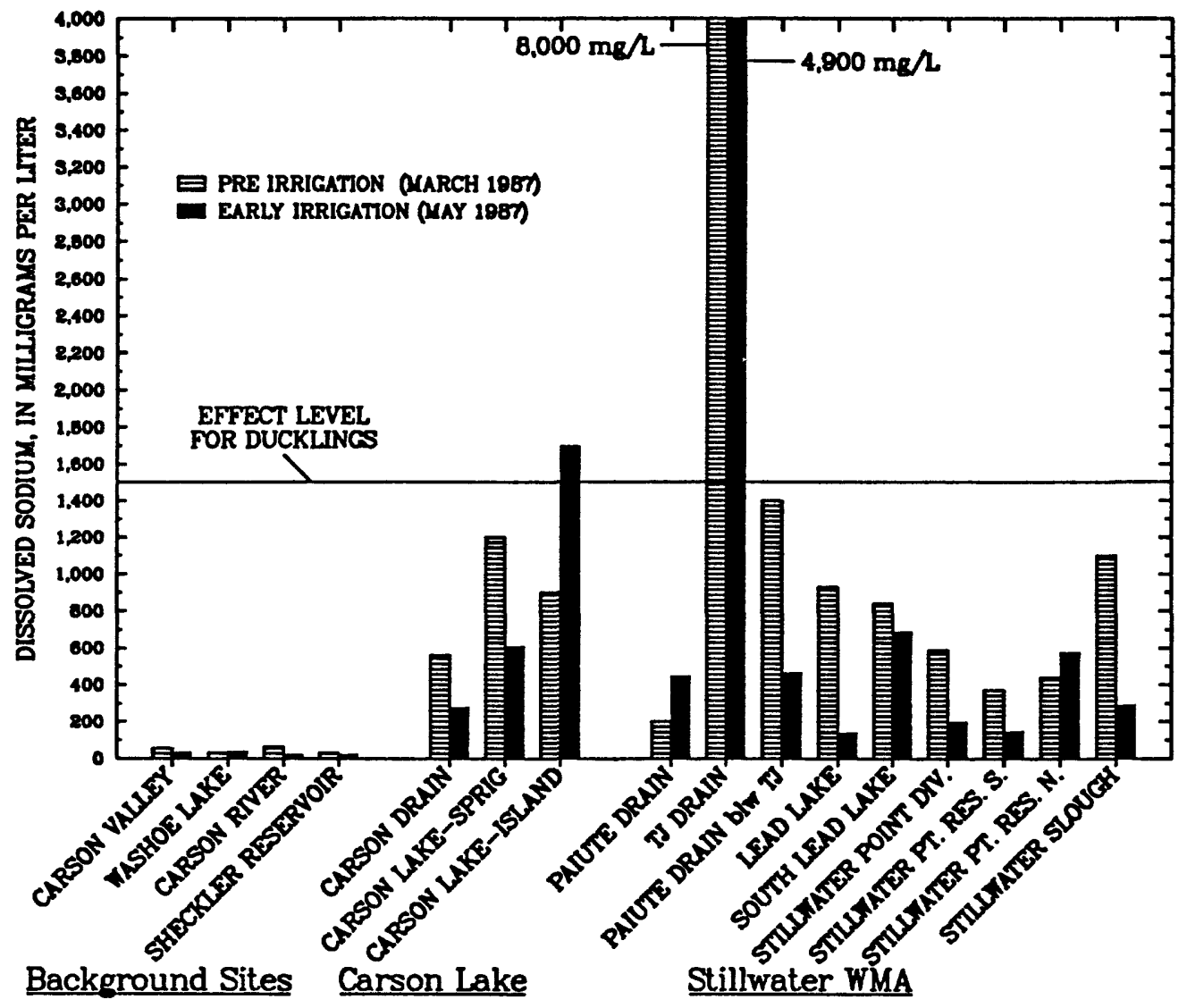

FIGURE 7.--Dissolved sodium concentrations for surface-water samples in the background sites, Carson Lake, and Stillwater Wildlife Management Area, in downstream order, 1986-87. Effect level for ducklings is from Mitcham and Wobesen (1988b, p. 30). Concentrations exceeding effect level may adversely impact the organism. Note: chronological data for 1986-87 are rearranged to simulate a single-year irrigation season.

\section{Trace Elements}

Concentrations of dissolved aluminum, barium, cadmium, chromium, copper, lead, lithium, molybdenum, nickel, silver, and vanadium in all samples were either below Nevada's respective criterion, if existing, for the protection of aquatic life and for propagation of wildlife (table 6), or less than the analytical reporting level. Results of analysis of these trace elements will not be discussed further in the context of water quality but may be found in table 14 at the end of this report.

\section{Arsenic}

Concentrations of dissolved arsenic in surface-water samples (figure 8) ranged from below the reporting level of $1 \mu \mathrm{g} / \mathrm{L}$ (microgram per liter) to $190 \mu \mathrm{g} / \mathrm{L}$ at sites receiving irrigation drainage (median $=44 \mu \mathrm{g} / \mathrm{L}, \mathrm{n}=$ 47). The Nevada $40-\mu \mathrm{g} / \mathrm{L}$ single-value criterion for the protection of aquatic life was exceeded in 69 percent of the samples. This criterion is also considered an effect level for amphibians (Birge, 1978) which formerly were found in great abundance in the wetlands and are now nearly absent. The highest arsenic concentrations in water were usually found (about 67 percent of the time at sites receiving irrigation drainage) in either the preirrigation or early-irrigation sampling round, or in both. Of the principal sampling sites in this reconnaissance, $\mathrm{TJ}$ drain had the highest recorded concentration of arsenic in water $(190 \mu \mathrm{g} / \mathrm{L})$. One of the supplemental sites, 
Pintail Bay in the Stillwater Marsh, however, showed a maximum dissolved-arsenic concentration of 1,400 $\mu \mathrm{g} / \mathrm{L}$ in July 1987 . High concentrations of arsenic in the surficial soil material and in the shallow ground water are known to occur naturally in the area (Glancy, 1986, p. 48). The arsenic probably is derived from weathering of arsenic-rich volcanic rock over geologic time.

Concentrations of dissolved arsenic in the six shallow ground-water samples ranged from 37 to $730 \mu \mathrm{g} / \mathrm{L}$. Five of the six samples exceeded the Nevada drinking-water standard of $50 \mu \mathrm{g} /$. None of the wells are used for drinking-water purposes.

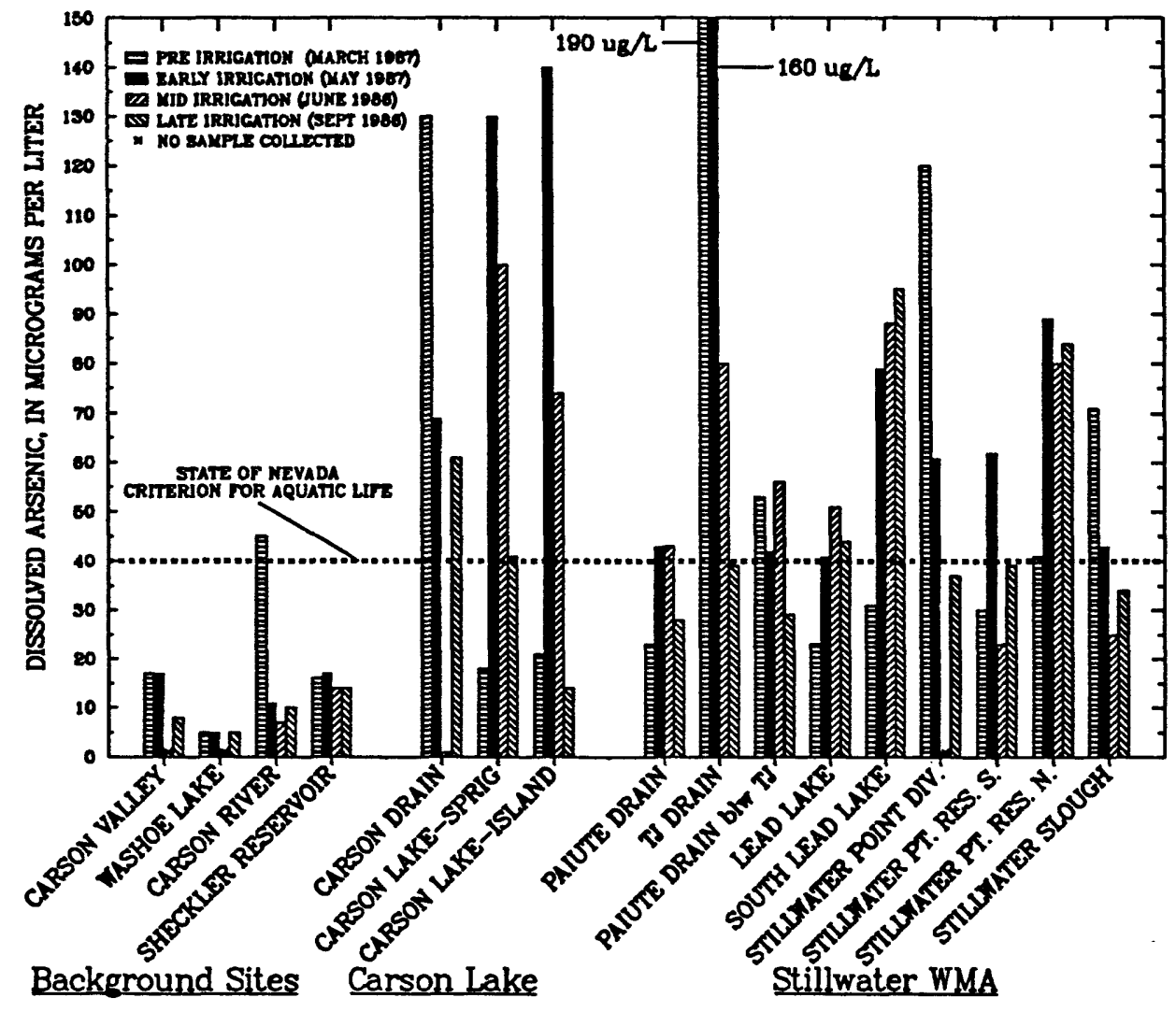

FIGURE 8.--Dissolved arsenic concentrations for surface-water samples in the background sites, Carson Lake, and Stillwater Wildlife Management Area, in downstream order, 1986-87. Water-quality criteria are recommended limiting concentrations for the protection of human health, aquatic life, or crops. Note: chronological data for 1986-87 are rearranged to simulate a single-year irrigation season.

\section{Boron}

Dissolved-boron concentrations in surface-water samples from the principal sampling sites that receive irrigation drainage ranged from 190 to $28,000 \mu \mathrm{g} / \mathrm{L}$ (figure 9), with a median of $2,200 \mu \mathrm{g} / \mathrm{L}$ in 47 samples. In contrast, the median boron concentration in water from the sampling sites unaffected by irrigation (background) was only $190 \mu \mathrm{g} / \mathrm{L}(\mathrm{n}=14)$. According to Birge and Black $(1977, \mathrm{p} .27)$, a boron concentration in water of $200 \mu \mathrm{g} / \mathrm{L}$ represents an effect level for fish reproduction. Poor fish production, of course, may affect resident fish-eating birds, such as the American white pelican. The $200-\mu \mathrm{g} / \mathrm{L}$ boron concentration (effect level) was exceeded in all water samples from all downstream sites during this reconnaissance investigation. 


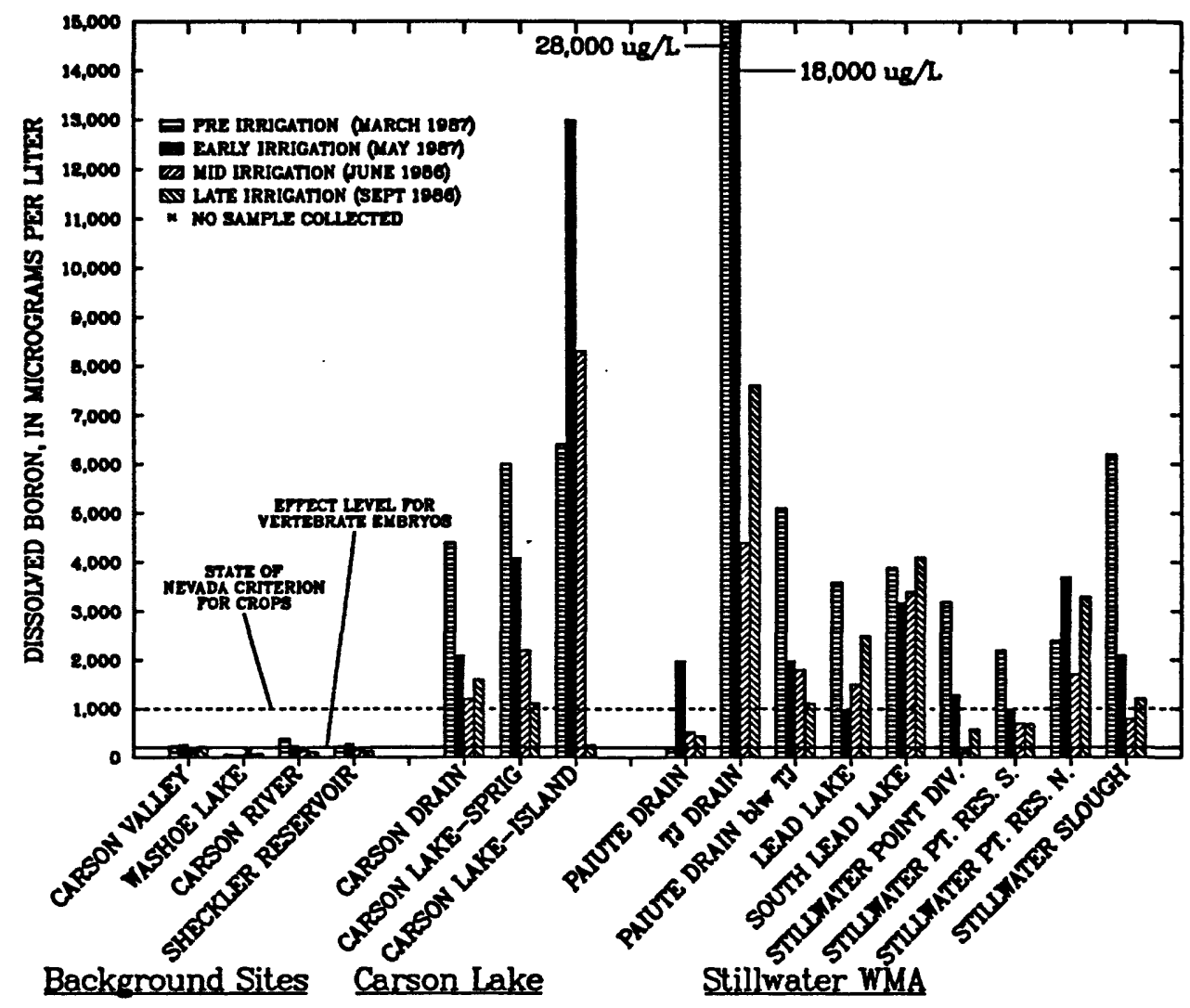

FIGURE 9.--Dissolved boron concentrations for surface-water samples in the background sites, Carson Lake, and Stillwater Wildlife Management Area, in downstream order, 1986-87. Effect level for fish is from Birge and Black (1977, p. 27). Concentrations exceeding effect level may adversely impact the organism. Water-quality criteria are recommended limiting concentrations for the protection of human health, aquatic life, or crops. Note: chronological data for 1986-87 are rearranged to simulate a single-year irrigation season.

For the protection of sensitive crops during long-term irrigation, the Nevada criterion for boron is $1,000 \mu \mathrm{g} / \mathrm{L}$. As with arsenic, the highest concentrations of dissolved boron were usually found in water samples collected during the pre- or early-irrigation season. Of the principal sampling sites, the maximum dissolved-boron concentration was in a water sample from TJ Drain in Stillwater WMA. Other areas that frequently had high boron concentrations were Lead Lake (site 12 in plate 1), Stillwater Point Reservoir (north end; site 17 in plate 1), and Carson Lake.

A logarithmic regression analysis of dissolved boron to dissolved solids (figure 10) in 46 water samples from drains and lakes reveals a strong positive relation between the two variables (correlation coefficient $r^{2}=0.91, \alpha=0.05$ ). The plot includes only data from samples that contained boron concentrations at or in excess of $1,000 \mu \mathrm{g} / \mathrm{L}$ and shows, for the range of data used to develop the relation, that as the dissolved-solids content of water increases, a corresponding increase in the concentration of dissolved boron can be expected. (For those interested in the relafiog between specific conductance and boron, the regression equation is: $\mathrm{B}=2.5$ [specific conductance ${ }^{.89}, \mu \mathrm{S} / \mathrm{cm}$ at $25^{\circ} \mathrm{C} ; \mathrm{r}^{2}=0.82, \alpha 0.05$.) 


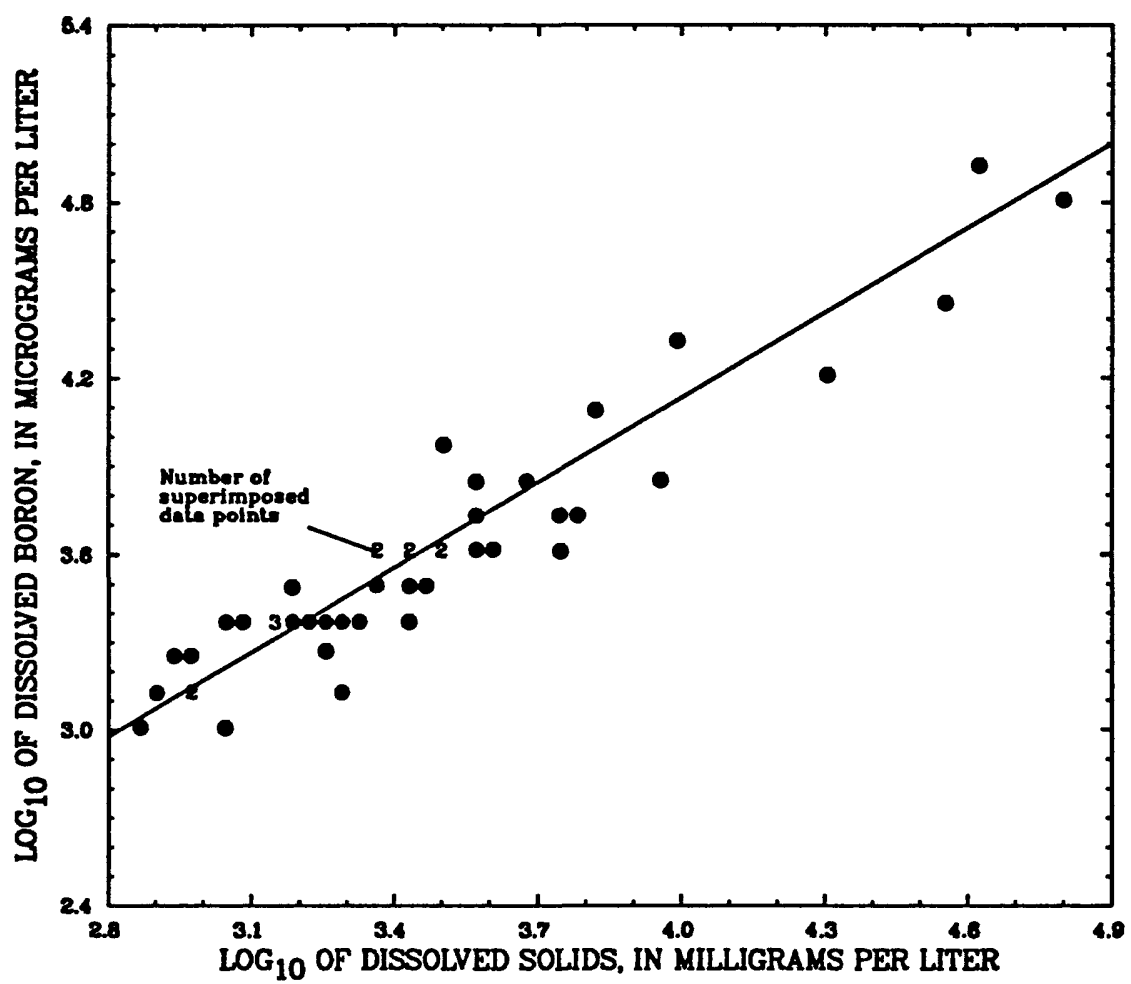

FIGURE 10.--Relation between log dissolved boron to log dissolved solids from agricultural drains and lakes in the Carson Desert, 1986-87.

For the six shallow ground-water sites, water samples contained concentrations of boron that ranged from 22,000 to $120,000 \mu \mathrm{g} / \mathrm{L}$. The highest concentration was found in observation well SW-AH-2 (site 29 in plate 1) near the south end of Stillwater Point Reservoir. These high concentrations of boron probably reflect the dissolution of buried evaporite deposits rich in boron that typify a closed basin in an arid setting. For comparison, seawater contains about $4,500 \mu \mathrm{g} / \mathrm{L}$ of boron $(\mathrm{Hem}, 1985, \mathrm{p} .7)$.

\section{Mercury}

Dissolved mercury in surface water ranged from less than $0.1 \mu \mathrm{g} / \mathrm{L}$ to $1.1 \mu \mathrm{g} / \mathrm{L}$ at the principal sampling sites. The median value for dissolved mercury was $<0.1 \mu \mathrm{g} / \mathrm{L}$ in water samples from the background as well as the downstream sites. Of the 47 water samples from the principal downstream sites, 27 samples, or 57 percent, had concentrations of dissolved mercury that were at or above the analytical reporting limit, thus exceeding the Nevada single-value criterion of $0.05 \mu \mathrm{g} / \mathrm{L}$ for the propagation of wildlife, but well below the aquatic life criterion of $4.1 \mu \mathrm{g} / \mathrm{L}$. Note that the $0.05-\mu \mathrm{g} / \mathrm{L}$-criterion is one-half the analytical reporting limit. The highest concentrations of dissolved mercury were found in a water sample from Lead Lake $(1.1 \mu \mathrm{g} / \mathrm{L})$ in May 1987 and from Stillwater Point Reservoir-south end $(0.9 \mu \mathrm{g} / \mathrm{L}$; site 16 in plate 1$)$ in September 1986. Because of the known affinity of mercury for particulate matter, high concentrations of mercury in filtered samples of surface water (and also ground water) were not expected. In fact, water samples from the six ground-water sites contained mercury at concentrations equal to or below the analytical reporting limit of $0.1 \mu \mathrm{g} / \mathrm{L}$. 


\section{Selenium}

Concentrations of dissolved selenium were low-- $1.0 \mu \mathrm{g} / \mathrm{L}$ or less--at all surface-water sites sampled as part of this investigation. In a separate study, however, the U.S. Bureau of Reclamation (1987a) reported concentrations of dissolved selenium from 16 to $26 \mu \mathrm{g} / \mathrm{L}$ in a minor tributary to TJ Drain. This minor tributary, named TJ Stub by the Bureau, is about 5 miles upgradient from the TJ Drain site that was sampled as part of this reconnaissance. Considering (1) the uncharacteristically high dissolved-solids concentrations in TJ Stub and (2) the similarity in water chemistry between samples from this site and samples of nearby shallow ground water (U.S. Bureau of Reclamation, 1987a, p. B14), the TJ Stub probably represents inflow of water from the shallow aquifer. According to their study, water samples from two test wells near to the TJ Stub site contained high concentrations of selenium ranging to a maximum of $200 \mu \mathrm{g} / \mathrm{L}$. For comparison, the Nevada single-value criterion for selenium is $260 \mu \mathrm{g} / \mathrm{L}$ for the protection of aquatic life, and $50 \mu \mathrm{g} / \mathrm{L}$ for the propagation of wildlife (table 6). But U.S. Environmental Protection Agency (1987, p. 34), suggests that most freshwater organisms will be protected if the 4-day average concentration of selenium does not exceed $5 \mu \mathrm{g} / \mathrm{L}$ more than once every 3 years, or a 1-hour average concentration does not exceed $20 \mu \mathrm{g} / \mathrm{L}$ more than once every 3 years, on the average. These water-quality criteria and the biological-effect range in water, 2 to $5 \mu \mathrm{g} / \mathrm{L}$ (Lemly and Smith, 1987, p. 9), were not exceeded in any water sample collected as part of this reconnaissance investigation.

As with the surface-water sites, the concentration of selenium in water samples from the six shallow ground-water sites (subsurface flow) were either equal to or below the analytical reporting limit of $1.0 \mu \mathrm{g} / \mathrm{L}$.

\section{Radioactive Substances}

Although the significance of elevated concentrations of radioactive substances to fish and wildlife is unknown at this time, information on these substances is considered important and is discussed here because sufficiently high concentrations of radionuclides above natural background amounts are harmful to human health. Gross-alpha values for 62 surface-water samples ranged from 1.3 to $420 \mu \mathrm{g} / \mathrm{L}$ as natural uranium (table 15). The highest concentrations of alpha-emitting elements were in samples from TJ Drain, Lead Lake, Carson Lake Drain (site 5 in plate 1), and Sprig Pond Unit of Carson Lake (site 6, plate 1). Gross beta (52 measurements) ranged from 3.6 to 480 picocuries per liter (pCi/L) as cesium-137 with the highest values in samples from TJ Drain, Lead Lake, and Carson Lake. Radium-226 activities were low in all samples, with 62 measurements ranging from $<0.1$ to $0.5 \mathrm{pCi} / \mathrm{L}$. Uranium concentrations ranged from 0.9 to $300 \mu \mathrm{g} / \mathrm{L}$. The highest value, from TJ Drain in March 1987, more than hundredfold greater than the median uranium concentration (about $3 \mu \mathrm{g} / \mathrm{L}$ ) in the Carson River background site. Other surface-water sites with high dissolved uranium concentrations were Lead Lake, Sprig Pond Unit of Carson Lake, and Washoe Lake (site 2 in plate 1 ).

Six shallow ground-water samples were analyzed for gross alpha and beta, radium-226, and uranium. High concentrations of alpha-emitting elements are present in the shallow ground water near Stillwater WMA and Carson Lake, with values ranging from 16 to $950 \mu \mathrm{g} / \mathrm{L}$ as natural uranium (table 18). Gross beta values ranged from 240 to $1,100 \mathrm{pCi} / \mathrm{L}$ as cesium-137 with the highest activities being present southwest of Stillwater WMA. Radium-226 activities were generally greater than those for surface water in the area and ranged from 0.5 to $2.1 \mathrm{pCi} / \mathrm{L}$. The higher activities were found southwest of Stillwater WMA. Uranium concentrations had a wide range $(1.9$ to $310 \mu \mathrm{g} / \mathrm{L})$ and were highest near Carson Lake. 
Methods used to determine gross activities (alpha and beta) are rapid, semiquantitative measures (Thatcher and others, 1977, p. 29) that are particularly inaccurate in water with high dissolved-solids content, such as those in the Stillwater and Carson Lake. Generally, surface water in Stillwater WMA had lower concentrations of alpha- and beta-emitting elements than were found in shallow ground water. Gross beta values are high compared to those for most ground and surface water. The data in tables 15 and 18 suggest that most of the activity measured in the gross alpha determinations comes from uranium. In most cases, gross alpha values are slightly higher than uranium values for the same sample. Background sites generally had low gross alpha activities except for Washoe Lake which is influenced by the uranium-rich granitic rocks of the Sierra Nevada (Otron and others, 1985, p. 24). The variation in gross alpha and uranium in surface water is due, most likely, to the different geochemistries of the various areas serviced by specific drains. The time of year, relative to the irrigation season, determines the amount of gross alpha and uranium in surface water, with preirrigation (just prior to the start of water deliveries) season having the highest concentrations of these two constituents. Ground-water samples were slightly higher in dissolved uranium and gross alpha than surfacewater samples. Uranium concentration in ground water is directly related to the redox state of the water. One sample (SW-AH-1, site 29 in plate 1) with low dissolved uranium $(1.9 \mu \mathrm{g} / \mathrm{L})$ had sulfide present at $0.6 \mathrm{mg} / \mathrm{L}$ and an Eh (redox potential) of -115 millivolts $(\mathrm{mV})$ indicating uranium was in a reduced, immobile state $\left(\mathrm{U}^{+4}\right.$ ).

Under oxidizing conditions (dissolved oxygen present and Eh values near $300 \mathrm{mV}$ ), uranium is highly soluble, especially in the presence of high concentrations of bicarbonate. The distribution of uranium in other areas of the Carson Desert has been described by Lico and others (1987) and for the Grant's Uranium District in New Mexico by Turner-Peterson and Fishman (1986). Radium-226 activity in surface water is low throughout the area and probably is controlled by radium-sulfate solubility or possibly by adsorption onto surface coatings of grains. Radium-226 values for ground-water samples were slightly higher than those for surface water in the study area. Lower activities in the surface water may be due to dilution of the subsurface drainage component of the drains and lakes by surface runoff from fields and spills from the distribution system. The significance of the elevated concentrations of radioactive substances to fish and wildlife is unknown at this time.

\section{Nitrogen, Phosphorus, and Carbon}

Information on the concentration of the compounds of nitrogen, phosphorus, and organic carbon are important from the standpoint of (1) acute toxicity (involving principally un-ionized ammonia on fish), (2) accelerated eutrophication of surface waters with attendant adverse water-quality problems (involving mainly nitrogen and phosphorus), and (3) trace-element transport in the water column and chemical-reducing conditions in bottom sediments (involving organic carbon).

The concentration of dissolved un-ionized ammonia as nitrogen (calculated $\mathrm{NH}_{3}$ as $\mathrm{N}$ ) in surface waters in Lahontan Valley affected by irrigation drainage ranged from less than 0.001 to $0.239 \mathrm{mg} / \mathrm{L}$ as $\mathrm{N}$, with a median concentration of $0.011 \mathrm{mg} / \mathrm{L}$ for 59 samples (table 13). The median concentration is below the Nevada singlevalue criterion of $0.0164 \mathrm{mg} / \mathrm{L}$ as $\mathrm{N}$ for propagation of cold-water aquatic life. The highest dissolved ammonia value $(0.239 \mathrm{mg} / \mathrm{L})$ was found at Lower Diagonal Drain--an auxiliary site (14 in plate 1$)$ just upstream from Stillwater Point Reservoir--in February 1986 when the water was unseasonably warm $\left(16^{\circ} \mathrm{C}\right)$, highly alkaline ( $\mathrm{pH}$ 9.2), supersaturated with respect to dissolved oxygen ( $>235$ percent), and appeared to contain considerable colloidal organic matter. 


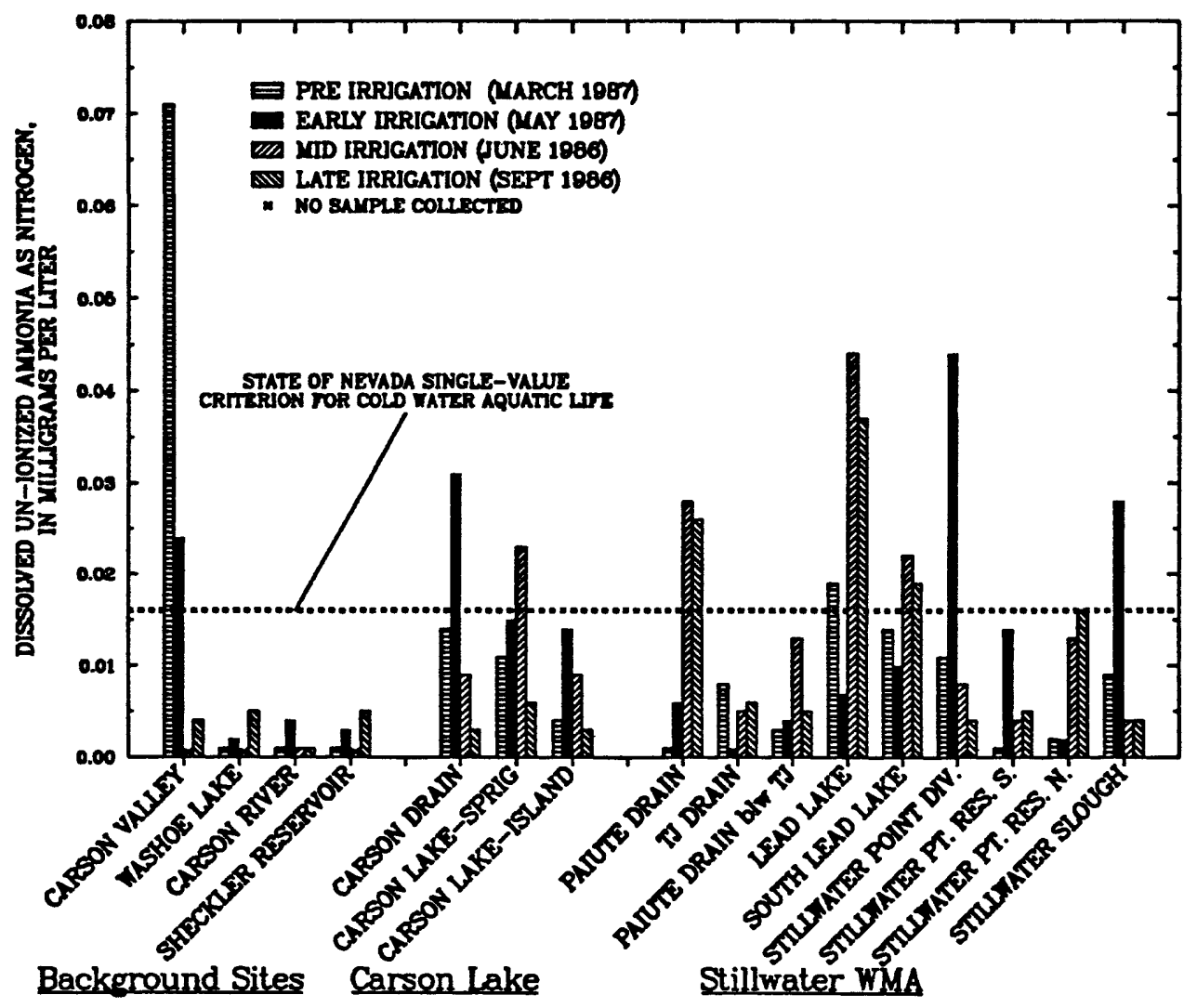

FIGURE 11.--Dissolved un-ionized ammonia $\left(\mathrm{NH}_{3}\right.$ as $\mathrm{N}$ ) concentrations for surface-water samples in the background sites, Carson Lake, and Stillwater Wildlife Management Area, in downstream order, 1986-87. Water-quality criteria are recommended limiting concentrations for the protection of human health, aquatic life, or crops. Note: chronological data for 1986-87 are rearranged to simulate a single-year irrigation season.

The concentration of un-ionized ammonia as nitrogen equaled or exceeded the $0.0164 \mathrm{mg} / \mathrm{L}$ criterion a total of 12 times at 8 of the 12 principal sites affected by irrigation drainage (figure 11). Sufficiently high unionized ammonia concentrations may have been a factor in the unexplained occasional fish die-offs in the Stillwater Marsh. A combination of high $\mathrm{pH}$ and high temperature in the summer months will contribute to high un-ionized ammonia concentrations.

Of the inorganic nitrogen species, dissolved ammonia $\left(\mathrm{NH}_{4}^{+} \text {as } \mathrm{N}\right)^{1}$ usually was found in greatest concentration. At the sampling sites affected by irrigation drainage, the values for 59 samples ranged from less than 0.01 to $0.95 \mathrm{mg} / \mathrm{L}$, with a median of $0.174 \mathrm{mg} / \mathrm{L}$. This median is about sixfold higher than that found at the background sites in this study and threefold higher than in applied water $[0.06 \mathrm{mg} / \mathrm{L}$ at Carson River below Lahontan Dam, a background site (3 in plate 1)] for 15 near-monthly samples reported by Garcia and Carman (1986, p. 100).

1 In table 13 at the back of this report, "nitrogen, ammonia, dissolved as $\mathrm{N}$ " is the analytically combined concentration of the ammonium ion, $\mathrm{NH}_{4}^{+}$, and un-ionized ammonia, $\mathrm{NH}_{3}$, expressed as elemental nitrogen, $\mathrm{N}$. 
Samples of ground water contained concentrations of dissolved ammonia $\left(\mathrm{NH}_{4}\right.$ as $\mathrm{N}$ ) and dissolved nitrite plus nitrate $\left(\mathrm{NO}_{2}+\mathrm{NO}\right.$, as $\left.\mathrm{N}\right)$ that ranged from 0.37 to $34.0 \mathrm{mg} / \mathrm{L}$, and less than $0.10 \mathrm{mg} / \mathrm{L}$ to $0.35 \mathrm{mg} / \mathrm{L}$, respectively (table 18). The unusually high ammonia concentration in the water sample from well SW-AH-1 (site 26 in plate 1), near Stillwater WMA, evidently reflects chemical-reducing conditions in the shallow aquifer at that site $(\mathrm{Eh}=-115 \mathrm{mV})$.

Of the 46 determinations of dissolved nitrite-plus-nitrate (as nitrogen) at the sites affected by irrigation drainage, 33 of them, or about 72 percent, were reported below the analytical reporting limit of $0.1 \mathrm{mg} / \mathrm{L}$. The Carson Lake Drain consistently had the highest dissolved nitrite-plus-nitrate concentrations of the downstream sampling sites, ranging from 0.52 to $1.8 \mathrm{mg} / \mathrm{L}$. For comparison, the median concentration of applied water was $0.03 \mathrm{mg} / \mathrm{L}$. The higher dissolved-ammonia concentrations compared to nitrate reflect biological transformation of organically combined nitrogen to ammonium nitrogen $\left(\mathrm{NH}_{4}^{+}\right.$) during organic matter degradation (Standford and others, 1970).

Concentrations of total phosphorus (TP) at the downstream sites ranged from $0.06 \mathrm{mg} / \mathrm{L}$ to $1.70 \mathrm{mg} / \mathrm{L}$, with the highest concentration found in Stillwater Point Diversion drain (site 15 in plate 1) in March 1987. This drain discharges to Stillwater Point Reservoir. The median TP concentration for the sites affected by irrigation drainage was $0.48 \mathrm{mg} / \mathrm{L}$, which is 1.3 times as great as that $(0.36 \mathrm{mg} / \mathrm{L})$ found at the background sites in this study and 1.8 times that $(0.26 \mathrm{mg} / \mathrm{L})$ reported by Garcia and Carman $(1986$, p. 100$)$ for applied water.

At the downstream sites, concentrations of dissolved orthophosphorus (OP)--the form most readily available for algal uptake--ranged from less than 0.01 to $1.0 \mathrm{mg} / \mathrm{L}$. Here, the highest concentration of $\mathrm{OP}$, as with TP, was found in sample water from Stillwater Point Diversion Drain. The median concentration of OP was about $0.065 \mathrm{mg} / \mathrm{L}$ for 48 samples, which, in contrast to TP, is less, by a factor of $2-3$, than that found in background water in this study (medium $=0.12 \mathrm{mg} / \mathrm{L}$ ) and in 1980 (median $=0.19 \mathrm{mg} / \mathrm{L}$; Garcia and Carman, 1986, p. 100). The decrease of OP in the downstream direction is due to its uptake by plants. Total phosphorus (a measure of the dissolved and suspended fractions) increases downstream because of the attrition of the suspended fraction of phosphorus. Fertilizers used on lawns and farm land are sources of nitrogen and phosphorus to receiving bodies of water. Effluent from sewage treatment plants are another source of these plant nutrients.

The high phosphorus concentrations (1.4-2.5 mg/L OP), as well as nitrogen, at the Carson Valley background site (essentially a slough, site 1 in plate 1) reflects the local input of treated domestic sewage.

A limited number of surface-water samples were collected for the determination of dissolved organic carbon (DOC) and suspended organic carbon (SOC) concentrations (table 13). Few such determinations, if any, have been made in high $\mathrm{pH}$, wetland environments in the arid west (E.M. Thurman, U.S. Geological Survey, oral commun., 1986). Concentrations of DOC ranged from 4.8 to $71 \mathrm{mg} / \mathrm{L}$ with a median of $11 \mathrm{mg} / \mathrm{L}$ for 12 samples. This median concentration is in the 10 to $20 \mathrm{mg} / \mathrm{L}$ average range reported for marshes (Thurman, 1985, p. 59). The highest concentration of DOC was in a water sample from the Carson Lake Drain in May 1987. The highest DOC concentration found in a lake-water sample was $38 \mathrm{mg} / \mathrm{L}$ in Sprig Pond Unit of Carson Lake in March 1987.

According to Thurman (1985, p. 9), DOC concentrations from 10 to $60 \mathrm{mg} / \mathrm{L}$, which are common to marshes, swamps, and bogs, have a dominating effect on water chemistry. Much of Thurman's discussion concerning the effects of dissolved organic compounds in wetlands (1985, p. 58-65) is based on the more abundant literature on low $\mathrm{pH}(<7.0)$ wetlands in humid environments. Waters with high $\mathrm{pH}$ in the arid wetlands favor organic decomposition by bacteria rather than the more acid-tolerant fungi common to swamps and bogs with low $\mathrm{pH}$. 
Most of the determinations of suspended organic carbon (table 13) were reported by the laboratory as "greater than," which makes interpretation of such data difficult.

\section{Bottom-Sediment Samples}

\section{Trace Elements}

Twenty bottom-sediment samples were collected from lakes and drains in the study area. Three of the sites (Washoe Lake, Carson River, and Sheckler Reservoir; site 4 in plate 1) were background sites unaffected by irrigation drainage. Most of the bottom-sediment samples were dark, fine-grained, anaerobic (hydrogen-sulfide odor) muds, except at some of the background sites. Samples ranged from sand at Sheckler Reservoir and Carson River to silty clay at Big Water (site 8 in plate 1), Island, and Sprig Pond Units in Carson Lake, and Paiute Drain (site 9 in plate 1) and Hunter Drain in Stillwater WMA. Particle-size distributions (table 9) clearly show the large percentages of material less than the 0.053 -millimeter $(<63 \mu \mathrm{m})$ fraction at the 18 downstream sites compared with the two background sites. The large percentage of the siltclay fraction (with the inherently larger ratio of surface area to volume) indicates the high potential for the adsorption of trace elements, especially metals.

A cursory examination of the trace-element data obtained in the present reconnaissance (table 16) compared with geochemical baselines for soils in the western United States (R.C. Severson, U.S. Geological Survey, written commun., 1987, using data from Shacklette and Boerngen, 1984), shows that the concentrations of arsenic, lithium, mercury, and molybdenum in the bottom-sediment samples equal or exceed the maximum baseline range in soils for each of these four constituents. When compared with typical soils of the Carson Desert (R.R. Tidball, U.S. Geological Survey, written commun., 1988) all bottom-sediment samples had trace-element concentrations within the range of these soils. Comparison of bottom sediments in this study with the geochemical data of Shacklette and Boemgen (1984) are questionable. Data reported by Shacklette and Boerngen are from samples of B-horizon soils (8-in. depth) that have no direct geochemical relation to the typical reduced bottom-sediment samples collected in this study. Analysis of whole sediment samples ( $<2 \mathrm{~mm}_{\text {fraction }}{ }^{2}$ ), as reported by Shacklette and Boerngen (1984, p. 3-5) and this study, show lower concentrations of trace elements than does the $<63 \mu \mathrm{m}$ or $<125 \mu \mathrm{m}$ fraction that is biologically available or geochemically active (Horowitz and Elrick, 1987). This is because surface coatings of iron and manganese (oxy)hydroxides and oxides and organic matter coat most grains. These coatings are efficient adsorbers of many trace elements, including arsenic, selenium, and most positively charged trace metals. Scientific research also has shown that a strong positive correlation exists between decreasing grain size and increasing trace-element concentrations (Horowitz and Elrick, 1987).

' $<2 \mathrm{~mm}$, material smaller than very fine gravel; $<125 \mu \mathrm{m}$, material smaller than very fine sand; $<62-63 \mu \mathrm{m}$, material smaller than coarse silt (Guy, 1969, p. 7) 


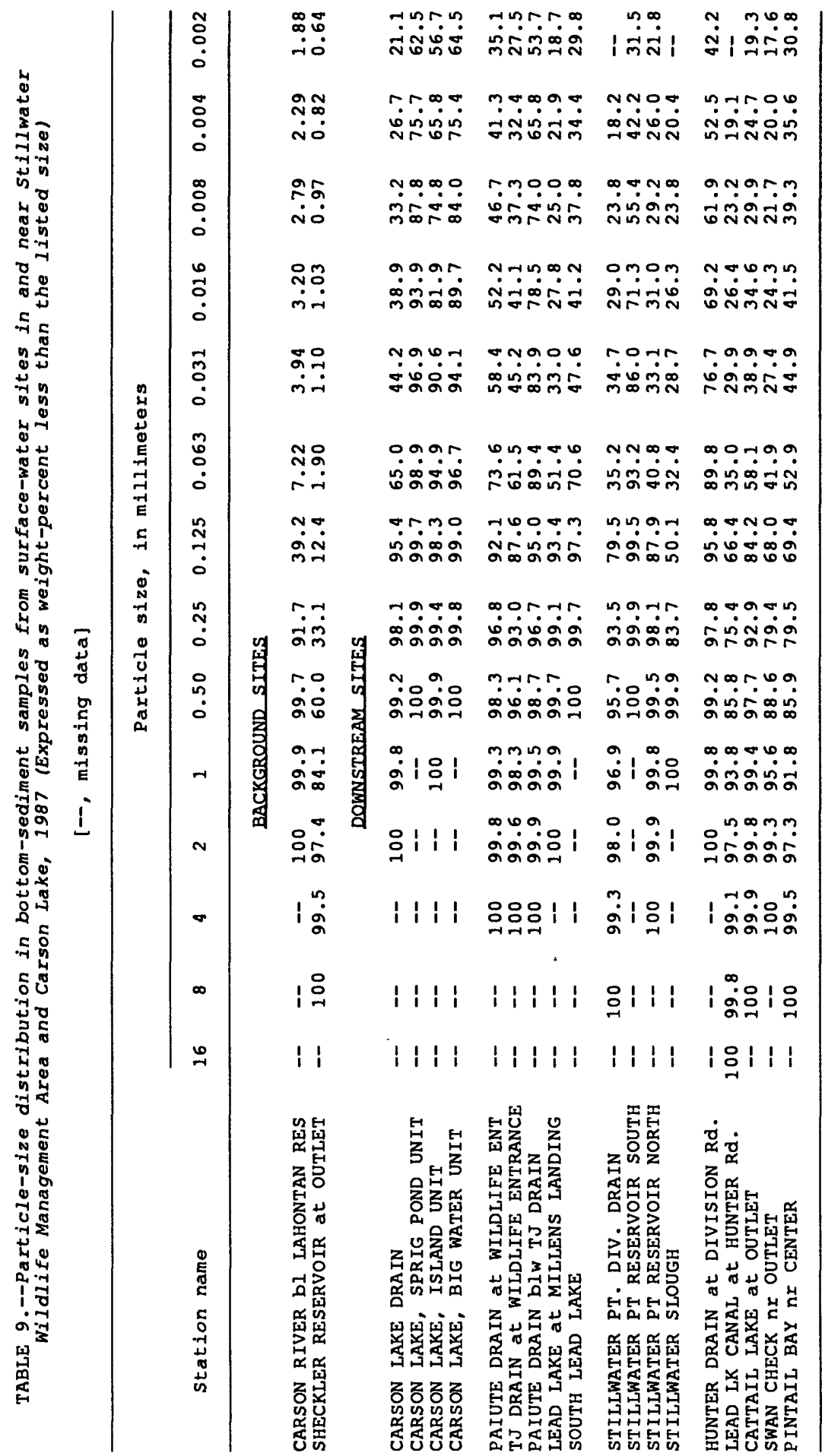


The highest concentrations of arsenic in the sediments in Stillwater WMA were found at the TJ Drain site (31 mg/kg)' and south Lead Lake (16 mg/kg); and at two Carson Lake sites; Island Unit (19 mg/kg) and Sprig Pond Unit ( $20 \mathrm{mg} / \mathrm{kg}$ ). Only one of these sites (TJ Drain) exceeded the maximum baseline value for soils of $22 \mathrm{mg} / \mathrm{kg}$ arsenic. Background concentrations of arsenic ranged from about 3 to $11 \mathrm{mg} / \mathrm{kg}$. Arsenic concentrations of lithic rock fragments from the shallow subsurface (20 feet of depth) about 1 mile north of Carson Lake (Lico and others, 1986 , table 6) are slightly greater $(28-36 \mathrm{mg} / \mathrm{kg}$ ) than those found in this study. Wholesediment samples in the same study had comparable arsenic concentrations $(4-25 \mathrm{mg} / \mathrm{kg})$ to those reported in this study.

The highest concentrations of total selenium in bottom-sediment samples also were found at TJ Drain and South Lead Lake; and two Carson Lake sites (the Sprig Pond and Island Units). Concentrations of selenium at sites downstream of irrigated areas ranged from 0.2 to $1.2 \mathrm{mg} / \mathrm{kg}$, whereas concentrations at background sites ranged from $<0.1$ to $0.6 \mathrm{mg} / \mathrm{kg}$. All bottom-sediment samples had selenium concentrations less than the maximum baseline value for soils of the western United States $(1.4 \mathrm{mg} / \mathrm{kg})$. The selenium concentration in sediment cores from wells (3.5-60.5 feet of depth) north of Carson Lake (Lico and others, 1986, table 7) ranged from $<0.02$ to $0.3 \mathrm{mg} / \mathrm{kg}$ for the $<62-\mu \mathrm{m}$ fraction. This may indicate that some of the bottom-sediment samples in the study area are enriched in selenium, especially those from the Sprig Pond and Island Units of Carson Lake, TJ Drain, and South Lead Lake. According to Lemly and Smith (1987, p. 9), a concentration of selenium in sediment equal to or greater than $4 \mu \mathrm{g} / \mathrm{g}$ dry weight is a level of concern to fish and wildlife.

Mercury concentrations ranged from 0.04 to $18 \mathrm{mg} / \mathrm{kg}$ at sites affected by irrigation drainage. The median background concentration for mercury in this study was $0.41 \mathrm{mg} / \mathrm{kg}$ and was exceeded in nine bottomsediment samples. For comparison, the maximum baseline concentration of mercury for soils in the western United States is $0.25 \mathrm{mg} / \mathrm{kg}$. The highest concentration of mercury $(18 \mathrm{mg} / \mathrm{kg})$ was found in bottom sediments from Carson Lake. Bottom sediment from Stillwater Slough, (site 18, plate 1) an old channel of the Carson River, had a mercury concentration of $14 \mathrm{mg} / \mathrm{kg}$. These values are 44 -fold and 34-fold greater, respectively, than the median background concentration. A moderately high concentration of mercury $(0.67 \mathrm{mg} / \mathrm{kg})$ also was found in sampled bottom sediments from Washoe Lake, a background site. Mercury-contaminated surficial sediments are widely distributed in the Carson Desert. High concentrations of mercury, in general, tend to be present in areas where the Carson River has deposited sediment in the recent past. In the late 1800's, about 7,000 tons of sediment-bound mercury was lost downstream from the upper Carson River basin during the milling of gold and silver ore (Smith, 1943, p. 247).

Molybdenum concentrations ranged from $<2$ to $11 \mathrm{mg} / \mathrm{kg}$ and five samples exceeded or equaled the maximum baseline value in soil ( $4.0 \mathrm{mg} / \mathrm{kg}$ ). Samples from TJ Drain (11 mg/kg), Sprig Pond Unit in Carson Lake $(7 \mathrm{mg} / \mathrm{kg}$ ), and South Lead Lake ( $7 \mathrm{mg} / \mathrm{kg}$, site 13 on plate 1) had the highest concentrations of molybdenum.

Lithium concentrations ranged from 25 to $94 \mathrm{mg} / \mathrm{kg}$ and equaled or exceeded the maximum baseline value in soils of $55 \mathrm{mg} / \mathrm{kg}$ in nine samples from the downstream sites. Stillwater Point Reservoir (north end) and Paiute Drain bottom sediments each had concentrations of $94 \mathrm{mg} / \mathrm{kg}$ lithium. Big Water Unit in Carson Lake and Washoe Lake (background site) had concentrations of 86 and $81 \mathrm{mg} / \mathrm{kg}$ lithium, respectively, in bottom-sediment samples.

\footnotetext{
' $\mathrm{mg} / \mathrm{kg}$ dry weight is equivalent to $\mu \mathrm{g} / \mathrm{g}$ dry weight.
} 


\section{Organochlorine Pesticides}

Bottom-sediment samples from 18 sites in the study area were analyzed for organochlorine pesticides. Organochlorine pesticides were present in sediment samples from 15 of the 18 sites (table 17). DDT and its metabolites, DDE and DDD, were the most common pesticides found and ranged in concentration from $<0.1$ to $0.2,<0.1$ to 2.1 , and $<0.1$ to $3.2 \mu \mathrm{g} / \mathrm{kg}$ dry weight, respectively. The highest concentrations of DDT and its metabolites were in samples from Williams Slough, a background site in Carson Valley. Samples from Carson Lake Drain and Stillwater Point Reservoir also contained measurable concentrations of DDT and its metabolites. A bottom-sediment sample from Cattail Lake (supplemental site) in Stillwater WMA contained chlordane at a concentration of $45 \mu \mathrm{g} / \mathrm{kg}$ dry weight. Chlordane also was present in bottom sediment from the Carson River below Lahontan Reservoir site at a concentration of $3.0 \mu \mathrm{g} / \mathrm{kg}$ dry weight.

Lindane was present in bottom-sediment samples collected from 3 of 18 sites. The concentrations were $4.7 \mu \mathrm{g} / \mathrm{kg}$ at Pintail Bay, $2.0 \mu \mathrm{g} / \mathrm{kg}$ at Hunter Drain, and $0.8 \mu \mathrm{g} / \mathrm{kg}$ at Cattail Lake. For the protection of aquatic life from chronic toxicity, the normalized' concentration of lindane $(340 \mu \mathrm{g} / \mathrm{kg})$ at Pintail Bay exceeded the mean sediment quality criteria (SQC) value $(160 \mu \mathrm{g} / \mathrm{kg})$ nearly twofold. For Hunter Drain, the normalized concentration $(140 \mu \mathrm{g} / \mathrm{kg})$ was only slightly less than the mean $S Q C$ value $(160 \mu \mathrm{g} / \mathrm{kg})$. For Cattail Lake, the normalized concentration $(60 \mu \mathrm{g} / \mathrm{kg})$ was nearly threefold less than the SQC value (U.S. Environmental Protection Agency, 1988, table 4).

Dieldrin was detected in bottom-sediment samples from four sites with a maximum reported concentration of $4.6 \mu \mathrm{g} / \mathrm{kg}$ at Cattail Lake. The normalized concentration of dieldrin $(810 \mu \mathrm{g} / \mathrm{kg})$ was greatly less than the mean SQC value $(20,000 \mu \mathrm{g} / \mathrm{kg})$ for the protection of aquatic life from chronic toxicity (U.S. Environmental Protection Agency, 1988, table 4).

Polychlorinated biphenyls (PCB's) were detected in two samples (Stillwater Point Reservoir south end, $6 \mu \mathrm{g} / \mathrm{kg}$, and Cattail Lake, $2 \mu \mathrm{g} / \mathrm{kg}$ ). For protecting the uses of aquatic life, the normalized concentration of PCB's for these two sites (1,000 $\mu \mathrm{g} / \mathrm{kg}$ and $350 \mu \mathrm{g} / \mathrm{kg}$, respectively) were well below the mean SQC value of $20,000 \mu \mathrm{g} / \mathrm{kg}$ (U.S. Environmental Protection Agency, 1988, table 4). No detectable levels (see table 17, at the back of this report) of PCN (pentachloronitrobenzene), endosulfan, endrin, toxaphene, mirex, or perthane were found in bottom-sediment samples from the 18 sites sampled. With the possible exception of lindane in sediments in terminal wetlands, the low concentrations of organochlorine pesticides found in bottom sediments collected as part of this study suggest that these man-made compounds are not an immediate threat to fish and wildlife in the area.

' Corrected for measured organic carbon content of bottom sediment. 


\section{Biological Samples}

In the study area, five trace elements have been identified in plant and animal tissues in sufficient concentration to cause some adverse effect or to be of concern, either directly or indirectly, to wetland organisms. The list presently includes arsenic, boron, chromium, mercury, and selenium. Other trace elements may represent potential contaminants but criteria do not exist to determine if the concentrations are high enough to cause an identifiable effect. As toxic substances accumulate in the environment, adverse biological effects eventually may become more apparent. Many of the known or suspected effects of biological concern, such as decreased nesting success, bird production, increased incidence of malformed young, reductions of key food species, and aquatic vegetation loss have been observed in the study area.

A total of 181 biological samples were analyzed by the laboratory for an array of organochlorine pesticides which have been used from time to time in the study area. All organochlorine results were less than the analytical reporting limits and are, therefore, not further commented on.

Because harmful concentrations of contaminants and their potential effects are not clearly defined at this time, all basic biological data are included in table 19.

The discussion in the following section is arranged alphabetically by trace-element contaminants and, for each element, the biota are discussed in order of ascending trophic level.

\section{Arsenic}

Plants

Arsenic concentrations in plant tissue ranged from less than the analytical reporting limit of $0.2 \mu \mathrm{g} / \mathrm{g}$ to $111 \mu \mathrm{g} / \mathrm{g}$ dry weight. Criteria to evaluate the significance of arsenic concentrations in aquatic plant tissues are unavailable. The Patuxent Wildlife Research Center (1987, p. 9-13), however, has determined that a diet which contains as little as $30 \mu \mathrm{g} / \mathrm{g}$ dry weight arsenic as sodium arsenate will retard growth of female mallard (Anas platyrhynchos) ducklings. Lower concentrations of arsenic were not evaluated. Concentrations greater than this $30-\mu \mathrm{g} / \mathrm{g}$ effect level were found in composite samples of filamentous algae at a total of six sites within Fernley WMA, Humboldt WMA, Massie Slough, and Carson Lake (ranging from $31.2 \mu \mathrm{g} / \mathrm{g}$ to $46.7 \mu \mathrm{g} / \mathrm{g}$ ); in samples of pondweed at a total of six sites within Humboldt WMA, Massie Slough, and Carson Lake (ranging from $32.4 \mu \mathrm{g} / \mathrm{g}$ to $82.4 \mu \mathrm{g} / \mathrm{g}$ ); and in samples of cattail and bulrush at a total of seven sites within Fernley WMA, Massie Slough, and Carson Lake (ranging from $32.6 \mu \mathrm{g} / \mathrm{g}$ to $111 \mu \mathrm{g} / \mathrm{g}$ dry weight).

As primary producers, all aquatic plans in the study area are important food items to one or more higher trophic levels. 
Insects

Criteria for arsenic concentrations in invertebrate tissue also are unavailable. Researchers from the Patuxent Wildlife Research Center (1987, p. 13) have identified a dietary effect concentration of $30.0 \mu \mathrm{g} / \mathrm{g}$ dry weight arsenic as sodium arsenate. Aquatic insects are an important diet item in ducklings of many species. As shown in figure 12, insects within the study area contain greater concentrations of arsenic compared to most of the samples from the background sites. The highest arsenic levels in composite insect samples (17.5 $\mu \mathrm{g} / \mathrm{g}$ dry weight) were collected in Mahala Slough (site 34 in plate 1), a wetland that does not produce many ducks. Juvenile ducks eat insects in combination with aquatic plants. Therefore, ducklings feeding on aquatic insects containing these elevated concentrations exclusively would accumulate a concentration of arsenic which would potentially retard their growth.

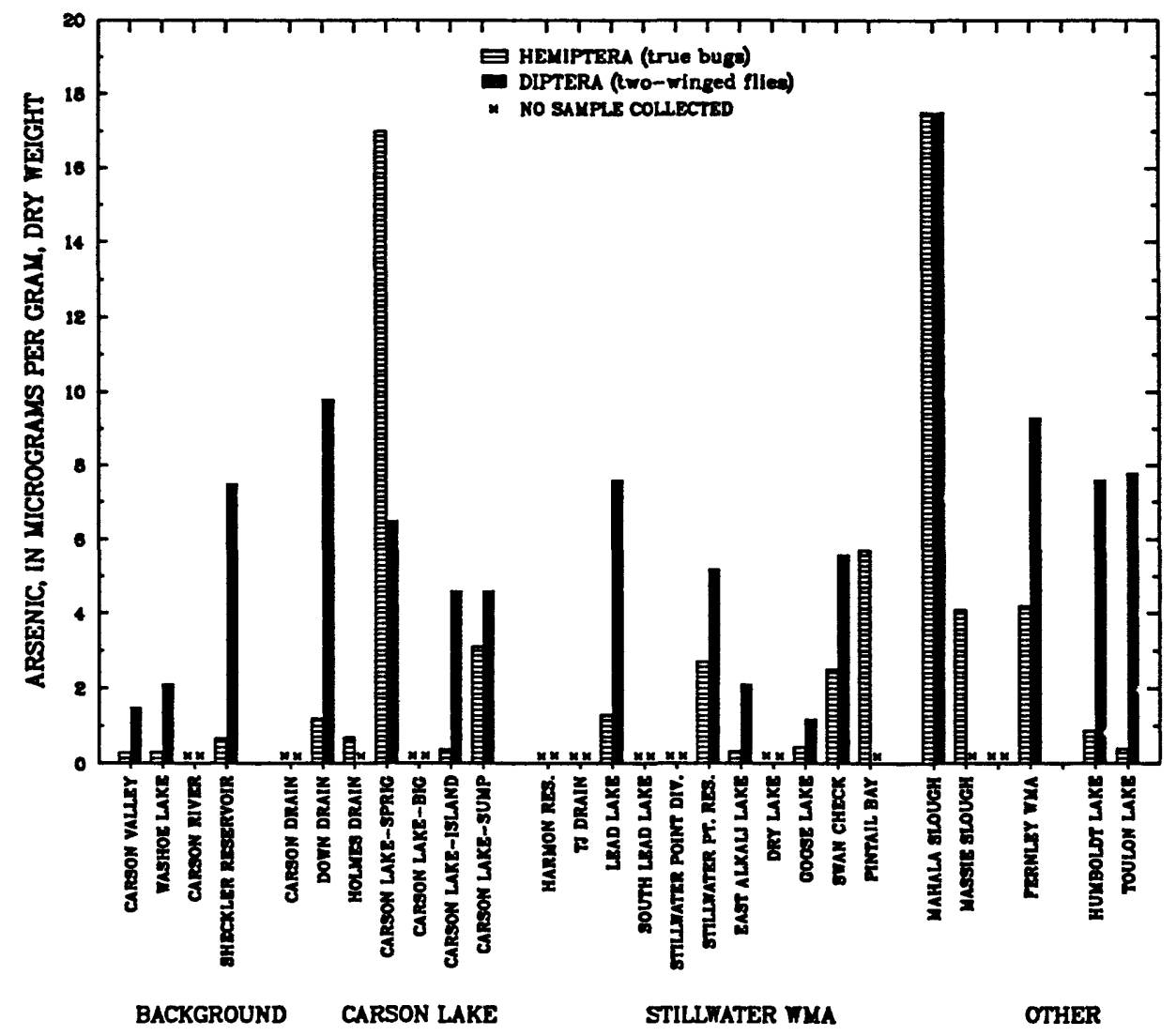

FIGURE 12.--Arsenic concentrations found in composite insect samples in the background sites, Carson Lake, and Stillwater, Femley, and Humboldt Wildlife Management Areas, in downstream order, 1986-87.

Fish

The concern level for arsenic residue in whole fish is $0.81 \mu \mathrm{g} / \mathrm{g}$ dry weight (Lowe and others, 1985, p. 370). Median arsenic concentrations exceeded this concern level in both carp (Cyprinus carpio) and mosquito fish (Gambusia affinis) from Carson Lake Drain at Carson Lake and in carp from Humboldt Lake (site 37 in plate 1) in Humboldt WMA (figures 13A and 13B). Tissue levels from the same species collected from the background sites, Carson Valley and Washoe Lake, were near or below the analytical reporting limit. Gilderhus (1966, p. 295) reported that a residue level of $4.68 \mu \mathrm{g} / \mathrm{g}$ dry weight in whole juvenile bluegills (Lepomis macrochirus) was associated with poor growth and survival. Median tissue level in composite wholebody mosquito fish samples from Massie Slough (site 35 in plate 1) approached $4.68 \mu \mathrm{g} / \mathrm{g}$ dry weight (figure 13B). No other species of fish was found during sampling efforts at Massie Slough. 

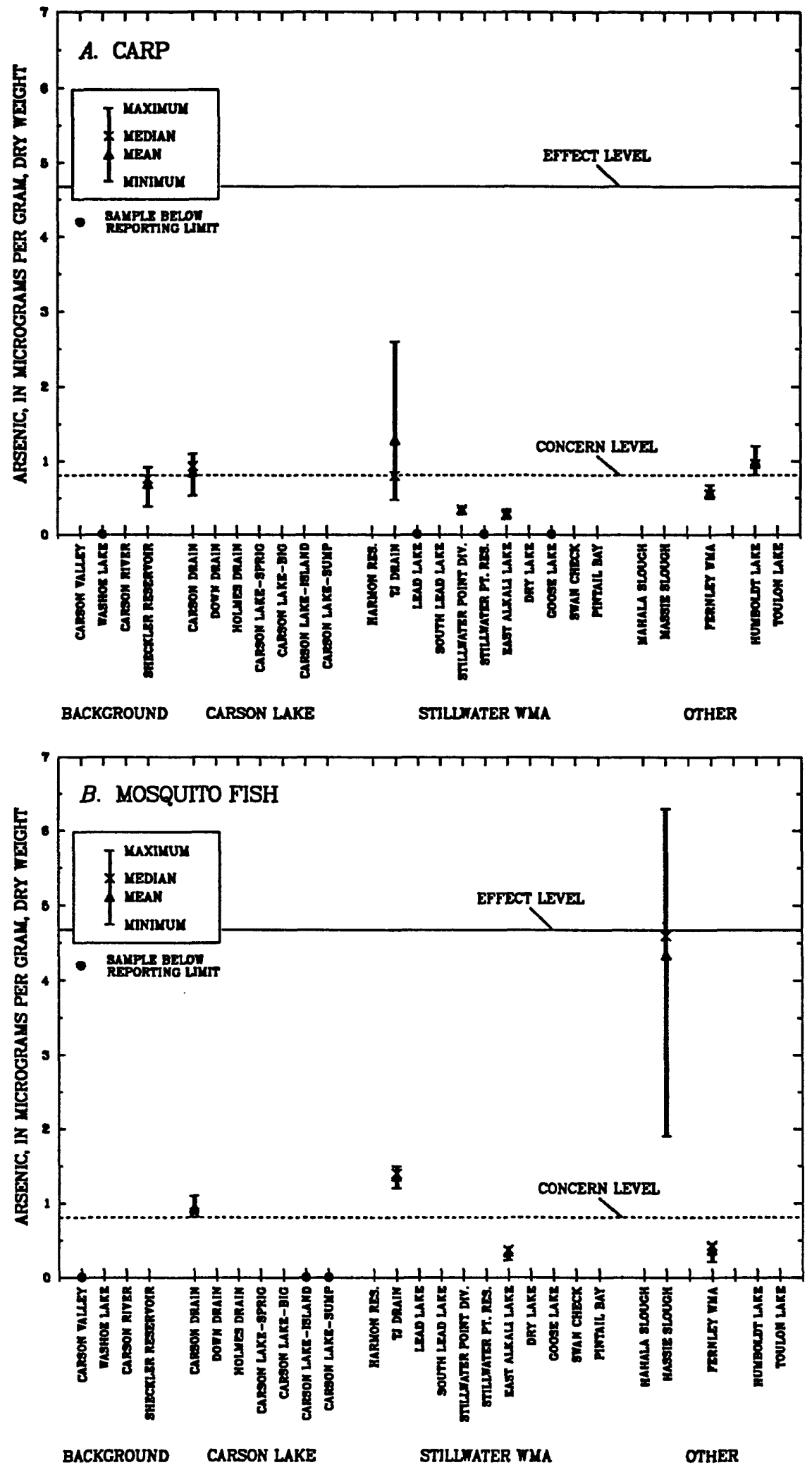

FIGURE 13.--Arithmetic means, medians, and maximum-minimum ranges of arsenic concentrations found in tissue of (A) carp and (B) mosquito fish, in the background sites, Carson Lake, and Stillwater, Femley, and Humboldt Wildlife Management Areas, in downstream order, 1986-87. Concem level for fish is 0.81 microgram per gram, dry weight (Lowe and others, 1985, p. 370); effect level for fish is 4.68 micrograms per gram, dry weight (Gilderhus, 1966, p. 295). (Samples not collected at all sites.) Concentrations exceeding concem level may indicate exposure of the organism to contaminants. Concentrations exceeding effect level may adversely impact the organism. 


\section{Birds}

Concentrations of arsenic in bird livers typically ranged from less than the analytical reporting limit to about $1.3 \mu \mathrm{g} / \mathrm{g}$ dry weight in the study areas and background sites (figures 14A and 14B). On the basis of arsenic bioassays, Geode (1985, p. 303) has defined a concern level for arsenic residue in bird livers of between 7.2 and $36.0 \mu \mathrm{g} / \mathrm{g}$ dry weight. The median value of arsenic residue in seven juvenile American coot (Fulica americana) livers from Massie Slough was $18.0 \mu \mathrm{g} / \mathrm{g}$ dry weight. In 1987 Massie Slough contained about 1,200 acres of wetlands. Birds collected in this study were believed to be the majority of the juvenile coots available. Coot production within the study area appeared unusually low for a wetland of this size.

\section{Boron}

\section{Plants}

Boron has been demonstrated to adversely affect growth of mallard ducklings at $100 \mu \mathrm{g} / \mathrm{g}$ dry weight in the diet (Patuxent Wildlife Research Center, 1987, p. 9-13). Boron concentrations in 22 of 28 plant tissue data, or 79 percent (figures 15A, 15B, and 16), exceed this effect criterion in Stillwater WMA, Fernley WMA, and Carson Lake. The highest median concentration observed was $760 \mu \mathrm{g} / \mathrm{g}$ dry weight in composite samples of Sago pondweed (Potamogeton pectinatus) from East Alkali Lake in Stillwater WMA. Sago pondweed is an important forage plant for waterfowl in the Stillwater WMA and management procedures are based upon production of this plant. Boron residue in similar plant tissues from the background sites were low (usually less than the reporting limit).

\section{Insects}

Criteria for evaluating direct effects of boron residue levels on aquatic insects are unavailable; however, indirect effects have been demonstrated. Growth of mallard ducklings is reduced when dietary concentrations of boron exceed $100 \mu \mathrm{g} / \mathrm{g}$ dry weight (Patuxent Wildlife Research Center, 1987, p. 9-13). Ducklings commonly feed upon invertebrates which are considered important dietary items because of their high protein content. The boron effect criterion (figure 17) was exceeded in dipteran larvae from Carson Lake Sump ( $180 \mu \mathrm{g} / \mathrm{g}$ dry weight) and in hemipteran adults from Pintail Bay in Stillwater WMA (217 $\mu \mathrm{g} / \mathrm{g}$ dry weight). Both wetland units are at times considered disposal areas for water which is of marginal utility for wildlife management purposes. The highest concentration of boron in water observed in this study was $73,000 \mu \mathrm{g} / \mathrm{L}$ in Pintail Bay. Concentrations of boron in insect tissue from the background sites ranged from 35.0 to $48.0 \mu \mathrm{g} / \mathrm{g}$ dry weight. Similar residue levels were found in most wetland units that were sampled (figure 17).

Because of the paucity of toxicological information concerning boron in fish, a discussion is not attempted here. Most of the boron concentrations in fish were less than or near the analytical reporting limit. 

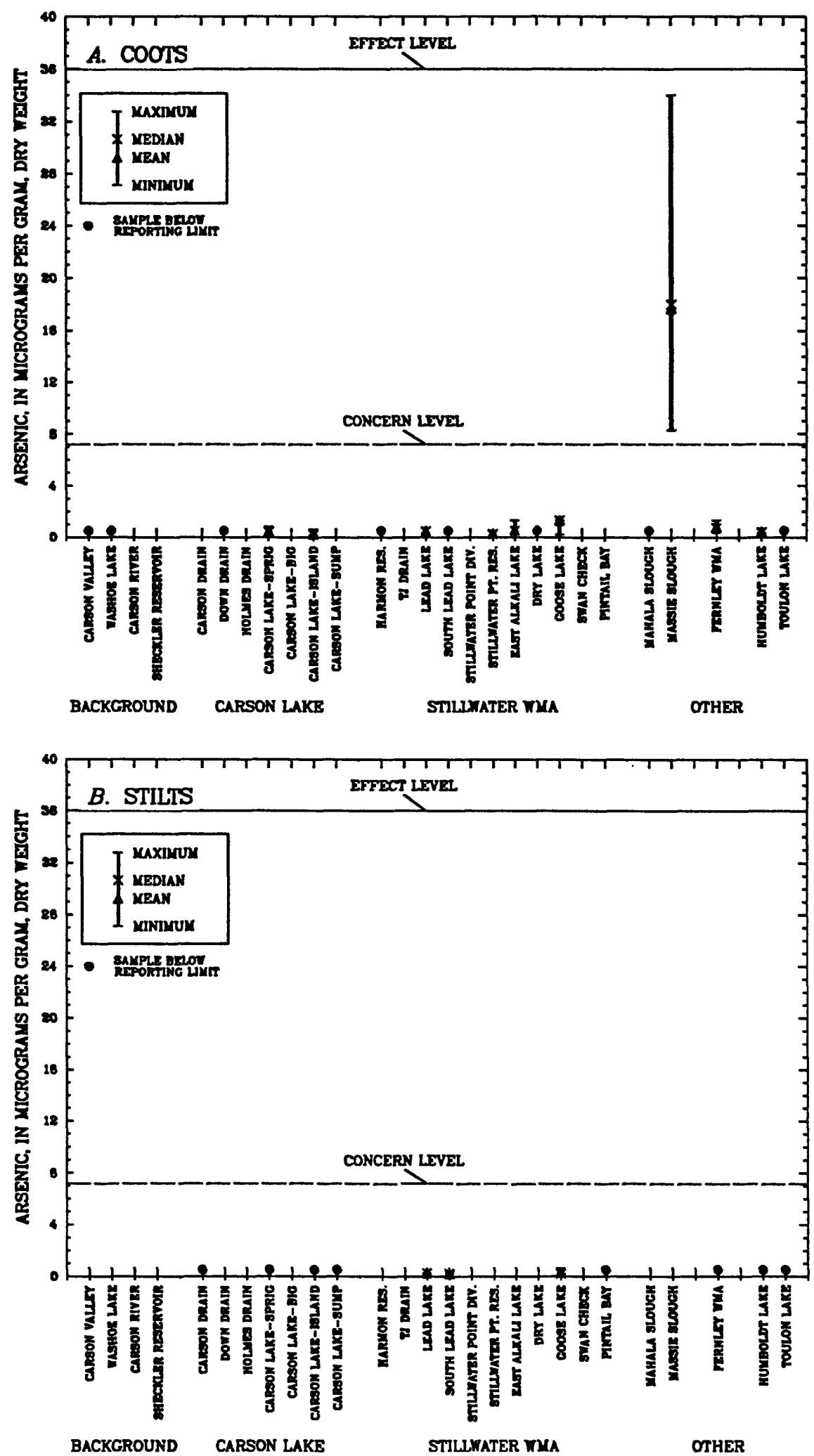

FIGURE 14.--Arithmetic means, medians, and maximum-minimum ranges of arsenic concentrations found in livers of (A) juvenile coots and (B) juvenile black-necked stilts in the background sites, Carson Lake, and Stillwater Wildlife Management Area, in downstream order, 1986-87. (Samples not collected at all sites.) Concem level for bird liver is from Geode (1985, p. 303). Concentrations exceeding concern level may indicate exposure of the organism to contaminants. 

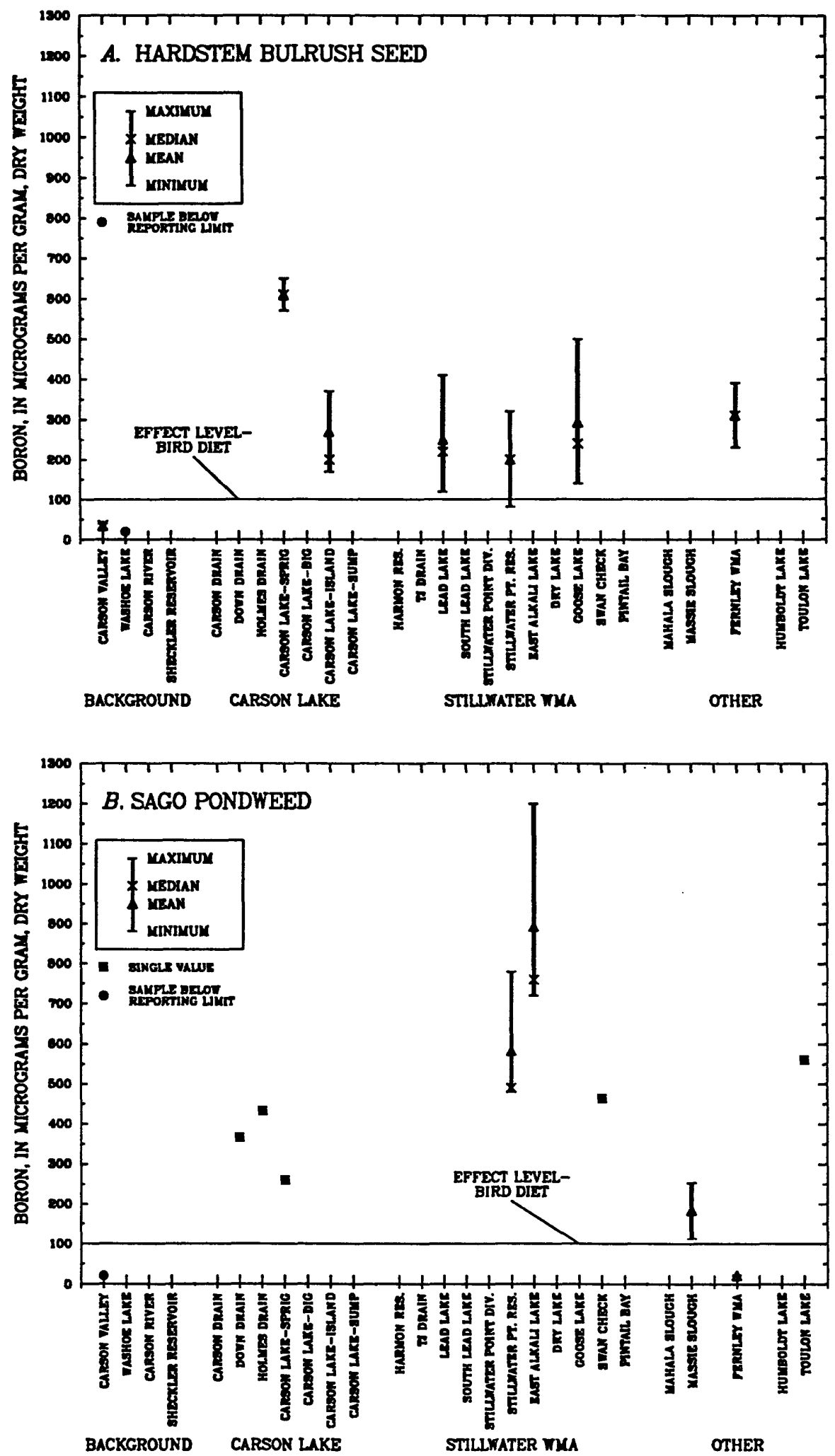

FIGURE 15.--Arithmetic means, medians, and maximum-minimum ranges of boron concentrations found in tissues of (A) hardstem bulnush seed and (B) sago pondweed, in the background sites, Carson Lake, and Stillwater and Fernley Wildlife Management Areas, in downstream order, 1986-87. Growh effect level for bird diet is from Patuxent Wildlife Research Center (1987, p. 9-13). (Samples not collected at all sites.) Concentrations exceeding effect level may adversely impact the organism. 


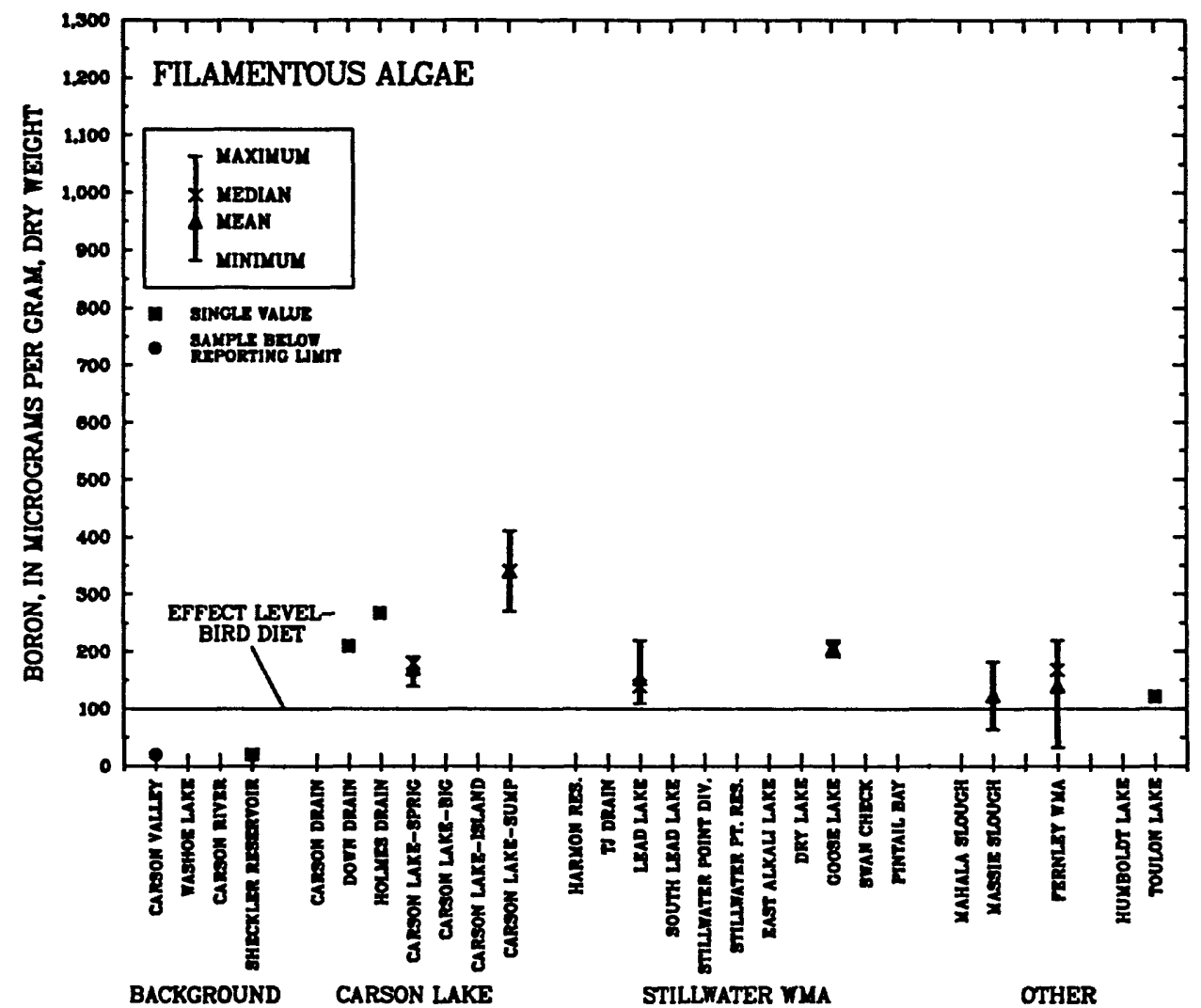

FIGURE 16.-Arithmetic means, medians, and maximum-minimum ranges of boron concentrations found in filamentous algal tissue in the background sites, Carson Lake, and Stillwater and Fernley Wildlife Management Areas, in downstream order, 1986-87. Effect level is for bird diet is from Patuxent Wildlife Research Center (1987, p. 9-13). (Samples not collected at all sites.) Concentrations exceeding effect level may adversely impact the organism.

Birds

The residue level of boron in mallard duck livers associated with impaired reproduction is $60 \mu \mathrm{g} / \mathrm{g}$ dry weight (Gregory J. Smith, U.S. Fish and Wildlife Service, oral commun., 1986). This criterion was exceeded in median boron residue levels in juvenile avocets (Recurvirostra americana) from the Sprig Pond Unit and Islands Unit in Carson Lake and in juvenile coots from Goose Lake in Stillwater WMA (site 32 in plate 1), and juvenile black-neck stilts (Himantopus mexicanus) from the Islands Unit in Carson Lake (figures 18A, 18B, and 19). All these juvenile birds were taken during 1986. Some boron in juvenile tissue might be attributable to areas outside Lahontan Valley with high ambient boron concentrations and appear in eggs of arriving migrating adults. Ten adult stilts were taken within days of arrival (April 1987) at the Islands Unit in Carson Lake. The median liver boron residue level in these 10 birds was $2.5 \mu \mathrm{g} / \mathrm{g}$ dry weight. Thus, juvenile stilts appear to accumulate boron within the study area. 
During 1987 an effort was made to verify the unusually high boron concentrations that were observed in juvenile birds during 1986. Juvenile stilts were taken in 1987 from the Islands Unit and Sprig Pond Unit in Carson Lake. The results indicated residue levels of boron ranging from less than the reporting limit to $4.0 \mu \mathrm{g} / \mathrm{g}$. The wide discrepancy of boron residue in liver, between 1986 and 1987, appears throughout the available data. For example, the highest residue concentration of boron in livers among the 198 stilts and coots represented in the 1987 data was only $13 \mu \mathrm{g} / \mathrm{g}$ dry weight. Whereas, the average boron residue level in livers of the 25 juvenile birds, represented in the four data sets exceeding effect criteria in 1986, was about $93 \mu \mathrm{g} / \mathrm{g}$ dry weight. Differences in laboratory analytical procedures or possible sample contamination, or both, were ruled out as a cause of the between-year boron concentrations. The large disparity in concentration requires further research.

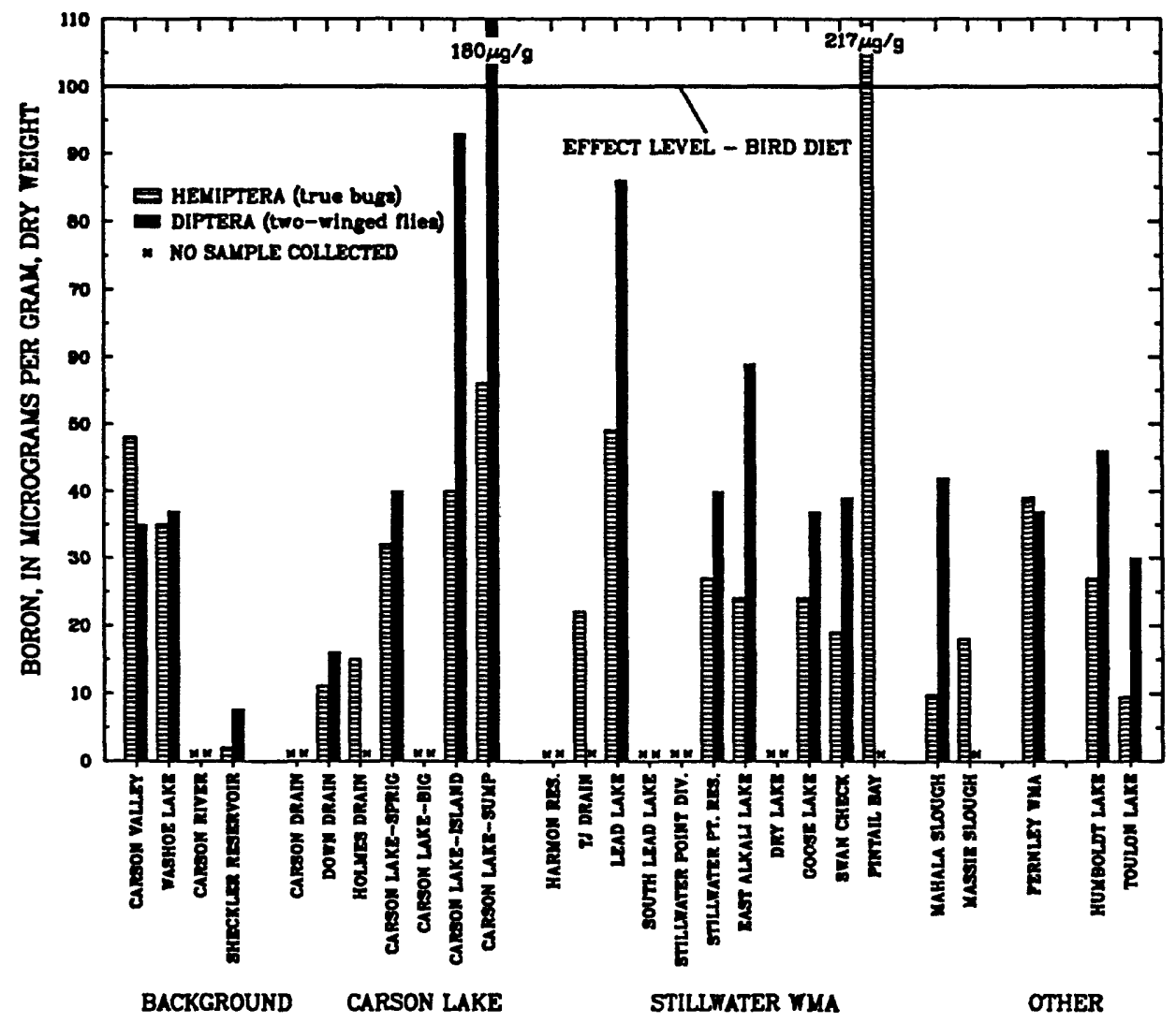

FIGURE 17.--Boron concentrations found in composite insect samples in the background sites, Carson Lake, and Still water, Femley, and Humboldt Wildlife Management Areas, in downstream order, 1986-87. Effect level for bird diet is from Patuxent Wildlife Research Center (1987, p. 9-13). (Samples not collected at all sites.) Concentrations exceeding concem level may indicate exposure of the organism to contaminants. 

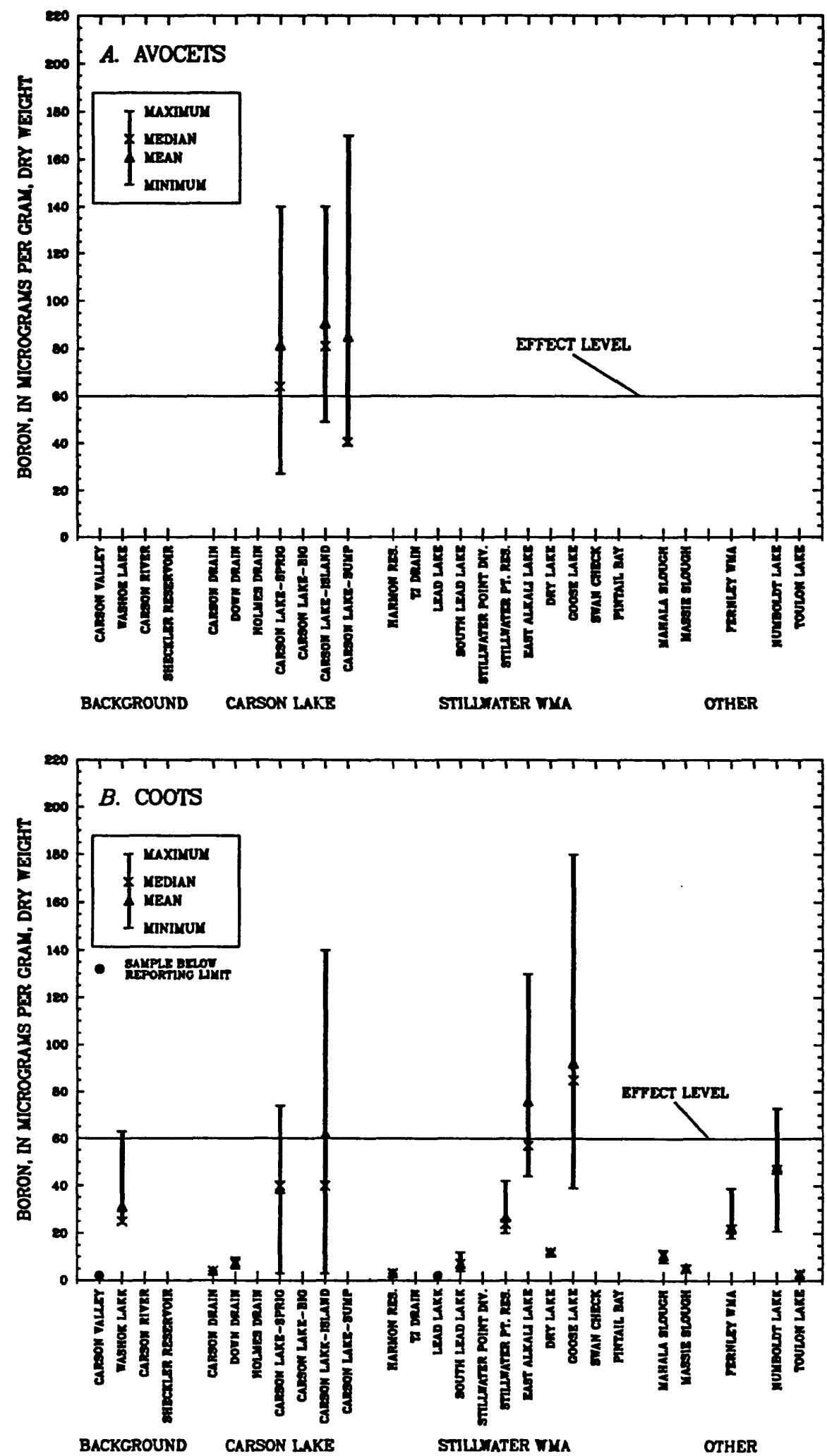

FIGURE 18.--Arithmetic means, medians, and maximum-minimum ranges of boron concentrations found in livers of (A) avocets and (B) coots, in the background sites, Carson Lake, and Stillwater, Fernley, and Humboldt Wildlife Management Areas, in downstream order, 1986-87. Effect level for bird liver is from Gregory J. Smith (U.S. Fish and Wildlife Service, oral commun., 1986). (Samples not collected at all sites.) 


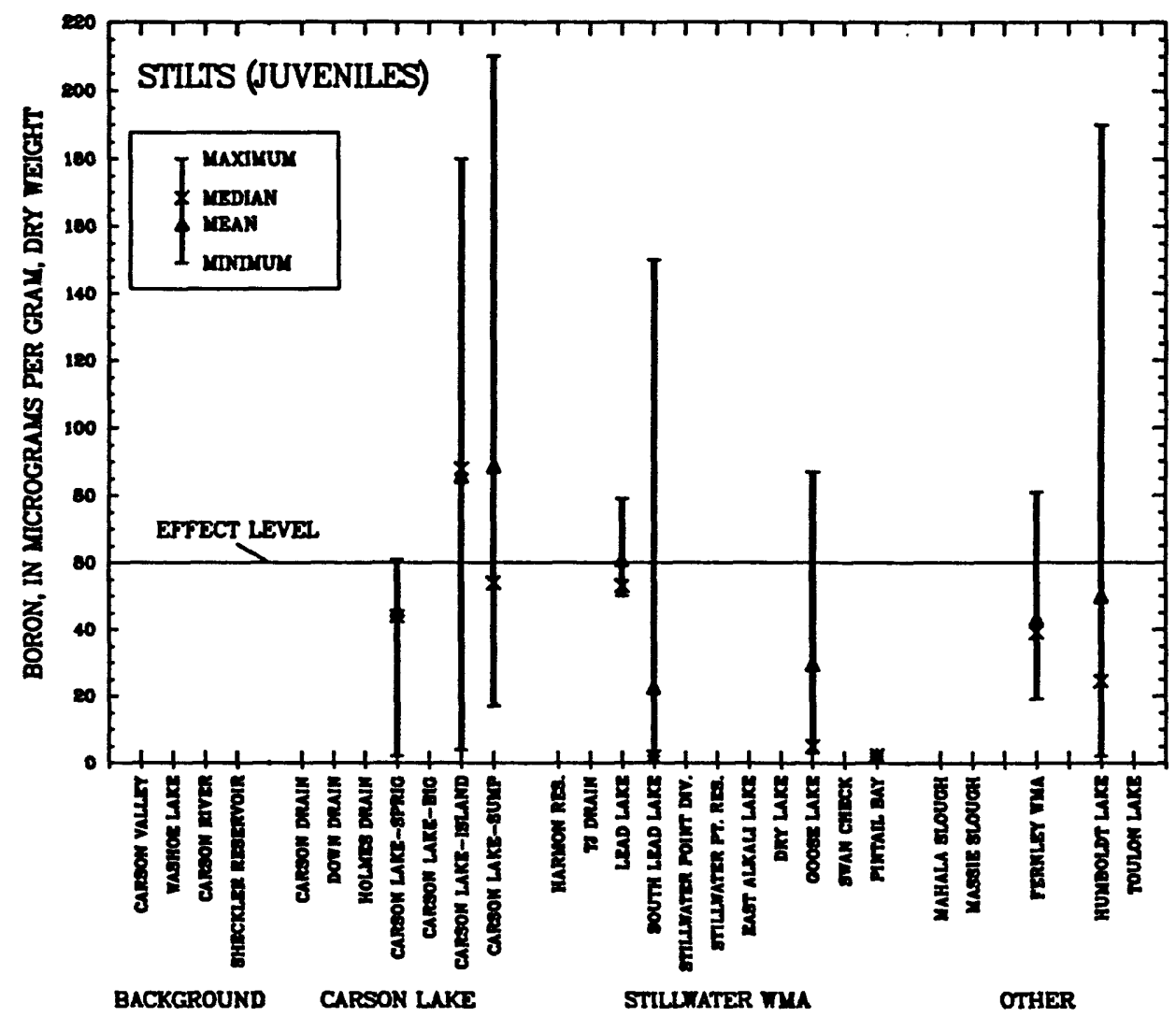

FIGURE 19.--Arithmetic means, medians, and maximum-minimum ranges of boron concentrations found in livers of black-necked stilt juveniles, in the background sites, Carson Lake, and Stillwater, Femley, and Humboldt Wildlife Management Areas, in downstream order, 1986-87. Effect level for bird liver is from Gregory J. Smith (U.S. Fish and Wildife Service, oral commun., 1986). (Samples not collected at all sites.) Concentrations exceeding effect level may adversely impact the organism.

\section{Chromium}

Plants

Haseltine and others $(1985$, p. 2) determined that dietary chromium concentrations at or above $36 \mu \mathrm{g} / \mathrm{g}$ dry weight adversely affects growth and survival of black ducks (Anas rubripes). This effect criterion was exceeded in alkali bulrush root and filamentous algae from Goose Lake in the Stillwater WMA, where the median concentrations were 47 and $45 \mu \mathrm{g} / \mathrm{g}$ dry weight, respectively. The highest concentration of chromium was $370 \mu \mathrm{g} / \mathrm{g}$ dry weight, also in alkali bulrush root from Goose Lake in Stillwater WMA. The effect criterion for chromium was also exceeded in bulrush and cattail at Carson Lake (60 and $64.1 \mu \mathrm{g} / \mathrm{g}$ ) and in Stillwater WMA (47.1 and $200 \mu \mathrm{g} / \mathrm{g})$, and in cattail at Fernley WMA $(38 \mu \mathrm{g} / \mathrm{g})$. The median concentration of chromium in cattail stem from Carson Valley (a background site) was $42 \mu \mathrm{g} / \mathrm{g}$ dry weight. As mentioned previously, this site may reflect the local input of treated domestic sewage, a common source of chromium (Eisler, 1986, p. 5).

\section{Insects}

Chromium in insect tissue ranged from less than the analytical reporting limit to $78 \mu \mathrm{g} / \mathrm{g}$ dry weight with a median of $6.2 \mu \mathrm{g} / \mathrm{g}$ for 20 samples above the reporting limit. 
Fish

The concern level of chromium in fish tissue is a concentration in excess of $4.0 \mu \mathrm{g} / \mathrm{g}$ dry weight (Eisler, 1986, p. 44). This criterion was exceeded in whole-body carp from Stillwater WMA and Humboldt WMA (figure 20), the highest median value for carp determined within the study area was $14.0 \mu \mathrm{g} / \mathrm{g}$ in carp from Stillwater Point Reservoir in Stillwater WMA. Whole-body mosquito fish from the Carson Valley background site exceeded the concern criteria with a median concentration of $16.0 \mu \mathrm{g} / \mathrm{g}$ dry weight. The elevated concentration of chromium in fish tissue is consistent with that measured in plant tissue.

Birds

Eisler (1986, p. 44) has defined a concern level for chromium in wildlife tissue to be a concentration in excess of $4.0 \mu \mathrm{g} / \mathrm{g}$ dry weight. The concern level was exceeded in avocet livers from Carson Lake Sump (median $12.2 \mu \mathrm{g} / \mathrm{g}$ dry weight), in coot livers from Goose Lake in Stillwater WMA (median $29 \mu \mathrm{g} / \mathrm{g}$ dry weight), and in coot livers from Lead Lake $(9.3$ and $4.8 \mu \mathrm{g} / \mathrm{g}$ ). The median of five juvenile coots from the Carson Valley background site was $8.0 \mu \mathrm{g} / \mathrm{g}$ dry weight. A juvenile coot from Washoe Lake, another background site, had a concentration of $5.3 \mu \mathrm{g} / \mathrm{g}$ in its liver.

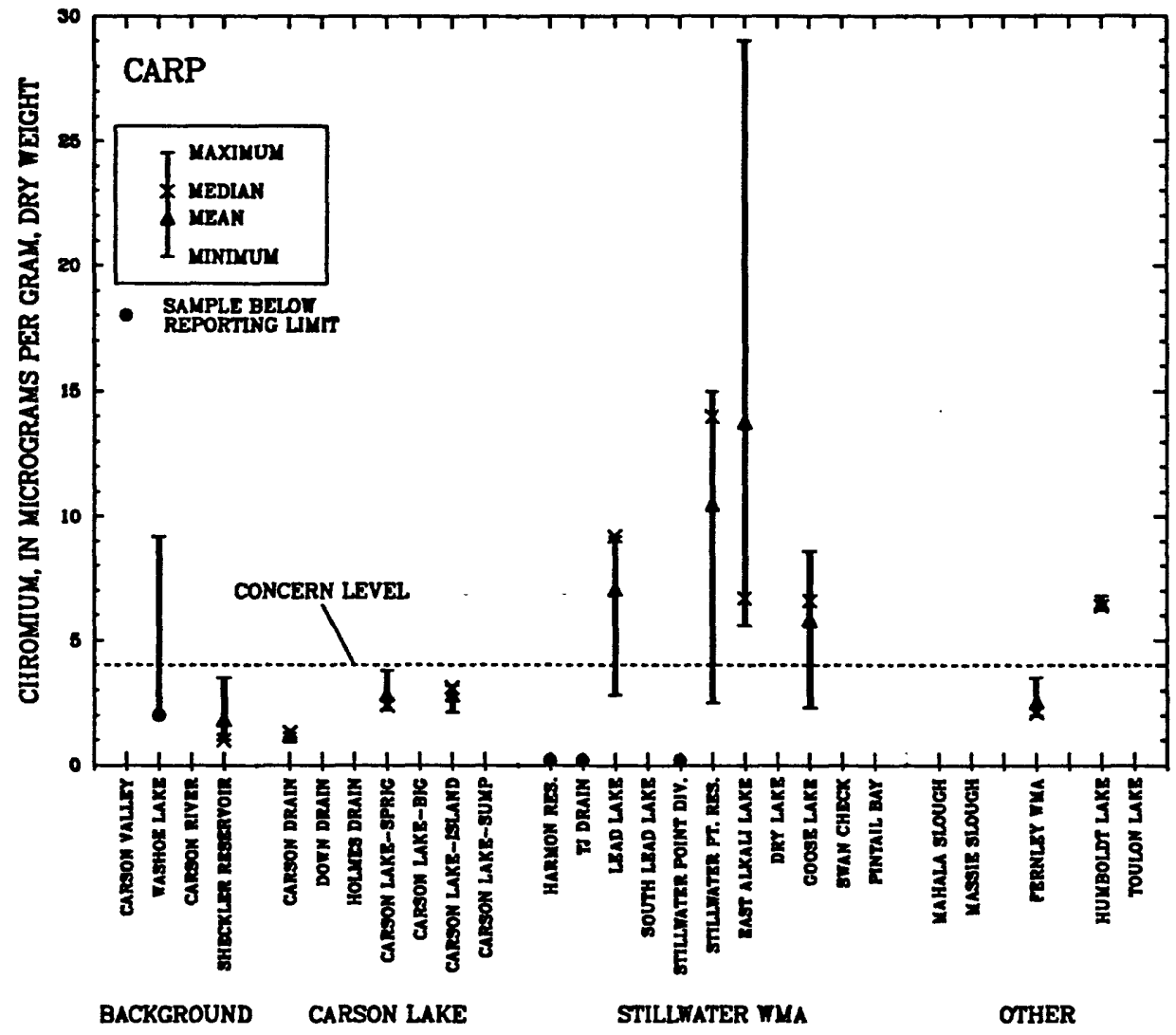

FIGURE 20.--Arithmetic means, medians, and maximum-minimum ranges of chromium concentrations found in tissue of carp in the background sites, Carson Lake, and Stillwater, Femley, and Humboldt Wildlife Management Areas, in downstream order, 1986-87. Concem level for fish tissue is from Eisler (1986, p. 44). (Samples not collected at all sites.) Concentrations exceeding concem level may indicate exposure of the organism to contaminants. 


\section{Copper}

Fish

The concern level for copper in fish is $3.67 \mu \mathrm{g} / \mathrm{g}$ dry weight (Lowe and others, 1985, p. 370). This baseline is exceeded by 10 of 21 median values in carp and mosquito fish tissue at sites affected by irrigation drainage (figures 21A and 21B). The highest median residue level observed was $9.4 \mu \mathrm{g} / \mathrm{g}$ dry weight in a composite mosquito fish sample from TJ Drain in Stillwater WMA. Copper residue in fish from the background sites, Washoe Lake and Carson Valley, were 3.55 and $3.70 \mu \mathrm{g} / \mathrm{g}$ dry weight, respectively. These two concentrations approached the concern criterion of $3.67 \mu \mathrm{g} / \mathrm{g}$.

\section{Mercury}

Plants

Heinz (1979, p. 395) observed adverse reproductive effects among mallards maintained on a diet containing as little as $0.39 \mu \mathrm{g} / \mathrm{g}$ dry weight, total mercury (or $0.36 \mu \mathrm{g} / \mathrm{g}$ methylmercury). This criterion is near the analytical reporting limit $(0.25 \mu \mathrm{g} / \mathrm{g})$ for plant and animal tissue in this study. Within major wetland units a total of 102 composite plant and plant part samples were analyzed for mercury. Of these 102 samples, five from Carson Lake and seven from Stillwater WMA exceeded this dietary effect criterion with concentrations ranging from 0.43 to $2.40 \mu \mathrm{g} / \mathrm{g}$ dry weight. Among plants sampled from the drains, Potamogeton sp. in Carson Lake Drain at Carson Lake (median $6.0 \mu \mathrm{g} / \mathrm{g}$ ) and TJ Drain in Stillwater WMA (median $2.0 \mu \mathrm{g} / \mathrm{g}$ ) were unusually high in mercury. Dietary effect levels of mercury are being exceeded in plants in some areas of Stillwater WMA and Carson Lake. Of 17 plant and plant part samples analyzed from the background sites, Carson Valley and Washoe Lake mercury concentrations were reported as less than the analytical reporting limit.

Insects

Suitable criteria for evaluating the significance of mercury residue in invertebrate tissue are not available. The dietary effect criterion of $0.39 \mu \mathrm{g} / \mathrm{g}$ mercury dry weight is used here as a guideline (Heinz, 1979, p. 395; Eisler, 1987, p. 74). This effect criterion was regularly exceeded in composite samples of insects (figure 22). Carson Lake wetland units and associated input drains (table 19) were notable in regard to mercury concentration: All nine samples analyzed exceeded $1.0 \mu \mathrm{g} / \mathrm{g}$ dry weight. The highest concentration was $5.4 \mu \mathrm{g} / \mathrm{g}$ dry weight in the Sprig Pond Unit of Carson Lake.

Concentrations of mercury in insects from the Carson Valley background site, Massie and Mahala Sloughs, Fernley WMA, and Humboldt WMA were less than $0.5 \mu \mathrm{g} / \mathrm{g}$. There is no history of mercury contamination in these areas. 


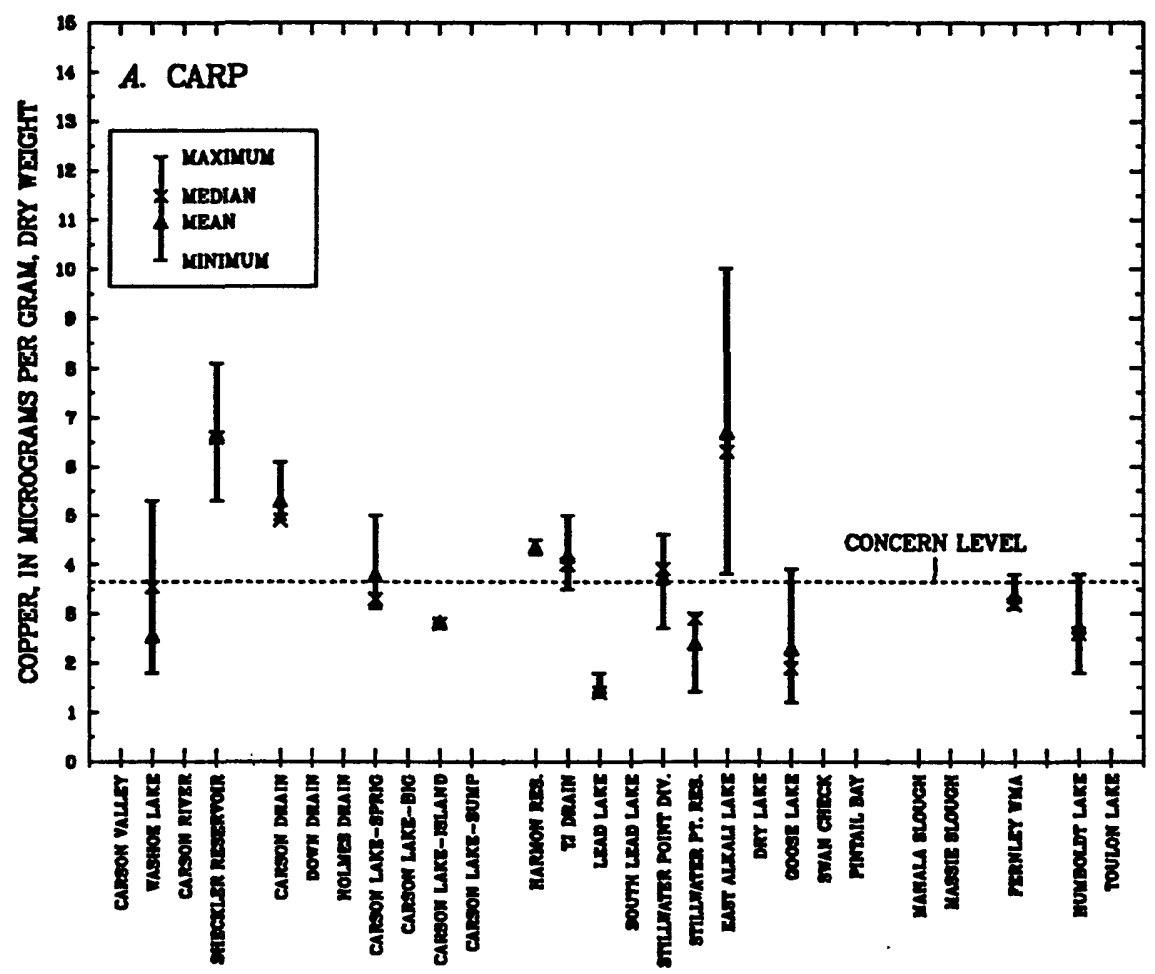

BACKCROUND CARSON LAKE STLLTATER MUA OTHER

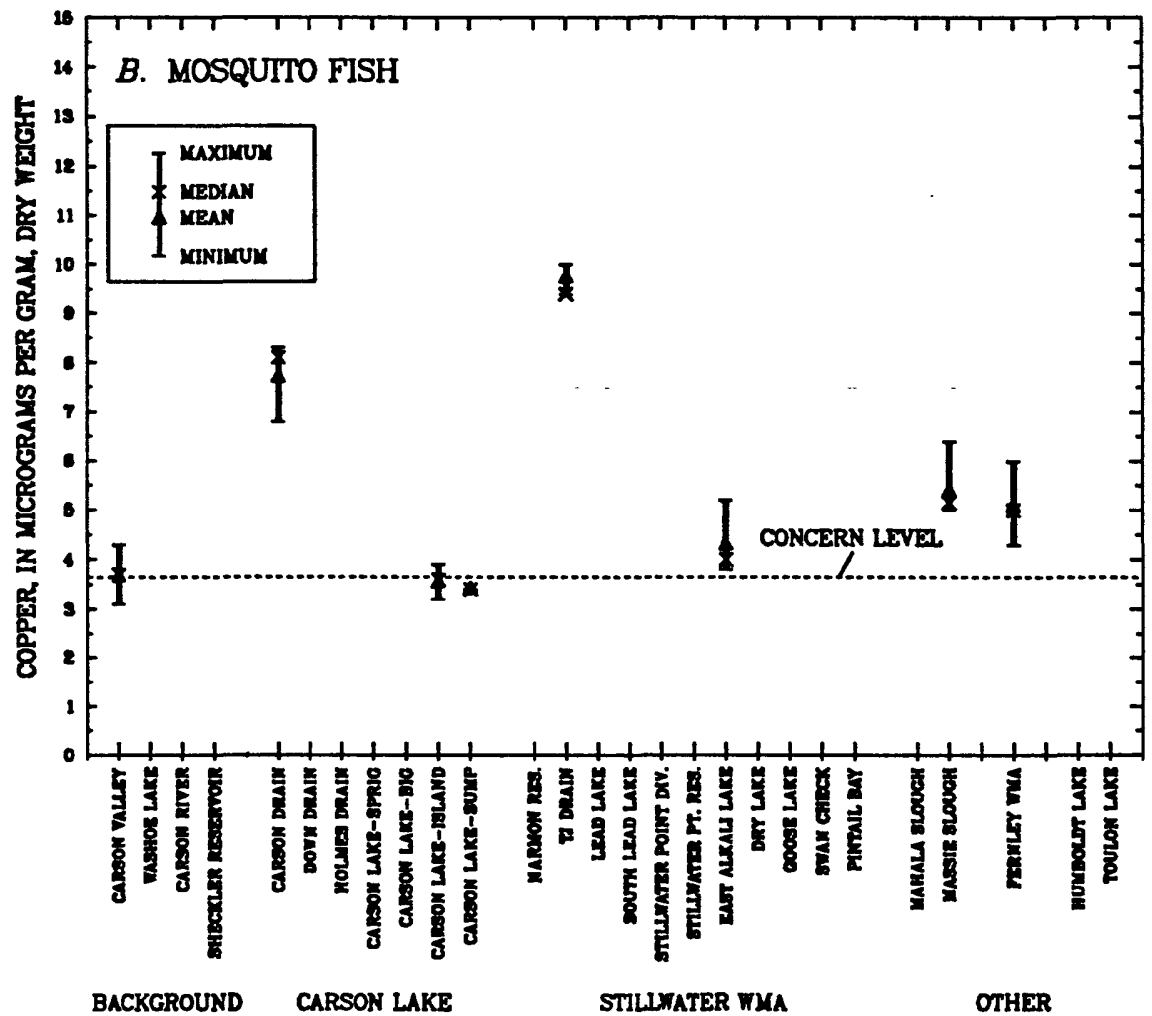

FIGURE 21.--Arithmetic means, medians, and maximum-minimum ranges of copper concentrations found in tissue of (A) carp and (B) mosquito fish in the background sites, Carson Lake, and Stillwater, Femley, and Humboldt Wildlife Management Areas, in downstream order, 1986-87. Concem level for fish tissue is from Lowe and others (1985, p. 370). (Samples not collected at all sites.) Concentrations exceeding concem level may indicate exposure of the organism to contaminants. 


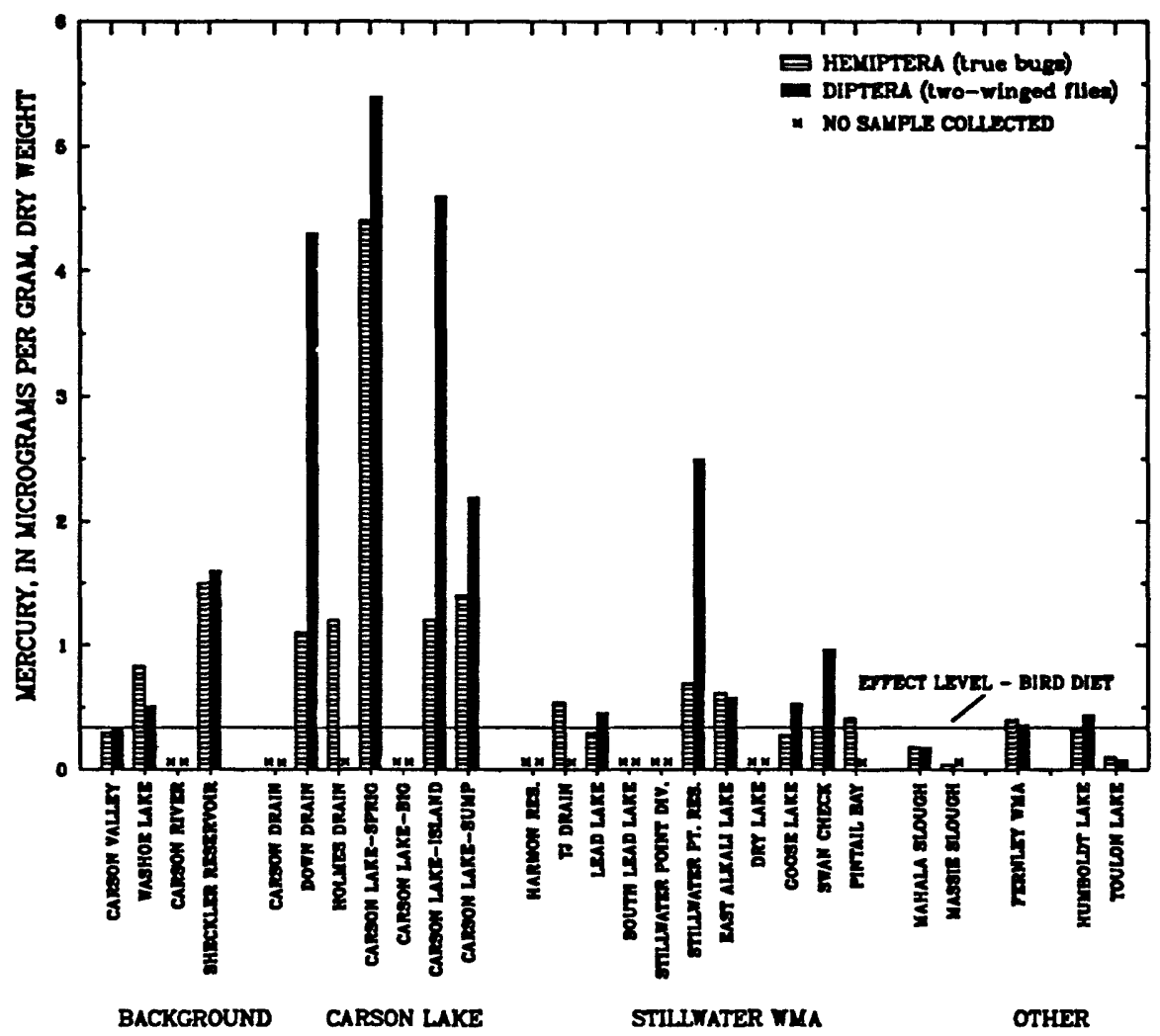

FIGURE 22.-Mercury concentrations found in composite insect samples in the background sites, Carson Lake, and Stillwater, Femley, and Humboldt Wildlife Management Areas, in downstream order, 1986-87. Effect level for bird diet is from Heinz (1979, p. 395). (Samples not collected at all sites.) Concentrations exceeding effect level may adversely impact the organism.

Fish

The concern level for mercury residue in whole fish that may impact fish reproduction is $0.65 \mu \mathrm{g} / \mathrm{g}$ dry weight (Lowe and others, 1985, p. 370). The mercury residue level in whole-body juvenile fathead minnows associated with reduced growth was $4.72 \mu \mathrm{g} / \mathrm{g}$ dry weight (Snarski and Olson, 1982, p. 153). Carp and mosquito fish from Carson Lake contained relatively high concentrations (1.0 to $2.0 \mu \mathrm{g} / \mathrm{g}$; figures $23 \mathrm{~A}$ and 23B). Few game fish were taken in these two important wildlife areas. One Sacramento perch (Archoplites interruptus) taken from Sprig Pond in Carson Lake, had a whole-body residue level of $5.70 \mu \mathrm{g} / \mathrm{g}$ mercury, and one smallmouth bass (Micropterus dolomieui) taken from Alkali Unit no. 1, Stillwater WMA, had a wholebody residue level of $2.1 \mu \mathrm{g} / \mathrm{g}$ dry weight. Three white bass (Morone chrysops) from Harmon Reservoir had a median whole-body mercury residue level of $4.8 \mu \mathrm{g} / \mathrm{g}$ dry weight (range 1.4 to $5.26 \mu \mathrm{g} / \mathrm{g}$ ). Cooper and others (1985, p. 57) have reported that carnivorus game fish may be expected to contain higher concentrations of mercury than herbivorus non-game fish within this study area. Game fish have become scarce in the major wetland units of Stillwater WMA and Carson Lake.

The effect criterion for mercury in fish as a dietary item for birds is $0.39 \mu \mathrm{g} / \mathrm{g}$ dry weight (Heinz, 1979, p. 395). Of 103 single fish or composite fish samples analyzed, 82 percent exceeded this value.

Carp from the Washoe Lake background site contained notably high concentrations of mercury. The median whole-body concentration was $3.7 \mu \mathrm{g} / \mathrm{g}$ dry weight. 

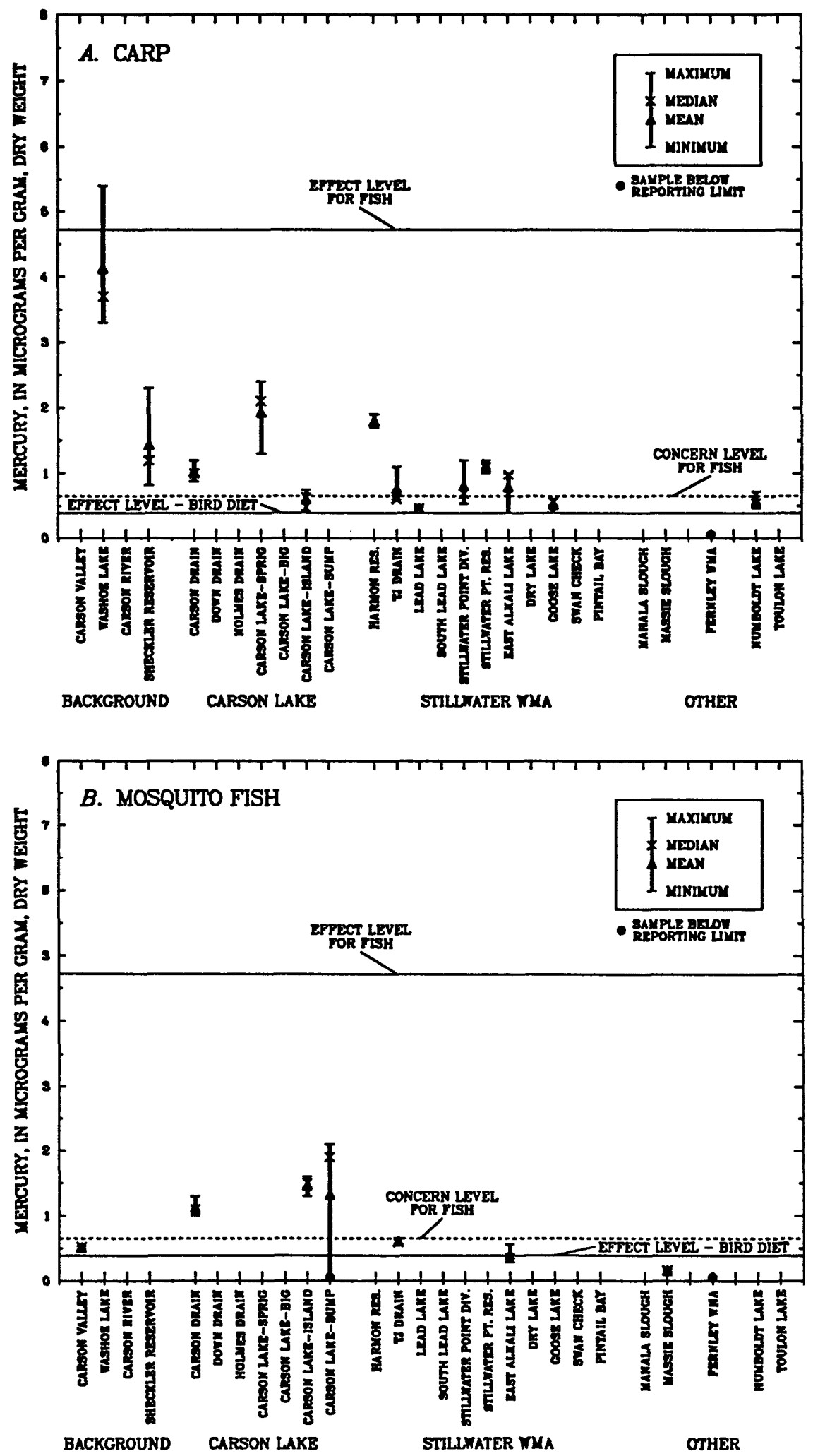

FIGURE 23.--Arithmetic means, medians, and maximum-minimum ranges of mercury concentrations found in fish tissues of (A) carp and (B) mosquito fish in the background sites, Carson Lake, and Stillwater, Femley, and Humboldt Wildlife Management Areas, in downstream order, 1986-87. Concem level for fish is from Lowe and others (1985, p. 370); effect level for fish is from Snarski and Olson (1982, p. 153); and effect level for bird diet is from Heinz (1979, p. 395). (Samples not collected at all sites.) Concentrations exceeding concem level may indicate exposure of the organism to contaminants. Concentrations exceeding effect level may adversely impact the organism. 


\section{Birds}

The mean liver residue level of mercury in female mallard ducks associated with reduced reproductive success is $4.3 \mu \mathrm{g} / \mathrm{g}$ dry weight (Heinz, 1979, p. 396). This effect criteria was frequently exceeded in livers of coots, stilts and ducks (figures 24, 25A, 25B, and 26). In Carson Lake and Stillwater WMA, 9 of 28 median liver mercury concentrations exceed the effect criterion. (Figure 26 also shows data for public health warning that will be discussed later in this report.)

The median mercury concentration in coot liver $(0.96 \mu \mathrm{g} / \mathrm{g})$ from Carson Valley, a background site, was comparable to residue levels found in other areas in this study uncontaminated by mercury, namely Massie and Mahala Sloughs, Humboldt WMA, and Fernley WMA. As stated previously, the Washoe Lake site was an unsatisfactory background site for mercury as indicated by the median concentration of mercury in coot liver $(12.0 \mu \mathrm{g} / \mathrm{g}$ dry weight) and moderately high concentrations of mercury in the sample of bottom sediment (table 16).

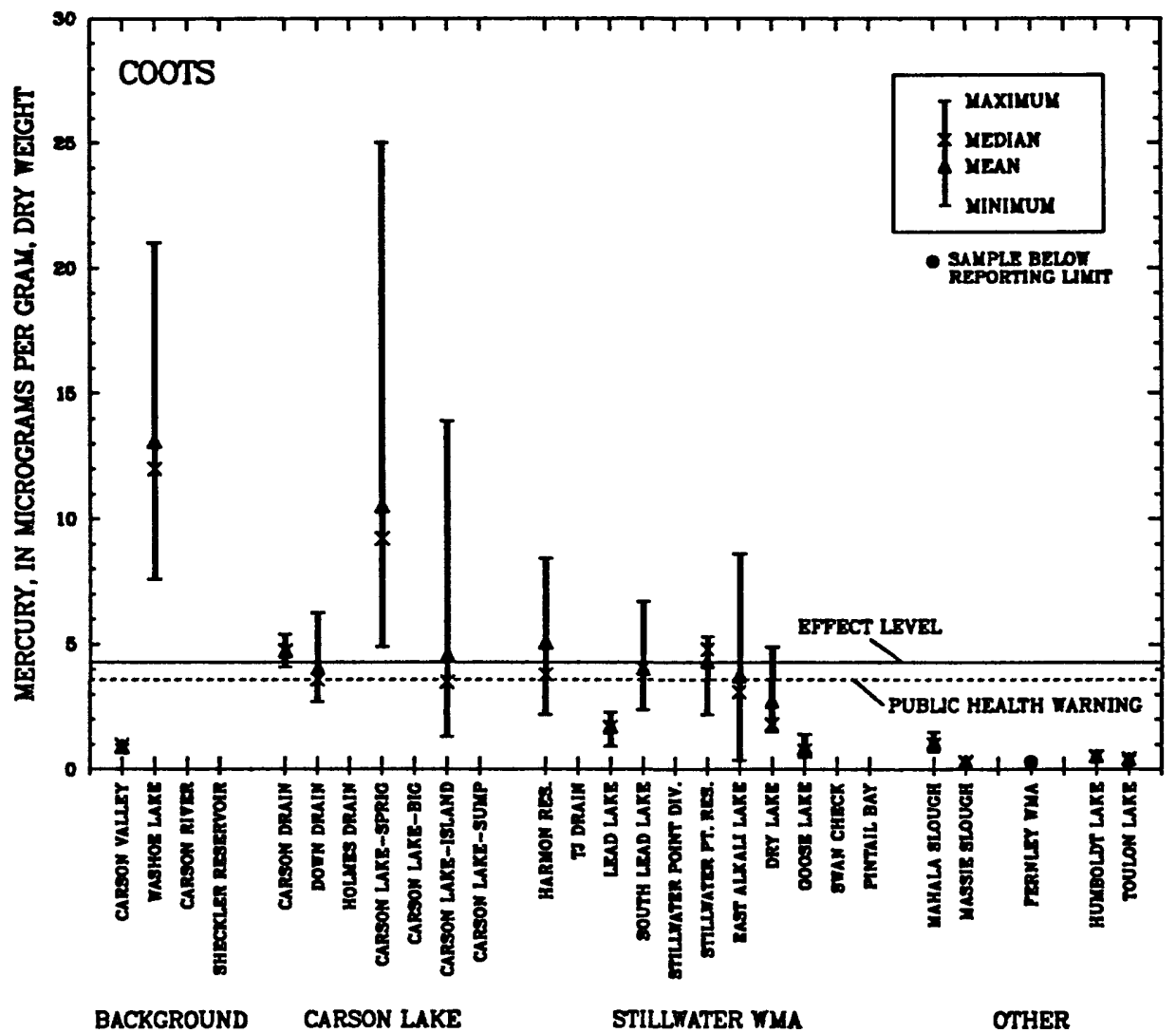

FIGURE 24.--Arithmetic means, medians, and maximum-minimum ranges of mercury concentrations found in livers of coots in the background sites, Carson Lake, and Stillwater, Fernley, and Humboldt Wildlife Management Areas, in downstream order, $1986-87$. Effect level for bird liver is from Heinz (1979, p. 396); Public Health Waming for duck muscle is from U.S. Food and Drug Administration $(1984$, p. 1). (Samples not collected at all sites.) Concentrations exceeding effect level may adversely impact the organism. 

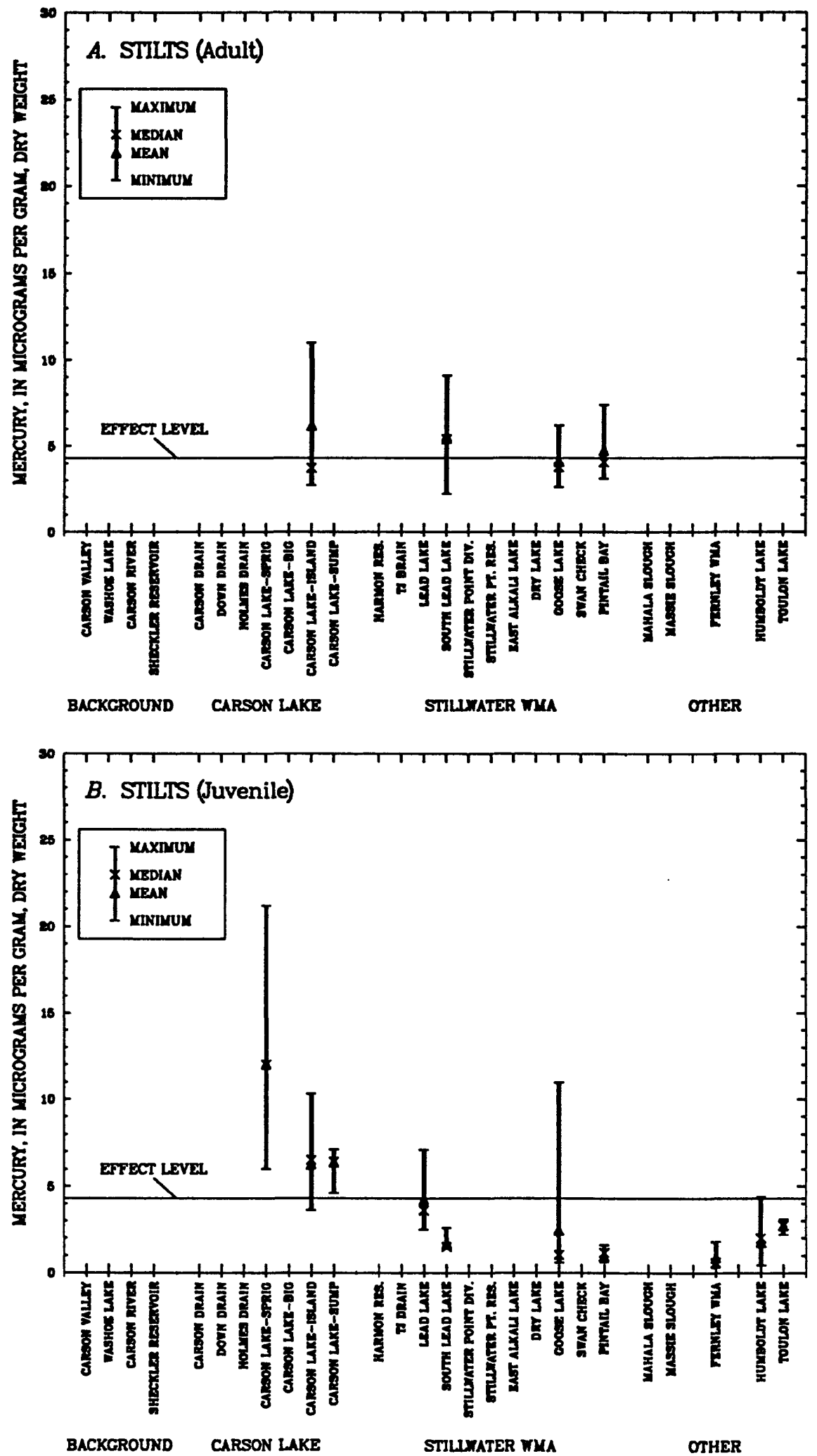

FIGURE 25.--Arithmetic means, medians, and maximum-minimum ranges of mercury concentrations found in livers of black-necked stilt (A) adults and (B) juveniles, in the background sites, Carson Lake, and Stillwater, Femley, and Humboldt Wildlife Management Areas, in downstream order, 1986-87. Effect level for bird liver is from Heinz (1979, p. 396). (Samples not collected at all sites.)

Concentrations exceeding effect level may adversely impact the organism. 


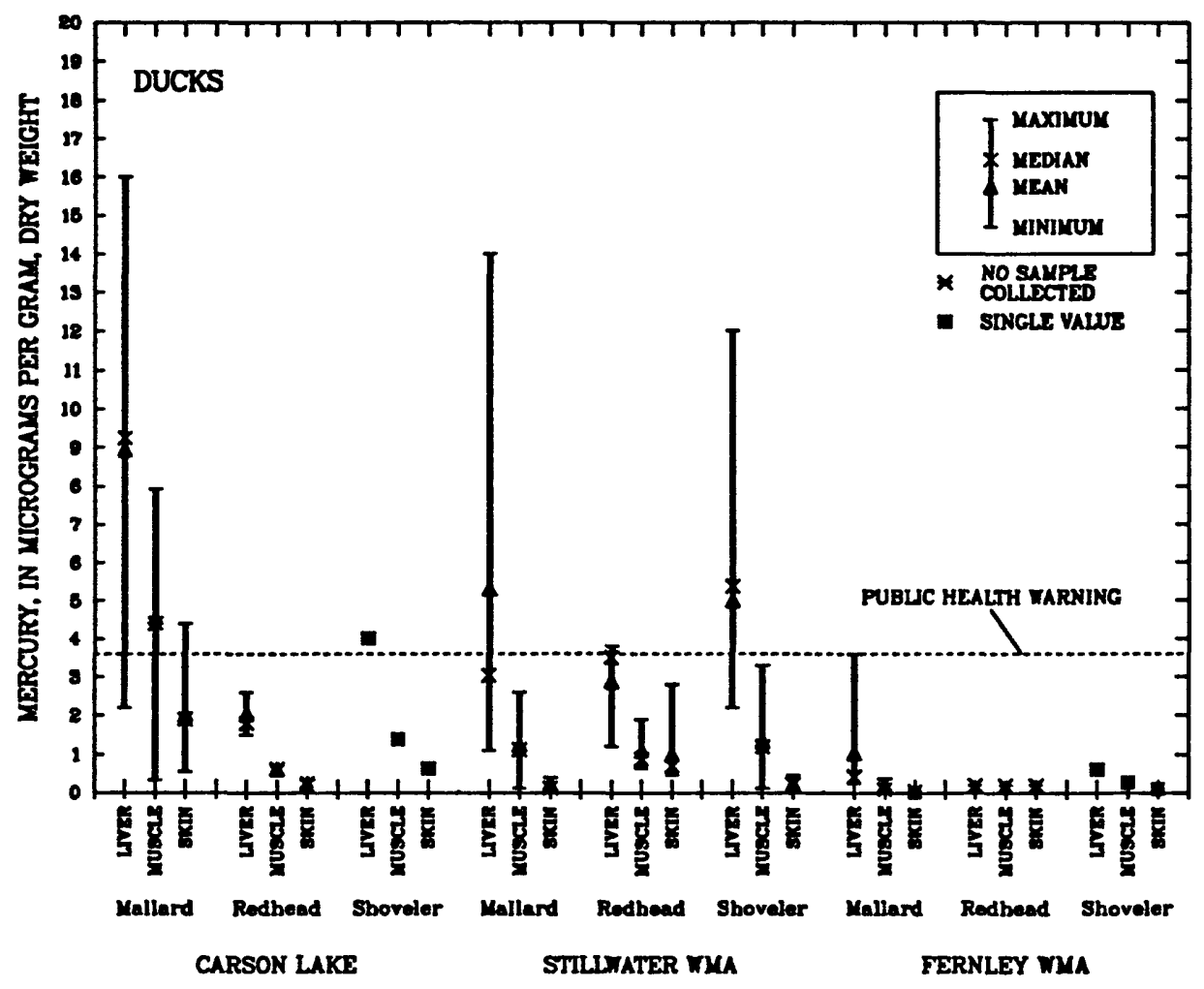

FIGURE 26.-Arithmetic means, medians, and maximum-minimum ranges of mercury concentrations found in mallard, redhead, and shoveler duck liver, muscle, and skin tissue, in the background sites, Carson Lake, and Stillwater and Femley Wildlife Management Areas, in downstream order, 1986-87. Public health waming for duck muscle is from U.S. Food and Drug Administration (1984, p. 1). (Samples not collected at all sites.)

\section{Selenium}

\section{Plants}

Two dietary effect criteria are used to describe the importance of selenium in plants. Lomly and Smith $(1987$, p. 9) have, on the basis of reproductive affects, identified an effect level for selenium in fish diets of $5.0 \mu \mathrm{g} / \mathrm{g}$ dry weight. For birds, Gregory J. Smith (U.S. Fish and Wildlife Service, oral commun., 1989) has documented both reduced hatching success and weight loss in female mallards with dietary selenium levels of $7.0 \mu \mathrm{g} / \mathrm{g}$ dry weight. In this study, the highest median selenium concentration observed in plants was $3.2 \mu \mathrm{g} / \mathrm{g}$ dry weight in filamentous algae from the Carson Lake Sump (a tertiary unit). 


\section{Insects}

Criteria to evaluate residue levels of selenium in insect tissue are not available. Accordingly, the dietary effect levels for fish $(5.0 \mu \mathrm{g} / \mathrm{g}$ dry weight; Lemley and Smith, 1987, p. 9) and birds (7.0 $\mu \mathrm{g} / \mathrm{g}$ dry weight; Gregory J. Smith, U.S. Fish and Wildlife Service, oral commun., 1989) are used as guidelines for interpretation of the insect data. The dietary effect criteria for fish $(5.0 \mu \mathrm{g} / \mathrm{g})$ was exceeded in composite insect samples from: Downs Drain at Carson Lake $(6.8 \mu \mathrm{g} / \mathrm{g})$, Mahala Slough $(6.5 \mu \mathrm{g} / \mathrm{g})$, and Toulon Lake $(5.4 \mu \mathrm{g} / \mathrm{g})$, Fernley WMA $(13.0 \mu \mathrm{g} / \mathrm{g})$, and Humboldt Lake $(5.1 \mu \mathrm{g} / \mathrm{g}$; figure 27). The dietary effect criteria for birds, $7.0 \mu \mathrm{g} / \mathrm{g}$ dry weight, was exceeded in composite insect samples from Femley WMA $(13.0 \mu \mathrm{g} / \mathrm{g})$, and approached the effect level at Downs Drain at Carson Lake and Mahala Slough (figure 27).

At the background sites, selenium residue levels in three composite insect tissue samples ranged from less than the analytical reporting limit $(0.3 \mu \mathrm{g} / \mathrm{g})$ to $1.7 \mu \mathrm{g} / \mathrm{g}$ dry weight. A fourth sample contained $0.8 \mu \mathrm{g} / \mathrm{g}$. The lowest selenium concentrations observed by Ohlendorf and others $(1986$, p. 55) in comparable insect tissue at Volta Wildlife Area, Calif. (unaffected by irrigation drainage), were 1.1 and $1.5 \mu \mathrm{g} / \mathrm{g}$ dry weight for hemiptera and diptera, respectively.

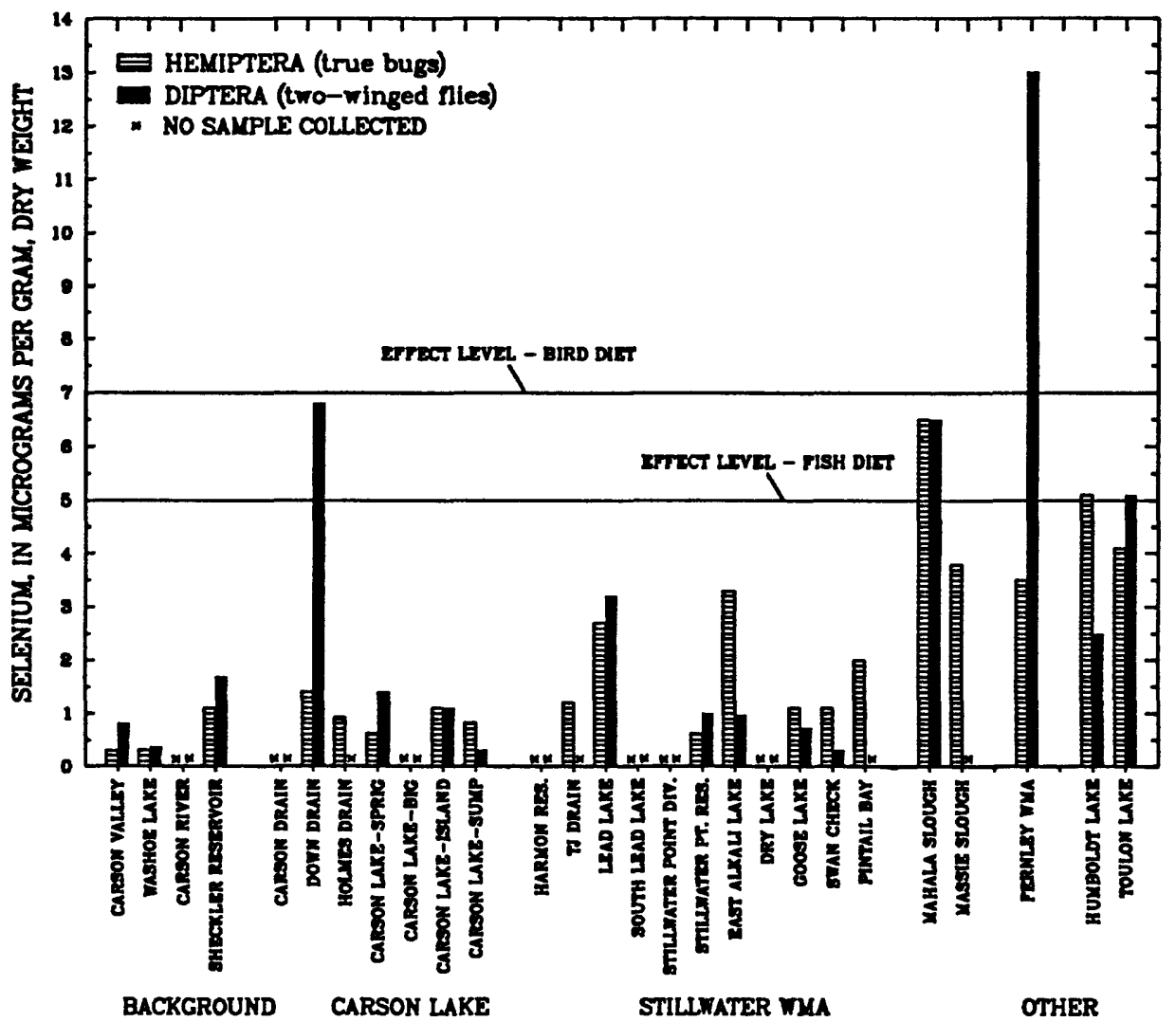

FIGURE 27.--Selenium concentrations found in composite insect samples in the background sites, Carson Lake, and Stillwater, Femley, and Humboldt Wildlife Management Areas, im downstream order, 1986-87. Effect level for fish diet is from Lemly and Smith (1987, p. 9); effect level for bird diet is from Patuxent Wildlife Research Center (1987, p. 21). (Samples not collected at all sites.) Concentrations exceeding effect level may adversely impact the organism. 
Fish

Criteria used to evaluate selenium residue in whole fish are: (1) concern, $4.0 \mu \mathrm{g} / \mathrm{g}$; (2) effect, $10.0 \mu \mathrm{g} / \mathrm{g}$ dry weight (Lillebo and others, 1988, p. 48); (3) effect fish diet, $5.0 \mu \mathrm{g} / \mathrm{g}$ (Lemly and Smith, 1987, p. 9); and (4) effect bird diet, $7.0 \mu \mathrm{g} / \mathrm{g}$ (Gregory J. Smith, U.S. Fish and Wildlife Service, oral commun., 1989).

Selenium residue levels in whole carp and composite mosquito fish from background sites and throughout the study area are shown in figures $28 \mathrm{~A}$ and $28 \mathrm{~B}$. The highest median concentration $(8.8 \mu \mathrm{g} / \mathrm{g}$ dry weight) was in whole carp from Fernley WMA. This value exceeded the dietary effect levels for fish and birds. Other high median residue levels were found in mosquito fish from Massie Slough $(5.1 \mu \mathrm{g} / \mathrm{g}$ ) and tui chub (Gila bicolor, not shown in figure 28) from Fernley WMA $(6.3 \mu \mathrm{g} / \mathrm{g})$. Fish from the background sites, Washoe Lake (carp, median $=1.1 \mu \mathrm{g} / \mathrm{g}$ ) and Carson Valley (mosquito fish, median $=0.73 \mu \mathrm{g} / \mathrm{g}$ ), contained lower selenium residue levels than those reported by Ohlendorf and others (1986, p. 55), for Volta Wildlife Area, Calif. (unaffected by irrigation drainage) in whole mosquito fish $(1.2$ to $1.4 \mu \mathrm{g} / \mathrm{g}$, dry weight). Within the Stillwater study area, fish typically contained residue levels between 1.0 and $3.0 \mu \mathrm{g} / \mathrm{g}$.

\section{Birds}

Two residue levels in bird livers are used as effect criteria to evaluate the possible adverse effects of selenium on birds: (1) The criterion for direct effects upon birds, $9.0 \mu \mathrm{g} / \mathrm{g}$ dry weight, is based upon residue levels in female mallard duck livers associated with decreased productivity and duckling survival (Lemly and Smith, 1987, p. 8); and (2) The dietary-effect criterion for protection of birds, $7.0 \mu \mathrm{g} / \mathrm{g}$ dry weight, is based upon residue levels in food expected to reduce hatching success in mallard ducks (Gregory J. Smith, U.S. Fish and Wildlife Service, oral commun., 1989). Selenium concentrations in coot, stilt, and duck livers are shown in figures $29,30 \mathrm{~A}, 30 \mathrm{~B}$, and 32 . The median selenium concentration in bird livers exceed both effect criteria in all major wetland areas sampled (Stillwater, Fernley and Humboldt WMAs, Carson Lake, and Massie and Mahala Sloughs) in at least one species. The highest median selenium concentrations were found in juvenile stilt livers from Humboldt Lake in the Humboldt WMA; $31.0 \mu \mathrm{g} / \mathrm{g}$ dry weight (10 data points, 20 livers, figure 30B) and coot livers from Mahala Slough $(34.0 \mu \mathrm{g} / \mathrm{g}$, figure 29$)$. Other exceptionally high median selenium concentrations found in bird livers include: juvenile stilts $(31.0 \mu \mathrm{g} / \mathrm{g})$ and mallard ducks $(26.0 \mu \mathrm{g} / \mathrm{g})$ in Fernley WMA, and avocets $(24.0 \mu \mathrm{g} / \mathrm{g}$, not shown in figures) in the Sprig Pond Unit in Carson Lake.

Only juvenile coots were taken from the background sites. The median selenium concentrations in coot livers were 1.4 and $1.5 \mu \mathrm{g} / \mathrm{g}$ dry weight, respectively, from Carson Valley and Washoe Lake. Of 253 bird liver or liver sets analyzed for selenium within the study areas, only 2 individual samples were at or below median selenium concentrations found at the background sites. 


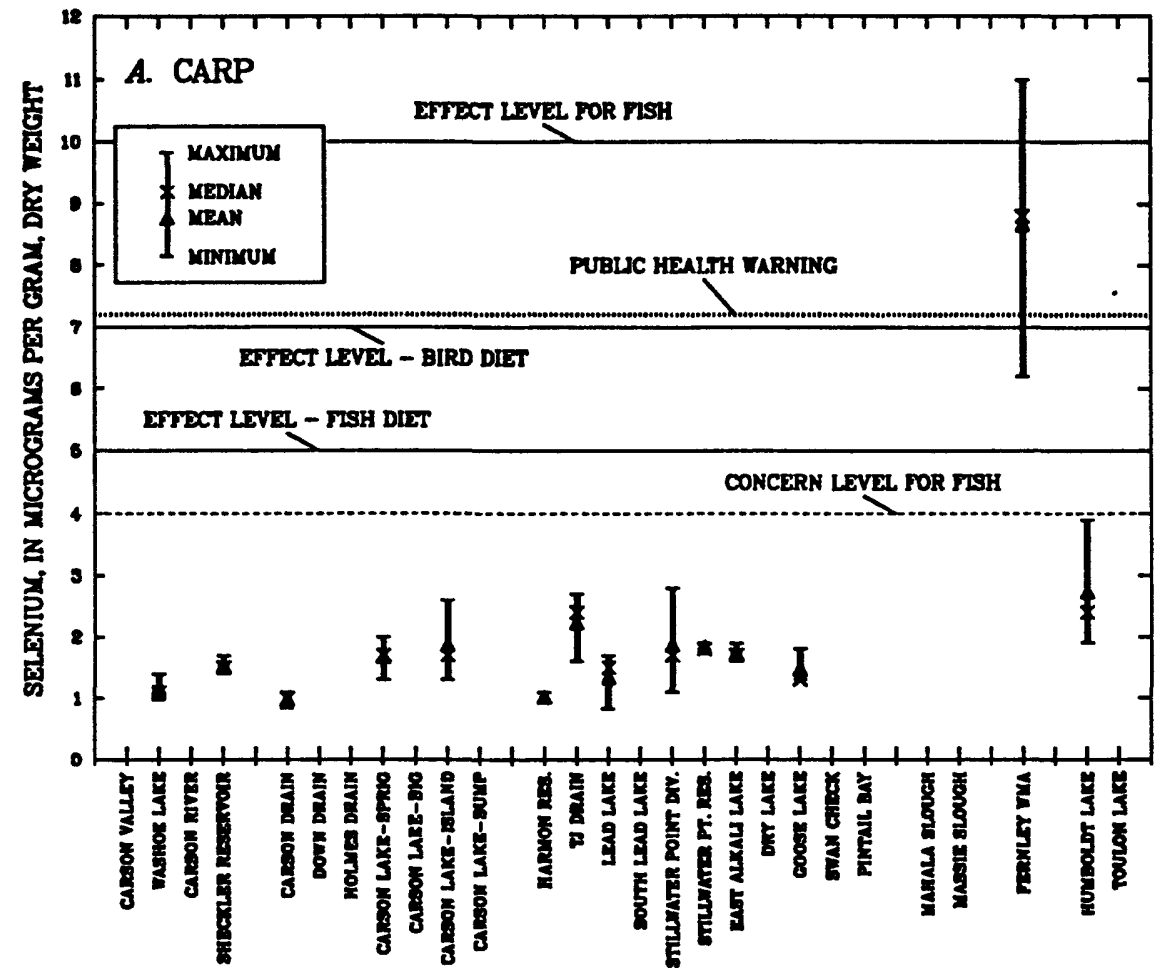

BACKGROUND CARSON LAKE STLLTATER MMA OTHER

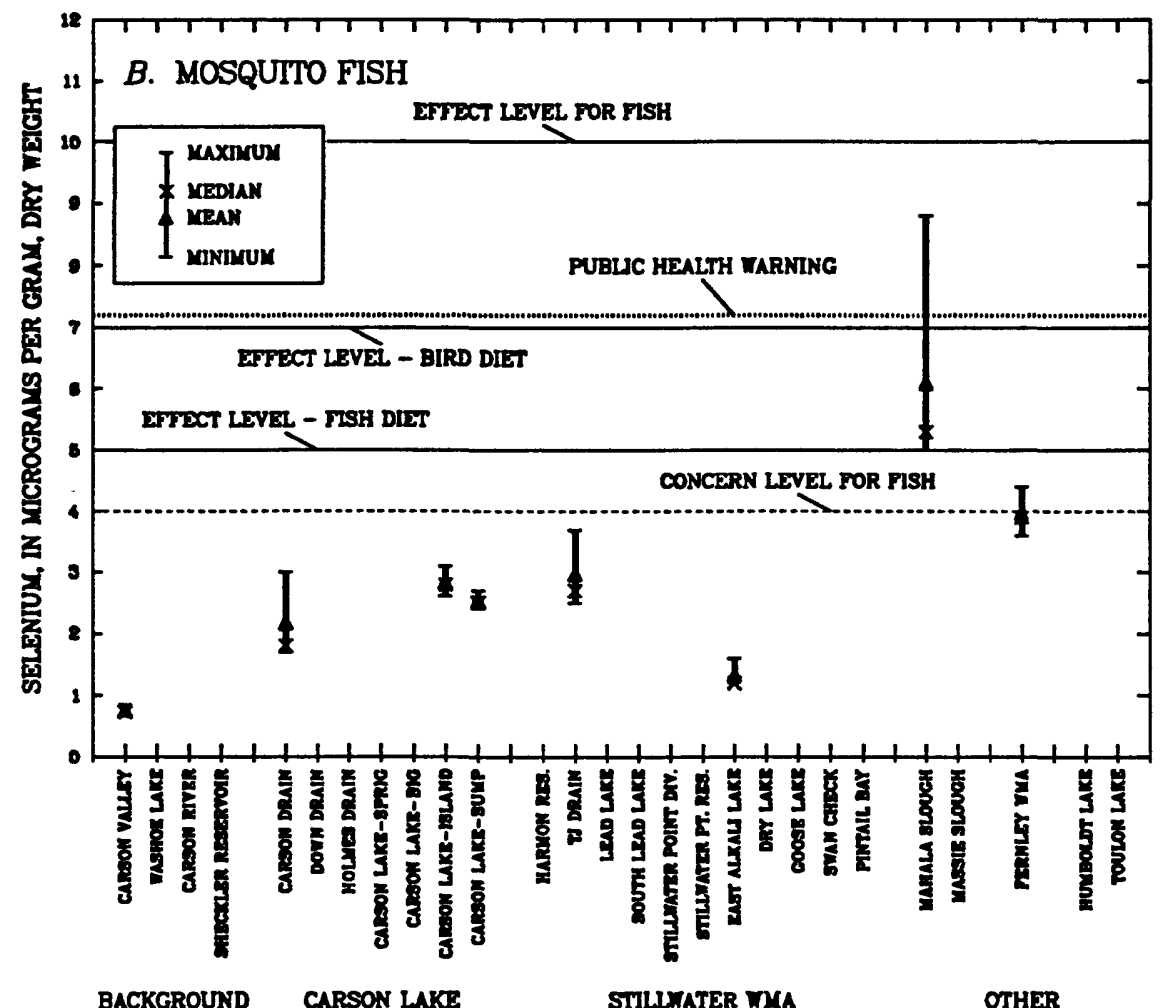

FIGURE 28.--Arithmetic means, medians, and maximum-minimum ranges of selenium concentrations found in tissue of (A) carp and (B) mosquito fish in the background sites, Carson Lake, and Stillwater, Femley, and Humboldt Wildlife Management Areas, in downstream order, 1986-87. Concem level for fish is from Lillebo and others (1988, p. 48); effect level for bird diet is from Gregory J. Smith (U.S. Fish and Wildlife Service, oral commun., 1989); Public Health Waming for fish and duck muscle is from Fan and others (1988, p. 54). (Samples not collected at all sites.) Concentrations exceeding concem level may indicate exposure of the organism to contaminants. Concentrations exceeding effect level may adversely impact the organism. 


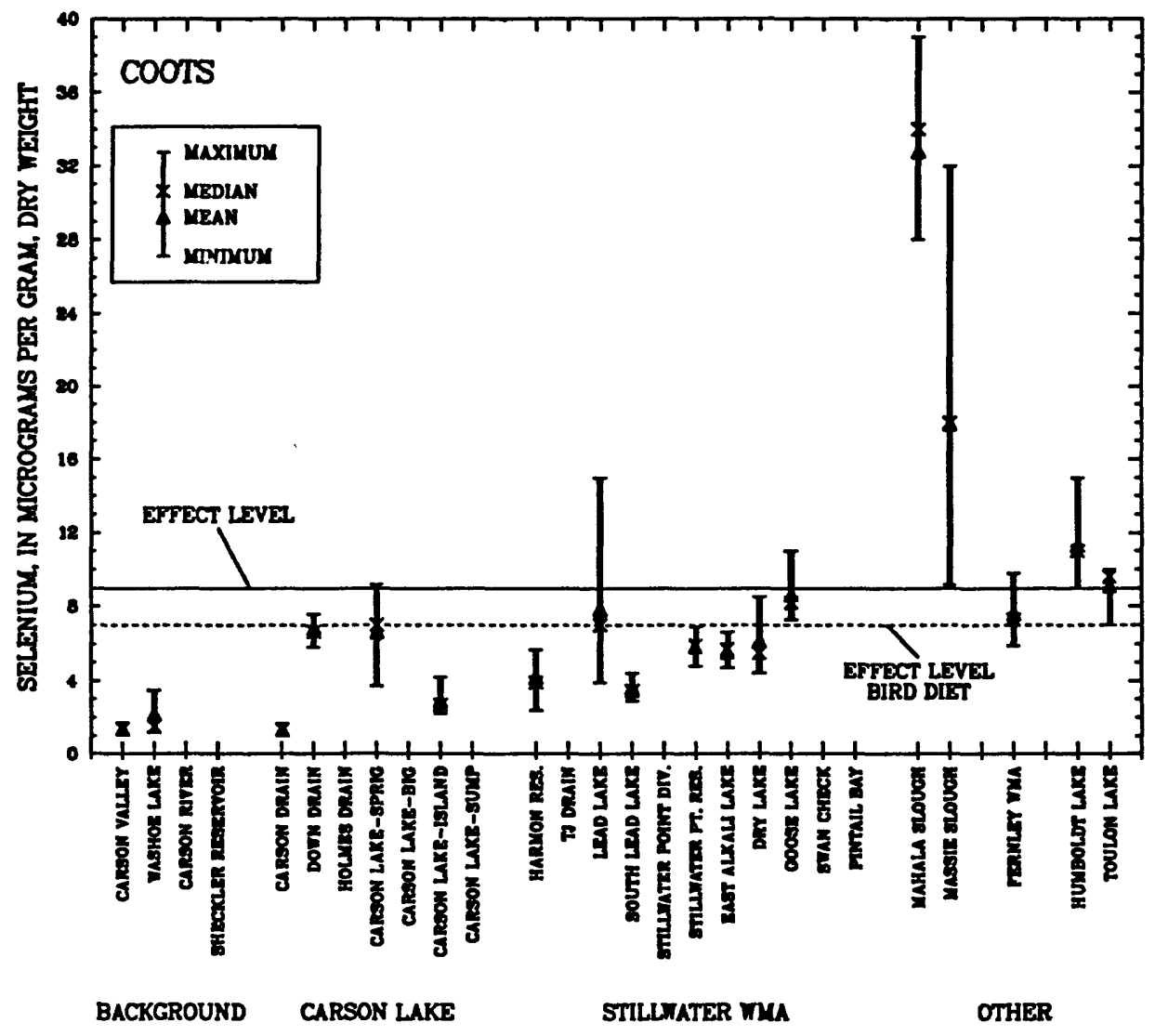

FIGURE 29.--Arithmetic means, medians, and maximum-minimum ranges of selenium concentrations found in livers of coots in the background sites, Carson Lake, and Stillwater, Femley, and Humboldt Wildlife Management Areas, in downstream order, $1986-87$. Effect level for bird liver is from Lemly and Smith (1987, p. 8); effect level for bird diet is from Patuxent Wildlife Research Center (1987, p. 21). (Samples not collected at all sites.) Concentrations exceeding effect level may adversely impact the organism. 

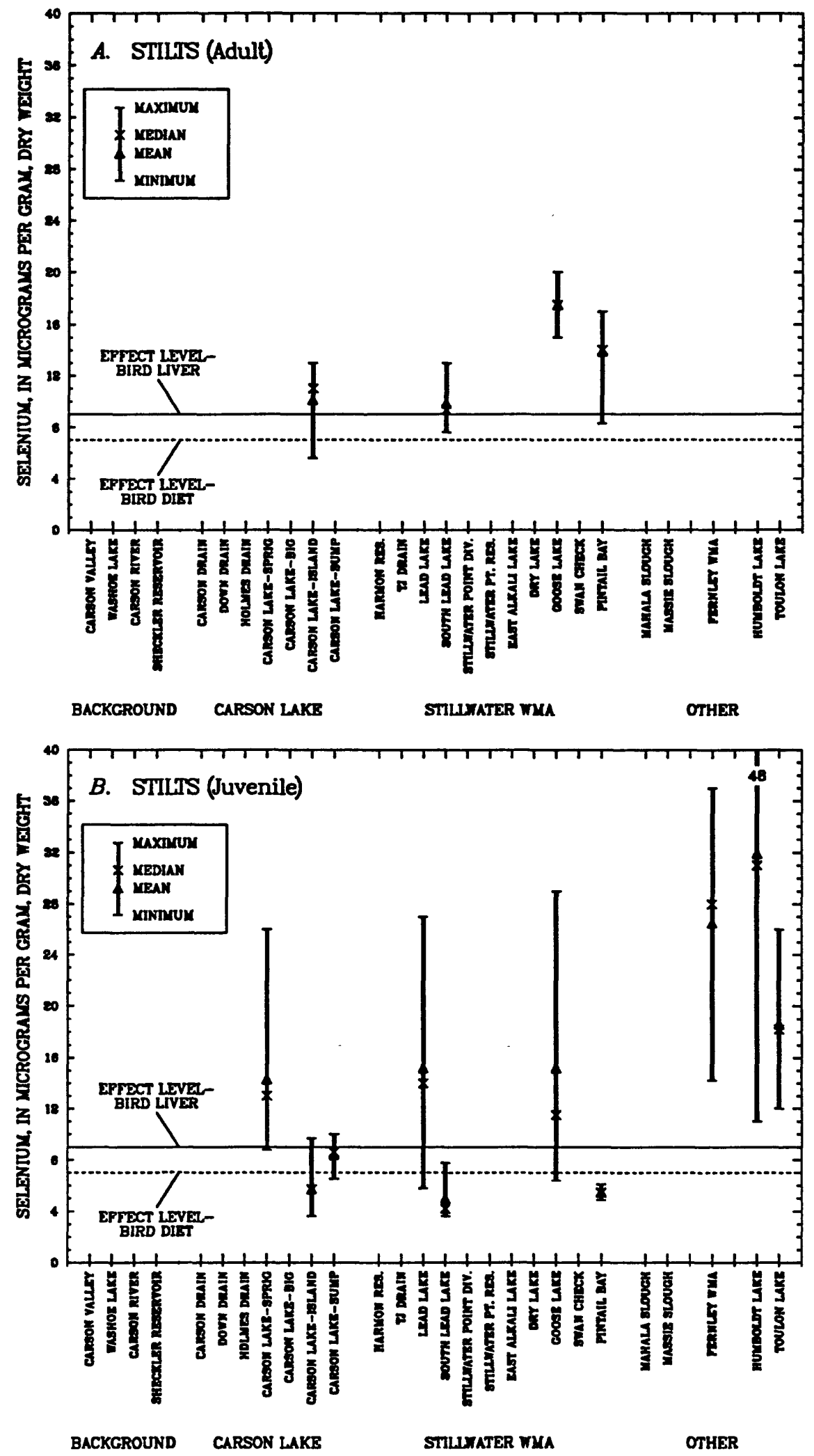

FIGURE 30.--Arithmetic means, medians, and maximum-minimum ranges of selenium concentrations found in livers of black-necked stilt (A) adults and (B) juveniles in the background sites, Carson Lake, and Stillwater, Femley, and Humboldt Wildlife Management Areas, in downstream order, 1986-87. Effect level for bird liver is from Lemly and Smith (1987, p. 8); effect level for bird diet is from Gregory J. Smith (U.S. Fish and Wildlife Service, oral commun, 1989). (Samples not collected at all sites.) Concentrations exceeding effect level may adversely impact the organism. 


\section{Zinc}

Fish

The 85th-percentile concentration of zinc residue in whole-body fish found in the National Contaminant Biomonitoring Program was $155 \mu \mathrm{g} / \mathrm{g}$ dry weight (Lowe and others, 1985, p. 370). From figure 31, it is apparent that this concem criterion was exceeded in carp from portions of Carson Lake and Stillwater WMA, and two background sites, Washoe Lake and Sheckler Reservoir. The highest median concentration, $322 \mu \mathrm{g} / \mathrm{g}$, was observed in carp from Sheckler Reservoir, a background site for water and bottom-sediment analysis.

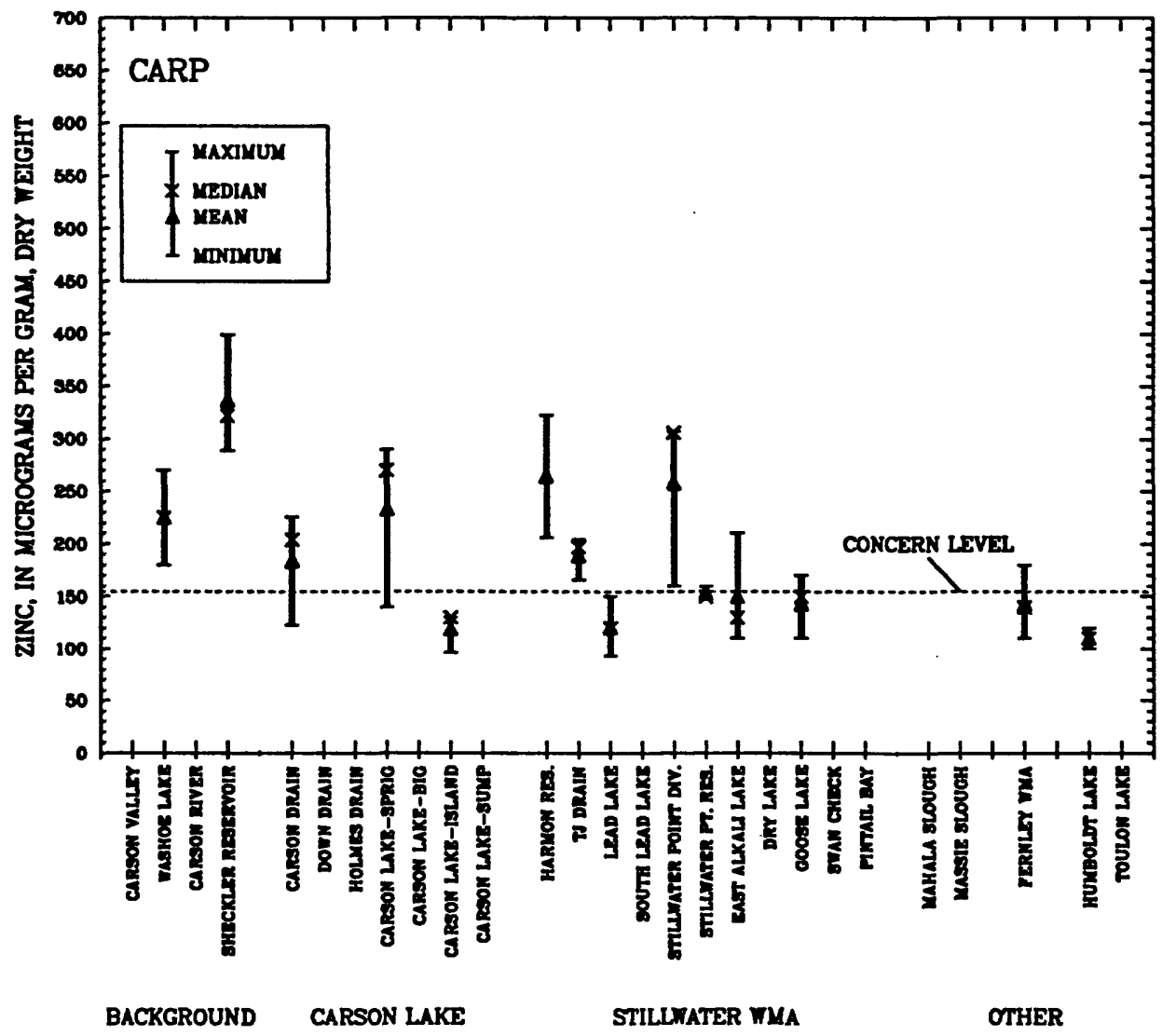

FIGURE 31.--Arithmetic means, medians, and maximum-minimum ranges of zinc concentrations found in carp tissue in the background sites, Carson Lake, and Stillwater, Femley, and Humboldt Wildlife Management Areas, in downstream order, 1986-87. Concem level for fish is from Lowe and others (1985, p. 370). (Samples not collected at all sites.) Concentrations exceeding concem level may indicate exposure of the organism to contaminants. 


\section{PUBLIC HEALTH WARNINGS}

\section{Mercury in Birds}

The public-health warning criterion for mercury residue in edible bird tissue, $3.6 \mu \mathrm{g} / \mathrm{g}$ dry weight, was exceeded in duck muscle and in duck and coot liver. The median concentration of mercury in mallard muscle was $4.4 \mu \mathrm{g} / \mathrm{g}$ in Carson Lake. Mercury residue in muscle of redheads and shovelers was consistently less than $3.6 \mu \mathrm{g} / \mathrm{g}$ dry weight (figure 26). Of 32 skin samples analyzed, only one--a mallard from West Lee Drain, Carson Lake-exceeded the criterion, with $4.4 \mu \mathrm{g} / \mathrm{g}$. As expected, duck liver contained the highest residue levels. Some of the higher mercury concentrations in liver were found at: Sprig Pond Unit in Carson Lake $(12.0 \mu \mathrm{g} / \mathrm{g})$; West Lee Drain at Carson Lake $(12.0 \mu \mathrm{g} / \mathrm{g})$; the Islands Unit in Carson Lake $(6.5 \mu \mathrm{g} / \mathrm{g})$; and Lead Lake in Stillwater WMA $(4.5 \mu \mathrm{g} / \mathrm{g}$ ). Liver residue in both redheads and shovelers (3.6 and $6.1 \mu \mathrm{g} / \mathrm{g}$, respectively) from Lead Lake in the Stillwater WMA were exceptionally high. As shown in figure 24, median residue concentrations in coot livers met or exceeded the public health warning criterion in 8 out of 18 data sets (44 percent).

\section{Selenium in Fish}

The public-health warning criterion for selenium in whole fish, $7.2 \mu \mathrm{g} / \mathrm{g}$ dry weight, was exceeded in carp. The median concentration of selenium in carp from Fernley WMA was $8.8 \mu \mathrm{g} / \mathrm{g}$.

\section{Selenium in Birds}

The public-health warning criterion for selenium residue in edible bird tissue, $7.2 \mu \mathrm{g} / \mathrm{g}$ dry weight, was exceeded in duck muscle, and in duck and coot liver. Mallard muscle from Femley WMA contained selenium ranging from 1.8 to $15.0 \mu \mathrm{g} / \mathrm{g}$, with a median of $5.9 \mu \mathrm{g} / \mathrm{g}$. A notable mallard muscle sample from the Sprig Pond Unit in Carson Lake contained a selenium concentration of $21.0 \mu \mathrm{g} / \mathrm{g}$ (figure 32).

In contrast to other body tissues, duck liver appears to concentrate selenium. Mallard livers from Fernley WMA contained exceptionally high selenium residues, with a median of $26.0 \mu \mathrm{g} / \mathrm{g}$ dry weight. Mallard livers from Stillwater WMA, however, had a median selenium residue level of $5.4 \mu \mathrm{g} / \mathrm{g}$. Median selenium levels in coot livers exceeded or approached the public-health warning criterion in the following areas: Mahala Slough $(34.0 \mu \mathrm{g} / \mathrm{g}) ;$ Massie Slough $(18.0 \mu \mathrm{g} / \mathrm{g}) ;$ Humboldt Lake $(11.0 \mu \mathrm{g} / \mathrm{g})$; Toulon Lake $(9.6 \mu \mathrm{g} / \mathrm{g}$; site 38 in plate 1); Goose Lake in Stillwater WMA (8.2 $\mu \mathrm{g} / \mathrm{g})$; Femley WMA $(7.3 \mu \mathrm{g} / \mathrm{g})$; Sprig Ponds Unit in Carson Lake $(7.0 \mu \mathrm{g} / \mathrm{g})$; and Lead Lake in Stillwater WMA $(7.0 \mu \mathrm{g} / \mathrm{g})$.

Skin appears to accumulate less selenium than either muscle or liver. Of the 32 samples of skin analyzed, all contained less than the $7.2-\mu \mathrm{g} / \mathrm{g}$-dry-weight criterion. 


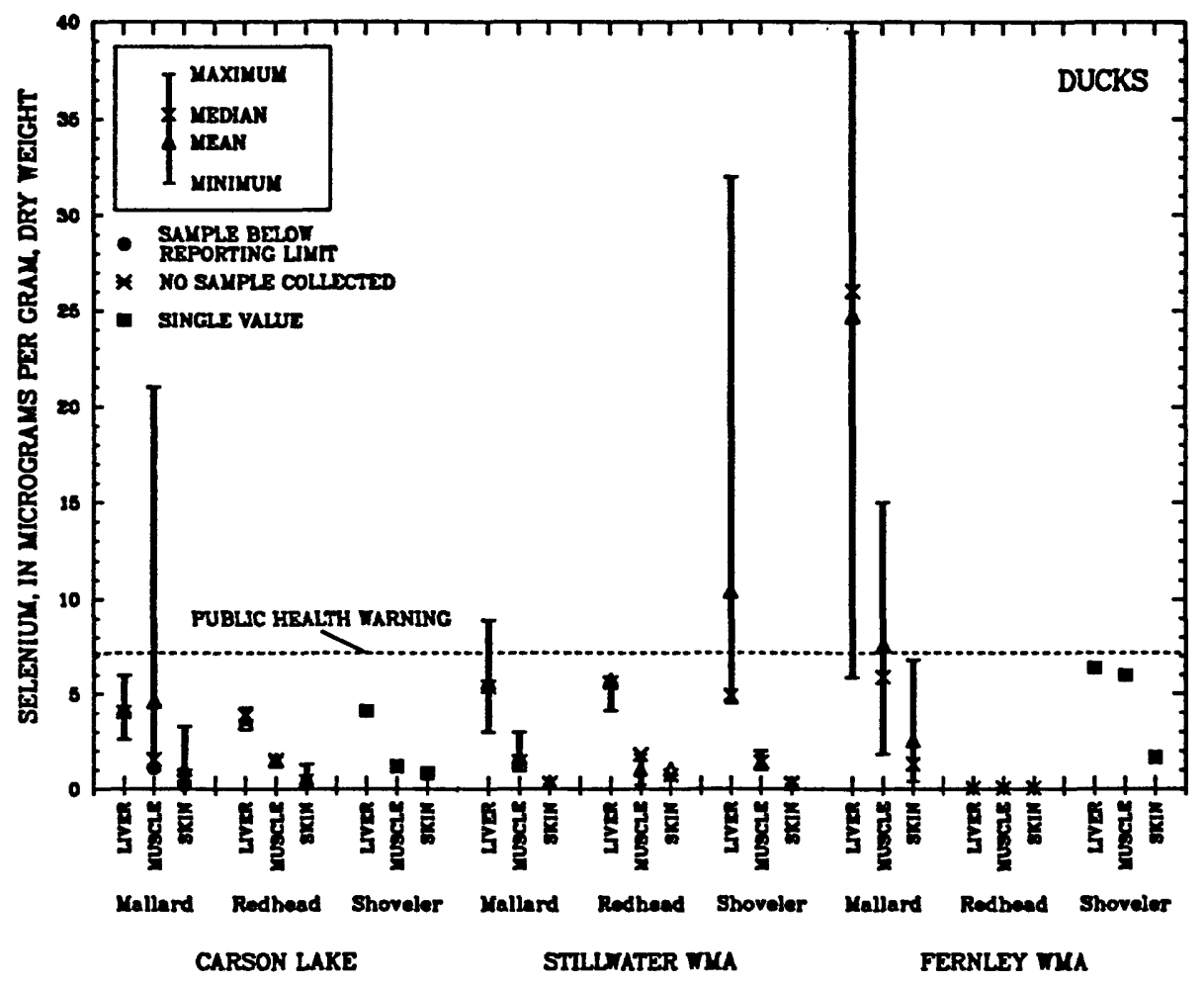

FIGURE 32.--Arithmetic means, medians, and maximum ranges of selenium concentrations found in mallard, redhead, and shoveler duck liver, muscle, and skin tissue, in the background sites, Carson Lake, and Stillwater and Fernley Wildlife Management Areas, in downstream order, 1986-87. Public health waming for duck muscle is from Fan and others (1988, p. 544). (Samples not collected at all sites.)

\section{BIOLOGICAL EFFECTS OF CONTAMINANTS}

On the basis of contaminant concentrations measured in biota during this study, both direct and indirect adverse effects may be predicted in migratory birds, fish, and the ecosystem as a whole. In addition, public health warning criteria for mercury and selenium are exceeded in some consumable fish and waterfowl. Specific contaminants in plant and animal tissues that have the potential to cause adverse biological effects have not yet been firmly established, but at this time (1986-89) arsenic, boron, mercury, selenium, and zinc appear elevated in these tissues. Other constituents or properties of water at or above some threshold values that may adversely affect aquatic life are chromium, copper, un-ionized ammonia, sodium, dissolved-solids concentration, and perhaps even dissolved-oxygen supersaturation. To date (1989), potential contaminants have been identified primarily through comparisons with documented thresholds found in the literature which are derived primarily from controlled laboratory experiments.

This report does not designate one constituent, or even a limited number of constituents, as being of the highest concern, in terms of potential adverse effects on plants and animals. This is due, but not limited to: (1) the need for improved understanding of possible antagonistic or synergistic effects that two or more trace elements may have on the biochemistry of an affected organism; (2) the scarcity of known dramatic embryonic deformities from the wetlands of the Carson Desert that can be attributed to a single contaminant, as observed in other wetland habitats (for example, Kesterson National Wildlife Refuge, Calif.; Ohlendorf and others, 1986); (3) the paucity of information concerning the ecology (hydrology, water and sediment chemistry, and 
associated biota) of oxygenated, high-pH wetlands in the arid west; and (4) the many subtle and puzzling adverse effects that wildlife biologists have observed in Stillwater Wildlife Management Area, which indicate that the wetland's ability to support a wide variety of healthy plant and animal communities is steadily declining.

Other gross indicators of habitat degradation include the following: migratory bird disease epidemics (Vega, 1987, p. 9); an unusually high incidence of unexplained migratory bird mortality observed at Stillwater WMA, Humboldt WMA, and Carson Lake; aquatic vegetation loss at an alarming rate at both Stillwater WMA and at Carson Lake; and only two or three species of macroinvertebrates are present at many sites. Reptiles and amphibians, formerly abundant, are now considered rare in many of the wetlands, and sport fish such as largemouth bass are now either scarce or absent (R.M. Anglin, U.S. Fish and Wildlife Service, 1987, oral commun.).

Considering the kinds and quantities of potentially toxic constituents that exceeded recommended criteria (arsenic, boron, selenium, and sodium, for example); and, furthermore, considering that these constituents and others were found in higher concentrations in irrigation return flows and in some wetlands compared to the background sites, it appears that (1) a contamination problem exists in some wetlands within the study area, and (2) that irrigation drainwater exerts a major role as the source of this contamination problem. In some areas, such as Fernley WMA, subsurface drainage of the shallow ground water to wetlands also is an important source of contamination. Several observations from the data can be made that may explain certain aspects of the problem. These observations are discussed below in three broad categories: direct effects, indirect effects, and human health.

\section{Direct Effects}

\section{Boron}

Large differences (up to 50 times) in the concentration of boron were observed in the juvenile bird livers collected between 1986 and 1987. Many of the juvenile bird livers collected in 1986 contained concentrations above effect levels, whereas those collected from the same species and general wetland units in 1987 contained residue levels similar to those from background sites. This inconsistency is not understood. Field sampling techniques and processing were identical in 1986 and 1987 and all the 1986 residue levels were well above analytical reporting limits.

One additional observation can be made of contaminant studies involving boron. Had this study been conducted in 1987 only, the existing boron contamination problem probably would not have been recognized. In short-term field studies, there is always the risk that not all pertinent factors will be identified.

\section{Selenium}

Selenium concentrations were generally less than the analytical reporting limit in water, and below the effect and concern criteria in water and in tissues from the background sites, Washoe Lake and Carson Valley. The primary source of selenium in wetland organisms appears to be from soils in and near irrigated areas. Henny (1987) reached a similar conclusion based on residues of selenium in early- and late-nesting white-faced ibis from Carson Lake. These birds, however, feed primarily in irrigated fields within the study area rather than in open-water wetlands. 
Lemly and Smith (1987, p. 4), described the process of biomagnification of selenium from water through successive trophic levels of a food chain. For example, some plants may bioconcentrate selenium by a factor of 500 , macroinvertebrates or zooplankton may concentrate selenium by a factor of 2 to 6 , and so on up the food chain. Such biomagnification is occurring in this study area and would account for the significant selenium residue concentrations found in juvenile bird livers. Although selenium was less than the analytical reporting limit $(1.0 \mu \mathrm{g} / \mathrm{L})$ in most filtered water samples, selenium residue in livers of many juvenile birds analyzed during this study exceeded the $9.0 \mu \mathrm{g} / \mathrm{g}$ effect criterion (Lemly and Smith, 1987, p. 8). Interpretation of the limited selenium data at hand indicates that the pathway of selenium is from the sediments to the insects to the birds. However, the absence of measurable concentrations of dissolved selenium in surface waters does not provide a basis for bioconcentration by producers, algae and vascular aquatic plants. Hypothetically, the pathways through which selenium enters the wetlands, and ultimately bird tissue, may be explained in several ways:

1. Selenium bound to sediments, detritus, or within living organisms such as algae may be moving through the irrigation drain systems. Operational spills of unused irrigation water are common occurrences and could easily transport sediments, detritus and living organisms downgradient into receiving wetlands. Selenium bound to particles larger than $0.45 \mu \mathrm{m}$ would not be accounted for in filtered water samples.

2. The Newlands Project was completed in 1916 and many of the agricultural fields have been drained for years. The selenium now being detected in various plant and animal tissues may have been previously transported (by way of surface or ground water) to the wetlands long ago. Samples of bottom sediment from Lead Lake and Carson Lake appeared to be slightly enriched with selenium.

3. Evidence indicates that selenium may be unevenly distributed areally (U.S. Bureau of Reclamation, 1987a) in the shallow alluvial aquifer beneath irrigated areas and adjacent lands. Mobilized selenium may be entering some downgradient wetlands directly (by way of subsurface flow), or may seep into selenium-laden subsurface water drains constructed below land surface some distance downgradient from irrigated lands.

4. Selenium may have been deposited in pre-existing wetlands and soils of created wetlands prior to agricultural development.

\section{Indirect Effects}

Biological effects on the ecosystem caused by multiple contaminants may be expressed in more subtle ways than was recently observed in California where direct adverse reproductive effects on migratory birds were documented with one element--selenium (Ohlendorf and others, 1986, p. 53). An understanding of hydrology and water management within terminal wetland ecosystems of the Great Basin, as well as changes in species diversity, wildlife-production trends, and stress-induced disease, may all offer insight to the affect of irrigation drainwater upon plants and animals in the study area. 


\section{Concentration of Dissolved Solids, Dissolved Oxygen, and Dissolved Un-ionized Ammonia}

Dissolved-solids concentrations and the dissolved-solids tolerance ranges of important wetland plants are part of the criteria used for regulation of water in the large, managed wetland areas (Stillwater, Humboldt, and Fernley WMAs, and Carson Lake). Untolerably high dissolved-solids concentrations are believed to be a major factor in the loss of emergent vegetation from Stillwater WMA (U.S. Department of the Interior, 1988, Appendix E, p. 76). In 1959, 3,300 acres of emergent plants existed in Stillwater WMA, while in 1987 only 600 acres remained (table 2). Similar emergent vegetation loss occurred at Carson Lake during this same time period. Stewart and Kantrud (1972, p. D19) provide data on responses of dominant emergent vegetation to changes in specific conductance. Dissolved solids measured during this study in some wetland areas can be expected to adversely affect existing aquatic vegetation. Indirect losses to fish and wildlife associated with the loss of emergent vegetation include:

1. Loss of nesting habitat for migratory birds including redhead ducks;

2. Loss of escape cover for juvenile fish; and

3. Loss of habitat for some invertebrate species which provide a forage base for fish and birds.

The unusually high dissolved-oxygen concentration and resulting saturation values are indicative of extremely high ambient productivity by the suspended (and attached) algae. According to some researchers, supersaturation with dissolved oxygen is harmful to some fish (McKee and Wolf, 1963, p. 181). Water highly saturated with oxygen (or other gas) may be acutely lethal to fish due to the formation of gas emboli inside the blood vascular system of exposed fish.

Untolerably high concentrations of un-ionized $\mathrm{NH}_{3}$, the most toxic form of aqueous nitrogen, have the potential to be acutely toxic to some sensitive fish or to cause the organism some physiological stress. Such stress, compounded by other attendant stressful factors--including high temperature, high dissolved-solids concentration, and too-low or too-high dissolved-oxygen concentration--may account for occasional and unexplained fish kills (Hoffman and Averett, 1982, p. A41).

\section{Avian Botulism}

The primary waterfowl and shorebird disease identified in the wetlands area is avian botulism, caused by the anaerobic bacterium, Clostridium botulinum, type C. Documented outbreaks of this disease in Stillwater WMA are summarized by Vega (1987, p. 9). Yearly waterfowl losses recorded since 1949 have ranged from "too few to mention" to 52,000 dead birds in 1983 . In some years, such as 1988 , the waterfowl losses due to botulism exceeded the total production. During 1988 , more than 20,000 birds died of avian botulism. Of this number, about 15,000 were migratory birds, mostly ducks. Only about 2,000 ducks were produced within the study area during 1988 (R.M. Anglin, U.S. Fish and Wildlife Service, oral commun., 1988).

Botulism outbreaks are associated with specific aquatic micro-environmental conditions. The causative organism is generally present in wetlands, but multiplies and produces the lethal toxin only under anaerobic conditions, which are associated with receding water levels, rotting organic matter, poor-quality water, and the presence of decaying invertebrate bodies which concentrate the toxin produced by the bacteria. Waterfowl and shorebirds are poisoned when they ingest decaying aquatic insects and maggots (Locke and Friend, 1987, p. 8394). Decomposing bodies of botulism-killed birds provide an anaerobic substrate for reproduction of Clostridium botulinum, and may accelerate the spread of botulism during outbreaks. 
Many of the wetlands within the study area are shallow and subject to rapid loss of water through evapotranspiration. This physical process causes an increase in the concentration of dissolved constituents, such as arsenic and boron, in the water. Water-quality conditions, including trace elements and salinity, which are toxic to invertebrates, have been demonstrated in both drain water and ponds at Stillwater WMA (Ingersoll and others, 1988, p. 9). When wetlands begin to dry up, toxic trace elements and salinity probably will increase in concentration above a threshold at which invertebrate mortality can be expected. Under such conditions botulism outbreaks may be stimulated by the increase production of toxin which is available to waterfowl using the area.

\section{Trace-Element Toxicity in Birds}

Although bird mortality is a common occurrence in parts of the study area, numerous necropsy reports (postmortem examination) provide no conclusion as to cause of death. Hundreds of the sick and dead birds were found in 1986 and 1987. The emaciated birds may be indicative of chronic trace-element toxicosis that could have been caused by one or more of the elements discussed previously. For example, Heinz and others (1988, p. 561) recorded reductions in food consumption and weight of mallard ducklings fed selenium. They reported that liver residue was not diagnostic of death, but suggested that "...selenium-induced starvation may have been related to duckling mortality."

\section{Human Health}

During the first year of this study, residues of mercury and selenium in some bird livers and wholebody fish were above criteria established for public health warnings in Nevada and California. Of the species initially collected, only carp and coots are now eaten by humans, but these species are not believed to be extremely popular among people within the study area. With this residue information, a decision was made to expand the study to include ducks which are routinely taken for human consumption from the larger managed wetland areas--Stillwater and Fernley WMAs and Carson Lake. Only ducks were sampled because a sport fishery no longer exists in the wetlands that receive irrigation drainage.

\section{Mercury in Ducks}

Edible portions of mallard ducks from Carson Lake exceeded the mercury criterion for public health wamings, as did coot livers from both Carson Lake and Stillwater WMA. Consumption of liver is considered a "worst case human exposure" because duck livers are not commonly eaten (Klasing and Pilch, 1988, p. 9). These observations were consistent with other tissue data gathered in this study. Tissues of all trophic levels from Carson Lake and portions of Stillwater WMA contain high residue levels of mercury. As mentioned previously, mercury appears to have been distributed along several channels of the Carson River prior to the completion of Lahontan Dam in 1915. High concentrations of mercury are seen in biota from wetland areas

closely aligned with these historic Carson River channels. Based on invertebrate and fish residue data, there is evidence of mercury redistribution through agriculture drainage (figures 22 and 23). 


\section{Selenium in Fish and Birds}

Selenium in both fish and birds from Fernley WMA exceeded public health warning criteria. This is consistent with effect and concem residue levels found in other tissues, such as insects, collected from Femley WMA. Approximately 40 percent of the water receipts in Fernley WMA is represented as shallow groundwater seepage from the Truckee Canal (Van Denburgh and Arteaga, 1985, p. 6). Seepage losses from the Truckee Canal flow through soils unassociated with irrigated lands. Selenium accumulation in biota may be from subsurface drainage of shallow ground water to wetlands in the Fernley WMA. The importance of that shallow ground water in the mobilization and movement of selenium has been documented by Deverel and Fujii (1988).

\section{SUMMARY}

A reconnaissance-level investigation was begun in June 1986 to determine whether the quality of irrigation drainage in and near the Stillwater Wildlife Management Area has caused or has potential to cause harmful effects on human health, fish and wildlife, or adversely affect other beneficial uses of water. This reconnaissance chiefly focused on human health and fish and wildlife concerns.

Water from the Carson and Truckee Rivers, of relatively low dissolved-solids content, is used to irrigate 55,000-62,000 acres of pasture and cropland, principally alfalfa, in an arid environment and commonly on alkaline soil. Irrigation water is used and sometimes reused as it flows--trending northeastward and southeastward--toward the topographic low areas of the Carson Desert. These low areas typically receive irrigation drainage of high dissolved-solids content and delineate the extent of the wetland habitats.

Samples of water, bottom sediment, and biota were collected from sites upstream and downstream from the Fallon agricultural area in the Carson Desert, known locally as Lahontan Valley. The samples from each of the three media were analyzed for a suite of potentially toxic trace elements. Other analyses included nitrogen, phosphorus, and radioactive substances in water, and organochlorine-pesticide residues in bottom sediments and biota. Water samples were collected four times (near seasonal) from June 1986 to September 1987, bottomsediment once during low-flow conditions, and biological samples were collected in 1986 from June through November, and in 1987 from April through August.

Table 10 provides a summary of the approximately 20 potentially toxic contaminants that were examined in the three sampling media and indicates whether the constituent concentration(s) is at a concern level for the indicated sampling medium. The results of this reconnaissance indicate that (1) arsenic, boron, mercury, and selenium concentrations are of primary concern to human health and fish and wildlife in and near Stillwater Wildlife Management Area; and (2) that chromium, copper, zinc, un-ionized $\mathrm{NH}_{3}$, dissolved-solids concentration, and the major ion, sodium, may approach a similar level of concern. The trace elements mentioned above are listed alphabetically, not by any preconceived order of toxicological importance.

On the basis of the data collected in this reconnaissance study, it is apparent that contamination exists within some wetland areas that receive irrigation drainwater or subsurface drainage of shallow ground water, or both. 


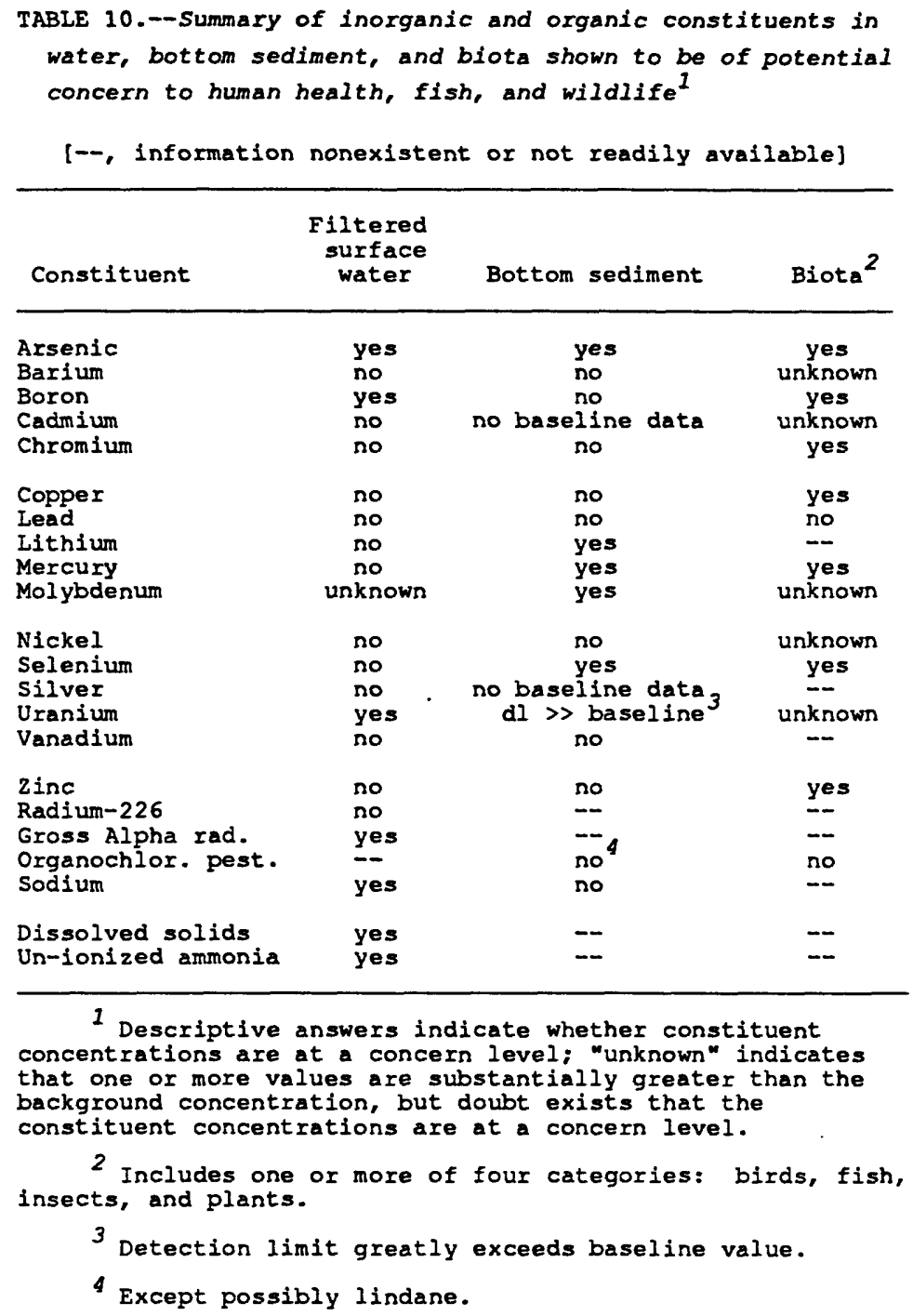

Important findings of this study include:

1. Dissolved solids (salinity) tended to increase greatly (overall eightfold to tenfold) at the drain sites compared with the upstream sites as a result of application and subsequent drainage of irrigation water on fields in the Fallon agricultural area. Evapotranspiration also is a major factor that concentrate solutes in water.

2. In general, the concentrations of solutes in drainwater were highest during the pre-irrigation season (winter), and lowest during the late-irrigation season (fall).

3. Dissolved solids and a major component, sodium, were found in sufficiently high concentrations, $4,800 \mathrm{mg} / \mathrm{L}$ and $1,500 \mathrm{mg} / \mathrm{L}$, respectively, in some wetlands to have an adverse effect on fresh water fish reproduction and duckling survival. 
4. Sixty-nine percent of the water samples contained arsenic concentrations that exceeded the $40-\mu \mathrm{g} / \mathrm{L}$ Nevada criterion for the protection of aquatic life and the effect level for amphibians.

5. Dissolved-boron concentrations were remarkably high in some wetlands and a significant, positive relation was shown between measured concentrations of boron and dissolved solids. The $200-\mu \mathrm{g} \Omega$ effect level of boron on fish reproduction was exceeded in all water samples from sites affected by irrigation drainage. Unexplained high concentrations of boron were found in bird livers in 1986 compared with those sampled in 1987.

6. The potential is great for toxic concentrations of un-ionized ammonia to form in the wetlands when $\mathrm{pH}$ and temperature of the water are high.

7. Sampled ground water can be characterized as brackish or saline (dominated by sodium, chloride, and sulfate), slightly alkaline, and containing high concentrations of arsenic, boron, and molybdenum.

8. Bottom sediments were anaerobic (with hydrogen sulfide odor) and, with the possible exception of lindane, contained low concentrations of organochlorine pesticides. Organochlorine pesticide residues in biota were mostly below the analytical reporting limit of 0.01 or $0.1 \mu \mathrm{g} / \mathrm{g}$.

9. Selenium concentrations were at or below analytical reporting limit $(1 \mu \mathrm{g} / \mathrm{L})$ in water sampled during this study. In contrast, elevated levels of selenium have been found in migratory birds from Lead Lake, Goose Lake, Carson Lake, Mahala and Massie Sloughs, and the Humboldt and Fernley WMA's. Selenium may be accumulating in livers of juvenile waterfowl in sufficient quantities to affect reproduction, and in bottom sediments within some wetlands.

10. Elevated concentrations of mercury (exceeding a background concentration of $0.41 \mathrm{mg} / \mathrm{kg}$ ) were found in sediments in old river channels of the Carson River that pre-date the Newlands Irrigation Project. Mercury appears to be biomagnified in the sampled biota in the study area.

11. Adverse biological effects observed during this reconnaissance ranged from gradual vegetative changes and species loss to sudden fish die-offs. A negative effect on the health of migratory birds using the area, as evidenced by infectious disease epidemics and long-term degradation of body conditions of many birds examined, was observed. 


\section{REFERENCES CITED}

Barnes, Ivan, 1964, Field measurement of alkalinity and pH: U.S. Geological Survey Water-Supply Paper 1535-H, $17 \mathrm{p}$.

Birge, WJ., and Black, J.A., 1977, Sensitivity of vertebrate embryos to boron compounds: U.S. Environmental Protection Agency, EPA-560/1-75-008, 64 p.

Birge, WJ., 1978, Embryo-larval bioassays on inorganic coal elements and in situ biomonitoring of coal-waste effluents, in Samuel, D.E., and others, eds., Surface mining and fish/wildlife needs in the eastern United States, 97 p. Available only through National Technical Information Service, Springfield, Va. 22161, accession no. PB-298 353.

Brown, W.M., Nowlin, J.O., Smith, L.H., and Flint, M.R., 1986, River-quality assessment of the Truckee and Carson River system, California and Nevada--Hydrologic characteristics: U.S. Geological Survey OpenFile Report 84-576, 201 p.

Cooper, J.J., Thomas, R.O., and Reed, S.M., 1985, Total mercury in sediment, water, and fishes in the Carson River drainage, west-central Nevada: Nevada Division of Environmental Protection, 96 p.

Deverel, S.J., and Fujii, Roger, 1988, Process affecting the distribution of selenium, in shallow ground water of agricultural areas, western San Joaquin Valley, California: Water Resources Research, v. 24, no. 4, p. 516-524.

Dollarhide, W.E., 1975, Soil Survey [of] Fallon-Fernley area, [and] parts of Churchill, Lyon, Storey, and Washoe Counties: Washington, D.C., U.S. Department of Agriculture, 112 p.

Eisler, Ronald, 1985, Selenium hazards to fish, wildlife, and invertebrates-A synoptic review: U.S. Fish and Wildlife Service Biological Report 85(1.5), 57 p.

----1986, Chromium hazards to fish, wildlife, and invertebrates--A synoptic review: U.S. Fish and Wildlife Service Biological Report 85(1.6), 60 p.

-----1987, Mercury hazards to fish, wildlife, and invertebrates--A synoptic review: U.S. Fish and Wildlife Service Biological Report 85 (1.10), 90 p.

Fan, A.M., Book, S.A., Neutra, R.R., and Epstein, D.M., 1988, Selenium and human health implications in California's San Joaquin Valley: Journal of Toxicology and Environmental Health, v. 23, p. 539-559.

Federal Inter-Agency Sedimentation Project, 1986, Instruments and reports for fluvial sediment investigations: Minneapolis, Minn., Federal Inter-Agency Sedimentation Project, 138 p.

Friedman, L.C., and Erdmann, D.E., 1982, Quality assurance practices for the chemical and biological analyses of water and fluvial sediments: U.S. Geological Survey Techniques of Water Resources Investigations, Book 5, Chapter A6, 181 p.

Friend, Milton, 1987, Avian cholera, in Field guide to wildlife disease: Washington, D.C., U.S. Fish and Wildlife Service Resource Publication 167, 255 p. 
Garcia, K.T., and Carman, R.L., 1986, Water-quality characteristics and nutrient and suspended-sediment loads, Carson River and Truckee Canal, western Nevada, water year 1980: U.S. Geological Survey Water-Resources Investigations Report 85-4147, $107 \mathrm{p}$.

Geode, A.A., 1985, Mercury, selenium, arsenic, and zinc in waders from the Dutch Wadden Sea: Environmental Pollution, v. 37A, p. 287-309.

Gilderhus, P.A., 1966, Some effects of sublethal concentrations of sodium arsenite on bluegills and the aquatic environment: Transactions of the American Fisheries Society, v. 95, no. 3, p. 289-296.

Gilliom, R.J., and Helsel, D.R., 1984, Estimation of distributional parameters for censored trace-level water-quality data--I. Estimation techniques: U.S. Geological Survey Open-File Report 84-729, 25 p.

Glancy, P.A., 1986, Geohydrology of the basalt and unconsolidated sedimentary aquifers in the Fallon area, Churchill County, Nevada: U.S. Geological Survey Water-Supply Paper 2263, 62 p.

Glancy, P.A., and Katzer, T.L., 1975, Water-resources appraisal of the Carson River basin, western Nevada: Nevada Division of Water Resources, Reconnaissance Report 59, $126 \mathrm{p}$.

Guy, H.P., 1969, Laboratory theory and methods for sediment analysis: U.S. Geological Survey Techniques of Water-Resources Investigations, Book 5, Chapter $\mathrm{Cl}, 58 \mathrm{p}$.

Hallock, R.J., Buchanan, C.C., and Herrig, D.M., 1981, Humboldt River and tributaries project--Hylton Dam and Reservoir, Elko County, Nevada: Reno, Nev., U.S. Fish and Wildlife Service, unpublished report, 86 p.

Haseltine, S.D., Sileo, L., Hoffman, O.J., and Mulhern, B.M., 1985, Effects of chromium on reproduction and growth of black duck: U.S. Fish and Wildlife Service, unpublished report, 25 p.

Heinz, G.H., 1979, Methylmercury--Reproductive and behavioral effects on three generations of mallard ducks: Journal of Wildlife Management, v. 43, no. 2, p. 394-401.

Heinz, G.H., Hoffman, D.J., and Gold, L.G., 1988, Toxicity of organic and inorganic selenium to mallard ducklings: Archives of Environmental Contamination and Toxicology, v. 17, p. 561-568.

Helsel, D.R., and Gilliom, R.J., 1985, Estimation of distributional parameters for censored trace-level waterquality data--II. Verification and applications: U.S. Geological Survey Open-File Report 85-86, 21 p.

Hem, J.D, 1985, Study and interpretation of the chemical characteristics of natural water (3d ed.): U.S. Geological Survey Water-Supply Paper 2254, 263 p.

Henny, Charles, 1987, Elevated mercury and selenium are found in White-Faced Ibis at Carson Lake, Nevada: Reno, Nev., U.S. Fish and Wildlife Service, Research Information Bulletin no. 87-70, July 1987, 1. p.

Hoffman, R.J., and Avereth, R.C., 1982, Influences of water temperature on aquatic biota, in Greeson, P.E., ed., Biota and biologic principles of the aquatic environment: U.S. Geological Survey Circular 848-A, p. A37-A42.

Horowitz, A.J., and Elrick, K.E., 1987, The relation of stream sediment surface area, grain size, and composition to trace element chemistry: Applied Geochemistry, v. 2, p. 437-451. 
Ingersoll, C.G., Dwyer, FJ., Nelson, M.K., Burch, S.A., and Buckler, D.R., 1988, Whole effluent toxicity of agricultural irrigation water entering Stillwater National Wildlife Refuge, NV--Acute toxicity studies with fish and aquatic invertebrates: Columbia, Mo., U.S. Fish and Wildlife Service, unpublished report, p. 16.

Klasing, S.A., and Pilch, S.M., 1988, Agricultural drainage water contamination in the San Joaquin Valley-A public health perspective for selenium, boron, and molybdenum: Sacramento, Health Officers Association of California, p. 135.

Lemly, A.D., and Smith, G.J., 1987, Aquatic cycling of selenium--Implications for fish and wildlife: U.S. Fish and Wildlife Service leaflet 12, $10 \mathrm{p}$.

Lico, M.S., Kharaka, Y.K., Carothers, W.W., and Wright, V.A., 1982, Methods for collection and analysis of geopressured geothermal and oil-field waters: U.S. Geological Survey Water-Supply Paper 2194, 21 p.

Lico, M.S., Welch, A.H., and Hughes, J.L., 1986, Hydrologic, lithologic, and chemical data for sediments in the shallow alluvial aquifer at two sites near Fallon, Churchill County, Nevada, 1984-85: U.S. Geological Survey Open-File Report 86-250, 43 p.

----1987, Geochemistry of ground-water in the shallow alluvial aquifer, Carson Desert, western Nevada, in Averett, R.C., and McKnight, D.M., Chemical quality of water and the hydrologic cycle: Chelsea, Mich., Lewis Publishers, p. 89-109.

Lillebo, P.H., Shaner, S., Carlson, P., Richard, N., and Dubarry, Paul, 1988, Regulation of agricultural drainage to the San Joaquin River--Appendix D. Water quality criteria for selenium and other trace elements for protection of aquatic life and its uses in the San Joaquin Valley: California State Water Resources Control Board Report W.O. 85-1, 151 p.

Locke, L.N., and Friend, Milton, 1987, Field guide to wildlife diseases, general field procedures and diagnosis: U.S. Fish and Wildlife Service Resources Publication 167, 225 p.

Lowe, T.P., May, T.W., Brumbaugh, W.G., and Kane, D.A., 1985, National Contaminant Biomonitoring Program-Concentrations of seven elements in freshwater fish, 1978-81: Archives of Environmental Contamination and Toxicology, v. 14, p. 363-388.

McKee, J.E., and Wolfe, H.W., 1963, Water quality criteria (2d ed.): California Water Quality Control Board Publication 3-A, $548 \mathrm{p}$.

Mitcham, S.A., and Wobeser, G., 1988a, Toxic effects of natural saline water on mallard ducklings: Journal of Wildlife Diseases, v. 24 , no. 1, p. $30-44$.

-----1988b, Effects of sodium and magnesium sulfate in drinking water on mallard ducklings: Journal of Wildlife Diseases, v. 24, no. 1, p. 45-50.

Morgan, D.S., 1982, Hydrogeology of the Stillwater area, Churchill County, Nevada: U.S. Geological Survey Open-File Report 82-345, 95 p. 
National Climatic Center, 1985-88, Climatological data, annual summary, Nevada, 1984-87: Asheville, N.C., National Oceanic and Atmospheric Administration, v. 99-v. 102, no. 13 (published annually).

Ohlendorf, H.M., Hoffman, D.J., Saiki, M.K., and Aldrich, T.W., 1986, Embryonic mortality and abnormalities of aquatic birds--Apparent impacts of selenium from irrigation drain water. Science of the Total Environment, v. 52, p. 49-63.

Olmsted, F.H., Glancy, P.A., Harrill, J.R., Rush, F.E., and Van Denburgh, A.S., 1975, Preliminary hydrogeologic appraisal of selected hydrothermal areas in northern and central Nevada: U.S. Geological Survey WaterResources Investigations Report 44-73, 78 p.

Otton, J.K., Zielinski, R.A., and Been, J.M., 1985, Uranium in Holocene valley-fill sediments and uranium, radon, and helium in waters, Lake Tahoe-Carson Range area, Nevada and California: U.S. Geological Survey Open-File Report 85-389, 30 p.

Patuxent Wildlife Research Center, 1987, Effects of irrigation drainage contaminants on wildlife: Laurel, Md., U.S. Fish and Wildlife Service, annual report FY 1987, 31 p.

Raven, Christopher, and Elston, Robert, eds., 1988, Preliminary investigations in Stillwater Marsh--Human prehistory and geochronology: Portland, Ore., U.S. Fish and Wildlife Service, Inter-mountain Research Report, p. 11-23.

Rollins, M.D., 1965, Water quality of Newlands Reclamation Project: Beltsville, Md., U.S. Department of Agriculture, $44 \mathrm{p}$.

Rowe, T.G., and Hoffman, R.J., (in press), Wildlife kills in the Carson Sink, western Nevada, winter of 1986-87, in Moody, D.W., Chase, E.B. and Aronson, D.A., compilers, National Water Summary, 1987-Hydrologic events and water supply and demand: U.S. Geological Survey Water-Supply Paper 2350.

Rush, F.E., 1968, Index of hydrographic areas in Nevada: Nevada Division of Water Resources, Information Report 6,38 p.

-..-1972, Hydrologic reconnaissance of Big and Little Soda Lakes, Churchill County, Nevada: Nevada Department of Conservation and Natural Resources, Water Resources - Information Report 11, 1 sheet.

Russell, I.C., 1885, Geologic history of Lake Lahontan, a Quaternary lake of northwestern Nevada: U.S. Geological Survey Monograph 11, 288 p.

Severson, R.C., Wilson, S.A., and McNeal, J.M, 1987, Analysis of bottom material collected at nine areas in the western United States for the DOI irrigation task group: U.S. Geological Survey Open-File Report 87490, $24 \mathrm{p}$.

Shacklette, H.T., and Boerngen, J.G., 1984, Element concentrations in soils and other surficial materials of the conterminous United States: U.S. Geological Survey Professional Paper 1134-A, 18 p.

Simpson, J.H., 1876, Report of explorations across the Great Basin in 1859: Reno, University of Nevada Press, $518 \mathrm{p}$. 
Sinclair, W.C., and Loeltz, O.J., 1963, Ground-water conditions in the Fernley-Wadsworth area, Churchill, Lyon, Storey, and Washoe Counties, Nevada: U.S. Geological Survey Water-Supply Paper 1619-AA, 22 p.

Skarheim, H.P., 1973, Tables of the fraction of ammonia in the undissociated form for $\mathrm{pH} 6$ to 9, temperature 0-30 ${ }^{\circ} \mathrm{C}$, TDS 0-3000 $\mathrm{mg} / \mathrm{L}$, and salinity $5-35 \mathrm{~g} / \mathrm{kg}$ : Berkeley, University of California, Sanitary Engineering Research Laboratory report 73-5, $33 \mathrm{p}$.

Smith, G.H., 1943, The history of the Comstock Lode, 1850-1920: University of Nevada Bulletin, Geology and Mining Series no. 37, 305 p.

Snarski, V.M., and Olson, G.F., 1982, Chronic toxicity and bioaccumulation of mercury chloride in the fathead minnow (Pimephales promelas): Aquatic Toxicology, v. 2, p. 143-156.

Stabler, Herman, 1904, Report on ground waters of the Carson Sink: U.S. Geological Survey, unpublished report, $49 \mathrm{p}$.

Standford, G., England, C.B., and Taylor, A.W., 1970, Fertilizer uses and water quality: U.S. Department of Agriculture ARS 41-168, $19 \mathrm{p}$.

Stephan, C.E., Mount, D.I., Hansen, D.J., Gentile, J.H., Chapman, G.A., and Brungs, W.A., 1985, Guidelines for deriving numerical national water quality criteria for the protection of aquatic organisms and their uses: Washington, D.C., U.S. Environmental Protection Agency, 98 p.

Stewart, R.E., and Kantrud, H.A., 1972, Vegetation of Prairie Potholes, North Dakota, in relation to quality of water and other environmental factors: U.S. Geological Survey Professional Paper 585-D, 36 p.

Strahorn, A.T., and Van Duyne, C., 1911, Soil survey of the Fallon area, Nevada: U.S. Department of Agriculture - Field Operations of the Bureau of Soils, 1909, 44 p.

Thatcher, L.L., Janzer, V.J., and Edwards, K.W., 1977, Methods for determination of radioactive substances in water and fluvial sediments: U.S. Geological Survey Techniques of Water-Resources Investigations, Book 5, Chapter A5, 95 p.

Thompson, S.P., and Merritt, K.L., 1988, Western Nevada wetlands--History and current status, in Blesse, R.E., and Goin, Peter, eds., Nevada Public Affairs Review: Reno, University of Nevada, no. 1, p. 40-45.

Thorstenson, D.E., and Fisher, D.W., 1979, The geochemistry of the Fox Hills-Basal Creek aquifer in southwestern North Dakota: Water Resources Research, v. 15, p. 1479-1498.

Thurman, E.M., 1985, Organic geochemistry of natural waters: Dordrecht, The Netherlands, Martinus Nijhoff/Dr W. Junk Publishers, 497 p.

Thurston, R.V., Russo, R.C., and Emerson, K., 1974, Aqueous ammonia equilibrium calibrations: Bozeman, Montana State University, Fisheries Bioassy Laboratory Technical Report 74-1, 18 p. plus appendix.

Turner-Peterson, G.E., and Fishman, N.S., 1986, Geologic and genetic models for uranium mineralization in the Morrison Formation, Grants Uranium Region, New Mexico, in Turner-Peterson, C.E., Santos, E.S., and Fishman, N.S., eds., A basin analysis case study--The Morrison Formation, Grants Uranium Region, New Mexico: American Association of Petroleum Geologists Studies in Geology, No. 22, p. 357-388. 
U.S. Bureau of Reclamation, 1986, Draft environmental impact statement for the Newlands Project proposed operating criteria and procedures, technical appendices, five numbered sections.

-----1987a, Fallon Indian Reservation water quality report: Sacramento, Calif., U.S. Bureau of Reclamation, Mid-Pacific Region, 62 p., with three appendices.

-----1987b, Final environmental impact statement for the Newlands Project proposed operating criteria and procedures: Washington, D.C., 332 p.

U.S. Department of the Interior, 1988, Final operating criteria and procedures, record of decision, Newlands Project, Nevada-California: Washington, D.C., 1988, 22 p., five numbered appendices.

U.S. Environmental Protection Agency, 1976, Quality criteria for water: Washington, D.C., 256 p.

-----1987, Ambient water quality criteria for selenium - 1987: Washington, D.C., 39 p.

-----1988, Interim sediment criteria values for nonpolar hydrophobic organic contaminants: Washington, D.C., 35 p.

U.S. Fish and Wildlife Service, 1985, Procedures for resource contaminant assessment contract analytical work: Washington, D.C., Habitat Resources Instructional Memorandum, 203 p.

U.S. Food and Drug Administration, 1984, Compliance policy guide for methyl mercury in fish: Report 7108.07, Federal Register, v. 49, no. 45663, 1 p.

U.S. Geological Survey, 1977, National handbook of recommended methods for water-data acquisition: Office of Water Data Acquisition, 12 numbered chapters.

Van Denburgh, A.S., 1973, Mercury in the Carson and Truckee River basins in Nevada: U.S. Geological Survey Open-File Report, 8 p.

Van Denburgh, A.S., and Arteaga, F.E., 1985, Revised water budget for the Fernley area, west-central Nevada: U.S. Geological Survey Open-File Report 84-712, 17 p.

Vega, Ramon, 1987, Historical review of avian botulism at Stillwater Wildlife Management Area: Fallon, Nev., U.S. Fish and Wildlife Service, unpublished report, p. 33.

Welch, A.H., and Plume, R.W., 1987, Water-quality assessment of the Carson River ground-water basin, Nevada and California--Project description: U.S. Geological Survey Open-File Report 87-104, 27 p.

Wershaw, R.L., Fishman, M.J., Grabbe, R.R., and Lowe, L.E., eds., 1987, Methods for the determination of organic substances in water and fluvial sediments: U.S. Geological Survey Techniques of Water-Resources Investigations, Book 5, Chapter A3,80 p.

Willden, Ronald, and Speed, R.C., 1974, Geology and mineral deposits of Churchill County, Nevada: Nevada Bureau of Mines and Geology Bulletin 83, $95 \mathrm{p}$. 


\section{SUPPLEMENTAL DATA}

$-85-$

page 87 follows 
TABLE 11.--Data from field measurements of physical and chemical constituents for surface-water samples in and near stillwater Wildlife Management Area and Carson Lake, 1986-87

[Abbreviations: ${ }^{\circ} \mathrm{C}$, degrees Celsius; $\mathrm{E}$, estimated; $\mathrm{ft}^{3} / \mathrm{s}$, cubic feet per second; mg/L, milligrams per liter; $\mu \mathrm{s} / \mathrm{cm}$, microsiemens per centimeter at 25 degrees Celsius; wh wat, whole water; --, no data available]

\begin{tabular}{|c|c|c|c|c|c|c|c|}
\hline Station name & Date & Time & $\begin{array}{l}\text { Watex } \\
\text { temper- } \\
\text { ature } \\
\left({ }^{\circ} \mathrm{C}\right)\end{array}$ & $\begin{array}{l}\text { Aix } \\
\text { temper- } \\
\text { ature } \\
\left({ }^{\circ} \mathrm{C}\right)\end{array}$ & $\begin{array}{l}\text { Stream- } \\
\text { flow, } \\
\text { instan- } \\
\text { tanȩous } \\
\text { (ft /s) }\end{array}$ & $\begin{array}{l}\text { Gage } \\
\text { height } \\
\text { (feet } \\
\text { above } \\
\text { datum) }\end{array}$ & $\begin{array}{l}\text { Spe- } \\
\text { cific } \\
\text { con- } \\
\text { duct- } \\
\text { ance } \\
(\mu s / c m)\end{array}$ \\
\hline WILLIAMS SLOUGH nX GENOA, NV (CARSON VALLEY) & $\begin{array}{l}09-04-86 \\
03-30-87 \\
05-18-87\end{array}$ & $\begin{array}{l}1300 \\
0830 \\
1300\end{array}$ & $\begin{array}{r}16.0 \\
6.0 \\
25.5\end{array}$ & $\begin{array}{r}31.0 \\
7.0 \\
21.0\end{array}$ & $\begin{array}{l}-- \\
--\end{array}$ & $\begin{array}{l}-- \\
-- \\
--\end{array}$ & $\begin{array}{l}431 \\
643 \\
405\end{array}$ \\
\hline WASHOE LAKE nY CARSON CITY, NV & $\begin{array}{l}09-04-86 \\
03-20-87 \\
05-18-87\end{array}$ & $\begin{array}{l}0900 \\
1000 \\
0930\end{array}$ & $\begin{array}{r}21.5 \\
3.0 \\
18.0\end{array}$ & $\begin{array}{r}22.0 \\
3.0 \\
16.5\end{array}$ & $\begin{array}{l}-- \\
--\end{array}$ & $\begin{array}{l}-- \\
--\end{array}$ & $\begin{array}{l}385 \\
347 \\
401\end{array}$ \\
\hline CARSON RIVER bI LAHONTAN RES nI FALLON, NV & $\begin{array}{l}06-10-86 \\
09-02-86 \\
03-13-87 \\
03-16-87 \\
05-11-87\end{array}$ & $\begin{array}{l}1000 \\
1100 \\
1300 \\
1730 \\
1330\end{array}$ & $\begin{array}{r}15.0 \\
21.0 \\
12.5 \\
6.5 \\
12.0\end{array}$ & $\begin{array}{r}23.0 \\
27.5 \\
12.5 \\
27.0\end{array}$ & $\begin{array}{c}1880 \\
881 \\
4.5 \\
256 \\
770\end{array}$ & $\begin{array}{l}5.38 \\
3.72 \\
2.08 \\
3.62 \\
4.76\end{array}$ & $\begin{array}{l}249 \\
197 \\
432 \\
239 \\
254\end{array}$ \\
\hline SHECKIER RESERVOIR at OUTLET nY FALLON, NV & $\begin{array}{l}06-10-86 \\
09-02-86 \\
03-19-87 \\
05-15-87\end{array}$ & $\begin{array}{l}1400 \\
1430 \\
0900 \\
1100\end{array}$ & $\begin{array}{r}23.0 \\
24.0 \\
6.5 \\
22.0\end{array}$ & $\begin{array}{r}30.0 \\
30.5 \\
6.0 \\
32.0\end{array}$ & $\begin{array}{l}-- \\
-- \\
-- \\
--\end{array}$ & $\begin{array}{l}-- \\
-- \\
--\end{array}$ & $\begin{array}{l}272 \\
224 \\
323 \\
271\end{array}$ \\
\hline CARSON LAKE DRAIN abV CARSON LAKE nI FALLON, NV & $\begin{array}{l}02-25-86 \\
06-03-86 \\
08-29-86 \\
03-13-87 \\
05-14-87\end{array}$ & $\begin{array}{l}1500 \\
1115 \\
0800 \\
1100 \\
0830\end{array}$ & $\begin{array}{l}19.0 \\
24.0 \\
17.0 \\
10.0 \\
18.0\end{array}$ & $\begin{array}{r}24.0 \\
30.0 \\
21.5 \\
9.0 \\
23.5\end{array}$ & $\begin{array}{l}E 8.0 \\
25 \\
23 \\
2.7 \\
14\end{array}$ & $\begin{array}{l}-- \\
-\overline{1} \\
1.14 \\
0.38 \\
0.97\end{array}$ & $\begin{array}{l}1990 \\
1110 \\
1350 \\
2950 \\
1740\end{array}$ \\
\hline CARSON LAKE, SPRIG POND UNIT, nI FALLON, NV & $\begin{array}{l}06-03-86 \\
08-29-86 \\
03-17-87 \\
05-14-87\end{array}$ & $\begin{array}{l}1430 \\
1000 \\
1600 \\
1100\end{array}$ & $\begin{array}{l}34.0 \\
21.0 \\
17.0 \\
27.5\end{array}$ & $\begin{array}{l}26.5 \\
26.0 \\
17.0 \\
30.5\end{array}$ & $\begin{array}{l}-- \\
-- \\
--\end{array}$ & $\begin{array}{l}-- \\
--\end{array}$ & $\begin{array}{r}1620 \\
839 \\
6940 \\
3700\end{array}$ \\
\hline CARSON LAKE, ISLAND UNIT, nI FALLON, NV & $\begin{array}{l}06-03-86 \\
09-03-86 \\
03-18-87 \\
05-14-87\end{array}$ & $\begin{array}{l}1900 \\
0830 \\
1630 \\
1330\end{array}$ & $\begin{array}{r}31.5 \\
19.0 \\
9.5 \\
31.5\end{array}$ & $\begin{array}{r}-\overline{-} \\
17.0 \\
8.0 \\
32.0\end{array}$ & $\begin{array}{l}-- \\
-- \\
-- \\
--\end{array}$ & $\begin{array}{l}-- \\
-- \\
--\end{array}$ & $\begin{array}{r}4740 \\
319 \\
5030 \\
8580\end{array}$ \\
\hline CARSON LAKE, BIG WATER UNIT, nI FALLON, NV & $\begin{array}{l}06-04-86 \\
03-24-87\end{array}$ & $\begin{array}{l}0900 \\
1245\end{array}$ & $\begin{array}{r}20.0 \\
9.5\end{array}$ & 9.0 & -- & -- & $\begin{array}{l}12000 \\
24600\end{array}$ \\
\hline PAIUTE DRAIN at WILDLIFE ENT nX STILLWATER, NV & $\begin{array}{l}06-05-86 \\
08-30-86 \\
03-12-87 \\
05-12-87 \\
07-02-87 \\
07-23-87\end{array}$ & $\begin{array}{l}1415 \\
1510 \\
1100 \\
1345 \\
1740 \\
1100\end{array}$ & $\begin{array}{r}24.5 \\
25.0 \\
7.0 \\
24.5 \\
29.0 \\
19.0\end{array}$ & $\begin{array}{r}-- \\
28.0 \\
14.0 \\
32.0 \\
-- \\
--\end{array}$ & $\begin{array}{l}14 \\
19 \\
4 \cdot 2 \\
14 \\
25\end{array}$ & $\begin{array}{r}2.66 \\
2.82 \\
2.00 \\
2.29 \\
-- \\
--\end{array}$ & $\begin{array}{r}670 \\
494 \\
1330 \\
994 \\
671 \\
712\end{array}$ \\
\hline TJ DRAIN at WILDLIFE ENTRANCE nI STIILWATER, NV & $\begin{array}{l}06-05-86 \\
09-01-86 \\
03-12-87 \\
05-12-87 \\
07-02-87 \\
07-22-87 \\
07-23-87\end{array}$ & $\begin{array}{l}1230 \\
1045 \\
0800 \\
1300 \\
1745 \\
2000 \\
0930\end{array}$ & $\begin{array}{r}24.0 \\
20.0 \\
6.5 \\
26.5 \\
30.5 \\
23.0 \\
17.5\end{array}$ & $\begin{array}{r}27.0 \\
26.5 \\
11.0 \\
29.5 \\
-- \\
-\overline{0}\end{array}$ & $\begin{array}{l}11 \\
4.7 \\
0.51 \\
0.58 \\
1.0 \\
9.0 \\
8.8\end{array}$ & $\begin{array}{l}-- \\
-- \\
-- \\
-- \\
-- \\
--\end{array}$ & $\begin{array}{r}7230 \\
12100 \\
41000 \\
25100 \\
9550 \\
4950 \\
4570\end{array}$ \\
\hline PAIUTE DRAIN bIW TJ DRAIN nI STILLWATER, NV & $\begin{array}{l}02-23-86 \\
06-05-86 \\
08-30-86 \\
03-12-87 \\
05-12-87\end{array}$ & $\begin{array}{l}1300 \\
1000 \\
1015 \\
1300 \\
1115\end{array}$ & $\begin{array}{r}11.0 \\
21.5 \\
20.5 \\
9.0 \\
22.0\end{array}$ & $\begin{array}{l}20.0 \\
24.0 \\
27.0 \\
16.0 \\
29.5\end{array}$ & $\begin{array}{l}\text { E20 } \\
39 \\
44 \\
5.0 \\
16\end{array}$ & $\begin{array}{l}-- \\
-- \\
-- \\
--\end{array}$ & $\begin{array}{l}2350 \\
2550 \\
1750 \\
7930 \\
3030\end{array}$ \\
\hline LEAD LAKE at MILLENS LANDING nr STILLWATER, NV & $\begin{array}{l}06-05-86 \\
08-26-86 \\
03-17-87 \\
05-12-87 \\
07-02-87\end{array}$ & $\begin{array}{l}1630 \\
1600 \\
1200 \\
0930 \\
1720\end{array}$ & $\begin{array}{l}26.0 \\
27.0 \\
11.0 \\
21.5 \\
30.0\end{array}$ & $\begin{array}{r}31.0 \\
17.0 \\
25.0 \\
--\end{array}$ & $\begin{array}{l}-- \\
-- \\
-- \\
-- \\
--\end{array}$ & $\begin{array}{l}-- \\
-- \\
-- \\
-- \\
--\end{array}$ & $\begin{array}{l}2780 \\
4030 \\
5570 \\
2900 \\
3530\end{array}$ \\
\hline
\end{tabular}


TABLE 11.--Data from field measurements of physical and chemical constituents for surface-water samples in and near Stillwater Wildlife Management Area and Carson Lake, 1986-87--Continued

LOWER DIAGONAL DRAIN at HWY $50 \mathrm{nr}$ FALLON, NV STILLWATER PT. DIV. DRAIN nI STILLWATER, NV

STILLWATER POINT RESERVOIR SOUTH NI STILLWATER NV

STILLWATER POINT RESERVOIR NORTH $\mathrm{nI}$ STILLWATER, NV

STILLWATER SLOUGH at STILLWATER, NV

STILLWATER SLOUGH CUTOFF DRAIN NI STILIWATER NV HUNTER DRAIN at DIVISION RD. nI. STILLWATER, NV LEAD IKK CANAL at HUNTER RD CROSSING $n I$ STILLWATER CATTAIL LAKE at OUTLET nr. STILLWATER, NV SWAN CHECK nI. OUTLET nI. STILLWATER, NV PINTAIL BAY $n r$. CENTER nr. STILLWATER, NV

\begin{tabular}{|c|c|c|c|c|c|c|}
\hline Date & Time & $\begin{array}{l}\text { Water } \\
\text { temper- } \\
\text { ature } \\
\left({ }^{\circ} \mathrm{C}\right)\end{array}$ & $\begin{array}{l}\text { Afr } \\
\text { temper- } \\
\text { ature } \\
\left({ }^{\circ} \mathrm{C}\right)\end{array}$ & $\begin{array}{l}\text { Stream- } \\
\text { flow, } \\
\text { instan- } \\
\text { tanȩous } \\
\left(\mathrm{ft}^{2} / \mathrm{s}\right)\end{array}$ & $\begin{array}{l}\text { Gage } \\
\text { height } \\
\text { (feet } \\
\text { above } \\
\text { datum) }\end{array}$ & $\begin{array}{l}\text { Spe- } \\
\text { cific } \\
\text { con- } \\
\text { duct- } \\
\text { ance } \\
(\mu \mathrm{s} / \mathrm{cm})\end{array}$ \\
\hline $\begin{array}{l}06-06-86 \\
08-27-86 \\
03-17-87 \\
05-12-87 \\
07-02-87\end{array}$ & $\begin{array}{l}1000 \\
0900 \\
0900 \\
0730 \\
1530\end{array}$ & $\begin{array}{r}23.0 \\
23.0 \\
7.0 \\
21.0 \\
29.0\end{array}$ & $\begin{array}{r}25.0 \\
24.0 \\
9.0 \\
21.0 \\
29.0\end{array}$ & $\begin{array}{l}-- \\
=- \\
=- \\
--\end{array}$ & $\begin{array}{l}-- \\
-- \\
-- \\
--\end{array}$ & $\begin{array}{l}3920 \\
4020 \\
5150 \\
4170 \\
4280\end{array}$ \\
\hline $\begin{array}{l}07-21-87 \\
07-22-87 \\
07-22-87 \\
07-22-87 \\
07-22-87\end{array}$ & $\begin{array}{l}2040 \\
0030 \\
0501 \\
0900 \\
2030\end{array}$ & $\begin{array}{l}18.5 \\
16.5 \\
15.5 \\
17.5 \\
23.0\end{array}$ & $\begin{array}{r}18.0 \\
15.0 \\
9.0 \\
17.0 \\
24.0\end{array}$ & $\begin{array}{l}-- \\
=- \\
=- \\
--\end{array}$ & $\begin{array}{l}-- \\
-- \\
--\end{array}$ & $\begin{array}{l}3980 \\
3980 \\
3980 \\
3980 \\
3980\end{array}$ \\
\hline $\begin{array}{l}07-23-87 \\
07-23-87 \\
07-24-87\end{array}$ & $\begin{array}{l}1230 \\
2130 \\
0400\end{array}$ & $\begin{array}{l}24.0 \\
22.0 \\
18.0\end{array}$ & $\begin{array}{l}29.0 \\
22.0 \\
13.0\end{array}$ & $=-$ & $\begin{array}{l}=- \\
--\end{array}$ & $\begin{array}{l}4240 \\
4240 \\
4240\end{array}$ \\
\hline $02-23-86$ & 1600 & 16.0 & 21.0 & E5.0 & -- & 1700 \\
\hline $\begin{array}{l}06-04-86 \\
08-27-86 \\
03-12-87 \\
03-26-87 \\
05-13-87\end{array}$ & $\begin{array}{l}1515 \\
1500 \\
1600 \\
1100 \\
1400\end{array}$ & $\begin{array}{l}22.0 \\
23.0 \\
10.0 \\
12.0 \\
26.5\end{array}$ & $\begin{array}{r}30.0 \\
25.0 \\
18.0 \\
-- \\
30.5\end{array}$ & $\begin{array}{c}97 \\
58 \\
5.6 \\
5.6 \\
36\end{array}$ & $\begin{array}{l}-- \\
=- \\
-- \\
--\end{array}$ & $\begin{array}{r}566 \\
567 \\
3120 \\
2300 \\
1290\end{array}$ \\
\hline $\begin{array}{l}06-09-86 \\
08-28-86 \\
03-18-87 \\
05-13-87\end{array}$ & $\begin{array}{l}1200 \\
1000 \\
1000 \\
1200\end{array}$ & $\begin{array}{r}19.5 \\
20.0 \\
7.5 \\
27.0\end{array}$ & $\begin{array}{r}24.0 \\
-\overline{8} \\
8.0 \\
30.0\end{array}$ & $\begin{array}{l}-- \\
-- \\
--\end{array}$ & $\begin{array}{l}4.16 \\
2.28 \\
4.10 \\
2.94\end{array}$ & $\begin{array}{r}843 \\
656 \\
2430 \\
1040\end{array}$ \\
\hline $\begin{array}{l}06-09-86 \\
08-28-86 \\
03-18-87 \\
05-13-87\end{array}$ & $\begin{array}{l}1500 \\
1330 \\
1015 \\
0900\end{array}$ & $\begin{array}{r}22.0 \\
22.0 \\
8.0 \\
19.0\end{array}$ & $\begin{array}{r}25.0 \\
30.0 \\
8.0 \\
22.0\end{array}$ & $\begin{array}{l}-- \\
-- \\
--\end{array}$ & $\begin{array}{l}4.16 \\
2.28 \\
4.10 \\
2.94\end{array}$ & $\begin{array}{l}1390 \\
2290 \\
2100 \\
3220\end{array}$ \\
\hline $\begin{array}{l}06-11-86 \\
06-11-86 \\
08-27-86 \\
03-13-87 \\
05-11-87\end{array}$ & $\begin{array}{l}0900 \\
1330 \\
1730 \\
0800 \\
1645\end{array}$ & $\begin{array}{r}19.0 \\
24.0 \\
23.0 \\
7.5 \\
25.0\end{array}$ & $\begin{array}{r}33.0 \\
-- \\
25.0 \\
9.0 \\
27.0\end{array}$ & $\begin{array}{l}\text { E20 } \\
\text { E20 } \\
18 \\
2.3 \\
17\end{array}$ & $\begin{array}{l}-- \\
-- \\
-- \\
--\end{array}$ & $\begin{array}{r}1350 \\
902 \\
1050 \\
6210 \\
2000\end{array}$ \\
\hline $06-11-86$ & 0900 & 19.0 & 33.0 & E20 & 0.60 & 1350 \\
\hline $07-22-87$ & 1100 & 19.5 & 22.0 & 0.21 & -- & 65700 \\
\hline $07-23-87$ & 1800 & 26.5 & 33.0 & 25 & -- & 3670 \\
\hline $07-22-87$ & 1700 & 18.5 & 19.0 & -- & -- & 12600 \\
\hline $07-23-87$ & 1400 & 29.5 & 29.0 & -- & - & 5310 \\
\hline $07-24-87$ & 1000 & 19.5 & 26.0 & -- & -- & 48800 \\
\hline
\end{tabular}


TABLE 11.--Data from field measurements of physical and chemical constituents for surface-water samples in and near Stillwater Wildlife Management Area and Carson Lake, 1986-87--Continued

\begin{tabular}{|c|c|c|c|c|c|c|}
\hline Station name & $\begin{array}{c}\text { Oxygen, } \\
\text { dis- } \\
\text { solved } \\
\text { (mg/L) }\end{array}$ & $\begin{array}{c}\text { Oxygen, } \\
\text { dis- } \\
\text { solved } \\
\text { (per- } \\
\text { cent } \\
\text { satur- } \\
\text { ation) }\end{array}$ & $\begin{array}{l}\mathrm{pH} \\
\text { (stand- } \\
\text { ard } \\
\text { units) }\end{array}$ & $\begin{array}{l}\text { Alka- } \\
\text { linity } \\
\text { wh wat } \\
\text { total } \\
\text { field } \\
\text { (mg/L as } \\
\left.\mathrm{CaCO}_{3}\right)\end{array}$ & $\begin{array}{c}\text { Bicar- } \\
\text { bonate } \\
\text { wh wat } \\
\text { total } \\
\text { field } \\
\left(\mathrm{mg}^{\prime} / \mathrm{L} \text { as }\right. \\
\left.\mathrm{HCO}_{3}\right)^{2}\end{array}$ & $\begin{array}{c}\text { Car- } \\
\text { bonate } \\
\text { wh wat } \\
\text { total } \\
\text { field } \\
\text { (mg/I } \\
\text { as } \mathrm{CO}_{3} \text { ) }\end{array}$ \\
\hline WILLIAMS SLOUGH $\mathrm{n}$ I GENOA, NV (CARSON VALLEY) & $\begin{array}{l}--\overline{6} \\
8.2\end{array}$ & $\begin{array}{r}-- \\
35 \\
121\end{array}$ & $\begin{array}{l}7.20 \\
8.00 \\
8.20\end{array}$ & $\begin{array}{l}153 \\
292 \\
168\end{array}$ & $\begin{array}{l}190 \\
360 \\
210\end{array}$ & $\begin{array}{l}-- \\
-- \\
--\end{array}$ \\
\hline WASHOE LAKE $n Y$ CARSON CITY, NV & $\begin{array}{r}7.1 \\
10.8 \\
9.1\end{array}$ & $\begin{array}{r}97 \\
98 \\
117\end{array}$ & $\begin{array}{l}8.70 \\
8.70 \\
8.60\end{array}$ & $\begin{array}{l}201 \\
221 \\
208\end{array}$ & $\begin{array}{l}220 \\
180 \\
220\end{array}$ & $\begin{array}{l}-- \\
43 \\
17\end{array}$ \\
\hline CARSON RIVER bI LAHONTAN RES nI FALLON, NV & $\begin{array}{r}9.0 \\
8.2 \\
11.9 \\
11.1\end{array}$ & $\begin{array}{r}104 \\
107 \\
129 \\
120\end{array}$ & $\begin{array}{r}7.93 \\
7.80 \\
8.80 \\
8.10\end{array}$ & $\begin{array}{r}76 \\
63 \\
160 \\
-\overline{84}\end{array}$ & $\begin{array}{r}93 \\
77 \\
170 \\
-- \\
100\end{array}$ & $\begin{array}{l}-- \\
-- \\
-- \\
--\end{array}$ \\
\hline SHECKLER RESERVOIR at OUTLET nI FALLON, NV & $\begin{array}{r}9.2 \\
8.7 \\
10.4 \\
7.2\end{array}$ & $\begin{array}{r}125 \\
121 \\
100 \\
99\end{array}$ & $\begin{array}{l}8.80 \\
8.60 \\
8.40 \\
9.00\end{array}$ & $\begin{array}{r}98 \\
65 \\
114 \\
98\end{array}$ & $\begin{array}{r}93 \\
72 \\
120 \\
100\end{array}$ & $\begin{array}{r}13 \\
4 \\
12 \\
10\end{array}$ \\
\hline CARSON LAKE DRAIN abV CARSON LAKE nI FALLON, NV & $\begin{array}{r}14.0 \\
6.7 \\
7.6 \\
17.0 \\
5.7\end{array}$ & $\begin{array}{r}175 \\
93 \\
91 \\
176 \\
70\end{array}$ & $\begin{array}{l}8.90 \\
8.10 \\
8.00 \\
8.70 \\
8.00\end{array}$ & $\begin{array}{l}232 \\
245 \\
386 \\
228\end{array}$ & $\begin{array}{l}280 \\
300 \\
440 \\
280\end{array}$ & $\begin{array}{l}-- \\
-- \\
\overline{17} \\
--\end{array}$ \\
\hline CARSON LAKE, SPRIG POND UNIT, nT FALLON, NV & $\begin{array}{r}>20.0 \\
17.0 \\
10.9 \\
5.7\end{array}$ & $\begin{array}{r}>300 \\
222 \\
135 \\
85\end{array}$ & $\begin{array}{l}9.10 \\
9.00 \\
8.50 \\
8.40\end{array}$ & $\begin{array}{l}234 \\
201 \\
530 \\
308\end{array}$ & $\begin{array}{l}160 \\
200 \\
610 \\
370\end{array}$ & $\begin{array}{r}62 \\
25 \\
17 \\
4\end{array}$ \\
\hline CARSON LAKE, ISLAND UNIT, nI FALLON, NV & $\begin{array}{r}15.4 \\
4.4 \\
9.9 \\
12.3\end{array}$ & $\begin{array}{r}249 \\
55 \\
103 \\
200\end{array}$ & $\begin{array}{l}8.50 \\
7.80 \\
8.60 \\
8.80\end{array}$ & $\begin{array}{l}604 \\
107 \\
460 \\
500\end{array}$ & $\begin{array}{l}440 \\
130 \\
520 \\
450\end{array}$ & $\begin{array}{r}140 \\
-- \\
19 \\
64\end{array}$ \\
\hline CARSON LAKE, BIG WATER UNIT, nI FALLON, NV & $\begin{array}{r}6.0 \\
12.6\end{array}$ & $\begin{array}{r}80 \\
140\end{array}$ & $\begin{array}{l}9.10 \\
9.40\end{array}$ & 880 & 260 & 220 \\
\hline PAIUTE DRAIN at WILDLIFE ENT nr STILLWATER, NV & $\begin{array}{l}8.4 \\
6.9 \\
9.7 \\
8.0 \\
9.4 \\
8.4\end{array}$ & $\begin{array}{r}118 \\
97 \\
93 \\
112 \\
143 \\
105\end{array}$ & $\begin{array}{l}9.00 \\
8.80 \\
8.60 \\
8.70 \\
9.10 \\
9.10\end{array}$ & $\begin{array}{l}144 \\
133 \\
244 \\
180 \\
-- \\
--\end{array}$ & $\begin{array}{l}140 \\
150 \\
250 \\
200 \\
-- \\
--\end{array}$ & $\begin{array}{r}19 \\
4 \\
24 \\
17 \\
-- \\
--\end{array}$ \\
\hline TJ DRAIN at WILDLIFE ENTRANCE nI STILLWATER, NV & $\begin{array}{r}10.4 \\
9.8 \\
5.6 \\
14.9 \\
9.5 \\
4.5 \\
6.4\end{array}$ & $\begin{array}{r}148 \\
130 \\
62 \\
235 \\
152 \\
62 \\
79\end{array}$ & $\begin{array}{l}8.10 \\
8.20 \\
8.20 \\
8.60 \\
8.80 \\
8.50 \\
8.40\end{array}$ & $\begin{array}{r}230 \\
212 \\
396 \\
266 \\
-- \\
-\overline{216}\end{array}$ & $\begin{array}{l}280 \\
260 \\
480 \\
270 \\
-- \\
-- \\
--\end{array}$ & $\begin{array}{l}-- \\
-- \\
-- \\
26 \\
-- \\
--\end{array}$ \\
\hline PAIUTE DRAIN bIW TJ DRAIN nI STILIWATER, NV & $\begin{array}{r}9.4 \\
5.4 \\
6.2 \\
11.4 \\
6.8\end{array}$ & $\begin{array}{r}98 \\
72 \\
80 \\
114 \\
91\end{array}$ & $\begin{array}{l}8.60 \\
8.60 \\
8.20 \\
8.50 \\
8.40\end{array}$ & $\begin{array}{l}-- \\
184 \\
135 \\
276 \\
188\end{array}$ & $\begin{array}{l}-- \\
220 \\
160 \\
260 \\
220\end{array}$ & $\begin{array}{r}-- \\
-- \\
-- \\
36 \\
7\end{array}$ \\
\hline LEAD LAKE at MILLENS LANDING $n r$ STILLWATER, NV & $\begin{array}{r}9.5 \\
9.3 \\
15.6 \\
5.1 \\
8.7\end{array}$ & $\begin{array}{r}138 \\
137 \\
167 \\
68 \\
136\end{array}$ & $\begin{array}{l}8.80 \\
8.60 \\
9.50 \\
8.30 \\
8.80\end{array}$ & $\begin{array}{l}170 \\
162 \\
182 \\
192 \\
--\end{array}$ & $\begin{array}{r}160 \\
190 \\
160 \\
220 \\
--\end{array}$ & $\begin{array}{r}24 \\
4 \\
62 \\
5 \\
--\end{array}$ \\
\hline
\end{tabular}


TABLE 11.--Data from field measurements of physical and chemical constituents for surface-water samples in and near Stillwater Wildlife Management Area and Carson Lake, 1986-87--Continued

\begin{tabular}{|c|c|c|c|c|c|c|}
\hline Station name & $\begin{array}{c}\text { Oxygen, } \\
\text { dis- } \\
\text { solved } \\
\text { (mg/L) }\end{array}$ & $\begin{array}{l}\text { Oxygen, } \\
\text { dis- } \\
\text { solved } \\
\text { (per- } \\
\text { cent } \\
\text { satur- } \\
\text { ation) }\end{array}$ & $\begin{array}{l}\text { pH } \\
\text { (stand- } \\
\text { ard } \\
\text { units) }\end{array}$ & $\begin{array}{l}\text { Alka- } \\
\text { linity } \\
\text { wh wat } \\
\text { total } \\
\text { field } \\
\left(\mathrm{mg}_{\mathrm{L}} \mathrm{L} \text { as }\right. \\
\left.\mathrm{CaCO}_{3}\right)\end{array}$ & $\begin{array}{c}\text { Bicar- } \\
\text { bonate } \\
\text { wh wat } \\
\text { total } \\
\text { field } \\
(\mathrm{mg} / \mathrm{L} \text { as } \\
\left.\mathrm{HCO}_{3}\right)\end{array}$ & $\begin{array}{c}\text { Car- } \\
\text { bonate } \\
\text { wh wat } \\
\text { total } \\
\text { field } \\
(\mathrm{mg} / \mathrm{L} \\
\left.\text { as } \mathrm{CO}_{3}\right)\end{array}$ \\
\hline \multirow[t]{3}{*}{ SOUTH LEAD LAKE $n r$ STILLWATER, NV } & $\begin{array}{r}9.5 \\
3.5 \\
12.0 \\
4.3 \\
12.6\end{array}$ & $\begin{array}{r}127 \\
48 \\
116 \\
57 \\
193\end{array}$ & $\begin{array}{l}9.20 \\
9.10 \\
8.80 \\
9.10 \\
9.10\end{array}$ & $\begin{array}{l}234 \\
189 \\
246 \\
264 \\
172\end{array}$ & $\begin{array}{r}210 \\
61 \\
250 \\
15 \\
130\end{array}$ & $\begin{array}{r}38 \\
35 \\
26 \\
150 \\
41\end{array}$ \\
\hline & $\begin{array}{r}11.6 \\
7.5 \\
3.6 \\
11.5 \\
20.0\end{array}$ & $\begin{array}{r}145 \\
90 \\
42 \\
141 \\
>241\end{array}$ & $\begin{array}{l}=- \\
=- \\
=- \\
--\end{array}$ & $\begin{array}{l}-- \\
=- \\
=- \\
--\end{array}$ & $\begin{array}{l}-- \\
=- \\
=- \\
--\end{array}$ & $\begin{array}{l}= \\
-- \\
-- \\
--\end{array}$ \\
\hline & $\begin{array}{r}16.7 \\
13.7 \\
4.0\end{array}$ & $\begin{array}{r}233 \\
184 \\
50\end{array}$ & $\begin{array}{l}=- \\
=- \\
--\end{array}$ & $\begin{array}{l}-- \\
--\end{array}$ & $\begin{array}{l}-- \\
-- \\
--\end{array}$ & $\begin{array}{l}-- \\
-- \\
--\end{array}$ \\
\hline LOWER DIAGONAL DRAIN at HWY $50 \mathrm{nr}$ FALLON, NV & $>20.0$ & $>235$ & 9.20 & -- & -- & -- \\
\hline STILLWATER PT. DIV. DRAIN nr STILLWATER, NV & $\begin{array}{r}5.9 \\
6.2 \\
20.0 \\
20.0 \\
6.6\end{array}$ & $\begin{array}{r}79 \\
84 \\
>200 \\
>200 \\
96\end{array}$ & $\begin{array}{r}7.90 \\
8.10 \\
9.30 \\
8.20\end{array}$ & $\begin{array}{l}146 \\
177 \\
374 \\
-- \\
248\end{array}$ & $\begin{array}{l}180 \\
220 \\
280 \\
-- \\
300\end{array}$ & $\begin{array}{l}-- \\
-\overline{8} \\
-- \\
--\end{array}$ \\
\hline STILLWATER POINT RESERVOIR SOUTH nI STILLWATER NV & $\begin{array}{l}6.3 \\
8.0 \\
9.7 \\
7.0\end{array}$ & $\begin{array}{r}79 \\
102 \\
95 \\
102\end{array}$ & $\begin{array}{l}8.00 \\
8.20 \\
8.90 \\
8.50\end{array}$ & $\begin{array}{l}153 \\
203 \\
296 \\
244\end{array}$ & $\begin{array}{l}190 \\
250 \\
310 \\
290\end{array}$ & $\begin{array}{r}-- \\
\overline{26} \\
5\end{array}$ \\
\hline STILLWATER POINT RESERVOIR NORTH nr STILLWATER, NV & $\begin{array}{r}9.6 \\
18.0 \\
9.7 \\
6.0\end{array}$ & $\begin{array}{r}128 \\
241 \\
95 \\
76\end{array}$ & $\begin{array}{r}9.00 \\
10.00 \\
8.80 \\
8.50\end{array}$ & $\begin{array}{l}250 \\
212 \\
288 \\
374\end{array}$ & $\begin{array}{r}250 \\
54 \\
300 \\
420\end{array}$ & $\begin{array}{r}29 \\
100 \\
26 \\
17\end{array}$ \\
\hline STILLWATER SLOUGH at STILIWATER, NV & $\begin{array}{l}5.9 \\
4.4 \\
6.3 \\
8.0 \\
5.3\end{array}$ & $\begin{array}{l}74 \\
61 \\
85 \\
79 \\
75\end{array}$ & $\begin{array}{l}7.90 \\
7.70 \\
8.10 \\
8.60 \\
8.20\end{array}$ & $\begin{array}{l}-- \\
189 \\
358 \\
240\end{array}$ & $\begin{array}{l}-- \\
-- \\
230 \\
350 \\
290\end{array}$ & $\begin{array}{l}-- \\
\overline{--} \\
41 \\
--\end{array}$ \\
\hline STILLWATER SLOUGH CUTOFF DRAIN nI STILLWATER NV & 5.9 & 74 & 7.90 & 164 & 200 & -- \\
\hline HUNTER DRAIN at DIVISION RD. nr. STILLWATER, NV & 11.4 & 188 & 8.70 & 290 & 130 & 110 \\
\hline LEAD LK CANAL at HUNTER RD CROSSING nI STILLWATER & $>20.0$ & $>200$ & 9.70 & 198 & 29 & 100 \\
\hline CATTAIL LAKE at OUTLET nr. STILLWATER, NV & 6.7 & 87 & 9.70 & 346 & 56 & 180 \\
\hline SWAN CHECK $n r$. OUTLET nr. STILLWATER, NV & $>20.0$ & $>300$ & 9.50 & 206 & 95 & 77 \\
\hline PINTAIL BAY nr. CENTER nr. STILLWATER, NV & 7.8 & 119 & 9.40 & 1980 & 930 & 730 \\
\hline
\end{tabular}


TABLE 12.--Data on water hardness and major dissolved chemical constituents for surface-water samples in and near Stillwater Wildlife Management Area and Carson Lake, 1986-87

[Abbreviations: ${ }^{\circ} \mathrm{C}$, degrees Celsius; E, estimated; mg/L, milligrams per liter; -- no data available: <, less than]

\begin{tabular}{|c|c|c|c|c|c|c|}
\hline Station name & Date & $\begin{array}{l}\text { Hard- } \\
\text { ness } \\
\text { (mg/L } \\
\text { as } \\
\mathrm{CaCO}_{3} \text { ) }\end{array}$ & $\begin{array}{l}\text { Calcium } \\
\text { dis- } \\
\text { solved } \\
\text { (mg/L } \\
\text { as Ca) }\end{array}$ & $\begin{array}{l}\text { Magne- } \\
\text { sium, } \\
\text { dis- } \\
\text { solved } \\
\text { (mg/L } \\
\text { as Mg) }\end{array}$ & $\begin{array}{l}\text { Sodium, } \\
\text { dis- } \\
\text { solved } \\
\text { (mg/L } \\
\text { as Na) }\end{array}$ & $\begin{array}{l}\text { Potas- } \\
\text { sium, } \\
\text { dis- } \\
\text { solved } \\
\text { (mg/L } \\
\text { as K) }\end{array}$ \\
\hline WILLIAMS SLOUGH NI GENOA, NV (CARSON VALLEY) & $\begin{array}{l}09-04-86 \\
03-30-87 \\
05-18-87\end{array}$ & $\begin{array}{l}-- \\
200 \\
130\end{array}$ & $\begin{array}{l}-- \\
54 \\
32\end{array}$ & $\begin{array}{l}-- \\
16\end{array}$ & $\begin{array}{l}-- \\
57 \\
37\end{array}$ & $\begin{array}{l}-- \\
10 \\
10\end{array}$ \\
\hline WASHOE LAKE nI CARSON CITY, NV & $\begin{array}{l}09-04-86 \\
03-20-87 \\
05-18-87\end{array}$ & $\begin{array}{l}110 \\
130\end{array}$ & $\begin{array}{l}-- \\
31 \\
36\end{array}$ & 10.5 & $\begin{array}{l}-- \\
33 \\
40\end{array}$ & $\begin{array}{l}-- \\
5.8 \\
6.9\end{array}$ \\
\hline CARSON RIVER bI LAHONTAN RES nI FALLON, NV & $\begin{array}{l}06-10-86 \\
09-02-86 \\
03-13-87 \\
05-11-87\end{array}$ & $\begin{array}{l}-- \\
-- \\
85 \\
79\end{array}$ & $\begin{array}{l}-- \\
24 \\
22\end{array}$ & $\begin{array}{l}-- \\
-- \\
5.1 \\
5.9\end{array}$ & $\begin{array}{l}-- \\
\overline{62} \\
22\end{array}$ & $\begin{array}{l}-- \\
-- \\
3.1\end{array}$ \\
\hline SHECKLER RESERVOIR at OUTLET nI FALLON, NV & $\begin{array}{l}06-10-86 \\
09-02-86 \\
03-19-87 \\
05-15-87\end{array}$ & $\begin{array}{l}-- \\
-- \\
97 \\
82\end{array}$ & $\begin{array}{l}-- \\
-- \\
28 \\
23\end{array}$ & $\begin{array}{l}-- \\
6.5 \\
5.9\end{array}$ & $\begin{array}{l}-- \\
-- \\
31 \\
25\end{array}$ & $\begin{array}{l}-- \\
-- \\
3.9\end{array}$ \\
\hline CARSON LAKE DRAIN abV CARSON LAKE nI FALLON, NV & $\begin{array}{l}02-25-86 \\
06-03-86 \\
08-29-86 \\
03-13-87 \\
05-14-87\end{array}$ & $\begin{array}{r}250 \\
-- \\
-- \\
310 \\
190\end{array}$ & $\begin{array}{l}53 \\
-- \\
-- \\
64 \\
44\end{array}$ & $\begin{array}{l}28 \\
-- \\
-- \\
36 \\
20\end{array}$ & $\begin{array}{r}340 \\
-- \\
-- \\
560 \\
280\end{array}$ & $\begin{array}{l}14 \\
-- \\
14 \\
10\end{array}$ \\
\hline CARSON LAKE, SPRIG POND UNIT, nI FALLON, NV & $\begin{array}{l}06-03-86 \\
08-29-86 \\
03-17-87 \\
05-14-87\end{array}$ & $\begin{array}{l}-- \\
790 \\
430\end{array}$ & $\begin{array}{r}-- \\
150 \\
96\end{array}$ & $\begin{array}{r}-- \\
100 \\
47\end{array}$ & $\begin{array}{r}-- \\
1200 \\
610\end{array}$ & $\begin{array}{l}-- \\
-- \\
35 \\
21\end{array}$ \\
\hline CARSON LAKE, ISLAND UNIT, nI FALLON, NV & $\begin{array}{l}06-03-86 \\
09-03-86 \\
03-18-87 \\
05-14-87\end{array}$ & $\begin{array}{l}-- \\
500 \\
680\end{array}$ & $\begin{array}{l}-- \\
\overline{82} \\
90\end{array}$ & $\begin{array}{r}-- \\
72 \\
110\end{array}$ & $\begin{array}{r}-- \\
900 \\
1700\end{array}$ & $\begin{array}{l}-- \\
-- \\
51\end{array}$ \\
\hline PAIUTE DRAIN at WILDLIFE ENT nI STILLWATER, NV & $\begin{array}{l}06-05-86 \\
08-30-86 \\
03-12-87 \\
05-12-87\end{array}$ & $\begin{array}{l}-- \\
200 \\
380\end{array}$ & $\begin{array}{l}-- \\
46 \\
68\end{array}$ & $\begin{array}{l}-- \\
-- \\
20 \\
52\end{array}$ & $\begin{array}{l}-- \\
200 \\
450\end{array}$ & $\begin{array}{l}-- \\
-\overline{8} .5 \\
12\end{array}$ \\
\hline TJ DRAIN at WILDLIFE ENTRANCE nI STILLWATER, NV & $\begin{array}{l}06-05-86 \\
09-01-86 \\
03-12-87 \\
05-12-87 \\
07-23-87\end{array}$ & $\begin{array}{r}-- \\
-- \\
4700 \\
3100 \\
460\end{array}$ & $\begin{array}{r}-- \\
-- \\
580 \\
410 \\
74\end{array}$ & $\begin{array}{r}-- \\
800 \\
510 \\
66\end{array}$ & $\begin{array}{r}-- \\
8000 \\
4900 \\
810\end{array}$ & $\begin{array}{r}-- \\
-- \\
100 \\
64 \\
17\end{array}$ \\
\hline PAIUTE DRAIN bIw TJ DRAIN nI STILLWATER, NV & $\begin{array}{l}02-23-86 \\
06-05-86 \\
08-30-86 \\
03-12-87 \\
05-12-87\end{array}$ & $\begin{array}{r}370 \\
-- \\
-- \\
940 \\
400\end{array}$ & $\begin{array}{r}59 \\
-- \\
-- \\
130 \\
69\end{array}$ & $\begin{array}{r}54 \\
-- \\
-- \\
150 \\
55\end{array}$ & $\begin{array}{r}410 \\
=- \\
1400 \\
470\end{array}$ & $\begin{array}{l}14 \\
-- \\
-- \\
21 \\
12\end{array}$ \\
\hline LEAD LAKE at MILLENS LANDING nI STILLWATER, NV & $\begin{array}{l}06-05-86 \\
08-26-86 \\
03-17-87 \\
05-12-87\end{array}$ & $\begin{array}{l}-- \\
-- \\
610 \\
170\end{array}$ & $\begin{array}{l}-- \\
\overline{81} \\
39\end{array}$ & $\begin{array}{r}-- \\
100 \\
17\end{array}$ & $\begin{array}{l}-- \\
930 \\
140\end{array}$ & $\begin{array}{l}-- \\
18 \\
8.5\end{array}$ \\
\hline SOUTH LEAD LAKE nI STILLWATER, NV & $\begin{array}{l}06-06-86 \\
08-27-86 \\
03-17-87 \\
05-12-87 \\
07-02-87\end{array}$ & $\begin{array}{l}-- \\
-- \\
610 \\
440 \\
460\end{array}$ & $\begin{array}{l}-- \\
-- \\
96 \\
64 \\
64\end{array}$ & $\begin{array}{l}-- \\
-- \\
91 \\
69 \\
72\end{array}$ & $\begin{array}{l}-- \\
840 \\
690 \\
750\end{array}$ & $\begin{array}{l}-- \\
-- \\
22 \\
19 \\
22\end{array}$ \\
\hline
\end{tabular}


TABLE 12.--Data on water hardness and major dissolved chemical constituents for surface-water samples in and near Stillwater Wildlife Management Area and Carson Lake, 1986-87--Continued

\begin{tabular}{|c|c|c|c|c|c|c|}
\hline Station name & Date & $\begin{array}{l}\text { Hard- } \\
\text { ness } \\
(\mathrm{mg} / \mathrm{L} \\
\mathrm{as} \\
\left.\mathrm{CaCO}_{3}\right)\end{array}$ & $\begin{array}{l}\text { Calcium } \\
\text { dis- } \\
\text { solved } \\
\text { (mg/L } \\
\text { as Ca) }\end{array}$ & $\begin{array}{l}\text { Magne- } \\
\text { sium, } \\
\text { dis- } \\
\text { solved } \\
\text { (mg/L } \\
\text { as } M g \text { ) }\end{array}$ & $\begin{array}{l}\text { Sodium, } \\
\text { dis- } \\
\text { solved } \\
\text { (mg/L } \\
\text { as } \mathrm{Na} \text { ) }\end{array}$ & $\begin{array}{l}\text { Potas- } \\
\text { sium, } \\
\text { dis- } \\
\text { solved } \\
\text { (mg/L } \\
\text { as } \mathrm{K} \text { ) }\end{array}$ \\
\hline LOWER DIAGONAL DRAIN at HWY $50 \mathrm{nr}$ FALLON, NV & $02-23-86$ & 200 & 46 & 20 & 330 & 13 \\
\hline STILLWATER PT. DIV. DRAIN nI STILLWATER, NV & $\begin{array}{l}06-04-86 \\
08-27-86 \\
03-12-87 \\
05-13-87\end{array}$ & $\begin{array}{r}-- \\
270 \\
190\end{array}$ & $\begin{array}{l}-- \\
-- \\
51\end{array}$ & $\begin{array}{l}-- \\
-- \\
29 \\
15\end{array}$ & $\begin{array}{l}-- \\
590 \\
200\end{array}$ & $\begin{array}{l}-- \\
-- \\
14 \\
11\end{array}$ \\
\hline STILIWATER POINT RESERVOIR SOUTH NI STILLWATER, NV & $\begin{array}{l}06-09-86 \\
08-28-86 \\
03-18-87 \\
05-13-87\end{array}$ & $\begin{array}{r}=- \\
210 \\
170\end{array}$ & $\begin{array}{l}-- \\
50 \\
44\end{array}$ & $\begin{array}{l}-- \\
21 \\
15\end{array}$ & $\begin{array}{l}-- \\
370 \\
150\end{array}$ & $\begin{array}{l}-- \\
-\overline{14} \\
12\end{array}$ \\
\hline STILLWATER POINT RESERVOIR NORTH AY STILLWATER, NV & $\begin{array}{l}06-09-86 \\
08-28-86 \\
03-18-87 \\
05-13-87\end{array}$ & $\begin{array}{l}=- \\
210 \\
260\end{array}$ & $\begin{array}{l}-- \\
-- \\
49 \\
53\end{array}$ & $\begin{array}{l}-- \\
-- \\
22 \\
32\end{array}$ & $\begin{array}{l}-- \\
440 \\
580\end{array}$ & $\begin{array}{l}-- \\
-\overline{14} \\
22\end{array}$ \\
\hline STILLWATER SLOUGH at STILLWATER, NV & $\begin{array}{l}08-27-86 \\
03-13-87 \\
05-11-87\end{array}$ & $\begin{array}{r}730 \\
310\end{array}$ & $\begin{array}{r}-\overline{160} \\
82\end{array}$ & $\begin{array}{l}-\overline{81} \\
26\end{array}$ & $\begin{array}{r}1100 \\
290\end{array}$ & $\begin{array}{l}-- \\
28 \\
12\end{array}$ \\
\hline STILLWATER SLOUGH CUTOFF DRAIN nY STILLWATER NV & $06-11-86$ & -- & -- & -- & -- & -- \\
\hline HUNTER DRAIN at DIVISION RD. nr. STILLWATER, NV & $07-22-87$ & 5000 & 710 & 780 & 18000 & 330 \\
\hline LEAD LK CANAL at HUNTER RD CROSSING nI STILLWATER & $07-23-87$ & 370 & 54 & 57 & 580 & 21 \\
\hline CATTAIL LAKE at OUTLET nr. STILLWATER, NV & $07-22-87$ & 280 & 31 & 49 & 2800 & 61 \\
\hline SWAN CHECK nr. OUTLET nr. STILLWATER, NV & $07-23-87$ & 470 & 64 & 75 & 960 & 31 \\
\hline PINTAIL BAY nI. CENTER nI. STILLWATER, NV & $07-24-87$ & 960 & 20 & 220 & 11000 & 450 \\
\hline
\end{tabular}


TABLE 12.--Data on water hardness and major dissolved chemical constituents for surface-water samples in and near St1llwater Wildlife Management Area and Carson Lake, 1986-87--Continued

\begin{tabular}{|c|c|c|c|c|c|}
\hline station name & $\begin{array}{l}\text { Sulfate, } \\
\text { dis- } \\
\text { solved } \\
\text { (mg/L } \\
\text { as } \mathrm{SO}_{4} \text { ' }\end{array}$ & $\begin{array}{l}\text { Chlo- } \\
\text { ride, } \\
\text { dis- } \\
\text { solved } \\
\text { (mg/L } \\
\text { as Cl) }\end{array}$ & $\begin{array}{l}\text { Fluo- } \\
\text { ride, } \\
\text { dis- } \\
\text { solved } \\
\text { (mg/L } \\
\text { as F) }\end{array}$ & $\begin{array}{l}\text { silica, } \\
\text { dis- } \\
\text { solved } \\
\text { (mg/L } \\
\text { as } \\
\mathrm{SiO}_{2} \text { ) }\end{array}$ & $\begin{array}{l}\text { Solids, } \\
\text { residue } \\
\text { at } 180^{\circ} \mathrm{C} \\
\text { dissolved } \\
\text { (mg/L) }\end{array}$ \\
\hline WILLIAMS SLOUGH nT GENOA, NV (CARSON VALIEY) & $\begin{array}{l}-- \\
58 \\
34\end{array}$ & $\begin{array}{l}-- \\
37 \\
14\end{array}$ & $\begin{array}{r}-\overline{0} \\
.40 \\
.20\end{array}$ & $\begin{array}{l}-- \\
36 \\
24\end{array}$ & $\begin{array}{l}240 \\
398 \\
278\end{array}$ \\
\hline WASHOE LAKE nI CARSON CITY, NV & $\begin{array}{l}-- \\
11 \\
14\end{array}$ & $\begin{array}{l}- \\
8.6 \\
9.4\end{array}$ & $\begin{array}{r}-70 \\
.70\end{array}$ & $\begin{array}{l}-- \\
33 \\
37\end{array}$ & $\begin{array}{l}234 \\
234 \\
259\end{array}$ \\
\hline CARSON RIVER bI LAHONTAN RES nI FALLON, NV & $\begin{array}{l}-- \\
-\overline{46} \\
28\end{array}$ & $\begin{array}{l}-- \\
-- \\
18 \\
12\end{array}$ & $\begin{array}{r}-- \\
-- \\
.40 \\
.20\end{array}$ & $\begin{array}{l}-- \\
-- \\
26 \\
20\end{array}$ & $\begin{array}{l}152 \\
169 \\
275 \\
168\end{array}$ \\
\hline SHECKLER RESERVOIR at OUTLET nI FALLON, NV & $\begin{array}{l}-- \\
-- \\
41 \\
33\end{array}$ & $\begin{array}{l}-- \\
-- \\
13 \\
13\end{array}$ & $\begin{array}{l}-- \\
-- \\
.40 \\
<.10\end{array}$ & $\begin{array}{l}-- \\
-- \\
18 \\
17\end{array}$ & $\begin{array}{l}172 \\
136 \\
238 \\
179\end{array}$ \\
\hline CARSON LAKE DRAIN abV CARSON LAKE nI FALLON, NV & $\begin{array}{c}310 \\
-- \\
510 \\
230\end{array}$ & $\begin{array}{r}270 \\
-- \\
480 \\
280\end{array}$ & $\begin{array}{r}.70 \\
-- \\
-- \\
.80 \\
.50\end{array}$ & $\begin{array}{l}25 \\
-- \\
-- \\
22 \\
23\end{array}$ & $\begin{array}{r}1210 \\
\text { E670 } \\
770 \\
1890 \\
1050\end{array}$ \\
\hline CARSON LAKE, SPRIG POND UNIT, nr FALLON, NV & $\begin{array}{r}-- \\
1300 \\
540\end{array}$ & $\begin{array}{r}-- \\
1400 \\
700\end{array}$ & $\begin{array}{l}-- \\
-- \\
1.1 \\
.60\end{array}$ & $\begin{array}{l}-- \\
-- \\
13 \\
24\end{array}$ & $\begin{array}{r}E 960 \\
484 \\
4630 \\
2250\end{array}$ \\
\hline CARSON LAKE, ISLAND UNIT, nY FALLON, NV & $\begin{array}{r}-- \\
1500 \\
1400\end{array}$ & $\begin{array}{r}-- \\
1000 \\
1900\end{array}$ & $\begin{array}{l}-- \\
-- \\
1.0 \\
1.0\end{array}$ & $\begin{array}{l}-- \\
\overline{13} \\
22\end{array}$ & $\begin{array}{r}\text { E2800 } \\
216 \\
3240 \\
5610\end{array}$ \\
\hline PAIUTE DRAIN at WILDLIFE ENT nI STILLWATER, NV & $\begin{array}{r}-- \\
-- \\
250 \\
300\end{array}$ & $\begin{array}{r}-- \\
150 \\
640\end{array}$ & $\begin{aligned} &-- \\
&-- \\
& .60 \\
& .50\end{aligned}$ & $\begin{array}{l}-- \\
-\overline{8} .2\end{array}$ & $\begin{array}{r}E 410 \\
282 \\
928 \\
1660\end{array}$ \\
\hline TJ DRAIN at WILDLIFE ENTRANCE nr STILLWATER, NV & $\begin{array}{r}-- \\
5000 \\
2700 \\
450\end{array}$ & $\begin{array}{r}-- \\
14000 \\
7600 \\
1100\end{array}$ & $\begin{array}{l}-- \\
-- \\
.80 \\
.40 \\
.50\end{array}$ & $\begin{array}{l}-- \\
16 \\
11\end{array}$ & $\begin{array}{c}E 4660 \\
7500 \\
29800 \\
17200 \\
2740\end{array}$ \\
\hline PAIUTE DRAIN bIW TJ DRAIN nY STILLWATER, NV & $\begin{array}{c}370 \\
-- \\
-- \\
940 \\
320\end{array}$ & $\begin{array}{r}530 \\
-- \\
-- \\
2000 \\
680\end{array}$ & $\begin{aligned} &-. .50 \\
&-- \\
& .60 \\
& .40\end{aligned}$ & $\begin{array}{l}5.9 \\
-- \\
-9.1 \\
15\end{array}$ & $\begin{array}{r}1520 \\
E 1500 \\
907 \\
5030 \\
1750\end{array}$ \\
\hline LEAD LAKE at MILLENS LANDING nY STILLWATER, NV & $\begin{array}{r}-- \\
650 \\
140\end{array}$ & $\begin{array}{r}-- \\
1400 \\
140\end{array}$ & $\begin{array}{rr}-- & \\
-- & \\
.60 \\
.50\end{array}$ & $\begin{array}{l}-- \\
15\end{array}$ & $\begin{array}{r}\text { E1650 } \\
2280 \\
3460 \\
590\end{array}$ \\
\hline SOUTH LEAD LAKE nr STILLWATER, NV & $\begin{array}{l}-- \\
610 \\
440 \\
510\end{array}$ & $\begin{array}{l}=- \\
1300 \\
1000 \\
1100\end{array}$ & $\begin{aligned} &-- \\
&-- \\
& .70 \\
& .40 \\
& .90\end{aligned}$ & $\begin{array}{l}-- \\
-- \\
3.7 \\
13\end{array}$ & $\begin{array}{r}\text { E2300 } \\
2220 \\
3190 \\
2450 \\
2610\end{array}$ \\
\hline
\end{tabular}


TABLE 12.--Data on water hardness and major dissolved chemical constituents for surface-water samples in and near Stillwater Wildlife Management Area and Carson Lake, 1986-87--Continued

\begin{tabular}{|c|c|c|c|c|c|}
\hline Station name & $\begin{array}{l}\text { Sulfate, } \\
\text { dis- } \\
\text { solved } \\
\text { (mg/L } \\
\text { as } \mathrm{SO}_{4} \text { ) }\end{array}$ & $\begin{array}{l}\text { Chlo- } \\
\text { ride, } \\
\text { dis- } \\
\text { solved } \\
\text { (mg/L } \\
\text { as Cl) }\end{array}$ & $\begin{array}{l}\text { Fluo- } \\
\text { ride, } \\
\text { dis- } \\
\text { solved } \\
\text { (mg/L } \\
\text { as F) }\end{array}$ & $\begin{array}{c}\text { Silica, } \\
\text { dis- } \\
\text { solved } \\
\text { (mg/L } \\
\text { as } \\
\text { sio }_{2} \text { ) }\end{array}$ & $\begin{array}{l}\text { Solids, } \\
\text { residue } \\
\text { at } 180^{\circ} \mathrm{C} \\
\text { dissolved } \\
\text { (mg/L) }\end{array}$ \\
\hline LOWER DIAGONAL DRAIN at HWY $50 \mathrm{nr}$ FALLON, NV & 330 & 220 & 0.70 & 19 & 1170 \\
\hline STILLWATER PT. DIV. DRAIN nI STILLWATER, NV & $\begin{array}{l}-- \\
400 \\
180\end{array}$ & $\begin{array}{l}-- \\
590 \\
140\end{array}$ & $\begin{array}{l}-- \\
-80 \\
.60\end{array}$ & $\begin{array}{l}-- \\
\overline{12} \\
28\end{array}$ & $\begin{array}{r}E 350 \\
338 \\
1940 \\
794\end{array}$ \\
\hline STILLWATER POINT RESERVOIR SOUTH nI STILLWATER, NV & $\begin{array}{r}-- \\
270 \\
150\end{array}$ & $\begin{array}{r}-- \\
\overline{370} \\
97\end{array}$ & $\begin{array}{l}-- \\
-.70 \\
.50\end{array}$ & $\begin{array}{l}-- \\
-- \\
16 \\
25\end{array}$ & $\begin{array}{r}469 \\
423 \\
1260 \\
652\end{array}$ \\
\hline STILLWATER POINT RESERVOIR NORTH nI STILLWATER, NV & $\begin{array}{r}-- \\
290 \\
400\end{array}$ & $\begin{array}{r}-- \\
-- \\
440 \\
580\end{array}$ & $\begin{array}{l}-- \\
-70 \\
1.0\end{array}$ & $\begin{array}{l}-- \\
-- \\
13 \\
23\end{array}$ & $\begin{array}{r}826 \\
1300 \\
1450 \\
1890\end{array}$ \\
\hline STILLWATER SLOUGH at STILLWATER, NV & $\begin{array}{l}--\overline{7} \\
250\end{array}$ & $\begin{array}{r}1600 \\
330\end{array}$ & $\begin{array}{l}--80 \\
0.30\end{array}$ & $\begin{array}{l}-- \\
22 \\
29\end{array}$ & $\begin{array}{r}595 \\
3940 \\
1180\end{array}$ \\
\hline STILLWATER SLOUGH CUTOFF DRAIN nI STILLWATER NV & -- & -- & -- & -- & 796 \\
\hline HUNTER DRAIN at DIVISION RD. nr. STILLWATER, NV & 6700 & 26000 & .70 & 7.2 & 53400 \\
\hline LEAD LK CANAL at HUNTER RD CROSSING nI STILLWATER & 410 & 750 & .70 & 10 & 1990 \\
\hline CATTAIL LAKE at OUTLET nr. STILLWATER, NV & 1400 & 3500 & 1.2 & 7.6 & 8310 \\
\hline SWAN CHECK nr. OUTLET nr. STILLWATER, NV & 610 & 1200 & .90 & 11 & 3140 \\
\hline PINTAIL BAY nr. CENTER nr. STILLWATER, NV & 4000 & 14000 & 2.1 & $<1.0$ & 35000 \\
\hline
\end{tabular}


TABLE 13.--Data on nutrient constituents for surface-water samples in and near stillwater wildife Management Area and Carson Lake, 1986-87

[Un-ionized ammonia was calculated from the laboratory ammonia concentration, water temperature, and pH at the time of sampling; <, less than; >, greater than; --, no data available; mg/L, mililgrams per liter]

\begin{tabular}{|c|c|c|c|c|c|c|}
\hline Station name & Date & $\begin{array}{c}\text { Nitro- } \\
\text { gen, } \\
\text { ammonia, } \\
\text { dis- } \\
\text { solved } \\
\text { (mg/L } \\
\text { as N) }\end{array}$ & $\begin{array}{l}\text { Dis- } \\
\text { solved } \\
\text { ammonia, } \\
\text { un- } \\
\text { ionized } \\
\text { (mg/L } \\
\text { as N) }\end{array}$ & $\begin{array}{c}\text { Nitro- } \\
\text { gen, } \\
\text { ammonia, } \\
\text { total } \\
\text { (mg/L } \\
\text { as N) }\end{array}$ & $\begin{array}{l}\text { Nitro- } \\
\text { gen, } \\
\text { nitrite, } \\
\text { dis- } \\
\text { solved } \\
\text { (mg/L } \\
\text { as N) }\end{array}$ & $\begin{array}{l}\text { Nitro- } \\
\text { gen } \\
\text { ammoniat } \\
\text { organic, } \\
\text { total } \\
\text { (mg/L } \\
\text { as N) }\end{array}$ \\
\hline WILLIAMS SLOUGH nI GENOA, NV (CARSON VALIEY) & $\begin{array}{l}09-04-86 \\
03-30-87 \\
05-18-87\end{array}$ & $\begin{array}{l}0.930 \\
5.30 \\
.280\end{array}$ & $\begin{array}{c}0.004 \\
.071 \\
.024\end{array}$ & $\begin{array}{c}0.950 \\
5.40 \\
--\end{array}$ & $\begin{array}{r}<0.010 \\
.100 \\
.040\end{array}$ & $\begin{array}{r}2.5 \\
7.3 \\
--\end{array}$ \\
\hline WASHOE LAKE NI CARSON CITY, NV & $\begin{array}{l}09-04-86 \\
03-20-87 \\
05-18-87\end{array}$ & $\begin{array}{l}.030 \\
.020 \\
.020\end{array}$ & $\begin{array}{l}.005 \\
.001 \\
.002\end{array}$ & $\begin{array}{l}.050 \\
.090 \\
-.\end{array}$ & $\begin{array}{l}<.010 \\
<.010 \\
<.010\end{array}$ & $\begin{array}{r}1.1 \\
3.4 \\
--\end{array}$ \\
\hline CARSON RIVER bI LAHONTAN RES nI FALLON, NV & $\begin{array}{l}06-10-86 \\
09-02-86 \\
03-13-87 \\
05-11-87\end{array}$ & $\begin{array}{r}.060 \\
.020 \\
<.010 \\
.140\end{array}$ & $\begin{array}{r}.001 \\
.001 \\
<.001 \\
.004\end{array}$ & $\begin{array}{l}.060 \\
.030 \\
.-\end{array}$ & $\begin{array}{l}-- \\
<.010 \\
<.010 \\
.020\end{array}$ & $\begin{array}{l}-7 \\
.70 \\
.80 \\
--\end{array}$ \\
\hline SHECKLER RESERVOIR at OUTLET nI FALLON, NV & $\begin{array}{l}09-02-86 \\
03-19-87 \\
05-15-87\end{array}$ & $\begin{array}{r}.030 \\
<.010 \\
.010\end{array}$ & $\begin{array}{r}<.005 \\
<.001 \\
.003\end{array}$ & $\begin{array}{l}.040 \\
.040 \\
-.\end{array}$ & $\begin{array}{l}<.010 \\
<.010 \\
<.010\end{array}$ & $\begin{array}{l}.90 \\
1.8 \\
--\end{array}$ \\
\hline CARSON LAKE DRAIN abv CARSON LAKE nI FALLON, NV & $\begin{array}{l}02-25-86 \\
06-03-86 \\
08-29-86 \\
03-13-87 \\
05-14-87\end{array}$ & $\begin{array}{l}.500 \\
.140 \\
.100 \\
.160 \\
.950\end{array}$ & $\begin{array}{l}.113 \\
.009 \\
.003 \\
.014 \\
.031\end{array}$ & $\begin{array}{l}-- \\
--120 \\
.120 \\
.140 \\
1.00\end{array}$ & $\begin{array}{l}.070 \\
-.040 \\
.040 \\
.040 \\
.090\end{array}$ & $\begin{array}{l}-- \\
-9 \\
1.90 \\
5.3\end{array}$ \\
\hline CARSON LAKE, SPRIG POND UNIT, nI FALLON, NV & $\begin{array}{l}06-03-86 \\
08-29-86 \\
03-17-87 \\
05-14-87\end{array}$ & $\begin{array}{l}.040 \\
.020 \\
.120 \\
.100\end{array}$ & $\begin{array}{l}.023 \\
.006 \\
.011 \\
.015\end{array}$ & $\begin{array}{l}-.110 \\
.230 \\
.-\end{array}$ & $\begin{array}{l}-- \\
<.010 \\
<.010 \\
.030\end{array}$ & $\begin{array}{r}-- \\
2.7 \\
4.8 \\
--\end{array}$ \\
\hline CARSON LAKE, ISLAND UNIT, nI FALLON, NV & $\begin{array}{l}06-03-86 \\
09-03-86 \\
03-18-87 \\
05-14-87\end{array}$ & $\begin{array}{l}.040 \\
.140 \\
.060 \\
.040\end{array}$ & $\begin{array}{l}.009 \\
.003 \\
.004 \\
.014\end{array}$ & $\begin{array}{l}-. \\
.180 \\
.140 \\
--\end{array}$ & $\begin{array}{l}.030 \\
<.010 \\
<.010\end{array}$ & 2.2 \\
\hline CARSON LAKE, BIG WATER UNIT, nI FALLON, NV & $06-04-86$ & .120 & .040 & -- & - & - \\
\hline PAIUTE DRAIN at WILDLIFE ENT nI STILLWATER, NV & $\begin{array}{l}06-05-86 \\
08-30-86 \\
03-12-87 \\
05-12-87\end{array}$ & $\begin{array}{l}.080 \\
.100 \\
.020 \\
.030\end{array}$ & $\begin{array}{l}.028 \\
.026 \\
.001 \\
.006\end{array}$ & $\begin{array}{l}-. \\
.190 \\
.060 \\
--\end{array}$ & $\begin{array}{l}-.020 \\
<.010 \\
<.010\end{array}$ & $\begin{array}{r}--\overline{3} \\
2.3 \\
--\end{array}$ \\
\hline TJ DRAIN at WILDLIFE ENTRANCE nI STILLWATER, NV & $\begin{array}{l}06-05-86 \\
09-01-86 \\
03-12-87 \\
05-12-87 \\
07-23-87\end{array}$ & $\begin{array}{l}.080 \\
.100 \\
.350 \\
.140 \\
.010\end{array}$ & $\begin{array}{l}.005 \\
.006 \\
.008 \\
.028 \\
.001\end{array}$ & $\begin{array}{l}.0 \\
.080 \\
.430 \\
.0 \\
.040\end{array}$ & $\begin{array}{l}-. \\
.010 \\
<.010 \\
<.010 \\
<.010\end{array}$ & $\begin{array}{l}-\overline{.80} \\
2.3 \\
-\overline{1.8}\end{array}$ \\
\hline PAIUTE DRAIN bIW TJ DRAIN nr STILIWATER, NV & $\begin{array}{l}02-23-86 \\
06-05-86 \\
08-30-86 \\
03-12-87 \\
05-12-87\end{array}$ & $\begin{array}{l}.050 \\
.090 \\
.080 \\
.050 \\
.040\end{array}$ & $\begin{array}{l}.004 \\
.013 \\
.005 \\
.003 \\
.004\end{array}$ & $\begin{array}{l}-- \\
-- \\
.150 \\
.080 \\
--\end{array}$ & $\begin{array}{l}.030 \\
-.020 \\
.020 \\
<.010 \\
<.010\end{array}$ & $\begin{array}{l}-- \\
1 .-5 \\
1.4 \\
2.5\end{array}$ \\
\hline LEAD LAKE at MIILENS LANDING nI STILLWATER, NV & $\begin{array}{l}06-05-86 \\
08-26-86 \\
03-17-87 \\
05-12-87\end{array}$ & $\begin{array}{l}.160 \\
.180 \\
.050 \\
.090\end{array}$ & $\begin{array}{l}.044 \\
.037 \\
.019 \\
.007\end{array}$ & $\begin{array}{l}-. \\
.650 \\
.070 \\
.-\end{array}$ & $\begin{array}{l}-.020 \\
<.010 \\
<.010\end{array}$ & $\begin{array}{l}-- \\
3.7 \\
2.0 \\
--\end{array}$ \\
\hline SOUTH LEAD IAKE nI STILLWATER, NV & $\begin{array}{l}06-06-86 \\
08-27-86 \\
03-17-87 \\
05-12-87 \\
07-02-87\end{array}$ & $\begin{array}{l}.050 \\
.050 \\
.170 \\
.030 \\
.390\end{array}$ & $\begin{array}{l}.022 \\
.019 \\
.014 \\
.010 \\
.190\end{array}$ & $\begin{array}{l}-.020 \\
.0220 \\
-. \\
.190\end{array}$ & $\begin{array}{r}-.010 \\
.010 \\
<.010 \\
<.230\end{array}$ & $\begin{array}{r}14^{--} \\
2.3 \\
1.9\end{array}$ \\
\hline
\end{tabular}


TABLE 13.--Data on nutrient constituents for surface-water samples in and near stillwater Wildife Management Area and Carson Lake, 1986-87--Continued

\begin{tabular}{|c|c|c|c|c|c|c|}
\hline Station name & Date & $\begin{array}{l}\text { Nitro- } \\
\text { gen, } \\
\text { ammonia, } \\
\text { dis- } \\
\text { solved } \\
\text { (mg/L } \\
\text { as } \mathrm{N} \text { ) }\end{array}$ & $\begin{array}{l}\text { Dis- } \\
\text { solved } \\
\text { ammonia, } \\
\text { un- } \\
\text { ionized } \\
\text { (mg/L } \\
\text { as N) }\end{array}$ & $\begin{array}{l}\text { Nitro- } \\
\text { gen, } \\
\text { ammonia, } \\
\text { total } \\
\text { (mg/L } \\
\text { as N) }\end{array}$ & $\begin{array}{l}\text { Nitro- } \\
\text { gen, } \\
\text { nitrite, } \\
\text { dis- } \\
\text { solved } \\
\text { (mg/L } \\
\text { as N) }\end{array}$ & $\begin{array}{l}\text { Nitro- } \\
\text { gen } \\
\text { ammoniat } \\
\text { organic, } \\
\text { total } \\
\text { (mg/L } \\
\text { as } N \text { ) }\end{array}$ \\
\hline LOWER DIAGONAL DRAIN at HWY $50 \mathrm{nK}$ FALLON, NV & $02-23-86$ & 0.750 & 0.239 & -- & 0.050 & -- \\
\hline STILLWATER PT. DIV. DRAIN n STILLWATER, NV & $\begin{array}{l}06-04-86 \\
08-27-86 \\
03-12-87 \\
05-13-87\end{array}$ & $\begin{array}{l}.240 \\
.060 \\
.040 \\
.480\end{array}$ & $\begin{array}{l}.008 \\
.004 \\
.011 \\
.044\end{array}$ & $\begin{array}{l}-. \\
0.050 \\
.050 \\
.960\end{array}$ & $\begin{array}{l}-. \\
.060 \\
.020 \\
.150\end{array}$ & $\begin{array}{l}-- \\
1.5 \\
3.2 \\
2.6\end{array}$ \\
\hline STILLWATER POINT RESERVOIR SOUTH $n$ r STILLWATER, NV & $\begin{array}{l}06-09-86 \\
08-28-86 \\
03-18-87 \\
05-13-87\end{array}$ & $\begin{array}{r}.110 \\
.080 \\
<.010 \\
.080\end{array}$ & $\begin{array}{r}.004 \\
.005 \\
<.001 \\
.014\end{array}$ & $\begin{array}{l}.2 \\
.140 \\
.07\end{array}$ & $\begin{array}{r}-- \\
.090 \\
<.010 \\
.020\end{array}$ & $\begin{array}{l}-- \\
3.6 \\
1.0 \\
--\end{array}$ \\
\hline STILLWATER POINT RESERVOIR NORTH nT STILLWATER, NV & $\begin{array}{l}06-09-86 \\
08-28-86 \\
03-18-87 \\
05-13-87\end{array}$ & $\begin{array}{l}.040 \\
.020 \\
.020 \\
.020\end{array}$ & $\begin{array}{l}.013 \\
.016 \\
.002 \\
.002\end{array}$ & $\begin{array}{l}-\overline{890} \\
.040 \\
--\end{array}$ & $\begin{array}{l}-- \\
<.010 \\
<.010 \\
<.010\end{array}$ & $\begin{array}{l}-- \\
4.8 \\
2.7 \\
--\end{array}$ \\
\hline STILLWATER SLOUGH at STILLWATER, NV & $\begin{array}{l}06-11-86 \\
08-27-86 \\
03-13-87 \\
05-11-87\end{array}$ & $\begin{array}{l}.150 \\
.060 \\
.150 \\
.340\end{array}$ & $\begin{array}{l}.004 \\
.004 \\
.009 \\
.028\end{array}$ & $\begin{array}{l}. \\
.140 \\
.140 \\
=-\end{array}$ & $\begin{array}{r}- \\
.060 \\
<.010 \\
.120\end{array}$ & $\begin{array}{l}-- \\
1.6 \\
1.7 \\
--\end{array}$ \\
\hline HUNTER DRAIN at DIVISION RD. nr. STILLWATER, NV & $07-22-87$ & .240 & .039 & .380 & $<.010$ & 11 \\
\hline LEAD IK CANAL at HUNTER RD CROSSING nT STILLWATER & $07-23-87$ & .030 & .023 & .050 & $<.010$ & 3.4 \\
\hline CATTAIL LAKE at OUTLET nr. STILLWATER, NV & $07-22-87$ & .050 & .032 & .060 & $<.010$ & 3.6 \\
\hline SWAN CHECK $n r$. OUTLET $n r$. STILLWATER, NV & $07-23-87$ & .030 & .021 & .070 & $<.010$ & 9.4 \\
\hline PINTAIL BAY nr. CENTER nr. STILLWATER, NV & $07-24-87$ & .130 & .064 & .220 & $<.010$ & 18 \\
\hline
\end{tabular}


TABLE 13.--Data on nutrient constituents for surface-water samples in and near stillwater wildife Management Area and Carson Lake, 1986-87--Continued

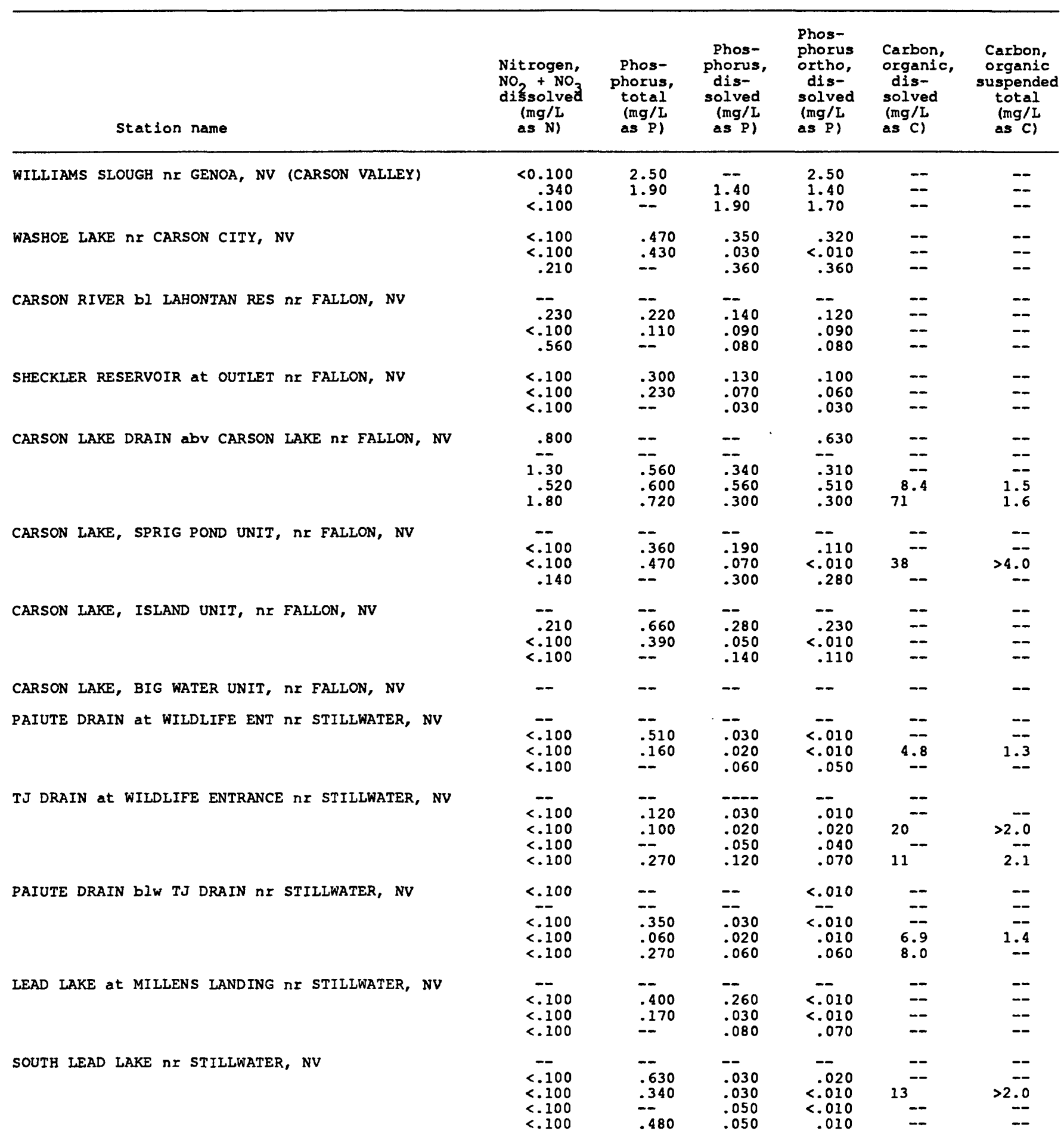


TABLE 13.--Data on nutrient constituents for surface-water samples in and near Stillwater wildlife Management Area and Carson Lake, 1986-87--Continued

\begin{tabular}{|c|c|c|c|c|c|c|}
\hline Station name & $\begin{array}{c}\text { Nitrogen, } \\
\mathrm{NO}_{2}+\mathrm{NO}_{3} \\
\text { dissolved } \\
\text { (mg/L } \\
\text { as N) }\end{array}$ & $\begin{array}{l}\text { Phos- } \\
\text { phorus, } \\
\text { total } \\
\text { (mg/L } \\
\text { as P) }\end{array}$ & $\begin{array}{l}\text { Phos- } \\
\text { phorus, } \\
\text { dis- } \\
\text { solved } \\
\text { (mg/L } \\
\text { as P) }\end{array}$ & $\begin{array}{l}\text { Phos- } \\
\text { phorus } \\
\text { ortho, } \\
\text { dis- } \\
\text { solved } \\
\text { (mg/I } \\
\text { as } P \text { ) }\end{array}$ & $\begin{array}{l}\text { Carbon, } \\
\text { organic, } \\
\text { dis- } \\
\text { solved } \\
\text { (mg/L } \\
\text { as C) }\end{array}$ & $\begin{array}{l}\text { Carbon, } \\
\text { organic } \\
\text { suspended } \\
\text { total } \\
\text { (mg/I } \\
\text { as C) }\end{array}$ \\
\hline LOWER DIAGONAL DRAIN at HWY $50 \mathrm{nr}$ FALLON, NV & 0.270 & -- & -- & 0.850 & -- & -- \\
\hline STILLWATER PT. DIV. DRAIN nY STILLWATER, NV & $\begin{array}{r}-- \\
.540 \\
<.100 \\
.810\end{array}$ & $\begin{array}{l}-- \\
0.520 \\
1.70 \\
.710\end{array}$ & $\begin{array}{l}-- \\
0.250 \\
1.10 \\
.440\end{array}$ & $\begin{array}{l}-- \\
.230 \\
1.00 \\
.420\end{array}$ & $\begin{array}{l}-- \\
9.2\end{array}$ & $\begin{array}{l}-- \\
1.6\end{array}$ \\
\hline STILIWATER POINT RESERVOIR SOUTH nI STILLWATER, NV & $\begin{array}{r}-. \\
.640 \\
.150 \\
<.100\end{array}$ & $\begin{array}{l}-. \\
.510 \\
.490 \\
--\end{array}$ & $\begin{array}{l}-. \\
.270 \\
.330 \\
.450\end{array}$ & $\begin{array}{l}-. \\
.230 \\
.290 \\
.430\end{array}$ & $\begin{array}{l}-- \\
-- \\
--\end{array}$ & $\begin{array}{l}-- \\
-- \\
--\end{array}$ \\
\hline STILLWATER POINT RESERVOIR NORTH nI STILLWATER, NV & $\begin{array}{l}-- \\
<.100 \\
<.100 \\
<.100\end{array}$ & $\begin{array}{l}.- \\
.320 \\
.640 \\
.-\end{array}$ & $\begin{array}{l}-. \\
.020 \\
.170 \\
.080\end{array}$ & $\begin{array}{l}-. \\
.020 \\
.130 \\
.070\end{array}$ & $\begin{array}{l}-- \\
-- \\
--\end{array}$ & $\begin{array}{l}-- \\
-- \\
--\end{array}$ \\
\hline STILLWATER SLOUGH at STILLWATER, NV & $\begin{array}{r}-- \\
.800 \\
<.100 \\
.730\end{array}$ & $\begin{array}{l}-- \\
.530 \\
.490 \\
--\end{array}$ & $\begin{array}{l}-. \\
.290 \\
.420 \\
.280\end{array}$ & $\begin{array}{l}-. \\
.250 \\
.350 \\
.240\end{array}$ & $\begin{array}{l}-- \\
-- \\
--\end{array}$ & $\begin{array}{l}-- \\
-- \\
--\end{array}$ \\
\hline HUNTER DRAIN at DIVISION RD. nr. STILLWATER, NV & $<.100$ & .490 & .070 & .030 & 20 & $>2.5$ \\
\hline LEAD LK CANAL at HUNTER RD CROSSING nI STILLWATER & $<.100$ & .580 & .040 & $<.010$ & 11 & $>5.0$ \\
\hline CATTAII LAKE at OUTLET nr. STILLWATER, NV & $<.100$ & .230 & .090 & .020 & -- & -- \\
\hline SWAN CHECK $n r$. OUTLET $n r$. STILLWATER, NV & $<.100$ & .820 & .050 & .010 & -- & -- \\
\hline PINTAIL BAY $\mathrm{nr}$. CENTER $\mathrm{nr}$. STILLWATER, NV & $<.100$ & .720 & .290 & .120 & -- & -- \\
\hline
\end{tabular}


TABLE 14.-Data on trace-element constituents for surface-water samples in and near stillwater Wildife Management Area and Carson Lake, 1986-87

[Abbreviations: $\mu g / L$, micrograms per liter; <, less than; --, no data available.]

\begin{tabular}{|c|c|c|c|c|c|c|c|}
\hline Station name & Date & $\begin{array}{l}\text { Alumi- } \\
\text { num, } \\
\text { dis- } \\
\text { solved } \\
(\mu g / L \\
\text { as Al) }\end{array}$ & $\begin{array}{l}\text { Alumi- } \\
\text { num, } \\
\text { total } \\
\text { recov- } \\
\text { erable } \\
(\mu g / L \\
\text { as Al) }\end{array}$ & $\begin{array}{c}\text { Arsenic, } \\
\text { dis- } \\
\text { solved } \\
(\mu g / L \\
\text { as As) }\end{array}$ & $\begin{array}{l}\text { Arsenic, } \\
\text { total } \\
(\mu g / L \\
\text { as As) }\end{array}$ & $\begin{array}{l}\text { Barium, } \\
\text { dis- } \\
\text { solved } \\
(\mu g / L \\
\text { as } \mathrm{Ba})\end{array}$ & $\begin{array}{c}\text { Barium, } \\
\text { total } \\
\text { recov- } \\
\text { erable } \\
(\mu \mathrm{g} / \mathrm{L} \\
\text { as } \mathrm{Ba})\end{array}$ \\
\hline WILLIAMS SLOUGH nI GENOA, NV & $\begin{array}{l}09-04-86 \\
03-30-87 \\
05-18-87\end{array}$ & $=$ & $\begin{array}{l}-- \\
--\end{array}$ & $\begin{array}{r}8 \\
17 \\
17\end{array}$ & $\begin{array}{l}-- \\
--\end{array}$ & $\begin{array}{r}41 \\
97 \\
100\end{array}$ & $\begin{array}{l}-- \\
--\end{array}$ \\
\hline WASHOE LAKE $n Y$ CARSON CITY, NV & $\begin{array}{l}09-04-86 \\
03-20-87 \\
05-18-87\end{array}$ & $\begin{array}{l}-- \\
--\end{array}$ & $=-$ & $\begin{array}{l}5 \\
5 \\
5\end{array}$ & $\begin{array}{l}-- \\
--\end{array}$ & $\begin{array}{r}120 \\
110 \\
71\end{array}$ & $\begin{array}{l}-- \\
--\end{array}$ \\
\hline CARSON RIVER bI LAHONTAN RES II FALLON, NV & $\begin{array}{l}06-10-86 \\
09-02-86 \\
03-13-87 \\
05-11-87\end{array}$ & $\begin{array}{l}-- \\
= \\
--\end{array}$ & $\begin{array}{l}-- \\
-- \\
--\end{array}$ & $\begin{array}{l}7 \\
10 \\
45 \\
11\end{array}$ & $\begin{array}{l}-- \\
=- \\
--\end{array}$ & $\begin{array}{l}41 \\
47 \\
39 \\
34\end{array}$ & $\begin{array}{l}-- \\
-- \\
--\end{array}$ \\
\hline SHECKLER RESERVOIR at OUTLET nI FALLON, NV & $\begin{array}{l}06-10-86 \\
09-02-86 \\
03-19-87 \\
05-15-87\end{array}$ & $\begin{array}{l}-- \\
-- \\
--\end{array}$ & $\begin{array}{l}-- \\
-- \\
--\end{array}$ & $\begin{array}{l}14 \\
14 \\
16 \\
17\end{array}$ & $\begin{array}{l}-- \\
=- \\
--\end{array}$ & $\begin{array}{l}38 \\
90 \\
48 \\
40\end{array}$ & $\begin{array}{l}-- \\
-- \\
--\end{array}$ \\
\hline CARSON LAKE DRAIN abv CARSON LAKE $n K$ FALLON, NV & $\begin{array}{l}02-25-86 \\
06-03-86 \\
08-29-86 \\
03-13-87 \\
05-14-87\end{array}$ & $\begin{array}{l}<10 \\
=- \\
=- \\
=-\end{array}$ & $\begin{array}{r}-- \\
\overline{--} \\
200 \\
5600\end{array}$ & $\begin{array}{r}120 \\
<1 \\
61 \\
130 \\
69\end{array}$ & $\begin{array}{r}-- \\
-- \\
140 \\
71\end{array}$ & $\begin{array}{r}100 \\
69 \\
60 \\
<100 \\
78\end{array}$ & $\begin{array}{r}-- \\
-\overline{-} \\
<100 \\
200\end{array}$ \\
\hline CARSON LAKE, SPRIG POND UNIT, nY FALLON, NV & $\begin{array}{l}06-03-86 \\
08-29-86 \\
03-17-87 \\
05-14-87\end{array}$ & $\begin{array}{l}-- \\
-- \\
--\end{array}$ & $\begin{array}{r}-- \\
14000 \\
--\end{array}$ & $\begin{array}{r}100 \\
41 \\
18 \\
130\end{array}$ & $\begin{array}{l}-- \\
-\overline{4} \\
--\end{array}$ & $\begin{array}{r}63 \\
56 \\
300 \\
200\end{array}$ & 300 \\
\hline CARSON LAKE, ISLAND UNIT, nI FALLON, NV & $\begin{array}{l}06-03-86 \\
09-03-86 \\
03-18-87 \\
05-14-87\end{array}$ & $\begin{array}{l}-- \\
-- \\
--\end{array}$ & $\begin{array}{l}-- \\
-- \\
--\end{array}$ & $\begin{array}{r}74 \\
14 \\
21 \\
140\end{array}$ & $\begin{array}{l}-- \\
=- \\
--\end{array}$ & $\begin{array}{l}100 \\
210 \\
100 \\
300\end{array}$ & $\begin{array}{l}-- \\
-- \\
--\end{array}$ \\
\hline CARSON LAKE, BIG WATER UNIT, nY FALLON, NV & $06-04-86$ & -- & -- & $<1$ & -- & -- & -- \\
\hline PAIUTE DRAIN at WILDLIFE ENT nr STILLWATER, NV & $\begin{array}{l}06-05-86 \\
08-30-86 \\
03-12-87 \\
05-12-87\end{array}$ & $\begin{array}{l}-- \\
-- \\
--\end{array}$ & 2900 & $\begin{array}{l}43 \\
28 \\
23 \\
43\end{array}$ & $\begin{array}{l}-- \\
29 \\
--\end{array}$ & $\begin{array}{l}200 \\
280 \\
110 \\
100\end{array}$ & $<100$ \\
\hline TJ DRAIN at WILDIIFE ENTRANCE nx STILLWATER, NV & $\begin{array}{l}06-05-86 \\
09-01-86 \\
03-12-87 \\
05-12-87 \\
07-23-87\end{array}$ & $\begin{array}{l}-- \\
=- \\
=- \\
--\end{array}$ & $\begin{array}{l}-- \\
610 \\
--\end{array}$ & $\begin{array}{r}80 \\
39 \\
190 \\
160 \\
65\end{array}$ & $\begin{array}{r}-- \\
220 \\
-- \\
--\end{array}$ & $\begin{array}{r}<100 \\
100 \\
100 \\
200 \\
100\end{array}$ & $\begin{array}{r}-- \\
0100 \\
--\end{array}$ \\
\hline PAIUTE DRAIN blW TJ DRAIN nI STILLWATER, NV & $\begin{array}{l}02-23-86 \\
06-05-86 \\
08-30-86 \\
03-12-87 \\
05-12-87\end{array}$ & $\begin{array}{l}20 \\
=- \\
=- \\
--\end{array}$ & $\begin{array}{r}-- \\
-- \\
2700 \\
6600\end{array}$ & $\begin{array}{l}26 \\
56 \\
29 \\
53 \\
42\end{array}$ & $\begin{array}{l}-- \\
-- \\
\overline{53} \\
44\end{array}$ & $\begin{array}{l}100 \\
-- \\
260 \\
200 \\
100\end{array}$ & $\begin{array}{l}-- \\
\overline{--} \\
100 \\
200\end{array}$ \\
\hline LEAD LAKE at MILLENS LANDING nI STILLWATER, NV & $\begin{array}{l}06-05-86 \\
08-26-86 \\
03-17-87 \\
05-12-87\end{array}$ & $\begin{array}{l}-- \\
-- \\
--\end{array}$ & $\begin{array}{l}=- \\
-- \\
--\end{array}$ & $\begin{array}{l}51 \\
44 \\
23 \\
41\end{array}$ & $\begin{array}{l}-- \\
-- \\
--\end{array}$ & $\begin{array}{r}100 \\
100 \\
100 \\
90\end{array}$ & $\begin{array}{l}-- \\
-- \\
--\end{array}$ \\
\hline SOUTH LEAD LAKE nI STILLWATER, NV & $\begin{array}{l}06-06-86 \\
08-27-86 \\
03-17-87 \\
05-12-87 \\
07-02-87\end{array}$ & $\begin{array}{l}-- \\
-- \\
-- \\
--\end{array}$ & $\begin{array}{r}-- \\
2700 \\
-- \\
--\end{array}$ & $\begin{array}{l}88 \\
95 \\
31 \\
79 \\
79\end{array}$ & $\begin{array}{l}-- \\
49 \\
--\end{array}$ & $\begin{array}{l}200 \\
100 \\
100 \\
100 \\
100\end{array}$ & $\begin{array}{c}-- \\
100 \\
--\end{array}$ \\
\hline
\end{tabular}


TABLE 14.--Data on trace-element constituents for surface-water samples in and near stillwater Wildife Management Area and Carson Lake, 1986-87--Continued

\begin{tabular}{|c|c|c|c|c|c|c|c|}
\hline Station name & Date & $\begin{array}{l}\text { Alumi- } \\
\text { num, } \\
\text { dis- } \\
\text { solved } \\
(\mu g / L \\
\text { as Al) }\end{array}$ & $\begin{array}{l}\text { Alumi- } \\
\text { num, } \\
\text { total } \\
\text { recov- } \\
\text { erable } \\
\text { ( } \mu \text { g/L } \\
\text { as Al) }\end{array}$ & $\begin{array}{c}\text { Arsenic, } \\
\text { dis- } \\
\text { solved } \\
\text { ( } \mu g / L \\
\text { as As) }\end{array}$ & $\begin{array}{c}\text { Arsenic, } \\
\text { total } \\
\text { ( } \mu g / L \\
\text { as As) }\end{array}$ & $\begin{array}{c}\text { Barium, } \\
\text { dis- } \\
\text { solved } \\
\text { ( } \mu g / \mathrm{L} \\
\text { as } \mathrm{Ba})\end{array}$ & $\begin{array}{c}\text { Barium, } \\
\text { total } \\
\text { recov- } \\
\text { erable } \\
\text { ( } \mu \text { g/L } \\
\text { as } \mathrm{Ba})\end{array}$ \\
\hline LOWER DIAGONAL DRAIN at HWY $50 \mathrm{nr}$ FALLON, NV & $02-23-86$ & 10 & -- & 110 & -- & 58 & -- \\
\hline STILLWATER PT. DIV. DRAIN nI STILLWATER, NV & $\begin{array}{l}06-04-86 \\
08-27-86 \\
03-12-87 \\
03-26-87 \\
05-13-87\end{array}$ & $\begin{array}{l}-- \\
-- \\
-- \\
-- \\
--\end{array}$ & $\begin{array}{r}-- \\
-- \\
760 \\
<10\end{array}$ & $\begin{array}{r}-\overline{37} \\
120 \\
\overline{61}\end{array}$ & $\begin{array}{l}-- \\
-- \\
\overline{98} \\
70\end{array}$ & $\begin{array}{r}48 \\
240 \\
100 \\
-\overline{80}\end{array}$ & $\begin{array}{l}-- \\
\overline{--} \\
100 \\
100\end{array}$ \\
\hline STILLWATER POINT RESERVOIR, SO. END, nI FALLON, NV & $\begin{array}{l}06-09-86 \\
08-28-86 \\
03-18-87 \\
05-13-87\end{array}$ & $\begin{array}{l}-- \\
-- \\
-- \\
--\end{array}$ & $\begin{array}{l}-- \\
-- \\
-- \\
--\end{array}$ & $\begin{array}{l}23 \\
39 \\
30 \\
62\end{array}$ & $\begin{array}{l}-- \\
-- \\
-- \\
--\end{array}$ & $\begin{array}{r}52 \\
110 \\
120 \\
78\end{array}$ & $\begin{array}{l}-- \\
-- \\
-- \\
--\end{array}$ \\
\hline STILLWATER POINT RESERVOIR NORTH nI STILLWATER, NV & $\begin{array}{l}06-09-86 \\
08-28-86 \\
03-18-87 \\
05-13-87\end{array}$ & $\begin{array}{l}-- \\
-- \\
-- \\
--\end{array}$ & $\begin{array}{l}-- \\
-- \\
-- \\
--\end{array}$ & $\begin{array}{l}80 \\
84 \\
41 \\
89\end{array}$ & $\begin{array}{l}-- \\
-- \\
--\end{array}$ & $\begin{array}{r}64 \\
100 \\
100 \\
100\end{array}$ & $\begin{array}{l}-- \\
-- \\
--\end{array}$ \\
\hline STILLWATER SLOUGH at STILLWATER, NV & $\begin{array}{l}06-11-86 \\
08-27-86 \\
03-13-87 \\
05-11-87\end{array}$ & $\begin{array}{l}-- \\
-- \\
-- \\
--\end{array}$ & $\begin{array}{l}-- \\
-- \\
-- \\
--\end{array}$ & $\begin{array}{l}25 \\
34 \\
71 \\
43\end{array}$ & $\begin{array}{l}-- \\
-- \\
-- \\
--\end{array}$ & $\begin{array}{r}81 \\
210 \\
200 \\
100\end{array}$ & $\begin{array}{l}-- \\
-- \\
-- \\
--\end{array}$ \\
\hline STILLWATER SLOUGH CUTOFF DRAIN NR STILLWATER NV & $06-11-86$ & -- & -- & 30 & -- & 81 & -- \\
\hline HUNTER DRAIN at DIVISION RD. nr. STILLWATER, NV & $07-22-87$ & -- & -- & 380 & -- & 200 & -- \\
\hline LEAD LK CANAL at HUNTER RD CROSSING nI STILLWATER & $07-23-87$ & -- & -- & 81 & -- & 100 & -- \\
\hline CATTAIL LAKE at OUTLET nr. STILLWATER, NV & $07-22-87$ & -- & -- & 190 & -- & 200 & -- \\
\hline SWAN CHECK $n r$. OUTLET $n r$. STILLWATER, NV & $07-23-87$ & -- & -- & 120 & -- & 400 & -- \\
\hline PINTAIL BAY nr. CENTER nr. STILLWATER, NV & $07-24-87$ & -- & -- & 1400 & -- & 300 & -- \\
\hline
\end{tabular}


TABLE 14.--Data on trace-element constituents for surface-water samples in and near stillwater wildlife Management Area and Carson Lake, 1986-87--Continued

\begin{tabular}{|c|c|c|c|c|c|c|c|}
\hline Station name & $\begin{array}{l}\text { Beryl- } \\
\text { lium, } \\
\text { dis- } \\
\text { solved } \\
\text { ( } \mu \mathrm{g} / \mathrm{L} \\
\text { as Be) }\end{array}$ & $\begin{array}{l}\text { Beryl- } \\
\text { lium, } \\
\text { total } \\
\text { recov- } \\
\text { erable } \\
\text { ( } \mu \mathrm{g} / \mathrm{L} \\
\text { as } \mathrm{Be})\end{array}$ & $\begin{array}{l}\text { Boron, } \\
\text { dis- } \\
\text { solved } \\
(\mu g / L \\
\text { as } B)\end{array}$ & $\begin{array}{l}\text { Cadmium, } \\
\text { dis- } \\
\text { solved } \\
\text { ( } \mu g / L \\
\text { as } C d)\end{array}$ & $\begin{array}{l}\text { Cadmium, } \\
\text { total } \\
\text { recov- } \\
\text { erable } \\
\text { ( } \mu g / L \\
\text { as Cd) }\end{array}$ & $\begin{array}{l}\text { Chro- } \\
\text { mium, } \\
\text { dis- } \\
\text { solved } \\
(\mu g / L \\
\text { as Cr) }\end{array}$ & $\begin{array}{c}\text { Chromium, } \\
\text { hexa- } \\
\text { valent, } \\
\text { dissolved } \\
(\mu \mathrm{g} / \mathrm{L} \\
\text { as } \mathrm{Cr})\end{array}$ \\
\hline WILLIAMS SLOUGH nr GENOA, NV & $\begin{array}{l}=- \\
=-\end{array}$ & $=$ & $\begin{array}{l}220 \\
230 \\
270\end{array}$ & $\begin{array}{l}3 \\
<1 \\
<1\end{array}$ & $\begin{array}{l}-- \\
=-\end{array}$ & $\begin{array}{l}<10 \\
<10 \\
<10\end{array}$ & $\begin{array}{l}<1 \\
--\end{array}$ \\
\hline WASHOE LAKE NI CARSON CITY, NV & $\begin{array}{l}=- \\
=-\end{array}$ & $=$ & $\begin{array}{l}70 \\
60 \\
60\end{array}$ & $\begin{array}{r}<1 \\
<10 \\
<1\end{array}$ & $\begin{array}{l}=- \\
=-\end{array}$ & $\begin{array}{l}<10 \\
<10 \\
<10\end{array}$ & $\begin{array}{l}<1 \\
=-\end{array}$ \\
\hline CARSON RIVER bI LAHONTAN RES II FALION, NV & $\begin{array}{l}-- \\
-- \\
-- \\
--\end{array}$ & $\begin{array}{l}-- \\
-- \\
--\end{array}$ & $\begin{array}{l}130 \\
110 \\
370 \\
250\end{array}$ & $\begin{array}{l}<1 \\
<1 \\
<1 \\
<1\end{array}$ & $\begin{array}{l}-- \\
-- \\
-- \\
--\end{array}$ & $\begin{array}{r}10 \\
<10 \\
<10 \\
<10\end{array}$ & $\begin{array}{l}<1 \\
<1 \\
-- \\
--\end{array}$ \\
\hline SHECKLER RESERVOIR at OUTLET II FALLON, NV & $\begin{array}{l}-- \\
=-\end{array}$ & $\begin{array}{l}-- \\
-- \\
--\end{array}$ & $\begin{array}{l}160 \\
120 \\
220 \\
280\end{array}$ & $\begin{array}{r}<1 \\
<10 \\
<1 \\
<1\end{array}$ & $\begin{array}{l}-- \\
-- \\
--\end{array}$ & $\begin{array}{l}<10 \\
<10 \\
<10 \\
<10\end{array}$ & $\begin{array}{l}<1 \\
<1 \\
-- \\
--\end{array}$ \\
\hline CARSON LAKE DRAIN abV CARSON LAKE II FALLON, NV & $\begin{array}{l}<10 \\
=- \\
=- \\
-\end{array}$ & $\begin{array}{l}=- \\
\overline{-} \\
<10 \\
<10\end{array}$ & $\begin{array}{l}2500 \\
1200 \\
1600 \\
4400 \\
2100\end{array}$ & $\begin{array}{r}1 \\
<1 \\
9 \\
<1 \\
<1\end{array}$ & $\begin{array}{l}=- \\
=- \\
<1 \\
<1\end{array}$ & $\begin{array}{l}<10 \\
<10 \\
<10 \\
<10 \\
<10\end{array}$ & $\begin{array}{l}<1 \\
<1 \\
<1 \\
-- \\
--\end{array}$ \\
\hline CARSON LAKE, SPRIG POND UNIT, NI FALLON, NV & $=$ & $\overline{--}$ & $\begin{array}{l}2200 \\
1100 \\
6000 \\
4100\end{array}$ & $\begin{array}{r}<1 \\
8 \\
<1 \\
<1\end{array}$ & $\begin{array}{l}-- \\
-- \\
--\end{array}$ & $\begin{array}{l}<10 \\
<10 \\
<10 \\
<10\end{array}$ & $\begin{array}{l}<1 \\
<1 \\
-- \\
--\end{array}$ \\
\hline CARSON LAKE, ISLAND UNIT, NI FALLON, NV & $\begin{array}{l}-- \\
=- \\
--\end{array}$ & $\begin{array}{l}-- \\
-- \\
-- \\
--\end{array}$ & $\begin{array}{r}8300 \\
250 \\
6400 \\
13000\end{array}$ & $\begin{array}{l}<1 \\
<1 \\
<1 \\
<1\end{array}$ & $\begin{array}{l}-- \\
-- \\
--\end{array}$ & $\begin{array}{l}<10 \\
<10 \\
<10 \\
<10\end{array}$ & $\begin{array}{l}<1 \\
<1 \\
--\end{array}$ \\
\hline CARSON LAKE, BIG WATER UNIT, nI FALLON, NV & -- & - & -- & -- & $<10$ & $<1$ & \\
\hline PAIUTE DRAIN AT WILDLIFE ENT NR STILLWATER, NV & $\begin{array}{l}-- \\
-- \\
--\end{array}$ & $\overline{-10}$ & $\begin{array}{r}510 \\
440 \\
190 \\
2000\end{array}$ & $\begin{array}{r}<1 \\
5 \\
1 \\
<1\end{array}$ & $\begin{array}{l}-- \\
-- \\
<1 \\
--\end{array}$ & $\begin{array}{l}<10 \\
<10 \\
<10 \\
<10\end{array}$ & $\begin{array}{l}<1 \\
<1 \\
-- \\
--\end{array}$ \\
\hline TJ DRAIN at WILDLIFE ENTRANCE nI STILLWATER, NV & $\begin{array}{l}=- \\
=- \\
=- \\
--\end{array}$ & $\begin{array}{l}-- \\
<10 \\
--\end{array}$ & $\begin{array}{r}4400 \\
7600 \\
28000 \\
18000 \\
3500\end{array}$ & $\begin{array}{l}<1 \\
<1 \\
<1 \\
<1 \\
<1\end{array}$ & $\begin{array}{l}-- \\
-- \\
-- \\
--\end{array}$ & $\begin{array}{r}<10 \\
20 \\
40 \\
20 \\
<10\end{array}$ & $\begin{array}{l}<1 \\
<1 \\
-- \\
-- \\
--\end{array}$ \\
\hline PAIUTE DRAIN blw TJ DRAIN nr STILLWATER, NV & $\begin{array}{c}<10 \\
-- \\
-- \\
--\end{array}$ & $\begin{array}{l}-- \\
-- \\
-\overline{10} \\
<10\end{array}$ & $\begin{array}{l}2000 \\
1800 \\
1100 \\
5100 \\
2000\end{array}$ & $\begin{array}{l}1 \\
<1 \\
12 \\
<1 \\
<1\end{array}$ & $\begin{array}{l}-- \\
-- \\
-- \\
<1 \\
<1\end{array}$ & $\begin{array}{r}<10 \\
<10 \\
<10 \\
10 \\
<10\end{array}$ & $\begin{array}{l}<1 \\
<1 \\
<1 \\
-- \\
--\end{array}$ \\
\hline LEAD LAKE at MILIENS LANDING nI STILLWATER, NV & $\begin{array}{l}-- \\
-- \\
--\end{array}$ & $\begin{array}{l}-- \\
-- \\
--\end{array}$ & $\begin{array}{r}1500 \\
2500 \\
3600 \\
970\end{array}$ & $\begin{array}{l}<1 \\
<1 \\
<1 \\
<1\end{array}$ & $\begin{array}{l}-- \\
-- \\
-- \\
--\end{array}$ & $\begin{array}{l}<10 \\
<10 \\
<10 \\
<10\end{array}$ & $\begin{array}{l}<1 \\
<1 \\
-- \\
--\end{array}$ \\
\hline SOUTH LEAD LAKE nI STILLWATER, NV & $\begin{array}{l}=- \\
-- \\
-- \\
--\end{array}$ & $\begin{array}{c}-- \\
<10 \\
--\end{array}$ & $\begin{array}{l}3400 \\
4100 \\
3900 \\
3200 \\
3600\end{array}$ & $\begin{array}{l}<1 \\
<1 \\
<1 \\
<1 \\
<1\end{array}$ & $\begin{array}{l}-- \\
-- \\
--\end{array}$ & $\begin{array}{r}<10 \\
10 \\
<10 \\
<10 \\
<10\end{array}$ & $\begin{array}{l}<1 \\
<1 \\
-- \\
--\end{array}$ \\
\hline
\end{tabular}


TABLE 14.--Data on trace-element constituents for surface-water samples in and near stillwater wildife Management Area and Carson Lake, 1986-87--Continued

\begin{tabular}{|c|c|c|c|c|c|c|c|}
\hline Station name & $\begin{array}{l}\text { Beryl- } \\
\text { lium, } \\
\text { dis- } \\
\text { solved } \\
\text { ( } \mu g / L \\
\text { as Be) }\end{array}$ & $\begin{array}{l}\text { Beryl- } \\
\text { lium, } \\
\text { total } \\
\text { recov- } \\
\text { erable } \\
(\mu \mathrm{g} / \mathrm{L} \\
\text { as } \mathrm{Be})\end{array}$ & $\begin{array}{l}\text { Boron, } \\
\text { dis- } \\
\text { solved } \\
\text { ( } \mu g / \mathrm{L} \\
\mathrm{as} \text { B) }\end{array}$ & $\begin{array}{l}\text { Cadmium, } \\
\text { dis- } \\
\text { solved } \\
\text { ( } \mu g / L \\
\text { as Cd) }\end{array}$ & $\begin{array}{l}\text { Cadmium, } \\
\text { total } \\
\text { recov- } \\
\text { erable } \\
\text { ( } \mu g / L \\
\text { as Cd) }\end{array}$ & $\begin{array}{l}\text { Chro- } \\
\text { mium, } \\
\text { dis- } \\
\text { solved } \\
\text { ( } \mu \text { g/L } \\
\text { as Cr) }\end{array}$ & $\begin{array}{c}\text { Chromium, } \\
\text { hexa- } \\
\text { valent, } \\
\text { dissolved } \\
(\mu g / \mathrm{l} \\
\text { as }(r)\end{array}$ \\
\hline LOWER DIAGONAL DRAIN at HWY $50 \mathrm{nr}$ FALLON, NV & $<0.5$ & -- & 2100 & $<1$ & -- & $<10$ & $<1$ \\
\hline STILLWATER PT. DIV. DRAIN nY STILLWATER, NV & $\begin{array}{l}-- \\
-- \\
--\end{array}$ & $\begin{array}{l}-- \\
-\overline{-} \\
<10 \\
<10\end{array}$ & $\begin{array}{r}5 \overline{50} \\
3200 \\
-- \\
1300\end{array}$ & $\begin{array}{l}-- \\
<1 \\
-1 \\
<1\end{array}$ & $\begin{aligned}<10 \\
-- \\
-- \\
<1 \\
<1\end{aligned}$ & $\begin{array}{l}<1 \\
<10 \\
<10 \\
-10\end{array}$ & $\begin{array}{l}<1 \\
-- \\
-- \\
--\end{array}$ \\
\hline STILLWATER POINT RESERVOIR, SO. END, nI FALLON, NV & $\begin{array}{l}-- \\
-- \\
--\end{array}$ & $\begin{array}{l}-- \\
-- \\
--\end{array}$ & $\begin{array}{r}690 \\
670 \\
2200 \\
1000\end{array}$ & $\begin{array}{r}<1 \\
4 \\
<1 \\
<1\end{array}$ & $\begin{array}{l}-- \\
-- \\
--\end{array}$ & $\begin{array}{l}<10 \\
<10 \\
<10 \\
<10\end{array}$ & $\begin{array}{l}<1 \\
<1 \\
-- \\
--\end{array}$ \\
\hline STILLWATER POINT RESERVOIR NORTH $n$ I STILLWATER, NV & $\begin{array}{l}-- \\
--\end{array}$ & $\begin{array}{l}-- \\
-- \\
--\end{array}$ & $\begin{array}{l}1700 \\
3300 \\
2400 \\
3700\end{array}$ & $\begin{array}{l}<1 \\
<1 \\
<1 \\
<1\end{array}$ & $\begin{array}{l}-- \\
-- \\
--\end{array}$ & $\begin{array}{l}<10 \\
<10 \\
<10 \\
<10\end{array}$ & $\begin{array}{l}<1 \\
<1 \\
-- \\
--\end{array}$ \\
\hline STILLWATER SLOUGH at STILLWATER, NV & $\begin{array}{l}-- \\
--\end{array}$ & $\begin{array}{l}-- \\
-- \\
--\end{array}$ & $\begin{array}{r}780 \\
1200 \\
6200 \\
2100\end{array}$ & $\begin{array}{r}1 \\
5 \\
<1 \\
<1\end{array}$ & $\begin{array}{l}-- \\
-- \\
--\end{array}$ & $\begin{array}{l}<10 \\
<10 \\
10 \\
<10\end{array}$ & $\begin{array}{l}<1 \\
<1 \\
-- \\
--\end{array}$ \\
\hline STILLWATER SLOUGH CUTOFF DRAIN nY STILLWATER NV & -- & - & 1300 & $<1$ & -- & $<10$ & $<1$ \\
\hline HUNTER DRAIN at DIVISION RD. nr. STILLWATER, NV & -- & -- & 62000 & $<1$ & -- & 50 & -- \\
\hline LEAD LK CANAL at HUNTER RD CROSSING nI STILLWATER & -- & -- & 3300 & $<1$ & -- & $<10$ & - \\
\hline CATTAIL LAKE at OUTLET nr. STILIWATER, NV & -- & -- & 19000 & $<1$ & -- & 20 & -- \\
\hline SWAN CHECK nr. OUTLET nr. STILLWATER, NV & -- & -- & 5300 & $<1$ & -- & 20 & -- \\
\hline PINTAIL BAY nr. CENTER nr. STILLWATER, NV & -- & - & 73000 & $<1$ & -- & 50 & -- \\
\hline
\end{tabular}


TABLE 14.--Data on trace-element constituents for surface-water samples in and near stillwater wildlife Management Area and Carson Lake, 1986-87--Continued

\begin{tabular}{|c|c|c|c|c|c|c|}
\hline Station name & $\begin{array}{l}\text { Chro- } \\
\text { mium, } \\
\text { total } \\
\text { recov- } \\
\text { erable } \\
\text { ( } \mu g / L \\
\text { as } C r)\end{array}$ & $\begin{array}{c}\text { Cobalt, } \\
\text { dis- } \\
\text { solved } \\
\text { ( } \mu g / L \\
\text { as } \mathrm{Co})\end{array}$ & $\begin{array}{c}\text { Cobalt, } \\
\text { total } \\
\text { recov- } \\
\text { erable } \\
(\mu g / L \\
\text { as }(0)\end{array}$ & $\begin{array}{c}\text { Copper, } \\
\text { dis- } \\
\text { solved } \\
\text { ( } \mu g / \mathrm{I} \\
\text { as } \mathrm{Cu})\end{array}$ & $\begin{array}{l}\text { Copper, } \\
\text { total } \\
\text { recov- } \\
\text { erable } \\
\text { ( } \mu g / L \\
\text { as } \mathrm{Cu})\end{array}$ & $\begin{array}{l}\text { Iron, } \\
\text { total } \\
\text { recov- } \\
\text { erable } \\
\text { ( } \mu g / L \\
\text { as Fe) }\end{array}$ \\
\hline WILLIAMS SLOUGH nI GENOA, NV & $=-$ & $\begin{array}{l}\overline{-} \\
\overline{--}\end{array}$ & $=$ & $\begin{array}{l}<10 \\
<10 \\
<10\end{array}$ & $\overline{-}$ & $\overline{--}$ \\
\hline WASHOE LAKE NY CARSON CITY, NV & $\overline{z-}$ & $\overline{--}$ & $\overline{--}$ & $\begin{array}{l}<10 \\
<10 \\
<10\end{array}$ & $\overline{--}$ & $\overline{--}$ \\
\hline CARSON RIVER bI LAHONTAN RES nI FALLON, NV & $\begin{array}{l}-- \\
-- \\
--\end{array}$ & $\begin{array}{l}-- \\
-- \\
--\end{array}$ & $\begin{array}{l}-- \\
-- \\
--\end{array}$ & $\begin{array}{l}<10 \\
<10 \\
<10 \\
<10\end{array}$ & $=-$ & $\begin{array}{l}-- \\
-- \\
--\end{array}$ \\
\hline SHECKLER RESERVOIR at OUTLET nI FALLON, NV & $\begin{array}{l}-- \\
-- \\
--\end{array}$ & $\begin{array}{l}-- \\
-- \\
--\end{array}$ & $\begin{array}{l}-- \\
-- \\
--\end{array}$ & $\begin{array}{l}<10 \\
<10 \\
<10 \\
<10\end{array}$ & $\begin{array}{l}-- \\
-- \\
--\end{array}$ & $\overline{--}$ \\
\hline CARSON LAKE DRAIN abV CARSON LAKE nI FALLON, NV & $\begin{array}{l}-- \\
=- \\
<1 \\
6\end{array}$ & $\begin{array}{l}<1 \\
=- \\
=-\end{array}$ & $\begin{array}{l}-- \\
-- \\
<1 \\
2\end{array}$ & $\begin{array}{r}1 \\
<10 \\
<10 \\
10 \\
<10\end{array}$ & $\begin{array}{r}-- \\
-\overline{6} \\
11\end{array}$ & $\begin{array}{r}\overline{--} \\
190 \\
5100\end{array}$ \\
\hline CARSON LAKE, SPRIG POND UNIT, nI FALLON, NV & $\frac{--}{5}$ & $\overline{--}$ & -- & $\begin{array}{r}<10 \\
<10 \\
<10 \\
10\end{array}$ & -- & 16000 \\
\hline CARSON LAKE, ISLAND UNIT, AT FALLON, NV & $\begin{array}{l}-- \\
-- \\
--\end{array}$ & $\begin{array}{l}-- \\
-- \\
--\end{array}$ & $\begin{array}{l}-- \\
-- \\
--\end{array}$ & $\begin{array}{r}20 \\
<10 \\
<10 \\
10\end{array}$ & $\begin{array}{l}-- \\
-- \\
--\end{array}$ & $\begin{array}{l}-- \\
--\end{array}$ \\
\hline CARSON LAKE, BIG WATER UNIT, nI FALLON, NV & -- & -- & $\cdot--$ & 30 & -- & -- \\
\hline PAIUTE DRAIN at WILDLIFE ENT nI STILLWATER, NV & $\begin{array}{l}-- \\
--\end{array}$ & $\begin{array}{l}-- \\
-- \\
--\end{array}$ & $\frac{--}{--}$ & $\begin{array}{r}10 \\
<10 \\
<10 \\
<10\end{array}$ & $\overline{--}$ & 3400 \\
\hline TJ DRAIN at WILDLIFE ENTRANCE nr STILLWATER, NV & $\begin{array}{l}-- \\
-- \\
--\end{array}$ & $\begin{array}{l}-- \\
=- \\
=-\end{array}$ & $\begin{array}{l}-- \\
--\end{array}$ & $\begin{array}{r}20 \\
20 \\
80 \\
30 \\
<10\end{array}$ & $\begin{array}{l}-- \\
--7 \\
-- \\
--\end{array}$ & $\begin{array}{l}-- \\
610 \\
--\end{array}$ \\
\hline PAIUTE DRAIN bIW TJ DRAIN nI STILLWATER, NV & $\begin{array}{l}-- \\
-- \\
-1 \\
8\end{array}$ & $\begin{array}{l}1 \\
-- \\
-- \\
--\end{array}$ & $\begin{array}{l}-- \\
-- \\
2 \\
2\end{array}$ & $\begin{array}{r}3 \\
10 \\
<10 \\
10 \\
10\end{array}$ & $\begin{array}{l}-- \\
\overline{--} \\
12 \\
12\end{array}$ & 3000 \\
\hline LEAD LAKE at MILLENS LANDING nI STILLWATER, NV & $\begin{array}{l}-- \\
-- \\
--\end{array}$ & $\begin{array}{l}-- \\
-- \\
--\end{array}$ & $\begin{array}{l}-- \\
-- \\
--\end{array}$ & $\begin{array}{r}10 \\
10 \\
<10 \\
<10\end{array}$ & $\begin{array}{l}-- \\
-- \\
--\end{array}$ & $\begin{array}{l}-- \\
-- \\
--\end{array}$ \\
\hline SOUTH LEAD LAKE nr STILLWATER, NV & $\begin{array}{l}-- \\
-- \\
<1 \\
--\end{array}$ & $\begin{array}{l}-- \\
\overline{--} \\
--\end{array}$ & $\begin{array}{l}-- \\
-\overline{3} \\
--\end{array}$ & $\begin{array}{r}10 \\
10 \\
<10 \\
<10 \\
<10\end{array}$ & $\begin{array}{l}-- \\
\overline{12} \\
\overline{--}\end{array}$ & $\begin{array}{r}-- \\
2800 \\
-- \\
-\end{array}$ \\
\hline
\end{tabular}


TABLE 14.--Data on trace-element constituents for surface-water samples in and near stillwater wildife Management Area and Carson Lake, 1986-87--Continued

\begin{tabular}{|c|c|c|c|c|c|c|}
\hline Station name & $\begin{array}{l}\text { Chro- } \\
\text { mium, } \\
\text { total } \\
\text { recov- } \\
\text { erable } \\
\text { ( } \mu g / L \\
\text { as } C r)\end{array}$ & $\begin{array}{l}\text { Cobalt, } \\
\text { dis- } \\
\text { solved } \\
\text { ( } \mu \mathrm{g} / \mathrm{L} \\
\text { as } \mathrm{Co})\end{array}$ & $\begin{array}{c}\text { Cobalt, } \\
\text { total } \\
\text { recov- } \\
\text { erable } \\
\text { ( } \mu \text { g/L } \\
\text { as Co) }\end{array}$ & $\begin{array}{c}\text { Copper, } \\
\text { dis- } \\
\text { solved } \\
\text { ( } \mu g / L \\
\text { as Cu) }\end{array}$ & $\begin{array}{l}\text { Copper, } \\
\text { total } \\
\text { recov- } \\
\text { erable } \\
\text { ( } \mu \text { g/L } \\
\text { as Cu) }\end{array}$ & $\begin{array}{l}\text { Iron, } \\
\text { total } \\
\text { recov- } \\
\text { erable } \\
\text { ( } \mu \mathrm{g} / \mathrm{L} \\
\text { as } \mathrm{Fe})\end{array}$ \\
\hline LOWER DIAGONAL DRAIN at HWY $50 \mathrm{nr}$ FALLON, NV & -- & 2 & -- & 2 & -- & -- \\
\hline STILLWATER PT. DIV. DRAIN nF STILLWATER, NV & $\begin{array}{l}-- \\
-- \\
7 \\
7\end{array}$ & $\begin{array}{l}-- \\
-- \\
=- \\
--\end{array}$ & $\begin{array}{l}-- \\
=- \\
-- \\
3\end{array}$ & $\begin{array}{r}<10 \\
<10 \\
10 \\
-10\end{array}$ & $\begin{array}{l}-- \\
-- \\
-5 \\
12\end{array}$ & $\begin{array}{r}-- \\
-- \\
850 \\
5200\end{array}$ \\
\hline STILLWATER POINT RESERVOIR, SO. END, nT FALLON, NV & $\begin{array}{l}-- \\
-- \\
-- \\
--\end{array}$ & $\begin{array}{l}-- \\
-- \\
--\end{array}$ & $\begin{array}{l}-- \\
-- \\
-- \\
--\end{array}$ & $\begin{array}{l}<10 \\
<10 \\
<10 \\
<10\end{array}$ & $\begin{array}{l}-- \\
-- \\
-- \\
--\end{array}$ & $\begin{array}{l}-- \\
-- \\
-- \\
--\end{array}$ \\
\hline STILIWATER POINT RESERVOIR NORTH NI STILLWATER, NV & $\begin{array}{l}-- \\
-- \\
-- \\
--\end{array}$ & $\begin{array}{l}-- \\
-- \\
-- \\
--\end{array}$ & $\begin{array}{l}-- \\
-- \\
-- \\
--\end{array}$ & $\begin{array}{r}<10 \\
10 \\
<10 \\
<10\end{array}$ & $\begin{array}{l}-- \\
-- \\
-- \\
--\end{array}$ & $\begin{array}{l}-- \\
-- \\
-- \\
--\end{array}$ \\
\hline STILLWATER SLOUGH at STILIWATER, NV & $\begin{array}{l}-- \\
-- \\
-- \\
--\end{array}$ & $\begin{array}{l}-- \\
-- \\
-- \\
--\end{array}$ & $\begin{array}{l}-- \\
--\end{array}$ & $\begin{array}{r}<10 \\
<10 \\
20 \\
<10\end{array}$ & $\begin{array}{l}-- \\
-- \\
-- \\
--\end{array}$ & $\begin{array}{l}-- \\
-- \\
-- \\
--\end{array}$ \\
\hline STILLWATER SLOUGH CUTOFF DRAIN NR STILLWATER NV & -- & -- & -- & $<10$ & -- & -- \\
\hline HUNTER DRAIN at DIVISION RD. nr. STILLWATER, NV & -- & -- & -- & 70 & -- & -- \\
\hline LEAD LK CANAL at HUNTER RD CROSSING nF STILIWATER & -- & -- & -- & $<10$ & -- & -- \\
\hline CATTAIL LAKE at OUTLET nF. STILLWATER, NV & -- & -- & -- & 20 & -- & -- \\
\hline SWAN CHECK nr. OUTLET nF. STILLWATER, NV & -- & -- & -- & $<10$ & -- & -- \\
\hline PINTAII BAY nr. CENTER nr. STILLWATER, NV & -- & -- & -- & 50 & -- & -- \\
\hline
\end{tabular}


TABLE 14.--Data on trace-element constituents for surface-water samples in and near stiliwater wildife Management Area and Carson Lake, 1986-87--Continued

\begin{tabular}{|c|c|c|c|c|c|c|}
\hline Station name & $\begin{array}{l}\text { Lead, } \\
\text { dis- } \\
\text { solved } \\
(\mu g / L \\
\text { as } \mathrm{Pb})\end{array}$ & $\begin{array}{l}\text { Lead, } \\
\text { total } \\
\text { recov- } \\
\text { erable } \\
(\mu g / L \\
\text { as } \mathrm{Pb})\end{array}$ & $\begin{array}{l}\text { Lithium, } \\
\text { dis- } \\
\text { solved } \\
\text { ( } \mu g / L \\
\text { as } L i)\end{array}$ & $\begin{array}{l}\text { Manga- } \\
\text { nese, } \\
\text { dis- } \\
\text { solved } \\
(\mu g / L \\
\text { as } M n)\end{array}$ & $\begin{array}{l}\text { Manga- } \\
\text { nese, } \\
\text { total } \\
\text { recov- } \\
\text { erable } \\
\text { ( } \mu g / L \\
\text { as } M n)\end{array}$ & $\begin{array}{l}\text { Mercury, } \\
\text { dis- } \\
\text { solved } \\
\text { ( } \mu \mathrm{g} / \mathrm{L} \\
\text { as } \mathrm{Hg})\end{array}$ \\
\hline WILLIAMS SLOUGH nr GENOA, NV & $\begin{array}{l}<5 \\
<5 \\
11\end{array}$ & $\begin{array}{l}-- \\
-- \\
--\end{array}$ & $\begin{array}{l}-\overline{24} \\
20\end{array}$ & $\begin{array}{l}-- \\
-- \\
--\end{array}$ & $\begin{array}{l}-- \\
-- \\
--\end{array}$ & $\begin{array}{r}<0.1 \\
<0.1 \\
0.4\end{array}$ \\
\hline WASHOE LAKE $\mathrm{n}$ K CARSON CITY, NV & $\begin{array}{r}<5 \\
<5 \\
5\end{array}$ & $\begin{array}{l}-- \\
--\end{array}$ & $\begin{array}{l}-\overline{19} \\
26\end{array}$ & $\begin{array}{l}-- \\
-- \\
--\end{array}$ & $=-$ & $\begin{array}{r}<0.1 \\
0.2 \\
<0.1\end{array}$ \\
\hline CARSON RIVER bI LAHONTAN RES $\mathrm{n} \times$ FALLON, NV & $\begin{array}{l}<1 \\
<5 \\
<5 \\
<5\end{array}$ & $\begin{array}{l}-- \\
-- \\
--\end{array}$ & $\begin{array}{l}-- \\
-\overline{33} \\
38\end{array}$ & $\begin{array}{l}-- \\
-- \\
--\end{array}$ & $\overline{--}$ & $\begin{array}{r}0.3 \\
<0.1 \\
<0.1 \\
0.2\end{array}$ \\
\hline SHECKLER RESERVOIR at OUTLET nK FALLON, NV & $\begin{array}{l}1 \\
<5 \\
<5 \\
<5\end{array}$ & $\begin{array}{l}-- \\
-- \\
--\end{array}$ & $\begin{array}{l}-- \\
\overline{22} \\
38\end{array}$ & $\begin{array}{l}-- \\
-- \\
-- \\
--\end{array}$ & $\begin{array}{l}-- \\
-- \\
--\end{array}$ & $\begin{array}{l}<0.1 \\
<0.1 \\
<0.1 \\
<0.1\end{array}$ \\
\hline CARSON LAKE DRAIN abV CARSON LAKE nI FALLON, NV & $\begin{array}{r}2 \\
<5 \\
<5 \\
<5 \\
<5\end{array}$ & $\begin{array}{l}-- \\
-- \\
-- \\
<5 \\
8\end{array}$ & $\begin{array}{l}70 \\
-- \\
-- \\
80 \\
61\end{array}$ & $\begin{array}{r}460 \\
-- \\
-- \\
--\end{array}$ & $\begin{array}{l}-- \\
-- \\
910 \\
320\end{array}$ & $\begin{array}{r}<0.1 \\
<0.1 \\
0.2 \\
0.2 \\
<0.1\end{array}$ \\
\hline CARSON LAKE, SPRIG POND UNIT, NE FALLON, NV & $\begin{array}{l}<1 \\
<5 \\
<5 \\
<5\end{array}$ & $\begin{array}{l}-- \\
-- \\
<5 \\
--\end{array}$ & $\begin{array}{r}-- \\
250 \\
120\end{array}$ & $\begin{array}{l}-- \\
-- \\
-- \\
--\end{array}$ & 1600 & $\begin{array}{r}0.3 \\
0.2 \\
0.3 \\
<0.1\end{array}$ \\
\hline CARSON LAKE, ISLAND UNIT, nI FALLON, NV & $\begin{array}{l}<5 \\
<5 \\
<5 \\
<5\end{array}$ & $\begin{array}{l}-- \\
-- \\
-- \\
--\end{array}$ & $\begin{array}{r}-- \\
190 \\
320\end{array}$ & $\begin{array}{l}-- \\
-- \\
-- \\
--\end{array}$ & $\begin{array}{l}-- \\
-- \\
--\end{array}$ & $\begin{array}{r}0.1 \\
<0.1 \\
<0.1 \\
0.1\end{array}$ \\
\hline CARSON LAKE, BIG WATER UNIT, nK FALLON, NV & $<5$ & -- & -- & -- & -- & $<0.1$ \\
\hline PAIUTE DRAIN at WILDLIFE ENT nI STILLWATER, NV & $\begin{array}{l}<1 \\
<5 \\
<5 \\
<5\end{array}$ & $\begin{array}{l}-- \\
-- \\
--\end{array}$ & $\begin{array}{r}-- \\
61 \\
120\end{array}$ & $\begin{array}{l}-- \\
-- \\
--\end{array}$ & $\begin{array}{r}-- \\
\overline{--} \\
--\end{array}$ & $\begin{array}{r}0.1 \\
<0.1 \\
0.7 \\
<0.1\end{array}$ \\
\hline TJ DRAIN at WILDLIFE ENTRANCE nY STILLWATER, NV & $\begin{array}{l}1 \\
<5 \\
<5 \\
34 \\
<5\end{array}$ & $\begin{array}{l}-- \\
-- \\
<5 \\
--\end{array}$ & $\begin{array}{r}2- \\
1400 \\
760 \\
10\end{array}$ & $\begin{array}{l}-- \\
-- \\
-- \\
--\end{array}$ & $\begin{array}{r}-- \\
620 \\
-- \\
--\end{array}$ & $\begin{array}{r}0.1 \\
0.1 \\
<0.1 \\
<0.1 \\
<0.1\end{array}$ \\
\hline PAIUTE DRAIN bIW TJ DRAIN NI STILLWATER, NV & $\begin{array}{l}2 \\
<1 \\
<5 \\
<5 \\
<5\end{array}$ & $\begin{array}{l}-- \\
-- \\
<5 \\
7\end{array}$ & $\begin{array}{r}100 \\
-- \\
240 \\
130\end{array}$ & $\begin{array}{l}40 \\
-- \\
-- \\
--\end{array}$ & $\begin{array}{r}-- \\
\overline{--} \\
200 \\
--\end{array}$ & $\begin{array}{r}<0.1 \\
0.4 \\
<0.1 \\
0.3 \\
<0.1\end{array}$ \\
\hline LEAD LAKE at MILLENS LANDING nr STILLWATER, NV & $\begin{array}{l}<5 \\
<5 \\
<5 \\
<5\end{array}$ & $\begin{array}{l}-- \\
-- \\
--\end{array}$ & $\begin{array}{r}2- \\
180 \\
63\end{array}$ & $\begin{array}{l}-- \\
-- \\
--\end{array}$ & $\begin{array}{l}-- \\
-- \\
--\end{array}$ & $\begin{array}{r}<0.1 \\
0.1 \\
<0.1 \\
1.1\end{array}$ \\
\hline SOUTH LEAD LAKE $\mathrm{n} r$ STILLWATER, NV & $\begin{array}{l}<1 \\
74 \\
<5 \\
<5 \\
<5\end{array}$ & $\begin{array}{l}-- \\
-\overline{<5} \\
-- \\
--\end{array}$ & $\begin{array}{r}-- \\
210 \\
190 \\
200\end{array}$ & $\begin{array}{l}-- \\
=- \\
-- \\
--\end{array}$ & $\begin{array}{l}-- \\
150 \\
--\end{array}$ & $\begin{array}{r}0.3 \\
<0.1 \\
0.2 \\
0.4 \\
0.4\end{array}$ \\
\hline
\end{tabular}


TABLE 14.--Data on trace-element constituents for surface-water samples in and near stillwater wildife Management Area and Carson Lake, 1986-87--Continued

\begin{tabular}{|c|c|c|c|c|c|c|}
\hline Station name & $\begin{array}{l}\text { Lead, } \\
\text { dis- } \\
\text { solved } \\
\text { ( } \mu g / \mathrm{L} \\
\text { as } \mathrm{Pb})\end{array}$ & $\begin{array}{l}\text { Lead, } \\
\text { total } \\
\text { recov- } \\
\text { erable } \\
\text { ( } \mu \mathrm{g} / \mathrm{I} \\
\text { as } \mathrm{Pb})\end{array}$ & $\begin{array}{c}\text { Lithium, } \\
\text { dis- } \\
\text { solved } \\
\text { ( } \mu g / I \\
\text { as } L i)\end{array}$ & $\begin{array}{l}\text { Manga- } \\
\text { nese, } \\
\text { dis- } \\
\text { solved } \\
(\mu g / L \\
\text { as } M n)\end{array}$ & $\begin{array}{l}\text { Manga- } \\
\text { nese, } \\
\text { total } \\
\text { recov- } \\
\text { erable } \\
(\mu g / I \\
\text { as } M n)\end{array}$ & $\begin{array}{c}\text { Mercury, } \\
\text { dis- } \\
\text { solved } \\
\text { ( } \mu g / \mathrm{L} \\
\text { as } \mathrm{Hg} \text { ) }\end{array}$ \\
\hline LOWER DIAGONAL DRAIN at HWY $50 \mathrm{nr}$ FALLON, NV & 3 & - & 57 & 530 & -- & 0.1 \\
\hline STILLWATER PT. DIV. DRAIN nI STILLWATER, NV & $\begin{array}{l}<1 \\
<5 \\
<5 \\
-- \\
<5\end{array}$ & $\begin{array}{l}-- \\
-- \\
<5 \\
7\end{array}$ & $\begin{array}{l}-- \\
-\overline{80} \\
\frac{61}{6}\end{array}$ & $\begin{array}{l}=- \\
=- \\
=-\end{array}$ & $\begin{array}{r}-- \\
1200 \\
340\end{array}$ & $\begin{array}{r}0.2 \\
0.1 \\
0.3 \\
-0.1\end{array}$ \\
\hline STILLWATER POINT RESERVOIR, SO. END, nT FALLON, NV & $\begin{array}{l}1 \\
<5 \\
<5 \\
<5\end{array}$ & $\begin{array}{l}-- \\
-- \\
--\end{array}$ & $\begin{array}{l}-- \\
98 \\
61\end{array}$ & $\begin{array}{l}-- \\
-- \\
--\end{array}$ & $\begin{array}{l}-- \\
-- \\
--\end{array}$ & $\begin{array}{r}0.2 \\
0.9 \\
<0.1 \\
<0.1\end{array}$ \\
\hline STILLWATER POINT RESERVOIR NORTH nI STILLWATER, NV & $\begin{array}{l}<1 \\
<5 \\
<5 \\
<5\end{array}$ & $\begin{array}{l}-- \\
--\end{array}$ & $\begin{array}{r}-- \\
90 \\
160\end{array}$ & $\begin{array}{l}-- \\
-- \\
--\end{array}$ & $\begin{array}{l}-- \\
-- \\
--\end{array}$ & $\begin{array}{r}<0.1 \\
0.1 \\
<0.1 \\
<0.1\end{array}$ \\
\hline STILLWATER SLOUGH at STILLWATER, NV & $\begin{array}{l}<1 \\
<5 \\
<5 \\
11\end{array}$ & $\begin{array}{l}-- \\
-- \\
--\end{array}$ & $\begin{array}{r}-- \\
270 \\
110\end{array}$ & $\begin{array}{l}-- \\
-- \\
--\end{array}$ & $\begin{array}{l}-- \\
-- \\
--\end{array}$ & $\begin{array}{l}-- \\
<0.1 \\
0.4 \\
0.1\end{array}$ \\
\hline STILLWATER SLOUGH CUTOFF DRAIN NR STILLWATER NV & $<5$ & -- & -- & -- & -- & 0.3 \\
\hline HUNTER DRAIN at DIVISION RD. nI. STILLWATER, NV & $<5$ & -- & 2800 & -- & -- & 0.3 \\
\hline LEAD LK CANAL at HUNTER RD CROSSING NI STILLWATER & $<5$ & -- & 190 & -- & -- & 0.1 \\
\hline CATTAIL LAKE at OUTLET nr. STILLWATER, NV & $<5$ & -- & 420 & -- & -- & $<0.1$ \\
\hline SWAN CHECK $n r$. OUTLET $n r$. STILLWATER, NV & $<5$ & -- & 260 & -- & -- & 0.1 \\
\hline PINTAIL BAY $n r$. CENTER $n r$. STILLWATER, NV & $<5$ & -- & 1500 & -- & -- & $<0.1$ \\
\hline
\end{tabular}


TABLE 14.--Data on trace-element constituents for surface-water samples in and near stillwater wildlife Management Area and Carson Lake, 1986-87--Continued

\begin{tabular}{|c|c|c|c|c|c|c|}
\hline Station name & $\begin{array}{c}\text { Mercury, } \\
\text { total } \\
\text { recov- } \\
\text { erable } \\
\text { ( } \mu \mathrm{g} / \mathrm{L} \\
\text { as } \mathrm{Hg})\end{array}$ & $\begin{array}{l}\text { Molyb- } \\
\text { denum, } \\
\text { dis- } \\
\text { solved } \\
\text { ( } \mu \mathrm{g} / \mathrm{L} \\
\text { as Mo) }\end{array}$ & $\begin{array}{l}\text { Molyb- } \\
\text { denum, } \\
\text { total } \\
\text { recov- } \\
\text { erable } \\
\text { ( } \mu \mathrm{g} / \mathrm{L} \\
\text { as Mo) }\end{array}$ & $\begin{array}{l}\text { Nickel, } \\
\text { dis- } \\
\text { solved } \\
\text { ( } \mu \text { g/L } \\
\text { as Ni) }\end{array}$ & $\begin{array}{l}\text { Nickel, } \\
\text { total } \\
\text { recov- } \\
\text { erable } \\
\text { ( } \mu g / \mathrm{L} \\
\text { as } \mathrm{Ni} \text { ) }\end{array}$ & $\begin{array}{l}\text { Sele- } \\
\text { nium, } \\
\text { dis- } \\
\text { solved } \\
\text { ( } \mu g / L \\
\text { as } S e)\end{array}$ \\
\hline WILLIAMS SLOUGH $\mathrm{nr}$ GENOA, NV & $\begin{array}{l}=- \\
=-\end{array}$ & $\begin{array}{r}2 \\
10 \\
<1\end{array}$ & $\begin{array}{l}=- \\
=-\end{array}$ & $\begin{array}{r}1 \\
2 \\
<1\end{array}$ & $\begin{array}{l}=- \\
=-\end{array}$ & $\begin{array}{l}<1 \\
<1 \\
<1\end{array}$ \\
\hline WASHOE LAKE nI CARSON CITY, NV & $\begin{array}{l}=- \\
=-\end{array}$ & $\begin{array}{r}4 \\
<1 \\
1\end{array}$ & $\begin{array}{l}=- \\
=-\end{array}$ & $\begin{array}{l}1 \\
<1 \\
<1\end{array}$ & $\begin{array}{l}=- \\
=- \\
=-\end{array}$ & $\begin{array}{l}<1 \\
<1 \\
<1\end{array}$ \\
\hline CARSON RIVER bI LAHONTAN RES nI FALLON, NV & $\begin{array}{l}-- \\
-- \\
-- \\
--\end{array}$ & $\begin{array}{r}3 \\
3 \\
13 \\
1\end{array}$ & $\begin{array}{l}-- \\
=- \\
=-\end{array}$ & $\begin{array}{r}1 \\
1 \\
1 \\
<1\end{array}$ & $\begin{array}{l}-- \\
-- \\
-- \\
--\end{array}$ & $\begin{array}{l}<1 \\
<1 \\
<1 \\
<1\end{array}$ \\
\hline SHECKLER RESERVOIR at OUTLET nI FALLON, NV & $\begin{array}{l}-- \\
-- \\
-- \\
--\end{array}$ & $\begin{array}{l}4 \\
4 \\
3 \\
4\end{array}$ & $\begin{array}{l}=- \\
=- \\
=-\end{array}$ & $\begin{array}{r}3 \\
3 \\
1 \\
<1\end{array}$ & $\begin{array}{l}-- \\
=- \\
=-\end{array}$ & $\begin{array}{l}<1 \\
<1 \\
<1 \\
<1\end{array}$ \\
\hline CARSON LAKE DRAIN abv CARSON LAKE nY FALLON, NV & $\begin{array}{l}=- \\
=- \\
\overline{0} .20 \\
2.4\end{array}$ & $\begin{array}{r}71 \\
28 \\
44 \\
160 \\
40\end{array}$ & $\begin{array}{r}-- \\
\overline{--} \\
120 \\
36\end{array}$ & $\begin{array}{r}3 \\
13 \\
2 \\
2 \\
<1\end{array}$ & $\begin{array}{r}-- \\
-- \\
-- \\
5 \\
3\end{array}$ & $\begin{array}{l}1 \\
1 \\
<1 \\
<1 \\
<1\end{array}$ \\
\hline CARSON LAKE, SPRIG POND UNIT, nI FALLON, NV & $\begin{array}{l}-- \\
-- \\
--\end{array}$ & $\begin{array}{r}2 \\
5 \\
140 \\
53\end{array}$ & $\begin{array}{l}-- \\
130 \\
--\end{array}$ & $\begin{array}{r}2 \\
2 \\
3 \\
<1\end{array}$ & $\begin{array}{l}-- \\
\overline{12} \\
--\end{array}$ & $\begin{array}{l}<1 \\
<1 \\
<1 \\
<1\end{array}$ \\
\hline CARSON LAKE, ISLAND UNIT, nI FALLON, NV & $\begin{array}{l}=- \\
=- \\
--\end{array}$ & $\begin{array}{r}4 \\
8 \\
50 \\
5\end{array}$ & $\begin{array}{l}=- \\
=- \\
--\end{array}$ & $\begin{array}{r}5 \\
2 \\
2 \\
<1\end{array}$ & $\begin{array}{l}=- \\
=- \\
=-\end{array}$ & $\begin{array}{l}<1 \\
<1 \\
<1 \\
<1\end{array}$ \\
\hline CARSON LAKE, BIG WATER UNIT, nr FALLON, NV & -- & 92 & -- & 6 & -- & -- \\
\hline PAIUTE DRAIN at WILDIIFE ENT nr STILLWATER, NV & $\begin{array}{l}-- \\
-- \\
-\end{array}$ & $\begin{array}{l}10 \\
16 \\
24 \\
39\end{array}$ & $\begin{array}{l}-- \\
30 \\
--\end{array}$ & $\begin{array}{r}1 \\
2 \\
4 \\
<1\end{array}$ & $\begin{array}{r}-- \\
-- \\
--\end{array}$ & $\begin{array}{l}<1 \\
<1 \\
<1 \\
<1\end{array}$ \\
\hline TJ DRAIN at WILDLIFE ENTRANCE nr STILLWATER, NV & $\begin{array}{l}=- \\
-- \\
<0.10 \\
=-\end{array}$ & $\begin{array}{r}110 \\
250 \\
860 \\
620 \\
86\end{array}$ & $\begin{array}{l}-- \\
940 \\
-- \\
--\end{array}$ & $\begin{array}{l}2 \\
3 \\
4 \\
3 \\
2\end{array}$ & $\begin{array}{l}-- \\
-- \\
-- \\
--\end{array}$ & $\begin{array}{r}1 \\
<1 \\
1 \\
<1 \\
<1\end{array}$ \\
\hline PAIUTE DRAIN bIW TJ DRAIN nI STILLWATER, NV & $\begin{array}{l}-- \\
=- \\
-0.30 \\
0.30\end{array}$ & $\begin{array}{r}50 \\
45 \\
44 \\
180 \\
36\end{array}$ & $\begin{array}{r}-- \\
\overline{-} \\
160 \\
74\end{array}$ & $\begin{array}{r}3 \\
1 \\
3 \\
<1 \\
<1\end{array}$ & $\begin{array}{r}-- \\
-- \\
-- \\
12 \\
6\end{array}$ & $\begin{array}{r}<1 \\
<1 \\
<1 \\
1 \\
<1\end{array}$ \\
\hline LEAD LAKE at MILLENS LANDING $n x$ STILLWATER, NV & $\begin{array}{l}-- \\
=- \\
--\end{array}$ & $\begin{array}{r}38 \\
100 \\
140 \\
11\end{array}$ & $\begin{array}{l}=- \\
-- \\
--\end{array}$ & $\begin{array}{r}5 \\
4 \\
<1 \\
<1\end{array}$ & $\begin{array}{l}-- \\
=- \\
--\end{array}$ & $\begin{array}{l}<1 \\
<1 \\
<1 \\
<1\end{array}$ \\
\hline SOUTH LEAD LAKE nT STILLWATER, NV & $\begin{array}{l}-- \\
-\overline{0} \\
-- \\
--\end{array}$ & $\begin{array}{r}74 \\
120 \\
100 \\
62 \\
86\end{array}$ & $\begin{array}{r}-- \\
110 \\
--\end{array}$ & $\begin{array}{r}<1 \\
3 \\
1 \\
<1 \\
<1\end{array}$ & $\begin{array}{l}-- \\
-5 \\
-- \\
--\end{array}$ & $\begin{array}{l}<1 \\
<1 \\
<1 \\
<1 \\
<1\end{array}$ \\
\hline
\end{tabular}


TABLE 14.--Data on trace-element constituents for surface-water samples in and near stillwater wildlife Management Area and Carson Lake, 1986-87--Continued

\begin{tabular}{|c|c|c|c|c|c|c|}
\hline Station name & $\begin{array}{l}\text { Mercury, } \\
\text { total } \\
\text { recov- } \\
\text { erable } \\
\text { ( } \mu g / L \\
\text { as } \mathrm{Hg} \text { ) }\end{array}$ & $\begin{array}{l}\text { Molyb- } \\
\text { denum, } \\
\text { dis- } \\
\text { solved } \\
\text { ( } \mu \text { g/L } \\
\text { as Mo) }\end{array}$ & $\begin{array}{l}\text { Molyb- } \\
\text { denum, } \\
\text { total } \\
\text { recov- } \\
\text { erable } \\
\text { ( } \mu g / L \\
\text { as Mo) }\end{array}$ & $\begin{array}{l}\text { Nickel, } \\
\text { dis- } \\
\text { solved } \\
\text { ( } \mu g / L \\
\text { as Ni) }\end{array}$ & $\begin{array}{l}\text { Nickel, } \\
\text { total } \\
\text { recov- } \\
\text { erable } \\
(\mu g / L \\
\text { as } N i)\end{array}$ & $\begin{array}{l}\text { Sele- } \\
\text { nium, } \\
\text { dis- } \\
\text { solved } \\
\text { ( } \mu \text { g/L } \\
\text { as Se) }\end{array}$ \\
\hline LOWER DIAGONAL DRAIN at HWY $50 \mathrm{nr}$ FALLON, NV & -- & 55 & -- & 2 & -- & 1 \\
\hline STILLWATER PT. DIV. DRAIN nT STILLWATER, NV & $\begin{array}{l}-- \\
-- \\
-0.40 \\
1.1\end{array}$ & $\begin{array}{l}11 \\
17 \\
58 \\
-- \\
32\end{array}$ & $\begin{array}{l}-- \\
-- \\
30 \\
36\end{array}$ & $\begin{array}{r}2 \\
3 \\
<1 \\
-- \\
<1\end{array}$ & $\begin{array}{c}-- \\
-- \\
-- \\
2 \\
3\end{array}$ & $\begin{array}{l}-- \\
<1 \\
--1\end{array}$ \\
\hline STILLWATER POINT RESERVOIR, SO. END, nI FALLON, NV & $\begin{array}{l}-- \\
-- \\
-- \\
--\end{array}$ & $\begin{array}{l}14 \\
21 \\
36 \\
24\end{array}$ & $\begin{array}{l}-- \\
-- \\
--\end{array}$ & $\begin{array}{r}1 \\
2 \\
1 \\
<1\end{array}$ & $\begin{array}{l}-- \\
-- \\
--\end{array}$ & $\begin{array}{l}<1 \\
<1 \\
<1 \\
<1\end{array}$ \\
\hline STILLWATER POINT RESERVOIR NORTH nI STILIWATER, NV & $\begin{array}{l}-- \\
-- \\
--\end{array}$ & $\begin{array}{l}26 \\
45 \\
40 \\
37\end{array}$ & $\begin{array}{l}-- \\
--\end{array}$ & $\begin{array}{r}3 \\
3 \\
2 \\
<1\end{array}$ & $\begin{array}{l}-- \\
-- \\
--\end{array}$ & $\begin{array}{l}<1 \\
<1 \\
<1 \\
<1\end{array}$ \\
\hline STILLWATER SLOUGH at STILLWATER, NV & $\begin{array}{l}-- \\
-- \\
--\end{array}$ & $\begin{array}{l}10 \\
23 \\
52 \\
30\end{array}$ & $\overline{--}$ & $\begin{array}{l}4 \\
3 \\
2 \\
2\end{array}$ & $\begin{array}{l}-- \\
-- \\
--\end{array}$ & $\begin{array}{l}<1 \\
<1 \\
<1 \\
<1\end{array}$ \\
\hline STIILWATER SLOUGH CUTOFF DRAIN NR STILLWATER NV & -- & 28 & -- & 4 & -- & $<1$ \\
\hline HUNTER DRAIN at DIVISION RD. nr. STILLWATER, NV & -- & 1600 & -- & 3 & -- & $<1$ \\
\hline LEAD LK CANAL at HUNTER RD CROSSING nI STILLWATER & -- & 75 & -- & 4 & -- & $<1$ \\
\hline CATTAIL LAKE at OUTLET nr. STILLWATER, NV & -- & 160 & -- & 4 & -- & $<1$ \\
\hline SWAN CHECK $n r$. OUTLET $n r$. STILLWATER, NV & -- & 120 & -- & 3 & -- & $<1$ \\
\hline PINTAIL BAY $n r$. CENTER nr. STILLWATER, NV & -- & 360 & -- & 5 & -- & $<1$ \\
\hline
\end{tabular}


TABLE 14.--Data on trace-element constituents for surface-water samples in and near Stillwater wildlife Management Area and Carson Lake, 1986-87--Continued

\begin{tabular}{|c|c|c|c|c|c|c|}
\hline Station name & $\begin{array}{l}\text { Sele- } \\
\text { nium, } \\
\text { total } \\
(\mu g / L \\
\text { as } S e)\end{array}$ & $\begin{array}{l}\text { Silver, } \\
\text { dis- } \\
\text { solved } \\
(\mu g / L \\
\text { as Ag) }\end{array}$ & $\begin{array}{l}\text { Silver, } \\
\text { total } \\
\text { recov- } \\
\text { erable } \\
(\mu g / L \\
\text { as Ag) }\end{array}$ & $\begin{array}{l}\text { Vana- } \\
\text { dium, } \\
\text { dis- } \\
\text { solved } \\
(\mu g / L \\
\text { as V) }\end{array}$ & $\begin{array}{l}\text { Zinc, } \\
\text { dis- } \\
\text { solved } \\
(\mu g / L \\
\text { as } \mathrm{Zn})\end{array}$ & $\begin{array}{l}\text { Zinc, } \\
\text { totai } \\
\text { recov- } \\
\text { erable } \\
\text { (fg/L } \\
\text { as } \mathrm{Zn} \text { ) }\end{array}$ \\
\hline WILLIAMS SLOUGH $\mathrm{nr}$ GENOA, NV & $=$ & $\begin{array}{l}<1.0 \\
<1.0 \\
<1.0\end{array}$ & $=$ & $\begin{array}{r}1 \\
7 \\
--\end{array}$ & $\begin{array}{r}<3 \\
6 \\
20\end{array}$ & $=$ \\
\hline WASHOE LAKE $n \mathrm{~K}$ CARSON CITY, NV & $=$ & $\begin{array}{l}<1.0 \\
<1.0 \\
<1.0\end{array}$ & $\overline{--}$ & $\begin{array}{l}17 \\
15 \\
27\end{array}$ & $\begin{array}{l}10 \\
10 \\
<3\end{array}$ & $=$ \\
\hline CARSON RIVER bI LAHONTAN RES nI FALLON, NV & $\begin{array}{l}-- \\
-- \\
--\end{array}$ & $\begin{array}{l}<1.0 \\
<1.0 \\
<1.0 \\
<1.0\end{array}$ & $=-$ & $\begin{array}{l}3 \\
5 \\
8 \\
3\end{array}$ & $\begin{array}{r}12 \\
19 \\
7 \\
14\end{array}$ & 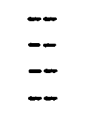 \\
\hline SHECKLER RESERVOIR at OUTLET nI FALLON, NV & $\begin{array}{l}-- \\
-- \\
--\end{array}$ & $\begin{array}{l}<1.0 \\
<1.0 \\
<1.0 \\
<1.0\end{array}$ & $=$ & $\begin{array}{l}8 \\
9 \\
6 \\
8\end{array}$ & $\begin{array}{r}5 \\
21 \\
<3 \\
6\end{array}$ & $\begin{array}{l}-- \\
--\end{array}$ \\
\hline CARSON LAKE DRAIN abV CARSON LAKE nI FALLON, NV & $\begin{array}{l}-- \\
-- \\
<1 \\
<1\end{array}$ & $\begin{array}{l}<1.0 \\
<1.0 \\
<1.0 \\
<1.0\end{array}$ & $\begin{array}{l}-- \\
-- \\
-- \\
<1\end{array}$ & $\begin{array}{r}44 \\
21 \\
18 \\
810 \\
11\end{array}$ & $\begin{array}{r}<10 \\
8 \\
12 \\
<10 \\
13\end{array}$ & $\begin{array}{r}-\overline{-} \\
\overline{10} \\
20\end{array}$ \\
\hline CARSON LAKE, SPRIG POND UNIT, NI FALLON, NV & $\begin{array}{l}-- \\
--\end{array}$ & $\begin{array}{l}<1.0 \\
<1.0 \\
<1.0 \\
<1.0\end{array}$ & $\overline{-\infty}$ & $\begin{array}{r}-- \\
<190 \\
<10\end{array}$ & $\begin{array}{r}9 \\
27 \\
20 \\
<10\end{array}$ & $\overline{-\infty}$ \\
\hline CARSON LAKE, ISLAND UNIT, nT FALION, NV & $\begin{array}{l}-- \\
-- \\
--\end{array}$ & $\begin{array}{l}<1.0 \\
<1.0 \\
<1.0 \\
<1.0\end{array}$ & $\begin{array}{l}-- \\
--\end{array}$ & $\begin{array}{r}14 \\
10 \\
<140 \\
<300\end{array}$ & $\begin{array}{l}20 \\
66 \\
20 \\
10\end{array}$ & $=$ \\
\hline CARSON LAKE, BIG WATER UNIT, nI FALLON, NV & - & $<1.0$ & -- & - & 30 & - \\
\hline PAIUTE DRAIN at WILDLIFE ENT nr STILLWATER, NV & $\overline{--}$ & $\begin{array}{r}<1.0 \\
<1.0 \\
1.0 \\
<1.0\end{array}$ & $\begin{array}{l}-- \\
-\overline{-} \\
--\end{array}$ & $\begin{array}{r}8 \\
14 \\
<24 \\
<25\end{array}$ & $\begin{array}{r}20 \\
27 \\
4 \\
10\end{array}$ & $\overline{--}$ \\
\hline TJ DRAIN at WILDLIFE ENTRANCE nr STILLWATER, NV & $\begin{array}{l}-- \\
-\overline{<1} \\
--\end{array}$ & $\begin{array}{r}<1.0 \\
<1.0 \\
<1.0 \\
<1.0 \\
1.0\end{array}$ & $\begin{array}{r}-- \\
-\overline{1} \\
--\end{array}$ & $\begin{array}{r}-- \\
60 \\
3200 \\
<60 \\
38\end{array}$ & $\begin{array}{r}30 \\
30 \\
40 \\
20 \\
<10\end{array}$ & $\begin{array}{l}-- \\
40 \\
--\end{array}$ \\
\hline PAIUTE DRAIN bIW TJ DRAIN nI STILLWATER, NV & $\begin{array}{l}-- \\
-- \\
<1 \\
<1\end{array}$ & $\begin{array}{l}<1.0 \\
<1.0 \\
<1.0 \\
<1.0\end{array}$ & $\begin{array}{l}-- \\
\overline{-} \\
-1 \\
<1\end{array}$ & $\begin{array}{r}15 \\
-- \\
14 \\
65 \\
<25\end{array}$ & $\begin{array}{l}<10 \\
-54 \\
54 \\
10 \\
20\end{array}$ & -- \\
\hline LEAD LAKE at MILLENS LANDING $n r$ STILLWATER, NV & $\begin{array}{l}-- \\
-- \\
--\end{array}$ & $\begin{array}{l}<1.0 \\
<1.0 \\
<1.0 \\
<1.0\end{array}$ & $\begin{array}{l}-- \\
-- \\
--\end{array}$ & $\begin{array}{r}17 \\
34 \\
<260 \\
10\end{array}$ & $\begin{array}{r}20 \\
10 \\
<10 \\
4\end{array}$ & $\begin{array}{l}-- \\
-- \\
--\end{array}$ \\
\hline SOUTH LEAD LAKE nr STILLWATER, NV & $\begin{array}{l}-- \\
-- \\
-1 \\
--\end{array}$ & $\begin{array}{l}<1.0 \\
<1.0 \\
<1.0 \\
<1.0 \\
<1.0\end{array}$ & $\begin{array}{l}-- \\
-\overline{-} \\
--\end{array}$ & $\begin{array}{r}-- \\
39 \\
<220 \\
<50 \\
31\end{array}$ & $\begin{array}{l}20 \\
20 \\
10 \\
20 \\
20\end{array}$ & $\begin{array}{l}-- \\
30 \\
-- \\
--\end{array}$ \\
\hline
\end{tabular}


TABLE 14.--Data on trace-element constituents for surface-water samples in and near stillwater wildlife Management Area and Carson Lake, 1986-87--Continued

\begin{tabular}{|c|c|c|c|c|c|c|}
\hline Station name & $\begin{array}{l}\text { Sele- } \\
\text { nium, } \\
\text { total } \\
(\mu g / I \\
\text { as } \mathrm{Se})\end{array}$ & $\begin{array}{l}\text { Silver, } \\
\text { dis- } \\
\text { solved } \\
\text { ( } \mu \mathrm{g} / \mathrm{L} \\
\text { as } \mathrm{Ag})\end{array}$ & $\begin{array}{c}\text { Silver, } \\
\text { total } \\
\text { recov- } \\
\text { erable } \\
\text { ( } \mu \mathrm{g} / \mathrm{L} \\
\text { as } \mathrm{Ag})\end{array}$ & $\begin{array}{l}\text { Vana- } \\
\text { dium, } \\
\text { dis- } \\
\text { solved } \\
(\mu g / L \\
\text { as V) }\end{array}$ & $\begin{array}{l}\text { Zinc, } \\
\text { dis- } \\
\text { solved } \\
(\mu g / L \\
\text { as } \mathrm{Zn})\end{array}$ & $\begin{array}{l}\text { Zinc, } \\
\text { total } \\
\text { recov- } \\
\text { erable } \\
(\mu g / I \\
\text { as } \mathrm{Z} \text { ) }\end{array}$ \\
\hline LOWER DIAGONAL DRAIN at HWY $50 \mathrm{nr}$ FALLON, NV & -- & -- & -- & 30 & 10 & -- \\
\hline STILLWATER PT. DIV. DRAIN nI STILLWATER, NV & $\begin{array}{l}-- \\
-- \\
-- \\
<1\end{array}$ & $\begin{array}{l}<1.0 \\
<1.0 \\
<1.0 \\
-1 \\
<1.0\end{array}$ & $\begin{array}{l}-- \\
-- \\
-- \\
<1 \\
<1\end{array}$ & $\begin{array}{r}9 \\
13 \\
<50 \\
-26\end{array}$ & $\begin{array}{r}-- \\
28 \\
<10 \\
\overline{10}\end{array}$ & $\begin{array}{l}-- \\
\overline{10} \\
30\end{array}$ \\
\hline STILLWATER POINT RESERVOIR, SO. END, nI FALLON, NV & $\begin{array}{l}-- \\
--\end{array}$ & $\begin{array}{l}<1.0 \\
<1.0 \\
<1.0 \\
<1.0\end{array}$ & $\begin{array}{l}-- \\
-- \\
--\end{array}$ & $\begin{array}{r}6 \\
14 \\
<40 \\
10\end{array}$ & $\begin{array}{r}12 \\
19 \\
<3 \\
8\end{array}$ & $\begin{array}{l}-- \\
-- \\
--\end{array}$ \\
\hline STILLWATER POINT RESERVOIR NORTH nI STILLWATER, NV & $\begin{array}{l}-- \\
-- \\
--\end{array}$ & $\begin{array}{l}<1.0 \\
<1.0 \\
<1.0 \\
<1.0\end{array}$ & $\begin{array}{l}-- \\
-- \\
--\end{array}$ & $\begin{array}{r}45 \\
16 \\
<70 \\
<25\end{array}$ & $\begin{array}{r}6 \\
10 \\
<10 \\
120\end{array}$ & $\begin{array}{l}-- \\
-- \\
-- \\
--\end{array}$ \\
\hline STILLWATER SLOUGH at STILLWATER, NV & $\begin{array}{l}-- \\
-- \\
--\end{array}$ & $\begin{array}{l}<1.0 \\
<1.0 \\
<1.0 \\
<1.0\end{array}$ & $\begin{array}{l}-- \\
-- \\
-- \\
--\end{array}$ & $\begin{array}{r}11 \\
14 \\
<100 \\
<40\end{array}$ & $\begin{array}{l}28 \\
20 \\
10 \\
30\end{array}$ & $\begin{array}{l}-- \\
-- \\
-- \\
--\end{array}$ \\
\hline STILLWATER SLOUGH CUTOFF DRAIN NR STILLWATER NV & -- & $<1.0$ & -- & 14 & 16 & -- \\
\hline HJNTER DRAIN at DIVISION RD. nI. STILLWATER, NV & -- & $<1.0$ & -- & 420 & 50 & -- \\
\hline LEAD LK CANAL at HUNTER RD CROSSING nI STILLWATER & -- & 1.0 & -- & 38 & $<10$ & -- \\
\hline CATTAIL LAKE at OUTLET nr. STILLWATER, NV & -- & 2.0 & -- & 68 & 10 & -- \\
\hline SWAN CHECK $n r$. OUTLET nr. STILLWATER, NV & -- & 2.0 & -- & 20 & 20 & -- \\
\hline PINTAIL BAY nI. CENTER nI. STILLWATER, NV & -- & 2.0 & -- & 240 & 40 & -- \\
\hline
\end{tabular}


TABLE 15.--Data on dissolved radiochemical constituents for surface-water samples in and near stillwater Wildife Management Area and Carson Lake, 1986-87

[Abbreviations: $\mu g / L$, micrograms per 11ter; pCi/L, picocuries per liter; <, less than; --, no data available.]

\begin{tabular}{|c|c|c|c|c|c|c|}
\hline Station name & Date & $\begin{array}{l}\text { Gross } \\
\text { alpha, } \\
\text { dis- } \\
\text { solved } \\
\text { (Hg/I } \\
\text { as } \\
\text { U-nat) }\end{array}$ & $\begin{array}{c}\text { Gross } \\
\text { beta, } \\
\text { dis- } \\
\text { solved } \\
(p c 1 / L \\
\text { as } \\
\text { Cs-137) }\end{array}$ & $\begin{array}{l}\text { Gross } \\
\text { beta, } \\
\text { dis- } \\
\text { solved } \\
(p C i / I \\
\text { as } 5 r / \\
\text { Y-90) }\end{array}$ & $\begin{array}{l}\text { Radium-226, } \\
\text { dissolved, } \\
\text { planchet } \\
\text { count } \\
\text { (pCi/L) }\end{array}$ & $\begin{array}{c}\text { Uranium, } \\
\text { natural, } \\
\text { dissolved } \\
\text { (Hg/L } \\
\text { as U) }\end{array}$ \\
\hline WILLIAMS SLOUGH nI GENOA, NV (CARSON VALLEY) & $\begin{array}{l}09-04-86 \\
03-30-87 \\
05-18-87\end{array}$ & $\begin{array}{l}<5.0 \\
13 \\
3.2\end{array}$ & $\begin{array}{l}13 \\
19 \\
14\end{array}$ & $\begin{array}{l}11 \\
15 \\
10\end{array}$ & $\begin{array}{r}<0.1 \\
<0.1 \\
0.1\end{array}$ & $\begin{array}{l}0.9 \\
10 \\
3.0\end{array}$ \\
\hline WASHOE LAKE NI CARSON CITY, NV & $\begin{array}{l}09-04-86 \\
03-20-87 \\
05-18-87\end{array}$ & $\begin{array}{l}48 \\
53 \\
64\end{array}$ & $\begin{array}{l}45 \\
47 \\
52\end{array}$ & $\begin{array}{l}36 \\
35 \\
39\end{array}$ & $\begin{array}{l}0.1 \\
0.2 \\
0.2\end{array}$ & $\begin{array}{l}62 \\
55 \\
59\end{array}$ \\
\hline CARSON RIVER bI LAHONTAN RES nI FALLON, NV & $\begin{array}{l}06-10-86 \\
09-02-86 \\
03-16-87 \\
05-11-87\end{array}$ & $\begin{array}{l}3.8 \\
2.3 \\
1.3 \\
3.2\end{array}$ & $\begin{array}{l}-. \\
3.6 \\
5.3 \\
6.1\end{array}$ & $\begin{array}{l}--2 \\
3.2 \\
4.2 \\
4.8\end{array}$ & $\begin{array}{l}<0.3 \\
<0.1 \\
<0.1 \\
<0.1\end{array}$ & $\begin{array}{l}3.4 \\
2.3 \\
2.5 \\
3.4\end{array}$ \\
\hline SHECKLER RESERVOIR at OUTLET nI FALION, NV & $\begin{array}{l}06-10-86 \\
09-02-86 \\
03-19-87 \\
05-15-87\end{array}$ & $\begin{array}{l}6.9 \\
2.6 \\
7.2 \\
4.4\end{array}$ & $\begin{array}{l}--5 \\
4.9 \\
7.5 \\
6.9\end{array}$ & $\begin{array}{l}--2 \\
4.3 \\
5.8 \\
5.5\end{array}$ & $\begin{array}{r}0.2 \\
0.2 \\
<0.1 \\
<0.1\end{array}$ & $\begin{array}{l}4.6 \\
2.5 \\
5.1 \\
3.9\end{array}$ \\
\hline CARSON LAKE DRAIN abV CARSON LAKE NI FALLON, NV & $\begin{array}{l}06-03-86 \\
08-29-86 \\
03-13-87 \\
05-14-87\end{array}$ & $\begin{array}{l}29 \\
42 \\
86 \\
45\end{array}$ & $\begin{array}{l}35 \\
31 \\
81 \\
51\end{array}$ & $\begin{array}{l}25 \\
22 \\
53 \\
33\end{array}$ & $\begin{array}{l}0.4 \\
0.2 \\
0.2 \\
0.2\end{array}$ & $\begin{array}{l}36 \\
36 \\
8.6 \\
40\end{array}$ \\
\hline CARSON LAKE, SPRIG POND UNIT, nI FALLON, NV & $\begin{array}{l}06-03-86 \\
08-29-86 \\
03-17-87 \\
05-14-87\end{array}$ & $\begin{array}{r}23 \\
17 \\
380 \\
31\end{array}$ & $\begin{array}{r}33 \\
20 \\
200 \\
61\end{array}$ & $\begin{array}{r}20 \\
15 \\
130 \\
40\end{array}$ & $\begin{array}{l}0.3 \\
0.2 \\
0.3 \\
0.2\end{array}$ & $\begin{array}{r}19 \\
14 \\
180 \\
29\end{array}$ \\
\hline CARSON LAKE, ISLAND UNIT, nI FALLON, NV & $\begin{array}{l}06-03-86 \\
09-03-86 \\
03-18-87 \\
05-14-87\end{array}$ & $\begin{array}{l}35 \\
4.8 \\
49 \\
35\end{array}$ & $\begin{array}{l}36 \\
9.3 \\
39 \\
79\end{array}$ & $\begin{array}{l}25 \\
7.9 \\
26 \\
53\end{array}$ & $\begin{array}{l}0.5 \\
0.3 \\
0.4 \\
0.5\end{array}$ & $\begin{array}{l}12 \\
3.6 \\
41 \\
26\end{array}$ \\
\hline PAIUTE DRAIN at WILDLIFE ENT nI STILLWATER, NV & $\begin{array}{l}06-05-86 \\
08-30-86 \\
03-12-87 \\
05-12-87\end{array}$ & $\begin{array}{l}14 \\
16 \\
29 \\
16\end{array}$ & $\begin{array}{l}13^{--} \\
36 \\
22\end{array}$ & $\begin{array}{l}10^{--} \\
23 \\
15\end{array}$ & $\begin{array}{r}0.2 \\
0.2 \\
<0.1 \\
<0.1\end{array}$ & $\begin{array}{l}9.8 \\
13 \\
28 \\
16\end{array}$ \\
\hline TJ DRAIN at WILDLIFE ENTRANCE nI STILLWATER, NV & $\begin{array}{l}06-05-86 \\
09-01-86 \\
03-12-87 \\
05-12-87\end{array}$ & $\begin{array}{r}82 \\
180 \\
300 \\
420\end{array}$ & $\begin{array}{l}77^{--} \\
480^{-} \\
300\end{array}$ & $\begin{array}{l}54^{--} \\
320^{--} \\
200\end{array}$ & $\begin{array}{l}0.2 \\
0.2 \\
0.2 \\
0.5\end{array}$ & $\begin{array}{r}15 \\
140 \\
300 \\
200\end{array}$ \\
\hline PAIUTE DRAIN bIW TJ DRAIN nI STILIWATER, NV & $\begin{array}{l}06-05-86 \\
08-30-86 \\
03-12-87 \\
05-12-87\end{array}$ & $\begin{array}{l}35 \\
20 \\
70 \\
30\end{array}$ & $\begin{array}{l}20^{--} \\
87 \\
31\end{array}$ & $\begin{array}{l}14^{--} \\
58 \\
20\end{array}$ & $\begin{array}{l}0.2 \\
0.1 \\
0.2 \\
0.2\end{array}$ & $\begin{array}{l}30 \\
24 \\
77 \\
28\end{array}$ \\
\hline LEAD LAKE at MIILENS LANDING nI STILLWATER, NV & $\begin{array}{l}06-05-86 \\
08-26-86 \\
03-17-87 \\
05-12-87\end{array}$ & $\begin{array}{r}25 \\
66 \\
120 \\
32\end{array}$ & $\begin{array}{l}44^{--} \\
89 \\
41\end{array}$ & $\begin{array}{l}29^{--} \\
56 \\
27\end{array}$ & $\begin{array}{l}0.2 \\
0.1 \\
0.4 \\
0.1\end{array}$ & $\begin{array}{l}25 \\
46 \\
70 \\
29\end{array}$ \\
\hline SOUTH LEAD LAKE NI STILLWATER, NV & $\begin{array}{l}06-06-86 \\
08-27-86 \\
03-17-87 \\
05-12-87\end{array}$ & $\begin{array}{l}41 \\
47 \\
61 \\
75\end{array}$ & $\begin{array}{l}53^{--} \\
79 \\
69\end{array}$ & $\begin{array}{l}31^{--} \\
53 \\
44\end{array}$ & $\begin{array}{l}0.3 \\
0.2 \\
0.3 \\
0.2\end{array}$ & $\begin{array}{l}35 \\
48 \\
55 \\
42\end{array}$ \\
\hline STILIWATER PT. DIV. DRAIN nI STILLWATER, NV & $\begin{array}{l}06-04-86 \\
08-27-86 \\
03-12-87 \\
05-13-87\end{array}$ & $\begin{array}{l}8.7 \\
11 \\
44 \\
20\end{array}$ & $\begin{array}{l}24 \\
16 \\
47 \\
39\end{array}$ & $\begin{array}{l}19 \\
12 \\
32 \\
27\end{array}$ & $\begin{array}{l}0.2 \\
0.1 \\
<0.1 \\
<0.1\end{array}$ & $\begin{array}{l}12 \\
17 \\
37 \\
32\end{array}$ \\
\hline STILLWATER POINT RESERVOIR SOUTH NI STILLWATER, NV & $\begin{array}{l}06-09-86 \\
08-28-86 \\
03-18-87 \\
05-13-87\end{array}$ & $\begin{array}{l}9.6 \\
17 \\
22 \\
24\end{array}$ & $\begin{array}{l}20^{--} \\
52 \\
33\end{array}$ & $\begin{array}{l}15 \\
34 \\
23\end{array}$ & $\begin{array}{r}0.2 \\
0.2 \\
0.1 \\
<0.1\end{array}$ & $\begin{array}{l}8.9 \\
21 \\
35 \\
8.3\end{array}$ \\
\hline STILLWATER POINT RESERVOIR NORTH nI STIIIWATER, NV & $\begin{array}{l}06-09-86 \\
08-28-86 \\
03-18-87 \\
05-13-87\end{array}$ & $\begin{array}{l}33 \\
17 \\
51 \\
71\end{array}$ & $\begin{array}{l}27^{--} \\
56 \\
65\end{array}$ & $\begin{array}{l}17^{--} \\
35 \\
43\end{array}$ & $\begin{array}{l}0.2 \\
0.1 \\
0.1 \\
0.2\end{array}$ & $\begin{array}{l}24 \\
11 \\
33 \\
39\end{array}$ \\
\hline STILLWATER SLOUGH at STILIWATER, NV & $\begin{array}{l}08-27-86 \\
03-13-87 \\
05-11-87\end{array}$ & $\begin{array}{l}17 \\
56 \\
16\end{array}$ & $\begin{array}{l}25 \\
72 \\
35\end{array}$ & $\begin{array}{l}18 \\
47 \\
23\end{array}$ & $\begin{array}{l}0.2 \\
0.3 \\
0.1\end{array}$ & $\begin{array}{l}19 \\
45 \\
21\end{array}$ \\
\hline STILLWATER SLOUGH CUTOFF DRAIN nI STILLWATER NV & $06-11-86$ & 29 & - & - & 0.2 & 15 \\
\hline
\end{tabular}


TABLE 16.--Data on total trace-element constituents and carbon in bottom-sediment samples in and near Stillwater Wildlife Management Area and Carson Lake, 1986-87

[Abbreviations: $\mathrm{mg} / \mathrm{kg}, \mathrm{milligrams}$ per kilogram; <, less than; --, no data availablé]

\begin{tabular}{|c|c|c|c|c|c|c|c|c|}
\hline Station name & Date & $\begin{array}{l}\text { Carbon, } \\
\text { total, } \\
\text { per- } \\
\text { cent }\end{array}$ & $\begin{array}{l}\text { Carbon, } \\
\text { inor- } \\
\text { ganic, } \\
\text { per- } \\
\text { cent }\end{array}$ & $\begin{array}{l}\text { Carbon, } \\
\text { organic, } \\
\text { percent }\end{array}$ & $\begin{array}{l}\text { Arsenic, } \\
\text { total } \\
\text { (mg/kg } \\
\text { as As) }\end{array}$ & $\begin{array}{l}\text { Barium, } \\
\text { total } \\
\text { (mg/kg } \\
\text { as Ba) }\end{array}$ & $\begin{array}{l}\text { Beryl- } \\
\text { lium, } \\
\text { totai } \\
\text { (mg/kg } \\
\text { as Be) }\end{array}$ & $\begin{array}{l}\text { Bismuth, } \\
\text { total } \\
\text { (mg/kg } \\
\text { as Bi) }\end{array}$ \\
\hline $\begin{array}{l}\text { WILLIAMS SLOUGH nI GENOA, NV (CARSON VALLEY) } \\
\text { WASHOE IAKE nI CARSON CITY, NV } \\
\text { CARSON RIVER bI LAHONTAN RES nr FALLON, NV } \\
\text { SHECKLER RESERVOIR at OUTLET nr FALLON, NV }\end{array}$ & $\begin{array}{l}09-04-86 \\
09-04-86 \\
03-23-87 \\
03-24-87\end{array}$ & $\begin{array}{l}-- \\
1.00 \\
0.50\end{array}$ & $\begin{array}{l}-- \\
0.19 \\
0.14\end{array}$ & $\begin{array}{l}-- \\
0.81 \\
0.36\end{array}$ & $\begin{array}{r}5.30 \\
2.80 \\
11.00 \\
8.80\end{array}$ & $\begin{array}{r}950 \\
430 \\
830 \\
1000\end{array}$ & $\begin{array}{r}1 \\
<1 \\
1 \\
2\end{array}$ & $\begin{array}{l}<10 \\
<10 \\
<10 \\
<10\end{array}$ \\
\hline $\begin{array}{l}\text { CARSON LAKE DRAIN abV CARSON LAKE nI FALLON } \\
\text { CARSON LAKE, SPRIG POND UNIT, nI FALLON, NV } \\
\text { CARSON LAKE, ISLAND UNIT, nI FALION, NV } \\
\text { CARSON LAKE, BIG WATER UNIT, nI FALLON, NV }\end{array}$ & $\begin{array}{l}03-24-87 \\
03-24-87 \\
03-24-87 \\
03-24-87\end{array}$ & $\begin{array}{l}1.08 \\
5.11 \\
2.87 \\
2.85\end{array}$ & $\begin{array}{l}0.23 \\
1.30 \\
1.25 \\
1.46\end{array}$ & $\begin{array}{l}0.85 \\
3.81 \\
1.62 \\
1.39\end{array}$ & $\begin{array}{l}10.00 \\
20.00 \\
19.00 \\
16.00\end{array}$ & $\begin{array}{l}850 \\
650 \\
740 \\
710\end{array}$ & $\begin{array}{l}1 \\
1 \\
1 \\
1\end{array}$ & $\begin{array}{l}<10 \\
<10 \\
<10 \\
<10\end{array}$ \\
\hline $\begin{array}{l}\text { PAIUTE DRAIN at WILDLIFE ENT nr STILLWATER } \\
\text { TJ DRAIN at WIIDLIFE ENTRANCE nr STILLWATER } \\
\text { PAIUTE DRAIN bIW TJ DRAIN nr STILLWATER, NV } \\
\text { LEAD LAKE at MILIENS IANDING nr STILLWATER } \\
\text { SOUTH LEAD LAKE nr STILLWATER, NV }\end{array}$ & $\begin{array}{l}03-25-87 \\
03-25-87 \\
03-25-87 \\
03-25-87 \\
03-25-87\end{array}$ & $\begin{array}{l}2.62 \\
2.02 \\
2.05 \\
1.75 \\
3.38\end{array}$ & $\begin{array}{l}1.27 \\
0.83 \\
1.77 \\
0.47 \\
0.82\end{array}$ & $\begin{array}{l}1.35 \\
1.19 \\
0.28 \\
1.28 \\
2.56\end{array}$ & $\begin{array}{r}14.00 \\
31.00 \\
8.90 \\
12.00 \\
16.00\end{array}$ & $\begin{array}{r}770 \\
720 \\
1200 \\
800 \\
710\end{array}$ & $\begin{array}{l}1 \\
1 \\
1 \\
1 \\
1\end{array}$ & $\begin{array}{l}<10 \\
<10 \\
<10 \\
<10 \\
<10\end{array}$ \\
\hline \multirow{2}{*}{$\begin{array}{l}\text { STILLWATER PT. DIV. DRAIN nI STI } \\
\text { STILLWATER POINT RESERVOIR SOUTH } \\
\text { STILLWATER POINT RESERVOIR NORTH } \\
\text { STILLWATER SIOUGH at STIILWATER, } \\
\\
\text { Station name }\end{array}$} & $\begin{array}{l}03-26-87 \\
03-26-87 \\
03-26-87 \\
03-26-87\end{array}$ & $\begin{array}{l}1.28 \\
1.22 \\
1.30 \\
1.04\end{array}$ & $\begin{array}{l}0.48 \\
0.47 \\
0.65 \\
0.24\end{array}$ & $\begin{array}{l}0.80 \\
0.75 \\
0.65 \\
0.80\end{array}$ & $\begin{array}{r}9.90 \\
9.60 \\
11.00 \\
7.80\end{array}$ & $\begin{array}{l}930 \\
890 \\
780 \\
810\end{array}$ & $\begin{array}{l}1 \\
1 \\
2 \\
1\end{array}$ & $\begin{array}{l}<10 \\
<10 \\
<10 \\
<10\end{array}$ \\
\hline & $\begin{array}{r}\text { Boron, } \\
\text { total } \\
(\mathrm{mg} / \mathrm{kg} \\
\text { as B) }\end{array}$ & $\begin{array}{l}\text { Cadmium, } \\
\text { total } \\
\text { (mg/kg } \\
\text { as Cd) }\end{array}$ & $\begin{array}{l}\text { Cerium, } \\
\text { total } \\
\text { (mg/kg } \\
\text { as Ce) }\end{array}$ & $\begin{array}{l}\text { Chromium, } \\
\text { total } \\
\text { (mg/kg } \\
\text { as Cr) }\end{array}$ & $\begin{array}{c}\text { Cobalt, } \\
\text { total } \\
(\mathrm{mg} / \mathrm{kg} \\
\text { as Col }\end{array}$ & $\begin{array}{l}\text { Copper, } \\
\text { total } \\
\text { (mg/kg } \\
\text { as Cu) }\end{array}$ & $\begin{array}{l}\text { Euro- } \\
\text { pium, } \\
\text { total } \\
\text { (mg/kg } \\
\text { as Eu) }\end{array}$ & $\begin{array}{c}\text { Gallium, } \\
\text { total } \\
\text { (mg/kg } \\
\text { as Ga) }\end{array}$ \\
\hline $\begin{array}{l}\text { WILLIAMS SLOUGH nI GENOA, NV (CARSON VALLEY) } \\
\text { WASHOE LAKE nI CARSON CITY, NV } \\
\text { CARSON RIVER bI LAHONTAN RES nr FALLON, NV } \\
\text { SHECKIER RESERVOIR at OUTLET nr FALLON, NV }\end{array}$ & $\begin{array}{l}3.10 \\
1.80 \\
5.60 \\
--\end{array}$ & $\begin{array}{l}<2 \\
<2 \\
<2 \\
<2\end{array}$ & $\begin{array}{l}59 \\
21 \\
69 \\
85\end{array}$ & $\begin{array}{r}49 \\
20 \\
85 \\
100\end{array}$ & $\begin{array}{l}18 \\
12 \\
18 \\
16\end{array}$ & $\begin{array}{l}38 \\
35 \\
32 \\
22\end{array}$ & $\begin{array}{l}<2 \\
<2 \\
<2 \\
<2\end{array}$ & $\begin{array}{r}19 \\
14 \\
19 \\
2\end{array}$ \\
\hline $\begin{array}{l}\text { CARSON LAKE DRAIN abv CARSON LAKE nI FALLON } \\
\text { CARSON LAKE, SPRIG POND UNIT, nI FALLON, NV } \\
\text { CARSON LAKE, ISLAND UNIT, nI FALLON, NV } \\
\text { CARSON LAKE, BIG WATER UNIT, nI FALION, NV }\end{array}$ & $\begin{array}{l}13.00 \\
30.00 \\
23.00 \\
77.00\end{array}$ & $\begin{array}{l}<2 \\
<2 \\
<2 \\
<2\end{array}$ & $\begin{array}{l}56 \\
53 \\
57 \\
54\end{array}$ & $\begin{array}{l}50 \\
32 \\
34 \\
32\end{array}$ & $\begin{array}{l}13 \\
15 \\
15 \\
15\end{array}$ & $\begin{array}{l}27 \\
53 \\
56 \\
45\end{array}$ & $\begin{array}{l}<2 \\
<2 \\
<2 \\
<2\end{array}$ & $\begin{array}{l}17 \\
17 \\
18 \\
18\end{array}$ \\
\hline $\begin{array}{l}\text { PAIUTE DRAIN at WILDLIFE ENT nr STILLWATER, NV } \\
\text { TJ DRAIN at WILDLIFE ENTRANCE nr STILLWATER } \\
\text { PAIUTE DRAIN bIW TJ DRAIN nI STILIWATER, NV } \\
\text { LEAD LAKE at MILLENS IANDING nI STILLWATER, NV } \\
\text { SOUTH LEAD LAKE nI STILLWATER, NV }\end{array}$ & $\begin{array}{r}7.10 \\
52.00 \\
11.00 \\
12.00 \\
20.00\end{array}$ & $\begin{array}{l}<2 \\
<2 \\
<2 \\
<2 \\
<2\end{array}$ & $\begin{array}{l}52 \\
52 \\
57 \\
53 \\
56\end{array}$ & $\begin{array}{l}42 \\
42 \\
34 \\
41 \\
43\end{array}$ & $\begin{array}{l}13 \\
12 \\
15 \\
11 \\
11\end{array}$ & $\begin{array}{l}32 \\
32 \\
41 \\
25 \\
30\end{array}$ & $\begin{array}{l}<2 \\
<2 \\
<2 \\
<2 \\
<2\end{array}$ & $\begin{array}{l}16 \\
15 \\
17 \\
16 \\
15\end{array}$ \\
\hline $\begin{array}{l}\text { STILLWATER PT. DIV. DRAIN nI STILLWATER, NV } \\
\text { STILLWATER POINT RESERVOIR SOUTH nr STILLWATER } \\
\text { STILLWATER POINT RESERVOIR NORTH nI STILLWATER } \\
\text { STILLWATER SLOUGH at STIILWATER, NV }\end{array}$ & $\begin{array}{r}7.10 \\
11.00 \\
14.00 \\
18.00\end{array}$ & $\begin{array}{l}<2 \\
<2 \\
<2 \\
<2\end{array}$ & $\begin{array}{l}60 \\
55 \\
64 \\
61\end{array}$ & $\begin{array}{l}43 \\
37 \\
58 \\
51\end{array}$ & $\begin{array}{l}13 \\
14 \\
15 \\
13\end{array}$ & $\begin{array}{l}31 \\
37 \\
38 \\
36\end{array}$ & $\begin{array}{l}<2 \\
<2 \\
<2 \\
<2\end{array}$ & $\begin{array}{l}18 \\
18 \\
18 \\
17\end{array}$ \\
\hline
\end{tabular}


TABLE 16.--Data on total trace-element constituents and carbon in bottom-sediment samples in and near stillwater Wildiffe Management Area and Carson Lake, 1986-87--Continued

\begin{tabular}{|c|c|c|c|c|c|c|c|c|}
\hline Station name & $\begin{array}{l}\text { Gold, } \\
\text { total } \\
\text { (mg/kg } \\
\text { as Au) }\end{array}$ & $\begin{array}{l}\text { Hol- } \\
\text { mium, } \\
\text { total } \\
\text { (mg/kg } \\
\text { as Ho) }\end{array}$ & $\begin{array}{l}\text { Iantha- } \\
\text { num, } \\
\text { total } \\
\text { (mg/kg } \\
\text { as Ia) }\end{array}$ & $\begin{array}{l}\text { Lead, } \\
\text { total } \\
(\mathrm{mg} / \mathrm{kg} \\
\mathrm{as} \mathrm{Pb})\end{array}$ & $\begin{array}{l}\text { Lithium, } \\
\text { total } \\
\text { (mg/kg } \\
\text { as Li) }\end{array}$ & $\begin{array}{l}\text { Manga- } \\
\text { nese, } \\
\text { total } \\
(\mathrm{mg} / \mathrm{kg} \\
\text { as } \mathrm{Mn})\end{array}$ & $\begin{array}{l}\text { Mercury, } \\
\text { total } \\
\text { (mg/kg } \\
\text { as } \mathrm{Hg})\end{array}$ & $\begin{array}{l}\text { Molyb- } \\
\text { denum, } \\
\text { total } \\
\text { (mg/kg } \\
\text { as Mo) }\end{array}$ \\
\hline $\begin{array}{l}\text { WILLIAMS SLOUGH nI GENOA, NV (CARSON VALLEY) } \\
\text { WASHOE LAKE nI CARSON CITY, NV } \\
\text { CARSON RIVER bI IAHONTAN RES nI FALLON, NV } \\
\text { SHECKLER RESERVOIR at OUTIET nI FALLON, NV }\end{array}$ & $\begin{array}{l}<8 \\
<8 \\
<8 \\
<8\end{array}$ & $\begin{array}{l}<4 \\
<4 \\
<4 \\
<4\end{array}$ & $\begin{array}{l}31 \\
13 \\
37 \\
47\end{array}$ & $\begin{array}{l}24 \\
19 \\
25 \\
21\end{array}$ & $\begin{array}{l}39 \\
81 \\
36 \\
25\end{array}$ & $\begin{array}{r}860 \\
530 \\
1400 \\
830\end{array}$ & $\begin{array}{l}0.08 \\
0.67 \\
6.60 \\
0.22\end{array}$ & $\begin{array}{l}<2 \\
<2 \\
<2 \\
<2\end{array}$ \\
\hline $\begin{array}{l}\text { CARSON LAKE DRAIN abv CARSON LAKE nI FALLON } \\
\text { CARSON LAKE, SPRIG POND UNIT, nI FALLON, NV } \\
\text { CARSON LAKE, ISIAND UNIT, nI FALLON, NV } \\
\text { CARSON LAKE, BIG WATER UNIT, nI FALLON, NV }\end{array}$ & $\begin{array}{l}<8 \\
<8 \\
<8 \\
<8\end{array}$ & $\begin{array}{l}<4 \\
<4 \\
<4 \\
<4\end{array}$ & $\begin{array}{l}31 \\
29 \\
31 \\
30\end{array}$ & $\begin{array}{l}16 \\
24 \\
46 \\
21\end{array}$ & $\begin{array}{l}30 \\
63 \\
67 \\
86\end{array}$ & $\begin{array}{r}680 \\
1200 \\
1100 \\
910\end{array}$ & $\begin{array}{r}1.70 \\
9.00 \\
18.00 \\
3.80\end{array}$ & $\begin{array}{l}4 \\
7 \\
4 \\
2\end{array}$ \\
\hline $\begin{array}{l}\text { PAIUTE DRAIN at WIIDLIFE ENT nr STILLWATER, NV } \\
\text { TJ DRAIN at WILDIIFE ENTRANCE nI STILLWATER, NV } \\
\text { PAIUTE DRAIN bIW TJ DRAIN nI STILIWATER, NV } \\
\text { LEAD LAKE at MILLENS ILANDING nI STILLWATER, NV } \\
\text { SOUTH LEAD LAKE NI STILLWATER, NV }\end{array}$ & $\begin{array}{l}<8 \\
<8 \\
<8 \\
<8 \\
<8\end{array}$ & $\begin{array}{l}<4 \\
<4 \\
<4 \\
<4 \\
<4\end{array}$ & $\begin{array}{l}28 \\
28 \\
32 \\
28 \\
30\end{array}$ & $\begin{array}{l}17 \\
16 \\
19 \\
17 \\
19\end{array}$ & $\begin{array}{l}55 \\
49 \\
94 \\
38 \\
52\end{array}$ & $\begin{array}{r}790 \\
670 \\
1100 \\
550 \\
620\end{array}$ & $\begin{array}{l}0.51 \\
0.18 \\
0.04 \\
0.35 \\
2.90\end{array}$ & $\begin{array}{r}<2 \\
11 \\
<2 \\
3 \\
7\end{array}$ \\
\hline $\begin{array}{l}\text { STILLWATER PT. DIV. DRAIN nI STILIWATER, NV } \\
\text { STILLWATER POINT RESERVOIR SOUTH nI STILIWATER } \\
\text { STIILWATER POINT RESERVOIR NORTH nI STILIWATER } \\
\text { STILLWATER SLOUGH at STILLWATER, NV }\end{array}$ & $\begin{array}{l}<8 \\
<8 \\
<8 \\
<8\end{array}$ & $\begin{array}{l}<4 \\
<4 \\
<4 \\
<4\end{array}$ & $\begin{array}{l}33 \\
30 \\
35 \\
33\end{array}$ & $\begin{array}{l}21 \\
19 \\
18 \\
23\end{array}$ & $\begin{array}{l}57 \\
72 \\
94 \\
43\end{array}$ & $\begin{array}{r}1100 \\
900 \\
840 \\
690\end{array}$ & $\begin{array}{r}2.80 \\
1.90 \\
0.08 \\
14.00\end{array}$ & $\begin{array}{r}<2 \\
<2 \\
<2 \\
3\end{array}$ \\
\hline
\end{tabular}

\begin{tabular}{|c|c|c|c|c|c|c|c|c|}
\hline Station name & $\begin{array}{l}\text { Neodym- } \\
\text { Lum, } \\
\text { total } \\
\text { (mg/kg } \\
\text { as Nd) }\end{array}$ & $\begin{array}{l}\text { Nickel, } \\
\text { total } \\
\text { (mg/kg } \\
\text { as Ni) }\end{array}$ & $\begin{array}{l}\text { Niobium, } \\
\text { total } \\
(\mathrm{mg} / \mathrm{kg} \\
\text { as } \mathrm{Nb})\end{array}$ & $\begin{array}{ll}\text { Scan- } & \text { S } \\
\text { dium, } & n \\
\text { total } & t \\
\text { (mg/kg i } & \text { as Sc) a }\end{array}$ & $\begin{array}{l}\text { Sele- } \\
\text { nium, } \\
\text { total } \\
\text { (mg/kg } \\
\text { as Se) }\end{array}$ & $\begin{array}{l}\text { Silver, } \\
\text { total } \\
(\mathrm{mg} / \mathrm{kg} \\
\text { as } \mathrm{Ag})\end{array}$ & $\begin{array}{l}\text { stron- } \\
\text { tium, } \\
\text { total } \\
\text { (mg/kg } \\
\text { as sr) }\end{array}$ & $\begin{array}{l}\text { Tanta- } \\
\text { lum, } \\
\text { total } \\
\text { (mg/kg } \\
\text { as Ta) }\end{array}$ \\
\hline $\begin{array}{l}\text { WILLIAMS SLOUGH nI GENOA, NV (CARSON VALLEY) } \\
\text { WASHOE LAKE nI CARSON CITY, NV } \\
\text { CARSON RIVER bI LAHONTAN RES nI FALION, NV } \\
\text { SHECKLER RESERVOIR at OUTLET nI FALION, NV }\end{array}$ & $\begin{array}{r}29 \\
9 \\
35 \\
43\end{array}$ & $\begin{array}{l}23 \\
11 \\
23 \\
26\end{array}$ & $\begin{array}{r}6 \\
<4 \\
8 \\
10\end{array}$ & $\begin{array}{r}13 \\
6 \\
12 \\
10\end{array}$ & $\begin{array}{r}0.20 \\
0.10 \\
0.60 \\
<0.10\end{array}$ & $\begin{array}{l}<2 \\
<2 \\
<2 \\
<2\end{array}$ & $\begin{array}{l}610 \\
620 \\
610 \\
570\end{array}$ & $\begin{array}{l}<40 \\
<40 \\
<40 \\
<40\end{array}$ \\
\hline $\begin{array}{l}\text { CARSON LAKE DRAIN abV CARSON LAKE nI FALION } \\
\text { CARSON LAKE, SPRIG POND UNIT, nI FALLON, NV } \\
\text { CARSON LAKE, ISLAND UNIT, nI FALION, NV } \\
\text { CARSON LAKE, BIG WATER UNIT, nI FALLON, NV }\end{array}$ & $\begin{array}{l}29 \\
26 \\
28 \\
27\end{array}$ & $\begin{array}{l}17 \\
22 \\
21 \\
22\end{array}$ & $\begin{array}{l}8 \\
5 \\
6 \\
7\end{array}$ & $\begin{array}{r}9 \\
10 \\
10 \\
10\end{array}$ & $\begin{array}{l}0.50 \\
1.20 \\
0.90 \\
0.30\end{array}$ & $\begin{array}{l}<2 \\
<2 \\
<2 \\
<2\end{array}$ & $\begin{array}{l}640 \\
580 \\
680 \\
820\end{array}$ & $\begin{array}{l}<40 \\
<40 \\
<40 \\
<40\end{array}$ \\
\hline $\begin{array}{l}\text { PAIUTE DRAIN at WILDLIFE ENT nI STILLWATER, NV } \\
\text { TJ DRAIN at WILDIIFE ENTRANCE nI STILLWATER } \\
\text { PAIUTE DRAIN bIW TJ DRAIN nI STILLWATER, NV } \\
\text { LEAD LAKE at MILIENS LANDING nI STILLWATER, NV } \\
\text { SOUTH LEAD LAKE NI STILLWATER, NV }\end{array}$ & $\begin{array}{l}25 \\
25 \\
27 \\
28 \\
28\end{array}$ & $\begin{array}{l}21 \\
19 \\
27 \\
16 \\
17\end{array}$ & $\begin{array}{r}4 \\
<4 \\
6 \\
7 \\
5\end{array}$ & $\begin{array}{r}10 \\
10 \\
9 \\
9 \\
9\end{array}$ & $\begin{array}{l}0.40 \\
0.80 \\
0.20 \\
0.50 \\
0.80\end{array}$ & $\begin{array}{l}<2 \\
<2 \\
<2 \\
<2 \\
<2\end{array}$ & $\begin{array}{l}590 \\
640 \\
810 \\
620 \\
650\end{array}$ & $\begin{array}{l}<40 \\
<40 \\
<40 \\
<40 \\
<40\end{array}$ \\
\hline \multirow[t]{2}{*}{$\begin{array}{l}\text { STILLWATER PT. DIV. DRAIN nI STILLWATER, NV } \\
\text { STILLWATER POINT RESERVOIR SOUTH nI STILLWATER } \\
\text { STILLWATER POINT RESERVOIR NORTH nI STILLWATER } \\
\text { STILLWATER SIOUGH at STILLWATER, NV }\end{array}$} & $\begin{array}{l}30 \\
26 \\
32 \\
31\end{array}$ & $\begin{array}{l}19 \\
19 \\
24 \\
18\end{array}$ & $\begin{array}{l}8 \\
7 \\
8 \\
8\end{array}$ & $\begin{array}{l}10 \\
10 \\
12 \\
10\end{array}$ & $\begin{array}{l}0.50 \\
0.40 \\
0.40 \\
0.70\end{array}$ & $\begin{array}{l}<2 \\
<2 \\
<2 \\
<2\end{array}$ & $\begin{array}{l}610 \\
570 \\
570 \\
630\end{array}$ & $\begin{array}{l}<40 \\
<40 \\
<40 \\
<40\end{array}$ \\
\hline & $\begin{array}{l}\text { Thorium, } \\
\text { total } \\
\text { (mg/kg } \\
\text { as } \mathrm{Th} \text { ) }\end{array}$ & $\begin{array}{l}\text { Tin, } \\
\text { total } \\
(\mathrm{mg} / \mathrm{kg} \\
\text { as } \mathrm{Sn})\end{array}$ & $\begin{array}{l}\text { Uranium, } \\
\text { total } \\
(\mathrm{mg} / \mathrm{kg} \\
\text { as } \mathrm{U})\end{array}$ & $\begin{array}{l}\text { Vanadium, } \\
\text { total } \\
(\mathrm{mg} / \mathrm{kg} \\
\mathrm{as} \mathrm{v})\end{array}$ & \multicolumn{2}{|c|}{$\begin{array}{l}\text { Ytterbium, } \\
\text { total } \\
(\mathrm{mg} / \mathrm{kg} \\
\text { as } \mathrm{Yb})\end{array}$} & $\begin{array}{l}\text { Yttrium, } \\
\text { total } \\
(\mathrm{mg} / \mathrm{kg} \\
\text { as Y) }\end{array}$ & $\begin{array}{l}\text { Zinc, } \\
\text { total } \\
(\mathrm{mg} / \mathrm{kg} \\
\text { as } \mathrm{Zn})\end{array}$ \\
\hline $\begin{array}{l}\text { WILIIAMS SLOUGH nY GENOA, NV (CARSON VALIEY) } \\
\text { WASHOE LAKE nI CARSON CITY, NV } \\
\text { CARSON RIVER bI IAHONTAN RES nI FALLON, NV } \\
\text { SHECKLER RESERVOIR at OUTIET nI FALLON, NV }\end{array}$ & $\begin{array}{l}11 \\
12 \\
26 \\
35\end{array}$ & $\begin{array}{l}<10 \\
<10 \\
<10 \\
<10\end{array}$ & $\begin{array}{l}<100 \\
<100 \\
<100 \\
<100\end{array}$ & $\begin{array}{r}110 \\
76 \\
170 \\
190\end{array}$ & $\begin{array}{r}2 \\
<1 \\
2 \\
3\end{array}$ & & $\begin{array}{r}14 \\
5 \\
19 \\
22\end{array}$ & $\begin{array}{r}110 \\
90 \\
100 \\
88\end{array}$ \\
\hline $\begin{array}{l}\text { CARSON LAKE DRAIN abV CARSON LAKE nI FALLON, NV } \\
\text { CARSON LAKE, SPRIG POND UNIT, nI FALLON, NV } \\
\text { CARSON LAKE, ISLAND UNIT, nI FALION, NV } \\
\text { CARSON LAKE, BIG WATER UNIT, nI FALLON, NV }\end{array}$ & $\begin{array}{l}14 \\
13 \\
14 \\
14\end{array}$ & $\begin{array}{l}<10 \\
<10 \\
<10 \\
<10\end{array}$ & $\begin{array}{l}<100 \\
<100 \\
<100 \\
<100\end{array}$ & $\begin{array}{r}110 \\
110 \\
92 \\
94\end{array}$ & $\begin{array}{l}2 \\
2 \\
2 \\
2\end{array}$ & & $\begin{array}{l}16 \\
13 \\
14 \\
14\end{array}$ & $\begin{array}{l}71 \\
96 \\
93 \\
89\end{array}$ \\
\hline $\begin{array}{l}\text { PAIUTE DRAIN at WILDLIFE ENT nI STILLWATER, NV } \\
\text { TJ DRAIN at WILDLIFE ENTRANCE nI STILLWATER, NV } \\
\text { PAIUTE DRAIN bIW TJ DRAIN nI STILIWATER, NV } \\
\text { LEAD LAKE at MILLENS LANDING nI STILLWATER, NV } \\
\text { SOUTH LEAD LAKE nI STILLWATER, NV }\end{array}$ & $\begin{array}{l}11 \\
10 \\
14 \\
12 \\
13\end{array}$ & $\begin{array}{l}<10 \\
<10 \\
<10 \\
<10 \\
<10\end{array}$ & $\begin{array}{l}<100 \\
<100 \\
<100 \\
<100 \\
<100\end{array}$ & $\begin{array}{l}93 \\
99 \\
92 \\
79 \\
88\end{array}$ & $\begin{array}{l}2 \\
2 \\
2 \\
2 \\
2\end{array}$ & & $\begin{array}{l}15 \\
15 \\
16 \\
16 \\
16\end{array}$ & $\begin{array}{l}73 \\
70 \\
80 \\
57 \\
59\end{array}$ \\
\hline $\begin{array}{l}\text { STILLWATER PT. DIV. DRAIN nI STILLWATER, NV } \\
\text { STILLWATER POINT RESERVOIR SOUTH nI STILLWATER } \\
\text { STILLWATER POINT RESERVOIR NORTH nI STILLWATER } \\
\text { STILIWATER SLOUGH at STILIWATER, NV }\end{array}$ & $\begin{array}{l}14 \\
12 \\
16 \\
14\end{array}$ & $\begin{array}{l}<10 \\
<10 \\
<10 \\
<10\end{array}$ & $\begin{array}{l}<100 \\
<100 \\
<100 \\
<100\end{array}$ & $\begin{array}{r}98 \\
94 \\
110 \\
97\end{array}$ & $\begin{array}{l}2 \\
2 \\
2 \\
2\end{array}$ & & $\begin{array}{l}16 \\
14 \\
18 \\
17\end{array}$ & $\begin{array}{l}77 \\
83 \\
85 \\
81\end{array}$ \\
\hline
\end{tabular}


TABLE 17.--Organochlorine pesticide residues and carbon in bottom-sediment samples in and near Stillwater Wildife Management Area and Carson Lake, 1986-87

[Abbreviations: g/kg, grams per kilogram; $\mu g / k g$, micrograms per kilogram, dry weight; $<$, less than; --, no data available]

\begin{tabular}{|c|c|c|c|c|c|}
\hline Station name & Date & $\begin{array}{l}\text { Carbon, } \\
\text { inor- } \\
\text { ganic, } \\
\text { total } \\
(g / k g \\
\text { as c) }\end{array}$ & $\begin{array}{l}\text { Carbon, } \\
\text { inor- } \\
\text { ganic + } \\
\text { organic, } \\
\text { total } \\
\text { (mg/kg } \\
\text { as c) }\end{array}$ & $\begin{array}{l}\text { Aldrin, } \\
\text { total } \\
(\mu g / \mathrm{kg})\end{array}$ & $\begin{array}{l}\text { Chlor- } \\
\text { dane, } \\
\text { total } \\
(\mu g / \mathrm{kg})\end{array}$ \\
\hline $\begin{array}{l}\text { WILLIAMS SLOUGH nI GENOA, NV (CARSON VALLEY) } \\
\text { WASHOE LAKE nI CARSON CITY, NV } \\
\text { CARSON RIVER BL IAHONTAN RES NR FALLON, NV } \\
\text { SHECKLER RESERVOIR at OUTIET nI FALLON, NV }\end{array}$ & $\begin{array}{r}09-04-86 \\
09-04-86 \\
03-23-87 \\
a_{03-24-87}\end{array}$ & $\overline{--}$ & $\overline{--}$ & $\begin{array}{l}<0.1 \\
<.1 \\
<.1 \\
<.1\end{array}$ & $\begin{array}{r}<1.0 \\
<1.0 \\
3.0 \\
2.0\end{array}$ \\
\hline $\begin{array}{l}\text { CARSON LAKE DRAIN abv CARSON LAKE nI FALLON, NV } \\
\text { CARSON LAKE, SPRIG POND UNIT, nI FALION, NV } \\
\text { CARSON IAKE, ISLAND UNIT, nI FALLON, NV } \\
\text { CARSON LAKE, BIG WATER UNIT, nI FALLON, NV }\end{array}$ & $\begin{array}{r}03-24-87 \\
03-24-87 \\
03-24-87 \\
03-24-87\end{array}$ & $\begin{array}{ll}11 \\
6.8 \\
13\end{array}$ & $\begin{array}{l}42 \\
20 \\
--\end{array}$ & $\begin{array}{r}<.1 \\
<.1 \\
- \\
-\end{array}$ & $\begin{array}{l}<1.0 \\
<1.0 \\
<1.0 \\
--\end{array}$ \\
\hline $\begin{array}{l}\text { PAIUTE DRAIN AT WILDLIFE ENT NR STILLWATER, NV } \\
\text { TJ DRAIN at WILDIIFE ENTRANCE nI STILLWATER, NV } \\
\text { LEAD LAKE at MILLENS LANDING nI STILIWATER, NV } \\
\text { SOUTH LEAD LAKE nI STILLWATER, NV }\end{array}$ & $\begin{array}{r}03-25-87 \\
03-25-87 \\
a_{03}-25-87 \\
03-25-87\end{array}$ & $\frac{5}{11}$ & $\frac{--}{15}$ & $\begin{array}{l}<.1 \\
<.1 \\
<.1\end{array}$ & $\begin{array}{l}<1.0 \\
<1.0 \\
<1.0\end{array}$ \\
\hline $\begin{array}{l}\text { STILLWATER PT. DIV. DRAIN nI STILLWATER, NV } \\
\text { STILLWATER POINT RESERVOIR, SO. END, nI FALLON, NV } \\
\text { STILLWATER POINT RESERVOIR NORTH nI STILLWATER, NV } \\
\text { STILLWATER SLOUGH at STIILWATER, NV }\end{array}$ & $\begin{array}{l}03-26-87 \\
03-26-87 \\
03-26-87 \\
03-26-87\end{array}$ & $\begin{array}{r}4.0 \\
5.6\end{array}$ & 9.9 & $\begin{array}{r}<.1 \\
<.1 \\
-- \\
<.1\end{array}$ & $\begin{array}{r}<1.0 \\
-1.0 \\
<1.0\end{array}$ \\
\hline $\begin{array}{l}\text { HUNTER DRAIN at DIVISION RD. nI. STILLWATER, NV } \\
\text { LEAD LK CANAL at HUNTER RD CROSSING nI STILLWATER } \\
\text { CATTAIL LAKE nI. INLET nI. STILLWATER, NV } \\
\text { SWAN CHECK nI. OUTLET nI. STILLWATER, NV } \\
\text { PINTAII BAY nI. CENTER nI. STILLWATER, NV }\end{array}$ & $\begin{array}{l}07-22-87 \\
07-23-87 \\
07-22-87 \\
07-23-87 \\
07-24-87\end{array}$ & $\begin{array}{l}17 \\
11 \\
8.3 \\
13 \\
22\end{array}$ & $\begin{array}{l}28 \\
36 \\
14 \\
39 \\
36\end{array}$ & $\begin{array}{l}<.1 \\
<.1 \\
<.1 \\
<.1\end{array}$ & $\begin{array}{l}<1.0 \\
<1.0 \\
45 \\
<1.0 \\
<1.0\end{array}$ \\
\hline Station name & $\begin{array}{l}\text { DDD } \\
\operatorname{total} \\
(\mu \mathrm{g} / \mathrm{kg})\end{array}$ & $\begin{array}{l}\text { DDE, } \\
\text { total } \\
(\mu g / \mathrm{kg})\end{array}$ & $\begin{array}{c}\text { DDT, } \\
\text { total } \\
(\mu \mathrm{g} / \mathrm{kg})\end{array}$ & $\begin{array}{l}\text { Diel- } \\
\text { drin, } \\
\text { total } \\
(\mu g / k g)\end{array}$ & $\begin{array}{l}\text { Endo- } \\
\text { sulfan, } \\
\text { total } \\
(\mu g / \mathrm{kg})\end{array}$ \\
\hline $\begin{array}{l}\text { WILLIAMS SLOUGH NI GENOA, NV } \\
\text { WASHOE LAKE NI CARSON CITY, NV } \\
\text { CARSON RIVER BI LAHONTAN RES NR FALLON, NV } \\
\text { SHECKLER RESERVOIR at OUTLET NI FALLON, NV }\end{array}$ & $\begin{array}{l}3.2 \\
<.1 \\
<.1 \\
<.1\end{array}$ & $\begin{array}{l}2.1 \\
<.1 \\
<.1 \\
<.1\end{array}$ & $\begin{array}{l}0.2 \\
<.1 \\
<.1 \\
<.1\end{array}$ & $\begin{array}{r}<0.1 \\
<.1 \\
.2 \\
<.1\end{array}$ & $\begin{array}{l}<0.1 \\
<.1 \\
<.1 \\
<.1\end{array}$ \\
\hline $\begin{array}{l}\text { CARSON LAKE DRAIN abV CARSON LAKE nI FALLON, NV } \\
\text { CARSON LAKE, SPRIG POND UNIT, nI FALION, NV } \\
\text { CARSON LAKE, ISLAND UNIT, nI FALLON, NV }\end{array}$ & $\begin{array}{l}.4 \\
<.1 \\
<.1\end{array}$ & $\begin{array}{r}1.3 \\
.2 \\
.4\end{array}$ & $\begin{array}{l}.2 \\
<.1 \\
<.1\end{array}$ & $\begin{array}{l}<.1 \\
<.1 \\
<.1\end{array}$ & $\begin{array}{l}<.1 \\
<.1 \\
<.1\end{array}$ \\
\hline $\begin{array}{l}\text { CARSON LAKE, BIG WATER UNIT, nI FALLON, NV } \\
\text { PAIUTE DRAIN AT WIIDIIFE ENT NR STILLWATER, NV } \\
\text { TJ DRAIN at WILDLIFE ENTRANCE nI STILLWATER, NV } \\
\text { LEAD LAKE at MILLENS LANDING nI STILLWATER, NV }\end{array}$ & $\begin{array}{l}<.1 \\
<.1 \\
<.1\end{array}$ & $\begin{array}{r}.1 \\
.1 \\
.3\end{array}$ & $\begin{array}{l}<.1 \\
<.1 \\
<.1\end{array}$ & $\begin{array}{l}<.1 \\
<.1 \\
<.1\end{array}$ & $\begin{array}{l}<.1 \\
<.1 \\
<.1\end{array}$ \\
\hline $\begin{array}{l}\text { SOUTH LEAD LAKE nI STILLWATER, NV } \\
\text { STILLWATER PT. DIV. DRAIN nI STILLWATER, NV } \\
\text { STILLWATER POINT RESERVOIR, SO. END, nI FALLON, NV } \\
\text { STILLWATER POINT RESERVOIR NORTH nI STILLWATER, NV }\end{array}$ & .7 & $\begin{array}{r}1.0 \\
1.4\end{array}$ & $\begin{array}{ll}<.1 \\
<1.0\end{array}$ & -1 & $\begin{array}{l}<-1 \\
<.1 \\
--\end{array}$ \\
\hline $\begin{array}{l}\text { STILLWATER SLOUGH at STILLWATER, NV } \\
\text { HUNTER DRAIN at DIVISION RD. nI. STILLWATER, NV } \\
\text { LEAD LK CANAL at HUNTER RD CROSSING nI STILLWATER } \\
\text { CATTAIL LAKE nI. INLET nI. STILLWATER, NV } \\
\text { SWAN CHECK nr. OUTLET nr. STILLWATER, NV } \\
\text { PINTAIL BAY nI. CENTER nI. STILLWATER, NV }\end{array}$ & $\begin{array}{l}<.5 \\
<.1 \\
<.1 \\
<.1 \\
<.1 \\
<.1\end{array}$ & $\begin{array}{r}.6 \\
<1.3 \\
<.5 \\
<.1\end{array}$ & $\begin{array}{l}<.1 \\
-- \\
<.1 \\
<.1 \\
--1 \\
<.1\end{array}$ & $\begin{array}{r}<.1 \\
<.1 \\
<.1 \\
4.6 \\
<.1 \\
<.1\end{array}$ & $\begin{array}{l}<.1 \\
<.1 \\
<.1 \\
<.1 \\
<.1 \\
<.1\end{array}$ \\
\hline
\end{tabular}


TABLE 17.--Organochlorine pesticide residues and carbon in bottom-sediment samples in and near Stillwater Wildlife Management Area and Carson Lake, 1986-87--Continued

\begin{tabular}{|c|c|c|c|c|c|}
\hline Station name & $\begin{array}{l}\text { Endrin, } \\
\text { total } \\
(\mu \mathrm{g} / \mathrm{kg})\end{array}$ & $\begin{array}{l}\text { Hepta- } \\
\text { chlor, } \\
\text { total } \\
(\mu \mathrm{g} / \mathrm{kg})\end{array}$ & $\begin{array}{l}\text { Hepta- } \\
\text { chlor } \\
\text { epoxide } \\
\text { total } \\
(\mu g / \mathrm{kg})\end{array}$ & $\begin{array}{l}\text { Lindane, } \\
\text { total } \\
(\mu \mathrm{g} / \mathrm{kg})\end{array}$ & $\begin{array}{l}\text { Meth- } \\
\text { oxy- } \\
\text { chlor, } \\
\text { total } \\
\text { (rg/kg) }\end{array}$ \\
\hline $\begin{array}{l}\text { WILLIAMS SLOUGH nI GENOA, NV } \\
\text { WASHOE IAKE nI CARSON CITY, NV } \\
\text { CARSON RIVER BL LAHONTAN RES NR FALLON, NV } \\
\text { SHECKLER RESERVOIR at OUTLET NI FALLON, NV }\end{array}$ & $\begin{array}{l}<0.1 \\
<0.1 \\
<0.1 \\
<0.1\end{array}$ & $\begin{array}{l}<0.1 \\
<0.1 \\
<0.1 \\
<0.1\end{array}$ & $\begin{array}{l}<0.1 \\
<0.1 \\
<0.1 \\
<0.1\end{array}$ & $\begin{array}{l}<0.1 \\
<0.1 \\
<0.1 \\
<0.1\end{array}$ & $\begin{array}{l}<0.1 \\
<0.1 \\
<6.0 \\
<0.1\end{array}$ \\
\hline $\begin{array}{l}\text { CARSON LAKE DRAIN abV CARSON LAKE nI FALLON, NV } \\
\text { CARSON LAKE, SPRIG POND UNIT, nI FALLON, NV } \\
\text { CARSON LAKE, ISLAND UNIT, NI FALLON,NV }\end{array}$ & $\begin{array}{l}<0.1 \\
<0.1 \\
<0.1\end{array}$ & $\begin{array}{l}<0.1 \\
<0.1 \\
<0.1\end{array}$ & $\begin{array}{l}<0.1 \\
<0.1 \\
<0.1\end{array}$ & $\begin{array}{l}<0.1 \\
<0.1 \\
<0.1\end{array}$ & $\begin{array}{l}<0.1 \\
<0.1 \\
<0.1\end{array}$ \\
\hline $\begin{array}{l}\text { CARSON LAKE, BIG WATER UNIT, nI FALLON, NV } \\
\text { PAIUTE DRAIN AT WILDLIFE ENT NR STILLWATER, NV } \\
\text { TJ DRAIN at WILDLIFE ENTRANCE nI STILLWATER, NV } \\
\text { LEAD LAKE at MILLENS LANDING nI STILLWATER, NV }\end{array}$ & $\begin{array}{l}<0.1 \\
<0.1 \\
<0.1\end{array}$ & $\begin{array}{l}<- \\
<0.1 \\
<0.1 \\
<0.1\end{array}$ & $\begin{array}{l}-- \\
<0.1 \\
<0.1 \\
<0.1\end{array}$ & $\begin{array}{l}<0.1 \\
<0.1 \\
<0.1\end{array}$ & $\begin{array}{l}-\overline{<0} \\
<0.1 \\
<0.1\end{array}$ \\
\hline $\begin{array}{l}\text { SOUTH LEAD LAKE nI STILLWATER, NV } \\
\text { STILLWATER PT. DIV. DRAIN nI STILLWATER, NV } \\
\text { STILLWATER POINT RESERVOIR, SO. END, nI FALLON, NV } \\
\text { STILLWATER POINT RESERVOIR NORTH nI STILLWATER, NV }\end{array}$ & $\begin{array}{l}<0.1 \\
<0.1\end{array}$ & $\begin{array}{r}-\overline{0.1} \\
<0.1 \\
--\end{array}$ & $\begin{array}{l}-- \\
<0.1 \\
<0.1 \\
--\end{array}$ & $\begin{array}{l}-- \\
<0.1 \\
<0.1 \\
--\end{array}$ & $\begin{array}{l}-\overline{<0} \\
<0.1 \\
--\end{array}$ \\
\hline \multirow[t]{2}{*}{$\begin{array}{l}\text { STILLWATER SLOUGH at STILLWATER, NV } \\
\text { HUNTER DRAIN at DIVISION RD. nI. STILLWATER, NV } \\
\text { LEAD LK CANAL at HUNTER RD CROSSING nI STILLWATER } \\
\text { CATTAIL LAKE nI. INLET nI. STILLWATER, NV } \\
\text { SWAN CHECK nI. OUTLET nI. STILLWATER, NV } \\
\text { PINTAIL BAY nr. CENTER nr. STILLWATER, NV }\end{array}$} & $\begin{array}{l}<0.1 \\
<0.1 \\
<0.1 \\
<0.1 \\
<0.1 \\
<0.1\end{array}$ & $\begin{array}{l}<0.1 \\
-- \\
<0.1 \\
<0.1 \\
<0.1 \\
<0.1\end{array}$ & $\begin{array}{r}<0.1 \\
<0.1 \\
0.2 \\
0.5 \\
<0.1 \\
<0.1\end{array}$ & $\begin{array}{r}<0.1 \\
2.0 \\
<0.1 \\
0.8 \\
<0.1 \\
4.7\end{array}$ & $\begin{array}{r}<0.1 \\
<0.1 \\
<0.1 \\
<0.1 \\
1.0 \\
<0.1\end{array}$ \\
\hline & $\begin{array}{l}\text { Mirex, } \\
\text { total } \\
(\mu g / k g)\end{array}$ & $\begin{array}{l}\text { Per- } \\
\text { thane } \\
(\mu g / k g)\end{array}$ & $\begin{array}{l}\text { PCB, } \\
\text { total } \\
(\mu g / k g)\end{array}$ & $\begin{array}{l}\text { PCN, } \\
\text { total } \\
(\mu g / k g)\end{array}$ & \\
\hline $\begin{array}{l}\text { WILLIAMS SLOUGH nI GENOA, NV } \\
\text { WASHOE LAKE NI CARSON CITY, NV } \\
\text { CARSON RIVER BL LAHONTAN RES NR FALLON, NV } \\
\text { SHECKIER RESERVOIR at OUTLET nI FALLON, NV }\end{array}$ & $\begin{array}{l}<0.1 \\
<0.1 \\
<0.1 \\
<0.1\end{array}$ & $\begin{array}{l}<1.00 \\
<1.00 \\
<1.00 \\
<1.00\end{array}$ & $\begin{array}{l}<1 \\
<1 \\
<1 \\
<1\end{array}$ & $\begin{array}{l}<1.0 \\
<1.0 \\
<1.0 \\
<1.0\end{array}$ & \\
\hline $\begin{array}{l}\text { CARSON LAKE DRAIN abV CARSON LAKE nI FALLON, NV } \\
\text { CARSON LAKE, SPRIG POND UNIT, NI FALLON, NV } \\
\text { CARSON LAKE, ISIAND UNIT, nI FALLON, NV }\end{array}$ & $\begin{array}{l}<0.1 \\
<0.1 \\
<0.1\end{array}$ & $\begin{array}{l}<1.00 \\
<1.00 \\
<1.00\end{array}$ & $\begin{array}{l}<1 \\
<1 \\
<1\end{array}$ & $\begin{array}{l}<1.0 \\
<1.0 \\
<1.0\end{array}$ & \\
\hline $\begin{array}{l}\text { CARSON LAKE, BIG WATER UNIT, nI FALLON, NV } \\
\text { PAIUTE DRAIN AT WILDLIFE ENT NR STILLWATER, NV } \\
\text { TJ DRAIN at WILDLIFE ENTRANCE nr STILLWATER, NV } \\
\text { LEAD LAKE at MILLENS LANDING nI STILIWATER, NV }\end{array}$ & $\begin{array}{l}<0 . \overline{1} \\
<0.1 \\
<0.1\end{array}$ & $\begin{array}{l}<1.00 \\
<1.00 \\
<1.00\end{array}$ & $\begin{array}{l}<1 \\
<1 \\
<1\end{array}$ & $\begin{array}{l}<1.0 \\
<1.0 \\
<1.0\end{array}$ & \\
\hline $\begin{array}{l}\text { SOUTH LEAD LAKE nI STILLWATER, NV } \\
\text { STILLWATER PT. DIV. DRAIN nI STILLWATER, NV } \\
\text { STILLWATER POINT RESERVOIR, SO. END, NI FALLON, NV } \\
\text { STILLWATER POINT RESERVOIR NORTH nI STILLWATER, NV }\end{array}$ & $\begin{array}{l}<\overline{-} . \overline{1} \\
<0.1 \\
--\end{array}$ & $\begin{array}{l}<1.0 \overline{0} \\
<1.00 \\
--\end{array}$ & $<\frac{1}{6}$ & $\begin{array}{l}<1.0 \\
<1.0 \\
--\end{array}$ & \\
\hline $\begin{array}{l}\text { STILLWATER SLOUGH at STILLWATER, NV } \\
\text { HUNTER DRAIN at DIVISION RD. NI. STILLWATER, NV } \\
\text { LEAD LK CANAL at HUNTER RD CROSSING nI STILLWATER } \\
\text { CATTAIL LAKE nI. INLET nI. STILLWATER, NV } \\
\text { SWAN CHECK nr. OUTLET nI. STILLWATER, NV } \\
\text { PINTAIL BAY nI. CENTER nr. STILLWATER, NV }\end{array}$ & $\begin{array}{l}<0.1 \\
<0.1 \\
<0.1 \\
<0.1 \\
<0.1 \\
<0.1\end{array}$ & $\begin{array}{l}<1.00 \\
<1.00 \\
<1.00 \\
<1.00 \\
<1.00 \\
<1.00\end{array}$ & $\begin{array}{r}<1 \\
<1 \\
<1 \\
2 \\
21 \\
<1 \\
<1\end{array}$ & $\begin{array}{l}<1.0 \\
<1.0 \\
<1.0 \\
<1.0 \\
<1.0 \\
<1.0\end{array}$ & \\
\hline
\end{tabular}

a Carbon analyses from $3 / 87$ sample. Other corresponding data from $10 / 87$ sample. 
TABLE 18.-Data on physical and chemical constituents for ground-water samples in and near Stillwater Wildlife Management Area and Carson Lake, 1986

[Abbreviations: ${ }^{\circ} \mathrm{C}$, degrees Celsius; IT-FID, incremental titration-field; mg/L, milligrams per liter; mV, millivolts; $\mu \mathrm{s} / \mathrm{cm}$, microsiemens per centimeter at $25^{\circ} \mathrm{C} ; \mu \mathrm{g} / \mathrm{L}$, micrograms per liter; pCi/L, picocuries per liter; <, less than; --, no data available]

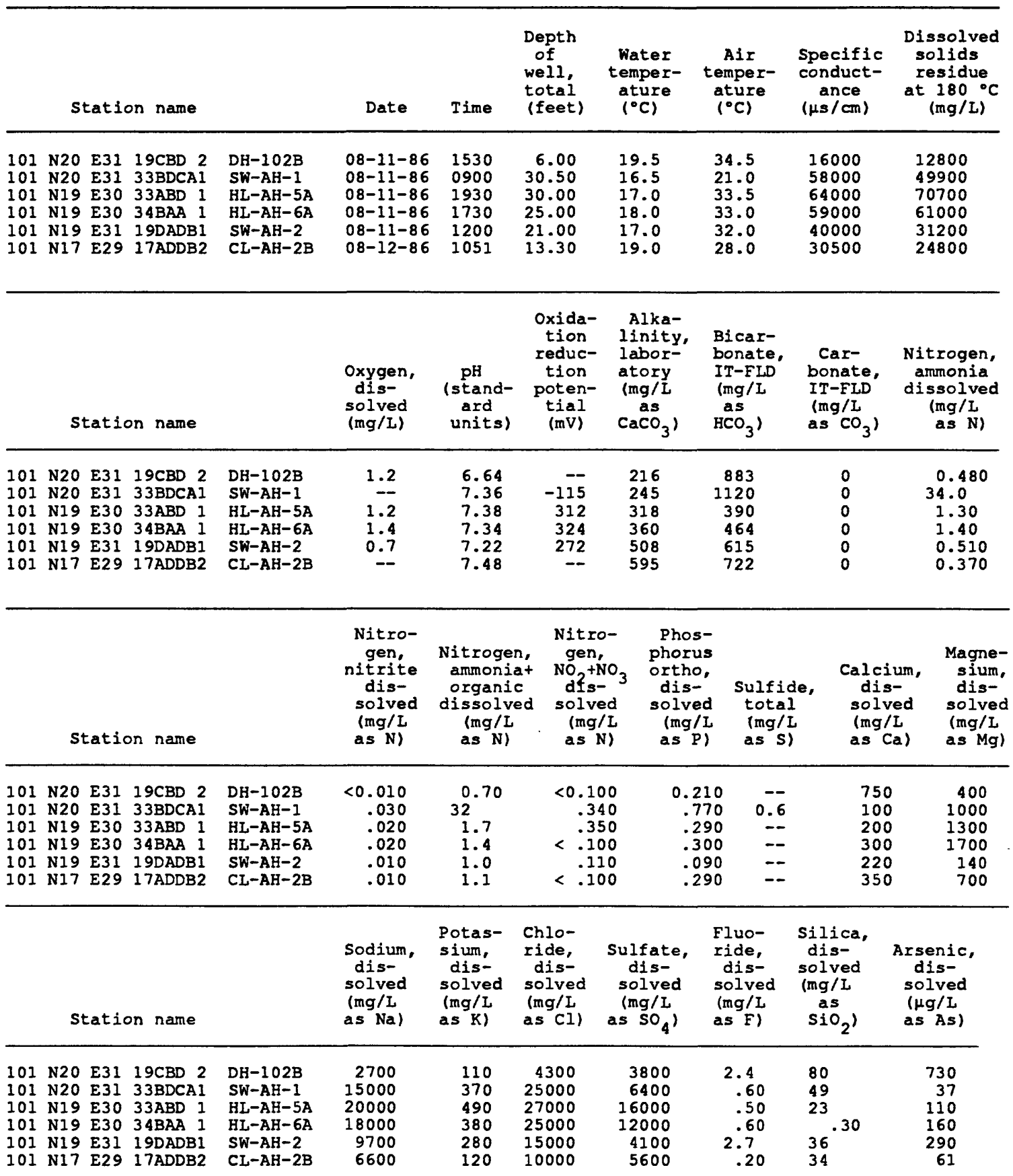


TABLE 18.--Data on physical and chemical constituents for ground-water samples in and near Stillwater Wildlife Management Area and Carson Lake, 1986--Continued

\begin{tabular}{|c|c|c|c|c|c|c|c|c|c|c|}
\hline & Sto & atio & on name & & $\begin{array}{l}\text { Beryl- } \\
\text { lium, } \\
\text { dis- } \\
\text { solved } \\
(\mu g / L \\
\text { as } \mathrm{Be})\end{array}$ & $\begin{array}{l}\text { Boron, } \\
\text { dis- } \\
\text { solved } \\
\text { (Hg/L } \\
\text { as B) }\end{array}$ & $\begin{array}{c}\text { Cadmium, } \\
\text { dis- } \\
\text { solved } \\
\text { ( } \mu g / L \\
\text { as Cd) }\end{array}$ & $\begin{array}{l}\text { Chro- } \\
\text { mium, } \\
\text { dis- } \\
\text { solved } \\
\text { (Hg/L } \\
\text { as } C r \text { ) }\end{array}$ & $\begin{array}{l}\text { Chromium, } \\
\text { hexa- } \\
\text { valent, } \\
\text { dissolved } \\
\text { ( } \mu g / L \\
\text { as } C r)\end{array}$ & $\begin{array}{l}\text { Cobalt, } \\
\text { dis- } \\
\text { solved } \\
(\mu g / L \\
\text { as Co) }\end{array}$ \\
\hline \multirow[t]{2}{*}{$\begin{array}{l}101 \\
101 \\
101 \\
101 \\
101 \\
101\end{array}$} & $\begin{array}{l}\text { N20 } \\
\text { N20 } \\
\text { N19 } \\
\text { N19 } \\
\text { N19 } \\
\text { N17 }\end{array}$ & $\begin{array}{l}\text { E31 } \\
\text { E31 } \\
\text { E30 } \\
\text { E30 } \\
\text { E31 } \\
\text { E29 }\end{array}$ & $\begin{array}{l}19 \mathrm{CBD} 2 \\
33 \mathrm{BDCA1} \\
33 \mathrm{ABD} 1 \\
34 \mathrm{BAA} 1 \\
\text { 19DADB1 } \\
17 \mathrm{ADDB2}\end{array}$ & $\begin{array}{l}\mathrm{DH}-102 \mathrm{~B} \\
\mathrm{SW}-\mathrm{AH}-1 \\
\mathrm{HL}-\mathrm{AH}-5 \mathrm{~A} \\
\mathrm{HL}-\mathrm{AH}-6 \mathrm{~A} \\
\mathrm{SW}-\mathrm{AH}-2 \\
\mathrm{CL}-\mathrm{AH}-2 \mathrm{~B}\end{array}$ & $\begin{array}{r}<10 \\
10 \\
10 \\
10 \\
10 \\
<10\end{array}$ & $\begin{array}{r}25000 \\
43000 \\
54000 \\
48000 \\
120000 \\
22000\end{array}$ & $\begin{array}{r}<1 \\
1 \\
<1 \\
1 \\
1 \\
<1\end{array}$ & $\begin{array}{l}20 \\
40 \\
50 \\
50 \\
20 \\
20\end{array}$ & $\begin{array}{l}<1 \\
<1 \\
<1 \\
<1 \\
<1 \\
<1\end{array}$ & $\begin{array}{r}7 \\
<1 \\
2 \\
1 \\
1 \\
3\end{array}$ \\
\hline & Sto & atio & on name & & $\begin{array}{l}\text { Copper, } \\
\text { dis- } \\
\text { solved } \\
\text { ( } \mu g / L \\
\text { as (u) }\end{array}$ & $\begin{array}{l}\text { Iron, } \\
\text { dis- } \\
\text { solved } \\
\text { (Hg/I } \\
\text { as Fe) }\end{array}$ & $\begin{array}{l}\text { Lead, } \\
\text { dis- } \\
\text { solved } \\
\text { ( } \mu \text { g/L } \\
\text { as } \mathrm{Pb})\end{array}$ & $\begin{array}{c}\text { Lithium, } \\
\text { dis- } \\
\text { solved } \\
\text { ( } \mu \text { g/L } \\
\text { as Li) }\end{array}$ & $\begin{array}{l}\text { Manga- } \\
\text { nese, } \\
\text { dis- } \\
\text { solved } \\
(\mu g / I \\
\text { as } M n)\end{array}$ & $\begin{array}{c}\text { Mercury, } \\
\text { dis- } \\
\text { solved } \\
\text { (Hg/L } \\
\text { as Hg) }\end{array}$ \\
\hline \multirow[t]{2}{*}{$\begin{array}{ll}1 & 01 \\
1 & 01 \\
1 & 01 \\
1 & 01 \\
1 & 01 \\
1 & 01\end{array}$} & $\begin{array}{l}\text { N20 } \\
\text { N20 } \\
\text { N19 } \\
\text { N19 } \\
\text { N19 } \\
\text { N17 }\end{array}$ & $\begin{array}{l}\text { E31 } \\
\text { E31 } \\
\text { E30 } \\
\text { E30 } \\
\text { E31 } \\
\text { E29 }\end{array}$ & $\begin{array}{l}19 \mathrm{CBD} 2 \\
33 \mathrm{BDCA1} \\
33 \mathrm{ABD} 1 \\
34 \mathrm{BAA} 1 \\
19 \mathrm{DADB} 1 \\
17 \mathrm{ADDB2}\end{array}$ & $\begin{array}{l}\mathrm{DH}-102 \mathrm{~B} \\
\mathrm{SW}-\mathrm{AH}-1 \\
\mathrm{HL}-\mathrm{AH}-5 \mathrm{~A} \\
\mathrm{HL}-\mathrm{AH}-6 \mathrm{~A} \\
\mathrm{SW}-\mathrm{AH}-2 \\
\mathrm{CL}-\mathrm{AH}-2 \mathrm{~B}\end{array}$ & $\begin{array}{l}4 \\
2 \\
9 \\
6 \\
5 \\
4\end{array}$ & $\begin{array}{r}150 \\
230 \\
330 \\
250 \\
130 \\
90\end{array}$ & $\begin{array}{l}<5 \\
<5 \\
<5 \\
<5 \\
<5 \\
<5\end{array}$ & $\begin{array}{r}2600 \\
2200 \\
900 \\
1000 \\
8200 \\
400\end{array}$ & $\begin{array}{r}1800 \\
340 \\
630 \\
640 \\
420 \\
1500\end{array}$ & $\begin{array}{r}<0.1 \\
<.1 \\
<.1 \\
<.1 \\
.1 \\
<.1\end{array}$ \\
\hline & & atio & on name & & $\begin{array}{l}\text { Molyb- } \\
\text { denum, } \\
\text { dis- } \\
\text { solved } \\
(\mu g / L \\
\text { as Mo) }\end{array}$ & $\begin{array}{l}\text { Nickel, } \\
\text { dis- } \\
\text { solved } \\
\text { ( } \mu \mathrm{g} / \mathrm{L} \\
\text { as Ni) }\end{array}$ & $\begin{array}{l}\text { Sele- } \\
\text { nium, } \\
\text { dis- } \\
\text { solved } \\
(\mu g / L \\
\text { as Se) }\end{array}$ & $\begin{array}{c}\text { Silver, } \\
\text { dis- } \\
\text { solved } \\
\text { (Hg/L } \\
\text { as Ag) }\end{array}$ & $\begin{array}{l}\text { Stron- } \\
\text { tium, } \\
\text { dis- } \\
\text { solved } \\
(\mu g / L \\
\text { as SI) }\end{array}$ & $\begin{array}{l}\text { Vana- } \\
\text { dium, } \\
\text { dis- } \\
\text { solved } \\
(\mu g / L \\
\text { as V) }\end{array}$ \\
\hline \multirow[t]{2}{*}{$\begin{array}{ll}1 & 01 \\
1 & 01 \\
1 & 01 \\
1 & 01 \\
1 & 01 \\
1 & 01\end{array}$} & $\begin{array}{l}\text { N20 } \\
\text { N20 } \\
\text { N19 } \\
\text { N19 } \\
\text { N19 } \\
\text { N17 }\end{array}$ & $\begin{array}{l}\text { E31 } \\
\text { E31 } \\
\text { E30 } \\
\text { E30 } \\
\text { E31 } \\
\text { E29 }\end{array}$ & $\begin{array}{l}\text { 19CBD } 2 \\
33 \mathrm{BDCA1} \\
33 \mathrm{ABD} 1 \\
34 \mathrm{BAA} 1 \\
19 \mathrm{AADB} 1 \\
17 \mathrm{ADDB} 2\end{array}$ & $\begin{array}{l}\mathrm{DH}-102 \mathrm{~B} \\
\mathrm{SW}-\mathrm{AH}-1 \\
\mathrm{HL}-\mathrm{AH}-5 \mathrm{~A} \\
\mathrm{HL}-\mathrm{AH}-6 \mathrm{~A} \\
\mathrm{SW}-\mathrm{AH}-2 \\
\mathrm{CL}-\mathrm{AH}-2 \mathrm{~B}\end{array}$ & $\begin{array}{r}850 \\
20 \\
1100 \\
940 \\
1500 \\
520\end{array}$ & $\begin{array}{r}16 \\
1 \\
2 \\
2 \\
4 \\
4\end{array}$ & $\begin{array}{l}<1 \\
<1 \\
<1 \\
<1 \\
<1 \\
<1\end{array}$ & $\begin{array}{r}<1.0 \\
<1.0 \\
<1.0 \\
<1.0 \\
<1.0 \\
1.0\end{array}$ & $\begin{array}{r}15000 \\
10000 \\
1700 \\
30000 \\
12000 \\
770\end{array}$ & $\begin{array}{r}80 \\
200 \\
200 \\
300 \\
200 \\
100\end{array}$ \\
\hline & Stat & tion & n name & & $\begin{array}{l}\text { Zinc, } \\
\text { dis- } \\
\text { solved } \\
\text { ( } \mu g / L \\
\text { as } Z n)\end{array}$ & $\begin{array}{c}\text { Gross } \\
\text { beta, } \\
\text { dis- } \\
\text { solved } \\
\text { (pci/L } \\
\text { as } \\
\text { cs-137) }\end{array}$ & $\begin{array}{l}\text { Radium- } \\
226, \\
\text { dis- } \\
\text { solved, } \\
\text { planchet } \\
\text { count } \\
\text { (pci/L) }\end{array}$ & $\begin{array}{l}\text { Uranium, } \\
\text { natural } \\
\text { dis- } \\
\text { solved } \\
\text { ( } \mu g / L \\
\text { as U) }\end{array}$ & $\begin{array}{l}\text { Gross } \\
\text { alpha, } \\
\text { dis- } \\
\text { solved } \\
\text { (Hg/L } \\
\text { as } \\
\text { U-nat) }\end{array}$ & $\begin{array}{l}\text { Gross } \\
\text { beta, } \\
\text { dis- } \\
\text { solved } \\
\text { (pCi/L } \\
\text { as Sr/ } \\
\text { Y-90) }\end{array}$ \\
\hline $\begin{array}{ll}1 & 01 \\
1 & 01 \\
1 & 01 \\
1 & 01 \\
1 & 01 \\
1 & 01\end{array}$ & $\begin{array}{l}\text { N20 } \\
\text { N20 } \\
\text { N19 } \\
\text { N19 } \\
\text { N19 } \\
\text { N17 }\end{array}$ & $\begin{array}{l}\text { E31 } \\
\text { E31 } \\
\text { E30 } \\
\text { E30 } \\
\text { E31 } \\
\text { E29 }\end{array}$ & $\begin{array}{l}\text { 19CBD } 2 \\
33 \mathrm{BDCA1} \\
33 \mathrm{ABD} 1 \\
34 \mathrm{BAA} 1 \\
\text { 19DADB1 } \\
17 \mathrm{ADDB} 2\end{array}$ & $\begin{array}{l}\mathrm{DH}-102 \mathrm{~B} \\
\mathrm{SW}-\mathrm{AH}-1 \\
\mathrm{HL}-\mathrm{AH}-5 \mathrm{~A} \\
\mathrm{HL}-\mathrm{AH}-6 \mathrm{~A} \\
\mathrm{SW}-\mathrm{AH}-2 \\
\mathrm{CL}-\mathrm{AH}-2 \mathrm{~B}\end{array}$ & $\begin{array}{l}30 \\
60 \\
80 \\
70 \\
30 \\
40\end{array}$ & $\begin{array}{r}240 \\
640 \\
1100 \\
1000 \\
570 \\
540\end{array}$ & $\begin{array}{r}0.5 \\
1.1 \\
2.1 \\
2.0 \\
.9 \\
.6\end{array}$ & $\begin{array}{c}280 \\
1.9 \\
240 \\
-- \\
120 \\
310\end{array}$ & $\begin{array}{r}120 \\
16 \\
380 \\
950 \\
200 \\
660\end{array}$ & $\begin{array}{l}160 \\
420 \\
700 \\
680 \\
380 \\
340\end{array}$ \\
\hline
\end{tabular}


TAbLe 19.--Data on trace-element constluents and percent molsture of blologlcal samples in st11Iwater wildife Management Area, Carson Lake, Fernley W1ldife Management Area, and Humboldt W1ldilfe Management Area, $1985-87$. Date from U.S. Fish and wildilfo service

LAbbrevlatlons: --, no data avallable; $A$, alkall; AD, adult; BN, black-necked; HS, hard atem; HWha, Humboldt W1ldlife Management Area; RT, root; SAC, Sacramento; SD, seed; SWMA, Stillwater WLldilfe Management Area; USFWS, U.S. Flsh and W1ldilfe Service; WM, Wlidilfe Management Area. All values in mlcrograms per gram, dry welght. NOrE: Except as noted, blrd tissue is IIver.l

\begin{tabular}{|c|c|c|c|c|c|c|c|c|c|c|c|c|}
\hline $\begin{array}{l}\text { UsFus } \\
\text { loca } 1 \\
\text { ID } \\
\text { number }\end{array}$ & Date & & Locat Ion & $\begin{array}{l}\text { Cate- } \\
\text { gory }\end{array}$ & Spectes & $\begin{array}{l}\text { Percent } \\
\text { molsture }\end{array}$ & $\begin{array}{c}\text { Arae- } \\
\text { nle }\end{array}$ & Boron & $\begin{array}{l}\text { Chro- } \\
\text { mlum }\end{array}$ & Lead & $\begin{array}{l}\text { Mer- } \\
\text { cury }\end{array}$ & $\begin{array}{l}\text { Sele- } \\
\text { n1um }\end{array}$ \\
\hline $\begin{array}{l}17 \\
18 \\
19 \\
20 \\
21\end{array}$ & $\begin{array}{l}06 / 17 / 86 \\
06 / 17 / 86 \\
06 / 17 / 86 \\
06 / 17 / 86 \\
06 / 27 / 86\end{array}$ & $\begin{array}{l}\text { CARSON } \\
\text { CARSON } \\
\text { CARSON } \\
\text { CARSON } \\
\text { CARSON }\end{array}$ & 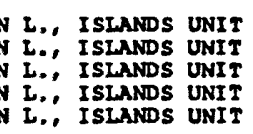 & $\begin{array}{l}\text { BIRD } \\
\text { BIRD } \\
\text { BIRD } \\
\text { BIRD } \\
\text { BIRD }\end{array}$ & $\begin{array}{l}\text { AVOCET } \\
\text { AVOCET } \\
\text { AVOCET } \\
\text { AVOCET } \\
\text { AVOCET }\end{array}$ & $\begin{array}{l}74.95 \\
73.72 \\
73.04 \\
75.24 \\
73.43\end{array}$ & $\begin{array}{r}<0.18 \\
<.17 \\
<.18 \\
<.17 \\
<.18\end{array}$ & $\begin{array}{r}63.0 \\
140.0 \\
120.0 \\
49.0 \\
81.0\end{array}$ & $\begin{array}{r}<1.20 \\
<1.10 \\
<1.10 \\
<1.20 \\
2.70\end{array}$ & $\begin{array}{l}<0.77 \\
<.75 \\
<.72 \\
<.80 \\
<.74\end{array}$ & $\begin{array}{l}0.38 \\
5.18 \\
2.00 \\
.70 \\
2.30\end{array}$ & $\begin{array}{l}3.30 \\
3.50 \\
4.80 \\
3.60 \\
4.00\end{array}$ \\
\hline $\begin{array}{l}22 \\
23 \\
25 \\
26 \\
32\end{array}$ & $\begin{array}{l}06 / 17 / 86 \\
06 / 17 / 86 \\
06 / 20 / 86 \\
06 / 20 / 86 \\
06 / 24 / 86\end{array}$ & $\begin{array}{l}\text { CARSON } \\
\text { CARSON } \\
\text { CARSON } \\
\text { CARSON } \\
\text { CARSON }\end{array}$ & $\begin{array}{l}\text { I., SPRIG PONDS } \\
\text { I., SPRIG PONDS } \\
N \text { L., SPRIG PONDS } \\
\text { L., SPRIG PONDS } \\
\text { I., SPRIG PONDS }\end{array}$ & $\begin{array}{l}\text { BIRD } \\
\text { BIRD } \\
\text { BIRD } \\
\text { BIRD } \\
\text { BIRD }\end{array}$ & $\begin{array}{l}\text { AVOCET } \\
\text { AVOCET } \\
\text { AVOCET } \\
\text { AVOCET } \\
\text { AVOCET }\end{array}$ & $\begin{array}{l}70.11 \\
73.46 \\
70.58 \\
74.38 \\
73.50\end{array}$ & $\begin{array}{l}<.15 \\
<.17 \\
<.17 \\
<.19 \\
<.18\end{array}$ & $\begin{array}{r}64.0 \\
140.0 \\
27.0 \\
130.0 \\
46.0\end{array}$ & $\begin{array}{r}<.96 \\
<1.10 \\
6.90 \\
<1.60 \\
2.00\end{array}$ & $\begin{array}{l}<.64 \\
<.75 \\
<1.00 \\
<1.10 \\
<.73\end{array}$ & $\begin{array}{l}1.80 \\
2.40 \\
5.00 \\
4.30 \\
2.40\end{array}$ & $\begin{array}{r}24.00 \\
28.00 \\
3.00 \\
18.00 \\
32.00\end{array}$ \\
\hline $\begin{array}{l}27 \\
28 \\
29 \\
30 \\
31\end{array}$ & $\begin{array}{l}06 / 20 / 86 \\
06 / 20 / 86 \\
06 / 20 / 86 \\
06 / 20 / 86 \\
06 / 24 / 86\end{array}$ & $\begin{array}{l}\text { CARSON } \\
\text { CARSON } \\
\text { CARSON } \\
\text { CARSON } \\
\text { CARSON }\end{array}$ & 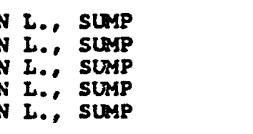 & $\begin{array}{l}\text { BIRD } \\
\text { BIRD } \\
\text { BIRD } \\
\text { BIRD } \\
\text { BIRD }\end{array}$ & $\begin{array}{l}\text { AVOCET } \\
\text { AVOCET } \\
\text { AVOCET } \\
\text { AVOCET } \\
\text { AVOCET }\end{array}$ & $\begin{array}{l}73.42 \\
75.84 \\
74.03 \\
73.90 \\
73.01\end{array}$ & $\begin{array}{r}<.18 \\
<.19 \\
<.18 \\
<.19 \\
<.17\end{array}$ & $\begin{array}{r}89.0 \\
39.0 \\
42.0 \\
170.0 \\
-0\end{array}$ & $\begin{array}{r}22.00 \\
3.30 \\
21.00 \\
2.00 \\
-\end{array}$ & 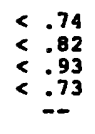 & $\begin{array}{l}2.00 \\
2.40 \\
3.90 \\
2.90 \\
7.70\end{array}$ & $\begin{array}{r}9.70 \\
18.00 \\
17.00 \\
8.60 \\
8.60\end{array}$ \\
\hline $\begin{array}{r}87628 \\
87650 \\
43 \\
44 \\
45\end{array}$ & $\begin{array}{l}08 / 06 / 87 \\
08 / 10 / 87 \\
07 / 10 / 86 \\
07 / 10 / 86 \\
07 / 10 / 86\end{array}$ & $\begin{array}{l}\text { CARSON } \\
\text { CARSON } \\
\text { CARSON } \\
\text { CARSON } \\
\text { CARSON }\end{array}$ & 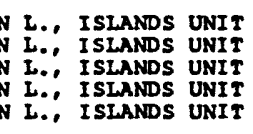 & $\begin{array}{l}\text { BIRD } \\
\text { BIRD } \\
\text { BIRD } \\
\text { BIRD } \\
\text { BIRD }\end{array}$ & $\begin{array}{l}\text { BN STILT } \\
\text { BN STILT } \\
\text { BN STILT } \\
\text { BN STILT } \\
\text { BN STIIT }\end{array}$ & $\begin{array}{l}69.60 \\
70.70 \\
72.69 \\
71.79 \\
70.31\end{array}$ & $\begin{array}{l}<.20 \\
<.20 \\
<.17 \\
<.16 \\
.17\end{array}$ & $\begin{array}{r}<2.0 \\
<2.0 \\
<18.0 \\
180.0 \\
66.0\end{array}$ & $\begin{array}{l}<1.00 \\
<1.00 \\
<1.10 \\
<1.00 \\
<.99\end{array}$ & $\begin{array}{l}<4.00 \\
<4.00 \\
<.72 \\
<.70 \\
<. .66\end{array}$ & $\begin{array}{r}9.04 \\
10.30 \\
5.70 \\
3.60 \\
6.50\end{array}$ & $\begin{array}{l}4.40 \\
9.70 \\
6.50 \\
3.90 \\
7.60\end{array}$ \\
\hline $\begin{array}{r}46 \\
47 \\
87610 \\
87611 \\
48\end{array}$ & $\begin{array}{l}07 / 10 / 86 \\
07 / 10 / 86 \\
07 / 30 / 87 \\
07 / 30 / 87 \\
07 / 10 / 86\end{array}$ & $\begin{array}{l}\text { CARSON } \\
\text { CARSON } \\
\text { CARSON } \\
\text { CARSON } \\
\text { CARSON }\end{array}$ & 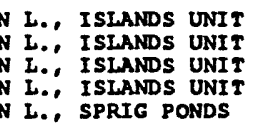 & $\begin{array}{l}\text { BIRD } \\
\text { BIRD } \\
\text { BIRD } \\
\text { BIRD } \\
\text { BIRD }\end{array}$ & $\begin{array}{l}\text { BN STILT } \\
\text { BN STILT } \\
\text { BN STILT } \\
\text { BN STILT } \\
\text { BN STILT }\end{array}$ & $\begin{array}{l}72.86 \\
72.01 \\
72.70 \\
72.10 \\
71.73\end{array}$ & $\begin{array}{l}<.18 \\
<.17 \\
<.20 \\
<.20 \\
<.16\end{array}$ & $\begin{array}{r}110.0 \\
150.0 \\
4.0 \\
4.0 \\
61.0\end{array}$ & $\begin{array}{r}<1.10 \\
10.00 \\
<1.00 \\
<1.00 \\
1.90\end{array}$ & $\begin{array}{l}<.71 \\
<.70 \\
<4.00 \\
<4.00 \\
<.70\end{array}$ & $\begin{array}{l}5.70 \\
3.70 \\
3.80 \\
7.97 \\
6.50\end{array}$ & $\begin{array}{l}5.70 \\
5.70 \\
3.60 \\
4.40 \\
8.80\end{array}$ \\
\hline $\begin{array}{r}49 \\
50 \\
68 \\
71 \\
87621\end{array}$ & $\begin{array}{l}07 / 10 / 86 \\
07 / 11 / 86 \\
07 / 15 / 86 \\
07 / 16 / 86 \\
08 / 04 / 87\end{array}$ & $\begin{array}{l}\text { CARSON } \\
\text { CARSON } \\
\text { CARSON } \\
\text { CARSON } \\
\text { CARSON }\end{array}$ & $\begin{array}{l}\text { N I.. SPRIG PONDS } \\
N \text { L.. SPRIG PONDS } \\
N \text { I.. SPRIG PONDS } \\
N \text { I.. SPRIG PONDS } \\
\text { N I.. SPRIG PONDS }\end{array}$ & $\begin{array}{l}\text { BIRD } \\
\text { BIRD } \\
\text { BIRD } \\
\text { BIRD } \\
\text { BIRD }\end{array}$ & $\begin{array}{l}\text { BN STILT } \\
\text { BN STILT } \\
\text { BN STIIT } \\
\text { BN STILT } \\
\text { BN STIIT }\end{array}$ & $\begin{array}{l}70.86 \\
71.73 \\
71.67 \\
71.11 \\
73.00\end{array}$ & $\begin{array}{l}<.16 \\
<.17 \\
<.15 \\
<.16 \\
.20\end{array}$ & $\begin{array}{r}44.0 \\
<17.0 \\
43.0 \\
45.0 \\
<2.0\end{array}$ & $\begin{array}{r}<1.00 \\
<1.00 \\
<1.00 \\
1.90 \\
<1.00\end{array}$ & $\begin{array}{l}<.68 \\
<.70 \\
<.68 \\
<.68 \\
<4.00\end{array}$ & $\begin{array}{r}6.00 \\
11.00 \\
12.00 \\
7.80 \\
15.20\end{array}$ & $\begin{array}{l}26.00 \\
14.00 \\
13.00 \\
13.00 \\
11.00\end{array}$ \\
\hline $\begin{array}{r}87626 \\
87627 \\
87684 \\
51 \\
52\end{array}$ & $\begin{array}{l}08 / 06 / 87 \\
08 / 06 / 87 \\
08 / 24 / 87 \\
07 / 11 / 86 \\
07 / 11 / 86\end{array}$ & $\begin{array}{l}\text { CARSON } \\
\text { CARSON } \\
\text { CARSON } \\
\text { CARSON } \\
\text { CARSON }\end{array}$ & 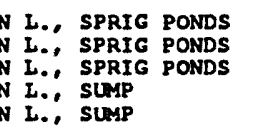 & $\begin{array}{l}\text { BIRD } \\
\text { BIRD } \\
\text { BIRD } \\
\text { BIRD } \\
\text { BIRD }\end{array}$ & $\begin{array}{l}\text { BN STILT } \\
\text { BN STILT } \\
\text { BN STILT } \\
\text { BN STILT } \\
\text { BN STILT }\end{array}$ & $\begin{array}{l}71.30 \\
72.10 \\
69.60 \\
70.95 \\
72.42\end{array}$ & $\begin{array}{l}<.20 \\
<.20 \\
<.20 \\
<.17 \\
<.18\end{array}$ & $\begin{array}{l}<2.0 \\
<2.0 \\
<2.0 \\
<17.0 \\
210.0\end{array}$ & $\begin{array}{l}<1.00 \\
<1.00 \\
<1.00 \\
<1.00 \\
4.80\end{array}$ & $\begin{array}{l}<4.00 \\
<4.00 \\
<4.00 \\
<.67 \\
<.72\end{array}$ & $\begin{array}{r}15.90 \\
12.00 \\
21.20 \\
7.10 \\
4.60\end{array}$ & $\begin{array}{r}5.60 \\
16.00 \\
6.00 \\
6.50 \\
8.30\end{array}$ \\
\hline $\begin{array}{l}53 \\
63 \\
64 \\
98 \\
99\end{array}$ & $\begin{array}{l}07 / 11 / 86 \\
07 / 15 / 86 \\
07 / 15 / 86 \\
07 / 31 / 86 \\
07 / 31 / 86\end{array}$ & $\begin{array}{l}\text { CARSON } \\
\text { CARSON } \\
\text { CARSON } \\
\text { FERNLE } \\
\text { FERNLE: }\end{array}$ & 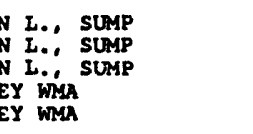 & $\begin{array}{l}\text { BIRD } \\
\text { BIRD } \\
\text { BIRD } \\
\text { BIRD } \\
\text { BIRD }\end{array}$ & $\begin{array}{l}\text { BN STILT } \\
\text { BN STILT } \\
\text { BN STILT } \\
\text { BN STILT } \\
\text { BN STILT }\end{array}$ & $\begin{array}{l}72.29 \\
71.76 \\
73.08 \\
72.62 \\
70.45\end{array}$ & $\begin{array}{l}<.17 \\
<.17 \\
<.18 \\
<.18 \\
<.17\end{array}$ & $\begin{array}{r}110.0 \\
47.0 \\
54.0 \\
19.0 \\
81.0\end{array}$ & $\begin{array}{r}5.80 \\
<1.00 \\
8.80 \\
2.30 \\
20.00\end{array}$ & $\begin{array}{l}<.71 \\
<.69 \\
<.73 \\
<.71 \\
1.50\end{array}$ & $\begin{array}{r}6.40 \\
7.80 \\
6.00 \\
1.32 \\
1.30\end{array}$ & $\begin{array}{r}10.00 \\
8.60 \\
8.80 \\
37.00 \\
16.00\end{array}$ \\
\hline $\begin{array}{r}100 \\
116 \\
117 \\
07663 \\
123\end{array}$ & $\begin{array}{l}07 / 31 / 86 \\
08 / 03 / 86 \\
08 / 03 / 86 \\
08 / 12 / 87 \\
08 / 04 / 86\end{array}$ & $\begin{array}{l}\text { FERNLE: } \\
\text { FERNLE } \\
\text { FERNLE } \\
\text { FERNLE } \\
\text { HWMA, }\end{array}$ & $\begin{array}{l}\text { EY WMA } \\
\text { EY WMA } \\
\text { EY WMA } \\
\text { EY WMA } \\
\text { HUMBOLDT IAKE }\end{array}$ & $\begin{array}{l}\text { BIRD } \\
\text { BIRD } \\
\text { BIRD } \\
\text { BIRD } \\
\text { BIRD }\end{array}$ & $\begin{array}{l}\text { BN STILT } \\
\text { BN STIIT } \\
\text { BN STILT } \\
\text { BN STILT } \\
\text { BN STILT }\end{array}$ & $\begin{array}{l}70.75 \\
72.03 \\
70.65 \\
70.70 \\
72.45\end{array}$ & $\begin{array}{r}.23 \\
<.17 \\
<.16 \\
<.20 \\
<.17\end{array}$ & $\begin{array}{l}19.0 \\
28.0 \\
39.0 \\
<2.0 \\
24.0\end{array}$ & $\begin{array}{l}1.40 \\
<1.00 \\
<1.00 \\
<1.00 \\
<1.10\end{array}$ & $\begin{array}{r}<.68 \\
2.80 \\
1.90 \\
<4.00 \\
<.72\end{array}$ & $\begin{array}{r}.72 \\
.57 \\
.43 \\
1.80 \\
4.40\end{array}$ & $\begin{array}{l}25.00 \\
36.00 \\
31.00 \\
14.20 \\
34.00\end{array}$ \\
\hline $\begin{array}{r}124 \\
125 \\
126 \\
127 \\
87612\end{array}$ & $\begin{array}{l}08 / 04 / 86 \\
08 / 04 / 86 \\
08 / 04 / 86 \\
08 / 04 / 86 \\
07 / 30 / 87\end{array}$ & $\begin{array}{l}\text { HWMA, } \\
\text { HWMA, } \\
\text { HWMA, } \\
\text { HWMA, } \\
\text { HWMA, }\end{array}$ & $\begin{array}{l}\text { HUMBOLDT LAKE } \\
\text { HUMBOIDT LAKE } \\
\text { HUMBOIDT LAKE } \\
\text { HUMBOLDT LAKE } \\
\text { HUMBOLDT LAKE }\end{array}$ & $\begin{array}{l}\text { BIRD } \\
\text { BIRD } \\
\text { BIRD } \\
\text { BIRD } \\
\text { BIRD }\end{array}$ & $\begin{array}{l}\text { BN STILT } \\
\text { BN STILT } \\
\text { BN STILT } \\
\text { BN STILT } \\
\text { BN STILT }\end{array}$ & $\begin{array}{l}74.21 \\
72.19 \\
72.38 \\
71.94 \\
74.90\end{array}$ & $\begin{array}{l}<.18 \\
<.17 \\
<.18 \\
<.17 \\
<.20\end{array}$ & $\begin{array}{r}25.0 \\
190.0 \\
110.0 \\
45.0 \\
2.0\end{array}$ & $\begin{array}{r}1.40 \\
1.90 \\
1.40 \\
2.60 \\
<1.00\end{array}$ & $\begin{array}{l}<.76 \\
<.81 \\
<.84 \\
<1.10 \\
<4.00\end{array}$ & $\begin{array}{r}.51 \\
.44 \\
.61 \\
.38 \\
2.50\end{array}$ & $\begin{array}{l}31.00 \\
29.00 \\
12.00 \\
29.00 \\
11.00\end{array}$ \\
\hline $\begin{array}{l}87613 \\
87614 \\
87668 \\
87669 \\
87664\end{array}$ & $\begin{array}{l}07 / 30 / 87 \\
07 / 30 / 87 \\
08 / 12 / 87 \\
08 / 12 / 87 \\
08 / 12 / 87\end{array}$ & $\begin{array}{l}\text { HWMA, } \\
\text { HWMA, } \\
\text { HWMA, } \\
\text { HWMA, } \\
\text { HWNA, }\end{array}$ & $\begin{array}{l}\text { HUMBOLDT LAKE } \\
\text { HUMBOIDT IAKE } \\
\text { HUMBOLDT LAKE } \\
\text { HUMBOIDT IAKE } \\
\text { TOULON LAKE }\end{array}$ & $\begin{array}{l}\text { BIRD } \\
\text { BIRD } \\
\text { BIRD } \\
\text { BIRD } \\
\text { BIRD }\end{array}$ & $\begin{array}{l}\text { BN STILT } \\
\text { BN STILT } \\
\text { BN STILT } \\
\text { BN STILT } \\
\text { BN STILT }\end{array}$ & $\begin{array}{l}73.30 \\
76.20 \\
71.10 \\
71.20 \\
69.40\end{array}$ & $\begin{array}{l}<.20 \\
<.20 \\
<.20 \\
<.20 \\
<.20\end{array}$ & $\begin{array}{l}<2.0 \\
<2.0 \\
<2.0 \\
<2.0 \\
<2.0\end{array}$ & $\begin{array}{l}<1.00 \\
<1.00 \\
<1.00 \\
<1.00 \\
<1.00\end{array}$ & $\begin{array}{l}<4.00 \\
<4.00 \\
<4.00 \\
<4.00 \\
<4.00\end{array}$ & $\begin{array}{l}2.40 \\
1.90 \\
2.10 \\
2.40 \\
2.70\end{array}$ & $\begin{array}{l}31.00 \\
48.00 \\
32.00 \\
23.00 \\
12.00\end{array}$ \\
\hline $\begin{array}{r}87665 \\
87666 \\
87667 \\
108 \\
109\end{array}$ & $\begin{array}{l}08 / 12 / 87 \\
08 / 12 / 87 \\
08 / 12 / 87 \\
07 / 31 / 86 \\
07 / 31 / 86\end{array}$ & $\begin{array}{l}\text { HWMA, } \\
\text { HWMA, } \\
\text { HWMA, } \\
\text { SWMA, } \\
\text { SWMA, }\end{array}$ & $\begin{array}{l}\text { TOULON LAKE } \\
\text { TOULON LAKE } \\
\text { TOULON LAKE } \\
\text { GOOSE IAKE } \\
\text { GOOSE LAKE }\end{array}$ & $\begin{array}{l}\text { BIRD } \\
\text { BIRD } \\
\text { BIRD } \\
\text { BIRD } \\
\text { BIRD }\end{array}$ & $\begin{array}{l}\text { BN STILT } \\
\text { BN STILI } \\
\text { BN STILT } \\
\text { BN STILT } \\
\text { BN STILT }\end{array}$ & $\begin{array}{l}70.70 \\
71.60 \\
71.40 \\
73.11 \\
72.36\end{array}$ & $\begin{array}{r}<.20 \\
<.20 \\
<.20 \\
.64 \\
.30\end{array}$ & $\begin{array}{r}<2.0 \\
<2.0 \\
<2.0 \\
<44.0 \\
<40.0\end{array}$ & $\begin{array}{l}<1.00 \\
<1.00 \\
<1.00 \\
10.00\end{array}$ & $\begin{array}{l}<4.00 \\
<4.00 \\
<4.00 \\
<.44 \\
<.40\end{array}$ & $\begin{array}{r}2.80 \\
3.10 \\
2.20 \\
11.00 \\
.85\end{array}$ & $\begin{array}{l}19.00 \\
17.50 \\
26.00 \\
29.00 \\
24.00\end{array}$ \\
\hline
\end{tabular}


TABLE 19.--Data on trace-element const1tuents and percent molsture of b10logical samples 1n st111water W1Id11fe Management Area, Carson Lake, Ferniey w1ldilfe Management Area, and Humboldt wildlife Management Area, $1985-87-C o n t$.

\begin{tabular}{|c|c|c|c|c|c|c|c|c|c|c|c|c|}
\hline $\begin{array}{l}\text { UsFws } \\
\text { local } \\
\text { ID } \\
\text { number }\end{array}$ & Dete & & Location & $\begin{array}{l}\text { Cate- } \\
\text { gory }\end{array}$ & Specles & $\begin{array}{l}\text { Percent } \\
\text { molsture }\end{array}$ & $\begin{array}{l}\text { Arse- } \\
\text { nic }\end{array}$ & Boron & $\begin{array}{l}\text { Chro- } \\
\text { m1um }\end{array}$ & Lead & $\begin{array}{l}\text { Mer- } \\
\text { cury }\end{array}$ & $\begin{array}{l}\text { sele- } \\
\text { n1um }\end{array}$ \\
\hline $\begin{array}{r}110 \\
111 \\
112 \\
97105 \\
67107\end{array}$ & $\begin{array}{l}07 / 31 / 86 \\
07 / 31 / 86 \\
07 / 31 / 86 \\
07 / 13 / 87 \\
07 / 13 / 87\end{array}$ & $\begin{array}{l}\text { swakd, } \\
\text { swayk, } \\
\text { swak, } \\
\text { swayk, } \\
\text { swark, }\end{array}$ & $\begin{array}{l}\text { coOsE IAKE } \\
\text { GoOsE IAKE } \\
\text { GOOSE IAKE } \\
\text { GOOSE LAKE } \\
\text { coOsE IAKE }\end{array}$ & $\begin{array}{l}\text { BIRD } \\
\text { BIRD } \\
\text { BIRD } \\
\text { BIRD } \\
\text { BIRD }\end{array}$ & $\begin{array}{l}\text { BN STILT } \\
\text { BN STILT } \\
\text { BN STILT } \\
\text { BN STILT } \\
\text { BN STILT }\end{array}$ & $\begin{array}{l}74.19 \\
74.20 \\
75.47 \\
73.80 \\
73.40\end{array}$ & $\begin{array}{r}0.45 \\
.45 \\
.42 \\
<.20 \\
<.20\end{array}$ & $\begin{array}{r}87.0 \\
75.0 \\
56.0 \\
3.0 \\
4.0\end{array}$ & $\begin{array}{c}6.00 \\
=- \\
01.00 \\
<1.00\end{array}$ & $\begin{array}{r}<0.37 \\
<.38 \\
<.39 \\
<4.00 \\
<4.00\end{array}$ & $\begin{array}{r}1.20 \\
5.10 \\
.78 \\
.61 \\
1.20\end{array}$ & $\begin{array}{r}12.00 \\
22.00 \\
22.00 \\
7.50 \\
6.40\end{array}$ \\
\hline $\begin{array}{r}87109 \\
87111 \\
87116 \\
80 \\
82\end{array}$ & $\begin{array}{l}07 / 13 / 87 \\
07 / 13 / 87 \\
07 / 13 / 87 \\
07 / 24 / 86 \\
07 / 25 / 86\end{array}$ & $\begin{array}{l}\text { swan, } \\
\text { shan, } \\
\text { swak, } \\
\text { swer, I } \\
\text { swak, }\end{array}$ & $\begin{array}{l}\text { COOSE LAKE } \\
\text { GOOSE IAKE } \\
\text { GOOSE IAKE } \\
\text { LEAD LAKE } \\
\text { LEAD LAKE }\end{array}$ & $\begin{array}{l}\text { BIRD } \\
\text { BIRD } \\
\text { BIRD } \\
\text { BIRD } \\
\text { BIRD }\end{array}$ & $\begin{array}{l}\text { BN STILT } \\
\text { BN STILT } \\
\text { BN STILT } \\
\text { BN STILT } \\
\text { BN STILT }\end{array}$ & $\begin{array}{l}73.90 \\
74.60 \\
71.70 \\
72.69 \\
70.56\end{array}$ & $\begin{array}{l}<.20 \\
<.20 \\
<.20 \\
.25 \\
.27\end{array}$ & $\begin{array}{r}4.0 \\
5.0 \\
3.0 \\
79.0 \\
50.0\end{array}$ & $\begin{array}{c}<1.00 \\
<1.00 \\
<1.00 \\
\ldots \\
\ldots\end{array}$ & $\begin{array}{l}<4.00 \\
<4.00 \\
<4.00 \\
<.36 \\
<.33\end{array}$ & $\begin{array}{r}.85 \\
.69 \\
2.00 \\
2.50 \\
2.70\end{array}$ & $\begin{array}{r}11.00 \\
7.00 \\
10.00 \\
13.00 \\
15.00\end{array}$ \\
\hline $\begin{array}{r}96 \\
87685 \\
87090 \\
87092 \\
87094\end{array}$ & $\begin{array}{l}07 / 30 / 86 \\
08 / 19 / 87 \\
07 / 13 / 87 \\
07 / 13 / 87 \\
07 / 13 / 87\end{array}$ & $\begin{array}{l}\text { swand, } \\
\text { swayd, } \\
\text { swash, } \\
\text { swan, } \\
\text { swen, }\end{array}$ & $\begin{array}{l}\text { LEAD IAKE } \\
\text { LEAD IAKE } \\
\text { PINTAIL BAY } \\
\text { PINTAIL BAY } \\
\text { PINTAII BAY }\end{array}$ & $\begin{array}{l}\text { BIRD } \\
\text { BIRD } \\
\text { BIRD } \\
\text { BIRD } \\
\text { BIRD }\end{array}$ & $\begin{array}{l}\text { BN STILT } \\
\text { BN STILT } \\
\text { BN STILT } \\
\text { BN STILT } \\
\text { BN STILT }\end{array}$ & $\begin{array}{l}72.55 \\
70.10 \\
71.80 \\
71.60 \\
72.60\end{array}$ & $\begin{array}{r}.19 \\
<.20 \\
.20 \\
<.20 \\
<.20\end{array}$ & $\begin{array}{r}53.0 \\
<2.0 \\
3.0 \\
3.0 \\
2.0\end{array}$ & $\begin{array}{l}<1.00 \\
<1.00 \\
<1.00 \\
<1.00\end{array}$ & $\begin{array}{l}<.35 \\
<4.00 \\
<4.00 \\
<4.00 \\
<4.00\end{array}$ & $\begin{array}{l}4.50 \\
7.12 \\
1.60 \\
.80 \\
.73\end{array}$ & $\begin{array}{r}27.00 \\
5.80 \\
4.90 \\
5.50 \\
5.40\end{array}$ \\
\hline $\begin{array}{r}87101 \\
101 \\
102 \\
87081 \\
87083\end{array}$ & $\begin{array}{l}07 / 13 / 87 \\
07 / 31 / 86 \\
07 / 31 / 86 \\
07 / 10 / 87 \\
07 / 10 / 87\end{array}$ & 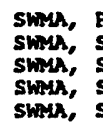 & $\begin{array}{l}\text { PINTAIL BAY } \\
\text { SOUTH IEAD WAKE } \\
\text { SOUTH LEAD LAKE } \\
\text { SOUTH IEAD IAKE } \\
\text { SOUTH LEAD LAKE }\end{array}$ & $\begin{array}{l}\text { BIRD } \\
\text { BIRD } \\
\text { BIRD } \\
\text { BIRD } \\
\text { BIRD }\end{array}$ & $\begin{array}{l}\text { BN STILT } \\
\text { BN STILT } \\
\text { BN STILT } \\
\text { BN STILT } \\
\text { BN STILT }\end{array}$ & $\begin{array}{l}72.80 \\
71.56 \\
74.69 \\
70.80 \\
73.00\end{array}$ & $\begin{array}{r}<.20 \\
.23 \\
.24 \\
<.20 \\
.40\end{array}$ & $\begin{array}{r}<2.0 \\
<57.0 \\
150.0 \\
2.0 \\
2.0\end{array}$ & $\begin{array}{c}<1.00 \\
-0 \\
<1.00 \\
<1.00\end{array}$ & $\begin{array}{r}<4.00 \\
<.57 \\
<.61 \\
<4.00 \\
<4.00\end{array}$ & $\begin{array}{l}.63 \\
1.70 \\
1.50 \\
1.40 \\
1.40\end{array}$ & $\begin{array}{l}6.10 \\
3.60 \\
4.10 \\
3.70 \\
4.20\end{array}$ \\
\hline $\begin{array}{l}87085 \\
87086 \\
87120 \\
87125 \\
87401\end{array}$ & $\begin{array}{l}07 / 10 / 87 \\
07 / 10 / 87 \\
07 / 20 / 87 \\
07 / 20 / 87 \\
04 / 09 / 87\end{array}$ & $\begin{array}{l}\text { Swan, } \\
\text { Swivd, } \\
\text { SwMA, } \\
\text { SWMA, } \\
\text { CARSÓN }\end{array}$ & $\begin{array}{l}\text { SOUTH LEAD LAKE } \\
\text { SOUTH IEAD LAKE } \\
\text { SOUTH IEAD LAKE } \\
\text { SOUTH IEAD IAKE } \\
\text { N I., ISLANDS UNIT }\end{array}$ & $\begin{array}{l}\text { BIRD } \\
\text { BIRD } \\
\text { BIRD } \\
\text { BIRD } \\
\text { BIRD }\end{array}$ & $\begin{array}{l}\text { BN STILT } \\
\text { BN STILT } \\
\text { BN STILT } \\
\text { BN STILT } \\
\text { BN STILT AD }\end{array}$ & $\begin{array}{l}71.00 \\
70.70 \\
71.40 \\
73.60 \\
71.50\end{array}$ & $\begin{array}{r}.20 \\
<.20 \\
<.30 \\
<.20 \\
<.20\end{array}$ & $\begin{aligned}<2.0 \\
<2.0 \\
3.0 \\
2.0 \\
2.0\end{aligned}$ & $\begin{array}{l}<1.00 \\
<1.00 \\
<1.00 \\
<1.00 \\
<1.00\end{array}$ & $\begin{array}{l}<4.00 \\
<4.00 \\
<4.00 \\
<4.00 \\
<4.00\end{array}$ & $\begin{array}{l}1.50 \\
1.80 \\
2.60 \\
1.40 \\
9.76\end{array}$ & $\begin{array}{r}1.20 \\
5.00 \\
7.30 \\
7.80 \\
11.00\end{array}$ \\
\hline $\begin{array}{l}87402 \\
87403 \\
87404 \\
87405 \\
87104\end{array}$ & $\begin{array}{l}04 / 09 / 87 \\
04 / 09 / 87 \\
04 / 09 / 87 \\
04 / 09 / 87 \\
07 / 13 / 87\end{array}$ & $\begin{array}{l}\text { CARSON } \\
\text { CARSON } \\
\text { CARSON } \\
\text { CARSON } \\
\text { SWAR, }\end{array}$ & $\begin{array}{l}\text { N L., I I ILANDS UNIT } \\
\text { N } 2 ., \text { ISIANDS UNIT } \\
\text { N L.. I I ILANDS UNIT } \\
\text { N I..' I ILANDS UNIT } \\
\text { GOOSE IAKE }\end{array}$ & $\begin{array}{l}\text { BIRD } \\
\text { BIRD } \\
\text { BIRD } \\
\text { BIRD } \\
\text { BIRD }\end{array}$ & $\begin{array}{l}\text { BN STILT AD } \\
\text { BN STILT AD } \\
\text { BN STILT AD } \\
\text { BN STILT AD } \\
\text { BN STILT AD }\end{array}$ & $\begin{array}{l}72.40 \\
68.70 \\
68.80 \\
70.40 \\
69.10\end{array}$ & $\begin{array}{l}<.20 \\
<.20 \\
<.20 \\
<.20 \\
<.20\end{array}$ & $\begin{array}{r}2.0 \\
3.0 \\
<2.0 \\
2.0 \\
4.0\end{array}$ & $\begin{array}{l}<1.00 \\
<1.00 \\
<1.00 \\
<1.00 \\
<1.00\end{array}$ & $\begin{array}{l}<4.00 \\
<4.00 \\
<4.00 \\
<4.00 \\
<4.00\end{array}$ & $\begin{array}{r}11.00 \\
3.70 \\
3.70 \\
2.70 \\
2.60\end{array}$ & $\begin{array}{r}13.00 \\
11.00 \\
10.00 \\
5.60 \\
15.00\end{array}$ \\
\hline $\begin{array}{l}87113 \\
87114 \\
87115 \\
87089 \\
87095\end{array}$ & $\begin{array}{l}07 / 13 / 87 \\
07 / 13 / 87 \\
07 / 13 / 87 \\
07 / 13 / 87 \\
07 / 13 / 87\end{array}$ & $\begin{array}{l}\text { swan, } \\
\text { swer, } \\
\text { swer, } \\
\text { swer, } \\
\text { swer, }\end{array}$ & $\begin{array}{l}\text { GOOSE LAKE } \\
\text { GOOSE IAKE } \\
\text { GOOSE LAKE } \\
\text { PINTAII BAY } \\
\text { PINTAII BAY }\end{array}$ & $\begin{array}{l}\text { BIRD } \\
\text { BIRD } \\
\text { BIRD } \\
\text { BIRD } \\
\text { BIRD }\end{array}$ & $\begin{array}{l}\text { BN STILT } \mathbf{A D} \\
\text { BN STILT } \mathrm{AD} \\
\mathrm{BN} \text { STILT AD } \\
\text { BN STILT } \mathrm{AD} \\
\mathrm{BN} \text { STILT } \mathrm{AD}\end{array}$ & $\begin{array}{l}68.30 \\
67.30 \\
69.50 \\
69.60 \\
70.20\end{array}$ & $\begin{array}{l}<.20 \\
<.20 \\
<.20 \\
<.20 \\
<.20\end{array}$ & $\begin{array}{r}3.0 \\
4.0 \\
3.0 \\
<2.0 \\
4.0\end{array}$ & $\begin{array}{l}<1.00 \\
<1.00 \\
<1.00 \\
<1.00 \\
<1.00\end{array}$ & $\begin{array}{l}<4.00 \\
<4.00 \\
<5.00 \\
<4.00 \\
<4.00\end{array}$ & $\begin{array}{l}2.60 \\
6.19 \\
1.90 \\
7.38 \\
4.10\end{array}$ & $\begin{array}{r}20.00 \\
17.00 \\
18.00 \\
8.30 \\
15.00\end{array}$ \\
\hline $\begin{array}{l}87096 \\
87097 \\
87098 \\
87099 \\
87079\end{array}$ & $\begin{array}{l}07 / 13 / 87 \\
07 / 13 / 87 \\
07 / 13 / 87 \\
07 / 13 / 87 \\
07 / 10 / 87\end{array}$ & 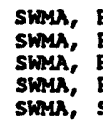 & $\begin{array}{l}\text { PINTAIL BAY } \\
\text { PINTAIL BAY } \\
\text { PINTAIL BAY } \\
\text { PINTAIL BAY } \\
\text { SOUTH LEAD LAKE }\end{array}$ & $\begin{array}{l}\text { BIRD } \\
\text { BIRD } \\
\text { BIRD } \\
\text { BIRD } \\
\text { BIRD }\end{array}$ & 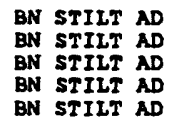 & $\begin{array}{l}69.30 \\
68.70 \\
70.20 \\
70.00 \\
70.00\end{array}$ & $\begin{array}{l}<.30 \\
<.20 \\
<.20 \\
<.30 \\
<.60\end{array}$ & $\begin{array}{r}<2.0 \\
3.0 \\
2.0 \\
2.0 \\
2.0\end{array}$ & $\begin{array}{l}<1.00 \\
<1.00 \\
<1.00 \\
<1.00 \\
<1.00\end{array}$ & $\begin{array}{l}<4.00 \\
<4.00 \\
<4.00 \\
<4.00 \\
<4.00\end{array}$ & $\begin{array}{l}3.10 \\
6.11 \\
4.00 \\
3.70 \\
5.68\end{array}$ & $\begin{array}{r}14.00 \\
13.00 \\
16.00 \\
17.00 \\
9.00\end{array}$ \\
\hline $\begin{array}{l}87080 \\
87119 \\
87124 \\
87550 \\
87551\end{array}$ & $\begin{array}{l}07 / 10 / 87 \\
07 / 16 / 87 \\
07 / 20 / 87 \\
07 / 14 / 87 \\
07 / 14 / 87\end{array}$ & $\begin{array}{l}\text { SWMA, } \\
\text { SWMA, } \\
\text { SWMA, } \\
\text { CARSON } \\
\text { CARSON }\end{array}$ & $\begin{array}{l}\text { SOUTH LEAD IAKE } \\
\text { SOUTH LEAD LAKE } \\
\text { SOUTH LEAD LAKE } \\
\text { N... DOWNS DRAIN } \\
\text { L.. DOWNS DRAIN }\end{array}$ & $\begin{array}{l}\text { BIRD } \\
\text { BIRD } \\
\text { BIRD } \\
\text { BIRD } \\
\text { BIRD }\end{array}$ & $\begin{array}{l}\text { BN STILT AD } \\
\text { BN STILT AD } \\
\text { BN STILT AD } \\
\text { COOT } \\
\text { COOT }\end{array}$ & $\begin{array}{l}68.40 \\
68.00 \\
72.90 \\
78.20 \\
77.70\end{array}$ & $\begin{array}{r}.20 \\
<.20 \\
<.20 \\
<.20 \\
.20\end{array}$ & $\begin{array}{l}<2.0 \\
<2.0 \\
<2.0 \\
7.1 \\
8.4\end{array}$ & $\begin{array}{l}<1.00 \\
<1.00 \\
<1.00 \\
<1.00 \\
<1.00\end{array}$ & $\begin{array}{l}<4.00 \\
<4.00 \\
<4.00 \\
<4.00 \\
<4.00\end{array}$ & $\begin{array}{l}9.09 \\
5.10 \\
2.20 \\
5.20 \\
4.10\end{array}$ & $\begin{array}{r}9.70 \\
7.60 \\
13.00 \\
5.80 \\
6.60\end{array}$ \\
\hline $\begin{array}{r}87552 \\
87553 \\
87554 \\
87555 \\
6\end{array}$ & $\begin{array}{l}07 / 14 / 87 \\
07 / 14 / 87 \\
07 / 14 / 87 \\
07 / 14 / 87 \\
06 / 03 / 86\end{array}$ & $\begin{array}{l}\text { CARSON } \\
\text { CARSON } \\
\text { CARSON } \\
\text { CARSON } \\
\text { CARSON }\end{array}$ & 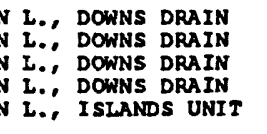 & $\begin{array}{l}\text { BIRD } \\
\text { BIRD } \\
\text { BIRD } \\
\text { BIRD } \\
\text { BIRD }\end{array}$ & $\begin{array}{l}\operatorname{coor} \\
\operatorname{coot} \\
\operatorname{coot} \\
\operatorname{coor} \\
\operatorname{coor}\end{array}$ & $\begin{array}{l}79.30 \\
75.20 \\
79.30 \\
78.90 \\
76.03\end{array}$ & $\begin{array}{l}<.20 \\
.20 \\
<.20 \\
<.20 \\
<.19\end{array}$ & $\begin{array}{r}8.1 \\
7.2 \\
5.0 \\
9.7 \\
120.0\end{array}$ & $\begin{array}{l}<1.00 \\
<1.00 \\
<1.00 \\
<1.00 \\
<1.20\end{array}$ & $\begin{array}{l}<4.00 \\
<4.00 \\
<4.00 \\
<4.00 \\
<.83\end{array}$ & $\begin{array}{l}3.10 \\
2.70 \\
6.27 \\
3.00 \\
1.80\end{array}$ & $\begin{array}{l}6.70 \\
7.60 \\
7.60 \\
6.60 \\
2.20\end{array}$ \\
\hline $\begin{array}{r}7 \\
8 \\
9 \\
10 \\
87606\end{array}$ & $\begin{array}{l}06 / 03 / 86 \\
06 / 03 / 86 \\
06 / 03 / 86 \\
06 / 03 / 86 \\
07 / 30 / 87\end{array}$ & $\begin{array}{l}\text { CARSON } \\
\text { CARSON } \\
\text { CARSON } \\
\text { CARSON } \\
\text { CARSON }\end{array}$ & 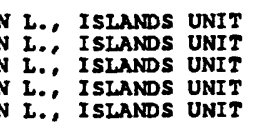 & $\begin{array}{l}\text { BIRD } \\
\text { BIRD } \\
\text { BIRD } \\
\text { BIRD } \\
\text { BIRD }\end{array}$ & $\begin{array}{l}\text { coor } \\
\text { coor } \\
\text { coor } \\
\text { coor } \\
\operatorname{coor}\end{array}$ & $\begin{array}{l}74.80 \\
73.80 \\
76.08 \\
77.02 \\
75.00\end{array}$ & $\begin{array}{r}.63 \\
.42 \\
<.20 \\
.26 \\
<.20\end{array}$ & $\begin{array}{r}10.0 \\
120.0 \\
120.0 \\
140.0 \\
3.0\end{array}$ & $\begin{array}{l}<1.20 \\
<1.10 \\
<1.20 \\
<1.30 \\
<1.00\end{array}$ & $\begin{array}{r}<.78 \\
<.76 \\
<.83 \\
<.84 \\
<4.00\end{array}$ & $\begin{array}{l}1.30 \\
3.10 \\
1.50 \\
1.10 \\
3.50\end{array}$ & $\begin{array}{l}3.40 \\
2.70 \\
3.60 \\
4.20 \\
2.30\end{array}$ \\
\hline $\begin{array}{l}87607 \\
87608 \\
87609 \\
87623 \\
87624\end{array}$ & $\begin{array}{l}07 / 30 / 87 \\
07 / 30 / 87 \\
07 / 30 / 87 \\
08 / 04 / 87 \\
08 / 04 / 87\end{array}$ & $\begin{array}{l}\text { CARSON } \\
\text { CARSON } \\
\text { CARSON } \\
\text { CARSON } \\
\text { CARSON }\end{array}$ & $\begin{array}{lll}N & \text { L., I I SLANDS UNIT } \\
N & \mathrm{~L} ., & \text { I SLANDS UNIT } \\
N & \mathrm{~L} ., & \text { I SLANDS UNIT } \\
N & \mathrm{~L} ., & \text { JI DEEP DRAIN } \\
N & \mathrm{~L} ., & \text { JI DEEP DRAIN }\end{array}$ & $\begin{array}{l}\text { BIRD } \\
\text { BIRD } \\
\text { BIRD } \\
\text { BIRD } \\
\text { BIRD }\end{array}$ & $\begin{array}{l}\text { coot } \\
\text { coot } \\
\text { coot } \\
\text { coot } \\
\text { coot }\end{array}$ & $\begin{array}{l}74.20 \\
74.80 \\
75.50 \\
72.70 \\
74.00\end{array}$ & $\begin{array}{r}.20 \\
.20 \\
<.20 \\
<.20 \\
<.20\end{array}$ & $\begin{array}{l}5.0 \\
4.0 \\
4.0 \\
4.0 \\
4.0\end{array}$ & $\begin{array}{l}<1.00 \\
<1.00 \\
<1.00 \\
<1.00 \\
<1.00\end{array}$ & $\begin{array}{l}<4.00 \\
<4.00 \\
<4.00 \\
<4.00 \\
<4.00\end{array}$ & $\begin{array}{r}6.18 \\
2.80 \\
13.90 \\
5.10 \\
4.10\end{array}$ & $\begin{array}{l}2.60 \\
2.30 \\
2.90 \\
1.70 \\
1.00\end{array}$ \\
\hline
\end{tabular}




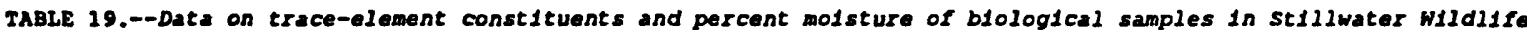
Management Area, Carson Lake, Fernley W1ldlife Management Area, and Humboldt Wildilfe Management Area, $1985-87-C o n t$.

\begin{tabular}{|c|c|c|c|c|c|c|c|c|c|c|c|}
\hline $\begin{array}{l}\text { UsFws } \\
\text { local } \\
\text { ID } \\
\text { number }\end{array}$ & Date & Iocation & $\begin{array}{l}\text { Cate- } \\
\text { gory }\end{array}$ & Species & $\begin{array}{l}\text { Percent } \\
\text { mo1sture }\end{array}$ & $\begin{array}{c}\text { Arse- } \\
\text { nic }\end{array}$ & Boron & $\begin{array}{l}\text { Chro- } \\
\text { m1 um }\end{array}$ & Lead & $\begin{array}{l}\text { Mer- } \\
\text { cury }\end{array}$ & $\begin{array}{l}\text { Sele- } \\
\text { nlum }\end{array}$ \\
\hline $\begin{array}{l}1 \\
2 \\
3 \\
1 \\
5\end{array}$ & $\begin{array}{l}06 / 03 / 86 \\
06 / 03 / 86 \\
06 / 03 / 86 \\
06 / 03 / 86 \\
06 / 03 / 86\end{array}$ & $\begin{array}{l}\text { CARSON L., SPRIG PONDS } \\
\text { CARSON L.: SPRIG PONDS } \\
\text { CARSON L.: SPRIG PONDS } \\
\text { CARSON L.: SPRIG PONDS } \\
\text { CARSON L., SPRIC PONDS }\end{array}$ & $\begin{array}{l}\text { BIRD } \\
\text { BIRD } \\
\text { BIRD } \\
\text { BIRD } \\
\text { BIRD }\end{array}$ & $\begin{array}{l}\text { coor } \\
\text { coot } \\
\text { COOT } \\
\text { COOT } \\
\text { CoOT }\end{array}$ & $\begin{array}{l}73.18 \\
76.18 \\
74.60 \\
74.80 \\
74.05\end{array}$ & $\begin{array}{l}0.17 \\
.43 \\
.53 \\
.11 \\
.23\end{array}$ & $\begin{array}{l}74.0 \\
46.0 \\
67.0 \\
37.0 \\
40.0\end{array}$ & $\begin{array}{r}2.10 \\
<1.30 \\
<1.20 \\
<1.20 \\
<1.20\end{array}$ & $\begin{array}{l}<0.74 \\
<.84 \\
<.79 \\
<.79 \\
<.76\end{array}$ & $\begin{array}{r}9.70 \\
25.00 \\
9.00 \\
9.20 \\
1.90\end{array}$ & $\begin{array}{l}8.60 \\
3.70 \\
9.20 \\
1.90 \\
7.80\end{array}$ \\
\hline $\begin{array}{l}87603 \\
87622 \\
87641 \\
87642 \\
87643\end{array}$ & $\begin{array}{l}07 / 29 / 87 \\
08 / 04 / 87 \\
08 / 10 / 87 \\
08 / 10 / 87 \\
08 / 10 / 87\end{array}$ & $\begin{array}{l}\text { CARSON L., SPRIG PONDS } \\
\text { CARSON L., SPRIG PONDS } \\
\text { CARSON L., WEST LEE DRAIN } \\
\text { CARSON L., WEST LEE DRAIN } \\
\text { CARSON L., WEST LEE DRAIN }\end{array}$ & $\begin{array}{l}\text { BIRD } \\
\text { BIRD } \\
\text { BIRD } \\
\text { BIRD } \\
\text { BIRD }\end{array}$ & $\begin{array}{l}\text { coor } \\
\text { coor } \\
\text { cooT } \\
\text { coor } \\
\text { coot }\end{array}$ & $\begin{array}{l}78.20 \\
75.30 \\
75.50 \\
74.60 \\
78.40\end{array}$ & $\begin{array}{r}.79 \\
.30 \\
<.20 \\
.20 \\
<.20\end{array}$ & $\begin{array}{l}1.0 \\
3.0 \\
2.0 \\
2.0 \\
8.2\end{array}$ & $\begin{array}{l}<1.00 \\
<1.00 \\
<1.00 \\
<1.00 \\
<1.00\end{array}$ & $\begin{array}{l}<4.00 \\
<4.00 \\
<4.00 \\
<4.00 \\
<4.00\end{array}$ & $\begin{array}{r}6.15 \\
9.27 \\
11.20 \\
6.06 \\
6.33\end{array}$ & $\begin{array}{l}5.20 \\
7.00 \\
1.80 \\
1.10 \\
2.90\end{array}$ \\
\hline $\begin{array}{r}87644 \\
87645 \\
87646 \\
138 \\
139\end{array}$ & $\begin{array}{l}08 / 10 / 87 \\
08 / 10 / 87 \\
08 / 10 / 87 \\
08 / 15 / 86 \\
08 / 15 / 86\end{array}$ & $\begin{array}{l}\text { CARSON I., WEST LEE DRAIN } \\
\text { CARSON L., WEST LEE DRAIN } \\
\text { CARSON L., WEST LEE DRAIN } \\
\text { CARSON VALLEY } \\
\text { CARSON VALLEY }\end{array}$ & $\begin{array}{l}\text { BIRD } \\
\text { BIRD } \\
\text { BIRD } \\
\text { BIRD } \\
\text { BIRD }\end{array}$ & $\begin{array}{l}\text { coor } \\
\text { coot } \\
\text { coot } \\
\text { coot } \\
\text { coor }\end{array}$ & $\begin{array}{l}75.80 \\
75.90 \\
75.60 \\
74.26 \\
75.00\end{array}$ & $\begin{array}{l}<.20 \\
<.20 \\
<.20 \\
.25 \\
<.29\end{array}$ & $\begin{array}{r}6.8 \\
2.0 \\
3.0 \\
<19.0 \\
30.0\end{array}$ & $\begin{array}{r}<1.00 \\
<1.00 \\
<1.00 \\
7.30 \\
8.00\end{array}$ & $\begin{array}{r}<4.00 \\
<4.00 \\
<4.00 \\
<.76 \\
<.80\end{array}$ & $\begin{array}{l}5.00 \\
3.50 \\
9.57 \\
1.00 \\
.68\end{array}$ & $\begin{array}{l}2.50 \\
1.80 \\
3.90 \\
1.10 \\
1.10\end{array}$ \\
\hline $\begin{array}{l}140 \\
141 \\
112 \\
133 \\
134\end{array}$ & $\begin{array}{l}08 / 15 / 86 \\
08 / 18 / 86 \\
08 / 18 / 86 \\
08 / 14 / 86 \\
08 / 14 / 86\end{array}$ & $\begin{array}{l}\text { CARSON VALLEY } \\
\text { CARSON VALLEY } \\
\text { CARSON VALLEY } \\
\text { FERNLEY WIA } \\
\text { FERNLEY WAA }\end{array}$ & $\begin{array}{l}\text { BIRD } \\
\text { BIRD } \\
\text { BIRD } \\
\text { BIRD } \\
\text { BIRD }\end{array}$ & $\begin{array}{l}\text { coor } \\
\text { coor } \\
\text { coor } \\
\text { coot } \\
\text { coor }\end{array}$ & $\begin{array}{l}76.27 \\
74.85 \\
75.14 \\
74.55 \\
74.01\end{array}$ & $\begin{array}{l}<.20 \\
.30 \\
<.28 \\
.72 \\
1.00\end{array}$ & $\begin{array}{r}<21.0 \\
37.0 \\
<20.0 \\
<20.0 \\
22.0\end{array}$ & $\begin{array}{r}8.30 \\
<2.00 \\
8.80 \\
<2.00 \\
2.50\end{array}$ & $\begin{array}{l}<.83 \\
<.78 \\
<.80 \\
<.78 \\
<.76\end{array}$ & $\begin{array}{r}.97 \\
.96 \\
.87 \\
<.17 \\
<.18\end{array}$ & $\begin{array}{l}1.70 \\
1.10 \\
1.20 \\
6.10 \\
5.90\end{array}$ \\
\hline $\begin{array}{r}135 \\
136 \\
137 \\
87483 \\
87583\end{array}$ & $\begin{array}{l}08 / 14 / 86 \\
08 / 24 / 86 \\
08 / 14 / 86 \\
07 / 06 / 87 \\
07 / 21 / 87\end{array}$ & $\begin{array}{l}\text { FERNLEY WM } \\
\text { FERNLEY WMA } \\
\text { FERNLEY WMA } \\
\text { HARMON RES. } \\
\text { HARSON RES. }\end{array}$ & $\begin{array}{l}\text { BIRD } \\
\text { BIRD } \\
\text { BIRD } \\
\text { BIRD } \\
\text { BIRD }\end{array}$ & $\begin{array}{l}\text { coor } \\
\text { coor } \\
\text { coor } \\
\text { coor } \\
\text { coot }\end{array}$ & $\begin{array}{l}78.58 \\
72.90 \\
75.63 \\
75.20 \\
78.30\end{array}$ & $\begin{array}{r}2.30 \\
.37 \\
.57 \\
<.20 \\
.20\end{array}$ & $\begin{array}{r}39.0 \\
<18.0 \\
24.0 \\
3.0 \\
3.0\end{array}$ & $\begin{array}{r}<2.30 \\
3.50 \\
<2.00 \\
<1.00 \\
<1.00\end{array}$ & $\begin{array}{r}<.92 \\
<.74 \\
<.81 \\
<4.00 \\
<4.00\end{array}$ & $\begin{array}{r}.10 \\
.17 \\
5.20 \\
3.80 \\
3.70\end{array}$ & $\begin{array}{l}8.90 \\
9.80 \\
7.30 \\
5.70 \\
3.30\end{array}$ \\
\hline $\begin{array}{r}87584 \\
87588 \\
87590 \\
87591 \\
128\end{array}$ & $\begin{array}{l}07 / 21 / 87 \\
07 / 27 / 87 \\
07 / 28 / 87 \\
07 / 28 / 87 \\
08 / 04 / 86\end{array}$ & $\begin{array}{l}\text { HARYON RES. } \\
\text { HARYON RES. } \\
\text { HARYON RES. } \\
\text { HARYON RES. } \\
\text { HWAA, HUMBOLDT LAKE }\end{array}$ & $\begin{array}{l}\text { BIRD } \\
\text { BIRD } \\
\text { BIRD } \\
\text { BIRD } \\
\text { BIRD }\end{array}$ & $\begin{array}{l}\text { coor } \\
\text { coor } \\
\text { coor } \\
\text { coor } \\
\text { coot }\end{array}$ & $\begin{array}{l}72.60 \\
75.10 \\
79.90 \\
76.10 \\
76.89\end{array}$ & $\begin{array}{l}<.20 \\
<.20 \\
<.20 \\
<.20 \\
.36\end{array}$ & $\begin{array}{r}3.0 \\
3.0 \\
3.0 \\
3.0 \\
<21.0\end{array}$ & $\begin{array}{l}<1.00 \\
<1.00 \\
<1.00 \\
<1.00 \\
<1.30\end{array}$ & $\begin{array}{l}<4.00 \\
<4.00 \\
<4.00 \\
<4.00 \\
<.84\end{array}$ & $\begin{array}{l}8.42 \\
5.64 \\
2.20 \\
6.70 \\
.41\end{array}$ & $\begin{array}{r}3.90 \\
5.20 \\
2.40 \\
1.60 \\
15.00\end{array}$ \\
\hline $\begin{array}{r}119 \\
120 \\
121 \\
122 \\
87478\end{array}$ & $\begin{array}{l}08 / 04 / 86 \\
08 / 07 / 86 \\
08 / 04 / 86 \\
08 / 04 / 86 \\
07 / 02 / 87\end{array}$ & $\begin{array}{l}\text { HWMA, HUMBOLDT LAKE } \\
\text { HWMA, HUMBOLDT LAKE } \\
\text { HWMA, HUMBOLDT LAKE } \\
\text { HWMA, HUMBOLDT LAKE } \\
\text { HWMA, TOULON LAKE }\end{array}$ & $\begin{array}{l}\text { BIRD } \\
\text { BIRD } \\
\text { BIRD } \\
\text { BIRD } \\
\text { BIRD }\end{array}$ & $\begin{array}{l}\text { coot } \\
\text { coOT } \\
\text { coOT } \\
\text { coOT } \\
\text { coot }\end{array}$ & $\begin{array}{l}75.67 \\
72.78 \\
76.64 \\
74.85 \\
74.30\end{array}$ & $\begin{array}{r}.39 \\
.10 \\
.65 \\
.36 \\
<.20\end{array}$ & $\begin{array}{r}39.0 \\
73.0 \\
17.0 \\
51.0 \\
2.0\end{array}$ & $\begin{array}{l}<1.20 \\
<1.20 \\
<1.30 \\
<1.20 \\
<1.00\end{array}$ & $\begin{array}{l}<.79 \\
<.72 \\
<.85 \\
<.78 \\
<4.00\end{array}$ & $\begin{array}{l}.75 \\
.35 \\
.68 \\
.53 \\
.44\end{array}$ & $\begin{array}{r}9.30 \\
11.00 \\
12.00 \\
9.00 \\
7.00\end{array}$ \\
\hline $\begin{array}{l}87479 \\
87480 \\
87481 \\
87482 \\
87406\end{array}$ & $\begin{array}{l}07 / 02 / 87 \\
07 / 02 / 87 \\
07 / 02 / 87 \\
07 / 02 / 87 \\
06 / 19 / 87\end{array}$ & $\begin{array}{l}\text { HWMA, TOULON LAKE } \\
\text { HWMA, TOULON LAKE } \\
\text { HWMA, TOULON LAKE } \\
\text { HWMA, TOULON LAKE } \\
\text { MAHALA SLOUGH }\end{array}$ & $\begin{array}{l}\text { BIRD } \\
\text { BIRD } \\
\text { BIRD } \\
\text { BIRD } \\
\text { BIRD }\end{array}$ & $\begin{array}{l}\text { coOT } \\
\text { coOT } \\
\text { COOT } \\
\text { COOT } \\
\text { coOT }\end{array}$ & $\begin{array}{l}77.50 \\
76.90 \\
76.80 \\
80.20 \\
75.20\end{array}$ & $\begin{array}{l}<.20 \\
<.20 \\
<.20 \\
<.20 \\
<.20\end{array}$ & $\begin{array}{r}3.0 \\
<2.0 \\
1.0 \\
3.0 \\
9.1\end{array}$ & $\begin{array}{l}<1.00 \\
<1.00 \\
<1.00 \\
<1.00 \\
<1.00\end{array}$ & $\begin{array}{l}<4.00 \\
<4.00 \\
<4.00 \\
<4.00 \\
<4.00\end{array}$ & $\begin{array}{r}.20 \\
.55 \\
.19 \\
.14 \\
2.10\end{array}$ & $\begin{array}{r}9.60 \\
10.00 \\
10.00 \\
9.10 \\
34.00\end{array}$ \\
\hline $\begin{array}{l}87407 \\
87408 \\
8715 \\
87424 \\
87496\end{array}$ & $\begin{array}{l}06 / 19 / 87 \\
06 / 19 / 87 \\
06 / 25 / 87 \\
06 / 29 / 87 \\
07 / 08 / 87\end{array}$ & $\begin{array}{l}\text { MAHALA SLOUGH } \\
\text { MAHAIA SLOUGH } \\
\text { MAHAIA SLOUGH } \\
\text { MAHAIA SLOUGH } \\
\text { MASSIE SLOUGH }\end{array}$ & $\begin{array}{l}\text { BIRD } \\
\text { BIRD } \\
\text { BIRD } \\
\text { BIRD } \\
\text { BIRD }\end{array}$ & $\begin{array}{l}\text { COOT } \\
\text { COOT } \\
\text { COOT } \\
\text { COOT } \\
\text { COOT }\end{array}$ & $\begin{array}{l}76.30 \\
76.10 \\
72.70 \\
74.90 \\
74.50\end{array}$ & $\begin{array}{r}<.20 \\
<.20 \\
.20 \\
.20 \\
18.00\end{array}$ & $\begin{array}{r}13.0 \\
11.0 \\
13.0 \\
7.7 \\
5.0\end{array}$ & $\begin{array}{l}<1.00 \\
<1.00 \\
<1.00 \\
<1.00 \\
<1.00\end{array}$ & $\begin{array}{l}<4.00 \\
<4.00 \\
<4.00 \\
<4.00 \\
<4.00\end{array}$ & $\begin{array}{l}1.01 \\
1.50 \\
.72 \\
.79 \\
.14\end{array}$ & $\begin{array}{l}39.00 \\
29.00 \\
39.00 \\
28.00 \\
20.00\end{array}$ \\
\hline $\begin{array}{l}87497 \\
87498 \\
87499 \\
87500 \\
87501\end{array}$ & $\begin{array}{l}07 / 08 / 87 \\
07 / 08 / 87 \\
07 / 08 / 87 \\
07 / 08 / 87 \\
07 / 08 / 87\end{array}$ & $\begin{array}{l}\text { MASSIE SLOUGH } \\
\text { MASSIE SLOUGH } \\
\text { MASSIE SIOUGH } \\
\text { MASSIE SLOUGH } \\
\text { MASSIE SLOUGH }\end{array}$ & $\begin{array}{l}\text { BIRD } \\
\text { BIRD } \\
\text { BIRD } \\
\text { BIRD } \\
\text { BIRD }\end{array}$ & $\begin{array}{l}\text { COOT } \\
\text { COOT } \\
\text { COOT } \\
\text { COOT } \\
\text { COOT }\end{array}$ & $\begin{array}{l}73.40 \\
75.90 \\
75.20 \\
76.70 \\
75.70\end{array}$ & $\begin{array}{r}8.30 \\
22.00 \\
12.00 \\
34.00 \\
21.00\end{array}$ & $\begin{array}{r}5.0 \\
5.0 \\
6.3 \\
6.4 \\
6.6\end{array}$ & $\begin{array}{l}<2.00 \\
<1.00 \\
<1.00 \\
<1.00 \\
<1.00\end{array}$ & $\begin{array}{l}<4.00 \\
<4.00 \\
<4.00 \\
<4.00 \\
<4.00\end{array}$ & $\begin{array}{l}.30 \\
.29 \\
.29 \\
.21 \\
.40\end{array}$ & $\begin{array}{r}18.00 \\
9.20 \\
18.00 \\
32.00 \\
10.00\end{array}$ \\
\hline $\begin{array}{r}87502 \\
85 \\
86 \\
87 \\
88\end{array}$ & $\begin{array}{l}07 / 08 / 87 \\
07 / 24 / 86 \\
07 / 24 / 86 \\
07 / 24 / 86 \\
07 / 24 / 86\end{array}$ & $\begin{array}{l}\text { MASSIE SLOUGH } \\
\text { SWMA, ALKALI UN. } 1 \\
\text { SWMA, ALKALI UN. \$1 } \\
\text { SWMA, ALKALI UN. } 1 \\
\text { SWMA, ALKALI UN. } 1\end{array}$ & $\begin{array}{l}\text { BIRD } \\
\text { BIRD } \\
\text { BIRD } \\
\text { BIRD } \\
\text { BIRD }\end{array}$ & $\begin{array}{l}\text { coot } \\
\text { coOT } \\
\text { COOT } \\
\text { COOT } \\
\text { coOT }\end{array}$ & $\begin{array}{l}75.10 \\
75.73 \\
74.40 \\
77.22 \\
74.75\end{array}$ & $\begin{array}{l}9.30 \\
.26 \\
.21 \\
.50 \\
.62\end{array}$ & $\begin{array}{r}4.0 \\
44.0 \\
93.0 \\
57.0 \\
130.0\end{array}$ & $\begin{array}{r}<1.00 \\
1.80 \\
<1.20 \\
<1.30 \\
1.20\end{array}$ & $\begin{array}{l}<4.00 \\
<.81 \\
<.77 \\
<.86 \\
<.79\end{array}$ & $\begin{array}{r}.41 \\
1.70 \\
.36 \\
5.10 \\
3.20\end{array}$ & $\begin{array}{r}18.00 \\
6.00 \\
1.90 \\
6.60 \\
5.70\end{array}$ \\
\hline $\begin{array}{r}89 \\
87232 \\
87133 \\
103 \\
104\end{array}$ & $\begin{array}{l}07 / 24 / 86 \\
07 / 27 / 87 \\
07 / 27 / 87 \\
07 / 32 / 86 \\
07 / 31 / 86\end{array}$ & $\begin{array}{l}\text { SWMA, ALKALI UN. \$1 } \\
\text { SWMAA, DRY IAKE } \\
\text { SWMA, DRY LAKE } \\
\text { SWMA, GOOSE LAKE } \\
\text { SWMA, GOOSE LAKE }\end{array}$ & $\begin{array}{l}\text { BIRD } \\
\text { BIRD } \\
\text { BIRD } \\
\text { BIRD } \\
\text { BIRD }\end{array}$ & $\begin{array}{l}\text { coot } \\
\text { COOT } \\
\text { COOT } \\
\text { COOT } \\
\text { COOT }\end{array}$ & $\begin{array}{l}76.54 \\
72.70 \\
73.60 \\
78.10 \\
77.53\end{array}$ & $\begin{array}{l}1.30 \\
5.20 \\
5.20 \\
1.30 \\
1.30\end{array}$ & $\begin{array}{l}56.0 \\
13.0 \\
12.0 \\
180.0 \\
120.0\end{array}$ & $\begin{array}{c}<1.30 \\
<1.00 \\
<1.00 \\
\ldots-\end{array}$ & $\begin{array}{l}<0.85 \\
<4.00 \\
<4.00 \\
<.44 \\
<.14\end{array}$ & $\begin{array}{l}8.60 \\
1.50 \\
1.80 \\
.91 \\
.77\end{array}$ & $\begin{array}{r}4.70 \\
5.50 \\
4.40 \\
9.00 \\
12.00\end{array}$ \\
\hline
\end{tabular}




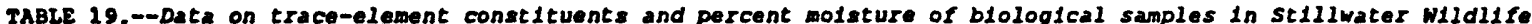
Management Area, Carson Lake, Fernley Wildlife Management Area, and Humboldt Wildlife Management Area, $1985-87--C o n t$.

\begin{tabular}{|c|c|c|c|c|c|c|c|c|c|c|c|c|c|}
\hline $\begin{array}{l}\text { USFWS } \\
\text { local } \\
\text { ID } \\
\text { number }\end{array}$ & Date & & Locat1on & $\begin{array}{l}\text { Cate- } \\
\text { gory }\end{array}$ & Specles & & $\begin{array}{l}\text { Percent } \\
\text { molst ure }\end{array}$ & $\begin{array}{c}\text { Arse- } \\
\text { nic }\end{array}$ & Boron & $\begin{array}{l}\text { Chro- } \\
\text { mitum }\end{array}$ & Lead & $\begin{array}{l}\text { Mer- } \\
\text { cury }\end{array}$ & $\begin{array}{l}\text { Sele- } \\
\text { niuna }\end{array}$ \\
\hline $\begin{array}{r}205 \\
206 \\
207 \\
34 \\
35\end{array}$ & $\begin{array}{l}07 / 31 / 86 \\
07 / 31 / 86 \\
07 / 31 / 86 \\
06 / 26 / 86 \\
06 / 26 / 86\end{array}$ & 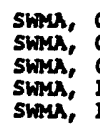 & $\begin{array}{l}\text { GOOSE LAKE } \\
\text { GOOSE LAKE } \\
\text { GOOSE LAKE } \\
\text { LEAD LAKE } \\
\text { LEAD LAKE }\end{array}$ & $\begin{array}{l}\text { BIRD } \\
\text { BIRD } \\
\text { BIRD } \\
\text { BIRD } \\
\text { BIRD }\end{array}$ & $\begin{array}{l}\text { coor } \\
\text { coor } \\
\text { coor } \\
\text { coor } \\
\text { crot }\end{array}$ & & $\begin{array}{l}77.43 \\
75.71 \\
76.67 \\
75.39 \\
73.65\end{array}$ & $\begin{array}{r}0.69 \\
.58 \\
1.30 \\
.70 \\
.32\end{array}$ & $\begin{array}{r}46.0 \\
<39.0 \\
85.0 \\
<40.0 \\
<36.0\end{array}$ & $\begin{array}{l}\bar{z} \\
\bar{z}\end{array}$ & $\begin{array}{l}<0.43 \\
<.39 \\
<.41 \\
<.40 \\
<.36\end{array}$ & $\begin{array}{l}0.70 \\
1.10 \\
.49 \\
2.30 \\
1.70\end{array}$ & $\begin{array}{r}7.70 \\
7.30 \\
8.20 \\
25.00 \\
7.00\end{array}$ \\
\hline $\begin{array}{r}36 \\
37 \\
41 \\
87135 \\
87136\end{array}$ & $\begin{array}{l}06 / 26 / 86 \\
06 / 26 / 86 \\
07 / 08 / 86 \\
08 / 04 / 87 \\
08 / 04 / 87\end{array}$ & 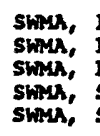 & $\begin{array}{l}\text { LEAD LAKE } \\
\text { IEAD LAKE } \\
\text { IEAD LAKE } \\
\text { SOUTH LEAD LAKE } \\
\text { SOUTH LEAD LAKE }\end{array}$ & $\begin{array}{l}\text { BIRD } \\
\text { BIRD } \\
\text { BIRD } \\
\text { BIRD } \\
\text { BIRD }\end{array}$ & $\begin{array}{l}\text { coor } \\
\text { coor } \\
\text { coor } \\
\text { coor } \\
\text { coor }\end{array}$ & & $\begin{array}{l}74.75 \\
76.72 \\
76.93 \\
74.70 \\
72.00\end{array}$ & $\begin{array}{r}.16 \\
.62 \\
.29 \\
<.20 \\
<.20\end{array}$ & $\begin{array}{r}12.0 \\
<42.0 \\
73.0 \\
1.0 \\
7.8\end{array}$ & $\begin{array}{l}= \\
= \\
<1.00 \\
<1.00\end{array}$ & $\begin{array}{l}<.39 \\
<.41 \\
<4.00 \\
<4.00\end{array}$ & $\begin{array}{l}2.10 \\
1.60 \\
.94 \\
6.27 \\
4.30\end{array}$ & $\begin{array}{l}9.10 \\
3.90 \\
4.20 \\
4.10 \\
3.40\end{array}$ \\
\hline $\begin{array}{l}87137 \\
87138 \\
87139 \\
87140 \\
87111\end{array}$ & $\begin{array}{l}08 / 04 / 87 \\
08 / 04 / 87 \\
08 / 04 / 87 \\
08 / 04 / 87 \\
08 / 04 / 87\end{array}$ & 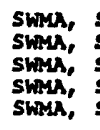 & $\begin{array}{ll}\text { SOUTH LEAD LAKE } \\
\text { SOUTH LEAD LAKE } \\
\text { SOUTH LEAD LAKE } \\
\text { SOUTH LEAD LAKE } \\
\text { SOUTH LEAD LAKE }\end{array}$ & $\begin{array}{l}\text { BIRD } \\
\text { BIRD } \\
\text { BIRD } \\
\text { BIRD } \\
\text { BIRD }\end{array}$ & $\begin{array}{l}\text { coor } \\
\text { coot } \\
\text { coor } \\
\text { coor } \\
\text { coot }\end{array}$ & & $\begin{array}{l}74.50 \\
73.50 \\
72.80 \\
76.20 \\
73.90\end{array}$ & $\begin{array}{l}<.20 \\
<.20 \\
<.20 \\
<.50 \\
<.20\end{array}$ & $\begin{array}{r}5.0 \\
7.1 \\
5.0 \\
7.8 \\
12.0\end{array}$ & $\begin{array}{l}<1.00 \\
<1.00 \\
<1.00 \\
<1.00 \\
<1.00\end{array}$ & $\begin{array}{l}<4.00 \\
<4.00 \\
<4.00 \\
<4.00 \\
<4.00\end{array}$ & $\begin{array}{l}2.70 \\
3.00 \\
4.60 \\
3.30 \\
3.30\end{array}$ & $\begin{array}{l}3.00 \\
3.50 \\
3.90 \\
2.90 \\
3.30\end{array}$ \\
\hline $\begin{array}{r}87142 \\
87143 \\
12 \\
83 \\
81\end{array}$ & $\begin{array}{l}08 / 04 / 87 \\
08 / 04 / 87 \\
07 / 08 / 86 \\
07 / 24 / 86 \\
07 / 24 / 86\end{array}$ & 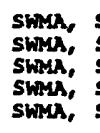 & $\begin{array}{l}\text { SOUTH LEAD LAKE } \\
\text { SOUTH LEAD LAKE } \\
\text { STILLWATER PT. RES. } \\
\text { STILLWATER PT. RES. } \\
\text { STILLWATER PT. RES. }\end{array}$ & $\begin{array}{l}\text { BIRD } \\
\text { BIRD } \\
\text { BIRD } \\
\text { BIRD } \\
\text { BIRD }\end{array}$ & $\begin{array}{l}\text { coot } \\
\text { coot } \\
\text { coot } \\
\text { coot } \\
\text { coor }\end{array}$ & & $\begin{array}{l}72.70 \\
74.30 \\
75.14 \\
74.05 \\
72.40\end{array}$ & $\begin{array}{r}<.20 \\
.20 \\
.10 \\
.21 \\
.29\end{array}$ & $\begin{array}{r}7.1 \\
6.2 \\
<20.0 \\
28.0 \\
24.0\end{array}$ & $\begin{array}{l}<1.00 \\
<1.00 \\
<1.20 \\
<1.10 \\
<1.10\end{array}$ & $\begin{aligned}<4.00 \\
<4.00 \\
2.00 \\
<.76 \\
<.72\end{aligned}$ & $\begin{array}{l}2.40 \\
3.80 \\
2.20 \\
5.20 \\
5.30\end{array}$ & $\begin{array}{l}3.40 \\
4.40 \\
5.30 \\
6.90 \\
4.80\end{array}$ \\
\hline $\begin{array}{l}92 \\
93 \\
74 \\
75 \\
76\end{array}$ & $\begin{array}{l}07 / 28 / 86 \\
07 / 28 / 86 \\
07 / 21 / 86 \\
07 / 21 / 86 \\
07 / 21 / 86\end{array}$ & $\begin{array}{l}\text { SWMU, } \\
\text { SWMA, } \\
\text { WASHOE } \\
\text { WASHOE } \\
\text { WASHOE }\end{array}$ & $\begin{array}{l}\text { STILLWATER PT. RES. } \\
\text { STILLWATER PT. RES. } \\
\text { E LAKE } \\
\text { E IAKE } \\
\text { E LAKE }\end{array}$ & $\begin{array}{l}\text { BIRD } \\
\text { BIRD } \\
\text { BIRD } \\
\text { BIRD } \\
\text { BIRD }\end{array}$ & $\begin{array}{l}\text { coor } \\
\text { coor } \\
\text { coor } \\
\text { coot } \\
\text { coot }\end{array}$ & & $\begin{array}{l}76.58 \\
74.58 \\
72.38 \\
75.00 \\
74.89\end{array}$ & $\begin{array}{l}<.19 \\
.16 \\
<.16 \\
<.20 \\
<.20\end{array}$ & $\begin{array}{r}23.0 \\
12.0 \\
25.0 \\
<29.0 \\
41.0\end{array}$ & $\begin{array}{r}1.40 \\
<1.20 \\
<1.10 \\
3.30 \\
1.30\end{array}$ & $\begin{array}{r}<.85 \\
<.82 \\
<.71 \\
<1.20 \\
<0.82\end{array}$ & $\begin{array}{r}4.20 \\
4.80 \\
12.00 \\
7.60 \\
21.00\end{array}$ & $\begin{array}{l}5.90 \\
6.30 \\
3.40 \\
1.30 \\
3.50\end{array}$ \\
\hline $\begin{array}{r}77 \\
78 \\
87131 \\
87141 \\
87617\end{array}$ & $\begin{array}{l}07 / 21 / 86 \\
07 / 21 / 86 \\
07 / 27 / 87 \\
08 / 01 / 87 \\
07 / 30 / 87\end{array}$ & $\begin{array}{l}\text { WASHOE } \\
\text { WASHOE } \\
\text { SWMA, } \\
\text { SWRA, } \\
\text { CARSON }\end{array}$ & $\begin{array}{l}\text { E LAKE } \\
\text { E LAKE } \\
\text { DRY LAKE } \\
\text { SOUTH LEAD LAKE } \\
\text { N L., I SLANDS UNIT }\end{array}$ & $\begin{array}{l}\text { BIRD } \\
\text { BIRD } \\
\text { BIRD } \\
\text { BIRD } \\
\text { BIRD }\end{array}$ & $\begin{array}{l}\text { COOT } \\
\text { COOT } \\
\text { COOT AD } \\
\text { COOT AD } \\
\text { MALLARD, }\end{array}$ & LIVER & $\begin{array}{l}73.57 \\
72.93 \\
72.30 \\
74.40 \\
73.40\end{array}$ & $\begin{array}{l}<.19 \\
1.90 \\
<.20 \\
.50 \\
.30\end{array}$ & $\begin{array}{r}63.0 \\
<24.0 \\
11.0 \\
9.3 \\
7.8\end{array}$ & $\begin{aligned} 5.30 \\
<1.40 \\
<1.00 \\
<1.00 \\
<1.00\end{aligned}$ & $\begin{array}{l}<1.10 \\
<.95 \\
<4.00 \\
<4.00 \\
<4.00\end{array}$ & $\begin{array}{r}11.00 \\
14.00 \\
4.90 \\
6.69 \\
6.50\end{array}$ & $\begin{array}{l}1.20 \\
1.50 \\
8.50 \\
4.10 \\
6.00\end{array}$ \\
\hline $\begin{array}{l}87634 \\
87636 \\
87639 \\
87649 \\
87630\end{array}$ & $\begin{array}{l}08 / 06 / 87 \\
08 / 06 / 87 \\
08 / 06 / 87 \\
08 / 10 / 87 \\
08 / 06 / 87\end{array}$ & $\begin{array}{l}\text { CARSON } \\
\text { CARSON } \\
\text { CARSON } \\
\text { CARSON } \\
\text { CARSON }\end{array}$ & 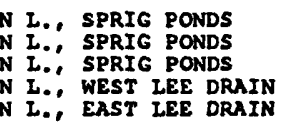 & $\begin{array}{l}\text { BIRD } \\
\text { BIRD } \\
\text { BIRD } \\
\text { BIRD } \\
\text { BIRD }\end{array}$ & $\begin{array}{l}\text { MALLARD, } \\
\text { MALLARD; } \\
\text { MALLARD; } \\
\text { MALLARD; } \\
\text { MALLARD; }\end{array}$ & $\begin{array}{l}\text { LIVER } \\
\text { LIVER } \\
\text { LIVER } \\
\text { LIVER } \\
\text { IIVER }\end{array}$ & $\begin{array}{l}76.00 \\
70.50 \\
74.50 \\
73.50 \\
71.50\end{array}$ & $\begin{array}{l}<.20 \\
<.20 \\
<.20 \\
<.20 \\
.20\end{array}$ & $\begin{array}{l}<2.0 \\
<2.0 \\
<2.0 \\
<2.0 \\
<2.0\end{array}$ & $\begin{array}{l}<1.00 \\
<1.00 \\
<1.00 \\
<1.00 \\
<1.00\end{array}$ & $\begin{array}{l}<4.00 \\
<4.00 \\
<4.00 \\
<4.00 \\
<4.00\end{array}$ & $\begin{array}{r}2.20 \\
16.00 \\
12.00 \\
12.00 \\
5.00\end{array}$ & $\begin{array}{l}3.50 \\
4.30 \\
5.30 \\
3.80 \\
2.60\end{array}$ \\
\hline $\begin{array}{l}87658 \\
87661 \\
87701 \\
87704 \\
87735\end{array}$ & $\begin{array}{l}08 / 23 / 87 \\
08 / 23 / 87 \\
08 / 18 / 87 \\
08 / 21 / 87 \\
08 / 21 / 87\end{array}$ & $\begin{array}{l}\text { FERNLE } \\
\text { FERNLE } \\
\text { FERNLE } \\
\text { FERNLE) } \\
\text { FERNLE }\end{array}$ & $\begin{array}{l}\text { EY } \\
\text { EY } \\
\text { EY } \\
\text { EY } \\
\text { EYA } \\
\text { EY } \\
\text { WMAA } \\
\text { WMA }\end{array}$ & $\begin{array}{l}\text { BIRD } \\
\text { BIRD } \\
\text { BIRD } \\
\text { BIRD } \\
\text { BIRD }\end{array}$ & $\begin{array}{l}\text { MALLARD, } \\
\text { MALLARD; } \\
\text { MALLARD; } \\
\text { MALLARD; } \\
\text { MALLARD, }\end{array}$ & $\begin{array}{l}\text { LIVER } \\
\text { LIVER } \\
\text { LIVER } \\
\text { LIVER } \\
\text { LIVER }\end{array}$ & $\begin{array}{l}70.90 \\
70.10 \\
74.30 \\
72.80 \\
72.60\end{array}$ & $\begin{array}{l}<.20 \\
<.20 \\
<.20 \\
2.00 \\
<.20\end{array}$ & $\begin{array}{l}<2.0 \\
<2.0 \\
<2.0 \\
<2.0 \\
<2.0\end{array}$ & $\begin{array}{l}<1.00 \\
<1.00 \\
<1.00 \\
<1.00 \\
<1.00\end{array}$ & $\begin{array}{l}<4.00 \\
<4.00 \\
<4.00 \\
<4.00 \\
<4.00\end{array}$ & $\begin{array}{r}.43 \\
3.60 \\
.38 \\
.25 \\
.48\end{array}$ & $\begin{array}{r}26.00 \\
31.00 \\
21.00 \\
39.50 \\
5.90\end{array}$ \\
\hline $\begin{array}{l}87707 \\
87710 \\
87747 \\
87744 \\
87631\end{array}$ & $\begin{array}{l}09 / 02 / 87 \\
08 / 27 / 87 \\
08 / 28 / 87 \\
08 / 26 / 87 \\
08 / 06 / 87\end{array}$ & $\begin{array}{l}\text { SWMA, } \\
\text { SWMA, } \\
\text { SWMAA, } \\
\text { SWMA, } \\
\text { CARSON }\end{array}$ & $\begin{array}{l}\text { LEAD LAKE } \\
\text { LEAD LAKE } \\
\text { LEAD LAKE } \\
\text { TULE LAKE } \\
\text { N L., EAST LEE DRAIN }\end{array}$ & $\begin{array}{l}\text { BIRD } \\
\text { BIRD } \\
\text { BIRD } \\
\text { BIRD } \\
\text { BIRD }\end{array}$ & $\begin{array}{l}\text { MALLARD, } \\
\text { MALLARD; } \\
\text { MALLARD; } \\
\text { MALLARD; } \\
\text { MALLARD; }\end{array}$ & $\begin{array}{l}\text { LIVER } \\
\text { LIVER } \\
\text { LIVER } \\
\text { LIVER } \\
\text { MUSCLE }\end{array}$ & $\begin{array}{l}69.30 \\
73.00 \\
70.10 \\
72.70 \\
74.90\end{array}$ & $\begin{array}{l}<.20 \\
<.20 \\
<.20 \\
<.75 \\
<.30\end{array}$ & $\begin{array}{r}<2.0 \\
3.0 \\
<2.0 \\
3.0 \\
<2.0\end{array}$ & $\begin{array}{l}<1.00 \\
<1.00 \\
<1.00 \\
<1.00 \\
<1.00\end{array}$ & $\begin{array}{l}<4.00 \\
<4.00 \\
<4.00 \\
<4.00 \\
<4.00\end{array}$ & $\begin{array}{r}1.60 \\
4.50 \\
14.00 \\
1.10 \\
.34\end{array}$ & $\begin{array}{l}3.00 \\
8.90 \\
7.00 \\
3.70 \\
1.70\end{array}$ \\
\hline $\begin{array}{l}87615 \\
87633 \\
87637 \\
87640 \\
87648\end{array}$ & $\begin{array}{l}07 / 30 / 87 \\
08 / 06 / 87 \\
08 / 06 / 87 \\
08 / 06 / 87 \\
08 / 10 / 87\end{array}$ & $\begin{array}{l}\text { CARSON } \\
\text { CARSON } \\
\text { CARSON } \\
\text { CARSON } \\
\text { CARSON }\end{array}$ & $\begin{array}{l}\text { N I., } \text { ISLANDS UNIT } \\
\text { N I., SPRIG PONDS } \\
\text { N I., SPRIG PONDS } \\
\text { N I., SPRIG PONDS } \\
\text { N I., WEST LEE DRAIN }\end{array}$ & $\begin{array}{l}\text { BIRD } \\
\text { BIRD } \\
\text { BIRD } \\
\text { BIRD } \\
\text { BIRD }\end{array}$ & $\begin{array}{l}\text { MALLARD, } \\
\text { MALLARD; } \\
\text { MALLARD; } \\
\text { MALLARD; } \\
\text { MALLARD, }\end{array}$ & $\begin{array}{l}\text { MUSCLE } \\
\text { MUSCLE } \\
\text { MUSCLE } \\
\text { MUSCLE } \\
\text { MUSCLE }\end{array}$ & $\begin{array}{l}\text { E } 79.30 \\
\text { E } 79.60 \\
\text { P3.60 } \\
\text { E } 76.30 \\
\text { E } 76.30\end{array}$ & $\begin{array}{r}.20 \\
<.20 \\
<.20 \\
<.20 \\
.20\end{array}$ & $\begin{array}{l}10.0 \\
<2.0 \\
<2.0 \\
<2.0 \\
<2.0\end{array}$ & $\begin{array}{l}<1.00 \\
<1.00 \\
<1.00 \\
<1.00 \\
<1.00\end{array}$ & $\begin{array}{l}<4.00 \\
<4.00 \\
<4.00 \\
<4.00 \\
<4.00\end{array}$ & $\begin{array}{l}4.50 \\
7.93 \\
4.00 \\
4.30 \\
6.22\end{array}$ & $\begin{array}{r}1.30 \\
21.00 \\
1.40 \\
1.80 \\
<1.10\end{array}$ \\
\hline $\begin{array}{l}87659 \\
87662 \\
87702 \\
87705 \\
87736\end{array}$ & $\begin{array}{l}08 / 13 / 87 \\
08 / 13 / 87 \\
08 / 18 / 87 \\
08 / 21 / 87 \\
08 / 21 / 87\end{array}$ & $\begin{array}{l}\text { FERNLE } \\
\text { FERNLE } \\
\text { FERNLE } \\
\text { FERNLE } \\
\text { FERNLE }\end{array}$ & $\begin{array}{l}\text { EY WWA } \\
\text { EY WMA } \\
\text { EY WMMA } \\
\text { EY WMA } \\
\text { EY WMA }\end{array}$ & $\begin{array}{l}\text { BIRD } \\
\text { BIRD } \\
\text { BIRD } \\
\text { BIRD } \\
\text { BIRD }\end{array}$ & $\begin{array}{l}\text { MALLARD, } \\
\text { MALLARD; } \\
\text { MALLARD; } \\
\text { MALLARD; } \\
\text { MALLARD; }\end{array}$ & $\begin{array}{l}\text { MUSCLE } \\
\text { MUSCLE } \\
\text { MUSCLE } \\
\text { MUSCLE } \\
\text { MUSCLE }\end{array}$ & 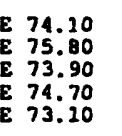 & $\begin{array}{r}<.20 \\
.20 \\
.30 \\
<.20 \\
.20\end{array}$ & $\begin{array}{l}<2.0 \\
<2.0 \\
<2.0 \\
<2.0 \\
<2.0\end{array}$ & $\begin{array}{l}<1.00 \\
<1.00 \\
<1.00 \\
1.00 \\
<1.00\end{array}$ & $\begin{array}{l}<4.00 \\
<4.00 \\
<4.00 \\
<4.00 \\
<4.00\end{array}$ & $\begin{array}{l}.10 \\
.38 \\
.09 \\
.10 \\
.26\end{array}$ & $\begin{array}{r}5.90 \\
10.00 \\
5.20 \\
15.00 \\
1.80\end{array}$ \\
\hline $\begin{array}{l}87708 \\
87712 \\
87748 \\
87745 \\
87629\end{array}$ & $\begin{array}{l}09 / 01 / 87 \\
08 / 27 / 87 \\
08 / 28 / 87 \\
08 / 26 / 87 \\
08 / 06 / 87\end{array}$ & $\begin{array}{l}\text { SWMA, } \\
\text { SWMA, } \\
\text { SWMA, } \\
\text { SWMA,, } \\
\text { CARSON }\end{array}$ & $\begin{array}{l}\text { LEAD LAKE } \\
\text { LEAD LAKE } \\
\text { LEAD LAKE } \\
\text { TULE LAKE } \\
\text { N L., EAST LEE DRAIN }\end{array}$ & $\begin{array}{l}\text { BIRD } \\
\text { BIRD } \\
\text { BIRD } \\
\text { BIRD } \\
\text { BIRD }\end{array}$ & $\begin{array}{l}\text { MALLARD, } \\
\text { MALLARD; } \\
\text { MALLARD, } \\
\text { MALLARD; } \\
\text { MALLARD, }\end{array}$ & $\begin{array}{l}\text { MUSCLE } \\
\text { MUSCLE } \\
\text { MUSCLE } \\
\text { MUSCLE } \\
\text { SKIN }\end{array}$ & $\begin{array}{l}\text { E } 73.30 \\
72.80 \\
\text { E } 73.10 \\
\text { E3.70 } \\
52.80\end{array}$ & $\begin{array}{l}<.20 \\
<.20 \\
<.20 \\
.20 \\
<.20\end{array}$ & $\begin{array}{l}<2.0 \\
<2.0 \\
<2.0 \\
<2.0 \\
<2.0\end{array}$ & $\begin{array}{l}<1.00 \\
<1.00 \\
<1.00 \\
<1.00 \\
<1.00\end{array}$ & $\begin{array}{l}<4.00 \\
<4.00 \\
<4.00 \\
<4.00 \\
<4.00\end{array}$ & $\begin{array}{l}.13 \\
1.90 \\
2.60 \\
.34 \\
1.20\end{array}$ & $\begin{array}{r}1.20 \\
3.00 \\
1.70 \\
.91 \\
.10\end{array}$ \\
\hline
\end{tabular}


TABLE 19.--Data on trace-element const1tuents and percent molsture of blological samples in st111water w1ldiffe Management irea, Carson Lake, Fernley W11dl1fe Management Area, and Huboldt W11dl1fe Management Area, $1985-87-C o n t$.

\begin{tabular}{|c|c|c|c|c|c|c|c|c|c|c|c|c|c|}
\hline \multirow{2}{*}{$\begin{array}{c}\text { UsFus } \\
\text { Iocel } \\
\text { ID } \\
\text { number } \\
87616 \\
87632 \\
87635 \\
87638 \\
87647\end{array}$} & \multirow{2}{*}{$\begin{array}{l}\text { Date } \\
7 / 30 / 87 \\
8 / 06 / 87 \\
8 / 06 / 87 \\
8 / 06 / 87 \\
8 / 10 / 87\end{array}$} & \multicolumn{2}{|c|}{ Location } & \multirow{2}{*}{$\begin{array}{l}\begin{array}{l}\text { Cate- } \\
\text { gory }\end{array} \\
\text { BIRD } \\
\text { BIRD } \\
\text { BIRD } \\
\text { BIRD } \\
\text { BIRD }\end{array}$} & \multicolumn{2}{|l|}{ specles } & $\begin{array}{l}\text { Percent } \\
\text { molsture }\end{array}$ & \multirow{2}{*}{$\begin{array}{r}\begin{array}{c}\text { Arse- } \\
\text { n1c }\end{array} \\
<0.20 \\
.20 \\
<.20 \\
<.20 \\
<.20\end{array}$} & \multirow{2}{*}{$\begin{array}{r}\text { Boron } \\
11.0 \\
4.0 \\
<2.0 \\
<2.0 \\
4.0\end{array}$} & \multirow{2}{*}{$\begin{array}{l}\begin{array}{l}\text { Chro- } \\
\text { m1um }\end{array} \\
<1.00 \\
<1.00 \\
<1.00 \\
<1.00 \\
<1.00\end{array}$} & \multirow{2}{*}{$\begin{array}{l}\text { Lead } \\
<4.00 \\
<4.00 \\
<4.00 \\
<4.00 \\
<4.00\end{array}$} & \multirow{2}{*}{$\begin{array}{l}\text { Mer- } \\
\text { cury }\end{array}$} & \multirow{2}{*}{$\begin{array}{l}\text { Sele- } \\
\text { nlum }\end{array}$} \\
\hline & & $\begin{array}{l}\text { CARSON L., } \\
\text { CARSON L., } \\
\text { CARSON L.: } \\
\text { CARSON L.: } \\
\text { CARSON L.: }\end{array}$ & $\begin{array}{l}\text { ISLANOS UNIT } \\
\text { SPRIG PONDS } \\
\text { SPRIG PONDS } \\
\text { SPRIG PONDS } \\
\text { WEST LEE DRAIN }\end{array}$ & & $\begin{array}{l}\text { MALLARD, } \\
\text { MALLARD; } \\
\text { MALLARD, } \\
\text { MALLARD, } \\
\text { MALLARD, }\end{array}$ & $\begin{array}{l}\text { SKIN } \\
\text { SKIN } \\
\text { SKIN } \\
\text { SKIN } \\
\text { SKIN }\end{array}$ & $\begin{array}{l}74.50 \\
72.70 \\
22.40 \\
75.40 \\
48.60\end{array}$ & & & & & & \\
\hline $\begin{array}{l}87657 \\
87660 \\
87700 \\
87703 \\
87734\end{array}$ & $\begin{array}{l}08 / 13 / 87 \\
08 / 13 / 87 \\
08 / 18 / 87 \\
08 / 21 / 87 \\
08 / 21 / 87\end{array}$ & 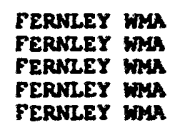 & & $\begin{array}{l}\text { BIRD } \\
\text { BIRD } \\
\text { BIRD } \\
\text { BIRD } \\
\text { BIRD }\end{array}$ & $\begin{array}{l}\text { MALIARD, } \\
\text { MALLARD, } \\
\text { MALLARD; } \\
\text { MALIARD, } \\
\text { MALIARD, }\end{array}$ & $\begin{array}{l}\text { SKIN } \\
\text { SKIN } \\
\text { SKIN } \\
\text { SKIN } \\
\text { SKIN }\end{array}$ & $\begin{array}{l}27.40 \\
51.60 \\
45.20 \\
63.20 \\
34.90\end{array}$ & $\begin{array}{l}<.20 \\
<.20 \\
<.20 \\
<.20 \\
<.20\end{array}$ & $\begin{array}{r}<2.0 \\
2.0 \\
2.0 \\
3.0 \\
<2.0\end{array}$ & $\begin{array}{r}<1.00 \\
<1.00 \\
.71 \\
<1.00 \\
<1.00\end{array}$ & $\begin{array}{l}<4.00 \\
<4.00 \\
<4.00 \\
<4.00 \\
<4.00\end{array}$ & $\begin{array}{l}.01 \\
.12 \\
.02 \\
.05 \\
.06\end{array}$ & $\begin{array}{r}1.20 \\
3.00 \\
1.30 \\
6.80 \\
.40\end{array}$ \\
\hline $\begin{array}{l}87706 \\
87709 \\
87746 \\
87743 \\
87620\end{array}$ & $\begin{array}{l}09 / 01 / 87 \\
08 / 27 / 87 \\
08 / 28 / 87 \\
08 / 26 / 87 \\
07 / 30 / 87\end{array}$ & $\begin{array}{l}\text { SWMA, LEAD } \\
\text { SWMA, LEAD } \\
\text { SWMA, LEAD } \\
\text { SWRA, TULE } \\
\text { CARSON L., }\end{array}$ & $\begin{array}{l}\text { LAKE } \\
\text { LAKE } \\
\text { LAKE } \\
\text { LAKE } \\
\text { BIG WATER }\end{array}$ & $\begin{array}{l}\text { BIRD } \\
\text { BIRD } \\
\text { BIRD } \\
\text { BIRD } \\
\text { BIRD }\end{array}$ & $\begin{array}{l}\text { MALLARD, } \\
\text { MALLARD; } \\
\text { MALLARD; } \\
\text { MALLARD; } \\
\text { REDHEAD, }\end{array}$ & $\begin{array}{l}\text { SKIN } \\
\text { SKIN } \\
\text { SKIN } \\
\text { SKIN } \\
\text { LIVER }\end{array}$ & $\begin{array}{l}46.30 \\
43.60 \\
29.70 \\
45.00 \\
75.20\end{array}$ & $\begin{array}{l}<.20 \\
<.20 \\
<.20 \\
.20 \\
<.20\end{array}$ & $\begin{array}{r}<2.0 \\
2.0 \\
<2.0 \\
<2.0 \\
12.0\end{array}$ & $\begin{array}{l}<1.00 \\
<1.00 \\
<1.00 \\
<1.00 \\
<1.00\end{array}$ & $\begin{array}{l}<4.00 \\
<4.00 \\
<4.00 \\
<4.00 \\
<4.00\end{array}$ & $\begin{array}{r}.04 \\
.38 \\
.39 \\
.10 \\
1.50\end{array}$ & $\begin{array}{r}.20 \\
.55 \\
.30 \\
.30 \\
4.30\end{array}$ \\
\hline $\begin{array}{l}87689 \\
87692 \\
87695 \\
87698 \\
87718\end{array}$ & $\begin{array}{l}08 / 17 / 87 \\
08 / 17 / 87 \\
08 / 17 / 87 \\
08 / 17 / 87 \\
08 / 25 / 87\end{array}$ & $\begin{array}{l}\text { CARSON L., } \\
\text { CARSON L., } \\
\text { CARSON L..' } \\
\text { CARSON L..' } \\
\text { SWAR, LEAD }\end{array}$ & $\begin{array}{l}\text { BIG WATER } \\
\text { BIG WATER } \\
\text { BIG WATER } \\
\text { BIG WATER } \\
\text { LAKE }\end{array}$ & $\begin{array}{l}\text { BIRD } \\
\text { BIRD } \\
\text { BIRD } \\
\text { BIRD } \\
\text { BIRD }\end{array}$ & $\begin{array}{l}\text { REDHEAD, } \\
\text { REDHEAD, } \\
\text { REDHEAD, } \\
\text { REDHEAD, } \\
\text { REDHEAD, }\end{array}$ & $\begin{array}{l}\text { LIVER } \\
\text { LIVER } \\
\text { LIVER } \\
\text { IIVER } \\
\text { LIVER }\end{array}$ & $\begin{array}{l}72.00 \\
71.20 \\
72.00 \\
72.60 \\
72.70\end{array}$ & $\begin{array}{l}<.20 \\
<.20 \\
<.20 \\
<.20 \\
.20\end{array}$ & $\begin{array}{l}27.0 \\
21.0 \\
25.0 \\
19.0 \\
<2.0\end{array}$ & $\begin{array}{l}<1.00 \\
<1.00 \\
<1.00 \\
<1.00 \\
<1.00\end{array}$ & $\begin{array}{r}10.00 \\
5.00 \\
<4.00 \\
<4.00 \\
<4.00\end{array}$ & $\begin{array}{l}2.60 \\
1.80 \\
1.80 \\
2.50 \\
1.80\end{array}$ & $\begin{array}{l}4.30 \\
3.90 \\
3.40 \\
3.80 \\
4.10\end{array}$ \\
\hline $\begin{array}{l}97721 \\
87724 \\
87738 \\
87741 \\
87618\end{array}$ & $\begin{array}{l}08 / 25 / 87 \\
08 / 25 / 87 \\
08 / 25 / 87 \\
08 / 27 / 87 \\
07 / 30 / 87\end{array}$ & $\begin{array}{l}\text { SWMA, LEAD } \\
\text { SWMA, LEAD } \\
\text { SWMA, LEAD } \\
\text { SWMA, LEAD } \\
\text { CARSON L., }\end{array}$ & $\begin{array}{l}\text { LAKE } \\
\text { IAKE } \\
\text { IAKE } \\
\text { LAKE } \\
\text { BIG WATER }\end{array}$ & $\begin{array}{l}\text { BIRD } \\
\text { BIRD } \\
\text { BIRD } \\
\text { BIRD } \\
\text { BIRD }\end{array}$ & $\begin{array}{l}\text { REDHEAD, } \\
\text { REDHEAD, } \\
\text { REDHEAD, } \\
\text { REDHEAD, } \\
\text { REDHEAD, }\end{array}$ & $\begin{array}{l}\text { LIVER } \\
\text { LIVER } \\
\text { IIVER } \\
\text { LIVER } \\
\text { MUSCLE }\end{array}$ & $\begin{array}{l}73.50 \\
72.50 \\
72.70 \\
67.70 \\
73.00\end{array}$ & $\begin{array}{l}<.20 \\
<.20 \\
<.20 \\
<.20 \\
<.20\end{array}$ & $\begin{array}{r}41.0 \\
18.0 \\
2.0 \\
14.0 \\
11.0\end{array}$ & $\begin{array}{l}<1.00 \\
<1.00 \\
<1.00 \\
<1.00 \\
<1.00\end{array}$ & $\begin{array}{l}<4.00 \\
<4.00 \\
<4.00 \\
<4.00 \\
<4.00\end{array}$ & $\begin{array}{l}3.50 \\
3.70 \\
1.20 \\
3.80 \\
.50\end{array}$ & $\begin{array}{l}5.20 \\
7.10 \\
6.60 \\
5.60 \\
1.70\end{array}$ \\
\hline $\begin{array}{l}87690 \\
87693 \\
87696 \\
87699 \\
87719\end{array}$ & $\begin{array}{l}08 / 17 / 87 \\
08 / 17 / 87 \\
08 / 17 / 87 \\
08 / 17 / 87 \\
08 / 25 / 87\end{array}$ & $\begin{array}{l}\text { CARSON L., } \\
\text { CARSON L., } \\
\text { CARSON L., } \\
\text { CARSON L.,' } \\
\text { SWMA, LEAD }\end{array}$ & $\begin{array}{l}\text { BIG WATER } \\
\text { BIG WATER } \\
\text { BIG WATER } \\
\text { BIG WATER } \\
\text { IAKE }\end{array}$ & $\begin{array}{l}\text { BIRD } \\
\text { BIRD } \\
\text { BIRD } \\
\text { BIRD } \\
\text { BIRD }\end{array}$ & $\begin{array}{l}\text { REDHEAD, } \\
\text { REDHEAD, } \\
\text { REDHEAD, } \\
\text { REDHEAD, } \\
\text { REDHEAD, }\end{array}$ & $\begin{array}{l}\text { MUSCLE } \\
\text { MUSCLE } \\
\text { MUSCLE } \\
\text { MUSCLE } \\
\text { MUSCLE }\end{array}$ & $\begin{array}{l}74.60 \\
78.80 \\
78.30 \\
74.60 \\
75.10\end{array}$ & $\begin{array}{r}.50 \\
.20 \\
<.10 \\
<.10 \\
.40\end{array}$ & $\begin{array}{l}29.0 \\
31.0 \\
34.0 \\
22.0 \\
<2.0\end{array}$ & $\begin{array}{l}<1.00 \\
<1.00 \\
<1.00 \\
<1.00 \\
<1.00\end{array}$ & $\begin{array}{l}<4.00 \\
<4.00 \\
<4.00 \\
<4.00 \\
<4.00\end{array}$ & $\begin{array}{l}.60 \\
.62 \\
.68 \\
.70 \\
.64\end{array}$ & $\begin{array}{l}1.40 \\
1.50 \\
1.40 \\
1.50 \\
2.30\end{array}$ \\
\hline $\begin{array}{l}87722 \\
87725 \\
87739 \\
87742 \\
87619\end{array}$ & $\begin{array}{l}08 / 25 / 87 \\
08 / 25 / 87 \\
08 / 25 / 87 \\
08 / 27 / 87 \\
07 / 30 / 87\end{array}$ & $\begin{array}{l}\text { SWMA, LEAD } \\
\text { SWMA, LEAD } \\
\text { SWMA, LEAD } \\
\text { SWMA, LEAD } \\
\text { CARSON I., }\end{array}$ & $\begin{array}{l}\text { LAKE } \\
\text { IAKE } \\
\text { LAKE } \\
\text { LAKE } \\
\text { BIG WATER }\end{array}$ & $\begin{array}{l}\text { BIRD } \\
\text { BIRD } \\
\text { BIRD } \\
\text { BIRD } \\
\text { BIRD }\end{array}$ & $\begin{array}{l}\text { REDHEAD, } \\
\text { REDHEAD; } \\
\text { REDHEAD; } \\
\text { REDHEAD; } \\
\text { REDHEAD; }\end{array}$ & $\begin{array}{l}\text { MUSCLE } \\
\text { MUSCLE } \\
\text { MUSCLE } \\
\text { MUSCLE } \\
\text { SKIN }\end{array}$ & $\begin{array}{l}77.90 \\
78.60 \\
73.60 \\
71.30 \\
64.40\end{array}$ & $\begin{array}{r}.48 \\
.44 \\
<.20 \\
<.20 \\
.40\end{array}$ & $\begin{array}{l}18.0 \\
21.0 \\
<2.0 \\
12.0 \\
11.0\end{array}$ & $\begin{array}{l}<1.00 \\
<1.00 \\
<1.00 \\
<1.00 \\
<1.00\end{array}$ & $\begin{array}{l}<4.00 \\
<4.00 \\
<4.00 \\
<4.00 \\
<4.00\end{array}$ & $\begin{array}{r}1.40 \\
1.90 \\
.63 \\
.88 \\
.33\end{array}$ & $\begin{array}{r}1.70 \\
1.80 \\
2.40 \\
<2.00 \\
1.30\end{array}$ \\
\hline $\begin{array}{l}87688 \\
87691 \\
87694 \\
87697 \\
87717\end{array}$ & $\begin{array}{l}08 / 17 / 87 \\
08 / 17 / 87 \\
08 / 17 / 87 \\
08 / 17 / 87 \\
08 / 25 / 87\end{array}$ & $\begin{array}{l}\text { CARSON L., } \\
\text { CARSON L.: } \\
\text { CARSON L.:, } \\
\text { CARSON L..' } \\
\text { SWMA, LEAD }\end{array}$ & $\begin{array}{l}\text { BIG WATER } \\
\text { BIG WATER } \\
\text { BIG WATER } \\
\text { BIG WATER } \\
\text { LAKE }\end{array}$ & $\begin{array}{l}\text { BIRD } \\
\text { BIRD } \\
\text { BIRD } \\
\text { BIRD } \\
\text { BIRD }\end{array}$ & $\begin{array}{l}\text { REDHEAD, } \\
\text { REDHEAD; } \\
\text { REDHEAD; } \\
\text { REDHEAD; } \\
\text { REDHEAD; }\end{array}$ & $\begin{array}{l}\text { SKIN } \\
\text { SKIN } \\
\text { SKIN } \\
\text { SKIN } \\
\text { SKIN }\end{array}$ & $\begin{array}{l}51.70 \\
64.80 \\
45.50 \\
37.70 \\
71.40\end{array}$ & $\begin{array}{l}.50 \\
.91 \\
.30 \\
.20 \\
.66\end{array}$ & $\begin{array}{r}18.0 \\
34.0 \\
16.0 \\
6.7 \\
.1\end{array}$ & $\begin{array}{l}<1.00 \\
<1.00 \\
<1.00 \\
<0.10 \\
<1.00\end{array}$ & $\begin{array}{l}<4.00 \\
<4.00 \\
<4.00 \\
<4.00 \\
<4.00\end{array}$ & $\begin{array}{l}.22 \\
.28 \\
.24 \\
.14 \\
.70\end{array}$ & $\begin{array}{r}.43 \\
.55 \\
.30 \\
.30 \\
1.50\end{array}$ \\
\hline $\begin{array}{l}87720 \\
87723 \\
87737 \\
87740 \\
87750\end{array}$ & $\begin{array}{l}08 / 25 / 87 \\
08 / 25 / 87 \\
08 / 25 / 87 \\
08 / 27 / 87 \\
08 / 17 / 87\end{array}$ & $\begin{array}{l}\text { SWMA, LEAD } \\
\text { SWMA, LEAD } \\
\text { SWMA, LEAD } \\
\text { SWMA, LEAD } \\
\text { CARSON L. }\end{array}$ & $\begin{array}{l}\text { LAKE } \\
\text { LAKE } \\
\text { LAKE } \\
\text { LAKE }\end{array}$ & $\begin{array}{l}\text { BIRD } \\
\text { BIRD } \\
\text { BIRD } \\
\text { BIRD } \\
\text { BIRD }\end{array}$ & $\begin{array}{l}\text { REDHEAD, } \\
\text { REDHEAD, } \\
\text { REDHEAD, } \\
\text { REDHEAD, } \\
\text { SHOVELER, }\end{array}$ & $\begin{array}{l}\text { SKIN } \\
\text { SKIN } \\
\text { SKIN } \\
\text { SKIN } \\
\text { LIVER }\end{array}$ & $\begin{array}{l}46.30 \\
56.90 \\
69.20 \\
46.90 \\
71.90\end{array}$ & $\begin{array}{r}.62 \\
.20 \\
<.20 \\
.20 \\
.20\end{array}$ & $\begin{array}{r}19.0 \\
17.0 \\
6.0 \\
10.0 \\
12.0\end{array}$ & $\begin{array}{l}<1.00 \\
<1.00 \\
<1.00 \\
<1.00 \\
<1.00\end{array}$ & $\begin{array}{l}<4.00 \\
<4.00 \\
<4.00 \\
<4.00 \\
<4.00\end{array}$ & $\begin{array}{r}.47 \\
.61 \\
.40 \\
2.80 \\
4.00\end{array}$ & $\begin{array}{r}.49 \\
.72 \\
1.80 \\
.59 \\
4.10\end{array}$ \\
\hline $\begin{array}{l}87715 \\
87727 \\
87730 \\
87756 \\
87759\end{array}$ & $\begin{array}{l}08 / 13 / 87 \\
08 / 28 / 87 \\
08 / 25 / 87 \\
08 / 26 / 87 \\
08 / 26 / 87\end{array}$ & $\begin{array}{l}\text { FERNLEY WHA } \\
\text { SWMA, LEAD } \\
\text { SWMA, LEAD } \\
\text { SWMA, LEAD } \\
\text { SWMA, LEAD }\end{array}$ & $\begin{array}{l}\text { LAKE } \\
\text { LAKE } \\
\text { LAKE } \\
\text { LAKE }\end{array}$ & $\begin{array}{l}\text { BIRD } \\
\text { BIRD } \\
\text { BIRD } \\
\text { BIRD } \\
\text { BIRD }\end{array}$ & $\begin{array}{l}\text { SHOVEIER, } \\
\text { SHOVELER, } \\
\text { SHOVELER, } \\
\text { SHOVELER, } \\
\text { SHOVEIER, }\end{array}$ & $\begin{array}{l}\text { LIVER } \\
\text { LIVER } \\
\text { IIVER } \\
\text { LIVER } \\
\text { LIVER }\end{array}$ & $\begin{array}{l}70.00 \\
74.10 \\
70.20 \\
70.80 \\
70.70\end{array}$ & $\begin{array}{l}<.20 \\
.40 \\
<.20 \\
<.20 \\
.20\end{array}$ & $\begin{array}{r}8.4 \\
13.0 \\
<2.0 \\
<2.0 \\
<2.0\end{array}$ & $\begin{array}{l}<1.00 \\
<1.00 \\
<1.00 \\
<1.00 \\
<1.00\end{array}$ & $\begin{array}{l}<4.00 \\
<4.00 \\
<4.00 \\
<4.00 \\
<4.00\end{array}$ & $\begin{array}{r}.61 \\
5.37 \\
3.00 \\
6.79 \\
12.00\end{array}$ & $\begin{array}{r}6.40 \\
4.90 \\
32.00 \\
4.90 \\
5.90\end{array}$ \\
\hline $\begin{array}{l}87753 \\
87749 \\
87714 \\
87726 \\
87729\end{array}$ & $\begin{array}{l}08 / 27 / 87 \\
08 / 17 / 87 \\
08 / 13 / 87 \\
08 / 28 / 87 \\
08 / 25 / 87\end{array}$ & $\begin{array}{l}\text { SWMA, TULE } \\
\text { CARSON L. } \\
\text { FERNLEY WMA } \\
\text { SWMA, LEAD } \\
\text { SWMA, LEAD }\end{array}$ & $\begin{array}{l}\text { IAKE } \\
\text { LAKE } \\
\text { LAKE }\end{array}$ & $\begin{array}{l}\text { BIRD } \\
\text { BIRD } \\
\text { BIRD } \\
\text { BIRD } \\
\text { BIRD }\end{array}$ & $\begin{array}{l}\text { SHOVELER, } \\
\text { SHOVELER, } \\
\text { SHOVELER, } \\
\text { SHOVELER, } \\
\text { SHOVELER, }\end{array}$ & $\begin{array}{l}\text { LIVER } \\
\text { SKIN } \\
\text { SKIN } \\
\text { SKIN } \\
\text { SKIN }\end{array}$ & $\begin{array}{l}67.20 \\
58.00 \\
48.50 \\
23.60 \\
35.20\end{array}$ & $\begin{array}{l}<.20 \\
<.20 \\
.30 \\
<.20 \\
<.20\end{array}$ & $\begin{array}{r}<2.0 \\
11.0 \\
2.0 \\
3.0 \\
1.0\end{array}$ & $\begin{array}{r}<1.00 \\
<1.00 \\
<1.00 \\
<.90 \\
<1.00\end{array}$ & $\begin{array}{l}<4.00 \\
<4.00 \\
<4.00 \\
<4.00 \\
<4.00\end{array}$ & $\begin{array}{r}2.20 \\
.64 \\
.10 \\
.21 \\
.23\end{array}$ & $\begin{array}{r}4.50 \\
.81 \\
1.70 \\
.30 \\
.51\end{array}$ \\
\hline $\begin{array}{l}87755 \\
87758 \\
87752 \\
87751 \\
87716\end{array}$ & $\begin{array}{l}08 / 26 / 87 \\
08 / 26 / 87 \\
08 / 27 / 87 \\
08 / 17 / 87 \\
08 / 13 / 87\end{array}$ & $\begin{array}{l}\text { SWMA, LEAD } \\
\text { SWAA, LEAD } \\
\text { SWMA, TULE } \\
\text { CARSON L. } \\
\text { EERNLEY WMA }\end{array}$ & $\begin{array}{l}\text { LAKE } \\
\text { LAKE } \\
\text { LAKE }\end{array}$ & $\begin{array}{l}\text { BIRD } \\
\text { BIRD } \\
\text { BIRD } \\
\text { BIRD } \\
\text { BIRD }\end{array}$ & $\begin{array}{l}\text { SHOVELER, } \\
\text { SHOVELER, } \\
\text { SHOVELER, } \\
\text { SHOVELER, } \\
\text { SHOVELER, }\end{array}$ & $\begin{array}{l}\text { SKIN } \\
\text { SKIN } \\
\text { SKIN } \\
\text { MUSCLE } \\
\text { MUSCLE }\end{array}$ & $\begin{array}{l}27.90 \\
19.70 \\
19.70 \\
74.20 \\
74.70\end{array}$ & $\begin{array}{l}<.20 \\
<.20 \\
<.20 \\
<.20 \\
.20\end{array}$ & $\begin{array}{l}<2.0 \\
<2.0 \\
2.0 \\
13.0 \\
<2.0\end{array}$ & $\begin{array}{l}<1.00 \\
<1.00 \\
<1.00 \\
<1.00 \\
<1.00\end{array}$ & $\begin{array}{l}<4.00 \\
<4.00 \\
<4.00 \\
<4.00 \\
<4.00\end{array}$ & $\begin{array}{r}.26 \\
.46 \\
.09 \\
1.40 \\
.28\end{array}$ & $\begin{array}{r}.20 \\
.30 \\
1.20 \\
6.00\end{array}$ \\
\hline
\end{tabular}


TABLE 19.--Data on trace-element const1tuents and percent molsture of blological samples in st111water w11d11fe Management Area, Carson Lake, Fernley Wildlife Management Area, and Humboldt Wildlife Management Area, 1985-87--Cont.

\begin{tabular}{|c|c|c|c|c|c|c|c|c|c|c|c|c|}
\hline $\begin{array}{l}\text { usfws } \\
\text { local } \\
\text { ID } \\
\text { number }\end{array}$ & Date & & Location & $\begin{array}{l}\text { Cate- } \\
\text { gory }\end{array}$ & specles & $\begin{array}{l}\text { Percent } \\
\text { molsture }\end{array}$ & $\begin{array}{c}\text { Arse- } \\
\text { nic }\end{array}$ & Boron & $\begin{array}{l}\text { Chro- } \\
\text { m1um }\end{array}$ & Lead & $\begin{array}{l}\text { Mer- } \\
\text { cury }\end{array}$ & $\begin{array}{l}\text { Sele- } \\
\text { nium }\end{array}$ \\
\hline $\begin{array}{l}87728 \\
87731 \\
87757 \\
87760 \\
87754\end{array}$ & $\begin{array}{l}08 / 28 / 87 \\
08 / 25 / 87 \\
08 / 26 / 87 \\
08 / 26 / 87 \\
08 / 27 / 87\end{array}$ & $\begin{array}{l}\text { shave, I } \\
\text { sward, I } \\
\text { sward, I } \\
\text { sway, I } \\
\text { sward, I }\end{array}$ & $\begin{array}{l}\text { LEAD LAKE } \\
\text { LEAD LAKE } \\
\text { LEAD LAKE } \\
\text { LEAD LAKE } \\
\text { TULE LAKE }\end{array}$ & $\begin{array}{l}\text { BIRD } \\
\text { BIRD } \\
\text { BIRD } \\
\text { BIRD } \\
\text { BIRD }\end{array}$ & $\begin{array}{l}\text { SHOVELER, MUSCLE } \\
\text { SHOVELER, MUSCLE } \\
\text { SHOVELER, MUSCLE } \\
\text { SHOVELER, MUSCLE } \\
\text { SHOVELER, MUSCLE }\end{array}$ & $\begin{array}{l}73.60 \\
72.50 \\
772.50 \\
E 72.80 \\
E 72.40\end{array}$ & $\begin{array}{r}<0.20 \\
<.20 \\
<.20 \\
<.20 \\
<.20\end{array}$ & $\begin{array}{r}12.0 \\
6.8 \\
<2.0 \\
<2.0 \\
<2.0\end{array}$ & $\begin{array}{l}<1.00 \\
<1.00 \\
<1.00 \\
<1.00 \\
<1.00\end{array}$ & $\begin{array}{l}<4.00 \\
<4.00 \\
<4.00 \\
<4.00 \\
<4.00\end{array}$ & $\begin{array}{l}1.60 \\
.32 \\
1.20 \\
3.30 \\
.50\end{array}$ & $\begin{array}{l}3.00 \\
2.00 \\
1.40 \\
3.40 \\
1.00\end{array}$ \\
\hline $\begin{array}{l}87600 \\
87601 \\
87681 \\
85001 \\
85002\end{array}$ & $\begin{array}{l}07 / 28 / 87 \\
07 / 28 / 87 \\
09 / 03 / 87 \\
07 / 29 / 85 \\
07 / 29 / 85\end{array}$ & $\begin{array}{l}\text { HARYON } \\
\text { HARYON } \\
\text { HARYON } \\
\text { CARSON } \\
\text { CARSON }\end{array}$ & $\begin{array}{l}\text { RES. } \\
\text { RES, } \\
\text { RES. } \\
\text { RE.. CARSON I DRAIH } \\
\text { L.. CARSON I DRAIH }\end{array}$ & $\begin{array}{l}\text { FISH } \\
\text { FISH } \\
\text { FISH } \\
\text { FISH } \\
\text { FISH }\end{array}$ & $\begin{array}{l}\text { BLACK BULLHEAD } \\
\text { BLACK BULLHEAD } \\
\text { BLACK BULLHEAD } \\
\text { CARP } \\
\text { CARP }\end{array}$ & $\begin{array}{l}76.40 \\
70.50 \\
78.90 \\
77.60 \\
77.30\end{array}$ & $\begin{array}{r}.23 \\
.59 \\
.37 \\
.51 \\
1.10\end{array}$ & $\begin{array}{l}<2.0 \\
<2.0 \\
<2.0 \\
=-\end{array}$ & $\begin{array}{r}<1.00 \\
6.00 \\
2.00 \\
1.30 \\
1.30\end{array}$ & $\begin{array}{r}<4.00 \\
<4.00 \\
<4.00 \\
<.40 \\
-1.30\end{array}$ & $\begin{array}{l}1.90 \\
1.10 \\
1.05 \\
1.00 \\
.88\end{array}$ & $\begin{array}{r}.92 \\
2.00 \\
1.70 \\
1.00 \\
.84\end{array}$ \\
\hline $\begin{array}{r}85003 \\
387 \\
388 \\
389 \\
355\end{array}$ & $\begin{array}{l}07 / 29 / 85 \\
11 / 03 / 86 \\
11 / 03 / 86 \\
11 / 03 / 86 \\
10 / 03 / 86\end{array}$ & $\begin{array}{l}\text { CARSON } \\
\text { CARSON } \\
\text { CARSON } \\
\text { CARSON } \\
\text { CARSON }\end{array}$ & 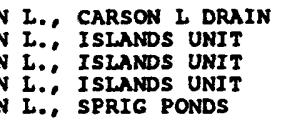 & $\begin{array}{l}\text { FISH } \\
\text { FISH } \\
\text { FISH } \\
\text { FISH } \\
\text { FISH }\end{array}$ & $\begin{array}{l}\text { CARP } \\
\text { CARP } \\
\text { CARP } \\
\text { CARP } \\
\text { CARP }\end{array}$ & $\begin{array}{l}78.50 \\
80.15 \\
77.65 \\
75.04 \\
77.38\end{array}$ & $\begin{array}{l}<.93 \\
<.20 \\
<.21 \\
<.16 \\
<.21\end{array}$ & $\begin{array}{r}<24.0 \\
<21.0 \\
<20.0 \\
38.0\end{array}$ & $\begin{array}{r}.90 \\
3.20 \\
3.10 \\
2.10 \\
<2.20\end{array}$ & $\begin{array}{l}<.90 \\
<.96 \\
<.85 \\
<.79 \\
<.86\end{array}$ & $\begin{array}{r}1.20 \\
.42 \\
.63 \\
.75 \\
1.30\end{array}$ & $\begin{array}{l}1.10 \\
1.30 \\
1.70 \\
2.60 \\
1.30\end{array}$ \\
\hline $\begin{array}{l}356 \\
357 \\
146 \\
147 \\
148\end{array}$ & $\begin{array}{l}10 / 03 / 86 \\
10 / 03 / 86 \\
09 / 09 / 86 \\
09 / 09 / 86 \\
09 / 09 / 86\end{array}$ & $\begin{array}{l}\text { CARSON } \\
\text { CARSON } \\
\text { FERNLEY } \\
\text { FERNLEY } \\
\text { FERWLEY }\end{array}$ & 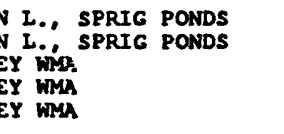 & $\begin{array}{l}\text { FISH } \\
\text { FISH } \\
\text { FISH } \\
\text { FISH } \\
\text { FISH }\end{array}$ & $\begin{array}{l}\text { CARP } \\
\text { CARP } \\
\text { CARP } \\
\text { CARP } \\
\text { CARP }\end{array}$ & $\begin{array}{l}80.37 \\
81.53 \\
75.62 \\
76.87 \\
79.72\end{array}$ & $\begin{array}{r}<.20 \\
<.23 \\
.49 \\
.67 \\
.55\end{array}$ & $\begin{array}{l}<24.0 \\
<27.0 \\
<20.0 \\
<21.0 \\
<25.0\end{array}$ & $\begin{array}{r}<2.40 \\
3.80 \\
<2.00 \\
<2.10 \\
3.50\end{array}$ & $\begin{array}{l}<.96 \\
1.20 \\
<.79 \\
<.85 \\
<.98\end{array}$ & $\begin{array}{l}2.10 \\
2.40 \\
<.17 \\
<.21 \\
<.23\end{array}$ & $\begin{array}{r}2.00 \\
1.70 \\
6.20 \\
8.80 \\
11.00\end{array}$ \\
\hline $\begin{array}{r}87484 \\
87678 \\
380 \\
381 \\
382\end{array}$ & $\begin{array}{l}07 / 06 / 87 \\
09 / 02 / 87 \\
10 / 29 / 86 \\
10 / 29 / 86 \\
10 / 29 / 86\end{array}$ & $\begin{array}{l}\text { HARYON } \\
\text { HARMON } \\
\text { HWMA, } \\
\text { HWMA, } \\
\text { HWWA, }\end{array}$ & $\begin{array}{l}\text { RES. } \\
\text { N RES. } \\
\text { HUMBOLDT LAKE } \\
\text { HUMBOLDT LAKE } \\
\text { HUMBOIDT LAKE }\end{array}$ & $\begin{array}{l}\text { FISH } \\
\text { FISH } \\
\text { FISH } \\
\text { FISH } \\
\text { FISH }\end{array}$ & $\begin{array}{l}\text { CARP } \\
\text { CARP } \\
\text { CARP } \\
\text { CARP } \\
\text { CARP }\end{array}$ & $\begin{array}{l}74.50 \\
76.20 \\
81.74 \\
78.04 \\
81.08\end{array}$ & $\begin{array}{r}.40 \\
.56 \\
.81 \\
.96 \\
1.20\end{array}$ & $\begin{array}{r}<2.0 \\
<2.0 \\
<27.0 \\
<23.0 \\
<26.0\end{array}$ & $\begin{array}{r}<1.00 \\
1.00 \\
6.80 \\
6.30 \\
6.40\end{array}$ & $\begin{array}{l}<4.00 \\
<4.00 \\
<1.10 \\
1.90 \\
<1.00\end{array}$ & $\begin{array}{l}1.90 \\
1.70 \\
.46 \\
.72 \\
.54\end{array}$ & $\begin{array}{l}1.10 \\
0.94 \\
3.90 \\
1.90 \\
2.40\end{array}$ \\
\hline $\begin{array}{r}87516 \\
87592 \\
87594 \\
87595 \\
390\end{array}$ & $\begin{array}{l}07 / 09 / 87 \\
07 / 27 / 87 \\
07 / 27 / 87 \\
07 / 27 / 87 \\
11 / 04 / 86\end{array}$ & $\begin{array}{l}\text { HWMA, } \\
\text { SHECKI. } \\
\text { SHECKLE } \\
\text { SHECKIE } \\
\text { SWMA, }\end{array}$ & $\begin{array}{l}\text { MIDDLE ARIY DRAIN } \\
\text { LER RES. } \\
\text { LER RES. } \\
\text { LER RES. } \\
\text { ALKALI UN. } 1\end{array}$ & $\begin{array}{l}\text { FISH } \\
\text { FISH } \\
\text { FISH } \\
\text { FISH } \\
\text { FISH }\end{array}$ & $\begin{array}{l}\text { CARP } \\
\text { CARP } \\
\text { CARP } \\
\text { CARP } \\
\text { CARP }\end{array}$ & $\begin{array}{l}80.10 \\
78.10 \\
78.50 \\
75.90 \\
76.67\end{array}$ & $\begin{array}{l}.31 \\
.92 \\
.76 \\
.38 \\
.34\end{array}$ & $\begin{array}{r}2.0 \\
<2.0 \\
<2.0 \\
<2.0 \\
<21.0\end{array}$ & $\begin{array}{r}1.00 \\
<1.00 \\
3.50 \\
<1.00 \\
5.60\end{array}$ & $\begin{array}{l}<4.00 \\
<4.00 \\
<4.00 \\
<4.00 \\
<.85\end{array}$ & $\begin{array}{r}.43 \\
1.20 \\
2.30 \\
.82 \\
.39\end{array}$ & $\begin{array}{l}3.80 \\
1.70 \\
1.40 \\
1.50 \\
1.70\end{array}$ \\
\hline $\begin{array}{l}391 \\
392 \\
338 \\
339 \\
340\end{array}$ & $\begin{array}{l}11 / 04 / 86 \\
11 / 04 / 86 \\
10 / 02 / 86 \\
10 / 02 / 86 \\
10 / 02 / 86\end{array}$ & $\begin{array}{l}\text { SWMA, } \\
\text { SWRA, } \\
\text { SWMA, } \\
\text { SWMA, } \\
\text { sWMA, }\end{array}$ & $\begin{array}{l}\text { ALKALI UN. I } \\
\text { ALKALI UN. } 1 \\
\text { GOOSE LAKE } \\
\text { GOOSE LAKE } \\
\text { COOSE LAKE }\end{array}$ & $\begin{array}{l}\text { FISH } \\
\text { FISH } \\
\text { FISH } \\
\text { FISH } \\
\text { FISH }\end{array}$ & $\begin{array}{l}\text { CARP } \\
\text { CARP } \\
\text { CARP } \\
\text { CARP } \\
\text { CARP }\end{array}$ & $\begin{array}{l}75.38 \\
77.68 \\
78.91 \\
75.09 \\
76.83\end{array}$ & $\begin{array}{r}.20 \\
.26 \\
.28 \\
<.17 \\
.45\end{array}$ & $\begin{array}{l}<20.0 \\
<22.0 \\
<23.0 \\
<20.0 \\
<21.0\end{array}$ & $\begin{array}{r}29.00 \\
6.70 \\
8.60 \\
6.60 \\
2.30\end{array}$ & $\begin{array}{l}<.79 \\
<.89 \\
<.92 \\
<.78 \\
<.85\end{array}$ & $\begin{array}{r}.98 \\
1.00 \\
.61 \\
.39 \\
.56\end{array}$ & $\begin{array}{l}1.90 \\
1.60 \\
1.80 \\
1.30 \\
1.30\end{array}$ \\
\hline $\begin{array}{r}373 \\
374 \\
375 \\
85007 \\
85008\end{array}$ & $\begin{array}{l}10 / 09 / 86 \\
10 / 09 / 86 \\
10 / 09 / 86 \\
07 / 29 / 85 \\
07 / 29 / 85\end{array}$ & $\begin{array}{l}\text { SWMA, I } \\
\text { SWMA, I } \\
\text { SWWM, I } \\
\text { SWMA, : } \\
\text { SWMA, S }\end{array}$ & $\begin{array}{l}\text { LEAD LAKE } \\
\text { LEAD LAKE } \\
\text { IEAD LAKE } \\
\text { STILLWATER PT. DIV. } \\
\text { STILLWATER PT. DIV. }\end{array}$ & $\begin{array}{l}\text { FISH } \\
\text { FISH } \\
\text { FISH } \\
\text { FISH } \\
\text { FISH }\end{array}$ & $\begin{array}{l}\text { CARP } \\
\text { CARP } \\
\text { CARP } \\
\text { CARP } \\
\text { CARP }\end{array}$ & $\begin{array}{r}75.47 \\
73.04 \\
76.72 \\
78.20 \\
71.60\end{array}$ & $\begin{array}{r}<.18 \\
.45 \\
<.21 \\
.34 \\
.28\end{array}$ & $\begin{array}{l}<19.0 \\
<18.0 \\
<21.0 \\
--\end{array}$ & $\begin{array}{r}9.20 \\
9.20 \\
2.80 \\
.90 \\
.70\end{array}$ & $\begin{array}{l}<.77 \\
<.71 \\
<.85 \\
<.40 \\
<.40\end{array}$ & $\begin{array}{l}.48 \\
.46 \\
.45 \\
.69 \\
.53\end{array}$ & $\begin{array}{l}1.70 \\
1.50 \\
.83 \\
2.80 \\
1.70\end{array}$ \\
\hline $\begin{array}{r}85009 \\
366 \\
367 \\
368 \\
85011\end{array}$ & $\begin{array}{l}07 / 29 / 85 \\
10 / 07 / 86 \\
10 / 07 / 86 \\
10 / 07 / 86 \\
07 / 29 / 85\end{array}$ & $\begin{array}{l}\text { SWMA, } \\
\text { SWMA, } \\
\text { SWMA, } \\
\text { SWMA, } \\
\text { SWMA, }\end{array}$ & $\begin{array}{l}\text { STILLWATER PT. DIV. } \\
\text { STILLAATER PT. RES. } \\
\text { STILLWATER PT. RES. } \\
\text { STILLWATER PT. RES. } \\
\text { TJ DRAIN }\end{array}$ & $\begin{array}{l}\text { FISH } \\
\text { FISH } \\
\text { FISH } \\
\text { FISH } \\
\text { FISH }\end{array}$ & $\begin{array}{l}\text { CARP } \\
\text { CARP } \\
\text { CARP } \\
\text { CARP } \\
\text { CARP }\end{array}$ & $\begin{array}{l}78.00 \\
76.38 \\
78.50 \\
81.20 \\
76.80\end{array}$ & $\begin{array}{r}.36 \\
<.19 \\
.60 \\
.40 \\
.47\end{array}$ & $\begin{array}{l}<21.0 \\
<23.0 \\
<26.0 \\
--\end{array}$ & $\begin{array}{r}<.50 \\
2.50 \\
15.00 \\
14.00 \\
<.40\end{array}$ & $\begin{array}{r}<.40 \\
<.84 \\
<.92 \\
<1.00 \\
<.40\end{array}$ & $\begin{array}{r}1.20 \\
1.20 \\
1.00 \\
1.10 \\
.60\end{array}$ & $\begin{array}{l}1.10 \\
1.80 \\
1.80 \\
1.90 \\
2.70\end{array}$ \\
\hline $\begin{array}{r}85012 \\
85013 \\
371 \\
372 \\
376\end{array}$ & $\begin{array}{l}07 / 29 / 85 \\
07 / 29 / 85 \\
10 / 08 / 86 \\
10 / 08 / 86 \\
10 / 10 / 86\end{array}$ & $\begin{array}{l}\text { SWMA, } \\
\text { SWMA, } \\
\text { WASHOE } \\
\text { WASHOE } \\
\text { WASHOE }\end{array}$ & $\begin{array}{l}\text { TJ DRAIN } \\
\text { TJ DRAIN } \\
\text { E LAKE } \\
\text { E LAKE } \\
\text { E LAKE }\end{array}$ & $\begin{array}{l}\text { FISH } \\
\text { FISH } \\
\text { FISH } \\
\text { FISH } \\
\text { FISH }\end{array}$ & $\begin{array}{l}\text { CARP } \\
\text { CARP } \\
\text { CARP } \\
\text { CARP } \\
\text { CARP }\end{array}$ & $\begin{array}{l}80.10 \\
80.40 \\
75.58 \\
74.85 \\
74.90\end{array}$ & $\begin{array}{r}.80 \\
2.60 \\
<.17 \\
.28 \\
<.17\end{array}$ & $\begin{array}{c}<.2 \\
-- \\
<20.0 \\
<19.0\end{array}$ & $\begin{array}{r}1.50 \\
3.30 \\
<2.00 \\
5.70 \\
9.30\end{array}$ & $\begin{array}{r}<.40 \\
<.40 \\
-.9 \\
1.95 \\
1.20\end{array}$ & $\begin{array}{l}.60 \\
1.10 \\
3.30 \\
5.40 \\
3.70\end{array}$ & $\begin{array}{r}1.60 \\
2.40 \\
1.10 \\
1.40 \\
.97\end{array}$ \\
\hline $\begin{array}{r}85004 \\
85005 \\
85006 \\
377 \\
378\end{array}$ & $\begin{array}{l}07 / 29 / 85 \\
07 / 29 / 85 \\
07 / 29 / 85 \\
10 / 23 / 86 \\
10 / 23 / 86\end{array}$ & $\begin{array}{l}\text { CARSON } \\
\text { CARSON } \\
\text { CARSON } \\
\text { CARSON } \\
\text { CARSON }\end{array}$ & $\begin{array}{lll}N & L ., & \text { CARSON I DRAIN } \\
N & I \ldots, \text { CARSON I DRAIN } \\
N & I \ldots, \text { CARSON I DRAIN } \\
N & \text { L., ISLANDS UNIT } \\
N & \text { L., I I SLANDS UNIT }\end{array}$ & $\begin{array}{l}\text { FISH } \\
\text { FISH } \\
\text { FISH } \\
\text { FISH } \\
\text { FISH }\end{array}$ & $\begin{array}{l}\text { MOSQUITOFISH } \\
\text { MOSQUITOFISH } \\
\text { MOSQUITOFISH } \\
\text { MOSQUITOFISH } \\
\text { MOSQUITOFISH }\end{array}$ & $\begin{array}{l}79.40 \\
79.50 \\
80.20 \\
80.57 \\
79.42\end{array}$ & $\begin{array}{r}.87 \\
1.10 \\
.86 \\
.25 \\
<.22\end{array}$ & $\begin{array}{c}-- \\
<25.0 \\
<23.0\end{array}$ & $\begin{array}{l}<.50 \\
1.50 \\
1.00 \\
3.00 \\
4.50\end{array}$ & $\begin{array}{r}<.40 \\
1.00 \\
.50 \\
<.99 \\
<.93\end{array}$ & $\begin{array}{l}1.10 \\
1.00 \\
1.30 \\
1.60 \\
1.50\end{array}$ & $\begin{array}{l}3.00 \\
1.80 \\
1.70 \\
2.60 \\
2.80\end{array}$ \\
\hline $\begin{array}{r}379 \\
87605 \\
384 \\
385 \\
386\end{array}$ & $\begin{array}{l}10 / 23 / 86 \\
07 / 23 / 87 \\
11 / 03 / 86 \\
11 / 03 / 86 \\
11 / 03 / 86\end{array}$ & $\begin{array}{l}\text { CARSON } \\
\text { CARSON } \\
\text { CARSON } \\
\text { CARSON } \\
\text { CARSON }\end{array}$ & 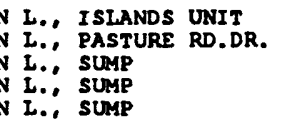 & $\begin{array}{l}\text { FISH } \\
\text { FISH } \\
\text { FISH } \\
\text { FISH } \\
\text { FISH }\end{array}$ & $\begin{array}{l}\text { MOSQUITOFISH } \\
\text { MOSQUITOFISH } \\
\text { MOSQUITOFISH } \\
\text { MOSQUITOFISH } \\
\text { MOSQUITOFISH }\end{array}$ & $\begin{array}{l}79.39 \\
77.30 \\
80.43 \\
80.63 \\
80.67\end{array}$ & $\begin{array}{r}.25 \\
2.40 \\
<.20 \\
<.25 \\
.31\end{array}$ & $\begin{array}{l}<24.0 \\
<2.0 \\
<25.0 \\
<26.0 \\
<26.0\end{array}$ & $\begin{array}{r}4.10 \\
<1.00 \\
3.20 \\
5.90 \\
<2.60\end{array}$ & $\begin{array}{l}<.97 \\
<4.00 \\
<1.00 \\
<1.00 \\
<1.00\end{array}$ & $\begin{array}{l}1.30 \\
2.80 \\
1.90 \\
<.23 \\
2.10\end{array}$ & $\begin{array}{l}3.10 \\
3.10 \\
2.70 \\
2.10 \\
2.50\end{array}$ \\
\hline
\end{tabular}


TABLE 19.--Data on trace-element const1tuents and percent mo1sture of blologlcal samples in st111water w11d11fe Management Area, Carson Lake, Fernley W1ldlife Management Area, and Humboldt W11dlife Management Area, $1985-87--C o n t$.

\begin{tabular}{|c|c|c|c|c|c|c|c|c|c|c|c|}
\hline $\begin{array}{l}\text { USFws } \\
\text { local } \\
\text { ID } \\
\text { number }\end{array}$ & Date & Location & $\begin{array}{l}\text { Cate- } \\
\text { gory }\end{array}$ & Species & $\begin{array}{l}\text { nt } \\
\text { ure }\end{array}$ & $\begin{array}{c}\text { Arse- } \\
\text { n1c }\end{array}$ & Boron & $\begin{array}{l}\text { Chro- } \\
\text { m1um }\end{array}$ & Lead & $\begin{array}{l}\text { Mer- } \\
\text { cury }\end{array}$ & $\begin{array}{l}\text { Sele- } \\
\text { n1um }\end{array}$ \\
\hline $\begin{array}{l}242 \\
243 \\
244 \\
143 \\
214\end{array}$ & $\begin{array}{l}09 / 22 / 86 \\
09 / 22 / 86 \\
09 / 22 / 86 \\
09 / 09 / 86 \\
09 / 09 / 86\end{array}$ & $\begin{array}{l}\text { CARSON VALLEY } \\
\text { CARSON VALLEY } \\
\text { CARSON VALLEY } \\
\text { FERNLEY WTMA } \\
\text { FERNLEY WMMA }\end{array}$ & $\begin{array}{l}\text { FISH } \\
\text { FISH } \\
\text { FISH } \\
\text { FISH } \\
\text { FISH }\end{array}$ & $\begin{array}{l}\text { MOSQUITOFISH } \\
\text { MOSQUITOFISH } \\
\text { MOSQUITOFISH } \\
\text { MOSQUITOFISH } \\
\text { MOSQUITOFISH }\end{array}$ & $\begin{array}{l}76.96 \\
75.00 \\
77.25 \\
75.80 \\
74.95\end{array}$ & $\begin{array}{r}<0.19 \\
<.17 \\
<.22 \\
.16 \\
.43\end{array}$ & $\begin{array}{l}<21.0 \\
<20.0 \\
<22.0 \\
<20.0 \\
<19.0\end{array}$ & $\begin{array}{r}16.00 \\
17.00 \\
13.00 \\
2.10 \\
2.50\end{array}$ & $\begin{array}{l}<0.85 \\
<.79 \\
<.86 \\
<.79 \\
<.77\end{array}$ & $\begin{array}{r}0.53 \\
.52 \\
.48 \\
<.38 \\
<.18\end{array}$ & $\begin{array}{r}0.85 \\
.73 \\
.69 \\
3.90 \\
1.40\end{array}$ \\
\hline $\begin{array}{l}145 \\
87503 \\
87504 \\
87505 \\
87586\end{array}$ & $\begin{array}{l}09 / 09 / 86 \\
07 / 08 / 87 \\
07 / 08 / 87 \\
07 / 08 / 87 \\
07 / 20 / 87\end{array}$ & $\begin{array}{l}\text { FERNLEY WMA } \\
\text { MASSIE SLOUGH } \\
\text { MASSIE SLOUGH } \\
\text { MASSIE SLOUGH } \\
\text { MASSIE SLOUGH }\end{array}$ & $\begin{array}{l}\text { FISH } \\
\text { FISH } \\
\text { FISH } \\
\text { FISH } \\
\text { FISH }\end{array}$ & $\begin{array}{l}\text { MOSQUITOFISH } \\
\text { MOSQUITOFISH } \\
\text { MOSQUITOFISH } \\
\text { MOSQUITOFISH } \\
\text { MOSQUITOFISH }\end{array}$ & $\begin{array}{l}75.58 \\
74.80 \\
76.40 \\
78.70 \\
83.40\end{array}$ & $\begin{array}{r}.21 \\
4.30 \\
4.90 \\
6.30 \\
1.90\end{array}$ & $\begin{array}{r}<20.0 \\
<2.0 \\
<2.0 \\
4.0 \\
6.3\end{array}$ & $\begin{array}{r}5.00 \\
<1.00 \\
<1.00 \\
<1.00 \\
<1.00\end{array}$ & $\begin{array}{l}<.79 \\
<4.00 \\
<4.00 \\
<4.00 \\
<4.00\end{array}$ & $\begin{array}{l}<.20 \\
.19 \\
.16 \\
.15 \\
.14\end{array}$ & $\begin{array}{l}3.60 \\
5.00 \\
5.10 \\
5.50 \\
8.80\end{array}$ \\
\hline $\begin{array}{r}172 \\
363 \\
365 \\
85010 \\
85014\end{array}$ & $\begin{array}{l}09 / 16 / 86 \\
10 / 06 / 86 \\
10 / 07 / 86 \\
07 / 29 / 85 \\
07 / 29 / 85\end{array}$ & $\begin{array}{l}\text { SWMA, ALKALI UN. } 11 \\
\text { SWMA, ALKALI UN. } 1 \\
\text { SWMA, ALKALI UN. } \\
\text { SWMA, STILIWATER PT. DIV. } \\
\text { SWMA, TJ DRAIN }\end{array}$ & $\begin{array}{l}\text { FISH } \\
\text { FISH } \\
\text { FISH } \\
\text { FISH } \\
\text { FISH }\end{array}$ & $\begin{array}{l}\text { MOSQUITOFISH } \\
\text { MOSQUITOFISH } \\
\text { MOSQUITOFISH } \\
\text { MOSQUITOFISH } \\
\text { MOSQUITOFISH }\end{array}$ & $\begin{array}{l}79.76 \\
77.32 \\
78.11 \\
77.50 \\
78.80\end{array}$ & $\begin{array}{r}.23 \\
.37 \\
.41 \\
.71 \\
3.50\end{array}$ & $\begin{array}{l}<24.0 \\
<21.0 \\
<22.0 \\
=-\end{array}$ & $\begin{array}{r}<2.40 \\
5.90 \\
<2.20 \\
<.90 \\
<.50\end{array}$ & $\begin{array}{r}<.96 \\
<.85 \\
<.86 \\
.90 \\
.40\end{array}$ & $\begin{array}{r}.56 \\
.35 \\
.28 \\
2.90 \\
.57\end{array}$ & $\begin{array}{l}1.60 \\
1.20 \\
1.20 \\
2.60 \\
2.70\end{array}$ \\
\hline $\begin{array}{r}85015 \\
85016 \\
394 \\
383 \\
87593\end{array}$ & $\begin{array}{l}07 / 29 / 85 \\
07 / 29 / 85 \\
10 / 03 / 86 \\
10 / 29 / 86 \\
07 / 27 / 87\end{array}$ & $\begin{array}{l}\text { SWMA, TJ DRAIN } \\
\text { SWMA, TJ DRAIN } \\
\text { CARSON I., SPRIG PONDS } \\
\text { HWRA, HUMBOLDT LAKE } \\
\text { SHECKLER RES. }\end{array}$ & $\begin{array}{l}\text { FISH } \\
\text { FISH } \\
\text { FISH } \\
\text { FISH } \\
\text { FISH }\end{array}$ & $\begin{array}{l}\text { MOSQUITOFISH } \\
\text { MOSQUITOFISH } \\
\text { SAC PERCH } \\
\text { SAC PERCH } \\
\text { SAC. BLACKFISH }\end{array}$ & $\begin{array}{r}78.80 \\
78.00 \\
68.51 \\
74.71 \\
80.90\end{array}$ & $\begin{array}{r}1.20 \\
3.40 \\
<.14 \\
.54 \\
.69\end{array}$ & $\begin{array}{l}-- \\
<15.0 \\
<19.0 \\
<2.0\end{array}$ & $\begin{array}{r}<.50 \\
<.90 \\
<3.50 \\
7.60 \\
1.00\end{array}$ & $\begin{array}{r}<.40 \\
.50 \\
<.61 \\
<.76 \\
<4.00\end{array}$ & $\begin{array}{r}.66 \\
.59 \\
5.70 \\
.66 \\
1.90\end{array}$ & $\begin{array}{l}2.50 \\
3.70 \\
1.90 \\
3.10 \\
1.30\end{array}$ \\
\hline $\begin{array}{r}87687 \\
173 \\
362 \\
364 \\
312\end{array}$ & $\begin{array}{l}09 / 09 / 87 \\
09 / 16 / 86 \\
10 / 06 / 86 \\
10 / 07 / 86 \\
09 / 30 / 86\end{array}$ & $\begin{array}{l}\text { SHECKLER RES. } \\
\text { SWMAA, ALKALI UN. } 1 \\
\text { SWMMA, ALKALI UN. } \\
\text { SWMM, ALKALI UN. II } \\
\text { SWMA, GOOSE LAKE }\end{array}$ & $\begin{array}{l}\text { FISH } \\
\text { FISH } \\
\text { FISH } \\
\text { FISH } \\
\text { FISH }\end{array}$ & $\begin{array}{l}\text { SAC. BLACKFISH } \\
\text { SHINERS } \\
\text { SHINERS } \\
\text { SHINERS } \\
\text { SHINERS }\end{array}$ & $\begin{array}{l}77.00 \\
78.10 \\
76.67 \\
76.80 \\
70.45\end{array}$ & $\begin{array}{r}.40 \\
<.18 \\
.36 \\
<.20 \\
<.16\end{array}$ & $\begin{array}{l}<2.0 \\
<23.0 \\
<20.0 \\
<22.0 \\
<16.0\end{array}$ & $\begin{array}{r}<1.00 \\
5.10 \\
4.40 \\
9.50 \\
2.70\end{array}$ & $\begin{array}{r}<4.00 \\
1.50 \\
1.70 \\
<.86 \\
<.64\end{array}$ & $\begin{array}{r}2.60 \\
.27 \\
.33 \\
.31 \\
.78\end{array}$ & $\begin{array}{l}.99 \\
1.70 \\
1.60 \\
1.60 \\
.96\end{array}$ \\
\hline $\begin{array}{l}313 \\
314 \\
393 \\
149 \\
150\end{array}$ & $\begin{array}{l}09 / 30 / 86 \\
09 / 30 / 86 \\
11 / 01 / 86 \\
09 / 09 / 86 \\
09 / 09 / 86\end{array}$ & $\begin{array}{l}\text { SWMA, COOSE LAKE } \\
\text { SWAMA, GOOSE LAKE } \\
\text { SWMA, ALKALI UN. II } \\
\text { FERNLEY WHA } \\
\text { FERNLEY WHA }\end{array}$ & $\begin{array}{l}\text { FISH } \\
\text { FISH } \\
\text { FISH } \\
\text { FISH } \\
\text { FISH }\end{array}$ & $\begin{array}{l}\text { SHINERS } \\
\text { SHINERS } \\
\text { SM MOUTH BASS } \\
\text { TUI CHUB } \\
\text { TUI CHUB }\end{array}$ & $\begin{array}{l}70.57 \\
70.41 \\
73.28 \\
75.94 \\
74.47\end{array}$ & $\begin{array}{r}.23 \\
<.14 \\
.23 \\
.35 \\
<.17\end{array}$ & $\begin{array}{l}<17.0 \\
<17.0 \\
<18.0 \\
<20.0 \\
<19.0\end{array}$ & $\begin{array}{r}3.20 \\
5.10 \\
12.00 \\
4.00 \\
3.40\end{array}$ & $\begin{array}{l}<.68 \\
<.67 \\
<.74 \\
<.79 \\
<.75\end{array}$ & $\begin{array}{r}.84 \\
.68 \\
2.10 \\
.27 \\
.46\end{array}$ & $\begin{array}{l}1.60 \\
1.20 \\
1.60 \\
6.70 \\
6.30\end{array}$ \\
\hline $\begin{array}{r}151 \\
87682 \\
87683 \\
315 \\
316\end{array}$ & $\begin{array}{l}09 / 09 / 86 \\
09 / 03 / 87 \\
09 / 03 / 87 \\
09 / 30 / 86 \\
09 / 30 / 86\end{array}$ & $\begin{array}{l}\text { FERNLEY WMA } \\
\text { HARMON RES. } \\
\text { HARMON RES. } \\
\text { SWMA, GOOSE LAKE } \\
\text { SWMA, GOOSE LAKE }\end{array}$ & $\begin{array}{l}\text { FISH } \\
\text { FISH } \\
\text { FISH } \\
\text { FISH } \\
\text { FISH }\end{array}$ & $\begin{array}{l}\text { TUI CHUB } \\
\text { TUI CHUB } \\
\text { TUI CHUB } \\
\text { TUI CHUB } \\
\text { TUI CHUB }\end{array}$ & $\begin{array}{l}73.81 \\
73.70 \\
75.80 \\
64.52 \\
69.94\end{array}$ & $\begin{array}{r}.21 \\
.36 \\
.36 \\
<.12 \\
<.14\end{array}$ & $\begin{array}{r}<18.0 \\
<2.0 \\
<2.0 \\
<14.0 \\
<16.0\end{array}$ & $\begin{array}{r}2.20 \\
<1.00 \\
2.00 \\
1.60 \\
2.30\end{array}$ & $\begin{array}{r}<.72 \\
<4.00 \\
<4.00 \\
<.55 \\
<.64\end{array}$ & $\begin{array}{l}.18 \\
.86 \\
.96 \\
.13 \\
.17\end{array}$ & $\begin{array}{l}5.50 \\
1.00 \\
1.00 \\
1.94 \\
1.30\end{array}$ \\
\hline $\begin{array}{r}317 \\
87602 \\
87679 \\
87680 \\
87596\end{array}$ & $\begin{array}{l}09 / 30 / 86 \\
07 / 28 / 87 \\
09 / 02 / 87 \\
09 / 03 / 87 \\
07 / 27 / 87\end{array}$ & $\begin{array}{l}\text { SWMA, COOSE LAKE } \\
\text { HARYON RES. } \\
\text { HARMON RES. } \\
\text { HARMON RES. } \\
\text { SHECKLER RES. }\end{array}$ & $\begin{array}{l}\text { FISH } \\
\text { FISH } \\
\text { FISH } \\
\text { FISH } \\
\text { FISH }\end{array}$ & $\begin{array}{l}\text { TUI CHUB } \\
\text { WHITE BASS } \\
\text { WHITE BASS } \\
\text { WHITE BASS } \\
\text { WHITE BASS }\end{array}$ & $\begin{array}{l}66.53 \\
72.60 \\
74.50 \\
76.00 \\
75.00\end{array}$ & $\begin{array}{r}<.25 \\
.32 \\
.30 \\
.20 \\
.22\end{array}$ & $\begin{array}{l}<15.0 \\
<2.0 \\
<2.0 \\
31.0 \\
<2.0\end{array}$ & $\begin{array}{r}1.60 \\
<1.00 \\
<1.00 \\
1.00 \\
<1.00\end{array}$ & $\begin{array}{l}<.59 \\
<4.00 \\
<4.00 \\
<4.00 \\
<4.00\end{array}$ & $\begin{array}{r}.19 \\
1.80 \\
1.40 \\
5.26 \\
.75\end{array}$ & $\begin{array}{l}2.80 \\
2.10 \\
1.20 \\
2.00 \\
1.70\end{array}$ \\
\hline $\begin{array}{r}87597 \\
87598 \\
87686 \\
87568 \\
33\end{array}$ & $\begin{array}{l}07 / 27 / 87 \\
07 / 27 / 87 \\
09 / 09 / 87 \\
07 / 14 / 87 \\
06 / 24 / 86\end{array}$ & $\begin{array}{l}\text { SHECKLER RES. } \\
\text { SHECKLER RES: } \\
\text { SHECKLER RES. } \\
\text { CARSON I.., DOWNS DRAIN } \\
\text { CARSON L., I ISLANDS UNIT }\end{array}$ & $\begin{array}{l}\text { FISH } \\
\text { FISH } \\
\text { FISH } \\
\text { INSECT } \\
\text { INSECT }\end{array}$ & $\begin{array}{l}\text { WHITE CRAPPIE } \\
\text { WHITE CRAPPIE } \\
\text { WHITE CRAPPIE } \\
\text { DIPTERA } \\
\text { DIPTERA }\end{array}$ & $\begin{array}{l}75.20 \\
76.20 \\
74.90 \\
90.30 \\
87.35\end{array}$ & $\begin{array}{r}.76 \\
.82 \\
.20 \\
9.80 \\
4.60\end{array}$ & $\begin{array}{l}<2.0 \\
<2.0 \\
<2.0 \\
16.0 \\
93.0\end{array}$ & $\begin{array}{r}1.00 \\
<1.00 \\
<1.00 \\
5.30 \\
<2.20\end{array}$ & $\begin{array}{r}<4.00 \\
<4.00 \\
<4.00 \\
7.00 \\
7.90\end{array}$ & $\begin{array}{r}.63 \\
.67 \\
1.10 \\
4.30 \\
4.60\end{array}$ & $\begin{array}{l}1.30 \\
1.30 \\
1.40 \\
6.80 \\
1.10\end{array}$ \\
\hline $\begin{array}{r}12 \\
13 \\
94 \\
8795 \\
129\end{array}$ & $\begin{array}{l}06 / 10 / 86 \\
06 / 10 / 86 \\
07 / 29 / 86 \\
07 / 06 / 87 \\
08 / 05 / 86\end{array}$ & $\begin{array}{l}\text { CARSON L., SPRIG PONDS } \\
\text { CARSON I., SUMP } \\
\text { CARSON VALLEY } \\
\text { ERB DEEP DRAIN } \\
\text { FERNLEY WMA }\end{array}$ & $\begin{array}{l}\text { INSECT } \\
\text { INSECT } \\
\text { INSECT } \\
\text { INSECT } \\
\text { INSECT }\end{array}$ & $\begin{array}{l}\text { DIPTERA } \\
\text { DIPTERA } \\
\text { DIPTERA } \\
\text { DIPTERA } \\
\text { DIPTERA }\end{array}$ & $\begin{array}{l}87.84 \\
85.91 \\
86.26 \\
87.70 \\
86.42\end{array}$ & $\begin{array}{r}6.50 \\
4.60 \\
1.50 \\
18.10 \\
9.30\end{array}$ & $\begin{array}{l}<40.0 \\
180.0 \\
<35.0 \\
12.0 \\
<37.0\end{array}$ & $\begin{array}{r}10.00 \\
6.10 \\
2.10 \\
6.20 \\
10.00\end{array}$ & $\begin{array}{r}9.70 \\
1.90 \\
2.70 \\
<4.00 \\
4.40\end{array}$ & $\begin{array}{l}5.40 \\
2.20 \\
<.34 \\
.17 \\
<.36\end{array}$ & $\begin{array}{r}1.40 \\
<.31 \\
.80 \\
5.60 \\
13.00\end{array}$ \\
\hline $\begin{array}{r}131 \\
87414 \\
87417 \\
87422 \\
40\end{array}$ & $\begin{array}{l}08 / 05 / 86 \\
06 / 23 / 87 \\
06 / 25 / 87 \\
06 / 25 / 87 \\
07 / 02 / 86\end{array}$ & $\begin{array}{l}\text { HWMA, HUMBOLDT LAKE } \\
\text { HWAM, TOULON LAKE } \\
\text { MAHALA SLOUGH } \\
\text { SHECKLER RES. } \\
\text { SWMA, ALKALI UN. } 1\end{array}$ & $\begin{array}{l}\text { INSECT } \\
\text { INSECT } \\
\text { INSECT } \\
\text { INSECT } \\
\text { INSECT }\end{array}$ & $\begin{array}{l}\text { DIPTERA } \\
\text { DIPTERA } \\
\text { DIPTERA } \\
\text { DIPTERA } \\
\text { DIPTERA }\end{array}$ & $\begin{array}{l}89.20 \\
85.40 \\
87.10 \\
87.00 \\
90.69\end{array}$ & $\begin{array}{r}7.60 \\
7.80 \\
17.50 \\
7.50 \\
2.10\end{array}$ & $\begin{array}{r}<46.0 \\
30.0 \\
42.0 \\
7.6 \\
59.0\end{array}$ & $\begin{array}{r}20.00 \\
5.10 \\
7.20 \\
10.00 \\
<3.20\end{array}$ & $\begin{array}{r}<1.90 \\
<4.00 \\
7.00 \\
8.00 \\
<2.10\end{array}$ & $\begin{array}{r}<.44 \\
.08 \\
.18 \\
1.60 \\
.58\end{array}$ & $\begin{array}{l}2.50 \\
5.10 \\
6.50 \\
1.70 \\
.97\end{array}$ \\
\hline $\begin{array}{r}370 \\
38 \\
87733 \\
87559 \\
79\end{array}$ & $\begin{array}{l}10 / 07 / 86 \\
07 / 02 / 86 \\
07 / 28 / 87 \\
07 / 13 / 87 \\
07 / 22 / 86\end{array}$ & $\begin{array}{l}\text { SWMA, GOOSE LAKE } \\
\text { SWMA, LEAD LAKE } \\
\text { SWMA, NAVY CABIN DRAIN } \\
\text { SWMA, SHAFFNER DR., IND. L. } \\
\text { SWMA, STILLWATER PT. RES. }\end{array}$ & $\begin{array}{l}\text { INSECT } \\
\text { INSECT } \\
\text { INSECT } \\
\text { INSECT } \\
\text { INSECT }\end{array}$ & $\begin{array}{l}\text { DIPTERA } \\
\text { DIPTERA } \\
\text { DIPTERA } \\
\text { DIPTERA } \\
\text { DIPTERA }\end{array}$ & $\begin{array}{l}86.53 \\
88.67 \\
88.80 \\
89.70 \\
87.40\end{array}$ & $\begin{array}{r}1.20 \\
7.60 \\
12.00 \\
7.50 \\
5.20\end{array}$ & $\begin{array}{r}<37.0 \\
<86.0 \\
26.0 \\
31.0 \\
<40.0\end{array}$ & $\begin{array}{r}18.00 \\
19.00 \\
6.10 \\
3.20 \\
4.30\end{array}$ & $\begin{array}{r}<1.50 \\
3.50 \\
<7.00 \\
<4.00 \\
2.90\end{array}$ & $\begin{array}{r}.53 \\
.46 \\
.79 \\
.55 \\
2.50\end{array}$ & $\begin{array}{l}<.74 \\
3.20 \\
.82 \\
7.00 \\
1.00\end{array}$ \\
\hline
\end{tabular}


TABLE 19.--Data on trace-element const1tuents and percent molsture of blologlcal samples in st12lwater w1ld1 fe Management Area, Carson Lake, Fernley Wildilfe Management Area, and Humboldt Wildilfe Management Area, $1985-87--C o n t$.

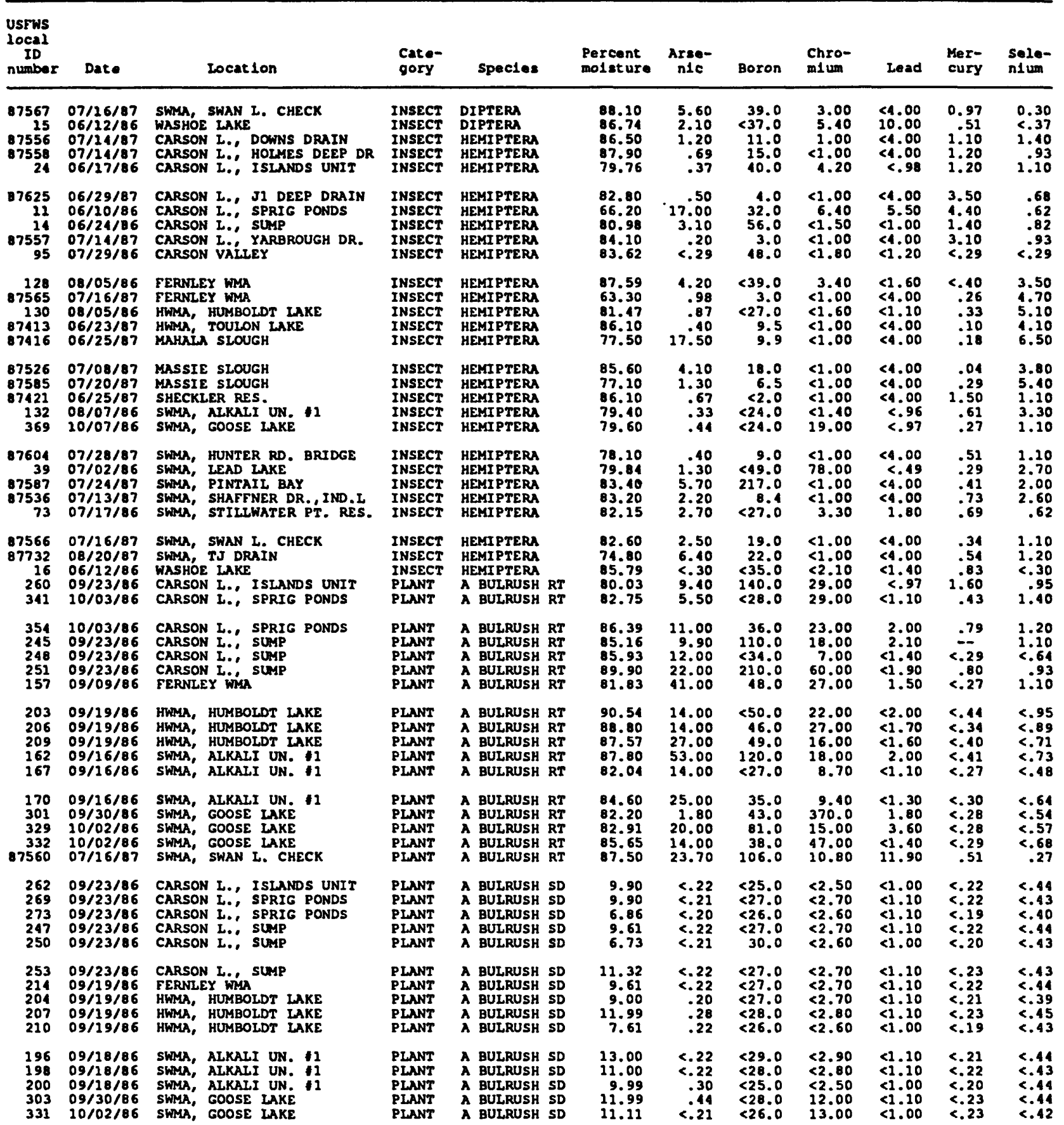


TABLE 19,--Data on trace-element constituents and percent molsture of biological samples in st111water w1ldilfe Management Area, Carson Lake, Fernley Wildlife Management Area, and Humboldt Wildlife Management Area, 1985-87--Cont.

\begin{tabular}{|c|c|c|c|c|c|c|c|c|c|c|c|}
\hline $\begin{array}{l}\text { UsFis } \\
\text { local } \\
\text { ID } \\
\text { number }\end{array}$ & Date & Location & $\begin{array}{l}\text { Cate- } \\
\text { gory }\end{array}$ & Specles & $\begin{array}{l}\text { Percent } \\
\text { molsture }\end{array}$ & $\begin{array}{l}\text { Arse- } \\
\text { n1c }\end{array}$ & Boron & $\begin{array}{l}\text { Chro- } \\
\text { mitum }\end{array}$ & Lead & $\begin{array}{l}\text { Mer- } \\
\text { cury }\end{array}$ & $\begin{array}{l}\text { sele- } \\
\text { nlum }\end{array}$ \\
\hline $\begin{array}{r}334 \\
87577 \\
87543 \\
87548 \\
87672\end{array}$ & $\begin{array}{l}10 / 02 / 86 \\
07 / 20 / 87 \\
07 / 14 / 87 \\
07 / 14 / 87 \\
08 / 24 / 87\end{array}$ & $\begin{array}{l}\text { SWAA, COOSE LAKE } \\
\text { CARSON I.. IA DEEP DRAIN } \\
\text { CARSON L.: DOWNS DRAIN } \\
\text { CARSON I.. HOLYES DEEP DR } \\
\text { CARSON I.. JI DEEP DRAIN }\end{array}$ & $\begin{array}{l}\text { PLANT } \\
\text { PLANT } \\
\text { PLANT } \\
\text { PLANT } \\
\text { PLANT }\end{array}$ & $\begin{array}{l}\text { A BULRUSH SD } \\
\text { ALGAE } \\
\text { ALGAE } \\
\text { ALGAE } \\
\text { ALGAE }\end{array}$ & $\begin{array}{r}8.91 \\
80.10 \\
80.60 \\
86.40 \\
80.60\end{array}$ & $\begin{array}{l}<0.19 \\
30.40 \\
17.80 \\
17.00 \\
11.00\end{array}$ & $\begin{array}{l}<27.0 \\
251.0 \\
210.0 \\
268.0 \\
229.0\end{array}$ & $\begin{array}{r}13.00 \\
9.75 \\
3.25 \\
2.28 \\
14.00\end{array}$ & $\begin{array}{r}<1.10 \\
23.40 \\
8.97 \\
10.90 \\
4.00\end{array}$ & $\begin{array}{r}<0.20 \\
1.90 \\
.65 \\
.16 \\
1.02\end{array}$ & $\begin{array}{r}<0.38 \\
.84 \\
1.07 \\
.13 \\
.20\end{array}$ \\
\hline $\begin{array}{r}87434 \\
87673 \\
87674 \\
271 \\
277\end{array}$ & $\begin{array}{l}06 / 30 / 87 \\
08 / 24 / 87 \\
08 / 24 / 87 \\
09 / 23 / 86 \\
09 / 23 / 86\end{array}$ & $\begin{array}{l}\text { CARSON I., PASTURE RD.DR. } \\
\text { CARSON I.. PIERI DP. DR. } \\
\text { CARSON I.., PIER IL DP. DR. } \\
\text { CARSON I.., SPRIG PONDS } \\
\text { CARSON I.. SPRIG PONDS }\end{array}$ & $\begin{array}{l}\text { PLANT } \\
\text { PLANT } \\
\text { PLNNT } \\
\text { PLNNT } \\
\text { PLANT }\end{array}$ & $\begin{array}{l}\text { ALGAE } \\
\text { ALGAE } \\
\text { ALGAE } \\
\text { ALGAE } \\
\text { ALGAE }\end{array}$ & $\begin{array}{l}84.80 \\
80.60 \\
62.10 \\
89.48 \\
82.01\end{array}$ & $\begin{array}{r}20.70 \\
32.00 \\
6.90 \\
3.60 \\
12.00\end{array}$ & $\begin{array}{l}230.0 \\
150.0 \\
120.0 \\
190.0 \\
140.0\end{array}$ & $\begin{array}{r}5.16 \\
10.00 \\
11.00 \\
14.00 \\
<2.70\end{array}$ & $\begin{array}{r}<54.00 \\
6.00 \\
5.00 \\
<1.90 \\
2.00\end{array}$ & $\begin{array}{r}1.14 \\
.90 \\
.61 \\
<.42 \\
1.50\end{array}$ & $\begin{array}{r}.65 \\
.30 \\
.30 \\
<.86 \\
<.56\end{array}$ \\
\hline $\begin{array}{r}347 \\
279 \\
280 \\
67677 \\
225\end{array}$ & $\begin{array}{l}10 / 03 / 86 \\
09 / 23 / 86 \\
09 / 23 / 86 \\
08 / 24 / 87 \\
09 / 22 / 86\end{array}$ & $\begin{array}{l}\text { CARSON I., SPRIG PONDS } \\
\text { CARSON I., SUMP } \\
\text { CARSON L.. SUMP } \\
\text { CARSON I.: YARBROUGH DR. } \\
\text { CARSON VALLEY }\end{array}$ & $\begin{array}{l}\text { PLANT } \\
\text { PLANT } \\
\text { PLANT } \\
\text { PLANT } \\
\text { PLANT }\end{array}$ & $\begin{array}{l}\text { ALGAE } \\
\text { ALGAE } \\
\text { ALGAE } \\
\text { ALGAE } \\
\text { ALGAE }\end{array}$ & $\begin{array}{l}84.16 \\
79.54 \\
92.92 \\
85.90 \\
93.96\end{array}$ & $\begin{array}{r}16.00 \\
26.00 \\
28.00 \\
8.90 \\
1.60\end{array}$ & $\begin{array}{l}180.0 \\
270.0 \\
110.0 \\
110.0 \\
<81.0\end{array}$ & $\begin{array}{r}9.80 \\
6.70 \\
<6.80 \\
14.00 \\
35.00\end{array}$ & $\begin{array}{r}<1.20 \\
3.10 \\
<2.70 \\
10.00 \\
<3.20\end{array}$ & $\begin{array}{r}.26 \\
2.40 \\
1.30 \\
.43 \\
<.83\end{array}$ & $\begin{array}{r}1.00 \\
3.80 \\
2.60 \\
<1.49\end{array}$ \\
\hline $\begin{array}{r}230 \\
237 \\
87491 \\
154 \\
212\end{array}$ & $\begin{array}{l}09 / 22 / 86 \\
09 / 22 / 86 \\
07 / 06 / 87 \\
09 / 09 / 86 \\
09 / 15 / 86\end{array}$ & $\begin{array}{l}\text { CARSON VALLEY } \\
\text { CARSON VAILEY } \\
\text { ERB DEEP DRAIN } \\
\text { FERNLEY WMA } \\
\text { FERNLY WMA }\end{array}$ & $\begin{array}{l}\text { PLANT } \\
\text { PLANT } \\
\text { PIANT } \\
\text { PLANT } \\
\text { PLANT }\end{array}$ & $\begin{array}{l}\text { ALGAE } \\
\text { ALGAE } \\
\text { ALGAE } \\
\text { ALGAE } \\
\text { ALGAE }\end{array}$ & $\begin{array}{l}91.30 \\
87.42 \\
88.10 \\
88.43 \\
83.78\end{array}$ & $\begin{array}{r}5.00 \\
9.90 \\
18.70 \\
6.70 \\
13.00\end{array}$ & $\begin{array}{l}<57.0 \\
<40.0 \\
116.0 \\
170.0 \\
210.0\end{array}$ & $\begin{array}{l}<5.70 \\
95.00 \\
3.95 \\
15.00 \\
17.00\end{array}$ & $\begin{array}{r}<2.30 \\
3.30 \\
16.30 \\
<1.70 \\
<1.20\end{array}$ & $\begin{array}{r}<.56 \\
<.37 \\
.33 \\
<.37 \\
<.30\end{array}$ & $\begin{array}{l}<.96 \\
<.70 \\
1.18 \\
<.70 \\
2.20\end{array}$ \\
\hline $\begin{array}{r}216 \\
87564 \\
87670 \\
87671 \\
87656\end{array}$ & $\begin{array}{l}09 / 19 / 86 \\
07 / 16 / 87 \\
08 / 19 / 87 \\
08 / 19 / 87 \\
08 / 12 / 87\end{array}$ & $\begin{array}{l}\text { FERNLEY WMA } \\
\text { FERNLEY WMA } \\
\text { FERNLEY WMA } \\
\text { FERNLEY WMA } \\
\text { HWMA, CARPENTER RD. DRAIN }\end{array}$ & $\begin{array}{l}\text { PLANT } \\
\text { PLANT } \\
\text { PLANT } \\
\text { PIANT } \\
\text { PLANT }\end{array}$ & $\begin{array}{l}\text { ALGAE } \\
\text { ALGAE } \\
\text { ALGAE } \\
\text { ALGAE } \\
\text { ALGAE }\end{array}$ & $\begin{array}{l}92.22 \\
90.10 \\
89.40 \\
85.30 \\
61.80\end{array}$ & $\begin{array}{l}14.00 \\
32.00 \\
12.00 \\
19.00 \\
14.00\end{array}$ & $\begin{array}{r}220.0 \\
165.0 \\
33.0 \\
45.0 \\
16.0\end{array}$ & $\begin{array}{r}<6.10 \\
7.58 \\
8.10 \\
24.00 \\
13.00\end{array}$ & $\begin{array}{r}<2.10 \\
23.90 \\
<4.00 \\
6.00 \\
9.00\end{array}$ & $\begin{array}{l}<.61 \\
<.25 \\
.10 \\
.07 \\
.05\end{array}$ & $\begin{array}{r}<1.20 \\
2.11 \\
1.80 \\
1.50 \\
1.00\end{array}$ \\
\hline $\begin{array}{l}87517 \\
87514 \\
87472 \\
87477 \\
87520\end{array}$ & $\begin{array}{l}07109 / 87 \\
07109 / 87 \\
07 / 02 / 87 \\
07 / 02 / 87 \\
07 / 09 / 87\end{array}$ & $\begin{array}{l}\text { HWMA, RENNIE RD. DRAIN } \\
\text { HWMA, SEVENTEEN DITCH } \\
\text { HWMA, TOULON IAKE } \\
\text { HWMA, UPPER ARMY DRAIN } \\
\text { HWMA, WESTFALL RD. DRAIN }\end{array}$ & $\begin{array}{l}\text { PLANT } \\
\text { PLANT } \\
\text { PLANT } \\
\text { PLANT } \\
\text { PLANT }\end{array}$ & $\begin{array}{l}\text { AIGAE } \\
\text { ALGAE } \\
\text { ALGAE } \\
\text { ALGAE } \\
\text { AIGAE }\end{array}$ & $\begin{array}{l}70.00 \\
78.60 \\
82.60 \\
70.10 \\
85.10\end{array}$ & $\begin{array}{l}31.20 \\
42.10 \\
25.90 \\
12.10 \\
27.90\end{array}$ & $\begin{array}{r}128.0 \\
223.0 \\
121.0 \\
91.0 \\
175.0\end{array}$ & $\begin{array}{r}6.57 \\
5.51 \\
1.95 \\
16.50 \\
1.95\end{array}$ & $\begin{array}{r}22.40 \\
15.00 \\
9.20 \\
40.10 \\
6.71\end{array}$ & $\begin{array}{l}<.08 \\
<.12 \\
<.14 \\
<.08 \\
<.17\end{array}$ & $\begin{array}{l}.35 \\
.94 \\
.68 \\
.50 \\
.84\end{array}$ \\
\hline $\begin{array}{r}87507 \\
87581 \\
87419 \\
307 \\
308\end{array}$ & $\begin{array}{l}07 / 08 / 87 \\
07 / 20 / 87 \\
06 / 25 / 87 \\
09 / 30 / 86 \\
09 / 30 / 86\end{array}$ & $\begin{array}{l}\text { MASSIE SLOUGH } \\
\text { MASSIE SIOUGH } \\
\text { SHECKLER RES. } \\
\text { SWMA, GOOSE LAKE } \\
\text { SWMA, COOSE LAKE }\end{array}$ & $\begin{array}{l}\text { PLANT } \\
\text { PIANT } \\
\text { PLANT } \\
\text { PLANT } \\
\text { PIANT }\end{array}$ & $\begin{array}{l}\text { ALGAE } \\
\text { ALGAE } \\
\text { ALGAE } \\
\text { ALGAE } \\
\text { ALGAE }\end{array}$ & $\begin{array}{l}74.50 \\
76.50 \\
82.70 \\
89.08 \\
91.45\end{array}$ & $\begin{array}{r}16.70 \\
11.90 \\
12.90 \\
6.30 \\
7.70\end{array}$ & $\begin{array}{r}63.5 \\
182.0 \\
20.1 \\
190.0 \\
220.0\end{array}$ & $\begin{array}{r}3.80 \\
26.70 \\
19.20 \\
6.80 \\
82.00\end{array}$ & $\begin{array}{r}13.30 \\
48.90 \\
63.00 \\
2.10 \\
<2.30\end{array}$ & $\begin{array}{l}<.10 \\
<.12 \\
2.37 \\
<.35 \\
<.46\end{array}$ & $\begin{array}{r}.96 \\
2.81 \\
.67 \\
<.78 \\
2.90\end{array}$ \\
\hline $\begin{array}{r}186 \\
187 \\
194 \\
87527 \\
87449\end{array}$ & $\begin{array}{l}09 / 18 / 86 \\
09 / 18 / 86 \\
09 / 18 / 86 \\
07 / 13 / 87 \\
06 / 30 / 87\end{array}$ & $\begin{array}{l}\text { SWMA, IEAD LAKE } \\
\text { SWMA, LEAD LAKE } \\
\text { SWMA, LEAD LAKE } \\
\text { SWMA, SHAFFNER DR. IND.I. } \\
\text { CARSON I.. I DEEP DRAIN }\end{array}$ & $\begin{array}{l}\text { PLANT } \\
\text { PLANT } \\
\text { PLANT } \\
\text { PLANT } \\
\text { PLANT }\end{array}$ & $\begin{array}{l}\text { ALGAE } \\
\text { ALGAE } \\
\text { ALGAE } \\
\text { ALGAE } \\
\text { CATTAIL RT }\end{array}$ & $\begin{array}{l}91.05 \\
81.33 \\
85.94 \\
57.00 \\
89.60\end{array}$ & $\begin{array}{r}7.80 \\
15.00 \\
28.00 \\
18.00 \\
30.80\end{array}$ & $\begin{array}{r}220.0 \\
110.0 \\
110.0 \\
35.1 \\
51.4\end{array}$ & $\begin{array}{r}<5.60 \\
15.00 \\
27.00 \\
5.95 \\
6.25\end{array}$ & $\begin{array}{r}<2.20 \\
3.40 \\
1.80 \\
12.20 \\
11.80\end{array}$ & $\begin{array}{r}<.52 \\
.47 \\
<.34 \\
.19 \\
.52\end{array}$ & $\begin{array}{r}<.89 \\
1.70 \\
3.40 \\
1.63 \\
.34\end{array}$ \\
\hline $\begin{array}{r}87433 \\
87411 \\
87537 \\
263 \\
87409\end{array}$ & $\begin{array}{l}06 / 30 / 87 \\
06 / 30 / 87 \\
07 / 14 / 87 \\
09 / 23 / 86 \\
06 / 22 / 87\end{array}$ & $\begin{array}{l}\text { CARSON I., } \text { C.I.DP.DR. MID } \\
\text { CARSON I.: C.I.DP.DR.UPPR } \\
\text { CARSON I.: DOWNS DRAIN } \\
\text { CARSON I.. ISLANDS UNIT } \\
\text { CARSON I., JI DEEP DRAIN }\end{array}$ & $\begin{array}{l}\text { PLANT } \\
\text { PLANT } \\
\text { PLANT } \\
\text { PLANT } \\
\text { PLANT }\end{array}$ & $\begin{array}{l}\text { CATTAIL RT } \\
\text { CATTAII RT } \\
\text { CATTAIL RT } \\
\text { CATTAII RT } \\
\text { CATTAII RT }\end{array}$ & $\begin{array}{l}91.00 \\
89.70 \\
94.50 \\
86.80 \\
90.20\end{array}$ & $\begin{array}{r}22.80 \\
6.55 \\
11.80 \\
3.00 \\
12.80\end{array}$ & $\begin{array}{r}51.2 \\
54.1 \\
196.0 \\
<38.0 \\
61.6\end{array}$ & $\begin{array}{r}3.56 \\
3.40 \\
6.18 \\
23.00 \\
3.06\end{array}$ & $\begin{array}{r}<11.10 \\
<9.71 \\
24.00 \\
<1.50 \\
<10.20\end{array}$ & $\begin{array}{r}<.28 \\
.28 \\
2.54 \\
.45 \\
.42\end{array}$ & $\begin{array}{l}.22 \\
.12 \\
.17 \\
.86 \\
.10\end{array}$ \\
\hline $\begin{array}{r}87439 \\
87411 \\
87676 \\
345 \\
348\end{array}$ & $\begin{array}{l}06 / 30 / 87 \\
06 / 22 / 87 \\
08 / 24 / 87 \\
10 / 03 / 86 \\
10 / 03 / 86\end{array}$ & 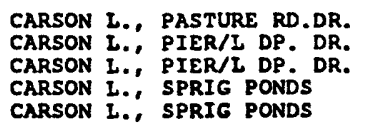 & $\begin{array}{l}\text { PLANT } \\
\text { PLANT } \\
\text { PLANT } \\
\text { PLANT } \\
\text { PLANT }\end{array}$ & $\begin{array}{l}\text { CATTAIL RT } \\
\text { CATTAII RT } \\
\text { CATTAII RT } \\
\text { CATTAII RT } \\
\text { CATTAIL RT }\end{array}$ & $\begin{array}{l}93.00 \\
89.10 \\
90.10 \\
90.00 \\
87.79\end{array}$ & $\begin{array}{r}26.00 \\
6.33 \\
8.50 \\
6.10 \\
.94\end{array}$ & $\begin{array}{r}88.6 \\
49.1 \\
15.0 \\
<48.0 \\
<40.0\end{array}$ & $\begin{array}{r}<1.10 \\
5.50 \\
6.00 \\
31.00 \\
24.00\end{array}$ & $\begin{array}{r}<14.30 \\
<9.17 \\
<4.00 \\
<1.90 \\
<1.60\end{array}$ & $\begin{array}{l}<.36 \\
<.23 \\
.23 \\
<.45 \\
<.35\end{array}$ & $\begin{array}{r}.21 \\
.06 \\
<.10 \\
<.84 \\
<.77\end{array}$ \\
\hline $\begin{array}{r}352 \\
87547 \\
217 \\
231 \\
234\end{array}$ & $\begin{array}{l}10 / 03 / 86 \\
07 / 14 / 87 \\
09 / 22 / 86 \\
09 / 22 / 86 \\
09 / 22 / 86\end{array}$ & $\begin{array}{l}\text { CARSON L., SPRIG PONDS } \\
\text { CARSON I.', YARBROUGH DR. } \\
\text { CARSON VALLEY } \\
\text { CARSON VALLEY } \\
\text { CARSON VALLEY }\end{array}$ & $\begin{array}{l}\text { PLANT } \\
\text { PLANT } \\
\text { PLANT } \\
\text { PLANT } \\
\text { PLANT }\end{array}$ & $\begin{array}{l}\text { CATTAIL RT } \\
\text { CATTAIL RT } \\
\text { CATTAIL RT } \\
\text { CATTAIL RT } \\
\text { CATTAIL RT }\end{array}$ & $\begin{array}{l}83.04 \\
91.30 \\
88.71 \\
77.32 \\
86.49\end{array}$ & $\begin{array}{r}1.50 \\
10.10 \\
15.00 \\
2.10 \\
2.20\end{array}$ & $\begin{array}{r}41.0 \\
56.0 \\
<44.0 \\
<21.0 \\
<36.0\end{array}$ & $\begin{array}{r}10.00 \\
20.20 \\
65.00 \\
1.90 \\
33.00\end{array}$ & $\begin{array}{r}<1.10 \\
<11.50 \\
3.50 \\
<.85 \\
<1.40\end{array}$ & $\begin{array}{r}<.28 \\
1.51 \\
.14 \\
<.21 \\
<.29\end{array}$ & $\begin{array}{l}<.57 \\
<.07 \\
<.76 \\
<.42 \\
<.57\end{array}$ \\
\hline $\begin{array}{r}87493 \\
152 \\
156 \\
158 \\
87452\end{array}$ & $\begin{array}{l}07 / 06 / 87 \\
09 / 09 / 86 \\
09 / 09 / 86 \\
09 / 09 / 86 \\
07 / 01 / 87\end{array}$ & $\begin{array}{l}\text { ERB DEEP DRAIN } \\
\text { FERNLEY WMA } \\
\text { FERNLEY WMA } \\
\text { FERNLEY WMA } \\
\text { FERNLEY WMA }\end{array}$ & $\begin{array}{l}\text { PLANT } \\
\text { PLANT } \\
\text { PLANT } \\
\text { PLANT } \\
\text { PLANT }\end{array}$ & $\begin{array}{l}\text { CATTAIL RT } \\
\text { CATTAIL RT } \\
\text { CATTAIL RT } \\
\text { CATTAIL RT } \\
\text { CATTAIL RT }\end{array}$ & $\begin{array}{l}93.10 \\
90.85 \\
91.10 \\
87.69 \\
84.20\end{array}$ & $\begin{array}{r}18.10 \\
23.00 \\
11.00 \\
81.00 \\
5.00\end{array}$ & $\begin{array}{r}94.2 \\
96.0 \\
<54.0 \\
81.0 \\
19.1\end{array}$ & $\begin{array}{r}<1.15 \\
12.00 \\
20.00 \\
35.00 \\
1.84\end{array}$ & $\begin{array}{r}<14.50 \\
<2.20 \\
<2.20 \\
<1.60 \\
6.33\end{array}$ & $\begin{array}{l}<.36 \\
<.54 \\
<.55 \\
<.34 \\
<.16\end{array}$ & $\begin{array}{r}.19 \\
1.10 \\
1.10 \\
<.63 \\
.19\end{array}$ \\
\hline
\end{tabular}


TABLE 19.--Data on trace-element constituents and percent molsture of blological samples in st11lwater Wildilfe Management Area, Carson Lake, Fernley wildlife Management Area, and Humboldt wildife Management Area, $1985-87--C o n t$.

\begin{tabular}{|c|c|c|c|c|c|c|c|c|c|c|c|}
\hline $\begin{array}{l}\text { USFws } \\
\text { local } \\
\text { ID } \\
\text { number }\end{array}$ & Date & Location & $\begin{array}{l}\text { Cate- } \\
\text { gory }\end{array}$ & Species & $\begin{array}{l}\text { Percent } \\
\text { moisture }\end{array}$ & $\begin{array}{c}\text { Arse- } \\
\text { nic }\end{array}$ & Boron & & Lead & $\begin{array}{l}\text { Mer- } \\
\text { cury }\end{array}$ & $\begin{array}{l}\text { Sele- } \\
\text { nlum }\end{array}$ \\
\hline $\begin{array}{l}87459 \\
87562 \\
87485 \\
87524 \\
87518\end{array}$ & $\begin{array}{l}07 / 01 / 87 \\
07 / 16 / 87 \\
07 / 06 / 87 \\
07 / 09 / 87 \\
07 / 09 / 87\end{array}$ & $\begin{array}{l}\text { FERNLEY WMA } \\
\text { FERNAEY WMA } \\
\text { HARMON RES. } \\
\text { HWAMA, CARPENTER RD. DRAIN } \\
\text { HWMA, RENNIE RD. DRAIN }\end{array}$ & $\begin{array}{l}\text { PLANT } \\
\text { PLANT } \\
\text { PLANT } \\
\text { PLANT } \\
\text { PLANT }\end{array}$ & $\begin{array}{l}\text { CATTAIL RT } \\
\text { CATTAIL RT } \\
\text { CATrAIL RT } \\
\text { CATTAIL RT } \\
\text { CATTAIL RT }\end{array}$ & $\begin{array}{l}89.10 \\
92.50 \\
93.10 \\
90.40 \\
89.80\end{array}$ & $\begin{array}{r}13.00 \\
131.0 \\
7.61 \\
11.40 \\
10.30\end{array}$ & $\begin{array}{l}10.9 \\
22.1 \\
51.2 \\
27.1 \\
<4.9\end{array}$ & $\begin{array}{r}2.92 \\
<1.37 \\
3.77 \\
5.94 \\
<1.00\end{array}$ & $\begin{array}{l}<9.10 \\
<13.30 \\
<14.50 \\
<10.10 \\
<9.80\end{array}$ & $\begin{array}{l}<0.24 \\
<.33 \\
.38 \\
<.26 \\
<.25\end{array}$ & $\begin{array}{r}0.63 \\
.19 \\
<.07 \\
.30 \\
.26\end{array}$ \\
\hline $\begin{array}{l}87473 \\
87466 \\
87521 \\
87569 \\
87509\end{array}$ & $\begin{array}{l}07 / 02 / 87 \\
07 / 02 / 87 \\
07 / 09 / 87 \\
07 / 17 / 87 \\
07 / 08 / 87\end{array}$ & $\begin{array}{l}\text { MWMA, SO. MERTDIAN RD.DR. } \\
\text { HWAM, TOULON IAKE } \\
\text { HWAMA, WESTFALL RD. DRAIN } \\
\text { MAHAIA SLOUGH } \\
\text { MASSIE SLOUGH }\end{array}$ & $\begin{array}{l}\text { PLANT } \\
\text { PINNT } \\
\text { PIANT } \\
\text { PIANT } \\
\text { PLANT }\end{array}$ & $\begin{array}{ll}\text { CATTAIL } & R T \\
\text { CATTAIL } & R T \\
\text { CATTAIL RT } \\
\text { CATTAIL } \\
\text { RT } \\
\text { CATTAIL RT }\end{array}$ & $\begin{array}{l}92.20 \\
93.70 \\
94.00 \\
90.60 \\
85.70\end{array}$ & $\begin{array}{r}2.54 \\
4.76 \\
4.50 \\
40.10 \\
88.10\end{array}$ & $\begin{array}{r}<6.9 \\
<7.9 \\
158.0 \\
61.0 \\
8.1\end{array}$ & $\begin{array}{r}1.67 \\
<2.59 \\
5.50 \\
2.28 \\
9.93\end{array}$ & $\begin{array}{r}<12.80 \\
<15.90 \\
<16.70 \\
<10.60 \\
<6.99\end{array}$ & $\begin{array}{l}<.32 \\
<.40 \\
<.42 \\
<.27 \\
<.17\end{array}$ & $\begin{array}{l}.09 \\
.22 \\
.53 \\
.38 \\
1.74\end{array}$ \\
\hline $\begin{array}{r}87579 \\
160 \\
165 \\
168 \\
87529\end{array}$ & $\begin{array}{l}07 / 20 / 87 \\
09 / 16 / 86 \\
09 / 16 / 86 \\
09 / 16 / 86 \\
07 / 13 / 87\end{array}$ & $\begin{array}{l}\text { MASSIE SLOVGH } \\
\text { SWMSA, ALKAII UN. \# } \\
\text { SWAA, ALKALI UN. } 12 \\
\text { SWMA, ALKALI UN, \#1 } \\
\text { SWMA, SHAFFNER DR., IND.L. }\end{array}$ & $\begin{array}{l}\text { PLANT } \\
\text { PLANT } \\
\text { PIANT } \\
\text { PLANT } \\
\text { PLANT }\end{array}$ & $\begin{array}{l}\text { CATTAIL RT } \\
\text { CATTAIL RT } \\
\text { CATTAIL RT } \\
\text { CATTAIL RT } \\
\text { CATTAIL RT }\end{array}$ & $\begin{array}{l}90.70 \\
88.56 \\
85.02 \\
84.86 \\
94.50\end{array}$ & $\begin{array}{r}22.00 \\
7.40 \\
7.60 \\
4.60 \\
7.05\end{array}$ & $\begin{array}{r}7.0 \\
73.0 \\
38.0 \\
55.0 \\
36.7\end{array}$ & $\begin{array}{r}5.59 \\
9.20 \\
18.00 \\
22.00 \\
47.10\end{array}$ & $\begin{array}{r}<10.80 \\
<1.70 \\
<1.30 \\
<1.30 \\
<18.20\end{array}$ & $\begin{array}{l}<.27 \\
<.14 \\
<.31 \\
<.33 \\
<.46\end{array}$ & $\begin{array}{r}.43 \\
<.86 \\
<.65 \\
<.65 \\
.94\end{array}$ \\
\hline $\begin{array}{l}177 \\
288 \\
290 \\
264 \\
346\end{array}$ & $\begin{array}{l}09 / 16 / 86 \\
09 / 16 / 86 \\
09 / 16 / 86 \\
09 / 23 / 86 \\
10 / 03 / 86\end{array}$ & $\begin{array}{l}\text { SWMA, STILIWATER PT. RES. } \\
\text { SWMA, STILLWATER PT. RES. } \\
\text { SWMA, STILLWATER PT. RES. } \\
\text { CARSON I.. ISLANDS UNIT } \\
\text { CARSON L.. SPRIG PONDS }\end{array}$ & $\begin{array}{l}\text { PLANT } \\
\text { PLANT } \\
\text { PLANT } \\
\text { PLANT } \\
\text { PLANT }\end{array}$ & $\begin{array}{l}\text { CATTAIL RT } \\
\text { CATTAIL RT } \\
\text { CATTAIL RT } \\
\text { CATTAII ST } \\
\text { CATTAIL ST }\end{array}$ & $\begin{array}{l}79.36 \\
89.86 \\
85.28 \\
76.64 \\
82.48\end{array}$ & $\begin{array}{r}7.20 \\
18.00 \\
12.00 \\
<.20 \\
<.27\end{array}$ & $\begin{array}{r}<24.0 \\
59.0 \\
120.0 \\
34.0 \\
<28.0\end{array}$ & $\begin{array}{r}20.00 \\
29.00 \\
19.00 \\
6.90 \\
26.00\end{array}$ & $\begin{array}{l}<.96 \\
<2.00 \\
<1.30 \\
<.85 \\
<1.10\end{array}$ & $\begin{array}{l}<.24 \\
<.95 \\
<.30 \\
<.21 \\
<.25\end{array}$ & $\begin{array}{l}<.48 \\
<.90 \\
<.58 \\
<.77 \\
<.54\end{array}$ \\
\hline $\begin{array}{l}349 \\
353 \\
218 \\
232 \\
235\end{array}$ & $\begin{array}{l}10 / 03 / 86 \\
10 / 03 / 86 \\
09 / 22 / 86 \\
09 / 22 / 86 \\
09 / 22 / 86\end{array}$ & $\begin{array}{l}\text { CARSON L.., SPRIG PONDS } \\
\text { CARSON L.. SPRIG PONDS } \\
\text { CARSON VAILEY } \\
\text { CARSON VALLEY } \\
\text { CARSON VALIEY }\end{array}$ & $\begin{array}{l}\text { PLANT } \\
\text { PLNNT } \\
\text { PLANT } \\
\text { PLANT } \\
\text { PLANT }\end{array}$ & $\begin{array}{ll}\text { CATTAIL } & \text { ST } \\
\text { CATTAII } & \text { ST } \\
\text { CATrAIL } & \text { ST } \\
\text { CATTAIL } & \text { ST } \\
\text { CATTAII } & \text { ST }\end{array}$ & $\begin{array}{l}85.10 \\
80.15 \\
84.84 \\
73.24 \\
75.79\end{array}$ & $\begin{array}{l}<.31 \\
<.24 \\
<.32 \\
.23 \\
<.21\end{array}$ & $\begin{array}{r}<32.0 \\
66.0 \\
<32.0 \\
20.0 \\
<20.0\end{array}$ & $\begin{array}{l}38.00 \\
13.00 \\
43.00 \\
12.00 \\
17.00\end{array}$ & $\begin{array}{l}<1.30 \\
<0.96 \\
<1.30 \\
<0.73 \\
<0.82\end{array}$ & $\begin{array}{l}<.31 \\
<.24 \\
<.32 \\
<.18 \\
<.21\end{array}$ & $\begin{array}{l}<.63 \\
<.47 \\
<.64 \\
<.35 \\
<.41\end{array}$ \\
\hline $\begin{array}{l}293 \\
297 \\
300 \\
318 \\
323\end{array}$ & $\begin{array}{l}09 / 09 / 86 \\
09 / 09 / 86 \\
09 / 09 / 86 \\
09 / 16 / 86 \\
09 / 16 / 86\end{array}$ & $\begin{array}{l}\text { FERNLEY WMA } \\
\text { FERNLEY WMA } \\
\text { FERNLEY WMA } \\
\text { SWMA, ALKALI UN. \$1 } \\
\text { SWMA, ALKALI UN. \$I }\end{array}$ & $\begin{array}{l}\text { PLANT } \\
\text { PLANT } \\
\text { PLANT } \\
\text { PLANT } \\
\text { PLANT }\end{array}$ & $\begin{array}{l}\text { CATTAIL } 5 T \\
\text { CATTAII } S T \\
\text { CATTAII ST } \\
\text { CATTAIL ST } \\
\text { CATTAIL ST }\end{array}$ & $\begin{array}{l}84.88 \\
89.10 \\
80.00 \\
80.19 \\
79.92\end{array}$ & $\begin{array}{l}1.10 \\
.56 \\
1.10 \\
<.21 \\
<.22\end{array}$ & $\begin{array}{l}35.0 \\
49.0 \\
77.0 \\
14.0 \\
11.0\end{array}$ & $\begin{array}{r}9.60 \\
38.00 \\
6.30 \\
200.0 \\
11.00\end{array}$ & $\begin{array}{l}<1.30 \\
<1.80 \\
<1.00 \\
<1.00 \\
<.96\end{array}$ & $\begin{array}{l}<.31 \\
<.45 \\
<.23 \\
<.23 \\
<.24\end{array}$ & $\begin{array}{l}<.53 \\
<.82 \\
<.49 \\
<.43 \\
<.44\end{array}$ \\
\hline $\begin{array}{l}325 \\
174 \\
182 \\
286 \\
220\end{array}$ & $\begin{array}{l}09 / 16 / 86 \\
09 / 16 / 86 \\
09 / 16 / 86 \\
09 / 16 / 86 \\
09 / 22 / 86\end{array}$ & $\begin{array}{l}\text { SWaAA, ALKALI UN. } 11 \\
\text { SWRA, STILLWATER PT. RES. } \\
\text { SWAAA, STILLWATER PT. RES. } \\
\text { SWMA, STILLWATER PT. RES. } \\
\text { CARSON VALLEY }\end{array}$ & $\begin{array}{l}\text { PLANT } \\
\text { PLANT } \\
\text { PLANT } \\
\text { PLANT } \\
\text { PLANT }\end{array}$ & $\begin{array}{l}\text { CATTAIL ST } \\
\text { CATTAIL ST } \\
\text { CATTAIL ST } \\
\text { CATTAIL ST } \\
\text { CHARA }\end{array}$ & $\begin{array}{l}82.17 \\
81.54 \\
78.01 \\
79.05 \\
87.82\end{array}$ & $\begin{array}{r}.38 \\
.54 \\
.84 \\
<.24 \\
3.90\end{array}$ & $\begin{array}{r}150.0 \\
<27.0 \\
120.0 \\
77.0 \\
<11.0\end{array}$ & $\begin{array}{l}21.00 \\
14.00 \\
20.00 \\
23.00 \\
28.00\end{array}$ & $\begin{array}{r}<1.10 \\
<1.10 \\
<.88 \\
<.94 \\
3.60\end{array}$ & $\begin{array}{l}<.26 \\
<.27 \\
<.22 \\
<.23 \\
<.39\end{array}$ & $\begin{array}{l}<.51 \\
<.53 \\
<.45 \\
<.48 \\
<.82\end{array}$ \\
\hline $\begin{array}{r}229 \\
238 \\
87450 \\
87575 \\
87430\end{array}$ & $\begin{array}{l}09 / 22 / 86 \\
09 / 22 / 86 \\
06 / 30 / 87 \\
07 / 20 / 87 \\
06 / 30 / 87\end{array}$ & $\begin{array}{l}\text { CARSON VALLEY } \\
\text { CARSON VALLEY } \\
\text { CARSON L.: I DEEP DRAIN } \\
\text { CARSON L.: IA DEEPP DRAIN } \\
\text { CARSON L., C.L.DP.DR. MID }\end{array}$ & $\begin{array}{l}\text { PLANT } \\
\text { PLANT } \\
\text { PLANT } \\
\text { PLANT } \\
\text { PLANT }\end{array}$ & $\begin{array}{l}\text { CHARA } \\
\text { CHARA } \\
\text { HS BULRUSH R } \\
\text { HS BULRUSH R } \\
\text { HS BULRUSH R }\end{array}$ & $\begin{array}{l}91.89 \\
89.81 \\
90.30 \\
88.60 \\
80.80\end{array}$ & $\begin{array}{r}3.90 \\
3.60 \\
21.10 \\
16.50 \\
26.00\end{array}$ & $\begin{aligned}<61.0 \\
<46.0 \\
22.0 \\
51.7 \\
27.9\end{aligned}$ & $\begin{array}{l}27.00 \\
39.00 \\
<1.03 \\
14.15 \\
31.86\end{array}$ & $\begin{array}{r}<2.40 \\
<1.90 \\
<10.30 \\
<8.77 \\
<5.21\end{array}$ & $\begin{array}{l}<.61 \\
<.45 \\
<.26 \\
<.22 \\
.22\end{array}$ & $\begin{array}{r}<.99 \\
<.89 \\
.28 \\
.21 \\
.14\end{array}$ \\
\hline $\begin{array}{l}87442 \\
87538 \\
87410 \\
87423 \\
87435\end{array}$ & $\begin{array}{l}06 / 30 / 87 \\
07 / 14 / 87 \\
06 / 22 / 87 \\
06 / 29 / 87 \\
06 / 30 / 87\end{array}$ & 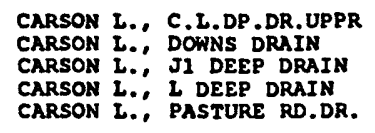 & $\begin{array}{l}\text { PLANT } \\
\text { PLANT } \\
\text { PLANT } \\
\text { PLANT } \\
\text { PLANT }\end{array}$ & $\begin{array}{l}\text { HS BULRUSH } \\
\text { HS BULRUSH } \\
\text { HS BULRUSH } \\
\text { HS BULRUSH } \\
\text { HS BULRUSH } \\
R\end{array}$ & $\begin{array}{l}82.70 \\
92.00 \\
90.60 \\
83.00 \\
8 B .20\end{array}$ & $\begin{array}{r}39.00 \\
5.94 \\
15.80 \\
12.20 \\
49.60\end{array}$ & $\begin{array}{l}11.7 \\
95.9 \\
37.9 \\
12.0 \\
60.0\end{array}$ & $\begin{array}{r}64.10 \\
5.38 \\
6.28 \\
17.90 \\
18.60\end{array}$ & $\begin{array}{r}9.88 \\
34.40 \\
<10.60 \\
<5.88 \\
<8.47\end{array}$ & $\begin{array}{r}.58 \\
1.28 \\
<.27 \\
<.31 \\
<.21\end{array}$ & $\begin{array}{l}.49 \\
.20 \\
.09 \\
.08 \\
.13\end{array}$ \\
\hline $\begin{array}{l}87412 \\
87675 \\
87545 \\
87453 \\
87460\end{array}$ & $\begin{array}{l}06 / 22 / 87 \\
08 / 24 / 87 \\
07 / 14 / 87 \\
07 / 01 / 87 \\
07 / 01 / 87\end{array}$ & $\begin{array}{l}\text { CARSON L.., PIER/L DP. DR. } \\
\text { CARSON L.: PIER/L DP. D DR. } \\
\text { CARSON L., YARBROUGH DR. } \\
\text { FERNIEY WMA } \\
\text { FERNLEY WMA }\end{array}$ & $\begin{array}{l}\text { PLANT } \\
\text { PLANT } \\
\text { PLANT } \\
\text { PLNNT } \\
\text { PLANT }\end{array}$ & $\begin{array}{l}\text { HS BULRUSH R } \\
\text { HS BULRUSH } \\
\text { HS BULRUSH } \\
\text { HS BULRUSH } \\
\text { HS BULRUSH } \\
\text { HS }\end{array}$ & $\begin{array}{l}86.20 \\
96.70 \\
88.00 \\
87.20 \\
88.20\end{array}$ & $\begin{array}{l}13.90 \\
12.00 \\
8.50 \\
32.60 \\
24.90\end{array}$ & $\begin{array}{r}33.5 \\
7.0 \\
34.7 \\
10.2 \\
24.7\end{array}$ & $\begin{array}{r}14.30 \\
30.00 \\
7.92 \\
5.27 \\
7.63\end{array}$ & $\begin{array}{l}<7.15 \\
<4.00 \\
<8.30 \\
<7.75 \\
<8.47\end{array}$ & $\begin{array}{r}<.18 \\
.18 \\
1.57 \\
<.19 \\
<2.12\end{array}$ & $\begin{array}{l}.09 \\
.10 \\
.06 \\
.30 \\
3.35\end{array}$ \\
\hline $\begin{array}{l}87563 \\
87486 \\
87525 \\
87519 \\
87467\end{array}$ & $\begin{array}{l}07 / 16 / 87 \\
07 / 06 / 87 \\
07 / 09 / 87 \\
07 / 09 / 87 \\
07 / 02 / 87\end{array}$ & $\begin{array}{l}\text { FERNLEY WMA } \\
\text { KARMON RES. } \\
\text { HWMA, CARPENTER RD. DRAIN } \\
\text { HWMA, RENNIE RD. DRAIN } \\
\text { HWMA, TOULON LAKE }\end{array}$ & $\begin{array}{l}\text { PLANT } \\
\text { PLANT } \\
\text { PLANT } \\
\text { PLANT } \\
\text { PLANT }\end{array}$ & $\begin{array}{l}\text { HS BULRUSH } \\
\text { HS BULRUSH } \\
\text { HS BULRUSH } \\
\text { HS BULRUSH } \\
\text { HS BULRUSH }\end{array}$ & $\begin{array}{l}87.90 \\
91.00 \\
83.70 \\
84.70 \\
90.60\end{array}$ & $\begin{array}{r}16.30 \\
5.83 \\
5.06 \\
9.28 \\
3.58\end{array}$ & $\begin{array}{r}8.7 \\
10.9 \\
7.5 \\
14.8 \\
16.1\end{array}$ & $\begin{array}{r}4.46 \\
6.56 \\
14.50 \\
7.19 \\
3.72\end{array}$ & $\begin{array}{r}<8.26 \\
<11.10 \\
<6.10 \\
<6.53 \\
<10.60\end{array}$ & $\begin{array}{l}<.21 \\
.33 \\
<.15 \\
<.16 \\
<.27\end{array}$ & $\begin{array}{l}.12 \\
.09 \\
.24 \\
.09 \\
.17\end{array}$ \\
\hline $\begin{array}{l}87522 \\
87570 \\
87508 \\
87580 \\
87589\end{array}$ & $\begin{array}{l}07 / 09 / 87 \\
07 / 17 / 87 \\
07 / 08 / 87 \\
07 / 20 / 87 \\
07 / 28 / 87\end{array}$ & $\begin{array}{l}\text { HWMA, WESTFALL R } \\
\text { MAHALA SLOUGH } \\
\text { MASSIE SLOUGH } \\
\text { MASSIE SLOUGH } \\
\text { MASSIE SLOUGH }\end{array}$ & $\begin{array}{l}\text { PLANT } \\
\text { PLANT } \\
\text { PLANT } \\
\text { PLANT } \\
\text { PLANT }\end{array}$ & $\begin{array}{l}\text { HS BULRUSH } \\
\text { HS BULRUSH } \\
\text { HS BULRUSH } \\
\text { HS BULRUSH } \\
\text { HS BULRUSH }\end{array}$ & $\begin{array}{l}85.80 \\
83.20 \\
84.80 \\
89.10 \\
89.10\end{array}$ & $\begin{array}{r}8.17 \\
18.40 \\
23.00 \\
28.90 \\
25.50\end{array}$ & $\begin{array}{r}32.0 \\
16.0 \\
38.6 \\
21.3 \\
.3\end{array}$ & $\begin{array}{r}2.39 \\
4.17 \\
18.90 \\
6.42 \\
12.10\end{array}$ & $\begin{array}{l}<7.04 \\
<5.95 \\
<6.56 \\
<9.43 \\
<9.17\end{array}$ & $\begin{array}{l}<.18 \\
<.15 \\
<.17 \\
<.24 \\
<.23\end{array}$ & $\begin{array}{r}.15 \\
.27 \\
3.76 \\
.32 \\
.42\end{array}$ \\
\hline
\end{tabular}


TABLE 19.--Data on trace-element constituents and percent molsture of blologlcal samples in st1liwater w1ld11fe Management drea, Carson Lake, Fernley Wildilfe Management Area, and Humboldt wildife Management Area, $1985-87-$ Cont.

\begin{tabular}{|c|c|c|c|c|c|c|c|c|c|c|c|}
\hline $\begin{array}{l}\text { USFws } \\
\text { local } \\
\text { ID } \\
\text { number }\end{array}$ & Date & Location & $\begin{array}{l}\text { Cate- } \\
\text { gory }\end{array}$ & Species & $\begin{array}{l}\text { Percent } \\
\text { molsture }\end{array}$ & $\begin{array}{c}\text { Arse- } \\
\text { nde }\end{array}$ & Boron & $\begin{array}{l}\text { Chro- } \\
\text { mlum }\end{array}$ & Lead & $\begin{array}{l}\text { Mer- } \\
\text { cury }\end{array}$ & $\begin{array}{l}\text { Sele- } \\
\text { nlum }\end{array}$ \\
\hline $\begin{array}{r}87418 \\
87530 \\
256 \\
259 \\
268\end{array}$ & $\begin{array}{l}06 / 25 / 87 \\
07 / 23 / 87 \\
09 / 23 / 86 \\
09 / 23 / 86 \\
09 / 23 / 86\end{array}$ & $\begin{array}{l}\text { SHECKLER RES. } \\
\text { SWRA, SHAFENER DR., IND.I. } \\
\text { CARSON I.: ISLANDS UNIT } \\
\text { CARSON I.:, ISLANDS UNIT } \\
\text { CARSON L., ISLANDS UNIT }\end{array}$ & $\begin{array}{l}\text { PLANT } \\
\text { PLANT } \\
\text { PLANT } \\
\text { PLANT } \\
\text { PLANT }\end{array}$ & $\begin{array}{l}\text { HS BULRUSH } \\
\text { HS BULRUSH } \\
\text { HS BULRUSH } \\
\text { HS BULRUSH } \\
\text { HS BULRUSH }\end{array}$ & $\begin{array}{r}88.80 \\
93.80 \\
8.92 \\
8.62 \\
25.53\end{array}$ & $\begin{array}{r}19.30 \\
2.18 \\
<.22 \\
<.21 \\
<.24\end{array}$ & $\begin{array}{l}<4.5 \\
11.9 \\
370.0 \\
200.0 \\
270.0\end{array}$ & $\begin{array}{r}6.79 \\
2.10 \\
<2.70 \\
<2.40 \\
<2.90\end{array}$ & $\begin{array}{r}<8.93 \\
<16.10 \\
<1.10 \\
<.94 \\
<1.10\end{array}$ & $\begin{array}{r}<0.22 \\
<.40 \\
<.20 \\
<.22 \\
<.24\end{array}$ & $\begin{array}{l}0.09 \\
.09 \\
<.44 \\
<.42 \\
<.47\end{array}$ \\
\hline $\begin{array}{l}270 \\
274 \\
223 \\
227 \\
241\end{array}$ & $\begin{array}{l}09 / 23 / 86 \\
09 / 23 / 86 \\
09 / 22 / 86 \\
09 / 22 / 86 \\
09 / 22 / 86\end{array}$ & $\begin{array}{l}\text { CARSON I., SPRIG PONDS } \\
\text { CARSON L., SPRIG PONDS } \\
\text { CARSON VALLEY } \\
\text { CARSON VALIEY } \\
\text { CARSON VALIEY }\end{array}$ & $\begin{array}{l}\text { PLANT } \\
\text { PLANT } \\
\text { PLANT } \\
\text { PIANT } \\
\text { PLANT }\end{array}$ & $\begin{array}{l}\text { HS BULRUSH } \\
\text { HS BULRUSH } \\
\text { HS BULRUSH } \\
\text { HS BULRUSH } \\
\text { HS BULRUSH }\end{array}$ & $\begin{array}{l}7.47 \\
6.86 \\
8.82 \\
6.86 \\
7.99\end{array}$ & $\begin{array}{r}<.22 \\
<.21 \\
.28 \\
.26 \\
<.22\end{array}$ & $\begin{array}{r}650.0 \\
570.0 \\
40.0 \\
26.0 \\
36.0\end{array}$ & $\begin{array}{r}3.60 \\
1.20 \\
19.00 \\
6.90 \\
11.00\end{array}$ & $\begin{array}{l}<1.00 \\
<2.10 \\
<2.10 \\
<2.10 \\
<1.10\end{array}$ & $\begin{array}{l}<.19 \\
<.19 \\
<.22 \\
<.21 \\
<.21\end{array}$ & $\begin{array}{l}<.43 \\
<.43 \\
<.44 \\
<.41 \\
<.43\end{array}$ \\
\hline $\begin{array}{l}213 \\
215 \\
195 \\
306 \\
311\end{array}$ & $\begin{array}{l}09 / 19 / 86 \\
09 / 19 / 86 \\
09 / 18 / 86 \\
09 / 30 / 86 \\
09 / 30 / 86\end{array}$ & $\begin{array}{l}\text { FERNLEY WMA } \\
\text { FERNLEY WMA } \\
\text { SWMA, ALKALI UN. } 12 \\
\text { SWMA, GOOSE LAKE } \\
\text { SWMA, GOOSE LAKE }\end{array}$ & $\begin{array}{l}\text { PLANT } \\
\text { PLANT } \\
\text { PLANT } \\
\text { PIANT } \\
\text { PLANT }\end{array}$ & $\begin{array}{l}\text { HS BULRUSH } \\
\text { HS BULRUSH } \\
\text { HS BULRUSH } \\
\text { HS BULRUSH } \\
\text { HS BULRUSH }\end{array}$ & $\begin{array}{r}9.00 \\
6.86 \\
5.50 \\
12.72 \\
9.99\end{array}$ & $\begin{array}{l}<.20 \\
<.21 \\
<.19 \\
<.20 \\
<.22\end{array}$ & $\begin{array}{l}230.0 \\
390.0 \\
630.0 \\
240.0 \\
500.0\end{array}$ & $\begin{array}{l}<2.70 \\
<2.60 \\
<2.40 \\
14.00 \\
23.00\end{array}$ & $\begin{array}{l}<1.10 \\
<1.10 \\
<.97 \\
<1.00 \\
<2.10\end{array}$ & $\begin{array}{l}<.22 \\
<.20 \\
<.21 \\
<.23 \\
<.22\end{array}$ & $\begin{array}{l}<.39 \\
<.43 \\
<.38 \\
<.41 \\
<.44\end{array}$ \\
\hline $\begin{array}{l}337 \\
185 \\
289 \\
192 \\
201\end{array}$ & $\begin{array}{l}10 / 02 / 86 \\
09 / 18 / 86 \\
09 / 18 / 86 \\
09 / 18 / 86 \\
09 / 18 / 86\end{array}$ & $\begin{array}{l}\text { SWMA, GOOSE LAKE } \\
\text { SWMM, LEAD LAKE } \\
\text { SWMA, LEAD LAKE } \\
\text { SWMA, LEAD LAKE } \\
\text { SWMAA, STILLWATER PT. RES. }\end{array}$ & $\begin{array}{l}\text { PLANT } \\
\text { PLANT } \\
\text { PLANT } \\
\text { PLANT } \\
\text { PLANT }\end{array}$ & $\begin{array}{l}\text { HS BULRUSH } \\
\text { HS BULRUSH } \\
\text { HS BULRUSH } \\
\text { HS BULRUSH } \\
\text { HS BULRUSH }\end{array}$ & $\begin{array}{r}8.73 \\
9.80 \\
6.66 \\
20.67 \\
6.93\end{array}$ & $\begin{array}{l}<.21 \\
<.22 \\
<.22 \\
<.22 \\
<.21\end{array}$ & $\begin{array}{r}140.0 \\
120.0 \\
220.0 \\
410.0 \\
81.0\end{array}$ & $\begin{array}{l}11.00 \\
<2.70 \\
13.00 \\
12.00 \\
11.00\end{array}$ & $\begin{array}{r}1.40 \\
<2.10 \\
<1.00 \\
<1.10 \\
<1.10\end{array}$ & $\begin{array}{l}<.22 \\
<.29 \\
<.21 \\
<.22 \\
<.20\end{array}$ & $\begin{array}{l}<.42 \\
<.44 \\
<.43 \\
<.43 \\
<.43\end{array}$ \\
\hline $\begin{array}{r}202 \\
285 \\
87448 \\
87576 \\
87443\end{array}$ & $\begin{array}{l}09 / 18 / 86 \\
09 / 26 / 86 \\
06 / 30 / 87 \\
07 / 20 / 87 \\
06 / 30 / 87\end{array}$ & $\begin{array}{l}\text { SWMA, STILLWWATER PT. RES. } \\
\text { WASHOE IAKE } \\
\text { CARSON I.: I DEEP DRAIN } \\
\text { CARSON I.: 1A DEEP DRAIN } \\
\text { CARSON L., C.I.DP.DR. UPPR }\end{array}$ & $\begin{array}{l}\text { PLANT } \\
\text { PLANT } \\
\text { PLANT } \\
\text { PLANT } \\
\text { PLANT }\end{array}$ & $\begin{array}{l}\text { HS BULRUSH } \\
\text { HS BULRUSH } \\
\text { PONDWEED } \\
\text { PONDWEED } \\
\text { PONDWEED }\end{array}$ & $\begin{array}{r}9.70 \\
8.91 \\
91.20 \\
90.80 \\
89.00\end{array}$ & $\begin{array}{r}<.22 \\
<.20 \\
34.80 \\
34.80 \\
14.10\end{array}$ & $\begin{array}{l}320.0 \\
<27.0 \\
248.0 \\
539.0 \\
254.0\end{array}$ & $\begin{array}{l}7.10 \\
20.00 \\
15.90 \\
10.90 \\
17.80\end{array}$ & $\begin{array}{l}<1.10 \\
<1.10 \\
44.00 \\
12.70 \\
11.30\end{array}$ & $\begin{array}{l}<.22 \\
<.20 \\
2.49 \\
1.09 \\
1.53\end{array}$ & $\begin{array}{l}<.44 \\
<.41 \\
1.29 \\
2.00 \\
.87\end{array}$ \\
\hline $\begin{array}{l}87544 \\
87549 \\
87425 \\
278 \\
87546\end{array}$ & $\begin{array}{l}07 / 14 / 87 \\
07 / 14 / 87 \\
06 / 29 / 87 \\
09 / 23 / 86 \\
07 / 14 / 87\end{array}$ & $\begin{array}{l}\text { CARSON L., } \text { DOWNS DRAIN } \\
\text { CARSON L.: HOLMES DEEP DR } \\
\text { CARSON L.: JI DEEE DRAIN } \\
\text { CARSON L.: SPRIG PONDS } \\
\text { CARSON L., YARBROUGH DR. }\end{array}$ & $\begin{array}{l}\text { PLANT } \\
\text { PLANT } \\
\text { PLANT } \\
\text { PLANT } \\
\text { PLANT }\end{array}$ & $\begin{array}{l}\text { PONDWEED } \\
\text { PONDWEED } \\
\text { PONDWEED } \\
\text { PONOWEED } \\
\text { PONDHEED }\end{array}$ & $\begin{array}{l}91.20 \\
87.40 \\
88.80 \\
88.64 \\
95.70\end{array}$ & $\begin{array}{r}35.10 \\
9.23 \\
7.86 \\
21.00 \\
11.20\end{array}$ & $\begin{array}{r}366.0 \\
432.0 \\
320.0 \\
260.0 \\
76.5\end{array}$ & $\begin{array}{r}19.10 \\
12.60 \\
17.50 \\
30.00 \\
6.51\end{array}$ & $\begin{array}{l}28.50 \\
17.10 \\
15.70 \\
<1.80 \\
28.80\end{array}$ & $\begin{array}{l}2.16 \\
.65 \\
1.17 \\
1.70 \\
3.13\end{array}$ & $\begin{array}{r}3.43 \\
.49 \\
.30 \\
<.71 \\
.98\end{array}$ \\
\hline $\begin{array}{r}224 \\
87492 \\
87451 \\
87458 \\
87523\end{array}$ & $\begin{array}{l}09 / 22 / 86 \\
07 / 06 / 87 \\
07 / 01 / 87 \\
07 / 01 / 87 \\
07 / 09 / 87\end{array}$ & $\begin{array}{l}\text { CARSON VALLEY } \\
\text { ERB DEEP DRAIN } \\
\text { FERNLEY WMA } \\
\text { FERNLEY WMA } \\
\text { HWMA, CARPENTER RD. DRAIN }\end{array}$ & $\begin{array}{l}\text { PLANT } \\
\text { PLANT } \\
\text { PLANT } \\
\text { PLANT } \\
\text { PLANT }\end{array}$ & $\begin{array}{l}\text { PONDWEED } \\
\text { PONDWEED } \\
\text { PONDWEED } \\
\text { PONDWEED } \\
\text { PONDWEED }\end{array}$ & $\begin{array}{l}89.90 \\
91.20 \\
87.50 \\
88.00 \\
86.30\end{array}$ & $\begin{array}{l}1.20 \\
25.00 \\
23.20 \\
28.30 \\
17.80\end{array}$ & $\begin{array}{r}<49.0 \\
336.0 \\
20.6 \\
22.2 \\
<3.7\end{array}$ & $\begin{array}{r}35.00 \\
6.25 \\
17.40 \\
9.42 \\
<.70\end{array}$ & $\begin{array}{r}<2.00 \\
<11.40 \\
18.50 \\
24.20 \\
<7.30\end{array}$ & $\begin{array}{l}<.45 \\
<.28 \\
<.20 \\
<.21 \\
<.18\end{array}$ & $\begin{array}{l}<.82 \\
1.12 \\
1.50 \\
7.96 \\
.82\end{array}$ \\
\hline $\begin{array}{l}87513 \\
87474 \\
87465 \\
87475 \\
87506\end{array}$ & $\begin{array}{l}07 / 09 / 87 \\
07 / 02 / 87 \\
07 / 02 / 87 \\
07 / 02 / 87 \\
07 / 08 / 87\end{array}$ & $\begin{array}{l}\text { HWMA, SEVENTEEN DITCH } \\
\text { HWMA, SO. MERIDIAN RD.DR. } \\
\text { HWMA, TOULON IAKE } \\
\text { HWMA, UPPER ARMY DRAIN } \\
\text { MASSIE SLOUGH }\end{array}$ & $\begin{array}{l}\text { PLANT } \\
\text { PLANT } \\
\text { PLANT } \\
\text { PLANT } \\
\text { PLANT }\end{array}$ & $\begin{array}{l}\text { PONDWEED } \\
\text { PONDWEED } \\
\text { PONDWEED } \\
\text { PONDWEED } \\
\text { PONDWEED }\end{array}$ & $\begin{array}{l}86.90 \\
83.60 \\
90.30 \\
87.50 \\
86.60\end{array}$ & $\begin{array}{l}32.40 \\
8.41 \\
13.60 \\
82.40 \\
90.30\end{array}$ & $\begin{array}{l}283.0 \\
216.0 \\
561.0 \\
431.0 \\
254.0\end{array}$ & $\begin{array}{r}8.47 \\
25.10 \\
5.26 \\
14.10 \\
9.63\end{array}$ & $\begin{array}{r}15.80 \\
32.60 \\
<10.30 \\
12.90 \\
9.63\end{array}$ & $\begin{array}{l}<.19 \\
<.15 \\
<.26 \\
<.20 \\
<.19\end{array}$ & $\begin{array}{r}1.07 \\
.54 \\
.87 \\
.96 \\
1.00\end{array}$ \\
\hline $\begin{array}{r}87582 \\
163 \\
166 \\
171 \\
87528\end{array}$ & $\begin{array}{l}07 / 20 / 87 \\
09 / 16 / 86 \\
09 / 16 / 86 \\
09 / 16 / 86 \\
07 / 13 / 87\end{array}$ & $\begin{array}{l}\text { MASSIE SLOUGH } \\
\text { SWMA, ALKALI UN. I } \\
\text { SWMA, ALKALI UN. I } \\
\text { SWMA, ALKALII UN. 1 } \\
\text { SWMA, SHAFFNER DR., IND.L. }\end{array}$ & $\begin{array}{l}\text { PLANT } \\
\text { PLANT } \\
\text { PLANT } \\
\text { PLANT } \\
\text { PLANT }\end{array}$ & $\begin{array}{l}\text { PONDWEED } \\
\text { PONDWEED } \\
\text { PONDWEED } \\
\text { PONDWEED } \\
\text { PONDWEED }\end{array}$ & $\begin{array}{l}87.10 \\
84.18 \\
86.29 \\
87.00 \\
91.00\end{array}$ & $\begin{array}{r}3.02 \\
4.80 \\
5.90 \\
7.30 \\
15.40\end{array}$ & $\begin{array}{r}113.0 \\
760.0 \\
1200.0 \\
720.0 \\
<5.6\end{array}$ & $\begin{array}{r}3.33 \\
19.00 \\
15.00 \\
17.00 \\
3.11\end{array}$ & $\begin{array}{r}<7.75 \\
1.40 \\
1.40 \\
1.50 \\
<11.10\end{array}$ & $\begin{array}{l}<.19 \\
<.29 \\
<.35 \\
<.37 \\
.40\end{array}$ & $\begin{array}{l}2.44 \\
<.61 \\
<.62 \\
<.76 \\
1.91\end{array}$ \\
\hline $\begin{array}{r}179 \\
180 \\
181 \\
87561 \\
85021\end{array}$ & $\begin{array}{l}09 / 16 / 86 \\
09 / 16 / 86 \\
09 / 16 / 86 \\
07 / 16 / 87 \\
07 / 29 / 85\end{array}$ & $\begin{array}{l}\text { SWAWh, STILLWATER PT. RES. } \\
\text { SWMMA, STILLWATER PT. RES. } \\
\text { SWMA, STILLWATER PT. RES. } \\
\text { SWMA, SWAN L. CHECK } \\
\text { CARSON L., CARSON I DRAIN }\end{array}$ & $\begin{array}{l}\text { PLANT } \\
\text { PLANT } \\
\text { PLANT } \\
\text { PLANT } \\
\text { PLANT }\end{array}$ & $\begin{array}{l}\text { PONDWEED } \\
\text { PONDWEED } \\
\text { PONDWEED } \\
\text { PONDWEED } \\
\text { PONDWEED }\end{array}$ & $\begin{array}{l}86.33 \\
86.73 \\
84.57 \\
84.80 \\
86.30\end{array}$ & $\begin{array}{l}6.80 \\
15.00 \\
10.00 \\
23.40 \\
22.60\end{array}$ & $\begin{array}{l}480.0 \\
780.0 \\
490.0 \\
464.0 \\
--\end{array}$ & $\begin{array}{r}10.00 \\
11.00 \\
7.20 \\
2.96 \\
9.50\end{array}$ & $\begin{array}{r}<1.40 \\
<1.50 \\
1.60 \\
<6.58 \\
5.00\end{array}$ & $\begin{array}{r}.51 \\
.67 \\
.72 \\
.24 \\
4.70\end{array}$ & $\begin{array}{r}.69 \\
1.20 \\
.84 \\
.33 \\
.73\end{array}$ \\
\hline $\begin{array}{l}85022 \\
85019 \\
85020 \\
85027 \\
85018\end{array}$ & $\begin{array}{l}07 / 29 / 85 \\
07 / 29 / 85 \\
07 / 29 / 85 \\
07 / 29 / 85 \\
07 / 29 / 85\end{array}$ & $\begin{array}{l}\text { CARSON L., CARSON I DRAIN } \\
\text { SWMAA, STILLWATER PT. RES. } \\
\text { SWMAA, STILLWATER PT. RES. } \\
\text { SWMA, TJ DRAIN } \\
\text { SWMA, TJ DRAIN }\end{array}$ & $\begin{array}{l}\text { PLANT } \\
\text { PLANT } \\
\text { PLANT } \\
\text { PLANT } \\
\text { PLANT }\end{array}$ & $\begin{array}{l}\text { PONDWEED } \\
\text { PONDWEED } \\
\text { PONDWEED } \\
\text { PONDWEED } \\
\text { PONDWEED }\end{array}$ & $\begin{array}{l}89.30 \\
85.30 \\
86.10 \\
87.90 \\
87.80\end{array}$ & $\begin{array}{r}14.00 \\
4.80 \\
5.60 \\
17.40 \\
26.20\end{array}$ & $\begin{array}{l}=- \\
= \\
= \\
=\end{array}$ & $\begin{array}{l}<.90 \\
4.60 \\
3.50 \\
4.10 \\
4.90\end{array}$ & $\begin{array}{l}5.90 \\
1.60 \\
2.70 \\
2.50 \\
3.90\end{array}$ & $\begin{array}{r}7.30 \\
.50 \\
.75 \\
1.20 \\
2.80\end{array}$ & $\begin{array}{r}<.47 \\
.48 \\
.34 \\
.83 \\
1.30\end{array}$ \\
\hline
\end{tabular}


TABLE 29.--Data on trace-element constituents and percent moisture of biological samples in stillwater wildiffe Management Area, Carson Lake, Fernley Wildlife Managament Area, and Humboldt Wildlife Management Area, 1985-87--Cont.

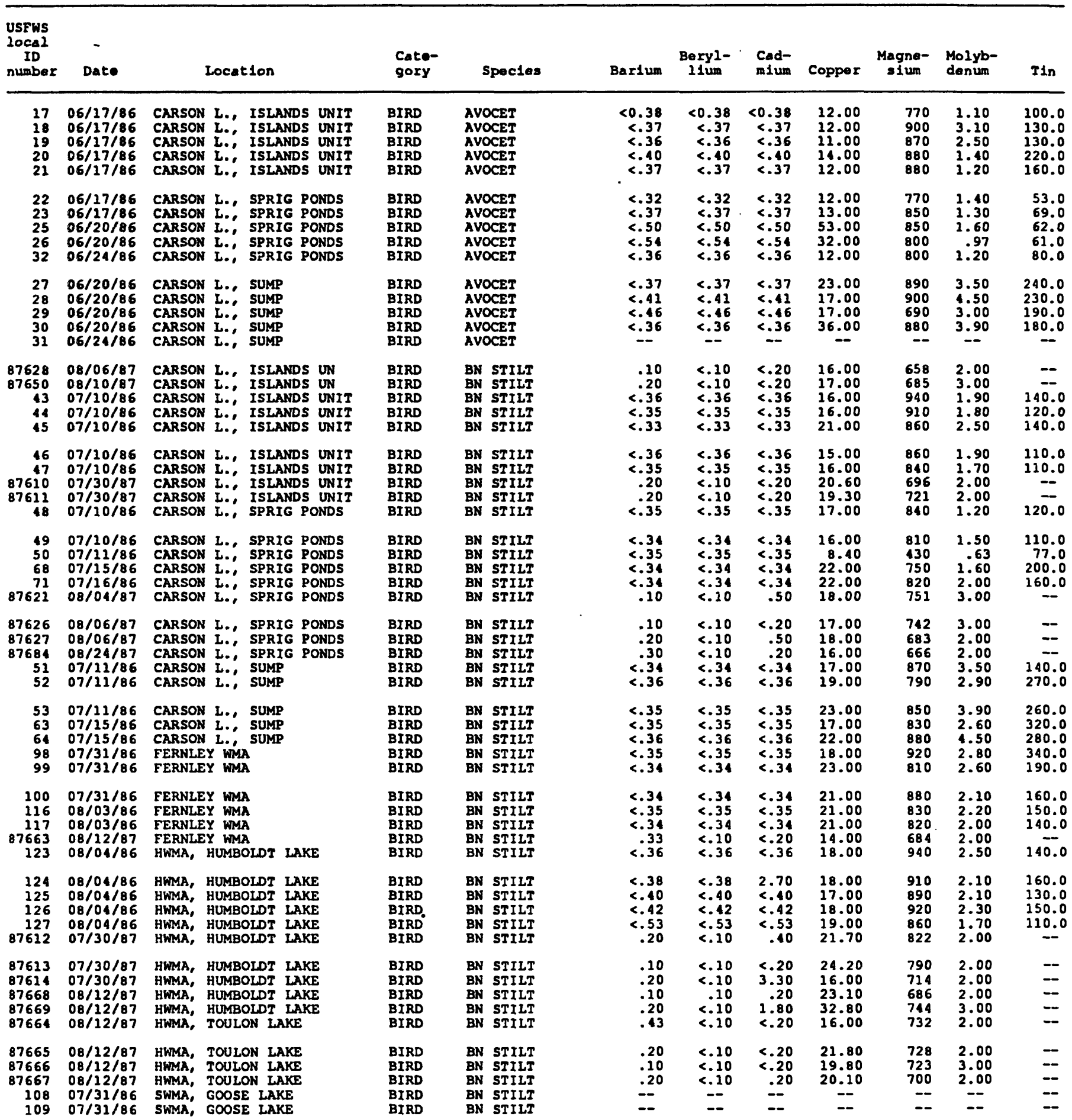


TABLE 19.--Data on trace-element constituents and percent molsture of blological samples in stillwater Wildife Management Area, Carson Lake, Fernley Wildlife Management Area, and Humboldt Wildlife Management Area, 1985-87--Cont.

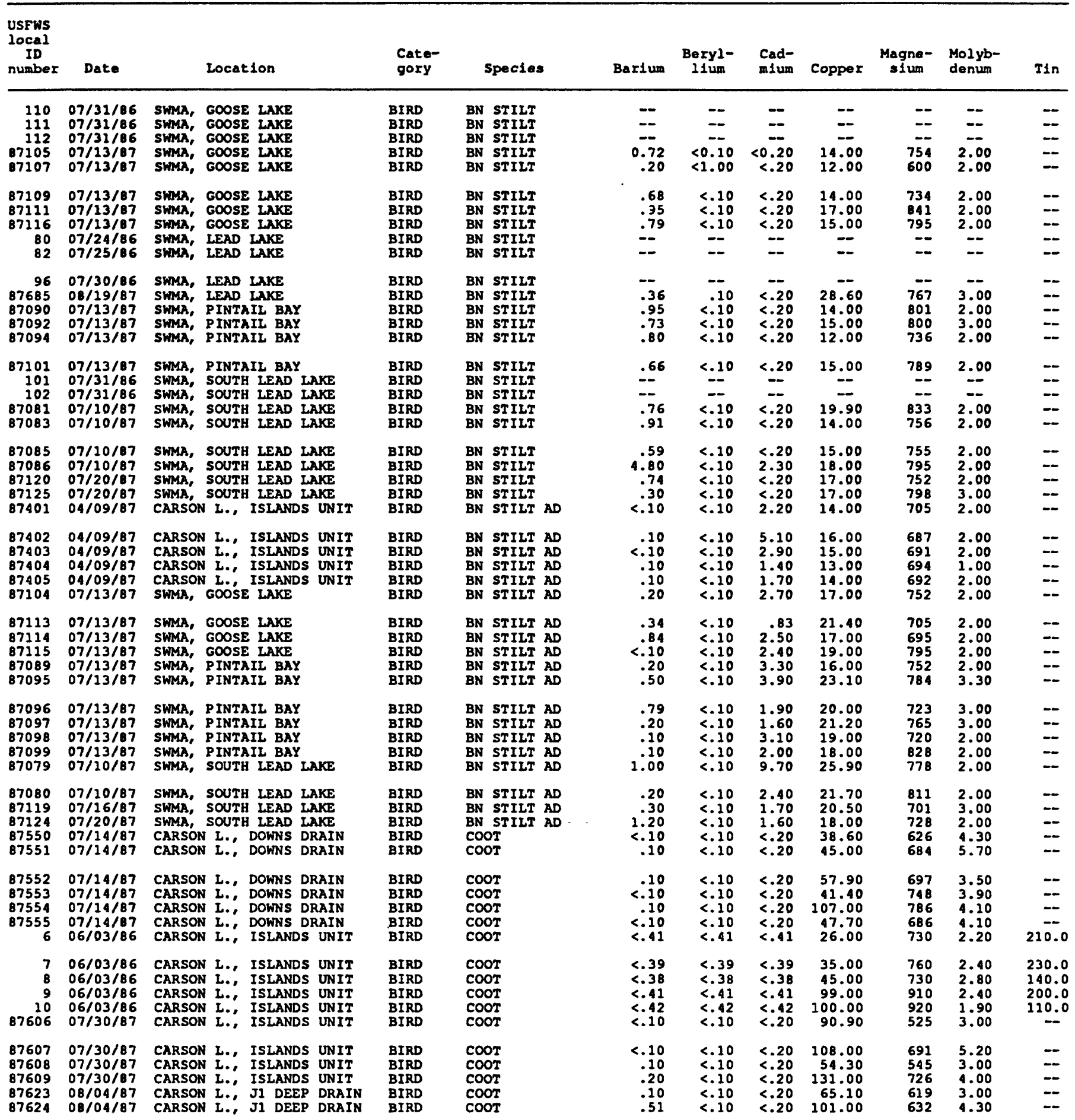


TABLE 19.-Data on trace-element constituents and percent molsture of biological samples in stillwater Wildife Management Area, Carson Lake, Fernley Wildlife Management Area, and Humbldt Wildife Management Area, ig85-87--Cont.

\begin{tabular}{|c|c|c|c|c|c|c|c|c|c|c|c|}
\hline $\begin{array}{l}\text { USFwS } \\
\text { local } \\
\text { ID } \\
\text { number }\end{array}$ & Date & Location & $\begin{array}{l}\text { Cate- } \\
\text { gory }\end{array}$ & Species & Barium & $\begin{array}{l}\text { Beryl- } \\
\text { Ilum }\end{array}$ & $\begin{array}{l}\text { Cad- } \\
\text { mium }\end{array}$ & Copper & $\begin{array}{l}\text { Magne- } \\
\text { sium }\end{array}$ & $\begin{array}{l}\text { Molyb- } \\
\text { denum }\end{array}$ & Tin \\
\hline $\begin{array}{l}1 \\
2 \\
3 \\
4 \\
5\end{array}$ & $\begin{array}{l}06 / 03 / 86 \\
06 / 03 / 86 \\
06 / 03 / 86 \\
06 / 03 / 86 \\
06 / 03 / 86\end{array}$ & $\begin{array}{l}\text { CARSON I., SPRIG PONDS } \\
\text { CARSON I.: SPRIG PONDS } \\
\text { CARSON I.: SPRIG PONDS } \\
\text { CARSON I., SPRIG PONDS } \\
\text { CARSON I., SPRIG PONDS }\end{array}$ & $\begin{array}{l}\text { BIRD } \\
\text { BIRD } \\
\text { BIRD } \\
\text { BIRD } \\
\text { BIRD }\end{array}$ & $\begin{array}{l}\text { cOOT } \\
\operatorname{coOT} \\
\text { coOT } \\
\text { coOT } \\
\text { COOT }\end{array}$ & $\begin{array}{l}<0.37 \\
<.42 \\
<.39 \\
<.39 \\
<.38\end{array}$ & $\begin{array}{l}<0.37 \\
<.42 \\
<.39 \\
<.39 \\
<.38\end{array}$ & $\begin{array}{l}<0.37 \\
<.42 \\
<.39 \\
<.39 \\
<.38\end{array}$ & $\begin{array}{l}140.00 \\
210.00 \\
94.00 \\
270.00 \\
140.00\end{array}$ & $\begin{array}{l}810 \\
800 \\
790 \\
870 \\
760\end{array}$ & $\begin{array}{l}4.00 \\
5.60 \\
3.40 \\
4.30 \\
3.00\end{array}$ & $\begin{array}{r}240.0 \\
130.0 \\
130.0 \\
76.0 \\
71.0\end{array}$ \\
\hline $\begin{array}{l}87603 \\
87622 \\
87642 \\
87642 \\
87643\end{array}$ & $\begin{array}{l}07 / 29 / 87 \\
08 / 04 / 87 \\
08 / 10 / 87 \\
08 / 10 / 87 \\
08 / 10 / 87\end{array}$ & $\begin{array}{lll}\text { CARSON I.., } & \text { SPRIG PONDS } \\
\text { CARSON I.. } & \text { SPRIG PONDS } \\
\text { CARSON I., } & \text { WEST LEE DRAIN } \\
\text { CARSON L., } & \text { WEST IEE DRAIN } \\
\text { CARSON I., } & \text { WEST LEE DRAIN }\end{array}$ & $\begin{array}{l}\text { BIRD } \\
\text { BIRD } \\
\text { BIRD } \\
\text { BIRD } \\
\text { BIRD }\end{array}$ & $\begin{array}{l}\text { COOT } \\
\text { COOT } \\
\text { COOT } \\
\text { COOT } \\
\text { COOT }\end{array}$ & $\begin{array}{l}.20 \\
.10 \\
.20 \\
.30 \\
.10\end{array}$ & $\begin{array}{r}<.10 \\
<.10 \\
.10 \\
<.10 \\
.10\end{array}$ & $\begin{array}{l}<.20 \\
<.20 \\
<.20 \\
<.20 \\
.30\end{array}$ & $\begin{array}{r}133.00 \\
147.00 \\
245.00 \\
29.10 \\
115.00\end{array}$ & $\begin{array}{l}832 \\
758 \\
682 \\
668 \\
937\end{array}$ & $\begin{array}{l}3.90 \\
4.50 \\
4.70 \\
2.00 \\
4.30\end{array}$ & $\begin{array}{l}= \\
\bar{z} \\
\overline{-}\end{array}$ \\
\hline $\begin{array}{r}87644 \\
87645 \\
87646 \\
138 \\
139\end{array}$ & $\begin{array}{l}08 / 10 / 87 \\
08 / 10 / 87 \\
08 / 10 / 87 \\
08 / 15 / 86 \\
08 / 15 / 86\end{array}$ & $\begin{array}{l}\text { CARSON I.. WEST LEE DRAIN } \\
\text { CARSON L.. WEST LEE DRAIN } \\
\text { CARSON I.. WEST LEE DRAIN } \\
\text { CARSON VALLEY } \\
\text { CARSON VALLEY }\end{array}$ & $\begin{array}{l}\text { BIRD } \\
\text { BIRD } \\
\text { BIRD } \\
\text { BIRD } \\
\text { BIRD }\end{array}$ & $\begin{array}{l}\text { COOT } \\
\text { COOT } \\
\text { COOT } \\
\text { COOT } \\
\text { COOT }\end{array}$ & $\begin{array}{r}.35 \\
.37 \\
.20 \\
<.38 \\
<.40\end{array}$ & $\begin{array}{r}.10 \\
<.10 \\
.10 \\
<.38 \\
<.40\end{array}$ & $\begin{array}{r}<.20 \\
<.20 \\
.40 \\
<.76 \\
.80\end{array}$ & $\begin{array}{r}48.60 \\
109.00 \\
172.00 \\
53.00 \\
56.00\end{array}$ & $\begin{array}{l}857 \\
813 \\
782 \\
770 \\
820\end{array}$ & $\begin{array}{l}5.00 \\
3.70 \\
4.50 \\
.98 \\
2.40\end{array}$ & $\begin{array}{c}\bar{z} \\
\bar{z} \\
450.0\end{array}$ \\
\hline $\begin{array}{l}240 \\
141 \\
142 \\
133 \\
134\end{array}$ & $\begin{array}{l}08 / 15 / 86 \\
08 / 18 / 86 \\
08 / 18 / 86 \\
08 / 14 / 86 \\
08 / 14 / 86\end{array}$ & $\begin{array}{l}\text { CARSON VALLEY } \\
\text { CARSON VALLEY } \\
\text { CARSON VALLEY } \\
\text { FERNLEY WMA } \\
\text { FERNLEY WMA }\end{array}$ & $\begin{array}{l}\text { BIRD } \\
\text { BIRD } \\
\text { BIRD } \\
\text { BIRD } \\
\text { BIRD }\end{array}$ & $\begin{array}{l}\text { COOT } \\
\text { COOT } \\
\text { COOT } \\
\text { COOT } \\
\text { COOT }\end{array}$ & $\begin{array}{l}<.41 \\
<.39 \\
<.40 \\
<.39 \\
<.38\end{array}$ & $\begin{array}{l}<.41 \\
<.39 \\
<.40 \\
<.39 \\
<.38\end{array}$ & $\begin{array}{l}<.83 \\
<.78 \\
<.80 \\
<.78 \\
<.76\end{array}$ & $\begin{array}{r}55.00 \\
47.00 \\
88.00 \\
9.40 \\
13.00\end{array}$ & $\begin{array}{l}840 \\
870 \\
760 \\
840 \\
730\end{array}$ & $\begin{array}{l}2.00 \\
2.90 \\
2.80 \\
4.90 \\
6.70\end{array}$ & $\begin{array}{r}440.0 \\
340.0 \\
270.0 \\
94.0 \\
91.0\end{array}$ \\
\hline $\begin{array}{r}135 \\
136 \\
137 \\
87483 \\
87583\end{array}$ & $\begin{array}{l}08 / 14 / 86 \\
08 / 14 / 86 \\
08 / 14 / 86 \\
07 / 06 / 87 \\
07 / 21 / 87\end{array}$ & $\begin{array}{l}\text { FERNLEY WMA } \\
\text { FERNLEY WMA } \\
\text { FERNLEY WMA } \\
\text { HARMON RES. } \\
\text { HARMON RES. }\end{array}$ & $\begin{array}{l}\text { BIRD } \\
\text { BIRD } \\
\text { BIRD } \\
\text { BIRD } \\
\text { BIRD }\end{array}$ & $\begin{array}{l}\text { COOT } \\
\text { COOT } \\
\text { COOT } \\
\text { COOT } \\
\text { COOT }\end{array}$ & $\begin{array}{l}<.46 \\
<.37 \\
<.40 \\
.20 \\
.20\end{array}$ & $\begin{array}{l}<.46 \\
<.37 \\
<.40 \\
<.10 \\
<.10\end{array}$ & $\begin{array}{l}<.92 \\
<.74 \\
<.81 \\
<.20 \\
<.20\end{array}$ & $\begin{array}{r}4.50 \\
42.00 \\
16.00 \\
124.00 \\
75.80\end{array}$ & $\begin{array}{l}810 \\
740 \\
750 \\
811 \\
777\end{array}$ & $\begin{array}{r}3.00 \\
4.90 \\
20.00 \\
3.90 \\
3.30\end{array}$ & $\begin{array}{r}51.0 \\
200.0 \\
220.0 \\
--\end{array}$ \\
\hline $\begin{array}{l}87584 \\
87588 \\
87590 \\
87591 \\
118\end{array}$ & $\begin{array}{l}07 / 21 / 87 \\
07 / 27 / 87 \\
07 / 28 / 87 \\
07 / 28 / 87 \\
08 / 04 / 86\end{array}$ & $\begin{array}{l}\text { HARMON RES. } \\
\text { HARMON RES. } \\
\text { HARMON RES. } \\
\text { HARMON RES. } \\
\text { HWMA, HUMBOLDT LAKE }\end{array}$ & $\begin{array}{l}\text { BIRD } \\
\text { BIRD } \\
\text { BIRD } \\
\text { BIRD } \\
\text { BIRD }\end{array}$ & $\begin{array}{l}\text { COOT } \\
\text { COOT } \\
\text { COOT } \\
\text { COOT } \\
\text { COOT }\end{array}$ & $\begin{array}{r}.20 \\
.20 \\
.20 \\
.74 \\
<.42\end{array}$ & $\begin{array}{l}<.10 \\
<.10 \\
<.10 \\
<.10 \\
<.42\end{array}$ & $\begin{array}{l}<.20 \\
.20 \\
<.20 \\
<.20 \\
<.42\end{array}$ & $\begin{array}{r}182.00 \\
136.00 \\
83.10 \\
139.00 \\
63.00\end{array}$ & $\begin{array}{l}913 \\
749 \\
722 \\
848 \\
840\end{array}$ & $\begin{array}{l}3.40 \\
4.20 \\
2.00 \\
3.20 \\
5.50\end{array}$ & $\bar{z}=$ \\
\hline $\begin{array}{r}119 \\
120 \\
121 \\
122 \\
87478\end{array}$ & $\begin{array}{l}08 / 04 / 86 \\
08 / 07 / 86 \\
08 / 04 / 86 \\
08 / 04 / 86 \\
07 / 02 / 87\end{array}$ & $\begin{array}{l}\text { HWMA, HUMBOLDT LAKE } \\
\text { HWMA, HUMBOIDT LAKE } \\
\text { HWMA, HUMBOLDT LAKE } \\
\text { HWMA, HUMBOLDT LAKE } \\
\text { HWMA, TOULON LAKE }\end{array}$ & $\begin{array}{l}\text { BIRD } \\
\text { BIRD } \\
\text { BIRD } \\
\text { BIRD } \\
\text { BIRD }\end{array}$ & $\begin{array}{l}\text { COOT } \\
\text { COOT } \\
\text { COOT } \\
\text { COOT } \\
\text { COOT }\end{array}$ & $\begin{array}{l}<.40 \\
<.36 \\
<.43 \\
<.39 \\
.10\end{array}$ & $\begin{array}{l}<.40 \\
<.36 \\
<.43 \\
<.39 \\
<.10\end{array}$ & $\begin{array}{l}<.40 \\
<.36 \\
<.43 \\
<.39 \\
<.20\end{array}$ & $\begin{array}{r}29.00 \\
80.00 \\
77.00 \\
110.00 \\
80.50\end{array}$ & $\begin{array}{r}870 \\
800 \\
820 \\
1,000 \\
784\end{array}$ & $\begin{array}{l}3.40 \\
4.40 \\
3.90 \\
4.50 \\
2.00\end{array}$ & $\begin{array}{l}65.0 \\
36.0 \\
65.0 \\
58.0 \\
--\end{array}$ \\
\hline $\begin{array}{l}87479 \\
87480 \\
87481 \\
87482 \\
87406\end{array}$ & $\begin{array}{l}07 / 02 / 87 \\
07 / 02 / 87 \\
07 / 02 / 87 \\
07 / 02 / 87 \\
06 / 19 / 87\end{array}$ & $\begin{array}{l}\text { HWMA, TOULON LAKE } \\
\text { HWMA, TOULON LAKE } \\
\text { HWMAA, TOULON LAKE } \\
\text { HWMA, TOULON LAKE } \\
\text { MAHALA SLOUGE }\end{array}$ & $\begin{array}{l}\text { BIRD } \\
\text { BIRD } \\
\text { BIRD } \\
\text { BIRD } \\
\text { BIRD }\end{array}$ & $\begin{array}{l}\text { COOT } \\
\text { COOT } \\
\text { COOT } \\
\text { COOT } \\
\text { COOT }\end{array}$ & $\begin{array}{l}<.10 \\
<.10 \\
<.10 \\
<.10 \\
<.10\end{array}$ & $\begin{array}{l}<.10 \\
<.10 \\
<.10 \\
<.10 \\
<.10\end{array}$ & $\begin{array}{l}<.20 \\
<.20 \\
<.20 \\
<.20 \\
<.20\end{array}$ & $\begin{array}{r}59.90 \\
135.00 \\
70.90 \\
135.00 \\
101.00\end{array}$ & $\begin{array}{l}738 \\
776 \\
776 \\
775 \\
702\end{array}$ & $\begin{array}{l}2.00 \\
3.00 \\
3.00 \\
3.50 \\
3.80\end{array}$ & $\begin{array}{l}= \\
= \\
= \\
=\end{array}$ \\
\hline $\begin{array}{l}87407 \\
87408 \\
87415 \\
87424 \\
87496\end{array}$ & $\begin{array}{l}06 / 19 / 87 \\
06 / 19 / 87 \\
06 / 25 / 87 \\
06 / 29 / 87 \\
07 / 08 / 87\end{array}$ & $\begin{array}{l}\text { MAHALA SLOUGH } \\
\text { MAHALA SLOUGH } \\
\text { MAHALA SLOUGH } \\
\text { MAHALA SLOUGG } \\
\text { MASSIE SLOUGH }\end{array}$ & $\begin{array}{l}\text { BIRD } \\
\text { BIRD } \\
\text { BIRD } \\
\text { BIRD } \\
\text { BIRD }\end{array}$ & $\begin{array}{l}\text { COOT } \\
\text { COOT } \\
\text { COOT } \\
\text { COOT } \\
\text { COOT }\end{array}$ & $\begin{array}{l}<.10 \\
<.10 \\
<.10 \\
<.10 \\
.10\end{array}$ & $\begin{array}{l}<.10 \\
<.10 \\
<.10 \\
<.10 \\
<.10\end{array}$ & $\begin{array}{l}<.20 \\
<.20 \\
<.20 \\
<.20 \\
<.20\end{array}$ & $\begin{array}{r}87.30 \\
55.60 \\
87.90 \\
74.80 \\
101.00\end{array}$ & $\begin{array}{l}717 \\
667 \\
670 \\
589 \\
756\end{array}$ & $\begin{array}{l}4.00 \\
4.00 \\
4.00 \\
3.00 \\
3.00\end{array}$ & $\begin{array}{l}= \\
=- \\
= \\
=\end{array}$ \\
\hline $\begin{array}{l}87497 \\
87498 \\
87499 \\
87500 \\
87502\end{array}$ & $\begin{array}{l}07 / 08 / 87 \\
07 / 08 / 87 \\
07 / 08 / 87 \\
07 / 08 / 87 \\
07 / 08 / 87\end{array}$ & $\begin{array}{l}\text { MASSIE SLOUGH } \\
\text { MASSIE SLOUGH } \\
\text { MASSIE SLOUGH } \\
\text { MASSIE SLOUGH } \\
\text { MASSIE SLOUGH }\end{array}$ & $\begin{array}{l}\text { BIRD } \\
\text { BIRD } \\
\text { BIRD } \\
\text { BIRD } \\
\text { BIRD }\end{array}$ & $\begin{array}{l}\text { COOT } \\
\text { COOT } \\
\text { COOT } \\
\text { COOT } \\
\text { COOT }\end{array}$ & $\begin{array}{l}.10 \\
.30 \\
.10 \\
.10 \\
.41\end{array}$ & $\begin{array}{l}<.10 \\
<.10 \\
<.10 \\
<.10 \\
<.10\end{array}$ & $\begin{array}{l}<.20 \\
<.20 \\
<.20 \\
.20 \\
<.20\end{array}$ & $\begin{array}{r}68.00 \\
92.20 \\
76.40 \\
56.30 \\
257.00\end{array}$ & $\begin{array}{l}730 \\
764 \\
736 \\
799 \\
856\end{array}$ & $\begin{array}{l}3.70 \\
6.70 \\
4.30 \\
5.60 \\
6.80\end{array}$ & $\begin{array}{l}= \\
= \\
= \\
=\end{array}$ \\
\hline $\begin{array}{r}87502 \\
85 \\
86 \\
87 \\
88\end{array}$ & $\begin{array}{l}07 / 08 / 87 \\
07 / 24 / 86 \\
07 / 24 / 86 \\
07 / 24 / 86 \\
07 / 24 / 86\end{array}$ & $\begin{array}{l}\text { MASSIE SLOUGH } \\
\text { SWMA, ALKALI UN. } 1 \\
\text { SWMA, ALKALI UN. I } \\
\text { SWMA, ALKALI UN. II } \\
\text { SWMA, ALKALI UN. }\end{array}$ & $\begin{array}{l}\text { BIRD } \\
\text { BIRD } \\
\text { BIRD } \\
\text { BIRD } \\
\text { BIRD }\end{array}$ & $\begin{array}{l}\text { COOT } \\
\text { COOT } \\
\text { COOT } \\
\text { COOT } \\
\text { COOT }\end{array}$ & $\begin{array}{l}<.10 \\
<.41 \\
<.38 \\
<.43 \\
<.39\end{array}$ & $\begin{array}{l}<.10 \\
<.41 \\
<.38 \\
<.43 \\
<.39\end{array}$ & $\begin{array}{l}<.20 \\
<.41 \\
<.38 \\
<.43 \\
<.39\end{array}$ & $\begin{array}{r}155.00 \\
14.00 \\
26.00 \\
95.00 \\
55.00\end{array}$ & $\begin{array}{l}813 \\
890 \\
850 \\
760 \\
940\end{array}$ & $\begin{array}{l}4.10 \\
4.90 \\
3.40 \\
4.10 \\
4.30\end{array}$ & $\begin{array}{l}160.0 \\
370.0 \\
220.0 \\
190.0\end{array}$ \\
\hline $\begin{array}{r}89 \\
87132 \\
87133 \\
103 \\
104\end{array}$ & $\begin{array}{l}07 / 24 / 86 \\
07 / 27 / 87 \\
07 / 27 / 87 \\
07 / 31 / 86 \\
07 / 31 / 86\end{array}$ & $\begin{array}{l}\text { SWMA, ALKALI UN. } 11 \\
\text { SWMA, DRY LAKE } \\
\text { SWMA, DRY LAKE } \\
\text { SWMA, GOSE LAKE } \\
\text { SWMA, GOOSE LAKE }\end{array}$ & $\begin{array}{l}\text { BIRD } \\
\text { BIRD } \\
\text { BIRD } \\
\text { BIRD } \\
\text { BIRD }\end{array}$ & $\begin{array}{l}\text { COOT } \\
\text { COOT } \\
\text { COOT } \\
\text { COOT } \\
\text { COOT }\end{array}$ & $\begin{array}{l}<.42 \\
.65 \\
.30 \\
=-\end{array}$ & $\begin{array}{l}<.42 \\
<.10 \\
<.10 \\
=-\end{array}$ & $\begin{array}{l}<.42 \\
<.20 \\
<.20 \\
=- \\
=-\end{array}$ & $\begin{array}{r}250.00 \\
33.70 \\
31.00 \\
=- \\
=\end{array}$ & $\begin{array}{l}930 \\
639 \\
621 \\
-- \\
--\end{array}$ & $\begin{array}{l}4.70 \\
4.00 \\
3.40 \\
=- \\
=\end{array}$ & $\begin{array}{l}56.0 \\
=- \\
=- \\
=-\end{array}$ \\
\hline
\end{tabular}


TABLE 19.--Data on trace-element constituents and percent moisture of biological samples in stillwater wildifo Management irea, Carson Lake, Fernley Wildlife Management Area, and Humboldt Wildife Management Area, ig85-87--Cont.

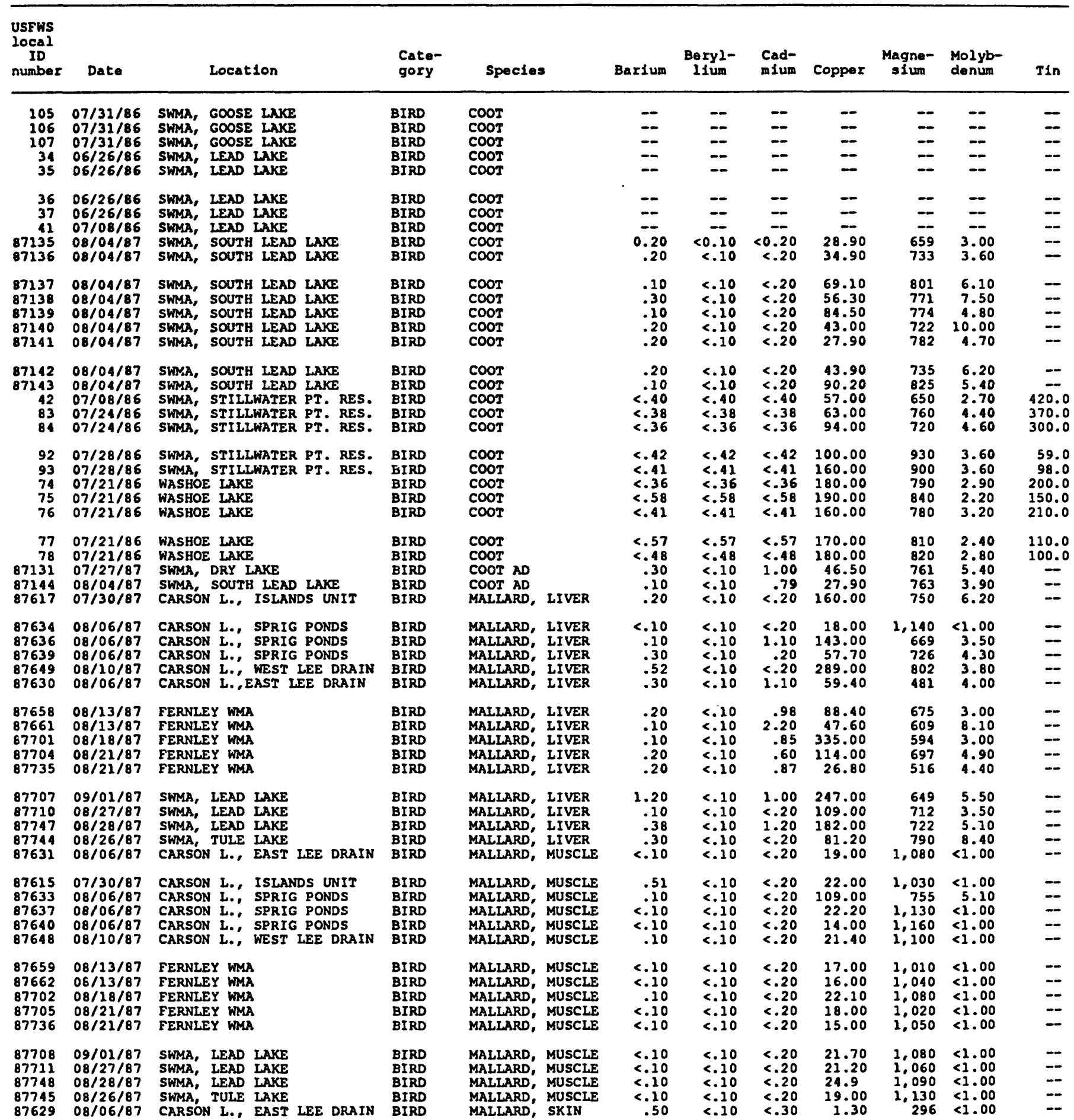


TABLE 19.-Data on trace-element constituents and percent moisture of biological samples in stillwater W1ldiffe Management Area, Carson Lake, Fernley Wildlife Management Area, and Humboldt Wildlife Management Area, 1985-87--Cont.

\begin{tabular}{|c|c|c|c|c|c|c|c|c|c|c|c|c|c|}
\hline \multirow{2}{*}{$\begin{array}{c}\text { USFWS } \\
\text { local } \\
\text { ID } \\
\text { numbar }\end{array}$} & \multirow{2}{*}{$\begin{array}{c}\text { Date } \\
07 / 30 / 87 \\
08 / 06 / 87 \\
08 / 06 / 87 \\
08 / 06 / 87 \\
08 / 10 / 87\end{array}$} & \multicolumn{2}{|c|}{ Location } & \multirow{2}{*}{$\begin{array}{l}\text { Cate- } \\
\text { gory } \\
\text { BIRD } \\
\text { BIRD } \\
\text { BIRD } \\
\text { BIRD } \\
\text { BIRD }\end{array}$} & \multicolumn{2}{|l|}{ Species } & \multirow{2}{*}{$\begin{array}{r}\text { Bar1um } \\
1.80 \\
.67 \\
<.10 \\
.20 \\
.95\end{array}$} & \multirow{2}{*}{$\begin{array}{c}\text { Beryl- } \\
11 \text { um } \\
<0.10 \\
<.10 \\
<.10 \\
<.10 \\
.10\end{array}$} & \multirow{2}{*}{$\begin{array}{r}\text { Cad- } \\
\text { mium } \\
<0.20 \\
<.30 \\
<.30 \\
<.30 \\
<.30\end{array}$} & \multirow{2}{*}{$\begin{array}{r}\text { Copper } \\
3.70 \\
3.90 \\
<.20 \\
.80 \\
5.80\end{array}$} & \multirow{2}{*}{$\begin{array}{r}\begin{array}{c}\text { Magne- } \\
\text { s1um }\end{array} \\
496 \\
597 \\
82 \\
288 \\
700\end{array}$} & \multirow{2}{*}{$\begin{array}{l}\begin{array}{l}\text { Molyb- } \\
\text { denum }\end{array} \\
<1.00 \\
<1.00 \\
<1.00 \\
<1.00 \\
<1.00\end{array}$} & \multirow{2}{*}{$\begin{array}{l}\text { Tin } \\
- \\
\overline{-} \\
\overline{-}\end{array}$} \\
\hline & & $\begin{array}{l}\text { CARSON L." } \\
\text { CARSON L.: } \\
\text { CARSON L., } \\
\text { CARSON L.” } \\
\text { CARSON L.. }\end{array}$ & $\begin{array}{l}\text { ISLANDS UNIT } \\
\text { SPRIG PONDS } \\
\text { SPRIG PONDS } \\
\text { SPRIG PONDS } \\
\text { WEST LEE DRAIN }\end{array}$ & & $\begin{array}{l}\text { MALIARD, } \\
\text { MALLARD, } \\
\text { MALIARD, } \\
\text { MALIARD, } \\
\text { MALLARD, }\end{array}$ & $\begin{array}{l}\text { SKIN } \\
\text { SKIN } \\
\text { SKIN } \\
\text { SKIN } \\
\text { SKIN }\end{array}$ & & & & & & & \\
\hline $\begin{array}{l}87657 \\
87660 \\
87700 \\
87703 \\
87734\end{array}$ & $\begin{array}{l}08 / 13 / 87 \\
08 / 13 / 87 \\
08 / 18 / 87 \\
08 / 21 / 87 \\
08 / 21 / 87\end{array}$ & $\begin{array}{l}\text { FERWLEY WM } \\
\text { FERHLEY WMA } \\
\text { FERWLEY WM } \\
\text { FERWLEY WM } \\
\text { FERWLEY WM }\end{array}$ & & $\begin{array}{l}\text { BIRD } \\
\text { BIRD } \\
\text { BIRD } \\
\text { BIRD } \\
\text { BIRD }\end{array}$ & $\begin{array}{l}\text { MALIARD, } \\
\text { MALIARD, } \\
\text { MALLARD, } \\
\text { MALLARD, } \\
\text { MALIARD, }\end{array}$ & $\begin{array}{l}\text { SKIN } \\
\text { SKIN } \\
\text { SKIN } \\
\text { SKIN } \\
\text { SKIN }\end{array}$ & $\begin{array}{l}.10 \\
.20 \\
.20 \\
.32 \\
.10\end{array}$ & $\begin{array}{l}.10 \\
.10 \\
.10 \\
.10 \\
.10\end{array}$ & $\begin{array}{l}<.30 \\
<.30 \\
<.30 \\
<.30 \\
<.30\end{array}$ & $\begin{array}{r}<.20 \\
<.84 \\
1.00 \\
1.70 \\
.50\end{array}$ & $\begin{array}{r}96 \\
211 \\
198 \\
397 \\
150\end{array}$ & $\begin{array}{l}<1.00 \\
<1.00 \\
<1.00 \\
<1.00 \\
<1.00\end{array}$ & $\begin{array}{l}-- \\
-- \\
--\end{array}$ \\
\hline $\begin{array}{l}87706 \\
87709 \\
87746 \\
87743 \\
87620\end{array}$ & $\begin{array}{l}09 / 01 / 87 \\
08 / 27 / 87 \\
08 / 28 / 87 \\
08 / 26 / 87 \\
07 / 30 / 87\end{array}$ & $\begin{array}{l}\text { SWMA, LEAD I } \\
\text { SWMA, LEAD I } \\
\text { SWMA, LEAD I } \\
\text { SWMA, TULE I } \\
\text { CARSON L.. E }\end{array}$ & $\begin{array}{l}\text { LAKE } \\
\text { LAKE } \\
\text { IAKE } \\
\text { IAKE } \\
\text { BIG WATER }\end{array}$ & $\begin{array}{l}\text { BIRD } \\
\text { BIRD } \\
\text { BIRD } \\
\text { BIRD } \\
\text { BIRD }\end{array}$ & $\begin{array}{l}\text { MALLARD, } \\
\text { MALIARD, } \\
\text { MALIARD, } \\
\text { MALLARD, } \\
\text { REDHEAD, }\end{array}$ & $\begin{array}{l}\text { SKIN } \\
\text { SKIN } \\
\text { SKIN } \\
\text { SKIN } \\
\text { IIVER }\end{array}$ & $\begin{array}{r}.20 \\
.10 \\
<.10 \\
.30 \\
.20\end{array}$ & $\begin{array}{r}.10 \\
.10 \\
.10 \\
.10 \\
<.10\end{array}$ & $\begin{array}{l}<.30 \\
<.30 \\
<.30 \\
<.30 \\
<.20\end{array}$ & $\begin{array}{r}1.10 \\
1.00 \\
.50 \\
1.10 \\
103.00\end{array}$ & $\begin{array}{l}204 \\
196 \\
125 \\
274 \\
735\end{array}$ & $\begin{array}{l}<1.00 \\
<1.00 \\
<1.00 \\
<1.00 \\
4.00\end{array}$ & $\begin{array}{l}-- \\
-- \\
-- \\
-- \\
--\end{array}$ \\
\hline $\begin{array}{l}87689 \\
87692 \\
87695 \\
87698 \\
87718\end{array}$ & $\begin{array}{l}08 / 17 / 87 \\
08 / 17 / 87 \\
08 / 17 / 87 \\
08 / 17 / 87 \\
08 / 25 / 87\end{array}$ & $\begin{array}{l}\text { CARSON L., } \\
\text { CARSON L., } \\
\text { CARSON L.. } \\
\text { CARSON L.' } \\
\text { SWMA, LEAD I }\end{array}$ & $\begin{array}{l}\text { BIG WATER } \\
\text { BIG WATER } \\
\text { BIG WATER } \\
\text { BIG WATER } \\
\text { IAKE }\end{array}$ & $\begin{array}{l}\text { BIRD } \\
\text { BIRD } \\
\text { BIRD } \\
\text { BIRD } \\
\text { BIRD }\end{array}$ & $\begin{array}{l}\text { REDHEAD, } \\
\text { REDHEAD, } \\
\text { REDHEAD, } \\
\text { REDHEAD, } \\
\text { REDHEAD, }\end{array}$ & $\begin{array}{l}\text { LIVER } \\
\text { LIVER } \\
\text { LIVER } \\
\text { LIVER } \\
\text { LIVER }\end{array}$ & $\begin{array}{l}.10 \\
.10 \\
.20 \\
.20 \\
.30\end{array}$ & $\begin{array}{l}<.10 \\
<.10 \\
<.10 \\
<.10 \\
<.10\end{array}$ & $\begin{array}{r}<.20 \\
<.20 \\
<.20 \\
<.20 \\
.70\end{array}$ & $\begin{array}{l}303.00 \\
243.00 \\
156.00 \\
358.00 \\
495.00\end{array}$ & $\begin{array}{l}872 \\
775 \\
822 \\
804 \\
675\end{array}$ & $\begin{array}{l}4.40 \\
3.70 \\
3.00 \\
3.00 \\
4.00\end{array}$ & $\begin{array}{l}-- \\
-- \\
--\end{array}$ \\
\hline $\begin{array}{l}87721 \\
87724 \\
87738 \\
87741 \\
87618\end{array}$ & $\begin{array}{l}08 / 25 / 87 \\
08 / 25 / 87 \\
08 / 25 / 87 \\
08 / 27 / 87 \\
07 / 30 / 87\end{array}$ & $\begin{array}{l}\text { SWMA, LEAD } \\
\text { SWMA, LEAD } \\
\text { SWMA, LEAD } \\
\text { SWMA, LEAD } \\
\text { CARSON L.. }\end{array}$ & $\begin{array}{l}\text { LAKE } \\
\text { LAKE } \\
\text { LAKE } \\
\text { LAKE } \\
\text { BIG WATER }\end{array}$ & $\begin{array}{l}\text { BIRD } \\
\text { BIRD } \\
\text { BIRD } \\
\text { BIRD } \\
\text { BIRD }\end{array}$ & $\begin{array}{l}\text { REDHEAD, } \\
\text { REDHEAD, } \\
\text { REDHEAD, } \\
\text { REDHEAD, } \\
\text { REDHEAD, }\end{array}$ & $\begin{array}{l}\text { LIVER } \\
\text { LIVER } \\
\text { LIVER } \\
\text { LIVER } \\
\text { MUSCLE }\end{array}$ & $\begin{array}{r}.20 \\
.20 \\
.47 \\
.20 \\
<.10\end{array}$ & $\begin{array}{l}<.10 \\
<.10 \\
<.10 \\
<.10 \\
<.10\end{array}$ & $\begin{array}{l}<.20 \\
<.20 \\
-2 \\
2.30 \\
<.20\end{array}$ & $\begin{array}{l}149.00 \\
105.00 \\
502.00 \\
177.00 \\
19.50\end{array}$ & $\begin{array}{r}837 \\
781 \\
763 \\
754 \\
1,030\end{array}$ & $\begin{array}{r}7.50 \\
3.80 \\
4.70 \\
6.50 \\
<1.00\end{array}$ & $\begin{array}{l}-- \\
-- \\
-- \\
--\end{array}$ \\
\hline $\begin{array}{l}87690 \\
87693 \\
87696 \\
87699 \\
87719\end{array}$ & $\begin{array}{l}08 / 17 / 87 \\
08 / 17 / 87 \\
08 / 17 / 87 \\
08 / 17 / 87 \\
08 / 25 / 87\end{array}$ & $\begin{array}{l}\text { CARSON L.. } \\
\text { CARSON L.: } \\
\text { CARSON L.. } \\
\text { CARSON I.: } \\
\text { SWMA, LEAD }\end{array}$ & $\begin{array}{l}\text { BIG WATER } \\
\text { BIG WATER } \\
\text { BIG WATER } \\
\text { BIG WATER } \\
\text { LAKE }\end{array}$ & $\begin{array}{l}\text { BIRD } \\
\text { BIRD } \\
\text { BIRD } \\
\text { BIRD } \\
\text { BIRD }\end{array}$ & $\begin{array}{l}\text { REDHEAD, } \\
\text { REDHEAD, } \\
\text { REDHEAD, } \\
\text { REDHEAD, } \\
\text { REDHEAD, }\end{array}$ & $\begin{array}{l}\text { MUSCLE } \\
\text { MUSCLE } \\
\text { MUSCLE } \\
\text { MUSCLE } \\
\text { MUSCLE }\end{array}$ & $\begin{array}{l}<.10 \\
.20 \\
<.10 \\
<.10 \\
<.10\end{array}$ & $\begin{array}{l}<.10 \\
<.10 \\
<.10 \\
<.10 \\
<.10\end{array}$ & $\begin{array}{l}<.20 \\
<.20 \\
<.20 \\
<.20 \\
<.20\end{array}$ & $\begin{array}{l}19.00 \\
19.00 \\
20.60 \\
21.40 \\
52.30\end{array}$ & $\begin{array}{l}1,060 \\
1,040 \\
1,070 \\
1,060 \\
1,200\end{array}$ & $\begin{array}{l}<1.00 \\
<1.00 \\
<1.00 \\
<1.00 \\
<1.00\end{array}$ & $\begin{array}{l}-- \\
-- \\
-- \\
--\end{array}$ \\
\hline $\begin{array}{l}87722 \\
87725 \\
87739 \\
87742 \\
87619\end{array}$ & $\begin{array}{l}08 / 25 / 87 \\
08 / 25 / 87 \\
08 / 25 / 87 \\
08 / 27 / 87 \\
07 / 30 / 87\end{array}$ & $\begin{array}{l}\text { SWMA, LEAD } \\
\text { SWMA, LEAD } \\
\text { SWMA, LEAD } \\
\text { SWMA, LEAD } \\
\text { CARSON L.. }\end{array}$ & $\begin{array}{l}\text { LAKE } \\
\text { LAKE } \\
\text { LAKE } \\
\text { LAKE } \\
\text { BIG WATER }\end{array}$ & $\begin{array}{l}\text { BIRD } \\
\text { BIRD } \\
\text { BIRD } \\
\text { BIRD } \\
\text { BIRD }\end{array}$ & $\begin{array}{l}\text { REDHEAD, } \\
\text { REDHEAD, } \\
\text { REDHEAD, } \\
\text { REDHEAD, } \\
\text { REDHEAD, }\end{array}$ & $\begin{array}{l}\text { MUSCLE } \\
\text { MUSCLE } \\
\text { MUSCLE } \\
\text { MUSCLE } \\
\text { SKIN }\end{array}$ & $\begin{array}{r}.10 \\
<.10 \\
<.10 \\
<.10 \\
.48\end{array}$ & $\begin{array}{l}<.10 \\
<.10 \\
<.10 \\
<.10 \\
<.10\end{array}$ & $\begin{array}{l}<.20 \\
<.20 \\
2.80 \\
<.20 \\
<.20\end{array}$ & $\begin{array}{l}16.00 \\
14.00 \\
38.80 \\
23.70 \\
3.10\end{array}$ & $\begin{array}{r}1,060 \\
1,000 \\
1,110 \\
988 \\
468\end{array}$ & $\begin{array}{l}1.00 \\
<1.00 \\
<1.00 \\
<1.00 \\
<1.00\end{array}$ & $\begin{array}{l}-- \\
-- \\
--\end{array}$ \\
\hline $\begin{array}{l}87688 \\
87691 \\
87694 \\
87697 \\
87717\end{array}$ & $\begin{array}{l}08 / 17 / 87 \\
08 / 17 / 87 \\
08 / 17 / 87 \\
08 / 17 / 87 \\
08 / 25 / 87\end{array}$ & $\begin{array}{l}\text { CARSON L., } \\
\text { CARSON I.. } \\
\text { CARSON L.. } \\
\text { CARSON L.. } \\
\text { SWMA, IEAD }\end{array}$ & $\begin{array}{l}\text { BIG WATER } \\
\text { BIG WATER } \\
\text { BIG WATER } \\
\text { BIG WATER } \\
\text { LAKE }\end{array}$ & $\begin{array}{l}\text { BIRD } \\
\text { BIRD } \\
\text { BIRD } \\
\text { BIRD } \\
\text { BIRD }\end{array}$ & $\begin{array}{l}\text { REDHEAD, } \\
\text { REDHEAD, } \\
\text { REDHEAD, } \\
\text { REDHEAD, } \\
\text { REDHEAD, }\end{array}$ & $\begin{array}{l}\text { SKIN } \\
\text { SKIN } \\
\text { SKIN } \\
\text { SKIN } \\
\text { SKIN }\end{array}$ & $\begin{array}{r}.30 \\
1.90 \\
.20 \\
.10 \\
4.00\end{array}$ & $\begin{array}{l}.10 \\
.20 \\
.10 \\
.10 \\
.34\end{array}$ & $\begin{array}{l}<.30 \\
<.30 \\
<.30 \\
<.30 \\
<.30\end{array}$ & $\begin{array}{r}1.20 \\
3.20 \\
1.30 \\
.69 \\
11.00\end{array}$ & $\begin{array}{l}284 \\
547 \\
213 \\
149 \\
692\end{array}$ & $\begin{array}{l}<1.00 \\
<1.00 \\
<1.00 \\
<1.00 \\
<1.00\end{array}$ & $\begin{array}{l}-- \\
-- \\
-- \\
--\end{array}$ \\
\hline $\begin{array}{l}87720 \\
87723 \\
87737 \\
87740 \\
87750\end{array}$ & $\begin{array}{l}08 / 25 / 87 \\
08 / 25 / 87 \\
08 / 25 / 87 \\
08 / 27 / 87 \\
08 / 17 / 87\end{array}$ & $\begin{array}{l}\text { SWMA, LEAD } \\
\text { SWMA, LEAD } \\
\text { SWMA, LEAD } \\
\text { SWMA, LEAD } \\
\text { CARSON L. }\end{array}$ & $\begin{array}{l}\text { LAKE } \\
\text { LAKE } \\
\text { LAKE } \\
\text { LAKE }\end{array}$ & $\begin{array}{l}\text { BIRD } \\
\text { BIRD } \\
\text { BIRD } \\
\text { BIRD } \\
\text { BIRD }\end{array}$ & $\begin{array}{l}\text { REDHEAD, } \\
\text { REDHEAD, } \\
\text { REDHEAD, } \\
\text { REDHEAD, } \\
\text { SHOVELER, }\end{array}$ & $\begin{array}{l}\text { SKIN } \\
\text { SKIN } \\
\text { SKIN } \\
\text { SKIN } \\
\text { LIVER }\end{array}$ & $\begin{array}{l}.30 \\
.20 \\
.35 \\
.10 \\
.10\end{array}$ & $\begin{array}{r}.10 \\
<.10 \\
<.10 \\
<.10 \\
<.10\end{array}$ & $\begin{array}{l}<.30 \\
<.30 \\
3.50 \\
<.30 \\
<.20\end{array}$ & $\begin{array}{r}1.60 \\
2.00 \\
11.00 \\
1.60 \\
110.00\end{array}$ & $\begin{array}{l}290 \\
351 \\
665 \\
300 \\
736\end{array}$ & $\begin{array}{l}<1.00 \\
<1.00 \\
<1.00 \\
<1.00 \\
3.60\end{array}$ & $\begin{array}{l}-- \\
-- \\
-- \\
--\end{array}$ \\
\hline $\begin{array}{l}87715 \\
87727 \\
87730 \\
87756 \\
87759\end{array}$ & $\begin{array}{l}08 / 13 / 87 \\
08 / 28 / 87 \\
08 / 25 / 87 \\
08 / 26 / 87 \\
08 / 26 / 87\end{array}$ & $\begin{array}{l}\text { FERWLEY WMA } \\
\text { SWMA, LEAD } \\
\text { SWMA, LEAD } \\
\text { SWMA, LEAD } \\
\text { SWMA, LEAD }\end{array}$ & $\begin{array}{l}\text { LAKE } \\
\text { LAKE } \\
\text { LAKE } \\
\text { LAKE }\end{array}$ & $\begin{array}{l}\text { BIRD } \\
\text { BIRD } \\
\text { BIRD } \\
\text { BIRD } \\
\text { BIRD }\end{array}$ & $\begin{array}{l}\text { SHOVELER, } \\
\text { SHOVELER, } \\
\text { SHOVEIER, } \\
\text { SHOVELER, } \\
\text { SHOVELER, }\end{array}$ & $\begin{array}{l}\text { LIVER } \\
\text { LIVER } \\
\text { LIVER } \\
\text { LIVER } \\
\text { LIVER }\end{array}$ & $\begin{array}{r}.41 \\
.20 \\
<.10 \\
.20 \\
<.10\end{array}$ & $\begin{array}{l}<.10 \\
<.10 \\
<.10 \\
<.10 \\
<.10\end{array}$ & $\begin{array}{r}3.20 \\
.66 \\
.30 \\
1.00 \\
1.90\end{array}$ & $\begin{array}{r}78.60 \\
81.80 \\
16.00 \\
84.80 \\
126.00\end{array}$ & $\begin{array}{l}783 \\
771 \\
799 \\
751 \\
794\end{array}$ & $\begin{array}{r}10.00 \\
5.30 \\
3.00 \\
2.00 \\
3.00\end{array}$ & $\begin{array}{l}-- \\
-- \\
-- \\
--\end{array}$ \\
\hline $\begin{array}{l}87753 \\
87749 \\
87714 \\
87726 \\
87729\end{array}$ & $\begin{array}{l}08 / 27 / 87 \\
08 / 17 / 87 \\
08 / 13 / 87 \\
08 / 28 / 87 \\
08 / 25 / 87\end{array}$ & $\begin{array}{l}\text { SWMA, TULE I } \\
\text { CARSON I. } \\
\text { FERWLEY WMA } \\
\text { SWMA, LEAD I } \\
\text { SWMA, LEAD I }\end{array}$ & $\begin{array}{l}\text { LAKE } \\
\text { LAKE } \\
\text { LAKE }\end{array}$ & $\begin{array}{l}\text { BIRD } \\
\text { BIRD } \\
\text { BIRD } \\
\text { BIRD } \\
\text { BIRD }\end{array}$ & $\begin{array}{l}\text { SHOVELER, } \\
\text { SHOVELER, } \\
\text { SHOVELER, } \\
\text { SHOVELER, } \\
\text { SHOVELER, }\end{array}$ & $\begin{array}{l}\text { LIVER } \\
\text { SKIN } \\
\text { SKIN } \\
\text { SKIN } \\
\text { SKIN }\end{array}$ & $\begin{array}{r}.10 \\
.33 \\
.10 \\
<.09 \\
.31\end{array}$ & $\begin{array}{l}<.10 \\
<.10 \\
<.10 \\
<.09 \\
<.10\end{array}$ & $\begin{array}{l}2.70 \\
<.30 \\
<.30 \\
<.30 \\
<.30\end{array}$ & $\begin{array}{r}94.00 \\
3.10 \\
.92 \\
.65 \\
1.20\end{array}$ & $\begin{array}{r}609 \\
408 \\
233 \\
95 \\
196\end{array}$ & $\begin{array}{r}7.40 \\
<1.00 \\
<1.00 \\
<.90 \\
<1.00\end{array}$ & $\begin{array}{l}-- \\
-- \\
-- \\
--\end{array}$ \\
\hline $\begin{array}{l}87755 \\
87758 \\
87752 \\
87751 \\
87716\end{array}$ & $\begin{array}{l}08 / 26 / 87 \\
08 / 26 / 87 \\
08 / 27 / 87 \\
08 / 17 / 87 \\
08 / 13 / 87\end{array}$ & $\begin{array}{l}\text { SWMA, LEAD } \\
\text { SWMA, LEAD I } \\
\text { SWMA, TULE } \\
\text { CARSON L. } \\
\text { FERNLEY WMA }\end{array}$ & $\begin{array}{l}\text { LAKE } \\
\text { LAKE } \\
\text { LAKE }\end{array}$ & $\begin{array}{l}\text { BIRD } \\
\text { BIRD } \\
\text { BIRD } \\
\text { BIRD } \\
\text { BIRD }\end{array}$ & $\begin{array}{l}\text { SHOVELER, } \\
\text { SHOVELER, } \\
\text { SHOVELER, } \\
\text { SHOVELER, } \\
\text { SHOVELER, }\end{array}$ & $\begin{array}{l}\text { SKIN } \\
\text { SKIN } \\
\text { SKIN } \\
\text { MUSCLE } \\
\text { MUSCLE }\end{array}$ & $\begin{array}{r}<.10 \\
<.10 \\
.40 \\
<.10 \\
.30\end{array}$ & $\begin{array}{l}<.10 \\
<.10 \\
<.10 \\
<.10 \\
<.10\end{array}$ & $\begin{array}{l}<.30 \\
<.30 \\
<.30 \\
<.20 \\
<.20\end{array}$ & $\begin{array}{r}.90 \\
<.20 \\
<.20 \\
26.70 \\
19.00\end{array}$ & $\begin{array}{r}113 \\
95 \\
107 \\
1,020 \\
1,100\end{array}$ & $\begin{array}{l}<1.00 \\
<1.00 \\
<1.00 \\
<1.00 \\
<1.00\end{array}$ & $\begin{array}{l}-- \\
-- \\
-- \\
--\end{array}$ \\
\hline
\end{tabular}


TABLE 19.--Data on trace-element constituents and percent molsture of blological samples in stiliwater Wildlife Management Area, Carson Lake, Fernley Wildlife Management Area, and Humboldt Wildlife Management Area, ig85-87--Cont.

\begin{tabular}{|c|c|c|c|c|c|c|c|c|c|c|c|c|}
\hline $\begin{array}{l}\text { USFWS } \\
\text { local } \\
\text { ID } \\
\text { number }\end{array}$ & Date & & Location & $\begin{array}{l}\text { Cate- } \\
\text { gory }\end{array}$ & Species & Barium & $\begin{array}{c}\text { Bery1- } \\
\text { lium }\end{array}$ & $\begin{array}{l}\text { Cad- } \\
\text { milum }\end{array}$ & Copper & $\begin{array}{l}\text { Magne- } \\
\text { sium }\end{array}$ & $\begin{array}{l}\text { Molyb- } \\
\text { denum }\end{array}$ & Tin \\
\hline $\begin{array}{l}87728 \\
87731 \\
87757 \\
87760 \\
87754\end{array}$ & $\begin{array}{l}08 / 28 / 87 \\
08 / 25 / 87 \\
08 / 26 / 87 \\
08 / 26 / 87 \\
08 / 27 / 87\end{array}$ & $\begin{array}{l}\text { SWMA, } \\
\text { SWMA, } \\
\text { SWMA, } \\
\text { SWMA, } \\
\text { SWMA, }\end{array}$ & $\begin{array}{l}\text { LEAD LAKE } \\
\text { LEAD LAKE } \\
\text { LEAD LAKE } \\
\text { LEAD LAKE } \\
\text { TULE LAKE }\end{array}$ & $\begin{array}{l}\text { BIRD } \\
\text { BIRD } \\
\text { BIRD } \\
\text { BIRD } \\
\text { BIRD }\end{array}$ & $\begin{array}{l}\text { SHOVELER, MUSCLE } \\
\text { SHOVELER, MUSCLE } \\
\text { SHOVELER, MUSCLE } \\
\text { SHOVELER, MUSCLE } \\
\text { SHOVELER, MUSCLE }\end{array}$ & $\begin{array}{l}<0.10 \\
<.10 \\
<.10 \\
<.10 \\
<.10\end{array}$ & $\begin{array}{l}<0.10 \\
<.10 \\
<.10 \\
<.10 \\
<.10\end{array}$ & $\begin{array}{l}<0.20 \\
<.20 \\
<.20 \\
<.20 \\
<.20\end{array}$ & $\begin{array}{l}28.80 \\
25.40 \\
35.00 \\
18.00 \\
19.50\end{array}$ & $\begin{array}{r}959 \\
972 \\
1,010 \\
1,110 \\
1,050\end{array}$ & $\begin{array}{l}<1.00 \\
<1.00 \\
<1.00 \\
<1.00 \\
<1.00\end{array}$ & $\begin{array}{l}=- \\
=- \\
=\end{array}$ \\
\hline $\begin{array}{l}87600 \\
87601 \\
87681 \\
85001 \\
85002\end{array}$ & $\begin{array}{l}07 / 28 / 87 \\
07 / 28 / 87 \\
09 / 03 / 87 \\
07 / 29 / 85 \\
07 / 29 / 85\end{array}$ & $\begin{array}{l}\text { HARMON } \\
\text { HARMON } \\
\text { HARMON } \\
\text { CARSON } \\
\text { CARSON }\end{array}$ & $\begin{array}{l}\text { RES. } \\
\text { RES, } \\
\text { RES. } \\
\text { L.. CARSON I DRAIN } \\
\text { L.. CARSON I DRAIN }\end{array}$ & $\begin{array}{l}\text { FISH } \\
\text { FISH } \\
\text { FISH } \\
\text { EISH } \\
\text { FISH }\end{array}$ & $\begin{array}{l}\text { BLACK BULLHEAD } \\
\text { BLACK BULLHEAD } \\
\text { BLACK BULLHEAD } \\
\text { CARP } \\
\text { CARP }\end{array}$ & $\begin{array}{l}11.90 \\
18.40 \\
21.90 \\
=- \\
=\end{array}$ & $\begin{array}{l}<.10 \\
<.10 \\
<.10 \\
-2 \\
=-\end{array}$ & $\begin{array}{l}<.20 \\
<.20 \\
<.30 \\
<.22 \\
<.22\end{array}$ & $\begin{array}{l}2.60 \\
4.70 \\
3.70 \\
4.90 \\
4.90\end{array}$ & $\begin{array}{r}1,350 \\
1,650 \\
1,780 \\
-- \\
--\end{array}$ & $\begin{array}{l}<1.00 \\
<1.00 \\
<1.00 \\
<.50 \\
<.40\end{array}$ & 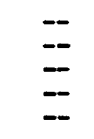 \\
\hline $\begin{array}{r}85003 \\
387 \\
388 \\
389 \\
355\end{array}$ & $\begin{array}{l}07 / 29 / 85 \\
11 / 03 / 86 \\
11 / 03 / 86 \\
11 / 03 / 86 \\
10 / 03 / 86\end{array}$ & $\begin{array}{l}\text { CARSON } \\
\text { CARSON } \\
\text { CARSON } \\
\text { CARSON } \\
\text { CARSON }\end{array}$ & $\begin{array}{l}\text { L.., CARSON I DRAIN } \\
\text { L.. ISLANDS UNIT } \\
\text { L.. ISLANDS UNIT } \\
\text { L.., ISLANDS UNIT } \\
\text { I., SPRIG PONDS }\end{array}$ & $\begin{array}{l}\text { FISH } \\
\text { FISH } \\
\text { FISH } \\
\text { FISH } \\
\text { FISH }\end{array}$ & $\begin{array}{l}\text { CARP } \\
\text { CARP } \\
\text { CARP } \\
\text { CARP } \\
\text { CARP }\end{array}$ & $\begin{array}{l}-. \\
5.80 \\
3.40 \\
4.70 \\
2.60\end{array}$ & $\begin{array}{l}-. \\
<.48 \\
<.42 \\
<.39 \\
<.43\end{array}$ & $\begin{array}{l}<.20 \\
<.96 \\
<.85 \\
<.79 \\
<.86\end{array}$ & $\begin{array}{l}6.10 \\
2.80 \\
2.80 \\
2.90 \\
3.30\end{array}$ & $\begin{array}{l}1,200 \\
1,300 \\
1,200 \\
1,100\end{array}$ & $\begin{array}{l}<.50 \\
<.96 \\
<.85 \\
<.79 \\
1.50\end{array}$ & $\begin{array}{r}11.0 \\
8.5 \\
16.0 \\
26.0\end{array}$ \\
\hline $\begin{array}{l}356 \\
357 \\
146 \\
147 \\
148\end{array}$ & $\begin{array}{l}10 / 03 / 86 \\
10 / 03 / 86 \\
09 / 09 / 86 \\
09 / 09 / 86 \\
09 / 09 / 86\end{array}$ & $\begin{array}{l}\text { CARSON } \\
\text { CARSON } \\
\text { FERNLE: } \\
\text { FERNLE: } \\
\text { FERNLE: }\end{array}$ & $\begin{array}{l}\text { L., SPRIG PONDS } \\
\text { I.., SPRIG PONDS } \\
\text { YY WMA } \\
\text { YY WMA } \\
\text { Y WMA }\end{array}$ & $\begin{array}{l}\text { FISH } \\
\text { FISH } \\
\text { FISH } \\
\text { FISH } \\
\text { FISH }\end{array}$ & $\begin{array}{l}\text { CARP } \\
\text { CARP } \\
\text { CARP } \\
\text { CARP } \\
\text { CARP }\end{array}$ & $\begin{array}{l}4.80 \\
7.40 \\
4.00 \\
3.40 \\
4.90\end{array}$ & $\begin{array}{l}<.48 \\
<.53 \\
<.40 \\
<.43 \\
<.49\end{array}$ & $\begin{array}{r}<.96 \\
<1.10 \\
<.79 \\
<.85 \\
<.98\end{array}$ & $\begin{array}{l}3.10 \\
5.00 \\
3.20 \\
3.10 \\
3.80\end{array}$ & $\begin{array}{l}1,400 \\
1,500 \\
960 \\
1,000 \\
1,200\end{array}$ & $\begin{array}{r}<.96 \\
<1.10 \\
5.80 \\
<.85 \\
<.98\end{array}$ & $\begin{array}{r}23.0 \\
120.0 \\
13.0 \\
24.0 \\
15.0\end{array}$ \\
\hline $\begin{array}{r}87484 \\
87678 \\
380 \\
381 \\
382\end{array}$ & $\begin{array}{l}07 / 06 / 87 \\
09 / 02 / 87 \\
10 / 29 / 86 \\
10 / 29 / 86 \\
10 / 29 / 86\end{array}$ & $\begin{array}{l}\text { HARMON } \\
\text { HARMON } \\
\text { HWMA, } \\
\text { HWMA, } \\
\text { HWMA, }\end{array}$ & $\begin{array}{l}\text { RES. } \\
\text { RES. } \\
\text { HUMBOIDT LAKE } \\
\text { HUMBOIDT LAKE } \\
\text { HUMBOIDT LAKE }\end{array}$ & $\begin{array}{l}\text { FISH } \\
\text { FISH } \\
\text { FISH } \\
\text { FISH } \\
\text { FISH }\end{array}$ & $\begin{array}{l}\text { CARP } \\
\text { CARP } \\
\text { CARP } \\
\text { CARP } \\
\text { CARP }\end{array}$ & $\begin{array}{r}10.20 \\
18.30 \\
4.30 \\
5.50 \\
4.10\end{array}$ & $\begin{array}{l}<.10 \\
<.10 \\
<.54 \\
<.45 \\
<.51\end{array}$ & $\begin{array}{r}<.20 \\
<.30 \\
<1.10 \\
<.91 \\
<1.00\end{array}$ & $\begin{array}{l}4.50 \\
4.20 \\
2.60 \\
1.80 \\
3.80\end{array}$ & $\begin{array}{l}1,600 \\
1,320 \\
1,500 \\
1,500 \\
1,600\end{array}$ & $\begin{array}{l}<1.00 \\
<1.00 \\
50.00 \\
<.91 \\
<1.00\end{array}$ & $\begin{array}{l}-- \\
-- \\
20.0 \\
32.0 \\
41.0\end{array}$ \\
\hline $\begin{array}{r}87516 \\
87592 \\
87594 \\
87595 \\
390\end{array}$ & $\begin{array}{l}07 / 09 / 87 \\
07 / 27 / 87 \\
07 / 27 / 87 \\
07 / 27 / 87 \\
11 / 04 / 86\end{array}$ & $\begin{array}{l}\text { HWMA, } \\
\text { SHECKI } \\
\text { SHECKL } \\
\text { SHECKI } \\
\text { SWMA, }\end{array}$ & $\begin{array}{l}\text { MIDDLE ARMY DRAIN } \\
\text { ER RES. } \\
\text { ER RES. } \\
\text { ER RES. } \\
\text { ALKALI UN. } 11\end{array}$ & $\begin{array}{l}\text { FISH } \\
\text { FISH } \\
\text { FISH } \\
\text { FISH } \\
\text { FISH }\end{array}$ & $\begin{array}{l}\text { CARP } \\
\text { CARP } \\
\text { CARP } \\
\text { CARP } \\
\text { CARP }\end{array}$ & $\begin{array}{r}6.40 \\
9.70 \\
13.50 \\
15.10 \\
14.00\end{array}$ & $\begin{array}{l}<.10 \\
<.10 \\
<.10 \\
<.10 \\
<.42\end{array}$ & $\begin{array}{l}<.20 \\
1.20 \\
.40 \\
1.20 \\
<.85\end{array}$ & $\begin{array}{l}4.00 \\
6.60 \\
8.10 \\
5.30 \\
3.80\end{array}$ & $\begin{array}{l}1,810 \\
1,550 \\
1,740 \\
1,830 \\
1,200\end{array}$ & $\begin{array}{l}<1.00 \\
<1.00 \\
<1.00 \\
<1.00 \\
<.85\end{array}$ & $\begin{array}{l}-- \\
-- \\
\overline{13.0}\end{array}$ \\
\hline $\begin{array}{l}391 \\
392 \\
338 \\
339 \\
340\end{array}$ & $\begin{array}{l}11 / 04 / 86 \\
12 / 04 / 86 \\
10 / 02 / 86 \\
10 / 02 / 86 \\
10 / 02 / 86\end{array}$ & $\begin{array}{l}\text { SWMA, } \\
\text { SWMA, } \\
\text { SWMA, } \\
\text { SWMA, } \\
\text { SWMA, }\end{array}$ & $\begin{array}{l}\text { ALKALI UN. } 1 \\
\text { ALKALI UN. } 1 \\
\text { GOOSE LAKE } \\
\text { GOOSE LAKE } \\
\text { GOOSE LAKE }\end{array}$ & $\begin{array}{l}\text { FISH } \\
\text { FISH } \\
\text { FISH } \\
\text { FISH } \\
\text { FISH }\end{array}$ & $\begin{array}{l}\text { CARP } \\
\text { CARP } \\
\text { CARP } \\
\text { CARP } \\
\text { CARP }\end{array}$ & $\begin{array}{l}5.50 \\
4.50 \\
2.80 \\
8.60 \\
5.10\end{array}$ & $\begin{array}{l}<.39 \\
<.45 \\
<.46 \\
<.39 \\
<.43\end{array}$ & $\begin{array}{l}<.79 \\
<.89 \\
<.92 \\
<.78 \\
<.85\end{array}$ & $\begin{array}{r}10.00 \\
6.30 \\
3.90 \\
1.20 \\
1.90\end{array}$ & $\begin{array}{l}1,100 \\
1,100 \\
1,200 \\
1,300 \\
1,300\end{array}$ & $\begin{array}{l}27.00 \\
<.89 \\
<.92 \\
<.78 \\
<.85\end{array}$ & $\begin{array}{r}6.1 \\
13.0 \\
91.0 \\
17.0 \\
8.1\end{array}$ \\
\hline $\begin{array}{r}373 \\
374 \\
375 \\
85007 \\
85008\end{array}$ & $\begin{array}{l}10 / 09 / 86 \\
10 / 09 / 86 \\
10 / 09 / 86 \\
07 / 29 / 85 \\
07 / 29 / 85\end{array}$ & $\begin{array}{l}\text { SWMA, } \\
\text { SWMA, } \\
\text { SWMA, } \\
\text { SWMA, } \\
\text { SWMA, }\end{array}$ & $\begin{array}{l}\text { LEAD LAKE } \\
\text { LEAD LAKE } \\
\text { LEAD LAKE } \\
\text { STILIWATER PT. DIV. } \\
\text { STILLWATER PT. DIV. }\end{array}$ & $\begin{array}{l}\text { FISH } \\
\text { FISH } \\
\text { FISH } \\
\text { FISH } \\
\text { FISH }\end{array}$ & $\begin{array}{l}\text { CARP } \\
\text { CARP } \\
\text { CARP } \\
\text { CARP } \\
\text { CARP }\end{array}$ & $\begin{array}{l}6.20 \\
5.00 \\
6.80 \\
=- \\
--\end{array}$ & $\begin{array}{l}<.38 \\
<.35 \\
<.42 \\
-- \\
--\end{array}$ & $\begin{array}{l}<.77 \\
<.71 \\
<.85 \\
<.20 \\
<.20\end{array}$ & $\begin{array}{l}1.40 \\
1.30 \\
1.80 \\
3.90 \\
2.70\end{array}$ & $\begin{array}{r}1,300 \\
1,200 \\
1,300 \\
-\end{array}$ & $\begin{array}{l}<.77 \\
1.30 \\
1.70 \\
<.50 \\
<.40\end{array}$ & $\begin{array}{r}120.0 \\
85.0 \\
14.0 \\
-- \\
--\end{array}$ \\
\hline $\begin{array}{r}85009 \\
366 \\
367 \\
368 \\
85011\end{array}$ & $\begin{array}{l}07 / 29 / 85 \\
10 / 07 / 86 \\
10 / 07 / 86 \\
10 / 07 / 86 \\
07 / 29 / 85\end{array}$ & $\begin{array}{l}\text { SWMA, } \\
\text { SWMA, } \\
\text { SWMA, } \\
\text { SWMA, } \\
\text { SWMA, }\end{array}$ & $\begin{array}{l}\text { STILLWATER PT. DIV. } \\
\text { STILLWATER PT. RES. } \\
\text { STILLWATER PT. RES. } \\
\text { STIILWATER PT. RES. } \\
\text { IJ DRAIN }\end{array}$ & $\begin{array}{l}\text { FISH } \\
\text { FISH } \\
\text { FISH } \\
\text { FISH } \\
\text { FISH }\end{array}$ & $\begin{array}{l}\text { CARP } \\
\text { CARP } \\
\text { CARP } \\
\text { CARP } \\
\text { CARP }\end{array}$ & $\begin{array}{r}7.60 \\
7.30 \\
11.00 \\
--\end{array}$ & $\begin{array}{l}-. \\
<.42 \\
<.46 \\
<.52 \\
--\end{array}$ & $\begin{array}{r}.20 \\
<.84 \\
<.92 \\
<1.00 \\
<.20\end{array}$ & $\begin{array}{l}4.60 \\
1.40 \\
3.00 \\
2.90 \\
4.00\end{array}$ & $\begin{array}{r}-0 \\
1,300 \\
1,400 \\
1,400 \\
--\end{array}$ & $\begin{array}{r}<.50 \\
<.84 \\
<.92 \\
<1.00 \\
<.40\end{array}$ & $\begin{array}{c}1 \overline{15.0} \\
100.0 \\
180.0 \\
\ldots\end{array}$ \\
\hline $\begin{array}{r}85012 \\
85013 \\
371 \\
372 \\
376\end{array}$ & $\begin{array}{l}07 / 29 / 85 \\
07 / 29 / 85 \\
10 / 08 / 86 \\
10 / 08 / 86 \\
10 / 10 / 86\end{array}$ & $\begin{array}{l}\text { SWMA, } \\
\text { SWMA, } \\
\text { WASHOE } \\
\text { WASHOE } \\
\text { WASHOE }\end{array}$ & $\begin{array}{l}\text { TJ DRAIN } \\
\text { TJ DRAIN } \\
\text { LRKE } \\
\text { LAKE } \\
\text { LAKE }\end{array}$ & $\begin{array}{l}\text { FISH } \\
\text { FISH } \\
\text { FISH } \\
\text { FISH } \\
\text { FISH }\end{array}$ & $\begin{array}{l}\text { CARP } \\
\text { CARP } \\
\text { CARP } \\
\text { CARP } \\
\text { CARP }\end{array}$ & $\begin{array}{l}-- \\
-- \\
-\overline{6} \\
5.30 \\
5.40\end{array}$ & $\begin{array}{l}-- \\
=- \\
-- \\
<.40 \\
<.39\end{array}$ & $\begin{array}{l}-- \\
<.20 \\
-- \\
<.79 \\
<.78\end{array}$ & $\begin{array}{l}3.50 \\
5.00 \\
-- \\
5.30 \\
1.80\end{array}$ & $\begin{array}{r}-- \\
-- \\
1,100 \\
1,100\end{array}$ & $\begin{array}{l}<.50 \\
<.50 \\
-. \\
.95 \\
<.78\end{array}$ & $\begin{array}{c}- \\
-- \\
-- \\
19.0 \\
54.0\end{array}$ \\
\hline $\begin{array}{r}85004 \\
85005 \\
85006 \\
377 \\
378\end{array}$ & $\begin{array}{l}07 / 29 / 85 \\
07 / 29 / 85 \\
07 / 29 / 85 \\
10 / 23 / 86 \\
10 / 23 / 86\end{array}$ & $\begin{array}{l}\text { CARSON } \\
\text { CARSON } \\
\text { CARSON } \\
\text { CARSON } \\
\text { CARSON }\end{array}$ & $\begin{array}{l}\text { L., CARSON I DRAIN } \\
\text { L., CARSON I DRAIN } \\
\text { I., CARSON L DRAIN } \\
\text { I., ISLANDS UNIT } \\
\text { L., ISLANDS UNIT }\end{array}$ & $\begin{array}{l}\text { FISH } \\
\text { FISH } \\
\text { FISH } \\
\text { FISH } \\
\text { FISH }\end{array}$ & $\begin{array}{l}\text { MOSQUITOFISH } \\
\text { MOSQUITOFISH } \\
\text { MOSQUITOEISH } \\
\text { MOSQUITOFISH } \\
\text { MOSQUITOFISH }\end{array}$ & $\begin{array}{r}-- \\
-- \\
11.00 \\
9.30\end{array}$ & $\begin{array}{l}-- \\
-- \\
\overline{-50} \\
<.47\end{array}$ & $\begin{array}{l}<.20 \\
<.20 \\
<.20 \\
<.99 \\
<.93\end{array}$ & $\begin{array}{l}6.80 \\
8.30 \\
8.10 \\
3.20 \\
3.60\end{array}$ & $\begin{array}{r}-- \\
-- \\
1,500 \\
1,400\end{array}$ & $\begin{array}{l}<.40 \\
<.40 \\
<.50 \\
<.99 \\
<.93\end{array}$ & $\begin{array}{l}-- \\
-- \\
1 \overline{13.0} \\
12.0\end{array}$ \\
\hline $\begin{array}{r}379 \\
87605 \\
384 \\
385 \\
386\end{array}$ & $\begin{array}{l}10 / 23 / 86 \\
07 / 23 / 87 \\
12 / 03 / 86 \\
11 / 03 / 86 \\
11 / 03 / 86\end{array}$ & $\begin{array}{l}\text { CARSON } \\
\text { CARSON } \\
\text { CARSON } \\
\text { CARSON } \\
\text { CARSON }\end{array}$ & $\begin{array}{l}\text { L., ISLANDS UNIT } \\
\text { L., PASTURE RD.DR. } \\
\text { L., SUMP } \\
\text { L., SUMP } \\
\text { L., SUMP }\end{array}$ & $\begin{array}{l}\text { FISH } \\
\text { FISH } \\
\text { FISH } \\
\text { FISH } \\
\text { FISH }\end{array}$ & $\begin{array}{l}\text { MOSQUITOFISH } \\
\text { MOSQUITOFISH } \\
\text { MOSQUITOFISH } \\
\text { MOSOUITOFISH } \\
\text { MOSQUITOEISH }\end{array}$ & $\begin{array}{r}12.00 \\
7.60 \\
12.00 \\
12.00 \\
12.00\end{array}$ & $\begin{array}{l}<.49 \\
<.10 \\
<.51 \\
<.51 \\
<.52\end{array}$ & $\begin{array}{l}<.97 \\
<.20 \\
<1.00 \\
<1.00 \\
<1.00\end{array}$ & $\begin{array}{l}3.90 \\
4.90 \\
3.40 \\
3.50 \\
3.40\end{array}$ & $\begin{array}{l}1,600 \\
1,530 \\
1,600 \\
1,500 \\
1,500\end{array}$ & $\begin{array}{r}<.97 \\
<1.00 \\
<1.00 \\
<1.00 \\
<1.00\end{array}$ & $\begin{array}{r}17.0 \\
=- \\
21.0 \\
11.0 \\
8.9\end{array}$ \\
\hline
\end{tabular}


TABLE 19.--Data on trace-element constituents and percent molsture of biological samples in stillwater Wildiffe Management Area, Carson Lake, Fernley Wildlife Management Area, and Humboldt Wildlife Management Area, 1985-87--Cont.

\begin{tabular}{|c|c|c|c|c|c|c|c|c|c|c|c|}
\hline $\begin{array}{c}\text { UsFus } \\
\text { local } \\
\text { ID } \\
\text { number }\end{array}$ & Date & Location & $\begin{array}{l}\text { Cate- } \\
\text { gory }\end{array}$ & Specles & Bardun & $\begin{array}{c}\text { Beryl- } \\
\text { IIum }\end{array}$ & $\begin{array}{l}\text { Cad- } \\
\text { m1um }\end{array}$ & Copper & $\begin{array}{l}\text { Magne- } \\
\text { sIum }\end{array}$ & $\begin{array}{l}\text { Molyb- } \\
\text { denum }\end{array}$ & $T$ In \\
\hline $\begin{array}{l}242 \\
243 \\
244 \\
143 \\
144\end{array}$ & $\begin{array}{l}09 / 22 / 86 \\
09 / 22 / 86 \\
09 / 22 / 86 \\
09 / 09 / 86 \\
09 / 09 / 86\end{array}$ & $\begin{array}{l}\text { CARSON VALLEY } \\
\text { CARSON VALLEY } \\
\text { CARSON VALLEY } \\
\text { FERNLEY WMA } \\
\text { FERNLEY WMA }\end{array}$ & $\begin{array}{l}\text { FISH } \\
\text { FISH } \\
\text { FISH } \\
\text { FISH } \\
\text { FISH }\end{array}$ & $\begin{array}{l}\text { MOSQUITOFISH } \\
\text { MOSQUITOFISH } \\
\text { MOSQUITOFISH } \\
\text { MOSQUITOFISH } \\
\text { MOSQUITOFISH }\end{array}$ & $\begin{array}{l}2.60 \\
2.40 \\
2.60 \\
4.70 \\
4.60\end{array}$ & $\begin{array}{r}<0.43 \\
<.39 \\
<.43 \\
<.39 \\
<.38\end{array}$ & $\begin{array}{r}<0.85 \\
<.79 \\
<.86 \\
<.79 \\
<.77\end{array}$ & $\begin{array}{l}3.10 \\
4.30 \\
3.70 \\
5.00 \\
4.30\end{array}$ & $\begin{array}{l}1,300 \\
1,200 \\
1,400 \\
1,100 \\
1,000\end{array}$ & $\begin{array}{r}<0.85 \\
<.79 \\
<.86 \\
<.79 \\
<.77\end{array}$ & $\begin{array}{l}14.0 \\
14.0 \\
24.0 \\
38.0 \\
18.0\end{array}$ \\
\hline $\begin{array}{r}145 \\
87503 \\
87504 \\
87505 \\
87586\end{array}$ & $\begin{array}{l}09 / 09 / 86 \\
07 / 08 / 87 \\
07 / 08 / 87 \\
07 / 08 / 87 \\
07 / 20 / 87\end{array}$ & $\begin{array}{l}\text { FERNLEY WMA } \\
\text { MASSIE SLOUGH } \\
\text { MASSIE SLOUGH } \\
\text { MASSIE SLOUGH } \\
\text { MASSIE SLOUGH }\end{array}$ & $\begin{array}{l}\text { FISH } \\
\text { FISH } \\
\text { FISH } \\
\text { FISH } \\
\text { FISH }\end{array}$ & $\begin{array}{l}\text { MOSQUITOFISH } \\
\text { MOSQUITOFISH } \\
\text { MOSQUITOFISH } \\
\text { MOSQUITOFISH } \\
\text { MOSOUITOFISH }\end{array}$ & $\begin{array}{r}4.80 \\
16.10 \\
14.40 \\
17.30 \\
22.10\end{array}$ & $\begin{array}{l}<.10 \\
<.10 \\
<.10 \\
<.10 \\
<.10\end{array}$ & $\begin{array}{l}<.79 \\
<.20 \\
<.20 \\
<.20 \\
<.20\end{array}$ & $\begin{array}{l}6.00 \\
5.10 \\
5.20 \\
6.10 \\
5.00\end{array}$ & $\begin{array}{l}1,100 \\
1,550 \\
1,580 \\
1,720 \\
1,520\end{array}$ & $\begin{array}{l}<.79 \\
<1.00 \\
<1.00 \\
<1.00 \\
<1.00\end{array}$ & $\begin{array}{c}22.0 \\
- \\
- \\
- \\
-\end{array}$ \\
\hline $\begin{array}{r}172 \\
363 \\
365 \\
85010 \\
85014\end{array}$ & $\begin{array}{l}09 / 16 / 86 \\
10 / 06 / 86 \\
10 / 07 / 86 \\
07 / 29 / 85 \\
07 / 29 / 85\end{array}$ & $\begin{array}{l}\text { SWMA, ALKALI UN. } 1 \\
\text { SWMA, ALKALI UN. I } \\
\text { SWMA, AIKALI UN. } 1 \\
\text { SWMA, STILLWATER PT. DIV. } \\
\text { SWMA, TJ DRAIN }\end{array}$ & $\begin{array}{l}\text { FISH } \\
\text { FISH } \\
\text { FISH } \\
\text { FISH } \\
\text { FISH }\end{array}$ & $\begin{array}{l}\text { MOSQUITOFISH } \\
\text { MOSQUITOFISH } \\
\text { MOSQUITOFISH } \\
\text { MOSOUITOFISH } \\
\text { MOSQUITOFISH }\end{array}$ & $\begin{array}{c}13.00 \\
13.00 \\
6.00 \\
-. \\
--\end{array}$ & $\begin{array}{l}<.48 \\
<.43 \\
<.43 \\
-- \\
--\end{array}$ & $\begin{array}{l}<.96 \\
<.85 \\
<.86 \\
<.20 \\
<.20\end{array}$ & $\begin{array}{l}5.20 \\
3.80 \\
4.00 \\
8.00 \\
9.40\end{array}$ & $\begin{array}{r}1,400 \\
1,200 \\
1,100 \\
-\end{array}$ & $\begin{array}{r}<.96 \\
<.85 \\
70.00 \\
<.40 \\
<.50\end{array}$ & $\begin{array}{r}13.0 \\
15.0 \\
8.4 \\
- \\
--\end{array}$ \\
\hline $\begin{array}{r}85015 \\
85016 \\
394 \\
383 \\
87593\end{array}$ & $\begin{array}{l}07 / 29 / 85 \\
07 / 29 / 85 \\
10 / 03 / 86 \\
10 / 29 / 86 \\
07 / 27 / 87\end{array}$ & $\begin{array}{l}\text { SWMA, TJ DRAIN } \\
\text { SWMA, TJ DRAIN } \\
\text { CARSON L.. SPRIG PONDS } \\
\text { HWMA, HUMBOLDT LAKE } \\
\text { SHECKLER RES. }\end{array}$ & $\begin{array}{l}\text { FISH } \\
\text { FISH } \\
\text { FISH } \\
\text { FISH } \\
\text { FISH }\end{array}$ & $\begin{array}{l}\text { MOSQUITOFISH } \\
\text { MOSQUITOFISH } \\
\text { SAC PERCH } \\
\text { SAC PERCH } \\
\text { SAC. BLACKFISH }\end{array}$ & $\begin{array}{r}-- \\
-\overline{61} \\
3.80 \\
11.20\end{array}$ & $\begin{array}{l}-- \\
-- \\
<.30 \\
<.38 \\
<.10\end{array}$ & $\begin{array}{l}<.20 \\
<.20 \\
<.61 \\
<.76 \\
.20\end{array}$ & $\begin{array}{r}9.90 \\
10.00 \\
6.10 \\
0.92 \\
19.60\end{array}$ & $\begin{array}{r}-\overline{-} \\
960 \\
1,300 \\
1,380\end{array}$ & $\begin{array}{r}<.50 \\
<.50 \\
<.61 \\
<.76 \\
<1.00\end{array}$ & $\begin{array}{r}-- \\
6.7 \\
19.0\end{array}$ \\
\hline $\begin{array}{r}87687 \\
273 \\
362 \\
364 \\
312\end{array}$ & $\begin{array}{l}09 / 09 / 87 \\
09 / 26 / 86 \\
10 / 06 / 86 \\
10 / 07 / 86 \\
09 / 30 / 86\end{array}$ & $\begin{array}{l}\text { SHECKLER RES, } \\
\text { SWMA, ALKALI UN. } 1 \\
\text { SWMA, ALKALI UN. 1 } \\
\text { SWMA, ALKALI UN. } 1 \\
\text { SWMA, GOOSE LAKE }\end{array}$ & $\begin{array}{l}\text { FISH } \\
\text { FISH } \\
\text { FISH } \\
\text { FISH } \\
\text { FISH }\end{array}$ & $\begin{array}{l}\text { SAC. BLACKF ISH } \\
\text { SHINERS } \\
\text { SHINERS } \\
\text { SHINERS } \\
\text { SHINERS }\end{array}$ & $\begin{array}{r}12.40 \\
14.00 \\
11.00 \\
13.00 \\
5.10\end{array}$ & $\begin{array}{l}<.10 \\
<.45 \\
<.41 \\
<.43 \\
<.32\end{array}$ & $\begin{array}{l}<.30 \\
<.90 \\
<.82 \\
<.86 \\
<.64\end{array}$ & $\begin{array}{r}15.00 \\
3.20 \\
3.50 \\
<.86 \\
.64\end{array}$ & $\begin{array}{l}1,270 \\
1,400 \\
1,300 \\
1,300 \\
1,100\end{array}$ & $\begin{array}{l}<1.00 \\
<.90 \\
<.82 \\
<.86 \\
<.64\end{array}$ & $\begin{array}{r}-1 \\
27.0 \\
30.0 \\
21.0 \\
7.7\end{array}$ \\
\hline $\begin{array}{l}313 \\
314 \\
393 \\
149 \\
150\end{array}$ & $\begin{array}{l}09 / 30 / 86 \\
09 / 30 / 86 \\
11 / 04 / 86 \\
09 / 09 / 86 \\
09 / 09 / 86\end{array}$ & $\begin{array}{l}\text { SWMA, GOOSE ILAKE } \\
\text { SWMA, GOOSE IAKE } \\
\text { SWMA, ALKALI UN. II } \\
\text { FERNLEY WMA } \\
\text { FERNLEY WMA }\end{array}$ & $\begin{array}{l}\text { FISH } \\
\text { FISH } \\
\text { FISH } \\
\text { FISH } \\
\text { EISH }\end{array}$ & $\begin{array}{l}\text { SHINERS } \\
\text { SHINERS } \\
\text { SM MOUTH BASS } \\
\text { TUI CHUB } \\
\text { TUI CHUB }\end{array}$ & $\begin{array}{l}1.10 \\
1.00 \\
2.20 \\
1.60 \\
1.50\end{array}$ & $\begin{array}{l}<.34 \\
<.33 \\
<.37 \\
<.39 \\
<.37\end{array}$ & $\begin{array}{l}<.68 \\
<.67 \\
<.74 \\
<.79 \\
<.75\end{array}$ & $\begin{array}{r}.88 \\
1.30 \\
5.74 \\
1.30 \\
3.90\end{array}$ & $\begin{array}{r}940 \\
950 \\
930 \\
1.000 \\
950\end{array}$ & $\begin{array}{l}<.68 \\
<.67 \\
<.74 \\
<.79 \\
<.75\end{array}$ & $\begin{array}{r}8.1 \\
10.0 \\
39.0 \\
16.0 \\
11.0\end{array}$ \\
\hline $\begin{array}{r}151 \\
87682 \\
87683 \\
315 \\
316\end{array}$ & $\begin{array}{l}09 / 09 / 86 \\
09 / 03 / 87 \\
09 / 03 / 87 \\
09 / 30 / 86 \\
09 / 30 / 86\end{array}$ & $\begin{array}{l}\text { FERNLEY WMA } \\
\text { HARMON RES. } \\
\text { HARMON RES, } \\
\text { SWMA, GOOSE LAKE } \\
\text { SWMA, GOOSE LAKE }\end{array}$ & $\begin{array}{l}\text { FISH } \\
\text { EISH } \\
\text { FISH } \\
\text { FISH } \\
\text { FISH }\end{array}$ & $\begin{array}{l}\text { TUI CHUB } \\
\text { TUI CHUB } \\
\text { TUI CHUB } \\
\text { TUI CHUB } \\
\text { TUI CHUB }\end{array}$ & $\begin{array}{r}1.40 \\
7.50 \\
14.90 \\
3.30 \\
3.80\end{array}$ & $\begin{array}{l}<.36 \\
<.10 \\
<.10 \\
<.27 \\
<.32\end{array}$ & $\begin{array}{l}<.72 \\
<.30 \\
<.30 \\
<.55 \\
<.64\end{array}$ & $\begin{array}{r}3.00 \\
2.00 \\
1.90 \\
.77 \\
.96\end{array}$ & $\begin{array}{r}920 \\
963 \\
1,440 \\
890 \\
970\end{array}$ & $\begin{array}{r}<.72 \\
<1.00 \\
<1.00 \\
<.55 \\
<.64\end{array}$ & $\begin{array}{c}12.0 \\
-- \\
\overline{8.8} \\
7.7\end{array}$ \\
\hline $\begin{array}{r}317 \\
87602 \\
87679 \\
87680 \\
87596\end{array}$ & $\begin{array}{l}09 / 30 / 86 \\
07 / 28 / 87 \\
09 / 02 / 87 \\
09 / 03 / 87 \\
07 / 27 / 87\end{array}$ & $\begin{array}{l}\text { SWMA, GOOSE LAKE } \\
\text { HARMON RES. } \\
\text { HARMON RES. } \\
\text { HARMON RES. } \\
\text { SHECKLER RES. }\end{array}$ & $\begin{array}{l}\text { FISH } \\
\text { FISH } \\
\text { FISH } \\
\text { FISH } \\
\text { FISH }\end{array}$ & $\begin{array}{l}\text { TUI CHUB } \\
\text { WHITE BASS } \\
\text { WHITE BASS } \\
\text { WHITE BASS } \\
\text { WHITE BASS }\end{array}$ & $\begin{array}{r}1.80 \\
5.70 \\
13.20 \\
3.70 \\
5.70\end{array}$ & $\begin{array}{l}<.29 \\
<.10 \\
<.10 \\
<.10 \\
<.10\end{array}$ & $\begin{array}{l}<.59 \\
<.20 \\
<.30 \\
<.30 \\
<.20\end{array}$ & $\begin{array}{r}.59 \\
5.00 \\
3.40 \\
14.00 \\
6.30\end{array}$ & $\begin{array}{r}890 \\
1,310 \\
1,540 \\
1,140 \\
1,620\end{array}$ & $\begin{array}{l}<.59 \\
<1.00 \\
<1.00 \\
<1.00 \\
<1.00\end{array}$ & $\begin{array}{l}7.6 \\
-- \\
-- \\
--\end{array}$ \\
\hline $\begin{array}{r}87597 \\
87598 \\
87686 \\
87568 \\
33\end{array}$ & $\begin{array}{l}07 / 27 / 87 \\
07 / 27 / 87 \\
09 / 09 / 87 \\
07 / 14 / 87 \\
06 / 24 / 86\end{array}$ & $\begin{array}{l}\text { SHECKLER RES. } \\
\text { SHECKLER RES. } \\
\text { SHECKLER RES. } \\
\text { CARSON L.. DOWNS DRAIN } \\
\text { CARSON L.. ISLANDS UNIT }\end{array}$ & $\begin{array}{l}\text { FISH } \\
\text { FISH } \\
\text { FISH } \\
\text { INSECT } \\
\text { INSECT }\end{array}$ & $\begin{array}{l}\text { WHITE CRAPPIE } \\
\text { WHITE CRAPPIE } \\
\text { WHITE CRAPPIE } \\
\text { DIPTERA } \\
\text { DIPTERA }\end{array}$ & $\begin{array}{r}8.00 \\
8.40 \\
8.40 \\
40.70 \\
54.00\end{array}$ & $\begin{array}{l}<.10 \\
<.10 \\
<.10 \\
.10 \\
<.75\end{array}$ & $\begin{array}{r}<.20 \\
<.20 \\
<.30 \\
.20 \\
<.75\end{array}$ & $\begin{array}{r}1.50 \\
1.00 \\
.50 \\
35.10 \\
30.00\end{array}$ & $\begin{array}{l}1,540 \\
1,540 \\
1,840 \\
3,850 \\
8,700\end{array}$ & $\begin{array}{r}<1.00 \\
<1.00 \\
<1.00 \\
2.00 \\
<.75\end{array}$ & $1,800.0$ \\
\hline $\begin{array}{r}12 \\
13 \\
94 \\
87495 \\
129\end{array}$ & $\begin{array}{l}06 / 10 / 86 \\
06 / 10 / 86 \\
07 / 29 / 86 \\
07 / 06 / 87 \\
08 / 05 / 86\end{array}$ & $\begin{array}{l}\text { CARSON L., SPRIG PONDS } \\
\text { CARSON L.: SUMP } \\
\text { CARSON VALLEY } \\
\text { ERB DEEP DRAIN } \\
\text { FERNLEY WMA }\end{array}$ & $\begin{array}{l}\text { INSECT } \\
\text { INSECT } \\
\text { INSECT } \\
\text { INSECT } \\
\text { INSECT }\end{array}$ & $\begin{array}{l}\text { DIPTERA } \\
\text { DIPTERA } \\
\text { DIPTERA } \\
\text { DIPTERA } \\
\text { DIPTERA }\end{array}$ & $\begin{array}{r}55.00 \\
33.00 \\
130.00 \\
69.30 \\
87.00\end{array}$ & $\begin{array}{l}<.81 \\
<.69 \\
<.70 \\
.10 \\
<.74\end{array}$ & $\begin{array}{l}1.20 \\
<.69 \\
<.70 \\
.20 \\
1.10\end{array}$ & $\begin{array}{l}60.00 \\
18.00 \\
23.00 \\
28.90 \\
40.00\end{array}$ & $\begin{array}{r}9,700 \\
3,900 \\
2,700 \\
3,760 \\
11,000\end{array}$ & $\begin{array}{r}.97 \\
2.50 \\
<.70 \\
<2.00 \\
<.74\end{array}$ & $\begin{array}{r}3,500.0 \\
530.0 \\
1,000.0 \\
\overline{3,400.0}\end{array}$ \\
\hline $\begin{array}{r}131 \\
87414 \\
87417 \\
87422 \\
40\end{array}$ & $\begin{array}{l}08 / 05 / 86 \\
06 / 23 / 87 \\
06 / 25 / 87 \\
06 / 25 / 87 \\
07 / 02 / 86\end{array}$ & $\begin{array}{l}\text { HWMA, HUMBOIDT IAKE } \\
\text { HWMA, TOULON LAKE } \\
\text { MAHALA SLOUGH } \\
\text { SHECKLER RES. } \\
\text { SWMA, ALKALI UN. \$1 }\end{array}$ & $\begin{array}{l}\text { INSECT } \\
\text { INSECT } \\
\text { INSECT } \\
\text { INSECT } \\
\text { INSECT }\end{array}$ & $\begin{array}{l}\text { DIPTERA } \\
\text { DIPTERA } \\
\text { DIPTERA } \\
\text { DIPTERA } \\
\text { DIPTERA }\end{array}$ & $\begin{array}{r}48.00 \\
146.00 \\
101.00 \\
116.00 \\
17.00\end{array}$ & $\begin{array}{r}<.93 \\
.20 \\
.20 \\
.30 \\
<1.10\end{array}$ & $\begin{array}{r}<.93 \\
.30 \\
.20 \\
1.70 \\
<1.10\end{array}$ & $\begin{array}{l}26.00 \\
18.00 \\
42.30 \\
39.70 \\
15.00\end{array}$ & $\begin{array}{r}4,100 \\
7,560 \\
10,600 \\
5,120 \\
3,200\end{array}$ & $\begin{array}{l}<.93 \\
<1.00 \\
<2.00 \\
<2.00 \\
<1.10\end{array}$ & $\begin{array}{c}590.0 \\
- \\
- \\
490.0\end{array}$ \\
\hline $\begin{array}{r}370 \\
38 \\
87733 \\
87559 \\
79\end{array}$ & $\begin{array}{l}10 / 07 / 86 \\
07 / 02 / 86 \\
07 / 28 / 87 \\
07 / 13 / 87 \\
07 / 22 / 86\end{array}$ & $\begin{array}{l}\text { SWMA, GOOSE LAKE } \\
\text { SWMA, LEAD LAKE } \\
\text { SWMA, NAVY CABIN DRAIN } \\
\text { SWMA, SHAFFNER DR., IND.L. } \\
\text { SWMA, STILLWATER PT. RES. }\end{array}$ & $\begin{array}{l}\text { INSECT } \\
\text { INSECT } \\
\text { INSECT } \\
\text { INSECT } \\
\text { INSECT }\end{array}$ & $\begin{array}{l}\text { DIPTERA } \\
\text { DIPTERA } \\
\text { DIPTERA } \\
\text { DIPTERA } \\
\text { DIPTERA }\end{array}$ & $\begin{array}{l}12.00 \\
66.00 \\
93.80 \\
49.00\end{array}$ & $\begin{array}{l}<.74 \\
-.78 \\
.58 \\
<.10 \\
<.79\end{array}$ & $\begin{array}{r}<1.50 \\
-2 \\
<.30 \\
<.20 \\
<1.60\end{array}$ & $\begin{array}{r}4.90 \\
26.00 \\
21.00 \\
16.00\end{array}$ & $\begin{array}{l}2,400 \\
5,940 \\
2,830 \\
3,300\end{array}$ & $\begin{array}{r}2.60 \\
-0 \\
3.00 \\
<1.00 \\
<1.60\end{array}$ & $\begin{array}{c}250.0 \\
- \\
- \\
\overline{-} \\
1,000.0\end{array}$ \\
\hline
\end{tabular}


TABLE 19.-Data on trace-element constituents and percent moisture of biological samples in stillwater Wildlife Management Area, Carson Lake, Fernley Wildlife Management Area, and Hunboldt Wildlife Management Area, $1985-87-C o n t$.

\begin{tabular}{|c|c|c|c|c|c|c|c|c|c|c|c|c|c|}
\hline $\begin{array}{l}\text { USFWS } \\
\text { local } \\
\text { ID } \\
\text { number }\end{array}$ & Date & & Location & $\begin{array}{l}\text { Cate- } \\
\text { gory }\end{array}$ & Species & & Barium & $\begin{array}{l}\text { Bery1- } \\
\text { llum }\end{array}$ & $\begin{array}{l}\text { Cad- } \\
\text { mium }\end{array}$ & Copper & & & Tin \\
\hline $\begin{array}{r}87567 \\
15 \\
87556 \\
87558 \\
24\end{array}$ & $\begin{array}{l}07 / 16 / 87 \\
06 / 12 / 86 \\
07 / 14 / 87 \\
07 / 19 / 87 \\
06 / 17 / 86\end{array}$ & $\begin{array}{l}\text { SWMA, } \\
\text { WASHOE } \\
\text { CARSON } \\
\text { CARSON } \\
\text { CARSON }\end{array}$ & $\begin{array}{l}\text { SWAN L. CHECK } \\
\text { LAKE } \\
\text { L., DOWNS DRAIN } \\
\text { L., HOLMES DEEP DR } \\
\text { L., ISLANDS UNIT }\end{array}$ & $\begin{array}{l}\text { INSECT } \\
\text { INSECT } \\
\text { INSECT } \\
\text { INSECT } \\
\text { INSECT }\end{array}$ & $\begin{array}{l}\text { DIPTERA } \\
\text { DIPTERA } \\
\text { HEMIPTERA } \\
\text { HEMIPTERA } \\
\text { HEMIPTERA }\end{array}$ & & $\begin{array}{r}39.80 \\
110.00 \\
12.60 \\
12.50 \\
.8 .90\end{array}$ & $\begin{array}{l}<0.10 \\
<.74 \\
<.10 \\
<.10 \\
<.49\end{array}$ & $\begin{array}{r}<0.20 \\
<.74 \\
.50 \\
.58 \\
.74\end{array}$ & $\begin{array}{l}15.00 \\
25.00 \\
31.50 \\
23.30 \\
34.00\end{array}$ & $\begin{array}{l}5,330 \\
9,100 \\
1,120 \\
1,350 \\
1,300\end{array}$ & $\begin{array}{l}<1.00 \\
<.74 \\
2.00 \\
2.00 \\
<.49\end{array}$ & $\begin{array}{c}4,000.0 \\
\overline{-} \\
34.0\end{array}$ \\
\hline $\begin{array}{r}87625 \\
11 \\
14 \\
87557 \\
95\end{array}$ & $\begin{array}{l}06 / 29 / 87 \\
06 / 10 / 86 \\
06 / 24 / 86 \\
07 / 14 / 87 \\
07 / 29 / 86\end{array}$ & $\begin{array}{l}\text { CARSON } \\
\text { CARSON } \\
\text { CARSON } \\
\text { CARSON } \\
\text { CARSON }\end{array}$ & $\begin{array}{l}\text { L.., JI DEEP DRAIN } \\
\text { L.., SPRIG PONDS } \\
\text { L.. SUMP } \\
\text { L., YARBROUGH DR. } \\
\text { VALLEY }\end{array}$ & $\begin{array}{l}\text { INSECT } \\
\text { INSECT } \\
\text { INSECT } \\
\text { INSECT } \\
\text { INSECT }\end{array}$ & $\begin{array}{l}\text { HEMIPTERA } \\
\text { HEMIPTERA } \\
\text { HEMIPTERA } \\
\text { HEMIPTERA } \\
\text { HEMIPTERA }\end{array}$ & & $\begin{array}{r}19.50 \\
35.00 \\
13.00 \\
6.40 \\
69.00\end{array}$ & $\begin{array}{l}.10 \\
<.29 \\
<.52 \\
<.10 \\
<.60\end{array}$ & $\begin{array}{r}.63 \\
.87 \\
<.52 \\
1.20 \\
<.60\end{array}$ & $\begin{array}{l}30.80 \\
27.00 \\
41.00 \\
28.60 \\
39.00\end{array}$ & $\begin{array}{l}1,230 \\
1,600 \\
2,000 \\
1,260 \\
1,500\end{array}$ & $\begin{array}{r}2.00 \\
2.60 \\
2.90 \\
<1.00 \\
<.60\end{array}$ & $\begin{array}{c}1,400.0 \\
200.0 \\
130.0\end{array}$ \\
\hline $\begin{array}{r}128 \\
87565 \\
130 \\
87913 \\
87416\end{array}$ & $\begin{array}{l}08 / 05 / 86 \\
07 / 16 / 87 \\
08 / 05 / 86 \\
06 / 23 / 87 \\
06 / 25 / 87\end{array}$ & $\begin{array}{l}\text { FERNLEY } \\
\text { FERNLEY } \\
\text { HWMA, } \\
\text { HWMA, I } \\
\text { MAHALA }\end{array}$ & $\begin{array}{l}\text { EY WMA } \\
\text { EY WMA } \\
\text { HUMBOLDT LAKE } \\
\text { TOULON LAKE } \\
\text { SLOUGH }\end{array}$ & $\begin{array}{l}\text { INSECT } \\
\text { INSECT } \\
\text { INSECT } \\
\text { INSECT } \\
\text { INSECT }\end{array}$ & $\begin{array}{l}\text { HEMIPTERA } \\
\text { HEMIPTERA } \\
\text { HEMIPTERA } \\
\text { HEMIPTERA } \\
\text { HEMIPTERA }\end{array}$ & & $\begin{array}{r}44.00 \\
3.90 \\
8.60 \\
6.50 \\
16.30\end{array}$ & $\begin{array}{l}<.78 \\
<.10 \\
<.54 \\
<.10 \\
<.10\end{array}$ & $\begin{array}{l}<.78 \\
.40 \\
<.54 \\
.60 \\
.40\end{array}$ & $\begin{array}{l}37.00 \\
20.20 \\
26.00 \\
23.40 \\
35.20\end{array}$ & $\begin{array}{l}6,600 \\
1,270 \\
1,400 \\
1,230 \\
2,310\end{array}$ & $\begin{array}{l}<.78 \\
2.00 \\
1.70 \\
2.00 \\
3.10\end{array}$ & $\begin{array}{c}840.0 \\
4 \overline{3.0} \\
=\end{array}$ \\
\hline $\begin{array}{r}87526 \\
87585 \\
87421 \\
132 \\
369\end{array}$ & $\begin{array}{l}07 / 08 / 87 \\
07 / 20 / 87 \\
06 / 25 / 87 \\
08 / 07 / 86 \\
10 / 07 / 86\end{array}$ & $\begin{array}{l}\text { MASSIE } \\
\text { MASSIE } \\
\text { SHECKLE } \\
\text { SWMA, A } \\
\text { SWMA, C }\end{array}$ & $\begin{array}{l}\text { SLOUGH } \\
\text { SLOUGH } \\
\text { LER RES. } \\
\text { ALKAII UN, } 1 \\
\text { GOOSE LAKE }\end{array}$ & $\begin{array}{l}\text { INSECT } \\
\text { INSECT } \\
\text { INSECT } \\
\text { INSECT } \\
\text { INSECT }\end{array}$ & $\begin{array}{l}\text { HEMIPTERA } \\
\text { HEMIPTERA } \\
\text { HEMIPTERA } \\
\text { HEMIPTERA } \\
\text { HEMIPTERA }\end{array}$ & & $\begin{array}{r}145.00 \\
6.70 \\
15.90 \\
5.80 \\
53.00\end{array}$ & $\begin{array}{l}<.10 \\
<.10 \\
<.10 \\
<.48 \\
<.49\end{array}$ & $\begin{array}{l}<.20 \\
.50 \\
1.20 \\
2.40 \\
<.97\end{array}$ & $\begin{array}{r}15.00 \\
26.60 \\
25.60 \\
27.00 \\
9.70\end{array}$ & $\begin{array}{l}1,210 \\
1,620 \\
1,380 \\
1,600 \\
1,400\end{array}$ & $\begin{array}{r}3.00 \\
2.00 \\
<1.00 \\
<.48 \\
2.60\end{array}$ & $\begin{array}{r}- \\
= \\
61.0 \\
280.0\end{array}$ \\
\hline $\begin{array}{r}87604 \\
39 \\
87587 \\
87536 \\
73\end{array}$ & $\begin{array}{l}07 / 28 / 87 \\
07 / 02 / 86 \\
07 / 24 / 87 \\
07 / 13 / 87 \\
07 / 17 / 86\end{array}$ & $\begin{array}{l}\text { SWMA, } \\
\text { SWMAA, I } \\
\text { SWMA, P } \\
\text { SWMA, S } \\
\text { SWMA, S }\end{array}$ & $\begin{array}{l}\text { HUNTER RD. BRIDGE } \\
\text { LEAD LAKE } \\
\text { PINTAIL BAY } \\
\text { SHAFFNER DR. IND.L } \\
\text { STILLWATER PT. RES. }\end{array}$ & $\begin{array}{l}\text { INSECT } \\
\text { INSECT } \\
\text { INSECT } \\
\text { INSECT } \\
\text { INSECT }\end{array}$ & $\begin{array}{l}\text { HEMIPTERA } \\
\text { HEMIPTERA } \\
\text { HEMIPTERA } \\
\text { HEMIPTERA } \\
\text { HEMIPTERA }\end{array}$ & & $\begin{array}{r}6.60 \\
-- \\
35.80 \\
80.30 \\
46.00\end{array}$ & $\begin{array}{l}<1.00 \\
--.10 \\
<.10 \\
<.10 \\
<.55\end{array}$ & $\begin{array}{l}.40 \\
.-20 \\
.20 \\
<.45\end{array}$ & $\begin{array}{l}20.60 \\
17.00 \\
25.70 \\
18.00\end{array}$ & $\begin{array}{l}1,290 \\
1,880 \\
1,250 \\
4,400\end{array}$ & $\begin{array}{l}2.00 \\
--.00 \\
3.00 \\
1.00 \\
<.55\end{array}$ & $\begin{array}{c}= \\
\overline{-} \\
960.0\end{array}$ \\
\hline $\begin{array}{r}87566 \\
87732 \\
16 \\
260 \\
341\end{array}$ & $\begin{array}{l}07 / 16 / 87 \\
08 / 20 / 87 \\
06 / 12 / 86 \\
09 / 23 / 86 \\
10 / 03 / 86\end{array}$ & $\begin{array}{l}\text { SWMA, S } \\
\text { SWMA, I } \\
\text { WASHOE } \\
\text { CARSON } \\
\text { CARSON }\end{array}$ & $\begin{array}{l}\text { SWAN L. CHECK } \\
\text { TJ DRAIN } \\
\text { LAKE } \\
\text { L..: ISLANDS UNIT } \\
\text { L., SPRIG PONDS }\end{array}$ & $\begin{array}{l}\text { INSECT } \\
\text { INSECT } \\
\text { INSECT } \\
\text { PIANT } \\
\text { PLANT }\end{array}$ & $\begin{array}{l}\text { HEMIPTERA } \\
\text { HEMIPTERA } \\
\text { HEMIPTERA } \\
\text { A BULRUSH } \\
\text { A BULRUSH }\end{array}$ & $\begin{array}{l}\text { RT } \\
\text { RT }\end{array}$ & $\begin{array}{r}143.00 \\
16.00 \\
27.00 \\
20.00 \\
47.00\end{array}$ & $\begin{array}{l}<.10 \\
.10 \\
<.70 \\
<.49 \\
1.10\end{array}$ & $\begin{array}{r}.20 \\
.20 \\
<.70 \\
<.97 \\
<1.10\end{array}$ & $\begin{array}{l}21.20 \\
53.60 \\
21.00 \\
14.00 \\
15.00\end{array}$ & $\begin{array}{l}1,670 \\
1,540 \\
1,500 \\
2,000 \\
3,000\end{array}$ & $\begin{array}{r}2.00 \\
3.00 \\
2.70 \\
33.00 \\
1.80\end{array}$ & $\begin{array}{r}-- \\
150.0 \\
500.0 \\
1,200.0\end{array}$ \\
\hline $\begin{array}{l}354 \\
245 \\
248 \\
251 \\
257\end{array}$ & $\begin{array}{l}10 / 03 / 86 \\
09 / 23 / 86 \\
09 / 23 / 86 \\
09 / 23 / 86 \\
09 / 09 / 86\end{array}$ & $\begin{array}{l}\text { CARSON } \\
\text { CARSON } \\
\text { CARSON } \\
\text { CARSON } \\
\text { EERNLEY }\end{array}$ & $\begin{array}{l}\text { L., SPRIG PONDS } \\
\text { L., SUMP } \\
\text { L., SUMP } \\
\text { L., SUMP } \\
\text { EY WMA }\end{array}$ & $\begin{array}{l}\text { PLANT } \\
\text { PLANT } \\
\text { PLANT } \\
\text { PLANT } \\
\text { PLANT }\end{array}$ & $\begin{array}{ll}\text { A } & \text { BULRUSH } \\
\text { A } & \text { BULRUSH } \\
\text { A } & \text { BULRUSH } \\
\text { A } & \text { BULRUSH } \\
\text { A } & \text { BULRUSH }\end{array}$ & $\begin{array}{l}\text { RT } \\
\text { RT } \\
\text { RT } \\
\text { RT } \\
\text { RT }\end{array}$ & $\begin{array}{l}39.00 \\
56.00 \\
22.00 \\
45.00 \\
52.00\end{array}$ & $\begin{array}{l}<.72 \\
<.65 \\
<.68 \\
<.94 \\
<.54\end{array}$ & $\begin{array}{l}<2.40 \\
<2.30 \\
<2.40 \\
<2.90 \\
<1.10\end{array}$ & $\begin{array}{l}11.00 \\
19.00 \\
14.00 \\
16.00 \\
14.00\end{array}$ & $\begin{array}{l}3,300 \\
5,100 \\
2,200 \\
2,600 \\
3,000\end{array}$ & $\begin{array}{r}2.20 \\
49.00 \\
<1.40 \\
2.10 \\
5.20\end{array}$ & $\begin{array}{r}1,200.0 \\
1,600.0 \\
470.0 \\
620.0 \\
1,500.0\end{array}$ \\
\hline $\begin{array}{l}203 \\
206 \\
209 \\
162 \\
167\end{array}$ & $\begin{array}{l}09 / 19 / 86 \\
09 / 19 / 86 \\
09 / 19 / 86 \\
09 / 16 / 86 \\
09 / 16 / 86\end{array}$ & $\begin{array}{l}\text { HWMA, } \\
\text { HWMA, } \\
\text { HWMA, } \\
\text { SWMA, } \\
\text { SWMA, }\end{array}$ & $\begin{array}{l}\text { HUMBOLDT LAKE } \\
\text { HUMBOLDT IAKE } \\
\text { HUMBOIDT IAKE } \\
\text { ALKALI UN. } \\
\text { ALKALI UN. }\end{array}$ & $\begin{array}{l}\text { PLANT } \\
\text { PLANT } \\
\text { PLANT } \\
\text { PLANT } \\
\text { PLANT }\end{array}$ & $\begin{array}{l}\text { A BULRUSH } \\
\text { A } \\
\text { A BULRUSH } \\
\text { A BULRUSH } \\
\text { A BULRUSH } \\
\text { BULRSA }\end{array}$ & $\begin{array}{l}R T \\
R T \\
R T \\
R T \\
R T\end{array}$ & $\begin{array}{l}30.00 \\
31.00 \\
22.00 \\
61.00 \\
35.00\end{array}$ & $\begin{array}{l}<1.00 \\
<.85 \\
<.79 \\
<.82 \\
<.54\end{array}$ & $\begin{array}{l}<2.00 \\
<2.70 \\
<1.60 \\
<1.60 \\
<1.10\end{array}$ & $\begin{array}{l}8.40 \\
3.90 \\
3.80 \\
8.50 \\
1.70\end{array}$ & $\begin{array}{l}3,000 \\
3,000 \\
2,800 \\
3,400 \\
1,700\end{array}$ & $\begin{array}{r}<2.00 \\
2.70 \\
2.90 \\
2.00 \\
1.60\end{array}$ & $\begin{array}{r}540.0 \\
320.0 \\
250.0 \\
1,200.0 \\
370.0\end{array}$ \\
\hline $\begin{array}{r}170 \\
301 \\
329 \\
332 \\
87560\end{array}$ & $\begin{array}{l}09 / 16 / 86 \\
09 / 30 / 86 \\
10 / 02 / 86 \\
10 / 02 / 86 \\
07 / 16 / 87\end{array}$ & $\begin{array}{l}\text { SWMA, A } \\
\text { SWMA, G } \\
\text { SWMA, G } \\
\text { SWMA, G } \\
\text { SWMA, S }\end{array}$ & $\begin{array}{l}\text { ALKALI UN. } \\
\text { GOOSE LAKE } \\
\text { GOOSE LAKE } \\
\text { GOOSE LAKE } \\
\text { SWAN L. CHECK }\end{array}$ & $\begin{array}{l}\text { PLANT } \\
\text { PLANT } \\
\text { PLANT } \\
\text { PLANT } \\
\text { PLANT }\end{array}$ & $\begin{array}{ll}\text { A } & \text { BULRUSH } \\
\text { A } & \text { BULRUSH } \\
\text { A } & \text { BULRUSH } \\
\text { A } & \text { BULRUSH } \\
\text { A BULRUSH }\end{array}$ & $\begin{array}{l}\text { RT } \\
\text { RT } \\
\text { RT } \\
\text { RT } \\
\text { RT }\end{array}$ & $\begin{array}{l}25.00 \\
27.00 \\
51.00 \\
32.00 \\
55.30\end{array}$ & $\begin{array}{l}<.65 \\
<.56 \\
.80 \\
<.69 \\
<.40\end{array}$ & $\begin{array}{r}<1.30 \\
<1.10 \\
<1.10 \\
<1.40 \\
<.40\end{array}$ & $\begin{array}{r}3.40 \\
11.00 \\
12.00 \\
10.00 \\
20.90\end{array}$ & $\begin{array}{l}1,900 \\
2,700 \\
4,400 \\
3,100 \\
6,130\end{array}$ & $\begin{array}{r}2.60 \\
13.00 \\
8.70 \\
7.20 \\
9.20\end{array}$ & $\begin{array}{r}360.0 \\
1,100.0 \\
1,800.0 \\
1,500.0 \\
<4.0\end{array}$ \\
\hline $\begin{array}{l}262 \\
269 \\
273 \\
247 \\
250\end{array}$ & $\begin{array}{l}09 / 23 / 86 \\
09 / 23 / 86 \\
09 / 23 / 86 \\
09 / 23 / 86 \\
09 / 23 / 86\end{array}$ & $\begin{array}{l}\text { CARSON } \\
\text { CARSON } \\
\text { CARSON } \\
\text { CARSON } \\
\text { CARSON }\end{array}$ & $\begin{array}{l}\text { L., ISLANDS UNIT } \\
\text { V., SPRIG PONDS } \\
\text { L., SPRIG PONDS } \\
\text { L., SUMP } \\
\text { L., SUMP }\end{array}$ & $\begin{array}{l}\text { PLANT } \\
\text { PLANT } \\
\text { PLANT } \\
\text { PLANT } \\
\text { PLANT }\end{array}$ & $\begin{array}{l}\text { A } \\
\text { A BULRUSH } \\
\text { A BULRUSH } \\
\text { A BULRUSH } \\
\text { A } \\
\text { BULRUSH }\end{array}$ & $\begin{array}{l}\text { SD } \\
\text { SD } \\
\text { SD } \\
\text { SD } \\
\text { SD }\end{array}$ & $\begin{array}{l}5.00 \\
4.40 \\
6.30 \\
3.20 \\
3.10\end{array}$ & $\begin{array}{l}<.50 \\
<.55 \\
<.53 \\
<.53 \\
<.52\end{array}$ & $\begin{array}{l}<1.00 \\
<1.10 \\
<1.10 \\
<1.100 \\
<1.00\end{array}$ & $\begin{array}{l}5.80 \\
3.30 \\
3.50 \\
6.90 \\
9.20\end{array}$ & $\begin{array}{l}1,200 \\
1,300 \\
1,500 \\
1,600 \\
1,500\end{array}$ & $\begin{array}{l}<1.00 \\
<1.10 \\
<1.10 \\
<1.10 \\
<1.00\end{array}$ & $\begin{array}{l}<5.0 \\
<5.5 \\
<5.3 \\
<5.3 \\
<5.2\end{array}$ \\
\hline $\begin{array}{l}253 \\
214 \\
204 \\
207 \\
210\end{array}$ & $\begin{array}{l}09 / 23 / 86 \\
09 / 29 / 86 \\
09 / 19 / 86 \\
09 / 19 / 86 \\
09 / 29 / 86\end{array}$ & $\begin{array}{l}\text { CARSON } \\
\text { FERNLEY } \\
\text { HWMA, } \\
\text { HWMA, } \\
\text { HWMA, }\end{array}$ & $\begin{array}{l}\text { N L., SUMP } \\
\text { EY WMA } \\
\text { HUMBOLDT LAKE } \\
\text { HUMBOLDT LAKE } \\
\text { HUMBOLDT LAKE }\end{array}$ & $\begin{array}{l}\text { PLANT } \\
\text { PLANT } \\
\text { PLANT } \\
\text { PLANT } \\
\text { PLANT }\end{array}$ & $\begin{array}{l}\text { A BULRUSH } \\
\text { A BULRUSH } \\
\text { A BULRUSH } \\
\text { A BULRUSH } \\
\text { A BULRUSH }\end{array}$ & $\begin{array}{l}\text { SD } \\
\text { SD } \\
\text { SD } \\
\text { SD } \\
\text { SD }\end{array}$ & $\begin{array}{l}5.30 \\
5.30 \\
4.40 \\
5.70 \\
4.10\end{array}$ & $\begin{array}{l}<.53 \\
<.53 \\
<.55 \\
<.57 \\
<.52\end{array}$ & $\begin{array}{l}<1.10 \\
<1.10 \\
<1.10 \\
<1.10 \\
<1.00\end{array}$ & $\begin{array}{l}8.60 \\
3.60 \\
2.50 \\
3.30 \\
3.60\end{array}$ & $\begin{array}{l}1,600 \\
1,500 \\
1,800 \\
1,700 \\
1,200\end{array}$ & $\begin{array}{l}<1.10 \\
<1.10 \\
<1.10 \\
<1.10 \\
<1.00\end{array}$ & $\begin{array}{l}<5.3 \\
<5.3 \\
<5.5 \\
<5.7 \\
<5.2\end{array}$ \\
\hline $\begin{array}{l}196 \\
198 \\
200 \\
303 \\
331\end{array}$ & $\begin{array}{l}09 / 28 / 86 \\
09 / 18 / 86 \\
09 / 18 / 86 \\
09 / 30 / 86 \\
10 / 02 / 86\end{array}$ & $\begin{array}{l}\text { SWMA, A } \\
\text { SWMA, A } \\
\text { SWMA, A } \\
\text { SWMA, G } \\
\text { SWMA, G }\end{array}$ & $\begin{array}{l}\text { ALKALI UN. } 1 \\
\text { ALKALI UN. } \\
\text { ALKALI UN. } \\
\text { GOOSE LAKE } \\
\text { GOOSE LAKE }\end{array}$ & $\begin{array}{l}\text { PLANT } \\
\text { PLANT } \\
\text { PLANT } \\
\text { PLANT } \\
\text { PLANT }\end{array}$ & $\begin{array}{ll}\text { A } & \text { BULRUSH } \\
\text { A } & \text { BULRUSH } \\
\text { A BULRUSH } \\
\text { A BULRUSH } \\
\text { A BULRUSH }\end{array}$ & $\begin{array}{l}\text { SD } \\
\text { SD } \\
\text { SD } \\
\text { SD } \\
\text { SD }\end{array}$ & $\begin{array}{r}6.90 \\
6.70 \\
10.00 \\
9.10 \\
8.30\end{array}$ & $\begin{array}{l}<.57 \\
<.56 \\
<.51 \\
<.57 \\
<.52\end{array}$ & $\begin{array}{l}<1.10 \\
<1.10 \\
<2.00 \\
<1.10 \\
<1.00\end{array}$ & $\begin{array}{r}1.80 \\
2.50 \\
3.00 \\
<1.10 \\
2.40\end{array}$ & $\begin{array}{l}1,500 \\
1,300 \\
1,400 \\
1,300 \\
1,400\end{array}$ & $\begin{array}{r}<1.10 \\
<1.10 \\
<1.00 \\
<1.10 \\
2.50\end{array}$ & $\begin{array}{r}5.7 \\
6.7 \\
<5.1 \\
200.0 \\
230.0\end{array}$ \\
\hline
\end{tabular}


TABLE 19.--Data on trace-alement constituents and percent moisture of blologlcal samples in stillwater wildlife Management Area, Carson Lake, Fernley Wildlife Management Area, and Humboldt Wildlife Management Area, 1985-87--Cont.

\begin{tabular}{|c|c|c|c|c|c|c|c|c|c|c|c|}
\hline $\begin{array}{l}\text { USFWS } \\
\text { Local } \\
\text { ID } \\
\text { number }\end{array}$ & Date & Location & $\begin{array}{l}\text { Cate- } \\
\text { gory }\end{array}$ & Species & Barlum & $\begin{array}{c}\text { Beryl- } \\
\text { llum }\end{array}$ & $\begin{array}{l}\text { Cad- } \\
\text { m1um }\end{array}$ & Copper & $\begin{array}{l}\text { Magne- } \\
\text { sium }\end{array}$ & $\begin{array}{l}\text { Molyb- } \\
\text { denum }\end{array}$ & $\operatorname{Tin}$ \\
\hline $\begin{array}{r}334 \\
87577 \\
87543 \\
87548 \\
87672\end{array}$ & $\begin{array}{l}10 / 02 / 86 \\
07 / 20 / 87 \\
07 / 14 / 87 \\
07 / 14 / 87 \\
08 / 24 / 87\end{array}$ & $\begin{array}{l}\text { SWMA, COOSE LAKE } \\
\text { CARSON L.., 1A DEEP DRAIN } \\
\text { CARSON L., DOWNS DRAIN } \\
\text { CARSON L.., HOLMES DEEP DR } \\
\text { CARSON L., JI DEEP DRAIN }\end{array}$ & $\begin{array}{l}\text { PLANT } \\
\text { PLANT } \\
\text { PLANT } \\
\text { PLANT } \\
\text { PLANT }\end{array}$ & $\begin{array}{l}\text { A BULRUSH SD } \\
\text { ALGAE } \\
\text { ALGAE } \\
\text { ALGAE } \\
\text { ALGAE }\end{array}$ & $\begin{array}{r}7.60 \\
38.50 \\
79.40 \\
132.00 \\
221.00\end{array}$ & $\begin{array}{r}<0.54 \\
.90 \\
<.26 \\
<.37 \\
.53\end{array}$ & $\begin{array}{r}<1.10 \\
<.25 \\
<.26 \\
<.37 \\
.30\end{array}$ & $\begin{array}{l}<1.10 \\
30.70 \\
7.63 \\
91.00 \\
19.00\end{array}$ & $\begin{array}{r}1,300 \\
8,030 \\
9,290 \\
14,300 \\
5,380\end{array}$ & $\begin{array}{r}3.80 \\
3.27 \\
<2.58 \\
<3.68 \\
3.00\end{array}$ & $\begin{array}{r}200.0 \\
<2.5 \\
<2.6 \\
<3.7 \\
\end{array}$ \\
\hline $\begin{array}{r}87434 \\
87673 \\
87674 \\
271 \\
277\end{array}$ & $\begin{array}{l}06 / 30 / 87 \\
08 / 24 / 87 \\
08 / 24 / 87 \\
09 / 23 / 86 \\
09 / 23 / 86\end{array}$ & $\begin{array}{l}\text { CARSON L., } \text { PASTURE RD.DR. } \\
\text { CARSON } \\
\text { CARS PIER/L DP. DR. } \\
\text { CARSON L., PIER/L DP: DR. } \\
\text { CARSON L.., SPRIG PONDS } \\
\text { CARSON L., SPRIG PONDS }\end{array}$ & $\begin{array}{l}\text { PLANT } \\
\text { PLANT } \\
\text { PLANT } \\
\text { PLANT } \\
\text { PLANT }\end{array}$ & $\begin{array}{l}\text { ALGAE } \\
\text { ALGAE } \\
\text { ALGAE } \\
\text { ALGAE } \\
\text { ALGAE }\end{array}$ & $\begin{array}{r}115.00 \\
141.00 \\
80.00 \\
43.00 \\
53.00\end{array}$ & $\begin{array}{r}<2.74 \\
.72 \\
.61 \\
<.94 \\
<.54\end{array}$ & $\begin{array}{r}<2.74 \\
.30 \\
<.20 \\
<1.90 \\
<1.10\end{array}$ & $\begin{array}{r}24.30 \\
18.00 \\
20.00 \\
4.70 \\
2.90\end{array}$ & $\begin{array}{r}10,300 \\
9,300 \\
5,870 \\
7,200 \\
2,300\end{array}$ & $\begin{array}{r}<27.40 \\
2.00 \\
5.00 \\
<1.90 \\
<1.10\end{array}$ & $\begin{array}{l}<27.4 \\
\overline{-1} \\
110.0 \\
420.0\end{array}$ \\
\hline $\begin{array}{r}347 \\
279 \\
280 \\
87677 \\
225\end{array}$ & $\begin{array}{l}10 / 03 / 86 \\
09 / 23 / 86 \\
09 / 23 / 86 \\
08 / 24 / 87 \\
09 / 22 / 86\end{array}$ & $\begin{array}{l}\text { CARSON L., SPRIG PONDS } \\
\text { CARSON L., SUMP } \\
\text { CARSON L.' SUMP } \\
\text { CARSON L., YARBROUGH DR. } \\
\text { CARSON VALIEY }\end{array}$ & $\begin{array}{l}\text { PLANT } \\
\text { PLANT } \\
\text { PLANT } \\
\text { PLANT } \\
\text { PLANT }\end{array}$ & $\begin{array}{l}\text { ALGAE } \\
\text { ALGAE } \\
\text { ALGAE } \\
\text { ALGAE } \\
\text { ALGAE }\end{array}$ & $\begin{array}{r}66.00 \\
51.00 \\
68.00 \\
194.00 \\
13.00\end{array}$ & $\begin{array}{r}<.60 \\
<.47 \\
<1.40 \\
<1.88 \\
<1.60\end{array}$ & $\begin{array}{l}<1.20 \\
<.93 \\
<2.70 \\
<.20 \\
<3.20\end{array}$ & $\begin{array}{r}2.90 \\
9.30 \\
11.00 \\
23.00 \\
8.10\end{array}$ & $\begin{array}{l}2,900 \\
5,200 \\
5,100 \\
9,550 \\
2,100\end{array}$ & $\begin{array}{r}<1.20 \\
<0.93 \\
2.70 \\
2.00 \\
<3.20\end{array}$ & $\begin{array}{r}550.0 \\
1,300.0 \\
780.0 \\
0.0 \\
520.0\end{array}$ \\
\hline $\begin{array}{r}230 \\
237 \\
87491 \\
154 \\
212\end{array}$ & $\begin{array}{l}09 / 22 / 86 \\
09 / 22 / 86 \\
07 / 06 / 87 \\
09 / 09 / 86 \\
09 / 19 / 86\end{array}$ & $\begin{array}{l}\text { CARSON VALLEY } \\
\text { CARSON VALLEY } \\
\text { ERB DEEP DRAIN } \\
\text { FERNLEY WMA } \\
\text { FERNLEY WMA }\end{array}$ & $\begin{array}{l}\text { PLANT } \\
\text { PLANT } \\
\text { PLANT } \\
\text { PLANT } \\
\text { PLANT }\end{array}$ & $\begin{array}{l}\text { ALGAE } \\
\text { ALGAE } \\
\text { ALGAE } \\
\text { ALGAE } \\
\text { ALGAE }\end{array}$ & $\begin{array}{l}52.00 \\
38.00 \\
59.20 \\
52.00 \\
19.00\end{array}$ & $\begin{array}{r}<1.10 \\
<.79 \\
.84 \\
<.83 \\
<.60\end{array}$ & $\begin{array}{l}<2.30 \\
<1.60 \\
<.42 \\
<1.70 \\
<1.20\end{array}$ & $\begin{array}{r}10.00 \\
21.00 \\
14.50 \\
9.50 \\
1.90\end{array}$ & $\begin{array}{l}4,000 \\
4,100 \\
5,030 \\
4,800 \\
3,500\end{array}$ & $\begin{array}{r}5.20 \\
2.70 \\
<4.20 \\
2.20 \\
2.30\end{array}$ & $\begin{array}{r}500.0 \\
1,100.0 \\
<4.2 \\
1,000.0 \\
52.0\end{array}$ \\
\hline $\begin{array}{r}216 \\
87564 \\
87670 \\
87671 \\
87656\end{array}$ & $\begin{array}{l}09 / 19 / 86 \\
07 / 16 / 87 \\
08 / 19 / 87 \\
08 / 19 / 87 \\
08 / 12 / 87\end{array}$ & $\begin{array}{l}\text { FERNLEY WMA } \\
\text { FERNLEY WMA } \\
\text { FERNLEY WMA } \\
\text { FERNLEY WMA } \\
\text { HWMA, CARPENTER RD. DRAIN }\end{array}$ & $\begin{array}{l}\text { PLANT } \\
\text { PLANT } \\
\text { PLANT } \\
\text { PLANT } \\
\text { PLANT }\end{array}$ & $\begin{array}{l}\text { ALGAE } \\
\text { ALGAE } \\
\text { ALGAE } \\
\text { ALGAE } \\
\text { ALGAE }\end{array}$ & $\begin{array}{r}22.00 \\
130.00 \\
304.00 \\
186.00 \\
238.00\end{array}$ & $\begin{array}{r}<1.20 \\
1.31 \\
.53 \\
.76 \\
.84\end{array}$ & $\begin{array}{r}<2.40 \\
<.51 \\
.50 \\
.30 \\
.60\end{array}$ & $\begin{array}{r}5.10 \\
18.60 \\
27.60 \\
22.00 \\
14.00\end{array}$ & $\begin{array}{r}5,800 \\
5,060 \\
7,870 \\
8,410 \\
10,900\end{array}$ & $\begin{array}{r}<2.40 \\
7.98 \\
3.00 \\
3.00 \\
<2.00\end{array}$ & $\begin{array}{c}290.0 \\
<5.1 \\
-- \\
--\end{array}$ \\
\hline $\begin{array}{l}87517 \\
87514 \\
87472 \\
87477 \\
87520\end{array}$ & $\begin{array}{l}07 / 09 / 87 \\
07 / 09 / 87 \\
07 / 02 / 87 \\
07 / 02 / 87 \\
07 / 09 / 87\end{array}$ & $\begin{array}{l}\text { HWMA, RENNIE RD. DRAIN } \\
\text { HWMA, SEVENTEEN DITCH } \\
\text { HWMA, TOULON LAKE } \\
\text { HWMA, UPPER ARMY DRAIN } \\
\text { HWMA, WESTFALL RD. DRAIN }\end{array}$ & $\begin{array}{l}\text { PLANT } \\
\text { PLANT } \\
\text { PLANT } \\
\text { PLANT } \\
\text { PLANT }\end{array}$ & $\begin{array}{l}\text { ALGAE } \\
\text { ALGAE } \\
\text { ALGAE } \\
\text { ALGAE } \\
\text { ALGAE }\end{array}$ & $\begin{array}{r}88.00 \\
121.00 \\
99.40 \\
155.00 \\
83.20\end{array}$ & $\begin{array}{r}.39 \\
.23 \\
<.29 \\
<1.33 \\
<.34\end{array}$ & $\begin{array}{r}<.19 \\
<.23 \\
<.29 \\
<1.33 \\
.60\end{array}$ & $\begin{array}{r}13.50 \\
23.60 \\
7.41 \\
19.70 \\
5.10\end{array}$ & $\begin{array}{r}7,300 \\
4,860 \\
16,000 \\
5,890 \\
10,700\end{array}$ & $\begin{array}{r}<1.90 \\
3.60 \\
<2.87 \\
<13.30 \\
<3.36\end{array}$ & $\begin{array}{r}15.5 \\
3.3 \\
<2.9 \\
<13.3 \\
17.4\end{array}$ \\
\hline $\begin{array}{r}87507 \\
87581 \\
87419 \\
307 \\
308\end{array}$ & $\begin{array}{l}07 / 08 / 87 \\
07 / 20 / 87 \\
06 / 25 / 87 \\
09 / 30 / 86 \\
09 / 30 / 86\end{array}$ & $\begin{array}{l}\text { MASSIE SLOUGH } \\
\text { MASSIE SLOUGH } \\
\text { SHECKLER RES. } \\
\text { SWMA, GOOSE LAKE } \\
\text { SWMA, GOOSE LAKE }\end{array}$ & $\begin{array}{l}\text { PLANT } \\
\text { PLANT } \\
\text { PLANT } \\
\text { PLANT } \\
\text { PLANT }\end{array}$ & $\begin{array}{l}\text { ALGAE } \\
\text { ALGAE } \\
\text { ALGAE } \\
\text { ALGAE } \\
\text { ALGAE }\end{array}$ & $\begin{array}{r}72.20 \\
52.80 \\
262.00 \\
51.00 \\
39.00\end{array}$ & $\begin{array}{r}.51 \\
1.32 \\
1.27 \\
<.88 \\
<1.10\end{array}$ & $\begin{array}{l}<.20 \\
<.21 \\
<.29 \\
<1.80 \\
<2.30\end{array}$ & $\begin{array}{r}7.25 \\
29.70 \\
28.60 \\
5.40 \\
11.00\end{array}$ & $\begin{array}{r}5,100 \\
8,170 \\
10,800 \\
5,100 \\
5,600\end{array}$ & $\begin{array}{l}<1.96 \\
<2.13 \\
<2.89 \\
49.00 \\
<2.30\end{array}$ & $\begin{array}{r}<2.0 \\
<2.1 \\
<2.9 \\
210.0 \\
1.400 .0\end{array}$ \\
\hline $\begin{array}{r}186 \\
187 \\
194 \\
87527 \\
87449\end{array}$ & $\begin{array}{l}09 / 28 / 86 \\
09 / 18 / 86 \\
09 / 18 / 86 \\
07 / 13 / 87 \\
06 / 30 / 87\end{array}$ & $\begin{array}{l}\text { SWMA, LEAD LAKE } \\
\text { SWMA, LEAD LAKE } \\
\text { SWMA, LEAD LAKE } \\
\text { SWMA, SHAFFNER DR. , IND.L. } \\
\text { CARSON L., I DEEP DRAIN }\end{array}$ & $\begin{array}{l}\text { PLANT } \\
\text { PLANT } \\
\text { PLANT } \\
\text { PLANT } \\
\text { PLANT }\end{array}$ & $\begin{array}{l}\text { ALGAE } \\
\text { ALGAE } \\
\text { ALGAE } \\
\text { ALGAE } \\
\text { CATTAIL RT }\end{array}$ & $\begin{array}{l}44.00 \\
33.00 \\
48.00 \\
31.60 \\
92.50\end{array}$ & $\begin{array}{r}<1.10 \\
<.53 \\
<.70 \\
.51 \\
.48\end{array}$ & $\begin{array}{r}<2.20 \\
1.10 \\
<1.40 \\
<.12 \\
<.48\end{array}$ & $\begin{array}{r}8.70 \\
11.00 \\
14.00 \\
8.49 \\
14.40\end{array}$ & $\begin{array}{l}4,500 \\
4,500 \\
4,500 \\
5,370 \\
3,190\end{array}$ & $\begin{array}{r}2.90 \\
3.70 \\
2.40 \\
<1.16 \\
<4.81\end{array}$ & $\begin{array}{r}760.0 \\
1,600.0 \\
1,600.0 \\
<1.2 \\
<4.8\end{array}$ \\
\hline $\begin{array}{l}87433 \\
87441 \\
87537 \\
263 \\
87409\end{array}$ & $\begin{array}{l}06 / 30 / 87 \\
06 / 30 / 87 \\
07 / 14 / 87 \\
09 / 23 / 86 \\
06 / 22 / 87\end{array}$ & $\begin{array}{l}\text { CARSON L., } \text { C.L.DP.DR. MID } \\
\text { CARSON L., } \text { C.L.DP.DR.UPPR } \\
\text { CARSON L., DOWNS DRAIN } \\
\text { CARSON L., ISLANDS UNIT } \\
\text { CARSON L., JI DEEP DRAIN }\end{array}$ & $\begin{array}{l}\text { PLANT } \\
\text { PLANT } \\
\text { PLANT } \\
\text { PLANT } \\
\text { PLANT }\end{array}$ & $\begin{array}{l}\text { CATTAIL RT } \\
\text { CATTAIL RT } \\
\text { CATTAIL RT } \\
\text { CATTAIL RT } \\
\text { CATTAIL RT }\end{array}$ & $\begin{array}{l}43.00 \\
33.60 \\
97.40 \\
18.00 \\
33.10\end{array}$ & $\begin{array}{l}<.56 \\
<.48 \\
<.91 \\
<.76 \\
<.05\end{array}$ & $\begin{array}{r}<.56 \\
<.48 \\
<.91 \\
<1.50 \\
<.51\end{array}$ & $\begin{array}{r}22.80 \\
7.09 \\
31.10 \\
6.40 \\
15.40\end{array}$ & $\begin{array}{l}4,270 \\
2,030 \\
6,740 \\
2,600 \\
3,300\end{array}$ & $\begin{array}{r}6.22 \\
<4.85 \\
<9.09 \\
1.50 \\
<5.10\end{array}$ & $\begin{array}{l}<5.6 \\
<4.8 \\
<9.1 \\
300.0 \\
<5.1\end{array}$ \\
\hline $\begin{array}{r}87439 \\
87411 \\
87676 \\
345 \\
348\end{array}$ & $\begin{array}{l}06 / 30 / 87 \\
06 / 22 / 87 \\
08 / 24 / 87 \\
10 / 03 / 86 \\
10 / 03 / 86\end{array}$ & 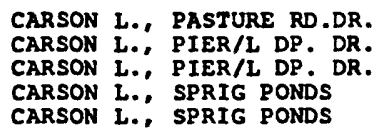 & $\begin{array}{l}\text { PLANT } \\
\text { PLANT } \\
\text { PLANT } \\
\text { PLANT } \\
\text { PLANT }\end{array}$ & $\begin{array}{l}\text { CATTAIL RT } \\
\text { CATTAIL RT } \\
\text { CATTAIL RT } \\
\text { CATTAIL RT } \\
\text { CATTAIL RT }\end{array}$ & $\begin{array}{l}24.30 \\
32.70 \\
34.70 \\
25.00 \\
13.00\end{array}$ & $\begin{array}{l}<.71 \\
<.46 \\
.20 \\
<.96 \\
<.81\end{array}$ & $\begin{array}{r}<.71 \\
<.46 \\
<.20 \\
<1.90 \\
<1.60\end{array}$ & $\begin{array}{r}12.90 \\
30.40 \\
6.00 \\
4.40 \\
6.00\end{array}$ & $\begin{array}{l}1,710 \\
2,580 \\
2,170 \\
2,400 \\
1,600\end{array}$ & $\begin{array}{r}<7.10 \\
4.59 \\
2.00 \\
<1.90 \\
<1.60\end{array}$ & $\begin{array}{l}<7.1 \\
<4.6 \\
290.0 \\
130.0\end{array}$ \\
\hline $\begin{array}{r}352 \\
8757 \\
217 \\
231 \\
234\end{array}$ & $\begin{array}{l}10 / 03 / 86 \\
07 / 14 / 87 \\
09 / 22 / 86 \\
09 / 22 / 86 \\
09 / 22 / 86\end{array}$ & $\begin{array}{l}\text { CARSON } 1 ., \text { SPRIG PONDS } \\
\text { CARSON L., YARBROUGH DR. } \\
\text { CARSON VALLEY } \\
\text { CARSON VALLEY } \\
\text { CARSON VALLEY }\end{array}$ & $\begin{array}{l}\text { PLANT } \\
\text { PLANT } \\
\text { PLANT } \\
\text { PLANT } \\
\text { PLANT }\end{array}$ & $\begin{array}{l}\text { CATTAIL RT } \\
\text { CATTAIL RT } \\
\text { CATTAIL RT } \\
\text { CATTAIL RT } \\
\text { CATTAIL RT }\end{array}$ & $\begin{array}{l}17.00 \\
28.50 \\
77.00 \\
14.00 \\
25.00\end{array}$ & $\begin{array}{l}<.57 \\
<.57 \\
<.88 \\
<.43 \\
<.72\end{array}$ & $\begin{array}{r}<1.10 \\
<.57 \\
<1.80 \\
<.85 \\
<1.40\end{array}$ & $\begin{array}{r}24.00 \\
16.80 \\
6.10 \\
2.80 \\
8.60\end{array}$ & $\begin{array}{l}1,800 \\
2,330 \\
1,700 \\
1,300 \\
1,600\end{array}$ & $\begin{array}{r}1.50 \\
<5.70 \\
3.90 \\
2.40 \\
1.70\end{array}$ & $\begin{array}{r}170.0 \\
<5.7 \\
1,600.0 \\
230.0 \\
570.0\end{array}$ \\
\hline $\begin{array}{r}87493 \\
152 \\
156 \\
158 \\
87452\end{array}$ & $\begin{array}{l}07 / 06 / 87 \\
09 / 09 / 86 \\
09 / 09 / 86 \\
09 / 09 / 86 \\
07 / 01 / 87\end{array}$ & $\begin{array}{l}\text { ERB DEEP DRAIN } \\
\text { FERNLEY WMA } \\
\text { FERNLEY WMA } \\
\text { FERNLEY WMA } \\
\text { FERNLEY WMA }\end{array}$ & $\begin{array}{l}\text { PLANT } \\
\text { PLANT } \\
\text { PLANT } \\
\text { PLANT } \\
\text { PLANT }\end{array}$ & $\begin{array}{l}\text { CATTAIL RT } \\
\text { CATTAIL RT } \\
\text { CATTAIL RT } \\
\text { CATTAIL RT } \\
\text { CATTAIL RT }\end{array}$ & $\begin{array}{l}23.60 \\
28.00 \\
35.00 \\
22.00 \\
35.80\end{array}$ & $\begin{array}{l}<.72 \\
<1.10 \\
<1.10 \\
<.79 \\
<.32\end{array}$ & $\begin{array}{l}<.72 \\
<2.20 \\
<2.20 \\
<1.60 \\
<.32\end{array}$ & $\begin{array}{r}7.54 \\
30.00 \\
4.10 \\
6.80 \\
3.92\end{array}$ & $\begin{array}{r}2,330 \\
3,700 \\
2,500 \\
2,500 \\
21\end{array}$ & $\begin{array}{r}<7.20 \\
6.10 \\
2.20 \\
1.90 \\
<3.20\end{array}$ & $\begin{array}{r}<10.2 \\
410.0 \\
280.0 \\
220.0 \\
<3.2\end{array}$ \\
\hline
\end{tabular}




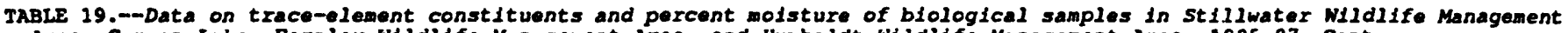
Area, Carson Lake, Fernley W1ldlife Masagement Area, and Humboldt Wildlife Management Area, 1985-87--Cont.

\begin{tabular}{|c|c|c|c|c|c|c|c|c|c|c|c|c|}
\hline $\begin{array}{l}\text { USFWS } \\
\text { local } \\
\text { ID } \\
\text { number }\end{array}$ & Date & Location & $\begin{array}{l}\text { Cate- } \\
\text { gory }\end{array}$ & Species & & Barium & $\begin{array}{c}\text { Beryl- } \\
\text { l1um }\end{array}$ & $\begin{array}{l}\text { Cad- } \\
\text { mium }\end{array}$ & Copper & $\begin{array}{l}\text { Magne- } \\
\text { sIum }\end{array}$ & $\begin{array}{l}\text { Molyb- } \\
\text { denum }\end{array}$ & Tin \\
\hline $\begin{array}{l}87459 \\
87562 \\
87485 \\
87524 \\
87518\end{array}$ & $\begin{array}{l}07 / 01 / 87 \\
07 / 16 / 87 \\
07 / 06 / 87 \\
07 / 09 / 87 \\
07 / 09 / 87\end{array}$ & $\begin{array}{l}\text { FERNLEY WYA } \\
\text { FERNLEY WMA } \\
\text { HARMON RES. } \\
\text { HWMA, CARPENTER RD. DRAIN } \\
\text { HWSA, RENHIE RD. DRAIN }\end{array}$ & $\begin{array}{l}\text { PLANT } \\
\text { PLANT } \\
\text { PLANT } \\
\text { PLANT } \\
\text { PLANT }\end{array}$ & $\begin{array}{l}\text { CATTAIL RT } \\
\text { CATTAIL RT } \\
\text { CATTAIL RT } \\
\text { CATTAIL RT } \\
\text { CATTAIL RT }\end{array}$ & & $\begin{array}{l}30.50 \\
59.10 \\
64.90 \\
70.50 \\
38.80\end{array}$ & $\begin{array}{l}<0.47 \\
<.67 \\
<.72 \\
<.52 \\
<.49\end{array}$ & $\begin{array}{r}<0.47 \\
<.67 \\
<.72 \\
<.52 \\
<.49\end{array}$ & $\begin{array}{r}3.58 \\
11.20 \\
16.40 \\
16.80 \\
41.70\end{array}$ & $\begin{array}{l}1,570 \\
2,320 \\
3,010 \\
3,470 \\
3,920\end{array}$ & $\begin{array}{l}<4.70 \\
<6.70 \\
<7.25 \\
<5.20 \\
<4.90\end{array}$ & $\begin{array}{l}<4.7 \\
<6.7 \\
<7.2 \\
<5.2 \\
<4.9\end{array}$ \\
\hline $\begin{array}{l}87473 \\
87466 \\
87521 \\
87569 \\
87509\end{array}$ & $\begin{array}{l}07 / 02 / 87 \\
07 / 02 / 87 \\
07 / 09 / 87 \\
07 / 27 / 87 \\
07 / 08 / 87\end{array}$ & $\begin{array}{l}\text { HWMA, SO. MERIDIAN RD.DR. } \\
\text { HWMA, TOULON LAKE } \\
\text { HWMA, WESTFALI RD. DRAIN } \\
\text { MAHAIA SLOUGH } \\
\text { MASSIE SLOUGH }\end{array}$ & $\begin{array}{l}\text { PLANT } \\
\text { PLANT } \\
\text { PLANT } \\
\text { PLANT } \\
\text { PLANT }\end{array}$ & $\begin{array}{l}\text { CATTAIL RT } \\
\text { CATTAIL RT } \\
\text { CATTAIL RT } \\
\text { CATTAIL RT } \\
\text { CATTAII RT }\end{array}$ & & $\begin{array}{l}39.40 \\
22.40 \\
56.00 \\
46.50 \\
57.10\end{array}$ & $\begin{array}{l}<.64 \\
<.79 \\
<.83 \\
<.53 \\
.49\end{array}$ & $\begin{array}{l}<.64 \\
<.79 \\
1.17 \\
<.53 \\
<.35\end{array}$ & $\begin{array}{r}12.80 \\
27.80 \\
9.67 \\
7.13 \\
11.10\end{array}$ & $\begin{array}{r}237 \\
3,430 \\
4,300 \\
2,740 \\
3,630\end{array}$ & $\begin{array}{l}<6.41 \\
<7.94 \\
<8.33 \\
<5.32 \\
<3.50\end{array}$ & $\begin{array}{l}<6.4 \\
<7.9 \\
<8.3 \\
<5.3 \\
<3.5\end{array}$ \\
\hline $\begin{array}{r}87579 \\
160 \\
165 \\
168 \\
87529\end{array}$ & $\begin{array}{l}07 / 20 / 87 \\
09 / 16 / 86 \\
09 / 16 / 86 \\
09 / 16 / 86 \\
07 / 13 / 87\end{array}$ & $\begin{array}{l}\text { MASSIE SLOUGH } \\
\text { SWMA, ALKALI UN. I } \\
\text { SWMA, ALKALI UN. I } \\
\text { SWMA, ALKALI UN. I } \\
\text { SWMA, SHAFENER DR., IND.L. }\end{array}$ & $\begin{array}{l}\text { PLANT } \\
\text { PLANT } \\
\text { PLANT } \\
\text { PLANT } \\
\text { PLANT }\end{array}$ & $\begin{array}{l}\text { CATTAIL RT } \\
\text { CATTAIL RT } \\
\text { CATTAIL RT } \\
\text { CATTAIL RT } \\
\text { CATTAIL RT }\end{array}$ & & $\begin{array}{l}45.30 \\
44.00 \\
26.00 \\
25.00 \\
30.50\end{array}$ & $\begin{array}{l}<.54 \\
<.85 \\
<.65 \\
<.66 \\
<.91\end{array}$ & $\begin{array}{r}<.54 \\
<1.70 \\
<1.30 \\
<1.30 \\
<.91\end{array}$ & $\begin{array}{l}9.35 \\
2.40 \\
4.20 \\
5.30 \\
9.82\end{array}$ & $\begin{array}{l}2,310 \\
2,200 \\
2,500 \\
2,200 \\
2,620\end{array}$ & $\begin{array}{r}<5.38 \\
<1.70 \\
2.10 \\
1.40 \\
<9.09\end{array}$ & $\begin{array}{l}<5.4 \\
470.0 \\
310.0 \\
170.0 \\
<9.1\end{array}$ \\
\hline $\begin{array}{l}177 \\
288 \\
290 \\
264 \\
346\end{array}$ & $\begin{array}{l}09 / 16 / 86 \\
09 / 16 / 86 \\
09 / 16 / 86 \\
09 / 23 / 86 \\
10 / 03 / 86\end{array}$ & $\begin{array}{l}\text { SWMA, STILLWATER PT. RES. } \\
\text { SWMA, STILLWATER PT. RES, } \\
\text { SWMA, STILIWATER PT. RES. } \\
\text { CARSON L., ISLANDS UNIT } \\
\text { CARSON L., SPRIG PONDS }\end{array}$ & $\begin{array}{l}\text { PLANT } \\
\text { PLANT } \\
\text { PLANT } \\
\text { PLANT } \\
\text { PLANT }\end{array}$ & $\begin{array}{l}\text { CATTAIL RT } \\
\text { CATTAIL RT } \\
\text { CATTAIL RT } \\
\text { CATTAIL ST } \\
\text { CATTAIL ST }\end{array}$ & & $\begin{array}{r}23.00 \\
76.00 \\
49.00 \\
20.00 \\
5.60\end{array}$ & $\begin{array}{l}<.48 \\
<.98 \\
<.64 \\
<.43 \\
<.56\end{array}$ & $\begin{array}{r}<.96 \\
<2.00 \\
<1.30 \\
<.85 \\
<1.10\end{array}$ & $\begin{array}{l}3.70 \\
5.30 \\
5.40 \\
2.00 \\
4.40\end{array}$ & $\begin{array}{l}1,800 \\
2,900 \\
2,600 \\
2,000 \\
1,400\end{array}$ & $\begin{array}{r}2.60 \\
<2.00 \\
6.50 \\
1.30 \\
1.70\end{array}$ & $\begin{array}{r}600.0 \\
880.0 \\
900.0 \\
16.0 \\
36.0\end{array}$ \\
\hline $\begin{array}{l}349 \\
353 \\
218 \\
232 \\
235\end{array}$ & $\begin{array}{l}10 / 03 / 86 \\
10 / 03 / 86 \\
09 / 22 / 86 \\
09 / 22 / 86 \\
09 / 22 / 86\end{array}$ & $\begin{array}{l}\text { CARSON L., SPRIG PONDS } \\
\text { CARSON L.: SPRIG PONDS } \\
\text { CARSON VALLLEY } \\
\text { CARSON VALLEY } \\
\text { CARSON VALLEY }\end{array}$ & $\begin{array}{l}\text { PLANT } \\
\text { PLANT } \\
\text { PLANT } \\
\text { PLANT } \\
\text { PLANT }\end{array}$ & $\begin{array}{l}\text { CATTAIL ST } \\
\text { CATTAIL ST } \\
\text { CATTAIL ST } \\
\text { CATTAIL ST } \\
\text { CATTAIL ST }\end{array}$ & & $\begin{array}{r}12.00 \\
5.80 \\
12.00 \\
9.50 \\
11.00\end{array}$ & $\begin{array}{l}<.65 \\
<.48 \\
<.65 \\
<.36 \\
<.41\end{array}$ & $\begin{array}{r}<1.30 \\
<.96 \\
<1.30 \\
<.73 \\
<.82\end{array}$ & $\begin{array}{l}2.30 \\
2.80 \\
1.30 \\
2.30 \\
1.40\end{array}$ & $\begin{array}{r}1,600 \\
1,300 \\
1,700 \\
880 \\
950\end{array}$ & $\begin{array}{r}1.80 \\
<.96 \\
3.40 \\
1.50 \\
.98\end{array}$ & $\begin{array}{r}19.0 \\
17.0 \\
600.0 \\
310.0 \\
120.0\end{array}$ \\
\hline $\begin{array}{l}293 \\
297 \\
300 \\
318 \\
323\end{array}$ & $\begin{array}{l}09 / 09 / 86 \\
09 / 09 / 86 \\
09 / 09 / 86 \\
09 / 16 / 86 \\
09 / 16 / 86\end{array}$ & $\begin{array}{l}\text { FERNLEY WMA } \\
\text { FERNLEY WMA } \\
\text { FERNLEY WMA } \\
\text { SWMA, ALKAII UN. \$I } \\
\text { SWMA, ALKALI UN. } 1\end{array}$ & $\begin{array}{l}\text { PLANT } \\
\text { PLANT } \\
\text { PLANT } \\
\text { PLANT } \\
\text { PLANT }\end{array}$ & $\begin{array}{l}\text { CATTAIL ST } \\
\text { CATTAII ST } \\
\text { CATTAII ST } \\
\text { CATTAIL ST } \\
\text { CATTAII ST }\end{array}$ & & $\begin{array}{l}12.00 \\
24.00 \\
10.00 \\
14.00 \\
12.00\end{array}$ & $\begin{array}{l}<.64 \\
<.91 \\
<.50 \\
<.50 \\
<.48\end{array}$ & $\begin{array}{l}<1.30 \\
<1.80 \\
<1.00 \\
<1.00 \\
<.96\end{array}$ & $\begin{array}{l}1.90 \\
2.50 \\
2.20 \\
8.80 \\
1.90\end{array}$ & $\begin{array}{l}2,400 \\
3,100 \\
2,800 \\
1,200 \\
1,300\end{array}$ & $\begin{array}{r}<1.30 \\
2.40 \\
1.10 \\
8.10 \\
<.96\end{array}$ & $\begin{array}{r}23.0 \\
44.0 \\
14.0 \\
260.0 \\
12.0\end{array}$ \\
\hline $\begin{array}{l}325 \\
174 \\
182 \\
286 \\
220\end{array}$ & $\begin{array}{l}09 / 16 / 86 \\
09 / 16 / 86 \\
09 / 16 / 86 \\
09 / 16 / 86 \\
09 / 22 / 86\end{array}$ & $\begin{array}{l}\text { SWMA, ALKALI UN. } 11 \\
\text { SWMA, STILLWATER PT. RES. } \\
\text { SWMA, STILLWATER PT. RES. } \\
\text { SWMA, STILLWATER PT. RES. } \\
\text { CARSON VALLEY }\end{array}$ & $\begin{array}{l}\text { PLANT } \\
\text { PLANT } \\
\text { PLANT } \\
\text { PLANT } \\
\text { PLANT }\end{array}$ & $\begin{array}{l}\text { CATTAIL ST } \\
\text { CATTAIL ST } \\
\text { CATTAIL ST } \\
\text { CATTAII ST } \\
\text { CHARA }\end{array}$ & & $\begin{array}{l}17.00 \\
18.00 \\
15.00 \\
12.00 \\
34.00\end{array}$ & $\begin{array}{l}<.57 \\
<.54 \\
<.44 \\
<.47 \\
<.82\end{array}$ & $\begin{array}{l}<1.10 \\
<1.10 \\
<.88 \\
<.94 \\
<1.60\end{array}$ & $\begin{array}{l}1.40 \\
1.40 \\
1.88 \\
3.30 \\
9.50\end{array}$ & $\begin{array}{r}760 \\
1,700 \\
730 \\
1,300 \\
4,400\end{array}$ & $\begin{array}{r}2.70 \\
<1.10 \\
2.70 \\
1.90 \\
<1.60\end{array}$ & $\begin{array}{r}26.0 \\
230.0 \\
200.0 \\
250.0 \\
240.0\end{array}$ \\
\hline $\begin{array}{r}229 \\
238 \\
87450 \\
87575 \\
87430\end{array}$ & $\begin{array}{l}09 / 22 / 86 \\
09 / 22 / 86 \\
06 / 30 / 87 \\
07 / 20 / 87 \\
06 / 30 / 87\end{array}$ & $\begin{array}{l}\text { CARSON VALLEY } \\
\text { CARSON VALLEY } \\
\text { CARSON L., I DEEP DRAIN } \\
\text { CARSON I., IA DEEP DRAIN } \\
\text { CARSON L., C.L.DP.DR. MID }\end{array}$ & $\begin{array}{l}\text { PLANT } \\
\text { PLANT } \\
\text { PLANT } \\
\text { PLANT } \\
\text { PLANT }\end{array}$ & $\begin{array}{l}\text { CHARA } \\
\text { CHARA } \\
\text { HS BULRUSH } \\
\text { HS BULRUSH } \\
\text { HS BULRUSH }\end{array}$ & $\begin{array}{l}\text { RT } \\
\text { RT } \\
\text { RT }\end{array}$ & $\begin{array}{l}29.00 \\
24.00 \\
29.20 \\
30.60 \\
30.60\end{array}$ & $\begin{array}{l}<1.20 \\
<.93 \\
<.52 \\
<.44 \\
<.26\end{array}$ & $\begin{array}{l}<2.40 \\
<1.90 \\
<.52 \\
<.44 \\
<.26\end{array}$ & $\begin{array}{r}11.00 \\
10.00 \\
281.00 \\
10.60 \\
5.26\end{array}$ & $\begin{array}{r}2,700 \\
2,900 \\
918 \\
1,040 \\
1,390\end{array}$ & $\begin{array}{r}<2.40 \\
<1.90 \\
<5.15 \\
<4.39 \\
6.61\end{array}$ & $\begin{array}{l}180.0 \\
260.0 \\
<5.2 \\
<4.4 \\
<2.6\end{array}$ \\
\hline $\begin{array}{l}87442 \\
87538 \\
87410 \\
87423 \\
87435\end{array}$ & $\begin{array}{l}06 / 30 / 87 \\
07 / 14 / 87 \\
06 / 22 / 87 \\
06 / 29 / 87 \\
06 / 30 / 87\end{array}$ & $\begin{array}{l}\text { CARSON L., C.L.DP.DR. UPPR } \\
\text { CARSON L., DOWNS DRAIN } \\
\text { CARSON I., J J DEEP DRAIN } \\
\text { CARSON L., I DEEP DRAIN } \\
\text { CARSON I., PASTURE RD.DR. }\end{array}$ & $\begin{array}{l}\text { PLANT } \\
\text { PIANT } \\
\text { PLANT } \\
\text { PLANT } \\
\text { PLANT }\end{array}$ & $\begin{array}{l}\text { HS BULRUSH } \\
\text { HS BULRUSH } \\
\text { HS BULRUSH } \\
\text { HS BULRUSH } \\
\text { HS BULRUSH }\end{array}$ & $\begin{array}{l}R T \\
R T \\
R T \\
R T \\
R T\end{array}$ & $\begin{array}{l}81.80 \\
57.00 \\
40.60 \\
19.50 \\
36.60\end{array}$ & $\begin{array}{l}<.29 \\
<.62 \\
<.53 \\
<.29 \\
<.42\end{array}$ & $\begin{array}{l}<.29 \\
<.62 \\
<.53 \\
<.29 \\
<.42\end{array}$ & $\begin{array}{r}13.80 \\
16.40 \\
19.10 \\
5.41 \\
12.30\end{array}$ & $\begin{array}{r}2,160 \\
3,820 \\
1,940 \\
953 \\
1,800\end{array}$ & $\begin{array}{r}8.84 \\
<6.25 \\
<5.30 \\
<2.90 \\
<4.20\end{array}$ & $\begin{array}{l}<2.9 \\
<6.3 \\
<5.3 \\
<2.9 \\
<4.2\end{array}$ \\
\hline $\begin{array}{l}87412 \\
87675 \\
87545 \\
87453 \\
87460\end{array}$ & $\begin{array}{l}06 / 22 / 87 \\
08 / 24 / 87 \\
07 / 14 / 87 \\
07 / 01 / 87 \\
07 / 01 / 87\end{array}$ & $\begin{array}{l}\text { CARSON I.. PIER/L DP. DR. } \\
\text { CARSON I.. PIER/L DP. DR. } \\
\text { CARSON L., YARBROUGH DR. } \\
\text { FERNLEY WMA } \\
\text { FERNLEY WMA }\end{array}$ & $\begin{array}{l}\text { PLANT } \\
\text { PLANT } \\
\text { PLANT } \\
\text { PLANT } \\
\text { PLANT }\end{array}$ & $\begin{array}{l}\text { HS BULRUSH } \\
\text { HS BULRUSH } \\
\text { HS BULRUSH } \\
\text { HS BULRUSH } \\
\text { HS BULRUSH }\end{array}$ & $\begin{array}{l}\mathbf{R T} \\
\mathbf{R T} \\
\mathrm{RT} \\
\mathrm{RT} \\
\mathrm{RT}\end{array}$ & $\begin{array}{l}20.10 \\
34.30 \\
28.80 \\
47.10 \\
22.70\end{array}$ & $\begin{array}{l}<.36 \\
.20 \\
<.42 \\
<.39 \\
<.42\end{array}$ & $\begin{array}{l}<.36 \\
<.20 \\
<.42 \\
<.39 \\
<.42\end{array}$ & $\begin{array}{r}10.90 \\
4.60 \\
7.00 \\
6.36 \\
5.85\end{array}$ & $\begin{array}{l}1,877 \\
1,320 \\
1,320 \\
1,270 \\
1,950\end{array}$ & $\begin{array}{r}<3.62 \\
<1.00 \\
<4.17 \\
<3.90 \\
8.81\end{array}$ & $\begin{array}{l}<3.6 \\
<-1.2 \\
<3.9 \\
<4.2\end{array}$ \\
\hline $\begin{array}{l}87563 \\
87486 \\
87525 \\
87519 \\
87467\end{array}$ & $\begin{array}{l}07 / 16 / 87 \\
07 / 06 / 87 \\
07 / 09 / 87 \\
07 / 09 / 87 \\
07 / 02 / 87\end{array}$ & $\begin{array}{l}\text { FERNLEY WMA } \\
\text { HARMON RES. } \\
\text { HWMA, CARPENTER RD. DRAIN } \\
\text { HWMA, RENNIE RD. DRAIN } \\
\text { HWMA, TOULON LAKE }\end{array}$ & $\begin{array}{l}\text { PLANT } \\
\text { PLANT } \\
\text { PLANT } \\
\text { PLANT } \\
\text { PLANT }\end{array}$ & $\begin{array}{l}\text { HS BULRUSH } \\
\text { HS BULRUSH } \\
\text { HS BULRUSH } \\
\text { HS BULRUSH } \\
\text { HS BULRUSH }\end{array}$ & $\begin{array}{l}\mathbf{R T} \\
\mathbf{R T} \\
\mathbf{R T} \\
\mathbf{R T} \\
\mathbf{R T}\end{array}$ & $\begin{array}{l}60.00 \\
40.00 \\
10.70 \\
15.40 \\
25.00\end{array}$ & $\begin{array}{l}<.41 \\
<.56 \\
<.31 \\
<.33 \\
<.53\end{array}$ & $\begin{array}{l}<.41 \\
<.56 \\
<.31 \\
<.33 \\
<.53\end{array}$ & $\begin{array}{r}7.27 \\
14.60 \\
3.87 \\
10.60 \\
8.72\end{array}$ & $\begin{array}{r}1,760 \\
1,470 \\
779 \\
1,160 \\
2,350\end{array}$ & $\begin{array}{l}<4.13 \\
<5.60 \\
<3.10 \\
<3.30 \\
<5.32\end{array}$ & $\begin{array}{l}<4.1 \\
<5.6 \\
<3.1 \\
<3.3 \\
<5.3\end{array}$ \\
\hline $\begin{array}{l}87522 \\
87570 \\
87508 \\
87580 \\
87589\end{array}$ & $\begin{array}{l}07 / 09 / 87 \\
07 / 17 / 87 \\
07 / 08 / 87 \\
07 / 20 / 87 \\
07 / 28 / 87\end{array}$ & $\begin{array}{l}\text { HWMA, WESTFALI RD. DRAIN } \\
\text { MAHALA SLOUGH } \\
\text { MASSIE SLOUGH } \\
\text { MASSIE SLOUGH } \\
\text { MASSIE SLOUGH }\end{array}$ & $\begin{array}{l}\text { PLANT } \\
\text { PLANT } \\
\text { PLANT } \\
\text { PLANT } \\
\text { PLANT }\end{array}$ & $\begin{array}{l}\text { HS BULRUSH } \\
\text { HS BULRUSH } \\
\text { HS BULRUSH } \\
\text { HS BULRUSH } \\
\text { HS BULRUSH }\end{array}$ & $\begin{array}{l}\text { RT } \\
\text { RT } \\
\text { RT } \\
\text { RT } \\
\text { RT }\end{array}$ & $\begin{array}{l}14.20 \\
14.60 \\
29.90 \\
26.40 \\
29.90\end{array}$ & $\begin{array}{l}<.35 \\
<.30 \\
<.33 \\
<.47 \\
<.46\end{array}$ & $\begin{array}{l}<.35 \\
<.30 \\
<.33 \\
<.47 \\
<.46\end{array}$ & $\begin{array}{l}6.90 \\
4.05 \\
7.50 \\
3.87 \\
3.21\end{array}$ & $\begin{array}{r}986 \\
1,260 \\
1,490 \\
1,110 \\
1,430\end{array}$ & $\begin{array}{r}<3.52 \\
4.52 \\
<3.29 \\
<4.72 \\
<4.59\end{array}$ & $\begin{array}{l}<3.5 \\
<3.0 \\
4.7 \\
<4.7 \\
<4.6\end{array}$ \\
\hline
\end{tabular}


TABLE 19.--Data on trace-element constituents and percent molsture of biologicel sanples in stillwater wildlife Management irea, Carson Lake, Fernley Wildilfe Management Area, and Humboldt Wildilfe Management Area, ig85-87--Cont.

\begin{tabular}{|c|c|c|c|c|c|c|c|c|c|c|c|}
\hline $\begin{array}{l}\text { USFWS } \\
\text { local } \\
\text { ID } \\
\text { number }\end{array}$ & Date & Location & $\begin{array}{l}\text { Cate- } \\
\text { gory }\end{array}$ & Species & Barium & $\begin{array}{c}\text { Bery1- } \\
\text { Ilum }\end{array}$ & $\begin{array}{l}\text { Cad- } \\
\text { mium }\end{array}$ & Copper & & & Tin \\
\hline $\begin{array}{r}87418 \\
87530 \\
256 \\
259 \\
268\end{array}$ & $\begin{array}{l}06 / 25 / 87 \\
07 / 13 / 87 \\
09 / 23 / 86 \\
09 / 23 / 86 \\
09 / 23 / 86\end{array}$ & $\begin{array}{l}\text { SHECKLER RES. } \\
\text { SWMA, SHAFFNER DR., IND.L. } \\
\text { CARSON L., ISLANDS UNIT } \\
\text { CARSON L.: ISLANDS UNIT } \\
\text { CARSON L., ISLANDS UNIT }\end{array}$ & $\begin{array}{l}\text { PLANT } \\
\text { PLANT } \\
\text { PLANT } \\
\text { PLANT } \\
\text { PLANT }\end{array}$ & $\begin{array}{l}\text { HS BULRUSH RT } \\
\text { HS BULRUSH RT } \\
\text { HS BULRUSH SD } \\
\text { HS BULRUSH SD } \\
\text { HS BULRUSH SD }\end{array}$ & $\begin{array}{r}24.30 \\
15.20 \\
2.20 \\
2.80 \\
4.60\end{array}$ & $\begin{array}{r}<.45 \\
<0.81 \\
<.54 \\
<.47 \\
<.57\end{array}$ & $\begin{array}{r}<.45 \\
<0.81 \\
<1.10 \\
<.94 \\
<1.10\end{array}$ & $\begin{array}{r}6.96 \\
<4.03 \\
6.10 \\
7.60 \\
6.20\end{array}$ & $\begin{array}{r}973 \\
1,290 \\
1,600 \\
1,600 \\
1,600\end{array}$ & $\begin{array}{l}<4.46 \\
<8.06 \\
<1.10 \\
<.94 \\
<1.10\end{array}$ & $\begin{aligned}< & 4.5 \\
< & 8.1 \\
< & 5.4 \\
< & 4.7 \\
& 8.9\end{aligned}$ \\
\hline $\begin{array}{l}270 \\
274 \\
223 \\
227 \\
241\end{array}$ & $\begin{array}{l}09 / 23 / 86 \\
09 / 23 / 86 \\
09 / 22 / 86 \\
09 / 22 / 86 \\
09 / 22 / 86\end{array}$ & $\begin{array}{l}\text { CARSON L., SPRIG PONDS } \\
\text { CARSON L. SPRIG PONDS } \\
\text { CARSON VALLEY } \\
\text { CARSON VALLEY } \\
\text { CARSON VALLEY }\end{array}$ & $\begin{array}{l}\text { PLANT } \\
\text { PLANT } \\
\text { PLANT } \\
\text { PLANT } \\
\text { PLANT }\end{array}$ & $\begin{array}{l}\text { HS BULRUSH SD } \\
\text { HS BULRUSH SD } \\
\text { HS BULRUSH SD } \\
\text { HS BULRUSH SD } \\
\text { HS BULRUSH SD }\end{array}$ & $\begin{array}{l}3.00 \\
3.20 \\
3.20 \\
2.10 \\
3.30\end{array}$ & $\begin{array}{l}<.51 \\
<.53 \\
<.54 \\
<.53 \\
<.54\end{array}$ & $\begin{array}{l}<1.00 \\
<1.10 \\
<1.10 \\
<1.10 \\
<1.10\end{array}$ & $\begin{array}{l}4.20 \\
4.70 \\
4.50 \\
2.90 \\
2.50\end{array}$ & $\begin{array}{l}1,500 \\
1,500 \\
1,300 \\
1,400 \\
1,000\end{array}$ & $\begin{array}{l}<1.00 \\
<1.10 \\
<1.10 \\
<1.10 \\
<1.10\end{array}$ & $\begin{array}{r}5.8 \\
5.9 \\
250.0 \\
100.0 \\
99.0\end{array}$ \\
\hline $\begin{array}{l}213 \\
215 \\
195 \\
306 \\
311\end{array}$ & $\begin{array}{l}09 / 19 / 86 \\
09 / 19 / 86 \\
09 / 18 / 86 \\
09 / 30 / 86 \\
09 / 30 / 86\end{array}$ & $\begin{array}{l}\text { FERNZEY WMA } \\
\text { FERNLEY WMA } \\
\text { SWMAA, ALKALI UN. } 11 \\
\text { SWMA, GOOSE LAKE } \\
\text { SWMAA, GOOSE LAKE }\end{array}$ & $\begin{array}{l}\text { PLANT } \\
\text { PLANT } \\
\text { PLANT } \\
\text { PLANT } \\
\text { PLANT }\end{array}$ & $\begin{array}{l}\text { HS BULRUSH SD } \\
\text { HS BULRUSH SD } \\
\text { HS BULRUSH SD } \\
\text { HS BULRUSH SD } \\
\text { HS BULRUSH SD }\end{array}$ & $\begin{array}{r}2.20 \\
2.10 \\
11.00 \\
6.30 \\
4.40\end{array}$ & $\begin{array}{l}<.55 \\
<.53 \\
<.49 \\
<.52 \\
<.56\end{array}$ & $\begin{array}{l}<1.10 \\
<1.10 \\
<.97 \\
<1.00 \\
<1.10\end{array}$ & $\begin{array}{l}4.60 \\
7.90 \\
5.40 \\
2.60 \\
3.20\end{array}$ & $\begin{array}{l}1,600 \\
1,600 \\
1,400 \\
1,300 \\
1,400\end{array}$ & $\begin{array}{r}<1.10 \\
<1.10 \\
<.97 \\
2.80 \\
2.80\end{array}$ & $\begin{array}{r}<5.5 \\
5.5 \\
<4.9 \\
250.0 \\
400.0\end{array}$ \\
\hline $\begin{array}{l}337 \\
185 \\
189 \\
192 \\
201\end{array}$ & $\begin{array}{l}10 / 02 / 86 \\
09 / 18 / 86 \\
09 / 18 / 86 \\
09 / 18 / 86 \\
09 / 18 / 86\end{array}$ & $\begin{array}{l}\text { SWMA, GOOSE LAKE } \\
\text { SWMA, LEAD LAKE } \\
\text { SWMA, LEAD LAKE } \\
\text { SWMA, LEAD LAKE } \\
\text { SWMA, STILLWATER PT. RES. }\end{array}$ & $\begin{array}{l}\text { PLANT } \\
\text { PLANT } \\
\text { PLANT } \\
\text { PLANT } \\
\text { PLANT }\end{array}$ & $\begin{array}{l}\text { HS BULRUSH SD } \\
\text { HS BULRUSH SD } \\
\text { HS BULRUSH SD } \\
\text { HS BULRUSH SD } \\
\text { HS BULRUSH SD }\end{array}$ & $\begin{array}{r}11.00 \\
5.40 \\
4.10 \\
5.40 \\
5.30\end{array}$ & $\begin{array}{l}<.53 \\
<.54 \\
<.51 \\
<.54 \\
<.53\end{array}$ & $\begin{array}{l}<1.10 \\
<1.10 \\
<1.00 \\
<1.10 \\
<1.10\end{array}$ & $\begin{array}{r}<1.10 \\
6.10 \\
5.20 \\
4.10 \\
<1.10\end{array}$ & $\begin{array}{l}1,600 \\
1,200 \\
1,400 \\
1,600 \\
680\end{array}$ & $\begin{array}{r}5.30 \\
<1.10 \\
<1.00 \\
2.10 \\
2.60\end{array}$ & $\begin{array}{r}170.0 \\
6.5 \\
220.0 \\
200.0 \\
220.0\end{array}$ \\
\hline $\begin{array}{r}202 \\
285 \\
87448 \\
87576 \\
87443\end{array}$ & $\begin{array}{l}09 / 18 / 86 \\
09 / 26 / 86 \\
06 / 30 / 87 \\
07 / 20 / 87 \\
06 / 30 / 87\end{array}$ & $\begin{array}{l}\text { SWMA, STILLWATER PT. RES. } \\
\text { WASHOE LAKE } \\
\text { CARSON L.: I DEEP DRAIN } \\
\text { CARSON L.: IA DEEP DRAIN } \\
\text { CARSON L.., C.L.DP.DR.UPPR }\end{array}$ & $\begin{array}{l}\text { PLANT } \\
\text { PLANT } \\
\text { PLANT } \\
\text { PLANT } \\
\text { PLANT }\end{array}$ & $\begin{array}{l}\text { HS BULRUSH SD } \\
\text { HS BULRUSH SD } \\
\text { PONDWEED } \\
\text { PONDWEED } \\
\text { PONDWEED }\end{array}$ & $\begin{array}{r}9.70 \\
5.40 \\
384.00 \\
294.00 \\
121.00\end{array}$ & $\begin{array}{r}<.54 \\
<.54 \\
.80 \\
.54 \\
<.45\end{array}$ & $\begin{array}{r}<1.10 \\
<1.10 \\
<.57 \\
<.54 \\
<.45\end{array}$ & $\begin{array}{r}4.00 \\
4.30 \\
229.20 \\
25.00 \\
219.00\end{array}$ & $\begin{array}{l}1,600 \\
1,300 \\
6,080 \\
6,270 \\
5,540\end{array}$ & $\begin{array}{l}2.60 \\
1.10 \\
6.82 \\
6.52 \\
7.27\end{array}$ & $\begin{array}{l}160.0 \\
230.0 \\
<5.7 \\
<5.4 \\
<4.5\end{array}$ \\
\hline $\begin{array}{l}87544 \\
87549 \\
87425 \\
278 \\
87546\end{array}$ & $\begin{array}{l}07 / 14 / 87 \\
07 / 14 / 87 \\
06 / 29 / 87 \\
09 / 23 / 86 \\
07 / 14 / 87\end{array}$ & $\begin{array}{lll}\text { CARSON } & \text { L., } & \text { DOWNS DRAIN } \\
\text { CARSON } & \text { L., } & \text { HOLNES DEEP DR } \\
\text { CARSON } & \text { L., } & \text { JI DEEP DRAIN } \\
\text { CARSON } & \text { L., SPRIG PONDS } \\
\text { CARSON } & \text { L., } & \text { YARBROUGH DR. }\end{array}$ & $\begin{array}{l}\text { PLANT } \\
\text { PLANT } \\
\text { PLANT } \\
\text { PLANT } \\
\text { PLANT }\end{array}$ & $\begin{array}{l}\text { PONDWEED } \\
\text { PONDWEED } \\
\text { PONDWEED } \\
\text { PONDWEED } \\
\text { PONDWEED }\end{array}$ & $\begin{array}{r}261.00 \\
148.00 \\
104.00 \\
33.00 \\
130.00\end{array}$ & $\begin{array}{r}<.57 \\
.71 \\
.62 \\
<.88 \\
<1.16\end{array}$ & $\begin{array}{r}<.57 \\
<.40 \\
<.45 \\
<1.80 \\
<1.16\end{array}$ & $\begin{array}{l}40.20 \\
19.90 \\
39.70 \\
23.00 \\
31.90\end{array}$ & $\begin{array}{l}9,380 \\
8,530 \\
5,150 \\
5,500 \\
5,910\end{array}$ & $\begin{array}{r}8.18 \\
4.13 \\
<4.50 \\
4.00 \\
<11.60\end{array}$ & $\begin{array}{r}<5.7 \\
<4.0 \\
<4.5 \\
79.0 \\
<11.6\end{array}$ \\
\hline $\begin{array}{r}224 \\
87492 \\
87451 \\
87458 \\
87523\end{array}$ & $\begin{array}{l}09 / 22 / 86 \\
07 / 06 / 87 \\
07 / 01 / 87 \\
07 / 01 / 87 \\
07 / 09 / 87\end{array}$ & $\begin{array}{l}\text { CARSON VALLEY } \\
\text { ERB DEEP DRAIN } \\
\text { FERNLEY WMA } \\
\text { FERNLEY WMA } \\
\text { HWMA, CARPENTER RD. DRAIN }\end{array}$ & $\begin{array}{l}\text { PLANT } \\
\text { PLANT } \\
\text { PLANT } \\
\text { PLANT } \\
\text { PLANT }\end{array}$ & $\begin{array}{l}\text { PONDWEED } \\
\text { PONDWEED } \\
\text { PONDWEED } \\
\text { PONDWEED } \\
\text { PONDWEED }\end{array}$ & $\begin{array}{r}37.00 \\
215.00 \\
294.00 \\
136.00 \\
28.90\end{array}$ & $\begin{array}{l}<.98 \\
<.57 \\
.96 \\
1.08 \\
<.36\end{array}$ & $\begin{array}{r}<2.00 \\
<.57 \\
<.39 \\
<.42 \\
<.36\end{array}$ & $\begin{array}{l}15.00 \\
12.90 \\
25.70 \\
26.40 \\
31.00\end{array}$ & $\begin{array}{l}2,100 \\
5,260 \\
4,860 \\
4,830 \\
2,920\end{array}$ & $\begin{array}{r}2.40 \\
6.02 \\
<4.00 \\
5.08 \\
<3.60\end{array}$ & $\begin{array}{l}150.0 \\
<5.7 \\
<4.0 \\
<4.2 \\
<3.7\end{array}$ \\
\hline $\begin{array}{l}87513 \\
87474 \\
87465 \\
87475 \\
87506\end{array}$ & $\begin{array}{l}07 / 09 / 87 \\
07 / 02 / 87 \\
07 / 02 / 87 \\
07 / 02 / 87 \\
07 / 08 / 87\end{array}$ & $\begin{array}{l}\text { HWMA, SEVENTEEN DITCH } \\
\text { HWMA, SO. MERIDIAN RD.DR. } \\
\text { HWMA, TOULON LAKE } \\
\text { HWMA, UPPER ARMY DRAIN } \\
\text { MASSIE SLOUGH }\end{array}$ & $\begin{array}{l}\text { PLANT } \\
\text { PLANT } \\
\text { PLANT } \\
\text { PLANT } \\
\text { PLANT }\end{array}$ & $\begin{array}{l}\text { PONDWEED } \\
\text { PONDWEED } \\
\text { PONDWEED } \\
\text { PONDWEED } \\
\text { PONDWEED }\end{array}$ & $\begin{array}{r}1.53 \\
163.00 \\
81.50 \\
129.00 \\
52.20\end{array}$ & $\begin{aligned}<.38 \\
.73 \\
<.52 \\
<.40 \\
.37\end{aligned}$ & $\begin{array}{l}<.38 \\
<.30 \\
<.52 \\
3.84 \\
<.37\end{array}$ & $\begin{array}{l}24.20 \\
70.70 \\
17.00 \\
20.70 \\
11.40\end{array}$ & $\begin{array}{r}6,580 \\
8,290 \\
10,500 \\
7,780 \\
4,610\end{array}$ & $\begin{array}{r}<3.82 \\
<3.05 \\
<5.15 \\
7.28 \\
4.85\end{array}$ & $\begin{array}{l}<3.8 \\
<3.0 \\
<5.2 \\
<4.0 \\
<3.7\end{array}$ \\
\hline $\begin{array}{r}87582 \\
163 \\
166 \\
171 \\
87528\end{array}$ & $\begin{array}{l}07 / 20 / 87 \\
09 / 16 / 86 \\
09 / 16 / 86 \\
09 / 16 / 86 \\
07 / 13 / 87\end{array}$ & $\begin{array}{l}\text { MASSIE SLOUGH } \\
\text { SWMA, ALKALI UN. } 1 \\
\text { SWMA, ALKALI UN. I } \\
\text { SWMA, ALKALI UN. 1 } \\
\text { SWMA, SHAFFNER DR., IND.L. }\end{array}$ & $\begin{array}{l}\text { PLANT } \\
\text { PLANT } \\
\text { PLANT } \\
\text { PLANT } \\
\text { PLANT }\end{array}$ & $\begin{array}{l}\text { PONDWEED } \\
\text { PONDWEED } \\
\text { PONDWEED } \\
\text { PONDWEED } \\
\text { PONDWEED }\end{array}$ & $\begin{array}{r}85.30 \\
89.00 \\
100.00 \\
86.00 \\
125.00\end{array}$ & $\begin{array}{l}.39 \\
<.62 \\
<.70 \\
<.77 \\
<.56\end{array}$ & $\begin{aligned}<.39 \\
<1.20 \\
<1.40 \\
<1.50 \\
<.56\end{aligned}$ & $\begin{array}{r}7.75 \\
5.10 \\
3.40 \\
1.80 \\
12.30\end{array}$ & $\begin{array}{l}5,360 \\
3,900 \\
3,700 \\
3,000 \\
4,170\end{array}$ & $\begin{array}{r}<3.87 \\
2.50 \\
3.70 \\
2.00 \\
<5.56\end{array}$ & $\begin{array}{l}<3.9 \\
540.0 \\
450.0 \\
340.0 \\
<5.6\end{array}$ \\
\hline $\begin{array}{r}179 \\
180 \\
181 \\
87561 \\
85021\end{array}$ & $\begin{array}{l}09 / 16 / 86 \\
09 / 16 / 86 \\
09 / 16 / 86 \\
07 / 16 / 87 \\
07 / 29 / 85\end{array}$ & $\begin{array}{l}\text { SWMA, STILLWATER PT. RES. } \\
\text { SWMA, STILLWATER PT. RES. } \\
\text { SWMA, STILLWATER PT. RES. } \\
\text { SWMA, SWAN L. CHECK } \\
\text { CARSON L., CARSON I DRAIN }\end{array}$ & $\begin{array}{l}\text { PLANT } \\
\text { PLANT } \\
\text { PLANT } \\
\text { PLANT } \\
\text { PLANT }\end{array}$ & $\begin{array}{l}\text { PONDWEED } \\
\text { PONDWEED } \\
\text { PONDWEED } \\
\text { PONDWEED } \\
\text { PONDWEED }\end{array}$ & $\begin{array}{l}57.00 \\
60.00 \\
80.00 \\
54.90 \\
--\end{array}$ & $\begin{array}{l}<.72 \\
<.75 \\
<.63 \\
<.33 \\
--\end{array}$ & $\begin{array}{r}<1.40 \\
<1.50 \\
<1.30 \\
<.33 \\
.30\end{array}$ & $\begin{array}{r}6.50 \\
6.90 \\
3.80 \\
6.51 \\
22.60\end{array}$ & $\begin{array}{r}3,900 \\
3,700 \\
3,500 \\
10,800 \\
--\end{array}$ & $\begin{array}{r}6.80 \\
3.40 \\
<1.30 \\
12.00 \\
4.90\end{array}$ & $\begin{array}{r}610.0 \\
480.0 \\
720.0 \\
<3.3 \\
--\end{array}$ \\
\hline $\begin{array}{l}85022 \\
85019 \\
85020 \\
85017 \\
85018\end{array}$ & $\begin{array}{l}07 / 29 / 85 \\
07 / 29 / 85 \\
07 / 29 / 85 \\
07 / 29 / 85 \\
07 / 29 / 85\end{array}$ & $\begin{array}{l}\text { CARSON L., CARSON I DRAIN } \\
\text { SWMA, STILLWWATER PT. RES. } \\
\text { SWMA, STILLWATER PT. RES. } \\
\text { SWMAA, TJ DRAIN } \\
\text { SWMA, TJ DRAIN }\end{array}$ & $\begin{array}{l}\text { PLANT } \\
\text { PLANT } \\
\text { PLANT } \\
\text { PLANT } \\
\text { PLANT }\end{array}$ & $\begin{array}{l}\text { PONDWEED } \\
\text { PONDWEED } \\
\text { PONDWEED } \\
\text { PONDWEED } \\
\text { PONDWEED }\end{array}$ & $\begin{array}{l}=- \\
=- \\
=-\end{array}$ & $\begin{array}{l}=- \\
=- \\
=-\end{array}$ & $\begin{array}{r}.30 \\
<.20 \\
<.20 \\
.40 \\
.70\end{array}$ & $\begin{array}{r}29.00 \\
8.20 \\
11.50 \\
10.70 \\
14.80\end{array}$ & $\begin{array}{l}=- \\
\overline{--} \\
=-\end{array}$ & $\begin{array}{l}5.10 \\
2.00 \\
2.20 \\
7.40 \\
9.80\end{array}$ & 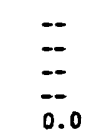 \\
\hline
\end{tabular}


TABLE 19.--Data on trace-element constituents and percent molsture of biological samples in stillwater Wildife Management Area, Carson Lake, Fernley Wildlife Management Area, and Humboldt Wildilfe Management Area, igb5-87--Cont.

\begin{tabular}{|c|c|c|c|c|c|c|c|c|c|c|c|c|}
\hline $\begin{array}{l}\text { USFWS } \\
\text { local } \\
\text { ID } \\
\text { number }\end{array}$ & Date & & Location & $\begin{array}{l}\text { Cate- } \\
\text { gory }\end{array}$ & Species & $\begin{array}{l}\text { Vana- } \\
\text { dium }\end{array}$ & Zine & $\begin{array}{c}\text { Alu- } \\
\text { minum }\end{array}$ & Iron & $\begin{array}{l}\text { Man- } \\
\text { ganese }\end{array}$ & Nickel & $\begin{array}{l}\text { Stron- } \\
\text { tium }\end{array}$ \\
\hline $\begin{array}{l}17 \\
18 \\
19 \\
20 \\
21\end{array}$ & $\begin{array}{l}06 / 17 / 86 \\
06 / 17 / 86 \\
06 / 17 / 86 \\
06 / 17 / 86 \\
06 / 17 / 86\end{array}$ & $\begin{array}{l}\text { CARSON } \\
\text { CARSON } \\
\text { CARSON } \\
\text { CARSON } \\
\text { CARSON }\end{array}$ & $\begin{array}{l}\text { L.” ISLANDS UNIT } \\
\text { L.: ISLANDS UNIT } \\
\text { L.: ISLANDS UNIT } \\
\text { L.: ISLANDS UNIT } \\
\text { L.. ISLANDS UNIT }\end{array}$ & $\begin{array}{l}\text { BIRD } \\
\text { BIRD } \\
\text { BIRD } \\
\text { BIRD } \\
\text { BIRD }\end{array}$ & $\begin{array}{l}\text { AVOCET } \\
\text { AVOCET } \\
\text { AVOCET } \\
\text { AVOCET } \\
\text { AVOCET }\end{array}$ & $\begin{array}{r}<0.38 \\
<.37 \\
<.36 \\
<.40 \\
<.37\end{array}$ & $\begin{array}{r}76.0 \\
97.0 \\
110.0 \\
88.0 \\
81.0\end{array}$ & $\begin{array}{r}10.0 \\
18.0 \\
18.0 \\
8.4 \\
16.0\end{array}$ & $\begin{array}{l}610 \\
820 \\
870 \\
630 \\
600\end{array}$ & $\begin{array}{l}11.0 \\
15.0 \\
14.0 \\
14.0 \\
13.0\end{array}$ & $\begin{array}{l}<1.20 \\
<1.10 \\
<1.10 \\
<1.20 \\
<1.10\end{array}$ & $\begin{array}{r}<0.38 \\
<.37 \\
<.36 \\
<.40 \\
<.37\end{array}$ \\
\hline $\begin{array}{l}22 \\
23 \\
25 \\
26 \\
32\end{array}$ & $\begin{array}{l}06 / 17 / 86 \\
06 / 17 / 86 \\
06 / 20 / 86 \\
06 / 20 / 86 \\
06 / 24 / 86\end{array}$ & $\begin{array}{l}\text { CARSON } \\
\text { CARSON } \\
\text { CARSON } \\
\text { CARSON } \\
\text { CARSON }\end{array}$ & $\begin{array}{l}\text { I.. SPRIG PONDS } \\
\text { L.. SPRIG PCNDS } \\
\text { L.: SPRIG PONDS } \\
\text { L.. SPRIG PONDS } \\
\text { L.: SPRIG PONDS }\end{array}$ & $\begin{array}{l}\text { BIRD } \\
\text { BIRD } \\
\text { BIRD } \\
\text { BIRD } \\
\text { BIRD }\end{array}$ & $\begin{array}{l}\text { AVOCET } \\
\text { AVOCET } \\
\text { AVOCET } \\
\text { AVOCET } \\
\text { AVOCET }\end{array}$ & $\begin{array}{l}<.32 \\
<.37 \\
<.50 \\
<.54 \\
<.36\end{array}$ & $\begin{array}{r}83.0 \\
75.0 \\
100.0 \\
97.0 \\
95.0\end{array}$ & $\begin{array}{r}8.7 \\
20.0 \\
7.5 \\
21.0 \\
13.0\end{array}$ & $\begin{array}{l}370 \\
440 \\
430 \\
390 \\
500\end{array}$ & $\begin{array}{l}13.0 \\
13.0 \\
16.0 \\
16.0 \\
14.0\end{array}$ & $\begin{array}{r}<0.96 \\
<1.10 \\
2.60 \\
<1.60 \\
<1.10\end{array}$ & $\begin{array}{l}<.32 \\
<.37 \\
<.50 \\
<.54 \\
<.36\end{array}$ \\
\hline $\begin{array}{l}27 \\
28 \\
29 \\
30 \\
31\end{array}$ & $\begin{array}{l}06 / 20 / 86 \\
06 / 20 / 86 \\
06 / 20 / 86 \\
06 / 20 / 86 \\
06 / 24 / 86\end{array}$ & $\begin{array}{l}\text { CARSON } \\
\text { CARSON } \\
\text { CARSON } \\
\text { CARSON } \\
\text { CARSON }\end{array}$ & $\begin{array}{ll}1 . . & \text { SUMP } \\
1 . & \text { SUMP } \\
1 . & \text { SUMP } \\
1 . & \text { SUMP } \\
1 . & \text { SUMP }\end{array}$ & $\begin{array}{l}\text { BIRD } \\
\text { BIRD } \\
\text { BIRD } \\
\text { BIRD } \\
\text { BIRD }\end{array}$ & $\begin{array}{l}\text { AVOCET } \\
\text { AVOCET } \\
\text { AVOCET } \\
\text { AVOCET } \\
\text { AVOCET }\end{array}$ & $\begin{array}{l}<.37 \\
<.41 \\
<.46 \\
<.36 \\
-.-\end{array}$ & $\begin{array}{r}130.0 \\
110.0 \\
90.0 \\
110.0 \\
-\end{array}$ & $\begin{array}{r}21.0 \\
7.0 \\
<4.6 \\
29.0 \\
-0\end{array}$ & $\begin{array}{r}1,200 \\
800 \\
720 \\
880 \\
--\end{array}$ & $\begin{array}{r}18.0 \\
16.0 \\
15.0 \\
17.0 \\
-0\end{array}$ & $\begin{array}{c}<1.10 \\
<1.20 \\
<1.40 \\
<1.10 \\
--\end{array}$ & $\begin{array}{l}<.37 \\
<.41 \\
<.46 \\
<.36 \\
-.\end{array}$ \\
\hline $\begin{array}{r}87628 \\
87650 \\
43 \\
44 \\
45\end{array}$ & $\begin{array}{l}08 / 06 / 87 \\
08 / 10 / 87 \\
07 / 10 / 86 \\
07 / 10 / 86 \\
07 / 10 / 86\end{array}$ & $\begin{array}{l}\text { CARSON } \\
\text { CARSON } \\
\text { CARSON } \\
\text { CARSON } \\
\text { CARSON }\end{array}$ & $\begin{array}{l}\text { L., ISIAANDS UNIT } \\
\text { I.., ISLANDS UNIT } \\
\text { I.., ISLANDS UNIT } \\
\text { I.., ISLANDS UNIT } \\
\text { I., ISLANDS UNIT }\end{array}$ & $\begin{array}{l}\text { BIRD } \\
\text { BIRD } \\
\text { BIRD } \\
\text { BIRD } \\
\text { BIRD }\end{array}$ & $\begin{array}{l}\text { BN STILT } \\
\text { BN STILT } \\
\text { BN STILT } \\
\text { BN STILT } \\
\text { BN STILT }\end{array}$ & $\begin{array}{l}<.30 \\
<.30 \\
<.36 \\
<.35 \\
<.33\end{array}$ & $\begin{array}{r}66.1 \\
85.7 \\
110.0 \\
98.0 \\
99.0\end{array}$ & $\begin{array}{r}<3.0 \\
<3.0 \\
6.1 \\
93.0 \\
8.9\end{array}$ & $\begin{array}{r}837 \\
1,460 \\
940 \\
770 \\
920\end{array}$ & $\begin{array}{r}9.0 \\
16.0 \\
17.0 \\
17.0 \\
14.0\end{array}$ & $\begin{array}{l}<1.00 \\
<1.00 \\
<1.10 \\
<1.00 \\
<.99\end{array}$ & $\begin{array}{r}.48 \\
.97 \\
<.36 \\
<.35 \\
<.33\end{array}$ \\
\hline $\begin{array}{r}46 \\
47 \\
87610 \\
87611 \\
48\end{array}$ & $\begin{array}{l}07 / 10 / 86 \\
07 / 10 / 86 \\
07 / 30 / 87 \\
07 / 30 / 87 \\
07 / 10 / 86\end{array}$ & $\begin{array}{l}\text { CARSON } \\
\text { CARSON } \\
\text { CARSON } \\
\text { CARSON } \\
\text { CARSON }\end{array}$ & $\begin{array}{l}\text { L.., ISLANDS UNIT } \\
\text { L.: ISLANDS UNIT } \\
\text { L.: ISLANDS UNIT } \\
\text { L.., ISLANDS UNIT } \\
\text { L., SPRIG PONDS }\end{array}$ & $\begin{array}{l}\text { BIRD } \\
\text { BIRD } \\
\text { BIRD } \\
\text { BIRD } \\
\text { BIRD }\end{array}$ & $\begin{array}{l}\text { BN STILT } \\
\text { BN STILT } \\
\text { BN STILT } \\
\text { BN STILT } \\
\text { BN STILT }\end{array}$ & $\begin{array}{l}<.36 \\
<.35 \\
<.30 \\
<.30 \\
<.35\end{array}$ & $\begin{array}{r}93.0 \\
100.0 \\
90.0 \\
95.4 \\
84.0\end{array}$ & $\begin{array}{r}20.0 \\
24.0 \\
4.0 \\
7.0 \\
12.0\end{array}$ & $\begin{array}{r}660 \\
770 \\
1,500 \\
633 \\
640\end{array}$ & $\begin{array}{l}18.0 \\
19.0 \\
14.0 \\
15.0 \\
16.0\end{array}$ & $\begin{array}{r}<1.10 \\
9.80 \\
<1.00 \\
<1.00 \\
<1.00\end{array}$ & $\begin{array}{l}<.36 \\
<.35 \\
1.20 \\
1.50 \\
<.35\end{array}$ \\
\hline $\begin{array}{r}49 \\
50 \\
68 \\
71 \\
87621\end{array}$ & $\begin{array}{l}07 / 10 / 86 \\
07 / 11 / 86 \\
07 / 15 / 86 \\
07 / 16 / 86 \\
08 / 04 / 87\end{array}$ & $\begin{array}{l}\text { CARSON } \\
\text { CARSON } \\
\text { CARSON } \\
\text { CARSON } \\
\text { CARSON }\end{array}$ & $\begin{array}{l}\text { L., SPRIG PONDS } \\
\text { L.., SPRIG PONDS } \\
\text { L.: SPRIG PONDS } \\
\text { I.: SPRIG PONDS } \\
\text { L.. SPRIG PONDS }\end{array}$ & $\begin{array}{l}\text { BIRD } \\
\text { BIRD } \\
\text { BIRD } \\
\text { BIRD } \\
\text { BIRD }\end{array}$ & $\begin{array}{l}\text { BN STILT } \\
\text { BN STILT } \\
\text { BN STILT } \\
\text { BN STILT } \\
\text { BN STILT }\end{array}$ & $\begin{array}{l}<.34 \\
<.35 \\
<.34 \\
<.34 \\
<.30\end{array}$ & $\begin{array}{r}81.0 \\
38.0 \\
95.0 \\
110.0 \\
100.0\end{array}$ & $\begin{array}{r}9.8 \\
11.0 \\
11.0 \\
11.0 \\
<3.0\end{array}$ & $\begin{array}{r}740 \\
490 \\
1,400 \\
1,100 \\
962\end{array}$ & $\begin{array}{r}15.0 \\
8.9 \\
15.0 \\
19.0 \\
16.0\end{array}$ & $\begin{array}{l}<1.00 \\
<1.00 \\
<1.00 \\
<1.00 \\
<1.00\end{array}$ & $\begin{array}{l}<.34 \\
<.35 \\
<.34 \\
<.34 \\
.63\end{array}$ \\
\hline $\begin{array}{r}87626 \\
87627 \\
87684 \\
51 \\
52\end{array}$ & $\begin{array}{l}08 / 06 / 87 \\
08 / 06 / 87 \\
08 / 24 / 87 \\
07 / 11 / 86 \\
07 / 11 / 86\end{array}$ & $\begin{array}{l}\text { CARSON } \\
\text { CARSON } \\
\text { CARSON } \\
\text { CARSON } \\
\text { CARSON }\end{array}$ & $\begin{array}{l}\text { I., SPRIG PONDS } \\
\text { L.. SPRIG PONDS } \\
\text { L.: SPRIG PONDS } \\
\text { L.., SUMP } \\
\text { L., SUMP }\end{array}$ & $\begin{array}{l}\text { BIRD } \\
\text { BIRD } \\
\text { BIRD } \\
\text { BIRD } \\
\text { BIRD }\end{array}$ & $\begin{array}{l}\text { BN STILT } \\
\text { BN STILT } \\
\text { BN STILT } \\
\text { BN STILT } \\
\text { BN STILT }\end{array}$ & $\begin{array}{l}<.40 \\
<.30 \\
<.30 \\
<.34 \\
<.36\end{array}$ & $\begin{array}{r}92.4 \\
89.1 \\
77.3 \\
100.0 \\
94.0\end{array}$ & $\begin{array}{r}<3.0 \\
<3.0 \\
4.0 \\
25.0 \\
30.0\end{array}$ & $\begin{array}{r}542 \\
1,300 \\
862 \\
940 \\
1,200\end{array}$ & $\begin{array}{l}15.0 \\
14.0 \\
12.0 \\
15.0 \\
16.0\end{array}$ & $\begin{array}{l}<1.00 \\
<1.00 \\
<1.00 \\
<1.00 \\
<1.10\end{array}$ & $\begin{array}{r}.67 \\
.76 \\
.32 \\
<.34 \\
<.36\end{array}$ \\
\hline $\begin{array}{l}53 \\
63 \\
64 \\
98 \\
99\end{array}$ & $\begin{array}{l}07 / 11 / 86 \\
07 / 15 / 86 \\
07 / 15 / 86 \\
07 / 31 / 86 \\
07 / 31 / 86\end{array}$ & $\begin{array}{l}\text { CARSON } \\
\text { CARSON } \\
\text { CARSON } \\
\text { FERNLEY } \\
\text { FERNLEY }\end{array}$ & $\begin{array}{l}\text { I., SUMP } \\
\text { L., SUMP } \\
\text { L.” SUMP } \\
\text { Y WMA } \\
Y \text { WMA }\end{array}$ & $\begin{array}{l}\text { BIRD } \\
\text { BIRD } \\
\text { BIRD } \\
\text { BIRD } \\
\text { BIRD }\end{array}$ & $\begin{array}{l}\text { BN STILT } \\
\text { BN STILT } \\
\text { BN STILT } \\
\text { BN STILT } \\
\text { BN STILT }\end{array}$ & $\begin{array}{l}<.35 \\
<.35 \\
<.36 \\
<.35 \\
<.34\end{array}$ & $\begin{array}{r}130.0 \\
90.0 \\
100.0 \\
92.0 \\
110.0\end{array}$ & $\begin{array}{r}15.0 \\
11.0 \\
9.1 \\
16.0 \\
15.0\end{array}$ & $\begin{array}{l}1,200 \\
2,600 \\
1,600 \\
2,800 \\
1,400\end{array}$ & $\begin{array}{l}17.0 \\
15.0 \\
17.0 \\
14.0 \\
15.0\end{array}$ & $\begin{array}{r}<1.10 \\
<1.00 \\
<1.10 \\
1.50 \\
20.00\end{array}$ & $\begin{array}{l}<.35 \\
<.35 \\
<.36 \\
<.35 \\
<.34\end{array}$ \\
\hline $\begin{array}{r}100 \\
116 \\
117 \\
87663 \\
123\end{array}$ & $\begin{array}{l}07 / 31 / 86 \\
08 / 03 / 86 \\
08 / 03 / 86 \\
08 / 12 / 87 \\
08 / 04 / 86\end{array}$ & $\begin{array}{l}\text { FERNLEY } \\
\text { FERNLEY } \\
\text { FERNLEY } \\
\text { FERNLEY } \\
\text { HWMA, H }\end{array}$ & $\begin{array}{ll}Y & \text { WMA } \\
Y & \text { WMA } \\
Y & \text { WMA } \\
Y & \text { WMA } \\
\text { HUMBOLDT LAKE }\end{array}$ & $\begin{array}{l}\text { BIRD } \\
\text { BIRD } \\
\text { BIRD } \\
\text { BIRD } \\
\text { BIRD }\end{array}$ & $\begin{array}{l}\text { BN STILT } \\
\text { BN STILT } \\
\text { BN STILT } \\
\text { BN STILT } \\
\text { BN STILT }\end{array}$ & $\begin{array}{l}<.34 \\
<.35 \\
<.34 \\
<.30 \\
<.36\end{array}$ & $\begin{array}{r}81.0 \\
83.0 \\
88.0 \\
75.8 \\
110.0\end{array}$ & $\begin{array}{r}7.1 \\
8.7 \\
8.5 \\
<3.0 \\
6.9\end{array}$ & $\begin{array}{r}1,100 \\
1,000 \\
1,100 \\
653 \\
1,100\end{array}$ & $\begin{array}{l}13.0 \\
18.0 \\
15.0 \\
12.0 \\
15.0\end{array}$ & $\begin{array}{l}<1.00 \\
<1.00 \\
<1.00 \\
<1.00 \\
<1.10\end{array}$ & $\begin{array}{r}<.34 \\
<.35 \\
<.34 \\
.96 \\
<.36\end{array}$ \\
\hline $\begin{array}{r}124 \\
125 \\
126 \\
127 \\
87612\end{array}$ & $\begin{array}{l}08 / 04 / 86 \\
08 / 04 / 86 \\
08 / 04 / 86 \\
08 / 04 / 86 \\
07 / 30 / 87\end{array}$ & $\begin{array}{ll}\text { HWMA, } & \text { H } \\
\text { HWMA, H } \\
\text { HWMA, H } \\
\text { HWMA, H } \\
\text { HWMA, H }\end{array}$ & $\begin{array}{ll}\text { HUMBOLDT } & \text { LAKE } \\
\text { HUMBOLDT } & \text { LAKE } \\
\text { HUMBOLDT } & \text { IAKE } \\
\text { HUMBOLDT } & \text { LAKE } \\
\text { HUMBOLDT } & \text { LAKE }\end{array}$ & $\begin{array}{l}\text { BIRD } \\
\text { BIRD } \\
\text { BIRD } \\
\text { BIRD } \\
\text { BIRD }\end{array}$ & $\begin{array}{l}\text { BN STILT } \\
\text { BN STIIT } \\
\text { BN STILT } \\
\text { BN STIII } \\
\text { BN STILT }\end{array}$ & $\begin{array}{l}<.38 \\
<.40 \\
<.42 \\
<.53 \\
<.30\end{array}$ & $\begin{array}{r}98.0 \\
81.0 \\
120.0 \\
82.0 \\
100.0\end{array}$ & $\begin{array}{r}7.2 \\
25.0 \\
21.0 \\
10.0 \\
<3.0\end{array}$ & $\begin{array}{r}1,100 \\
890 \\
1,000 \\
730 \\
1,020\end{array}$ & $\begin{array}{l}16.0 \\
17.0 \\
16.0 \\
12.0 \\
14.0\end{array}$ & $\begin{array}{l}<1.10 \\
<1.20 \\
<1.30 \\
<1.60 \\
<1.00\end{array}$ & $\begin{array}{l}<.38 \\
<.40 \\
<.42 \\
<.53 \\
1.20\end{array}$ \\
\hline $\begin{array}{l}87613 \\
87614 \\
87668 \\
87669 \\
87664\end{array}$ & $\begin{array}{l}07 / 30 / 87 \\
07 / 30 / 87 \\
08 / 12 / 87 \\
08 / 12 / 87 \\
08 / 12 / 87\end{array}$ & $\begin{array}{ll}\text { HWMA, } & \text { H } \\
\text { HWMA, H } \\
\text { HWMA, H } \\
\text { HWMA, H } \\
\text { HWMA, }\end{array}$ & $\begin{array}{l}\text { HUMBOLDT LAKE } \\
\text { HUMBOLDT LAKE } \\
\text { HUMBOLDT LAKE } \\
\text { HUMBOLDT LAKE } \\
\text { TOULON LAKE }\end{array}$ & $\begin{array}{l}\text { BIRD } \\
\text { BIRD } \\
\text { BIRD } \\
\text { BIRD } \\
\text { BIRD }\end{array}$ & $\begin{array}{l}\text { BN STILI } \\
\text { BN STILT } \\
B N \text { STIIT } \\
\text { BN STILT } \\
\text { BN STILT }\end{array}$ & $\begin{array}{l}<.30 \\
<.30 \\
<.30 \\
<.30 \\
<.30\end{array}$ & $\begin{array}{l}96.7 \\
86.0 \\
87.7 \\
93.8 \\
88.1\end{array}$ & $\begin{array}{r}<3.0 \\
5.0 \\
<3.0 \\
<3.0 \\
<3.0\end{array}$ & $\begin{array}{r}798 \\
1,070 \\
771 \\
941 \\
918\end{array}$ & $\begin{array}{l}14.0 \\
11.0 \\
12.0 \\
13.0 \\
12.0\end{array}$ & $\begin{array}{l}<1.00 \\
<1.00 \\
<1.00 \\
<1.00 \\
<1.00\end{array}$ & $\begin{array}{r}.94 \\
.30 \\
.32 \\
.39 \\
1.20\end{array}$ \\
\hline $\begin{array}{r}87665 \\
87666 \\
87667 \\
108 \\
109\end{array}$ & $\begin{array}{l}08 / 12 / 87 \\
08 / 12 / 87 \\
08 / 12 / 87 \\
07 / 31 / 86 \\
07 / 31 / 86\end{array}$ & $\begin{array}{l}\text { HWMA, T } \\
\text { HWMA, T } \\
\text { HWMA, T } \\
\text { SWMA, G } \\
\text { SWMA, G }\end{array}$ & $\begin{array}{l}\text { TOULON LAKE } \\
\text { TOULON LAKE } \\
\text { TOULON LAKE } \\
\text { GOOSE LAKE } \\
\text { GOOSE LAKE }\end{array}$ & $\begin{array}{l}\text { BIRD } \\
\text { BIRD } \\
\text { BIRD } \\
\text { BIRD } \\
\text { BIRD }\end{array}$ & $\begin{array}{l}\text { BN STILI } \\
\text { BN STILT } \\
\text { BN STILT } \\
\text { BN STILI } \\
\text { BN STILI }\end{array}$ & $\begin{array}{l}<.30 \\
<.30 \\
<.30 \\
-- \\
--\end{array}$ & $\begin{array}{r}88.0 \\
87.4 \\
88.0 \\
-- \\
--\end{array}$ & $\begin{array}{r}<3.0 \\
<3.0 \\
<3.0 \\
-. \\
--\end{array}$ & $\begin{array}{r}961 \\
1,130 \\
1,450 \\
=-\end{array}$ & $\begin{array}{r}15.0 \\
14.0 \\
13.0 \\
=- \\
=\end{array}$ & $\begin{array}{c}<1.00 \\
<1.00 \\
<1.00 \\
=- \\
--\end{array}$ & $\begin{array}{l}.96 \\
1.20 \\
.67 \\
.- \\
--\end{array}$ \\
\hline
\end{tabular}


TABLE 19.-Data on trace-element constituents and percent molsture of blological samples in stillwater Wildlife Management Area, Carson Lake, Fernley Wildlife Management Area, and Humboldt Wildife Management Area, I985-87--Cont.

\begin{tabular}{|c|c|c|c|c|c|c|c|c|c|c|c|c|}
\hline $\begin{array}{l}\text { USFWS } \\
\text { local } \\
\text { ID } \\
\text { number }\end{array}$ & Date & & Location & $\begin{array}{l}\text { Cate- } \\
\text { gory }\end{array}$ & Species & $\begin{array}{l}\text { Vana- } \\
\text { dium }\end{array}$ & Zinc & $\underset{\text { minum }}{\text { Alu- }}$ & Iron & $\begin{array}{c}\text { Man- } \\
\text { ganese }\end{array}$ & N1ckel & $\begin{array}{l}\text { Stron- } \\
\text { tium }\end{array}$ \\
\hline $\begin{array}{r}110 \\
111 \\
112 \\
87105 \\
87107\end{array}$ & $\begin{array}{l}07 / 31 / 86 \\
07 / 31 / 86 \\
07 / 31 / 86 \\
07 / 13 / 87 \\
07 / 13 / 87\end{array}$ & $\begin{array}{l}\text { SWMA, } \\
\text { SWMA, } \\
\text { SWMA, } \\
\text { SWMA, } \\
\text { SWMA, }\end{array}$ & $\begin{array}{l}\text { GOOSE LAKE } \\
\text { GOOSE LAKE } \\
\text { GOOSE LAKE } \\
\text { GOOSE LAKE } \\
\text { GOOSE LAKE }\end{array}$ & $\begin{array}{l}\text { BIRD } \\
\text { BIRD } \\
\text { BIRD } \\
\text { BIRD } \\
\text { BIRD }\end{array}$ & $\begin{array}{l}\text { BN STILT } \\
\text { BN STILT } \\
\text { BN STILT } \\
\text { BN STILT } \\
\text { BN STILT }\end{array}$ & $\begin{array}{c}-- \\
\overline{--} \\
<0.30 \\
<.30\end{array}$ & $\begin{array}{r}=- \\
\overline{--} \\
96.1 \\
70.5\end{array}$ & $\begin{array}{r}=- \\
=- \\
<3.0 \\
<3.0\end{array}$ & $\begin{array}{r}=- \\
=- \\
1,250 \\
1.060\end{array}$ & $\begin{array}{r}-- \\
-\overline{-} \\
13.0 \\
8.2\end{array}$ & $\begin{array}{c}-- \\
\overline{-} \\
<1.00 \\
<1.00\end{array}$ & $\begin{array}{l}=- \\
\overline{-} \\
1.90 \\
1.50\end{array}$ \\
\hline $\begin{array}{r}87109 \\
87111 \\
87116 \\
80 \\
82\end{array}$ & $\begin{array}{l}07 / 13 / 87 \\
07 / 13 / 87 \\
07 / 13 / 87 \\
07 / 24 / 86 \\
07 / 25 / 86\end{array}$ & $\begin{array}{l}\text { SWMA, } \\
\text { SWMA, } \\
\text { SWMA, } \\
\text { SWMA, I } \\
\text { SWMA, I }\end{array}$ & $\begin{array}{l}\text { GOOSE LAKE } \\
\text { GOOSE LAKE } \\
\text { GOOSE LAKE } \\
\text { LEAD LAKE } \\
\text { LEAD LAKE }\end{array}$ & $\begin{array}{l}\text { BIRD } \\
\text { BIRD } \\
\text { BIRD } \\
\text { BIRD } \\
\text { BIRD }\end{array}$ & $\begin{array}{l}\text { BN STILT } \\
\text { BN STILT } \\
\text { BN STILT } \\
\text { BN STILT } \\
\text { BN STILT }\end{array}$ & $\begin{array}{l}<.30 \\
<.30 \\
<.30 \\
-- \\
=-\end{array}$ & $\begin{array}{r}89.8 \\
98.2 \\
102.0 \\
=- \\
--\end{array}$ & $\begin{array}{r}3.0 \\
<3.0 \\
<3.0 \\
=-\end{array}$ & $\begin{array}{r}1,860 \\
1,700 \\
708 \\
-- \\
--\end{array}$ & $\begin{array}{r}11.0 \\
12.0 \\
12.0 \\
=-\end{array}$ & $\begin{array}{c}<1.00 \\
<1.00 \\
<1.00 \\
--\end{array}$ & $\begin{array}{l}2.10 \\
3.70 \\
1.80 \\
-- \\
--\end{array}$ \\
\hline $\begin{array}{r}96 \\
87685 \\
87090 \\
87092 \\
87094\end{array}$ & $\begin{array}{l}07 / 30 / 86 \\
08 / 19 / 87 \\
07 / 13 / 87 \\
07 / 13 / 87 \\
07 / 13 / 87\end{array}$ & $\begin{array}{l}\text { SWMA, I } \\
\text { SWMA, I } \\
\text { SWMA, P } \\
\text { SWMA, P } \\
\text { SWMA, E }\end{array}$ & $\begin{array}{l}\text { LEAD LAKE } \\
\text { LEAD LAKE } \\
\text { PINTAIL BAY } \\
\text { PINTAIL BAY } \\
\text { PINTAIL BAY }\end{array}$ & $\begin{array}{l}\text { BIRD } \\
\text { BIRD } \\
\text { BIRD } \\
\text { BIRD } \\
\text { BIRD }\end{array}$ & $\begin{array}{l}\text { BN STILT } \\
\text { BN STILT } \\
\text { BN STILT } \\
\text { BN STILT } \\
\text { BN STILT }\end{array}$ & $\begin{array}{l}-. \\
<.30 \\
<.30 \\
<.30 \\
<.30\end{array}$ & $\begin{array}{r}117.0 \\
91.8 \\
201.0 \\
97.3\end{array}$ & $\begin{array}{r}-- \\
<3.0 \\
<3.0 \\
<3.0 \\
<3.0\end{array}$ & $\begin{array}{r}1,310 \\
1,350 \\
898 \\
785\end{array}$ & $\begin{array}{l}-- \\
17.0 \\
12.0 \\
14.0 \\
14.0\end{array}$ & $\begin{array}{l}-- \\
<1.00 \\
<1.00 \\
<1.00 \\
<1.00\end{array}$ & $\begin{array}{l}-- \\
1.10 \\
2.40 \\
2.20 \\
1.90\end{array}$ \\
\hline $\begin{array}{r}87101 \\
101 \\
102 \\
87081 \\
87083\end{array}$ & $\begin{array}{l}07 / 13 / 87 \\
07 / 31 / 86 \\
07 / 31 / 86 \\
07 / 10 / 87 \\
07 / 10 / 87\end{array}$ & $\begin{array}{l}\text { SWMA, } \\
\text { SWMA, S } \\
\text { SWMA, S } \\
\text { SWMA, S } \\
\text { SWMA, S }\end{array}$ & $\begin{array}{l}\text { PINTAIL BAY } \\
\text { SOUTH LEAD LAKE } \\
\text { SOUTH LEAD LAKE } \\
\text { SOUTH LEAD LAKE } \\
\text { SOUTH LEAD LAKE }\end{array}$ & $\begin{array}{l}\text { BIRD } \\
\text { BIRD } \\
\text { BIRD } \\
\text { BIRD } \\
\text { BIRD }\end{array}$ & $\begin{array}{l}\text { BN STILT } \\
\text { BN STILT } \\
\text { BN STILT } \\
\text { BN STILT } \\
\text { BN STILT }\end{array}$ & $\begin{array}{l}<.30 \\
=- \\
<.30 \\
<.30\end{array}$ & $\begin{array}{r}95.0 \\
=- \\
101.0 \\
85.7\end{array}$ & $\begin{array}{r}6.0 \\
-- \\
6.0 \\
<3.0\end{array}$ & $\begin{array}{r}1,120 \\
=- \\
616 \\
1,090\end{array}$ & $\begin{array}{r}14.0 \\
=- \\
14.0 \\
11.0\end{array}$ & $\begin{array}{c}<1.00 \\
=-- \\
<1.00 \\
<1.00\end{array}$ & $\begin{array}{l}1.90 \\
=- \\
2.60 \\
1.80\end{array}$ \\
\hline $\begin{array}{l}87085 \\
87086 \\
87120 \\
87125 \\
87401\end{array}$ & $\begin{array}{l}07 / 10 / 87 \\
07 / 10 / 87 \\
07 / 20 / 87 \\
07 / 20 / 87 \\
04 / 09 / 87\end{array}$ & $\begin{array}{l}\text { SWMA, S } \\
\text { SWMA, S } \\
\text { SWMA, S } \\
\text { SWMA, S } \\
\text { CARSON }\end{array}$ & $\begin{array}{l}\text { SOUTH LEAD LAKE } \\
\text { SOUTH LEAD LAKE } \\
\text { SOUTH LEAD LAKE } \\
\text { SOUTH LEAD LAKE } \\
\text { N L., ISLANDS UNIT }\end{array}$ & $\begin{array}{l}\text { BIRD } \\
\text { BIRD } \\
\text { BIRD } \\
\text { BIRD } \\
\text { BIRD }\end{array}$ & $\begin{array}{l}\text { BN STILT } \\
\text { BN STILT } \\
\text { BN STILT } \\
\text { BN STILT } \\
\text { BN STILT AD }\end{array}$ & $\begin{array}{l}<.30 \\
<.30 \\
<.30 \\
<.30 \\
<.30\end{array}$ & $\begin{array}{r}82.0 \\
82.9 \\
103.0 \\
92.6 \\
73.6\end{array}$ & $\begin{array}{r}4.0 \\
<3.0 \\
<3.0 \\
<3.0 \\
4.0\end{array}$ & $\begin{array}{r}597 \\
786 \\
1,660 \\
1.170 \\
513\end{array}$ & $\begin{array}{l}11.0 \\
11.0 \\
13.0 \\
13.0 \\
11.0\end{array}$ & $\begin{array}{l}<1.00 \\
<1.00 \\
<1.00 \\
<1.00 \\
<1.00\end{array}$ & $\begin{array}{r}2.20 \\
.82 \\
1.90 \\
1.40 \\
.20\end{array}$ \\
\hline $\begin{array}{l}87402 \\
87403 \\
87404 \\
87405 \\
87104\end{array}$ & $\begin{array}{l}04 / 09 / 87 \\
04 / 09 / 87 \\
04 / 09 / 87 \\
04 / 09 / 87 \\
07 / 13 / 87\end{array}$ & $\begin{array}{l}\text { CARSON } \\
\text { CARSON } \\
\text { CARSON } \\
\text { CARSON } \\
\text { SWMA, }\end{array}$ & $\begin{array}{l}\text { L., ISLANDS UNIT } \\
\text { L., ISLANDS UNIT } \\
\text { L., ISLANDS UNIT } \\
\text { L..' ISLANDS UNIT } \\
\text { GOOSE LAKE }\end{array}$ & $\begin{array}{l}\text { BIRD } \\
\text { BIRD } \\
\text { BIRD } \\
\text { BIRD } \\
\text { BIRD }\end{array}$ & $\begin{array}{lll}\text { BN } & \text { STILT } & A D \\
\text { BN } & \text { STILT } & A D \\
\text { BN STILT } & A D \\
\text { SN } & \text { STILT } & A D \\
\text { BN STILT } & A D\end{array}$ & $\begin{array}{l}<.30 \\
<.30 \\
<.30 \\
<.30 \\
<.30\end{array}$ & $\begin{array}{l}84.9 \\
78.9 \\
71.6 \\
83.6 \\
85.1\end{array}$ & $\begin{array}{r}3.0 \\
3.0 \\
<3.0 \\
3.0 \\
<3.0\end{array}$ & $\begin{array}{r}535 \\
498 \\
1,240 \\
706 \\
643\end{array}$ & $\begin{array}{r}11.0 \\
11.0 \\
11.0 \\
13.0 \\
9.9\end{array}$ & $\begin{array}{l}<1.00 \\
<1.00 \\
<1.00 \\
<1.00 \\
<2.00\end{array}$ & $\begin{array}{l}.34 \\
.20 \\
.20 \\
.20 \\
.91\end{array}$ \\
\hline $\begin{array}{l}87113 \\
87114 \\
87115 \\
87089 \\
87095\end{array}$ & $\begin{array}{l}07 / 13 / 87 \\
07 / 13 / 87 \\
07 / 13 / 87 \\
07 / 13 / 87 \\
07 / 13 / 87\end{array}$ & $\begin{array}{l}\text { SWMA, C } \\
\text { SWMAA, } \\
\text { SWMA, } \\
\text { SWMA, } \\
\text { SWMA, F }\end{array}$ & $\begin{array}{l}\text { GOOSE LAKE } \\
\text { GOOSE LAKE } \\
\text { GOOSE LAKE } \\
\text { PINTAIL BAY } \\
\text { PINTAIL BAY }\end{array}$ & $\begin{array}{l}\text { BIRD } \\
\text { BIRD } \\
\text { BIRD } \\
\text { BIRD } \\
\text { BIRD }\end{array}$ & $\begin{array}{lll}\text { BN } & \text { STILT } & A D \\
\text { BN STILT } & A D \\
\text { BN STILT } & A D \\
\text { BN STILT } & A D \\
\text { BN STILT } & A D\end{array}$ & $\begin{array}{l}<.30 \\
<.30 \\
<.40 \\
<.30 \\
<.30\end{array}$ & $\begin{array}{r}91.2 \\
91.5 \\
92.6 \\
92.0 \\
100.0\end{array}$ & $\begin{array}{l}<3.0 \\
<3.0 \\
<4.0 \\
9.0 \\
<3.0\end{array}$ & $\begin{array}{r}1,340 \\
1,010 \\
986 \\
589 \\
1,230\end{array}$ & $\begin{array}{r}11.0 \\
10.0 \\
12.0 \\
14.0 \\
9.9\end{array}$ & $\begin{array}{l}<1.00 \\
<1.00 \\
<1.00 \\
<1.00 \\
<1.00\end{array}$ & $\begin{array}{r}.68 \\
.67 \\
.48 \\
.89 \\
2.00\end{array}$ \\
\hline $\begin{array}{l}87096 \\
87097 \\
87098 \\
87099 \\
87079\end{array}$ & $\begin{array}{l}07 / 13 / 87 \\
07 / 13 / 87 \\
07 / 13 / 87 \\
07 / 13 / 87 \\
07 / 10 / 87\end{array}$ & $\begin{array}{l}\text { SWMA, } \\
\text { SWMA, } \\
\text { SWMA, } \\
\text { SWMA, } \\
\text { SWMA, }\end{array}$ & $\begin{array}{l}\text { PINTAIL BAY } \\
\text { PINTAIL BAY } \\
\text { PINTAIL BAY } \\
\text { PINTAIL BAY } \\
\text { SOUTH IEAD LAKE }\end{array}$ & $\begin{array}{l}\text { BIRD } \\
\text { BIRD } \\
\text { BIRD } \\
\text { BIRD } \\
\text { BIRD }\end{array}$ & $\begin{array}{l}\text { BN STILT } \\
\text { SN } \\
\text { STILT } \\
\text { BN } \\
\text { STILT } \\
\text { BN } \\
\text { STILT } \\
\text { BN STILT } \\
\text { SD }\end{array}$ & $\begin{array}{l}<.30 \\
<.30 \\
<.30 \\
<.30 \\
<.30\end{array}$ & $\begin{array}{r}95.4 \\
105.0 \\
102.0 \\
109.0 \\
152.0\end{array}$ & $\begin{array}{l}4.0 \\
5.0 \\
3.0 \\
4.0 \\
6.0\end{array}$ & $\begin{array}{r}1,520 \\
1,550 \\
943 \\
865 \\
1,060\end{array}$ & $\begin{array}{l}14.0 \\
15.0 \\
14.0 \\
14.0 \\
14.0\end{array}$ & $\begin{array}{l}<1.00 \\
<1.00 \\
<1.00 \\
<1.00 \\
<1.00\end{array}$ & $\begin{array}{r}.83 \\
.83 \\
.39 \\
1.20 \\
1.10\end{array}$ \\
\hline $\begin{array}{l}87080 \\
87119 \\
87124 \\
87550 \\
87551\end{array}$ & $\begin{array}{l}07 / 10 / 87 \\
07 / 16 / 87 \\
07 / 20 / 87 \\
07 / 14 / 87 \\
07 / 14 / 87\end{array}$ & $\begin{array}{l}\text { SWMA, } \\
\text { SWMA, } \\
\text { SWMA, } \\
\text { CARSON } \\
\text { CARSON }\end{array}$ & $\begin{array}{l}\text { SOUTH LEAD LAKE } \\
\text { SOUTH LEAD LAKE } \\
\text { SOUTH LEAD LAKE } \\
\text { L., DOWNS DRAIN } \\
\text { L., DOWNS DRAIN }\end{array}$ & $\begin{array}{l}\text { BIRD } \\
\text { BIRD } \\
\text { BIRD } \\
\text { BIRD } \\
\text { BIRD }\end{array}$ & $\begin{array}{l}\text { BN STILT AD } \\
\text { BN STILT AD } \\
\text { BN STILT AD } \\
\text { COOT } \\
\text { COOT }\end{array}$ & $\begin{array}{r}<.30 \\
<.30 \\
<.30 \\
.30 \\
<.30\end{array}$ & $\begin{array}{r}108.0 \\
86.2 \\
85.8 \\
161.0 \\
192.0\end{array}$ & $\begin{array}{r}4.0 \\
<3.0 \\
6.0 \\
<3.0 \\
<3.0\end{array}$ & $\begin{array}{r}766 \\
3,480 \\
741 \\
1,150 \\
1,390\end{array}$ & $\begin{array}{r}13.0 \\
12.0 \\
12.0 \\
7.5 \\
9.3\end{array}$ & $\begin{array}{l}<1.00 \\
<1.00 \\
<1.00 \\
<1.00 \\
<1.00\end{array}$ & $\begin{array}{l}.66 \\
.57 \\
.74 \\
.60 \\
.59\end{array}$ \\
\hline $\begin{array}{r}87552 \\
87553 \\
87554 \\
87555 \\
6\end{array}$ & $\begin{array}{l}07 / 14 / 87 \\
07 / 14 / 87 \\
07 / 14 / 87 \\
07 / 14 / 87 \\
06 / 03 / 86\end{array}$ & $\begin{array}{l}\text { CARSON } \\
\text { CARSON } \\
\text { CARSON } \\
\text { CARSON } \\
\text { CARSON }\end{array}$ & 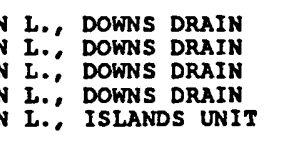 & $\begin{array}{l}\text { BIRD } \\
\text { BIRD } \\
\text { BIRD } \\
\text { BIRD } \\
\text { BIRD }\end{array}$ & $\begin{array}{l}\text { COOT } \\
\text { COOT } \\
\text { COOT } \\
\text { COOT } \\
\text { COOT }\end{array}$ & $\begin{array}{l}<.30 \\
<.30 \\
<.30 \\
<.30 \\
<.41\end{array}$ & $\begin{array}{l}156.0 \\
216.0 \\
215.0 \\
176.0 \\
150.0\end{array}$ & $\begin{array}{l}<3.0 \\
<3.0 \\
<3.0 \\
<3.0 \\
24.0\end{array}$ & $\begin{array}{l}1,100 \\
4,040 \\
1,590 \\
816 \\
1,400\end{array}$ & $\begin{array}{l}10.0 \\
12.0 \\
10.0 \\
10.0 \\
11.0\end{array}$ & $\begin{array}{l}<1.00 \\
<1.00 \\
<1.00 \\
<1.00 \\
<1.20\end{array}$ & $\begin{array}{r}.72 \\
.38 \\
.73 \\
.66 \\
1.70\end{array}$ \\
\hline $\begin{array}{r}7 \\
8 \\
9 \\
10 \\
87606\end{array}$ & $\begin{array}{l}06 / 03 / 86 \\
06 / 03 / 86 \\
06 / 03 / 86 \\
06 / 03 / 86 \\
07 / 30 / 87\end{array}$ & $\begin{array}{l}\text { CARSON } \\
\text { CARSON } \\
\text { CARSON } \\
\text { CARSON } \\
\text { CARSON }\end{array}$ & $\begin{array}{ll}N & \text { L., ISLANDS UNIT } \\
N & \mathrm{~L} \\
\mathrm{~N} \\
\mathrm{~N} \\
\mathrm{~N} \\
\mathrm{~N} \\
\mathrm{~N}\end{array}$ & $\begin{array}{l}\text { BIRD } \\
\text { BIRD } \\
\text { BIRD } \\
\text { BIRD } \\
\text { BIRD }\end{array}$ & $\begin{array}{l}\operatorname{cooT} \\
\operatorname{cooT} \\
\operatorname{cooT} \\
\operatorname{cooT} \\
\operatorname{cooT}\end{array}$ & $\begin{array}{l}<.39 \\
<.38 \\
<.41 \\
<.42 \\
<.30\end{array}$ & $\begin{array}{l}170.0 \\
150.0 \\
210.0 \\
200.0 \\
111.0\end{array}$ & $\begin{array}{l}14.0 \\
25.0 \\
17.0 \\
17.0 \\
<3.0\end{array}$ & $\begin{array}{r}1,600 \\
980 \\
1,300 \\
720 \\
553\end{array}$ & $\begin{array}{r}9.1 \\
11.0 \\
13.0 \\
13.0 \\
7.9\end{array}$ & $\begin{array}{l}<1.20 \\
<1.10 \\
<1.20 \\
<1.30 \\
<1.00\end{array}$ & $\begin{array}{l}<.39 \\
<.38 \\
<.41 \\
<.42 \\
.52\end{array}$ \\
\hline $\begin{array}{l}87607 \\
87608 \\
87609 \\
87623 \\
87624\end{array}$ & $\begin{array}{l}07 / 30 / 87 \\
07 / 30 / 87 \\
07 / 30 / 87 \\
08 / 04 / 87 \\
08 / 04 / 87\end{array}$ & $\begin{array}{l}\text { CARSON } \\
\text { CARSON } \\
\text { CARSON } \\
\text { CARSON } \\
\text { CARSON }\end{array}$ & 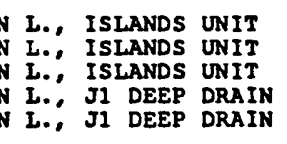 & $\begin{array}{l}\text { BIRD } \\
\text { BIRD } \\
\text { BIRD } \\
\text { BIRD } \\
\text { BIRD }\end{array}$ & $\begin{array}{l}\text { coot } \\
\text { COOT } \\
\text { COOT } \\
\text { COOT } \\
\text { COOT }\end{array}$ & $\begin{array}{l}<.30 \\
<.30 \\
<.30 \\
<.30 \\
<.30\end{array}$ & $\begin{array}{l}196.0 \\
126.0 \\
276.0 \\
148.0 \\
197.0\end{array}$ & $\begin{array}{r}<3.0 \\
<3.0 \\
<3.0 \\
<3.0 \\
3.0\end{array}$ & $\begin{array}{r}854 \\
1,660 \\
679 \\
730 \\
2,120\end{array}$ & $\begin{array}{r}11.0 \\
8.6 \\
14.0 \\
13.0 \\
26.0\end{array}$ & $\begin{array}{l}<1.00 \\
<1.00 \\
<1.00 \\
<1.00 \\
<1.00\end{array}$ & $\begin{array}{r}.48 \\
.58 \\
.83 \\
.49 \\
1.20\end{array}$ \\
\hline
\end{tabular}


TABLE 19.-Data on trace-element constituents and percent mofsture of biological samples in stillwater wildiffe Management Area, Carson Lake, Ferniey wildlife Management Area, and Humbldt wildlife Management Area, $1985-87-$ Cont.

\begin{tabular}{|c|c|c|c|c|c|c|c|c|c|c|c|c|}
\hline $\begin{array}{c}\text { USFis } \\
\text { local } \\
\text { ID } \\
\text { number }\end{array}$ & Date & Location & $\begin{array}{l}\text { Cate- } \\
\text { gory }\end{array}$ & Spec1es & & $\begin{array}{l}\text { Vana- } \\
\text { d1um }\end{array}$ & 2 Inc & $\underset{\text { minum }}{\text { Alu- }}$ & Iron & $\begin{array}{c}\text { Man- } \\
\text { ganese }\end{array}$ & N1ckel & $\begin{array}{l}\text { stron- } \\
\text { tium }\end{array}$ \\
\hline $\begin{array}{r}105 \\
106 \\
107 \\
34 \\
35\end{array}$ & $\begin{array}{l}07 / 32 / 86 \\
07 / 32 / 86 \\
07 / 32 / 86 \\
06 / 26 / 86 \\
06 / 26 / 86\end{array}$ & $\begin{array}{l}\text { SWMA, GOOSE LAKE } \\
\text { SWMA, GOOSE LAKE } \\
\text { SWMA, GOOSE LAKE } \\
\text { SWMA, LEAD LAKE } \\
\text { SWMA, LEAD LAKE }\end{array}$ & $\begin{array}{l}\text { BIRD } \\
\text { BIRD } \\
\text { BIRD } \\
\text { BIRD } \\
\text { BIRD }\end{array}$ & $\begin{array}{l}\text { coot } \\
\text { coot } \\
\text { coot } \\
\text { coot } \\
\text { coot }\end{array}$ & & $=$ & $\begin{array}{l}=- \\
= \\
=\end{array}$ & $\begin{array}{l}-- \\
\overline{-} \\
--\end{array}$ & $\begin{array}{l}-- \\
-- \\
-- \\
--\end{array}$ & $\begin{array}{l}-\overline{-} \\
-- \\
--\end{array}$ & $\begin{array}{l}=- \\
=- \\
--\end{array}$ & $\begin{array}{l}=- \\
\overline{--} \\
=-\end{array}$ \\
\hline $\begin{array}{r}36 \\
37 \\
41 \\
87135 \\
87136\end{array}$ & $\begin{array}{l}06 / 26 / 86 \\
06 / 26 / 86 \\
07 / 08 / 86 \\
08 / 04 / 87 \\
08 / 04 / 87\end{array}$ & $\begin{array}{l}\text { SWMA, LEAD IAKE } \\
\text { SWMA, LEAD LAKE } \\
\text { SWMA, LEAD LAKE } \\
\text { SWMA, SOUTH LEAD LAKE } \\
\text { SWMA, SOUTH LEAD LAKE }\end{array}$ & $\begin{array}{l}\text { BIRD } \\
\text { BIRD } \\
\text { BIRD } \\
\text { BIRD } \\
\text { BIRD }\end{array}$ & $\begin{array}{l}\text { cooT } \\
\text { coOI } \\
\text { cooT } \\
\text { CoOI } \\
\text { cooT }\end{array}$ & & $\begin{array}{c}-. \\
-. \\
.50 \\
.50\end{array}$ & $\begin{array}{r}-\overline{-} \\
163.0 \\
201.0\end{array}$ & $\begin{array}{r}-- \\
\overline{-0} \\
<3.0\end{array}$ & $\begin{array}{r}-\overline{-} \\
1,720 \\
1,190\end{array}$ & $\begin{array}{l}-- \\
-- \\
7.7 \\
9.8\end{array}$ & $\begin{array}{c}-- \\
-- \\
<1.00 \\
<1.00\end{array}$ & $\begin{array}{l}-- \\
-- \\
-\overline{0.93} \\
1.50\end{array}$ \\
\hline $\begin{array}{l}87137 \\
87138 \\
87139 \\
87140 \\
87142\end{array}$ & $\begin{array}{l}08 / 04 / 87 \\
08 / 04 / 87 \\
08 / 04 / 87 \\
08 / 04 / 87 \\
08 / 04 / 87\end{array}$ & $\begin{array}{l}\text { SWMA, SOUTH LEAD LAKE } \\
\text { SWMA, SOUTH LEAD LAKE } \\
\text { SWMA, SOUTH LEAD LAKE } \\
\text { SWMA, SOUTH LEAD LAKE } \\
\text { SWMA, SOUTH LEAD LAKE }\end{array}$ & $\begin{array}{l}\text { BIRD } \\
\text { BIRD } \\
\text { BIRD } \\
\text { BIRD } \\
\text { BIRD }\end{array}$ & $\begin{array}{l}\text { coor } \\
\text { coot } \\
\text { coor } \\
\text { coot } \\
\text { coot }\end{array}$ & & $\begin{array}{r}.60 \\
.50 \\
<.30 \\
<.30 \\
.60\end{array}$ & $\begin{array}{l}176.0 \\
167.0 \\
228.0 \\
148.0 \\
187.0\end{array}$ & $\begin{array}{l}<3.0 \\
<3.0 \\
<3.0 \\
<3.0 \\
<3.0\end{array}$ & $\begin{array}{l}1,140 \\
3,630 \\
2,070 \\
2,450 \\
1,330\end{array}$ & $\begin{array}{r}7.2 \\
14.0 \\
21.0 \\
7.8 \\
11.0\end{array}$ & $\begin{array}{l}<1.00 \\
<1.00 \\
<1.00 \\
<1.00 \\
<1.00\end{array}$ & $\begin{array}{l}1.40 \\
1.60 \\
1.20 \\
1.30 \\
2.20\end{array}$ \\
\hline $\begin{array}{r}87142 \\
87143 \\
42 \\
83 \\
84\end{array}$ & $\begin{array}{l}08 / 04 / 87 \\
08 / 04 / 87 \\
07 / 08 / 86 \\
07 / 24 / 86 \\
07 / 24 / 86\end{array}$ & $\begin{array}{l}\text { SWMA, SOUTH LEAD IAKE } \\
\text { SWMA, SOITH LEAD LAKE } \\
\text { SWMA, SIILWATER PI. RES. } \\
\text { SWMA, STILLWATER PT. RES. } \\
\text { SWMA, STILLWATER PT. RES. }\end{array}$ & $\begin{array}{l}\text { BIRD } \\
\text { BIRD } \\
\text { BIRD } \\
\text { BIRD } \\
\text { BIRD }\end{array}$ & $\begin{array}{l}\text { cooT } \\
\text { coOT } \\
\text { coOT } \\
\text { coOT } \\
\text { COOT }\end{array}$ & & $\begin{array}{r}.80 \\
.50 \\
<.40 \\
<.38 \\
<.36\end{array}$ & $\begin{array}{l}186.0 \\
210.0 \\
130.0 \\
180.0 \\
160.0\end{array}$ & $\begin{array}{r}<3.0 \\
<3.0 \\
9.2 \\
9.5 \\
9.1\end{array}$ & $\begin{array}{l}1,560 \\
1,430 \\
2,800 \\
3,200 \\
2,200\end{array}$ & $\begin{array}{r}8.8 \\
14.0 \\
6.0 \\
7.4 \\
6.3\end{array}$ & $\begin{array}{l}<1.00 \\
<1.00 \\
<1.20 \\
<1.10 \\
<1.10\end{array}$ & $\begin{array}{l}1.30 \\
1.20 \\
<.40 \\
<.38 \\
<.36\end{array}$ \\
\hline $\begin{array}{l}92 \\
93 \\
74 \\
75 \\
76\end{array}$ & $\begin{array}{l}07 / 28 / 86 \\
07 / 28 / 86 \\
07 / 21 / 86 \\
07 / 21 / 86 \\
07 / 21 / 86\end{array}$ & $\begin{array}{l}\text { SWMA, STILLWATER PT. RES. } \\
\text { SWMA, STILLWATER PT. RES. } \\
\text { WASHOE IAKE } \\
\text { WASHOE IAKE } \\
\text { WASHOE LAKE }\end{array}$ & $\begin{array}{l}\text { BIRD } \\
\text { BIRD } \\
\text { BIRD } \\
\text { BIRD } \\
\text { BIRD }\end{array}$ & $\begin{array}{l}\text { coot } \\
\text { coot } \\
\text { coot } \\
\text { coot } \\
\text { coot }\end{array}$ & & $\begin{array}{r}<.42 \\
<.49 \\
<.36 \\
<.58 \\
<.41\end{array}$ & $\begin{array}{l}190.0 \\
230.0 \\
180.0 \\
190.0 \\
230.0\end{array}$ & $\begin{array}{r}18.0 \\
21.0 \\
3.9 \\
7.6 \\
8.6\end{array}$ & $\begin{array}{r}380 \\
640 \\
1,300 \\
910 \\
1,300\end{array}$ & $\begin{array}{r}17.0 \\
13.0 \\
13.0 \\
6.3 \\
9.6\end{array}$ & $\begin{array}{l}<1.30 \\
<1.20 \\
<1.10 \\
<1.70 \\
<1.20\end{array}$ & $\begin{array}{l}<.42 \\
<.41 \\
<.36 \\
<.58 \\
<.41\end{array}$ \\
\hline $\begin{array}{r}77 \\
78 \\
87131 \\
87144 \\
87617\end{array}$ & $\begin{array}{l}07 / 21 / 86 \\
07 / 21 / 86 \\
07 / 27 / 87 \\
08 / 04 / 87 \\
07 / 30 / 87\end{array}$ & $\begin{array}{l}\text { WASHOE LAKE } \\
\text { WASHOE LAKE } \\
\text { SWMA, DRY LAKE } \\
\text { SWMA, SOUTH LEAD LAKE } \\
\text { CARSON L., ISLANDS UNIT }\end{array}$ & $\begin{array}{l}\text { BIRD } \\
\text { BIRD } \\
\text { BIRD } \\
\text { BIRD } \\
\text { BIRD }\end{array}$ & $\begin{array}{l}\text { COOT } \\
\text { COOT } \\
\text { COOT AD } \\
\text { COOT AD } \\
\text { MALIARD, }\end{array}$ & LIVER & $\begin{array}{l}<.57 \\
<.48 \\
1.90 \\
2.10 \\
<.30\end{array}$ & $\begin{array}{l}220.0 \\
180.0 \\
171.0 \\
223.0 \\
137.0\end{array}$ & $\begin{array}{r}11.0 \\
<4.8 \\
6.0 \\
<3.0 \\
<3.0\end{array}$ & $\begin{array}{r}640 \\
690 \\
4,890 \\
2,410 \\
5,190\end{array}$ & $\begin{array}{r}7.7 \\
9.2 \\
11.0 \\
7.4 \\
11.0\end{array}$ & $\begin{array}{l}1.70 \\
<1.40 \\
<1.00 \\
<1.00 \\
<1.00\end{array}$ & $\begin{array}{l}<.57 \\
<.48 \\
.75 \\
1.50 \\
.88\end{array}$ \\
\hline $\begin{array}{l}87634 \\
87636 \\
87639 \\
87649 \\
87630\end{array}$ & $\begin{array}{l}08 / 06 / 87 \\
08 / 06 / 87 \\
08 / 06 / 87 \\
08 / 10 / 87 \\
08 / 06 / 87\end{array}$ & $\begin{array}{lll}\text { CARSON L., } & \text { SPRIG PONDS } \\
\text { CARSON L., SPRIG PONDS } \\
\text { CARSON L., SPRIG PONDS } \\
\text { CARSON L., WEST LEE DRAIN } \\
\text { CARSON L., } \text { EAST LEE DRAIN }\end{array}$ & $\begin{array}{l}\text { BIRD } \\
\text { BIRD } \\
\text { BIRD } \\
\text { BIRD } \\
\text { BIRD }\end{array}$ & $\begin{array}{l}\text { MALIAAR, } \\
\text { MALLARD, } \\
\text { MALIARD, } \\
\text { MALLARD, } \\
\text { MALLARD, }\end{array}$ & $\begin{array}{l}\text { LIVER } \\
\text { LIVER } \\
\text { LIVER } \\
\text { LIVER } \\
\text { LIVER }\end{array}$ & $\begin{array}{l}<.30 \\
<.30 \\
<.30 \\
<.30 \\
<.30\end{array}$ & $\begin{array}{r}41.0 \\
147.0 \\
146.0 \\
134.0 \\
88.5\end{array}$ & $\begin{array}{r}5.0 \\
<3.0 \\
<3.0 \\
5.0 \\
<3.0\end{array}$ & $\begin{array}{r}240 \\
2,470 \\
3,880 \\
1,130 \\
3,490\end{array}$ & $\begin{array}{r}1.3 \\
10.0 \\
11.0 \\
19.0 \\
7.3\end{array}$ & $\begin{array}{l}<1.00 \\
<1.00 \\
<1.00 \\
<1.00 \\
<1.00\end{array}$ & $\begin{array}{r}.20 \\
.33 \\
.78 \\
2.30 \\
.30\end{array}$ \\
\hline $\begin{array}{l}87658 \\
87661 \\
87701 \\
87704 \\
87735\end{array}$ & $\begin{array}{l}08 / 13 / 87 \\
08 / 13 / 87 \\
08 / 18 / 87 \\
08 / 21 / 87 \\
08 / 21 / 87\end{array}$ & $\begin{array}{l}\text { FERNLEY WMA } \\
\text { FERNLEY WMA } \\
\text { FERNLEY WMA } \\
\text { FERNLEY WMA } \\
\text { FERNLEY WMA }\end{array}$ & $\begin{array}{l}\text { BIRD } \\
\text { BIRD } \\
\text { BIRD } \\
\text { BIRD } \\
\text { BIRD }\end{array}$ & $\begin{array}{l}\text { MALLARD, } \\
\text { MALLARD, } \\
\text { MALLARD, } \\
\text { MALLARD, } \\
\text { MALLARD, }\end{array}$ & $\begin{array}{l}\text { LIVER } \\
\text { LIVER } \\
\text { LIVER } \\
\text { LIVER } \\
\text { LIVER }\end{array}$ & $\begin{array}{l}<.30 \\
<.30 \\
<.30 \\
.70 \\
<.30\end{array}$ & $\begin{array}{r}181.0 \\
151.0 \\
143.0 \\
179.0 \\
73.0\end{array}$ & $\begin{array}{r}<3.0 \\
7.0 \\
<3.0 \\
5.0 \\
<3.0\end{array}$ & $\begin{array}{l}3,510 \\
5,310 \\
2,020 \\
2,850 \\
3,200\end{array}$ & $\begin{array}{r}15.0 \\
12.0 \\
7.9 \\
14.0 \\
14.0\end{array}$ & $\begin{array}{l}<1.00 \\
<1.00 \\
<1.00 \\
<1.00 \\
<1.00\end{array}$ & $\begin{array}{l}.58 \\
.30 \\
.53 \\
.62 \\
.59\end{array}$ \\
\hline $\begin{array}{l}87707 \\
87710 \\
87747 \\
87744 \\
87631\end{array}$ & $\begin{array}{l}09 / 01 / 87 \\
08 / 27 / 87 \\
08 / 28 / 87 \\
08 / 26 / 87 \\
08 / 06 / 87\end{array}$ & $\begin{array}{l}\text { SWMA, LEAD LAKE } \\
\text { SWMA, LEAD LAKE } \\
\text { SWMA, LEAD LAKE } \\
\text { SWMA, TULE LAKE } \\
\text { CARSON L., EAST LEE DRAIN }\end{array}$ & $\begin{array}{l}\text { BIRD } \\
\text { BIRD } \\
\text { BIRD } \\
\text { BIRD } \\
\text { BIRD }\end{array}$ & $\begin{array}{l}\text { MALLARD, } \\
\text { MALLARD, } \\
\text { MALLARD, } \\
\text { MALLARD, } \\
\text { MALLARD, }\end{array}$ & $\begin{array}{l}\text { LIVER } \\
\text { LIVER } \\
\text { LIVER } \\
\text { LIVER } \\
\text { MUSCLE }\end{array}$ & $\begin{array}{l}<.30 \\
<.30 \\
<.30 \\
<.30 \\
<.30\end{array}$ & $\begin{array}{r}109.0 \\
135.0 \\
154.0 \\
123.0 \\
35.6\end{array}$ & $\begin{array}{r}9.4 \\
7.0 \\
<3.0 \\
<3.0 \\
4.0\end{array}$ & $\begin{array}{r}4,370 \\
2,200 \\
5,270 \\
1,420 \\
334\end{array}$ & $\begin{array}{r}11.0 \\
12.0 \\
11.0 \\
12.0 \\
1.3\end{array}$ & $\begin{array}{l}<1.00 \\
<1.00 \\
<1.00 \\
<1.00 \\
<1.00\end{array}$ & $\begin{array}{r}1.10 \\
.78 \\
.90 \\
1.30 \\
<.10\end{array}$ \\
\hline $\begin{array}{l}87615 \\
87633 \\
87637 \\
87640 \\
87648\end{array}$ & $\begin{array}{l}07 / 30 / 87 \\
08 / 06 / 87 \\
08 / 06 / 87 \\
08 / 06 / 87 \\
08 / 10 / 87\end{array}$ & $\begin{array}{l}\text { CARSON L., ISLANDS UNIT } \\
\text { CARSON L., SPRIG PONDS } \\
\text { CARSON L., SPRIG PONDS } \\
\text { CARSON L., SPRIG PONDS } \\
\text { CARSON L., WEST LEE DRAIN }\end{array}$ & $\begin{array}{l}\text { BIRD } \\
\text { BIRD } \\
\text { BIRD } \\
\text { BIRD } \\
\text { BIRD }\end{array}$ & $\begin{array}{l}\text { MALLARD, } \\
\text { MALLARD, } \\
\text { MALLARD, } \\
\text { MALLARD, } \\
\text { MALLARD, }\end{array}$ & $\begin{array}{l}\text { MUSCLE } \\
\text { MUSCLE } \\
\text { MUSCLE } \\
\text { MUSCLE } \\
\text { MUSCLE }\end{array}$ & $\begin{array}{l}<.30 \\
<.30 \\
<.30 \\
<.30 \\
<.30\end{array}$ & $\begin{array}{r}72.6 \\
169.0 \\
47.3 \\
43.0 \\
37.1\end{array}$ & $\begin{array}{r}28.0 \\
<3.0 \\
5.0 \\
<3.0 \\
8.0\end{array}$ & $\begin{array}{r}325 \\
2,390 \\
233 \\
177 \\
162\end{array}$ & $\begin{array}{r}3.7 \\
11.0 \\
2.2 \\
1.5 \\
1.2\end{array}$ & $\begin{array}{l}<1.00 \\
<1.00 \\
<1.00 \\
<1.00 \\
<1.00\end{array}$ & $\begin{array}{r}1.30 \\
.61 \\
<.10 \\
.20 \\
.46\end{array}$ \\
\hline $\begin{array}{l}87659 \\
87662 \\
87702 \\
87705 \\
87736\end{array}$ & $\begin{array}{l}08 / 13 / 87 \\
08 / 13 / 87 \\
08 / 18 / 87 \\
08 / 21 / 87 \\
08 / 21 / 87\end{array}$ & $\begin{array}{l}\text { FERNLEY WMA } \\
\text { FERNLEY WMA } \\
\text { FERNLEY WMA } \\
\text { FERNLEY WMA } \\
\text { FERNLEY WMA }\end{array}$ & $\begin{array}{l}\text { BIRD } \\
\text { BIRD } \\
\text { BIRD } \\
\text { BIRD } \\
\text { BIRD }\end{array}$ & $\begin{array}{l}\text { MALLARD, } \\
\text { MALLARD, } \\
\text { MALILARD, } \\
\text { MALLARD, } \\
\text { MALILARD, }\end{array}$ & $\begin{array}{l}\text { MUSCLE } \\
\text { MUSCLE } \\
\text { MUSCLE } \\
\text { MUSCLE } \\
\text { MUSCLE }\end{array}$ & $\begin{array}{l}<.30 \\
<.30 \\
<.30 \\
<.30 \\
<.30\end{array}$ & $\begin{array}{l}41.1 \\
42.6 \\
45.3 \\
47.2 \\
38.5\end{array}$ & $\begin{array}{l}5.0 \\
6.0 \\
6.0 \\
3.0 \\
3.0\end{array}$ & $\begin{array}{l}284 \\
297 \\
258 \\
235 \\
265\end{array}$ & $\begin{array}{l}1.6 \\
1.7 \\
1.6 \\
1.6 \\
1.8\end{array}$ & $\begin{array}{r}<1.00 \\
<1.00 \\
<1.00 \\
2.00 \\
<1.00\end{array}$ & $\begin{array}{l}.10 \\
.10 \\
.20 \\
.20 \\
<.10\end{array}$ \\
\hline $\begin{array}{l}87708 \\
87711 \\
87748 \\
87745 \\
87629\end{array}$ & $\begin{array}{l}09 / 01 / 87 \\
08 / 27 / 87 \\
08 / 28 / 87 \\
08 / 26 / 87 \\
08 / 06 / 87\end{array}$ & $\begin{array}{l}\text { SWMA, LEAD LAKE } \\
\text { SWMA, LEAD LAKE } \\
\text { SWMA, LEAD LAKE } \\
\text { SWMA, TULE LAKE } \\
\text { CARSON L., EAST LEE DRAIN }\end{array}$ & $\begin{array}{l}\text { BIRD } \\
\text { BIRD } \\
\text { BIRD } \\
\text { BIRD } \\
\text { BIRD }\end{array}$ & $\begin{array}{l}\text { MALLARD, } \\
\text { MALLARD, } \\
\text { MALIARD, } \\
\text { MALILARD, } \\
\text { MALILARD, }\end{array}$ & $\begin{array}{l}\text { MUSCLE } \\
\text { MUSCLE } \\
\text { MUSCLE } \\
\text { MUSCLE } \\
\text { SKIN }\end{array}$ & $\begin{array}{l}<.30 \\
<.30 \\
<.30 \\
<.30 \\
<.30\end{array}$ & $\begin{array}{l}44.5 \\
41.7 \\
38.5 \\
49.0 \\
31.9\end{array}$ & $\begin{array}{r}6.0 \\
<3.0 \\
<3.0 \\
<3.0 \\
65.0\end{array}$ & $\begin{array}{l}236 \\
203 \\
264 \\
195 \\
116\end{array}$ & $\begin{array}{l}1.6 \\
1.8 \\
1.5 \\
1.5 \\
1.3\end{array}$ & $\begin{array}{l}1.00 \\
<1.00 \\
<1.00 \\
<1.00 \\
<1.00\end{array}$ & $\begin{array}{r}<.10 \\
.20 \\
.10 \\
.20 \\
.63\end{array}$ \\
\hline
\end{tabular}


TABLE 19.--Data on trace-element constituents and percent molsture of blological samples in st111water wildlife Management Area, Carson Lake, Fernley WIldlife Management Area, and Humboldt wildlife Management Area, 1985-87--Cont.

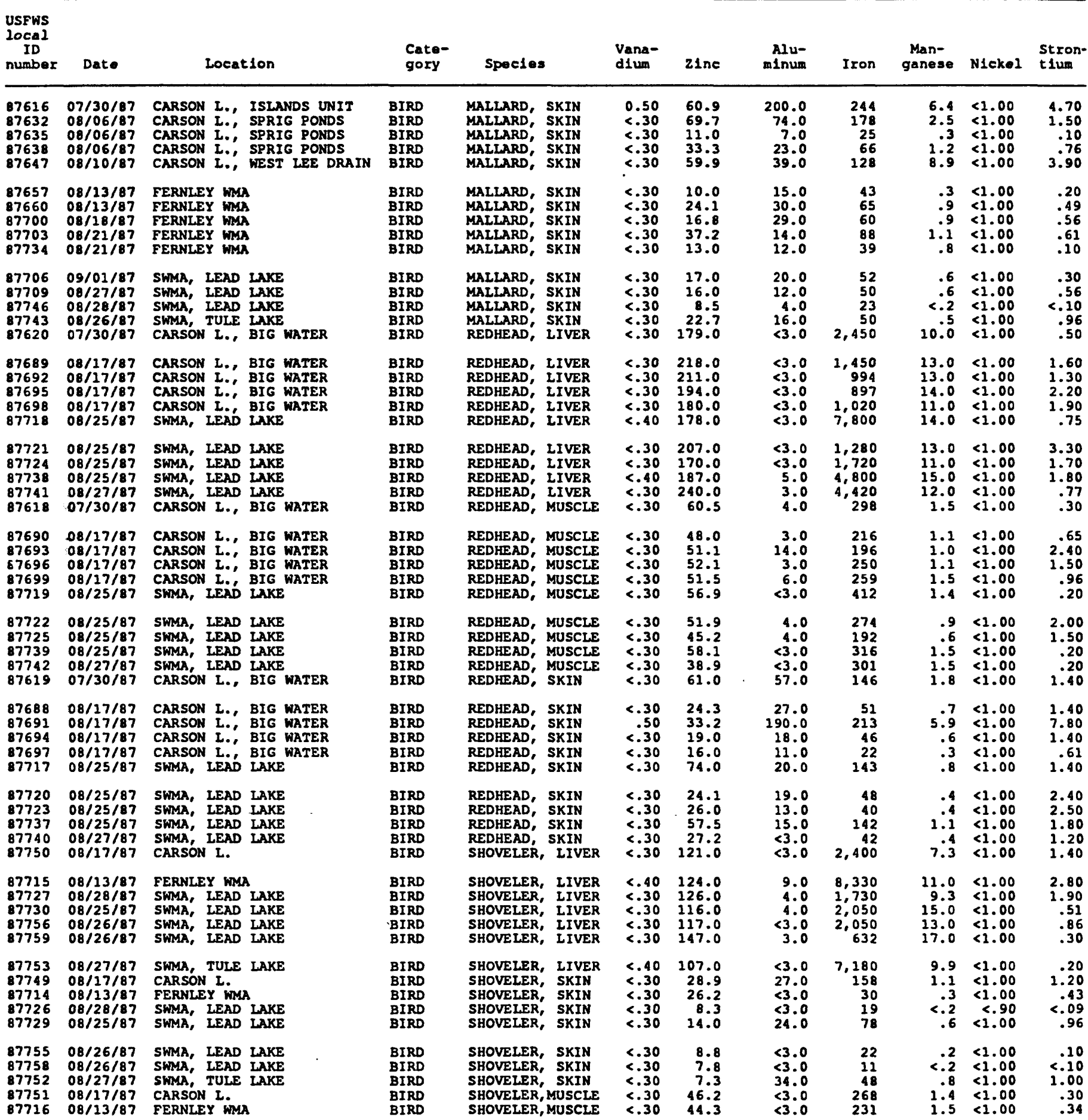


TABLE 19.--Date on trace-element constituents and percent molsture of biological samples in stillwater Wildiffe Management Area, Carson Lake, Fernley Wildlife Management Area, and Humboldt Wildlife Management Area, ig85-87--Cont.

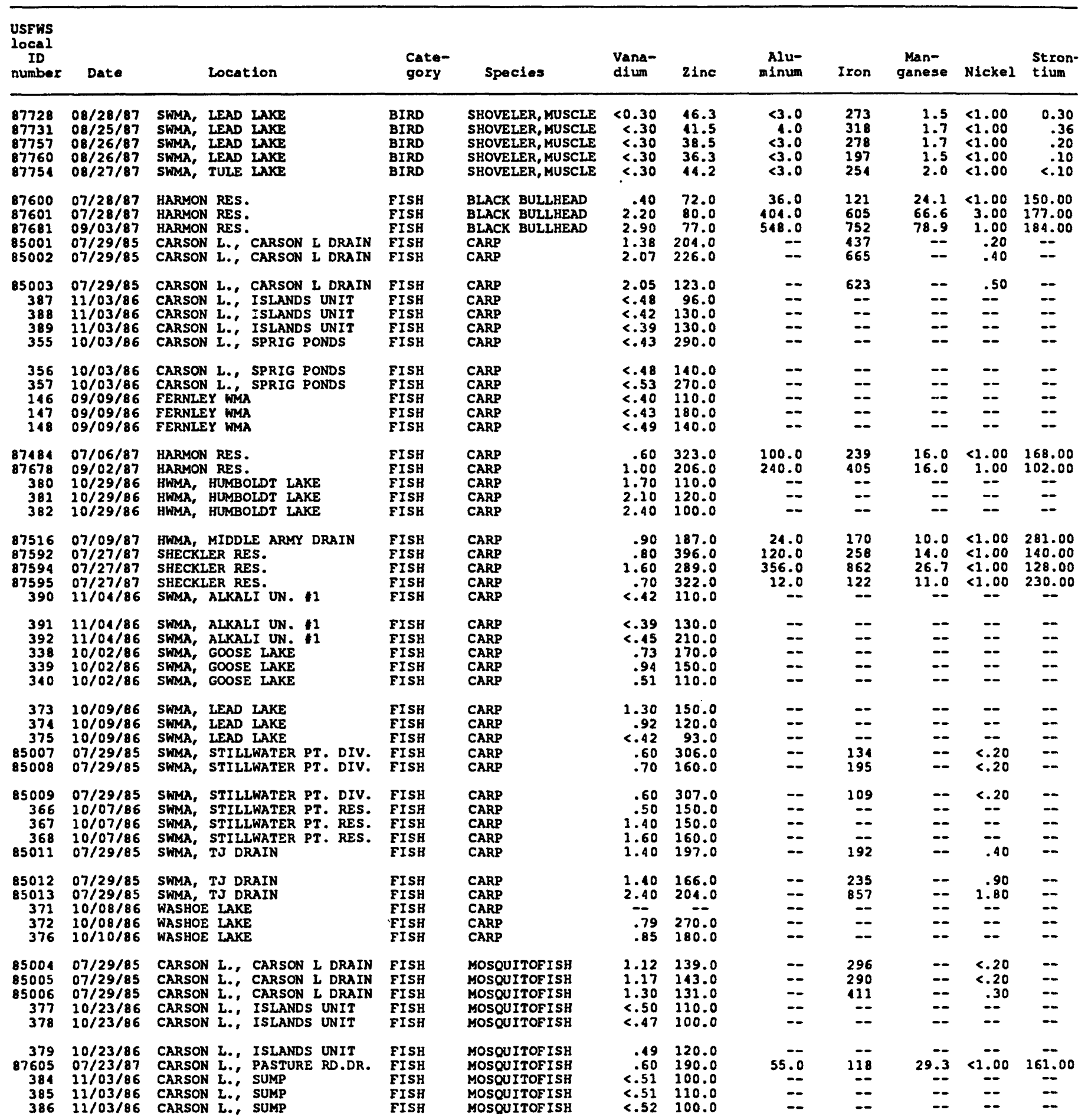


TABLE 19.-Data on trace-element constituents and percent molsture of biological samples in stiliwater wild11fe Management Area, Carson Lake, Fernley WIIdlife Management Area, and Humboldt WIIdlife Management Area, 1985-87--Cont.

\begin{tabular}{|c|c|c|c|c|c|c|c|c|c|c|c|}
\hline $\begin{array}{l}\text { USFWS } \\
\text { local } \\
\text { ID } \\
\text { number }\end{array}$ & Date & Location & $\begin{array}{l}\text { Cate- } \\
\text { gory }\end{array}$ & Species & $\begin{array}{l}\text { Vana- } \\
\text { dium }\end{array}$ & Zine & $\begin{array}{c}\text { Alu- } \\
\text { minum }\end{array}$ & Iron & $\begin{array}{c}\text { Man- } \\
\text { ganese }\end{array}$ & N1ckel & $\begin{array}{l}\text { Stron- } \\
\text { tium }\end{array}$ \\
\hline $\begin{array}{l}242 \\
243 \\
244 \\
143 \\
144\end{array}$ & $\begin{array}{l}09 / 22 / 86 \\
09 / 22 / 86 \\
09 / 22 / 86 \\
09 / 09 / 86 \\
09 / 09 / 86\end{array}$ & $\begin{array}{l}\text { CARSON VALLEY } \\
\text { CARSON VALLEY } \\
\text { CARSON VALLEY } \\
\text { FERNLEY WMA } \\
\text { FERNLEY WMA }\end{array}$ & $\begin{array}{l}\text { FISH } \\
\text { FISH } \\
\text { FISH } \\
\text { FISH } \\
\text { FISH }\end{array}$ & $\begin{array}{l}\text { MOSOUITOFISH } \\
\text { MOSQUITOFISH } \\
\text { MOSQUITOFISH } \\
\text { MOSQUITOFISH } \\
\text { MOSQUITOFISH }\end{array}$ & $\begin{array}{l}0.68 \\
1.00 \\
1.40 \\
<.39 \\
<.38\end{array}$ & $\begin{array}{l}150.0 \\
140.0 \\
160.0 \\
110.0 \\
110.0\end{array}$ & $\begin{array}{l}= \\
=- \\
=\end{array}$ & $\begin{array}{l}-- \\
-- \\
--\end{array}$ & $=-$ & $=-$ & $=$ \\
\hline $\begin{array}{r}145 \\
87503 \\
87504 \\
87505 \\
87586\end{array}$ & $\begin{array}{l}09 / 09 / 86 \\
07 / 08 / 87 \\
07 / 08 / 87 \\
07 / 08 / 87 \\
07 / 20 / 87\end{array}$ & $\begin{array}{l}\text { FERNLEY MA } \\
\text { MASSIE SLOUGH } \\
\text { MASSIE SLOUGH } \\
\text { MASSIE SLOUGH } \\
\text { MASSIE SLOUGH }\end{array}$ & $\begin{array}{l}\text { FISH } \\
\text { FISH } \\
\text { FISH } \\
\text { FISH } \\
\text { FISH }\end{array}$ & $\begin{array}{l}\text { MOSQUITOEISH } \\
\text { MOSQUITOFISH } \\
\text { MOSQUITOFISH } \\
\text { MOSQUITOFISH } \\
\text { MOSQUITOFISH }\end{array}$ & $\begin{array}{l}<.40 \\
1.20 \\
1.50 \\
2.50 \\
1.60\end{array}$ & $\begin{array}{l}100.0 \\
163.0 \\
157.0 \\
155.0 \\
152.0\end{array}$ & $\begin{array}{r}47 . \overline{0} \\
130.0 \\
280.0 \\
190.0\end{array}$ & $\begin{array}{l}1 \overline{32} \\
205 \\
386 \\
261\end{array}$ & $\begin{array}{r}16.0 \\
17.0 \\
31.5 \\
122.0\end{array}$ & $\begin{array}{l}<1.00 \\
<1.00 \\
<1.00 \\
<1.00\end{array}$ & $\begin{array}{l}225.00 \\
233.00 \\
277.00 \\
269.00\end{array}$ \\
\hline $\begin{array}{r}172 \\
363 \\
365 \\
85010 \\
85014\end{array}$ & $\begin{array}{l}09 / 16 / 86 \\
10 / 06 / 86 \\
10 / 07 / 86 \\
07 / 29 / 85 \\
07 / 29 / 85\end{array}$ & $\begin{array}{l}\text { SWMA, ALKALI UN. } 1 \\
\text { SWMA, ALKALI UN. } 1 \\
\text { SWMA, ALKALI UN. I } \\
\text { SWMA, STILLWATER PT. DIV. } \\
\text { SWMA, TJ DRAIN }\end{array}$ & $\begin{array}{l}\text { FISH } \\
\text { FISH } \\
\text { FISH } \\
\text { FISH } \\
\text { FISH }\end{array}$ & $\begin{array}{l}\text { MOSQUITOFISH } \\
\text { MOSQUITOFISH } \\
\text { MOSQUITOFISH } \\
\text { MOSQUITOFISH } \\
\text { MOSOUITOFISH }\end{array}$ & $\begin{array}{r}<.48 \\
<.43 \\
.43 \\
.80 \\
.90\end{array}$ & $\begin{array}{l}110.0 \\
100.0 \\
100.0 \\
146.0 \\
132.0\end{array}$ & $=$ & $\begin{array}{l}-- \\
286 \\
289\end{array}$ & $\begin{array}{l}-- \\
-- \\
--\end{array}$ & $\begin{array}{l}-- \\
-- \\
0.40 \\
0.50\end{array}$ & $\overline{--}$ \\
\hline $\begin{array}{r}85015 \\
85016 \\
394 \\
383 \\
87593\end{array}$ & $\begin{array}{l}07 / 29 / 85 \\
07 / 29 / 85 \\
10 / 03 / 86 \\
10 / 29 / 86 \\
07 / 27 / 87\end{array}$ & $\begin{array}{l}\text { SWMA, TJ DRAIN } \\
\text { SWMA, IJ DRAIN } \\
\text { CARSON L., SPRIG PONDS } \\
\text { HWMA, HURBOLDT LAKE } \\
\text { SHECKLER RES. }\end{array}$ & $\begin{array}{l}\text { FISH } \\
\text { FISH } \\
\text { FISH } \\
\text { FISH } \\
\text { FISH }\end{array}$ & $\begin{array}{l}\text { MOSQUITOFISH } \\
\text { MOSQUITOFISH } \\
\text { SAC PERCH } \\
\text { SAC PERCH } \\
\text { SAC. BLACKFISH }\end{array}$ & $\begin{array}{l}.70 \\
1.80 \\
5.30 \\
1.10 \\
2.70\end{array}$ & $\begin{array}{r}131.0 \\
129.0 \\
32.0 \\
35.0 \\
104.0\end{array}$ & $\begin{array}{r}-- \\
=- \\
=- \\
270.0\end{array}$ & $\begin{array}{r}224 \\
718 \\
\overline{446}\end{array}$ & $14 . \overline{--}$ & $\begin{array}{c}0.40 \\
0.90 \\
-.- \\
-1.00\end{array}$ & 100.00 \\
\hline $\begin{array}{r}87687 \\
173 \\
362 \\
364 \\
312\end{array}$ & $\begin{array}{l}09 / 09 / 87 \\
09 / 16 / 86 \\
10 / 06 / 86 \\
10 / 07 / 86 \\
09 / 30 / 86\end{array}$ & $\begin{array}{l}\text { SHECKLER RES. } \\
\text { SWMA, ALKALI UN. } 1 \\
\text { SWMA, ALKALI UN. I } \\
\text { SWMA, ALKALI UN. } 1 \\
\text { SWMA, GOOSE IUKE }\end{array}$ & $\begin{array}{l}\text { FISH } \\
\text { FISH } \\
\text { FISH } \\
\text { FISH } \\
\text { FISH }\end{array}$ & $\begin{array}{l}\text { SAC. BLACKFISH } \\
\text { SHINERS } \\
\text { SHINERS } \\
\text { SHINERS } \\
\text { SHINERS }\end{array}$ & $\begin{array}{r}1.90 \\
<.45 \\
.49 \\
<.43 \\
.71\end{array}$ & $\begin{array}{r}80.0 \\
130.0 \\
110.0 \\
130.0 \\
130.0\end{array}$ & $\begin{array}{r}190.0 \\
=- \\
-- \\
--\end{array}$ & $\begin{array}{r}267 \\
-- \\
--\end{array}$ & $\begin{array}{r}10.0 \\
=- \\
=-\end{array}$ & $\begin{array}{c}<1.00 \\
-- \\
-- \\
-\end{array}$ & $\begin{array}{c}109.00 \\
- \\
= \\
=\end{array}$ \\
\hline $\begin{array}{l}313 \\
314 \\
393 \\
149 \\
150\end{array}$ & $\begin{array}{l}09130 / 86 \\
09 / 30 / 86 \\
11 / 04 / 86 \\
09 / 09 / 86 \\
09 / 09 / 86\end{array}$ & $\begin{array}{l}\text { SWMA, GOOSE LAKE } \\
\text { SWMA, GOOSE IAKE } \\
\text { SWMA, ALKALI UN. } 1 \\
\text { FERNLEY WMA } \\
\text { FERNLEY WMA }\end{array}$ & $\begin{array}{l}\text { FISH } \\
\text { FISH } \\
\text { FISH } \\
\text { FISH } \\
\text { FISH }\end{array}$ & $\begin{array}{l}\text { SHINERS } \\
\text { SHINERS } \\
\text { SM MOUTH BASS } \\
\text { TUI CHUB } \\
\text { TUI CHUB }\end{array}$ & $\begin{array}{r}.54 \\
<.33 \\
<.37 \\
<.39 \\
<.37\end{array}$ & $\begin{array}{l}88.0 \\
87.0 \\
40.0 \\
94.0 \\
75.0\end{array}$ & $\begin{array}{l}=- \\
=- \\
=-\end{array}$ & $=-$ & 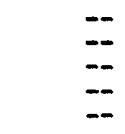 & $=-$ & $=$ \\
\hline $\begin{array}{r}151 \\
87682 \\
87683 \\
315 \\
316\end{array}$ & $\begin{array}{l}09 / 09 / 86 \\
09 / 03 / 87 \\
09 / 03 / 87 \\
09 / 30 / 86 \\
09 / 30 / 86\end{array}$ & $\begin{array}{l}\text { FERNLEY WMA } \\
\text { HARMON RES. } \\
\text { HARMON RES. } \\
\text { SWMA, GOOSE LAKE } \\
\text { SWMA, GOOSE LAKE }\end{array}$ & $\begin{array}{l}\text { FISH } \\
\text { FISH } \\
\text { FISH } \\
\text { FISH } \\
\text { FISH }\end{array}$ & $\begin{array}{l}\text { TUI CHUB } \\
\text { TUI CHUB } \\
\text { TUI CHUB } \\
\text { TUI CHUB } \\
\text { TUI CHUB }\end{array}$ & $\begin{array}{l}<.36 \\
.50 \\
1.50 \\
.66 \\
.58\end{array}$ & $\begin{array}{l}80.0 \\
41.0 \\
61.6 \\
38.0 \\
53.0\end{array}$ & $\begin{array}{r}72.0 \\
230.0 \\
--\end{array}$ & $\begin{array}{r}127 \\
287 \\
--\end{array}$ & $\begin{array}{r}-- \\
13.4 \\
13.0 \\
--\end{array}$ & $\begin{array}{c}<1.00 \\
<1.00 \\
-- \\
--\end{array}$ & $\begin{array}{l}27.00 \\
89.40 \\
-- \\
--\end{array}$ \\
\hline $\begin{array}{r}317 \\
87602 \\
87679 \\
87680 \\
87596\end{array}$ & $\begin{array}{l}09 / 30 / 86 \\
07 / 28 / 87 \\
09 / 02 / 87 \\
09 / 03 / 87 \\
07 / 27 / 87\end{array}$ & $\begin{array}{l}\text { SWMA, GOOSE LAKE } \\
\text { HARMON RES. } \\
\text { HARMON RES. } \\
\text { HARMON. RES. } \\
\text { SHECKLER RES. }\end{array}$ & $\begin{array}{l}\text { FISH } \\
\text { FISH } \\
\text { FISH } \\
\text { FISH } \\
\text { FISH }\end{array}$ & $\begin{array}{l}\text { TUI CHUB } \\
\text { WHITE BASS } \\
\text { WHITE BASS } \\
\text { WHITE BASS } \\
\text { WHITE BASS }\end{array}$ & $\begin{array}{r}.53 \\
<.30 \\
<.30 \\
<.30 \\
<.30\end{array}$ & $\begin{array}{l}55.0 \\
60.2 \\
79.5 \\
57.6 \\
73.6\end{array}$ & $\begin{array}{r}9.9 \\
23.0 \\
21.0 \\
11.0\end{array}$ & $\begin{array}{l}-79 \\
79 \\
74 \\
86\end{array}$ & $\begin{array}{r}19.0 \\
16.0 \\
3.5 \\
5.4\end{array}$ & $\begin{array}{l}<1.00 \\
<1.00 \\
<1.00 \\
<1.00\end{array}$ & $\begin{array}{r}123.00 \\
132.00 \\
70.10 \\
164.00\end{array}$ \\
\hline $\begin{array}{r}87597 \\
87598 \\
87686 \\
87568 \\
33\end{array}$ & $\begin{array}{l}07 / 27 / 87 \\
07 / 27 / 87 \\
09 / 09 / 87 \\
07 / 14 / 87 \\
06 / 24 / 86\end{array}$ & $\begin{array}{l}\text { SHECKLER RES. } \\
\text { SHECKLER RES. } \\
\text { SHECKLER RES. } \\
\text { CARSON I., DOWNS DRAIN } \\
\text { CARSON I. ISLANDS UNIT }\end{array}$ & $\begin{array}{l}\text { FISH } \\
\text { FISH } \\
\text { FISH } \\
\text { INSECT } \\
\text { INSECT }\end{array}$ & $\begin{array}{l}\text { WHITE CRAPPIE } \\
\text { WHITE CRAPPIE } \\
\text { WHITE CRAPPIE } \\
\text { DIPTERA } \\
\text { DIPTERA }\end{array}$ & $\begin{array}{r}.40 \\
.40 \\
23.40 \\
16.00\end{array}$ & $\begin{array}{r}73.3 \\
75.0 \\
83.8 \\
110.0 \\
81.0\end{array}$ & $\begin{array}{r}33.0 \\
15.0 \\
12.0 \\
7,420.0 \\
12,000.0\end{array}$ & $\begin{array}{r}61 \\
40 \\
44 \\
8,950 \\
12,000\end{array}$ & $\begin{array}{r}12.0 \\
12.0 \\
20.3 \\
192 \cdot 0 \\
250.0\end{array}$ & $\begin{array}{r}<1.00 \\
<1.00 \\
<1.00 \\
5.10 \\
3.30\end{array}$ & $\begin{array}{r}194.00 \\
210.00 \\
246.00 \\
43.70 \\
140.00\end{array}$ \\
\hline $\begin{array}{r}12 \\
13 \\
94 \\
87495 \\
129\end{array}$ & $\begin{array}{l}06 / 10 / 86 \\
06 / 10 / 86 \\
07 / 29 / 86 \\
07 / 06 / 87 \\
08 / 05 / 86\end{array}$ & $\begin{array}{l}\text { CARSON L., SPRIG PONDS } \\
\text { CARSON L.: SUMP } \\
\text { CARSON VALLEY } \\
\text { ERB DEEP DRAIN } \\
\text { FERNLEY WMA }\end{array}$ & $\begin{array}{l}\text { INSECT } \\
\text { INSECT } \\
\text { INSECT } \\
\text { INSECT } \\
\text { INSECT }\end{array}$ & $\begin{array}{l}\text { DIPTERA } \\
\text { DIPTERA } \\
\text { DIPTERA } \\
\text { DIPTERA } \\
\text { DIPTERA }\end{array}$ & $\begin{array}{l}35.00 \\
10.00 \\
12.00 \\
34.30 \\
32.00\end{array}$ & $\begin{array}{r}110.0 \\
61.0 \\
38.0 \\
84.2 \\
71.0\end{array}$ & $\begin{array}{r}19,000.0 \\
6,100.0 \\
4,500.0 \\
7,850.0 \\
34,000.0\end{array}$ & $\begin{array}{r}21,000 \\
5,300 \\
4,100 \\
10,400 \\
19,000\end{array}$ & $\begin{array}{r}1,000.0 \\
100.0 \\
150.0 \\
609.0 \\
420.0\end{array}$ & $\begin{array}{r}9.70 \\
<2.10 \\
3.90 \\
5.50 \\
8.50\end{array}$ & $\begin{array}{r}130.00 \\
100.00 \\
75.00 \\
48.80 \\
150.00\end{array}$ \\
\hline $\begin{array}{r}131 \\
87414 \\
87417 \\
87422 \\
40\end{array}$ & $\begin{array}{l}08 / 05 / 86 \\
06 / 23 / 87 \\
06 / 25 / 87 \\
06 / 25 / 87 \\
07 / 02 / 86\end{array}$ & $\begin{array}{l}\text { HWMA, HUMBOLDT LAKE } \\
\text { HWMA, TOULON LAKE } \\
\text { MAHALA SLOUGH } \\
\text { SHECKLER RES. } \\
\text { SWMA, ALKALI UN. II }\end{array}$ & $\begin{array}{l}\text { INSECT } \\
\text { INSECT } \\
\text { INSECT } \\
\text { INSECT } \\
\text { INSECT }\end{array}$ & $\begin{array}{l}\text { DIPTERA } \\
\text { DIPTERA } \\
\text { DIPTERA } \\
\text { DIPTERA } \\
\text { DIPTERA }\end{array}$ & $\begin{array}{r}16.00 \\
14.00 \\
72.30 \\
37.60 \\
8.50\end{array}$ & $\begin{array}{l}44.0 \\
71.0 \\
85.7 \\
94.8 \\
55.0\end{array}$ & $\begin{array}{r}8,000.0 \\
7,850.0 \\
12,800.0 \\
12,600.0 \\
2,500.0\end{array}$ & $\begin{array}{r}4,300 \\
6,340 \\
13,100 \\
14,900 \\
3,400\end{array}$ & $\begin{array}{r}270.0 \\
276.0 \\
350.0 \\
389.0 \\
61.0\end{array}$ & $\begin{array}{r}8.30 \\
4.60 \\
7.00 \\
7.90 \\
<3.20\end{array}$ & $\begin{array}{r}200.00 \\
330.00 \\
217.00 \\
52.70 \\
51.00\end{array}$ \\
\hline $\begin{array}{r}370 \\
38 \\
87733 \\
87559 \\
79\end{array}$ & $\begin{array}{l}10 / 07 / 86 \\
07 / 02 / 86 \\
07 / 28 / 87 \\
07 / 13 / 87 \\
07 / 22 / 86\end{array}$ & $\begin{array}{l}\text { SWMA, GOOSE LAKE } \\
\text { SWMA, LEAD LAKE } \\
\text { SWMA, NAVY CABIN DRAIN } \\
\text { SWMA, SHAFFNER DR., IND.L. } \\
\text { SWMA, STILLWATER PT. RES. }\end{array}$ & $\begin{array}{l}\text { INSECT } \\
\text { INSECT } \\
\text { INSECT } \\
\text { INSECT } \\
\text { INSECT }\end{array}$ & $\begin{array}{l}\text { DIPTERA } \\
\text { DIPTERA } \\
\text { DIPTERA } \\
\text { DIPTERA } \\
\text { DIPTERA }\end{array}$ & $\begin{array}{l}6.50 \\
27.00 \\
13.00 \\
13.00\end{array}$ & $\begin{array}{l}53.0 \\
65.6 \\
66.7 \\
73.0\end{array}$ & $\begin{array}{r}-\overline{-} \\
10,300.0 \\
4,220.0 \\
\ldots\end{array}$ & $\begin{array}{r}-- \\
9,250 \\
5,520 \\
--\end{array}$ & $\begin{array}{r}-- \\
176.0 \\
556.0 \\
.-\end{array}$ & $\begin{array}{l}-- \\
6.80 \\
3.00 \\
--\end{array}$ & $\begin{array}{l}115.00 \\
239.00 \\
\ldots\end{array}$ \\
\hline
\end{tabular}


TABLE 19.--Data on trace-element constituents and percent molsture of blologlcal samples in st111water W1ldiffe Management Area, Carson Lake, Fernley Wildl1fe Management Area, and Humboldt Wildlife Management Area, 1985-87--Cont.

\begin{tabular}{|c|c|c|c|c|c|c|c|c|c|c|c|c|}
\hline $\begin{array}{l}\text { USFWS } \\
\text { local } \\
\text { ID } \\
\text { number }\end{array}$ & Date & Location & $\begin{array}{l}\text { Cate- } \\
\text { gory }\end{array}$ & Spectes & & $\begin{array}{l}\text { Vana- } \\
\text { dium }\end{array}$ & 21 ne & $\begin{array}{c}\text { Mlu- } \\
\text { minum }\end{array}$ & Iron & $\begin{array}{l}\text { Man- } \\
\text { ganese }\end{array}$ & N1ckel & $\begin{array}{l}\text { Stron- } \\
\text { tium }\end{array}$ \\
\hline $\begin{array}{r}87567 \\
15 \\
87556 \\
87558 \\
24\end{array}$ & $\begin{array}{l}07 / 16 / 87 \\
06 / 12 / 86 \\
07 / 14 / 87 \\
07 / 14 / 87 \\
06 / 17 / 86\end{array}$ & $\begin{array}{l}\text { SWRA, SWAN I. CHECK } \\
\text { WASHOE LAKE } \\
\text { CARSON L.: DOWNS DRAIN } \\
\text { CARSON L.: HOLMES DEEP DR } \\
\text { CARSON L., ISLANDS UNIT }\end{array}$ & $\begin{array}{l}\text { INSECT } \\
\text { INSECT } \\
\text { INSECT } \\
\text { INSECT } \\
\text { INSECT }\end{array}$ & $\begin{array}{l}\text { DIPIERA } \\
\text { DIPTERA } \\
\text { HEMIPTERA } \\
\text { HEMIPTERA } \\
\text { HEMIPTERA }\end{array}$ & & $\begin{array}{r}16.00 \\
37.00 \\
1.60 \\
2.00 \\
<.49\end{array}$ & $\begin{array}{r}46.0 \\
110.0 \\
167.0 \\
174.0 \\
160.0\end{array}$ & $\begin{array}{r}4,000.0 \\
16,000.0 \\
260.0 \\
542.0 \\
160.0\end{array}$ & $\begin{array}{r}4,200 \\
22,000 \\
484 \\
686 \\
240\end{array}$ & $\begin{array}{r}86.5 \\
600.0 \\
35.7 \\
54.5 \\
60.0\end{array}$ & $\begin{array}{r}3.00 \\
5.00 \\
<1.00 \\
<1.00 \\
1.60\end{array}$ & $\begin{array}{l}99.20 \\
72.00 \\
28.90 \\
25.10 \\
25.00\end{array}$ \\
\hline $\begin{array}{r}87625 \\
11 \\
14 \\
87557 \\
95\end{array}$ & $\begin{array}{l}06 / 29 / 87 \\
06 / 20 / 86 \\
06 / 24 / 86 \\
07 / 14 / 87 \\
07 / 29 / 86\end{array}$ & $\begin{array}{l}\text { CARSON L., JI DEEP DRAIN } \\
\text { CARSON L.: SPRIG PONDS } \\
\text { CARSON L.: SUMP } \\
\text { CARSON L.: YARBROUGH DR. } \\
\text { CARSON VALLLY }\end{array}$ & $\begin{array}{l}\text { INSECT } \\
\text { INSECT } \\
\text { INSECT } \\
\text { INSECT } \\
\text { INSECT }\end{array}$ & $\begin{array}{l}\text { HEMIPTERA } \\
\text { HEMIPTERA } \\
\text { HEMIPTERA } \\
\text { HEMIPTERA } \\
\text { HEMIPTERA }\end{array}$ & & $\begin{array}{r}1.80 \\
34.00 \\
4.30 \\
.96 \\
1.40\end{array}$ & $\begin{array}{l}182.0 \\
100.0 \\
130.0 \\
215.0 \\
170.0\end{array}$ & $\begin{array}{r}547.0 \\
9,300.0 \\
1,100.0 \\
290.0 \\
850.0\end{array}$ & $\begin{array}{r}686 \\
9,300 \\
1,200 \\
456 \\
790\end{array}$ & $\begin{array}{r}60.7 \\
420.0 \\
45.0 \\
46.6 \\
76.0\end{array}$ & $\begin{array}{r}<1.00 \\
7.60 \\
<1.50 \\
<1.00 \\
<1.80\end{array}$ & $\begin{array}{r}29.60 \\
160.00 \\
54.00 \\
17.70 \\
44.00\end{array}$ \\
\hline $\begin{array}{r}128 \\
87565 \\
130 \\
87413 \\
87416\end{array}$ & $\begin{array}{l}08 / 05 / 86 \\
07 / 16 / 87 \\
08 / 05 / 86 \\
06 / 23 / 87 \\
06 / 25 / 87\end{array}$ & $\begin{array}{l}\text { FERNLEY WMA } \\
\text { FERNLEY WMA } \\
\text { HWMA, HUMBOLDT ILAKE } \\
\text { HWMA, TOULON LAKE } \\
\text { MAHALA SLOUGH }\end{array}$ & $\begin{array}{l}\text { INSECT } \\
\text { INSECT } \\
\text { INSECT } \\
\text { INSECT } \\
\text { INSECT }\end{array}$ & $\begin{array}{l}\text { HEMIPTERA } \\
\text { HEMIPTERA } \\
\text { HEMIPTERA } \\
\text { HEMIPTERA } \\
\text { HEMIPTERA }\end{array}$ & & $\begin{array}{r}13.00 \\
.60 \\
1.10 \\
.60 \\
1.10\end{array}$ & $\begin{array}{l}150.0 \\
192.0 \\
170.0 \\
175.0 \\
205.0\end{array}$ & $\begin{array}{r}11,000.0 \\
50.0 \\
260.0 \\
180.0 \\
120.0\end{array}$ & $\begin{array}{r}8.300 \\
152 \\
310 \\
270 \\
251\end{array}$ & $\begin{array}{r}200.0 \\
40.0 \\
43.0 \\
18.0 \\
52.6\end{array}$ & $\begin{array}{r}3.60 \\
<1.00 \\
<1.60 \\
<1.00 \\
<1.00\end{array}$ & $\begin{array}{l}<0.78 \\
25.60 \\
22.00 \\
19.80 \\
33.30\end{array}$ \\
\hline $\begin{array}{r}87526 \\
87585 \\
87421 \\
132 \\
369\end{array}$ & $\begin{array}{l}07 / 08 / 87 \\
07 / 20 / 87 \\
06 / 25 / 87 \\
08 / 07 / 86 \\
10 / 07 / 86\end{array}$ & $\begin{array}{l}\text { MASSIE SLOUGH } \\
\text { MASSIE SLOUGH } \\
\text { SHECKLER RES. } \\
\text { SWMA, ALKALI UN. I } \\
\text { SWMA, GOOSE ILAKE }\end{array}$ & $\begin{array}{l}\text { INSECT } \\
\text { INSECT } \\
\text { INSECT } \\
\text { INSECT } \\
\text { INSECT }\end{array}$ & $\begin{array}{l}\text { HEMIPTERA } \\
\text { HEMIPTERA } \\
\text { HEMIPTERA } \\
\text { HEMIPTERA } \\
\text { HEMIPTERA }\end{array}$ & & $\begin{array}{r}2.50 \\
.90 \\
2.40 \\
.77 \\
1.70\end{array}$ & $\begin{array}{l}204.0 \\
202.0 \\
176.0 \\
190.0 \\
170.0\end{array}$ & $\begin{array}{l}370.0 \\
290.0 \\
610.0 \\
310.0\end{array}$ & $\begin{array}{r}561 \\
399 \\
870 \\
380 \\
--\end{array}$ & $\begin{array}{l}27.0 \\
51.3 \\
42.2 \\
26.0 \\
-\end{array}$ & $\begin{array}{l}<1.00 \\
<1.00 \\
<1.00 \\
<1.40 \\
-\infty\end{array}$ & $\begin{array}{l}33.30 \\
26.20 \\
11.60 \\
19.00 \\
-\end{array}$ \\
\hline $\begin{array}{r}87604 \\
39 \\
87587 \\
87536 \\
73\end{array}$ & $\begin{array}{l}07 / 28 / 87 \\
07 / 02 / 86 \\
07 / 24 / 87 \\
07 / 13 / 87 \\
07 / 17 / 86\end{array}$ & $\begin{array}{l}\text { SWMA, HUNTER RD. BRIDGE } \\
\text { SWMA, LEAD LAKE } \\
\text { SWMA, PINTAIL BAY } \\
\text { SWMA, SHAFFNER DR. IND.L } \\
\text { SWMA, STILLWATER PT. RES. }\end{array}$ & $\begin{array}{l}\text { INSECT } \\
\text { INSECT } \\
\text { INSECT } \\
\text { INSECT } \\
\text { INSECT }\end{array}$ & $\begin{array}{l}\text { HEMIPTERA } \\
\text { HEMIPTERA } \\
\text { HEMIPTERA } \\
\text { HEMIPTERA } \\
\text { HEMIPTERA }\end{array}$ & & $\begin{array}{r}.70 \\
1.0 \\
1.30 \\
12.00 \\
2.00\end{array}$ & $\begin{array}{l}116.0 \\
117.0 \\
200.0 \\
140.0\end{array}$ & $\begin{array}{r}140.0 \\
290.0 \\
268.0 \\
7,400.0\end{array}$ & $\begin{array}{r}266 \\
-50 \\
406 \\
524 \\
6,200\end{array}$ & $\begin{array}{r}20.0 \\
-.0 \\
12.0 \\
79.6 \\
180.0\end{array}$ & $\begin{array}{l}<1.00 \\
<1.00 \\
<1.00 \\
3.30\end{array}$ & $\begin{array}{l}27.40 \\
-. \\
96.10 \\
46.00 \\
60.00\end{array}$ \\
\hline $\begin{array}{r}87566 \\
87732 \\
16 \\
260 \\
341\end{array}$ & $\begin{array}{l}07 / 16 / 87 \\
08 / 20 / 87 \\
06 / 12 / 86 \\
09 / 23 / 86 \\
10 / 03 / 86\end{array}$ & $\begin{array}{l}\text { SWMA, SWAN L. CHECK } \\
\text { SWMA, TJ DRAIN } \\
\text { WASHOE LAKE } \\
\text { CARSON L.. ISLANDS UNIT } \\
\text { CARSON L., SPRIG PONDS }\end{array}$ & $\begin{array}{l}\text { INSECT } \\
\text { INSECT } \\
\text { INSECT } \\
\text { PLANT } \\
\text { PLANT }\end{array}$ & $\begin{array}{l}\text { HEMIPTERA } \\
\text { HEMIPTERA } \\
\text { HEMIPTERA } \\
\text { A BULRUSH } \\
\text { A BULRUSH }\end{array}$ & RT & $\begin{array}{r}2.90 \\
4.50 \\
2.00 \\
17.00 \\
16.00\end{array}$ & $\begin{array}{r}141.0 \\
119.0 \\
180.0 \\
7.1 \\
24.0\end{array}$ & $\begin{array}{r}464.0 \\
1.050 .0 \\
890.0 \\
=-\end{array}$ & $\begin{array}{r}606 \\
1,210 \\
930 \\
-- \\
--\end{array}$ & $\begin{array}{r}20.0 \\
232.0 \\
83.0 \\
-. \\
-\end{array}$ & $\begin{array}{c}<1.00 \\
<1.00 \\
<2.10 \\
-- \\
--\end{array}$ & $\begin{array}{l}97.90 \\
87.40 \\
15.00 \\
-- \\
--\end{array}$ \\
\hline $\begin{array}{l}354 \\
245 \\
248 \\
251 \\
157\end{array}$ & $\begin{array}{l}10 / 03 / 86 \\
09 / 23 / 86 \\
09 / 23 / 86 \\
09 / 23 / 86 \\
09 / 09 / 86\end{array}$ & $\begin{array}{l}\text { CARSON L., SPRIG PONDS } \\
\text { CARSON L., SUMP } \\
\text { CARSON L.:, SUMP } \\
\text { CARSON L., SUMP } \\
\text { EERNLEY WMA }\end{array}$ & $\begin{array}{l}\text { PLANT } \\
\text { PLANT } \\
\text { PLANT } \\
\text { PLANT } \\
\text { PLANT }\end{array}$ & $\begin{array}{l}\text { A BULRUSH } \\
\text { A BULRUSH } \\
\text { A BULRUSH } \\
\text { A BULRUSH } \\
\text { A BULRUSH }\end{array}$ & $\begin{array}{l}R T \\
R T \\
R T \\
R T\end{array}$ & $\begin{array}{r}19.00 \\
40.00 \\
12.00 \\
10.00 \\
6.70\end{array}$ & $\begin{array}{l}19.0 \\
29.0 \\
12.0 \\
13.0 \\
37.0\end{array}$ & $\begin{array}{l}=- \\
=- \\
=\end{array}$ & $\begin{array}{l}-- \\
-- \\
--\end{array}$ & $\begin{array}{l}-- \\
-- \\
--\end{array}$ & $=-$ & $\begin{array}{l}-- \\
-- \\
--\end{array}$ \\
\hline $\begin{array}{l}203 \\
206 \\
209 \\
162 \\
167\end{array}$ & $\begin{array}{l}09 / 19 / 86 \\
09 / 19 / 86 \\
09 / 19 / 86 \\
09 / 16 / 86 \\
09 / 16 / 86\end{array}$ & $\begin{array}{l}\text { HWMA, HUMBOIDT LAKE } \\
\text { HWMA, HUMBOIDT LAKE } \\
\text { HWMA, HUMBOIDT LAKE } \\
\text { SWMA, ALKALI UN. } 1 \\
\text { SWMA, ALKALI UN. } 1\end{array}$ & $\begin{array}{l}\text { PLANT } \\
\text { PLANT } \\
\text { PLANT } \\
\text { PLANT } \\
\text { PLANT }\end{array}$ & $\begin{array}{l}\text { A BULRUSH } \\
\text { A BULRUSH } \\
\text { A BULRUSH } \\
\text { A BULRUSH } \\
\text { A BULRUSH }\end{array}$ & $\begin{array}{l}R T \\
R T \\
R T \\
R T \\
R T\end{array}$ & $\begin{array}{r}<1.00 \\
<.85 \\
<.79 \\
21.00 \\
70.00\end{array}$ & $\begin{array}{l}<10.0 \\
<8.5 \\
<7.9 \\
10.0 \\
<5.4\end{array}$ & $\begin{array}{l}=- \\
=- \\
--\end{array}$ & $\begin{array}{l}-- \\
-- \\
--\end{array}$ & $=$ & $=$ & $\overline{--}$ \\
\hline $\begin{array}{r}170 \\
301 \\
329 \\
332 \\
87560\end{array}$ & $\begin{array}{l}09 / 16 / 86 \\
09 / 30 / 86 \\
10 / 02 / 86 \\
10 / 02 / 86 \\
07 / 16 / 87\end{array}$ & $\begin{array}{l}\text { SWMA, ALKALI UN. } 1 \\
\text { SWMA, GOOSE LAKE } \\
\text { SWMA, GOOSE I.AKE } \\
\text { SWMA, GOOSE I.AKE } \\
\text { SWMA, SWAN L. CHECK }\end{array}$ & $\begin{array}{l}\text { PLANT } \\
\text { PLANT } \\
\text { PLANT } \\
\text { PLANT } \\
\text { PLANT }\end{array}$ & $\begin{array}{l}\text { A BULRUSH } \\
\text { A BULRUSH } \\
\text { A BULRUSH } \\
\text { A BULRUSH } \\
\text { A BULRUSH }\end{array}$ & $\begin{array}{l}R T \\
R T \\
R T \\
R T \\
R T\end{array}$ & $\begin{array}{l}10.00 \\
17.00 \\
32.00 \\
19.00 \\
26.80\end{array}$ & $\begin{array}{r}<6.5 \\
9.6 \\
20.0 \\
12.0 \\
27.5\end{array}$ & $4,430 . \overline{0}$ & 5,230 & $175 . \overline{0}$ & 12.70 & $14 \overline{-} .00$ \\
\hline $\begin{array}{l}262 \\
269 \\
273 \\
247 \\
250\end{array}$ & $\begin{array}{l}09 / 23 / 86 \\
09 / 23 / 86 \\
09 / 23 / 86 \\
09 / 23 / 86 \\
09 / 23 / 86\end{array}$ & $\begin{array}{lll}\text { CARSON L.., ISLANDS UNIT } \\
\text { CARSON L.. } \\
\text { CARSON LPIG PONDS } \\
\text { CARSON L.: } \\
\text { CARRIG PONDS } \\
\text { CARSON } \\
\text { L., SUMP }\end{array}$ & $\begin{array}{l}\text { PLANT } \\
\text { PLANT } \\
\text { PLANT } \\
\text { PLANT } \\
\text { PLANT }\end{array}$ & $\begin{array}{l}\text { A BULRUSH } \\
\text { A BULRUSH } \\
\text { A BULRUSH } \\
\text { A BULRUSH } \\
\text { A BULRUSH }\end{array}$ & $\begin{array}{l}S D \\
S D \\
S D \\
S D \\
S D\end{array}$ & $\begin{array}{l}<.50 \\
<.55 \\
<.53 \\
<.53 \\
<.52\end{array}$ & $\begin{array}{l}16.0 \\
18.0 \\
13.0 \\
28.0 \\
22.0\end{array}$ & $\begin{array}{l}-- \\
-- \\
--\end{array}$ & $\begin{array}{l}-- \\
-- \\
-\end{array}$ & $=$ & $\begin{array}{l}=- \\
=- \\
--\end{array}$ & $\begin{array}{l}=- \\
\overline{--} \\
--\end{array}$ \\
\hline $\begin{array}{l}253 \\
214 \\
204 \\
207 \\
210\end{array}$ & $\begin{array}{l}09 / 23 / 86 \\
09 / 19 / 86 \\
09 / 19 / 86 \\
09 / 19 / 86 \\
09 / 19 / 86\end{array}$ & $\begin{array}{l}\text { CARSON L.. SUMP } \\
\text { FERNLEY WMA } \\
\text { HWMA, HUMBOIDT IAKE } \\
\text { HWMA, HUMBOLDT LAKE } \\
\text { HWMA, HUMBOLDT LAKE }\end{array}$ & $\begin{array}{l}\text { PLANT } \\
\text { PLANT } \\
\text { PLANT } \\
\text { PLANT } \\
\text { PLANT }\end{array}$ & $\begin{array}{l}\text { A BULRUSH } \\
\text { A BULRUSH } \\
\text { A BULRUSH } \\
\text { A BULRUSH } \\
\text { A BULRUSH }\end{array}$ & $\begin{array}{l}S D \\
S D \\
S D \\
S D \\
S D\end{array}$ & $\begin{array}{l}<.53 \\
<.53 \\
<.55 \\
<.57 \\
.52\end{array}$ & $\begin{array}{r}18.0 \\
8.0 \\
13.0 \\
6.0 \\
14.0\end{array}$ & $\begin{array}{l}-- \\
-- \\
--\end{array}$ & $\begin{array}{l}-- \\
-- \\
--\end{array}$ & $=$ & $=-$ & $=-$ \\
\hline $\begin{array}{l}196 \\
198 \\
200 \\
303 \\
331\end{array}$ & $\begin{array}{l}09 / 18 / 86 \\
09 / 18 / 86 \\
09 / 18 / 86 \\
09 / 30 / 86 \\
10 / 02 / 86\end{array}$ & $\begin{array}{l}\text { SWMA, ALKALI UN. } 1 \\
\text { SWMA, ALKALI UN. II } \\
\text { SWMA, ALKALI UN. I } \\
\text { SWMA, GOOSE LAKE } \\
\text { SWMA, GOOSE IAKE }\end{array}$ & $\begin{array}{l}\text { PLANT } \\
\text { PLANT } \\
\text { PLANT } \\
\text { PLANT } \\
\text { PLANT }\end{array}$ & $\begin{array}{l}\text { A BULRUSH } \\
\text { A BULRUSH } \\
\text { A BULRUSH } \\
\text { A BULRUSH } \\
\text { A BULRUSH }\end{array}$ & $\begin{array}{l}S D \\
S D \\
S D \\
S D \\
S D\end{array}$ & $\begin{array}{l}<.57 \\
<.56 \\
<.51 \\
<.57 \\
<.52\end{array}$ & $\begin{array}{l}9.5 \\
13.0 \\
13.0 \\
12.0 \\
10.0\end{array}$ & $\begin{array}{l}-- \\
-- \\
--\end{array}$ & $\begin{array}{l}-- \\
-- \\
--\end{array}$ & $=$ & $=$ & $=$ \\
\hline
\end{tabular}


TABLE 19.--Data on trace-element constituents and percent moisture of blologlcal samples in st11lwater wildiffe Management Area, Carson Lake, Fernley Wildilfe Management Area, and Humboldt Wildlife Management Area, j985-87--Cont.

\begin{tabular}{|c|c|c|c|c|c|c|c|c|c|c|c|}
\hline $\begin{array}{l}\text { USFWS } \\
\text { local } \\
\text { ID } \\
\text { number }\end{array}$ & Date & Location & $\begin{array}{l}\text { Cate- } \\
\text { gory }\end{array}$ & Species & $\begin{array}{l}\text { Vana- } \\
\text { dium }\end{array}$ & 2 inc & $\begin{array}{c}\text { Alu- } \\
\text { minum }\end{array}$ & Iron & $\begin{array}{c}\text { Man- } \\
\text { ganese }\end{array}$ & Nickel & $\begin{array}{l}\text { Stron- } \\
\text { tium }\end{array}$ \\
\hline $\begin{array}{r}334 \\
87577 \\
87543 \\
67548 \\
87672\end{array}$ & $\begin{array}{l}10 / 02 / 86 \\
07 / 20 / 87 \\
07 / 14 / 87 \\
07 / 14 / 87 \\
08 / 24 / 87\end{array}$ & $\begin{array}{l}\text { SWMA, GOOSE LAKE } \\
\text { CARSON L.. IA DEEP DRAIN } \\
\text { CARSON L.: DOWNS DRAIN } \\
\text { CARSON L.: HOLMES DEEP DR } \\
\text { CARSON L.. JI DEEP DRAIN }\end{array}$ & $\begin{array}{l}\text { PLANT } \\
\text { PLANT } \\
\text { PLANT } \\
\text { PLANT } \\
\text { PLANT }\end{array}$ & $\begin{array}{l}\text { A BULRUSH SD } \\
\text { ALGAE } \\
\text { ALGAE } \\
\text { ALGAE } \\
\text { ALGAE }\end{array}$ & $\begin{array}{l}1.10 \\
36.70 \\
10.90 \\
16.10 \\
26.00\end{array}$ & $\begin{array}{l}7.3 \\
54.5 \\
23.5 \\
59.6 \\
50.9\end{array}$ & $\begin{array}{r}12,100.0 \\
3,920.0 \\
6,050.0 \\
7,610.0\end{array}$ & $\begin{array}{r}12,600 \\
3,730 \\
5,180 \\
8,097\end{array}$ & $\begin{array}{r}6,530.0 \\
1,860.0 \\
877.0 \\
1,080.0\end{array}$ & $\begin{array}{r}12.90 \\
3.97 \\
20.30 \\
8.60\end{array}$ & $\begin{array}{r}372.00 \\
3.97 \\
585.00 \\
163.00\end{array}$ \\
\hline $\begin{array}{r}87434 \\
87673 \\
87674 \\
271 \\
277\end{array}$ & $\begin{array}{l}06 / 30 / 87 \\
08 / 24 / 87 \\
08 / 24 / 87 \\
09 / 23 / 86 \\
09 / 23 / 86\end{array}$ & $\begin{array}{lll}\text { CARSON } & L ., & \text { PASTURE RD.DR. } \\
\text { CARSON } & \text { L., } & \text { PIER/L DP. DR. } \\
\text { CARSON } & \text { L., } & \text { PIER/L DP. DR. } \\
\text { CARSON L., SPRIG PONDS } \\
\text { CARSON L.. } \\
\text { SPRIG PONDS }\end{array}$ & $\begin{array}{l}\text { PLANT } \\
\text { PLANT } \\
\text { PLANT } \\
\text { PLANT } \\
\text { PLANT }\end{array}$ & $\begin{array}{l}\text { ALGAE } \\
\text { ALGAE } \\
\text { ALGAE } \\
\text { ALGAE } \\
\text { ALGAE }\end{array}$ & $\begin{array}{r}27.40 \\
31.00 \\
35.50 \\
1.50 \\
3.70\end{array}$ & $\begin{array}{l}42.8 \\
46.1 \\
36.6 \\
<9.4 \\
<5.4\end{array}$ & $\begin{array}{r}10,200.0 \\
13,200.0 \\
9,410.0 \\
= \\
=\end{array}$ & $\begin{array}{r}8,220 \\
12,600 \\
9,390 \\
=-\end{array}$ & $\begin{array}{r}1.360 .0 \\
762.0 \\
498.0 \\
=-\end{array}$ & $\begin{array}{r}<21.90 \\
9.10 \\
9.20 \\
-- \\
--\end{array}$ & $\begin{array}{c}658.00 \\
326.00 \\
164.00 \\
\ldots \\
\ldots\end{array}$ \\
\hline $\begin{array}{r}347 \\
279 \\
280 \\
87677 \\
225\end{array}$ & $\begin{array}{l}10 / 03 / 86 \\
09 / 23 / 86 \\
09 / 23 / 86 \\
08 / 24 / 87 \\
09 / 22 / 86\end{array}$ & $\begin{array}{l}\text { CARSON L., SPRIG PONDS } \\
\text { CARSON L.. SUMP } \\
\text { CARSON L.. SUMP } \\
\text { CARSON L.: YARBROUGH DR. } \\
\text { CARSON VALLEY }\end{array}$ & $\begin{array}{l}\text { PLANT } \\
\text { PLANT } \\
\text { PLANT } \\
\text { PLANT } \\
\text { PLANT }\end{array}$ & $\begin{array}{l}\text { ALGAE } \\
\text { ALGAE } \\
\text { ALGAE } \\
\text { ALGAE } \\
\text { ALGAE }\end{array}$ & $\begin{array}{r}5.40 \\
19.00 \\
12.00 \\
40.20 \\
2.90\end{array}$ & $\begin{array}{r}8.6 \\
24.0 \\
27.0 \\
61.5 \\
12.0\end{array}$ & $17,700 . \overline{0}$ & 16,600 & $1,600 . \overline{0}$ & 10.00 & 154.00 \\
\hline $\begin{array}{r}230 \\
237 \\
87491 \\
154 \\
212\end{array}$ & $\begin{array}{l}09 / 22 / 86 \\
09 / 22 / 86 \\
07 / 06 / 87 \\
09 / 09 / 86 \\
09 / 19 / 86\end{array}$ & $\begin{array}{l}\text { CARSON VALLEY } \\
\text { CARSON VALLEY } \\
\text { ERB DEEP DRAIN } \\
\text { FERNLEY WMA } \\
\text { FERNLEY WMA }\end{array}$ & $\begin{array}{l}\text { PLANT } \\
\text { PLANT } \\
\text { PIANT } \\
\text { PLANT } \\
\text { PLANT }\end{array}$ & $\begin{array}{l}\text { ALGAE } \\
\text { ALGAE } \\
\text { ALGAE } \\
\text { ALGAE } \\
\text { ALGAE }\end{array}$ & $\begin{array}{l}7.30 \\
14.00 \\
27.70 \\
<.83 \\
<.60\end{array}$ & $\begin{array}{l}77.0 \\
97.0 \\
34.0 \\
<8.3 \\
<6.0\end{array}$ & $9,330.0$ & 9,500 & $1,940 . \overline{0}$ & $\begin{array}{l}-- \\
-\overline{64} \\
--\end{array}$ & 129.00 \\
\hline $\begin{array}{r}216 \\
87564 \\
87670 \\
87671 \\
87656\end{array}$ & $\begin{array}{l}09 / 19 / 86 \\
07 / 16 / 87 \\
08 / 19 / 87 \\
08 / 19 / 87 \\
08 / 12 / 87\end{array}$ & $\begin{array}{l}\text { FERNLEY WMA } \\
\text { FERNLEY WMA } \\
\text { FERNLEY WMA } \\
\text { FERNLEY WMA } \\
\text { HWMA, CARPENTER RD. DRATN }\end{array}$ & $\begin{array}{l}\text { PLANT } \\
\text { PLANT } \\
\text { PLANT } \\
\text { PLANT } \\
\text { PLANT }\end{array}$ & $\begin{array}{l}\text { ALGAE } \\
\text { ALGAE } \\
\text { ALGAE } \\
\text { ALGAE } \\
\text { ALGAE }\end{array}$ & $\begin{array}{l}<1.20 \\
61.80 \\
37.90 \\
49.80 \\
36.60\end{array}$ & $\begin{array}{r}<12.0 \\
31.7 \\
87.0 \\
80.2 \\
46.0\end{array}$ & $\begin{array}{r}12,700.0 \\
8,540.0 \\
16,400.0 \\
15,100.0\end{array}$ & $\begin{array}{r}10,600 \\
13,000 \\
16,500 \\
9,910\end{array}$ & $\begin{array}{l}1,770.0 \\
7,100.0 \\
1,850.0 \\
1,770.0\end{array}$ & $\begin{array}{r}6.97 \\
7.10 \\
15.00 \\
9.70\end{array}$ & $\begin{array}{l}161.00 \\
207.00 \\
122.00 \\
511.00\end{array}$ \\
\hline $\begin{array}{l}87517 \\
87514 \\
87472 \\
87477 \\
87520\end{array}$ & $\begin{array}{l}07 / 09 / 87 \\
07 / 09 / 87 \\
07 / 02 / 87 \\
07 / 02 / 87 \\
07 / 09 / 87\end{array}$ & $\begin{array}{l}\text { HWMA, RENNIE RD. DRAIN } \\
\text { HWMA, SEVENTEEN DITCH } \\
\text { HWMA, TOULON LAKE } \\
\text { HWMA, UPPER ARMY DRAIN } \\
\text { HWMA, WESTFALL RD. DRAIN }\end{array}$ & $\begin{array}{l}\text { PLANT } \\
\text { PLANT } \\
\text { PLANT } \\
\text { PLANT } \\
\text { PLANT }\end{array}$ & $\begin{array}{l}\text { ALGAE } \\
\text { ALGAE } \\
\text { ALGAE } \\
\text { ALGAE } \\
\text { ALGAE }\end{array}$ & $\begin{array}{r}17.60 \\
37.10 \\
6.90 \\
32.50 \\
17.90\end{array}$ & $\begin{array}{r}25.8 \\
30.5 \\
11.2 \\
57.9 \\
6.6\end{array}$ & $\begin{array}{r}6,900.0 \\
1,100.0 \\
2,200.0 \\
11,200.0 \\
479.0\end{array}$ & $\begin{array}{r}4,930 \\
4,450 \\
1,790 \\
11,500 \\
407\end{array}$ & $\begin{array}{r}220.0 \\
5,700.0 \\
142.0 \\
30100 \\
866.0\end{array}$ & $\begin{array}{r}6.93 \\
13.40 \\
2.36 \\
<10.70 \\
3.29\end{array}$ & $\begin{array}{l}753.00 \\
461.00 \\
466.00 \\
184.00 \\
509.00\end{array}$ \\
\hline $\begin{array}{r}87507 \\
87581 \\
874: 9 \\
307 \\
308\end{array}$ & $\begin{array}{l}07 / 08 / 87 \\
07 / 20 / 87 \\
06 / 25 / 87 \\
09 / 30 / 86 \\
09 / 30 / 86\end{array}$ & $\begin{array}{l}\text { MASSIE SLOUGH } \\
\text { MASSIE SLOUGH } \\
\text { SHECKLER RES. } \\
\text { SWMA, GOOSE LAKE } \\
\text { SWMA, GOOSE LAKE }\end{array}$ & $\begin{array}{l}\text { PLANT } \\
\text { PLANT } \\
\text { PLANT } \\
\text { PLANT } \\
\text { PLANT }\end{array}$ & $\begin{array}{l}\text { ALGAE } \\
\text { ALGAE } \\
\text { ALGAE } \\
\text { ALGAE } \\
\text { ALGAE }\end{array}$ & $\begin{array}{r}16.40 \\
46.00 \\
49.70 \\
5.60 \\
11.00\end{array}$ & $\begin{array}{r}18.8 \\
56.6 \\
86.1 \\
<8.8 \\
<11.0\end{array}$ & $\begin{array}{r}5,730.0 \\
15,200.0 \\
18,700.0 \\
- \\
--\end{array}$ & $\begin{array}{r}5,490 \\
15,300 \\
20,200 \\
- \\
--\end{array}$ & $\begin{array}{r}149.0 \\
1.140 .0 \\
22900 \\
=-\end{array}$ & $\begin{array}{r}3.22 \\
19.60 \\
17.00 \\
=- \\
--\end{array}$ & $\begin{array}{c}339.00 \\
189.00 \\
23.10 \\
\ldots \\
=\end{array}$ \\
\hline $\begin{array}{r}186 \\
187 \\
194 \\
87527 \\
87449\end{array}$ & $\begin{array}{l}09 / 18 / 86 \\
09 / 18 / 86 \\
09 / 18 / 86 \\
07 / 13 / 87 \\
06 / 30 / 87\end{array}$ & $\begin{array}{l}\text { SWMA, LEAD LAKE } \\
\text { SWMA, LEAD LAKE } \\
\text { SWMA, LEAD IAKE } \\
\text { SWMA, SHAFFNER DR. , IND.I. } \\
\text { CARSON L.. I DEEP DRAIN }\end{array}$ & $\begin{array}{l}\text { PLANT } \\
\text { PLANT } \\
\text { PLANT } \\
\text { PLANT } \\
\text { PLANT }\end{array}$ & $\begin{array}{l}\text { ALGAE } \\
\text { ALGAE } \\
\text { ALGAE } \\
\text { ALGAE } \\
\text { CATTAIL RT }\end{array}$ & $\begin{array}{l}13.00 \\
24.00 \\
18.00 \\
21.30 \\
22.70\end{array}$ & $\begin{array}{r}11.0 \\
28.0 \\
18.0 \\
26.5 \\
33.2\end{array}$ & $\begin{array}{r}\overline{-} \\
6,100.0 \\
4,850.0\end{array}$ & $\begin{array}{r}-- \\
10,200 \\
8,520\end{array}$ & $\begin{array}{l}\ldots- \\
2,230.0 \\
1,770.0\end{array}$ & $\begin{array}{l}-- \\
-- \\
5.91 \\
6.73\end{array}$ & $\begin{array}{c}-- \\
778.00 \\
93.60\end{array}$ \\
\hline $\begin{array}{r}87433 \\
87441 \\
87537 \\
263 \\
87409\end{array}$ & $\begin{array}{l}06 / 30 / 87 \\
06 / 30 / 87 \\
07 / 14 / 87 \\
09 / 23 / 86 \\
06 / 22 / 87\end{array}$ & 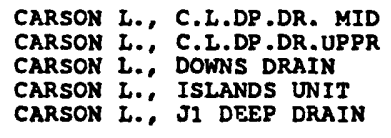 & $\begin{array}{l}\text { PLANT } \\
\text { PLANT } \\
\text { PLANT } \\
\text { PLANT } \\
\text { PIANT }\end{array}$ & $\begin{array}{l}\text { CATTAIL RT } \\
\text { CATTAIL RT } \\
\text { CATTAIL RT } \\
\text { CATTAIL RT } \\
\text { CATTAIL RT }\end{array}$ & $\begin{array}{r}17.20 \\
6.12 \\
29.50 \\
5.20 \\
11.10\end{array}$ & $\begin{array}{l}39.1 \\
20.5 \\
50.7 \\
57.6 \\
23.9\end{array}$ & $\begin{array}{r}2,020.0 \\
1,650.0 \\
11,100.0 \\
2,960.0\end{array}$ & $\begin{array}{r}3,210 \\
2,550 \\
11,000 \\
4,470\end{array}$ & $\begin{array}{r}742.0 \\
574.0 \\
464.0 \\
256.0\end{array}$ & $\begin{array}{r}6.89 \\
<3.88 \\
<7.27 \\
7.14\end{array}$ & $\begin{array}{r}113.00 \\
72.40 \\
152.00 \\
79.10\end{array}$ \\
\hline $\begin{array}{r}87439 \\
87411 \\
87676 \\
345 \\
348\end{array}$ & $\begin{array}{l}06 / 30 / 87 \\
06 / 22 / 87 \\
08 / 24 / 87 \\
10 / 03 / 86 \\
10 / 03 / 86\end{array}$ & $\begin{array}{l}\text { CARSON I.. } \text { PASTURE RD.DR. } \\
\text { CARSON L., PIER/L DP. DR. } \\
\text { CARSON L., PIER/L DR. DR. } \\
\text { CARSON L., SPRIG PONDS } \\
\text { CARSON I.. SPRIG PONDS }\end{array}$ & $\begin{array}{l}\text { PLANT } \\
\text { PLANT } \\
\text { PLANT } \\
\text { PLANT } \\
\text { PLANT }\end{array}$ & $\begin{array}{l}\text { CATTAIL RT } \\
\text { CATTAIL RT } \\
\text { CATTAIL RT } \\
\text { CATTAIL RT } \\
\text { CATTAIL RT }\end{array}$ & $\begin{array}{r}<7.10 \\
5.87 \\
6.30 \\
3.70 \\
.97\end{array}$ & $\begin{array}{l}24.7 \\
36.1 \\
24.0 \\
13.0 \\
12.0\end{array}$ & $\begin{array}{r}1,210.0 \\
1,720.0 \\
1,980.0 \\
\ldots \\
\ldots\end{array}$ & $\begin{array}{r}2,970 \\
3,150 \\
2,980 \\
-- \\
--\end{array}$ & $\begin{array}{r}234.0 \\
256.0 \\
225.0 \\
.-\end{array}$ & $\begin{array}{r}5.86 \\
11.70 \\
4.00 \\
-. \\
--\end{array}$ & $\begin{array}{l}49.00 \\
81.70 \\
62.90 \\
- \\
-\end{array}$ \\
\hline $\begin{array}{r}352 \\
87547 \\
217 \\
231 \\
234\end{array}$ & $\begin{array}{l}10 / 03 / 86 \\
07 / 14 / 87 \\
09 / 22 / 86 \\
09 / 22 / 86 \\
09 / 22 / 86\end{array}$ & $\begin{array}{l}\text { CARSON L.. SPRIG PONDS } \\
\text { CARSON L. YARBROUGH DR. } \\
\text { CARSON VALLLEY } \\
\text { CARSON VALLEY } \\
\text { CARSON VALLEY }\end{array}$ & $\begin{array}{l}\text { PLANT } \\
\text { PLANT } \\
\text { PLANT } \\
\text { PIANT } \\
\text { PIANT }\end{array}$ & $\begin{array}{l}\text { CATTAIL RT } \\
\text { CATTAIL RT } \\
\text { CATTAIL RT } \\
\text { CATTAIL RT } \\
\text { CATTAIL RT }\end{array}$ & $\begin{array}{l}2.20 \\
6.78 \\
6.50 \\
5.00 \\
2.50\end{array}$ & $\begin{array}{l}15.0 \\
33.7 \\
25.0 \\
7.4 \\
9.7\end{array}$ & $\begin{array}{r}2,250.0 \\
= \\
=\end{array}$ & $\begin{array}{r}2,460 \\
=- \\
- \\
--\end{array}$ & $\begin{array}{r}-- \\
369.0 \\
=- \\
=-\end{array}$ & 14.10 & $\begin{array}{l}71.30 \\
- \\
-\end{array}$ \\
\hline $\begin{array}{r}87493 \\
152 \\
156 \\
158 \\
87452\end{array}$ & $\begin{array}{l}07 / 06 / 87 \\
09 / 09 / 86 \\
09 / 09 / 86 \\
09 / 09 / 86 \\
07 / 01 / 87\end{array}$ & $\begin{array}{l}\text { ERB DEEP DRAIN } \\
\text { FERNLEY WMA } \\
\text { FERNLEY WMA } \\
\text { FERNLEY WMA } \\
\text { FERNLEY WMA }\end{array}$ & $\begin{array}{l}\text { PLANT } \\
\text { PLANT } \\
\text { PLANT } \\
\text { PLANT } \\
\text { PLANT }\end{array}$ & $\begin{array}{l}\text { CATTAIL RT } \\
\text { CATTAIL RT } \\
\text { CATTAIL RT } \\
\text { CATTAIL RT } \\
\text { CATTAIL RT }\end{array}$ & $\begin{array}{l}<7.20 \\
<1.10 \\
<1.10 \\
<.79 \\
8.92\end{array}$ & $\begin{array}{r}12.9 \\
<11.0 \\
<11.0 \\
<7.9 \\
14.2\end{array}$ & $\frac{813.0}{=-}$ & $\begin{array}{r}1,680 \\
=- \\
- \\
3,740\end{array}$ & $\begin{array}{r}493.0 \\
=- \\
118.0\end{array}$ & $\begin{array}{c}<5.80 \\
-. \\
-. \\
2.66\end{array}$ & $\begin{array}{l}67.70 \\
- \\
- \\
42.80\end{array}$ \\
\hline
\end{tabular}


TABLE 19.-Data on trace-element constituents and percent molsture of blologlcal samples in stillwater wildife Management Area, Carson Lake, Fernley Wildlife Management Area, and Humboldt Wildilfe Management Area, ig85-87--Cont.

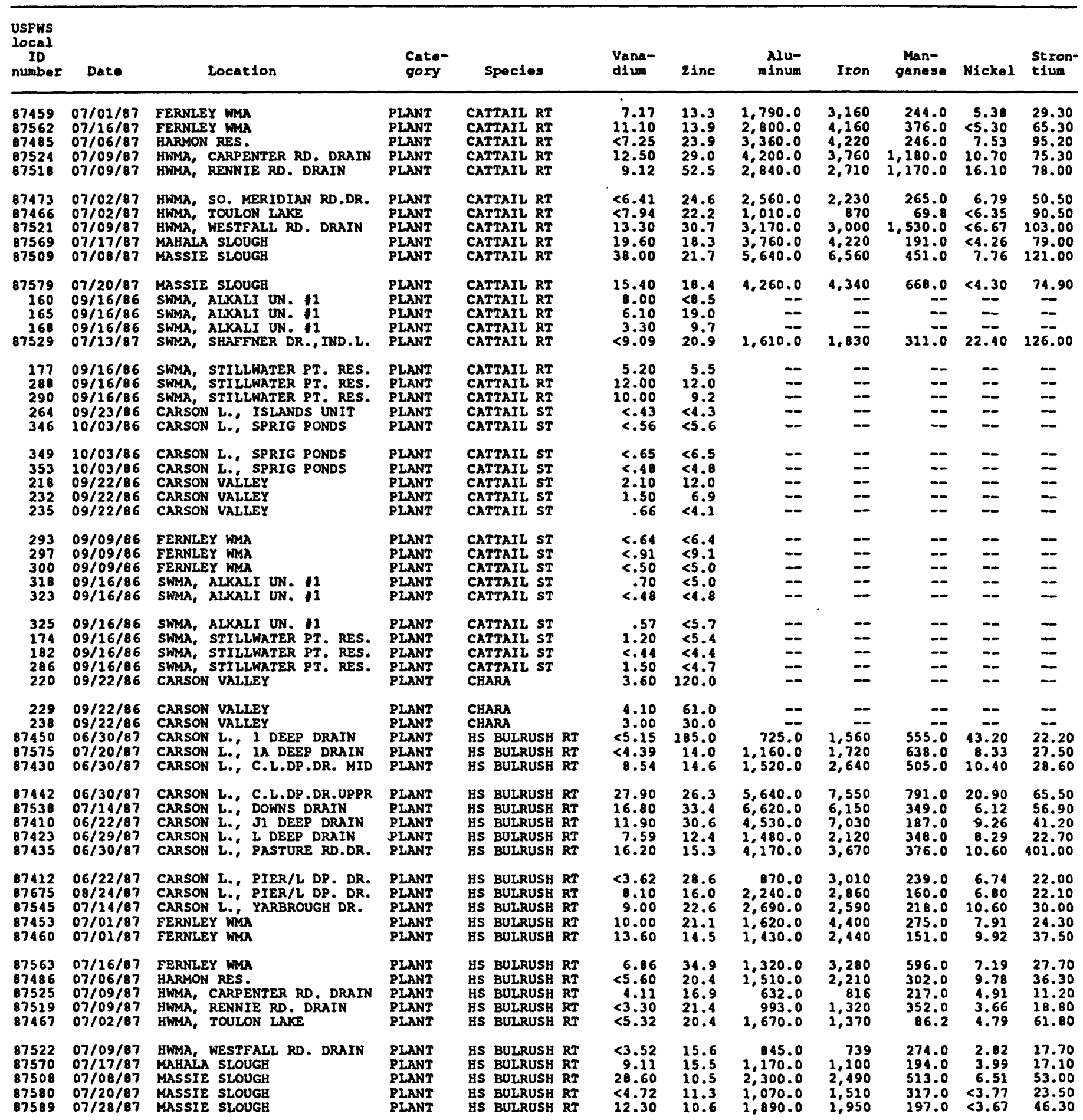


TABLE 19.-Date on trace-element constituents and percent molsture of biologlcal samples in st111water illilfe Management Area, Carson Lake, Fernley W1Idlife Management Area, and Humboldt wildlife Management Area, 1985-87--Cont.

\begin{tabular}{|c|c|c|c|c|c|c|c|c|c|c|c|c|}
\hline $\begin{array}{c}\text { USFWS } \\
\text { local } \\
\text { ID } \\
\text { number }\end{array}$ & Date & Location & $\begin{array}{l}\text { Cate- } \\
\text { gory }\end{array}$ & Species & & $\begin{array}{l}\text { Vana- } \\
\text { dium }\end{array}$ & $2 \ln c$ & $\underset{\text { minum }}{\text { Alu- }}$ & Iron & $\begin{array}{c}\text { Man- } \\
\text { ganese }\end{array}$ & Nickel & $\begin{array}{l}\text { Stron- } \\
\text { tium }\end{array}$ \\
\hline $\begin{array}{r}87418 \\
87530 \\
256 \\
259 \\
268\end{array}$ & $\begin{array}{l}06 / 25 / 87 \\
07 / 13 / 87 \\
09 / 23 / 86 \\
09 / 23 / 86 \\
09 / 23 / 86\end{array}$ & $\begin{array}{l}\text { SHECKLER RES. } \\
\text { SWMA, SHAFFNER DR., IND.I. } \\
\text { CARSON L., ISLANDS UNIT } \\
\text { CARSON L.', ISLANDS UNIT } \\
\text { CARSON L., ISLANDS UNIT }\end{array}$ & $\begin{array}{l}\text { PLANT } \\
\text { PLANT } \\
\text { PLANT } \\
\text { PLANT } \\
\text { PLANT }\end{array}$ & $\begin{array}{l}\text { HS BULRUSH } \\
\text { HS BULRUSH } \\
\text { HS BULRUSH } \\
\text { HS BULRUSH } \\
\text { HS BULRUSH }\end{array}$ & $\begin{array}{l}\text { RT } \\
\text { RT } \\
\text { SD } \\
\text { SD } \\
\text { SD }\end{array}$ & $\begin{array}{r}<4.46 \\
<8.06 \\
<.54 \\
<.47 \\
<.57\end{array}$ & $\begin{array}{l}23.5 \\
17.4 \\
17.0 \\
17.0 \\
13.0\end{array}$ & $\begin{array}{r}834.0 \\
219.0 \\
=- \\
=-\end{array}$ & $\begin{array}{r}6,230 \\
282 \\
- \\
= \\
=-\end{array}$ & $\begin{array}{r}239.0 \\
217.0 \\
.- \\
- \\
-\end{array}$ & $\begin{array}{c}11.90 \\
<6.45 \\
=- \\
=- \\
=-\end{array}$ & $\begin{array}{l}22.10 \\
35.00 \\
=- \\
= \\
=-\end{array}$ \\
\hline $\begin{array}{l}270 \\
274 \\
223 \\
227 \\
241\end{array}$ & $\begin{array}{l}09 / 23 / 86 \\
09 / 23 / 86 \\
09 / 22 / 86 \\
09 / 22 / 86 \\
09 / 22 / 86\end{array}$ & $\begin{array}{l}\text { CARSON L., SPRIG PONDS } \\
\text { CARSON L.: SPRIG PONDS } \\
\text { CARSON VALLEY } \\
\text { CARSON VALLEY } \\
\text { CARSON VALLEY }\end{array}$ & $\begin{array}{l}\text { PLANT } \\
\text { PLANT } \\
\text { PLANT } \\
\text { PLANT } \\
\text { PLANT }\end{array}$ & $\begin{array}{l}\text { HS BULRUSH } \\
\text { HS BULRUSH } \\
\text { HS BULRUSH } \\
\text { HS BULRUSH } \\
\text { HS BULRUSH }\end{array}$ & $\begin{array}{l}\text { SD } \\
\text { SD } \\
\text { SD } \\
\text { SD } \\
\text { SD }\end{array}$ & $\begin{array}{l}<.51 \\
<.53 \\
1.70 \\
.63 \\
.98\end{array}$ & $\begin{array}{l}15.0 \\
20.0 \\
9.8 \\
16.0 \\
<5.4\end{array}$ & $\begin{array}{l}=- \\
= \\
= \\
=\end{array}$ & $\begin{array}{l}= \\
-- \\
--\end{array}$ & $\begin{array}{l}= \\
=- \\
= \\
=\end{array}$ & $\begin{array}{l}-- \\
=- \\
=-\end{array}$ & $\begin{array}{l}-- \\
-- \\
--\end{array}$ \\
\hline $\begin{array}{l}213 \\
215 \\
195 \\
306 \\
311\end{array}$ & $\begin{array}{l}09 / 19 / 86 \\
09 / 19 / 86 \\
09 / 18 / 86 \\
09 / 30 / 86 \\
09 / 30 / 86\end{array}$ & $\begin{array}{l}\text { FERWLEY WMA } \\
\text { FERNLEY WMA } \\
\text { SWMA, ALKALI UN. I } \\
\text { SWMA, GOOSE LAKE } \\
\text { SWMA, GOOSE IAKE }\end{array}$ & $\begin{array}{l}\text { PLANT } \\
\text { PLANT } \\
\text { PLANT } \\
\text { PLANT } \\
\text { PLANT }\end{array}$ & $\begin{array}{l}\text { HS BULRUSH } \\
\text { HS BULRUSH } \\
\text { HS BULRUSH } \\
\text { HS BULRUSH } \\
\text { HS BULRUSH }\end{array}$ & $\begin{array}{l}\text { SD } \\
\text { SD } \\
\text { SD } \\
\text { SD } \\
\text { SD }\end{array}$ & $\begin{array}{l}<.55 \\
<.53 \\
<.49 \\
.63 \\
1.00\end{array}$ & $\begin{array}{r}<5.5 \\
<5.3 \\
11.0 \\
8.5 \\
11.0\end{array}$ & $\begin{array}{l}=- \\
=- \\
=- \\
=-\end{array}$ & $=$ & $\begin{array}{l}=- \\
=- \\
=\end{array}$ & $\begin{array}{l}=- \\
=- \\
=-\end{array}$ & $\begin{array}{l}-- \\
= \\
--\end{array}$ \\
\hline $\begin{array}{l}337 \\
185 \\
189 \\
192 \\
201\end{array}$ & $\begin{array}{l}10 / 02 / 86 \\
09 / 18 / 86 \\
09 / 18 / 86 \\
09 / 18 / 86 \\
09 / 18 / 86\end{array}$ & $\begin{array}{l}\text { SWMA, GOOSE LAKE } \\
\text { SWMA, LEAD LAKE } \\
\text { SWMA, LEAD LAKE } \\
\text { SWMA, LEAD LAKE } \\
\text { SWMA, STILLWATER PT. RES. }\end{array}$ & $\begin{array}{l}\text { PLANT } \\
\text { PLANT } \\
\text { PLANT } \\
\text { PLANT } \\
\text { PLANT }\end{array}$ & $\begin{array}{l}\text { HS BULRUSH } \\
\text { HS BULRUSH } \\
\text { HS BULRUSH } \\
\text { HS BULRUSH } \\
\text { HS BULRUSH }\end{array}$ & $\begin{array}{l}\text { SD } \\
\text { SD } \\
\text { SD } \\
\text { SD } \\
\text { SD }\end{array}$ & $\begin{array}{r}.64 \\
.65 \\
<.51 \\
.65 \\
1.30\end{array}$ & $\begin{array}{r}6.0 \\
0.8 \\
10.0 \\
15.0 \\
<5.3\end{array}$ & $\begin{array}{l}=- \\
=- \\
=-\end{array}$ & $\begin{array}{l}-- \\
-- \\
--\end{array}$ & $\begin{array}{l}-- \\
=- \\
=- \\
=-\end{array}$ & $\begin{array}{l}-- \\
-- \\
--\end{array}$ & $\begin{array}{l}-- \\
=- \\
-- \\
--\end{array}$ \\
\hline $\begin{array}{r}202 \\
285 \\
87448 \\
87576 \\
57443\end{array}$ & $\begin{array}{l}09 / 18 / 86 \\
09 / 26 / 86 \\
06 / 30 / 87 \\
07 / 20 / 87 \\
06 / 30 / 87\end{array}$ & $\begin{array}{l}\text { SWMA, STILLWATER PT. RES. } \\
\text { WASHOE IAKE } \\
\text { CARSON L., I DEEP DRAIN } \\
\text { CARSON L.' 1A DEEP DRAIN } \\
\text { CARSON L., C.L.DP.DR.UPPR }\end{array}$ & $\begin{array}{l}\text { PLANT } \\
\text { PLANT } \\
\text { PLANT } \\
\text { PLANT } \\
\text { PLANT }\end{array}$ & $\begin{array}{l}\text { HS BULRUSH } \\
\text { HS BULRUSH } \\
\text { PONDWEED } \\
\text { PONDWEED } \\
\text { PONDWEED }\end{array}$ & $\begin{array}{l}\text { SD } \\
\text { SD }\end{array}$ & $\begin{array}{r}.86 \\
.65 \\
44.20 \\
35.80 \\
36.40\end{array}$ & $\begin{array}{l}14.0 \\
14.0 \\
57.2 \\
46.8 \\
96.4\end{array}$ & $\begin{array}{r}=- \\
11,200.0 \\
6,650.0 \\
5,280.0\end{array}$ & $\begin{array}{r}=- \\
10,400 \\
7,280 \\
7,330\end{array}$ & $\begin{array}{r}-- \\
9,530.0 \\
6,020.0 \\
3,370.0\end{array}$ & $\begin{array}{c}-- \\
16.00 \\
10.40 \\
70.10\end{array}$ & $\begin{array}{l}-- \\
209.00 \\
304.00 \\
151.00\end{array}$ \\
\hline $\begin{array}{r}87544 \\
87549 \\
87425 \\
278 \\
87546\end{array}$ & $\begin{array}{l}07 / 14 / 87 \\
07 / 14 / 87 \\
06 / 29 / 87 \\
09 / 23 / 86 \\
07 / 14 / 87\end{array}$ & $\begin{array}{l}\text { CARSON L., DOWNS DRAIN } \\
\text { CARSON L., HOLMES DEEP DR } \\
\text { CARSON L., JI DEEP DRAIN } \\
\text { CARSON L.: SPRIG PONDS } \\
\text { CARSON L., YARBROUGH DR. }\end{array}$ & $\begin{array}{l}\text { PLANT } \\
\text { PLANT } \\
\text { PLANT } \\
\text { PLANT } \\
\text { PLANT }\end{array}$ & $\begin{array}{l}\text { PONDWEED } \\
\text { PONDWEED } \\
\text { PONDWEED } \\
\text { PONDWEED } \\
\text { PONDWEED }\end{array}$ & & $\begin{array}{r}46.60 \\
25.30 \\
25.80 \\
8.10 \\
30.50\end{array}$ & $\begin{array}{l}75.1 \\
45.1 \\
71.8 \\
13.0 \\
72.6\end{array}$ & $\begin{array}{r}14,200.0 \\
9,290.0 \\
7,800.0 \\
14,400.0\end{array}$ & $\begin{array}{r}14,800 \\
9,570 \\
9,140 \\
12,500\end{array}$ & $\begin{array}{r}1,270.0 \\
2,980.0 \\
822.0 \\
1,220.0\end{array}$ & $\begin{array}{c}24.20 \\
15.80 \\
47.10 \\
-.0 \\
10.00\end{array}$ & $\begin{array}{l}227.00 \\
197.00 \\
142.00 \\
135.00\end{array}$ \\
\hline $\begin{array}{r}224 \\
87492 \\
87451 \\
87458 \\
87523\end{array}$ & $\begin{array}{l}09 / 22 / 86 \\
07 / 06 / 87 \\
07 / 01 / 87 \\
07 / 01 / 87 \\
07 / 09 / 87\end{array}$ & $\begin{array}{l}\text { CARSON VALLEY } \\
\text { ERB DEEP DRAIN } \\
\text { FERNLEY WMA } \\
\text { FERNLEY WMA } \\
\text { HWMA, CARPENTER RD. DRAIN }\end{array}$ & $\begin{array}{l}\text { PLANT } \\
\text { PLANT } \\
\text { PLANT } \\
\text { PLANT } \\
\text { PLANT }\end{array}$ & $\begin{array}{l}\text { PONDWEED } \\
\text { PONDWEED } \\
\text { PONDWEED } \\
\text { PONDWEED } \\
\text { PONDWEED }\end{array}$ & & $\begin{array}{r}5.30 \\
28.20 \\
36.70 \\
37.30 \\
6.79\end{array}$ & $\begin{array}{l}27.0 \\
28.2 \\
53.8 \\
67.9 \\
39.1\end{array}$ & $\begin{array}{r}5,100.0 \\
10,200.0 \\
14,200.0 \\
2,120.0\end{array}$ & $\begin{array}{r}5,330 \\
13,000 \\
14,800 \\
20\end{array}$ & $\begin{array}{r}<1.7 \\
2,760.0 \\
526.0 \\
869.0\end{array}$ & $\begin{array}{l}11.50 \\
20.80 \\
13.20 \\
12.00\end{array}$ & $\begin{array}{r}157.00 \\
161.00 \\
102.00 \\
58.10\end{array}$ \\
\hline $\begin{array}{l}87513 \\
87474 \\
87465 \\
87475 \\
87506\end{array}$ & $\begin{array}{l}07 / 09 / 87 \\
07 / 02 / 87 \\
07 / 02 / 87 \\
07 / 02 / 87 \\
07 / 08 / 87\end{array}$ & $\begin{array}{l}\text { HWMA, SEVENTEEN DITCH } \\
\text { HWMA, SO. MERIDIAN RD.DR. } \\
\text { HWMA, TOULON LAKE } \\
\text { HWMA, UPPER ARMY DRAIN } \\
\text { MASSIE SLOUGH }\end{array}$ & $\begin{array}{l}\text { PLANT } \\
\text { PLANT } \\
\text { PLANT } \\
\text { PLANT } \\
\text { PLANT }\end{array}$ & $\begin{array}{l}\text { PONDWEED } \\
\text { PONDWEED } \\
\text { PONDWEED } \\
\text { PONDWEED } \\
\text { PONDWEED }\end{array}$ & & $\begin{array}{r}30.20 \\
28.90 \\
8.45 \\
31.70 \\
22.20\end{array}$ & $\begin{array}{l}36.3 \\
74.4 \\
53.2 \\
52.6 \\
16.9\end{array}$ & $\begin{array}{r}5,820.0 \\
11,800.0 \\
3,050.0 \\
5,840.0 \\
4,010.0\end{array}$ & $\begin{array}{r}4,900 \\
10,500 \\
2,520 \\
4,820 \\
4,160\end{array}$ & $\begin{array}{r}2,730.0 \\
1,880.0 \\
103.0 \\
4,400.0 \\
506.0\end{array}$ & $\begin{array}{r}20.10 \\
59.20 \\
5.26 \\
14.30 \\
8.73\end{array}$ & $\begin{array}{l}212.00 \\
170.00 \\
428.00 \\
192.00 \\
183.00\end{array}$ \\
\hline $\begin{array}{r}87582 \\
163 \\
166 \\
171 \\
87528\end{array}$ & $\begin{array}{l}07 / 20 / 87 \\
09 / 16 / 86 \\
09 / 16 / 86 \\
09 / 16 / 86 \\
07 / 13 / 87\end{array}$ & $\begin{array}{l}\text { MASSIE SLOUGH } \\
\text { SWMA, ALKALI UN. I } \\
\text { SWMA, ALKALI UN. I } \\
\text { SWMA, ALKALI UN. I } \\
\text { SWMA, SHAFENER DR., IND.L. }\end{array}$ & $\begin{array}{l}\text { PLANT } \\
\text { PLANT } \\
\text { PLANT } \\
\text { PLANT } \\
\text { PLANT }\end{array}$ & $\begin{array}{l}\text { PONDWEED } \\
\text { PONDWEED } \\
\text { PONDWEED } \\
\text { PONDWEED } \\
\text { PONDWEED }\end{array}$ & & $\begin{array}{r}11.00 \\
9.90 \\
7.70 \\
6.50 \\
18.80\end{array}$ & $\begin{array}{r}22.8 \\
8.5 \\
9.7 \\
8.6 \\
31.7\end{array}$ & $\begin{array}{r}3,830.0 \\
=- \\
=- \\
2,720.0\end{array}$ & $\begin{array}{r}2,950 \\
=- \\
=- \\
3,590\end{array}$ & $\begin{array}{r}190.0 \\
=- \\
=- \\
2,260.0\end{array}$ & $\begin{array}{l}3.72 \\
=- \\
-- \\
5.00\end{array}$ & $\begin{array}{l}22.90 \\
- \\
= \\
541.00\end{array}$ \\
\hline $\begin{array}{r}179 \\
180 \\
181 \\
87561 \\
85021\end{array}$ & $\begin{array}{l}09 / 16 / 86 \\
09 / 16 / 86 \\
09 / 16 / 86 \\
07 / 16 / 87 \\
07 / 29 / 85\end{array}$ & $\begin{array}{l}\text { SWMA, STILLWATER PT. RES. } \\
\text { SWMA, STILLWATER PT. RES. } \\
\text { SWMA, STILLWATER PT. RES. } \\
\text { SWMA, SWAN L. CHECK } \\
\text { CARSON L., CARSON I DRAIN }\end{array}$ & $\begin{array}{l}\text { PLANT } \\
\text { PLANT } \\
\text { PLANT } \\
\text { PLANT } \\
\text { PLANT }\end{array}$ & $\begin{array}{l}\text { PONDWEED } \\
\text { PONDWEED } \\
\text { PONDWEED } \\
\text { PONDWEED } \\
\text { PONDWEED }\end{array}$ & & $\begin{array}{r}7.20 \\
8.50 \\
9.60 \\
17.80 \\
33.20\end{array}$ & $\begin{array}{r}9.4 \\
7.8 \\
12.0 \\
29.7 \\
40.4\end{array}$ & $2,960 . \overline{-}$ & $\begin{array}{r}-\overline{-} \\
3,290 \\
11,533\end{array}$ & 118.0 & $\begin{array}{l}-- \\
=- \\
=- \\
3.29 \\
8.80\end{array}$ & $\begin{array}{c}-- \\
\overline{--} \\
34.00 \\
--\end{array}$ \\
\hline $\begin{array}{l}85022 \\
85019 \\
85020 \\
85017 \\
85018\end{array}$ & $\begin{array}{l}07 / 29 / 85 \\
07 / 29 / 85 \\
07 / 29 / 85 \\
07 / 29 / 85 \\
07 / 29 / 85\end{array}$ & $\begin{array}{l}\text { CARSON L., CARSON I DRAIN } \\
\text { SWMA, STILLWATER PT. RES. } \\
\text { SWMA, STILLWATER PT. RES. } \\
\text { SWMA, TJ DRAIN } \\
\text { SWMA, TJ DRAIN }\end{array}$ & $\begin{array}{l}\text { PLANT } \\
\text { PLANT } \\
\text { PLANT } \\
\text { PLANT } \\
\text { PLANT }\end{array}$ & $\begin{array}{l}\text { PONDWEED } \\
\text { PONDWEED } \\
\text { PONDWEED } \\
\text { PONDWEED } \\
\text { PONDWEED }\end{array}$ & & $\begin{array}{l}42.30 \\
10.20 \\
15.10 \\
18.40 \\
26.80\end{array}$ & $\begin{array}{l}50.0 \\
17.0 \\
23.7 \\
24.6 \\
37.6\end{array}$ & $\begin{array}{l}=- \\
=- \\
=-\end{array}$ & $\begin{array}{r}15,047 \\
3,993 \\
6,331 \\
5,471 \\
8,057\end{array}$ & $\begin{array}{l}=- \\
=- \\
=- \\
=-\end{array}$ & $\begin{array}{r}15.90 \\
3.30 \\
4.80 \\
4.80 \\
7.10\end{array}$ & $\begin{array}{l}= \\
= \\
= \\
=-\end{array}$ \\
\hline
\end{tabular}

